\title{
A evolução recente do setor bancário no Brasil
}

\author{
Patrícia Olga Camargo
}

CAMARGO, PO. A evolução recente do setor bancário no Brasil [online]. São Paulo: Editora UNESP; São Paulo: Cultura Acadêmica, 2009. 322 p. ISBN 978-85-7983-039-6. Available from SciELO Books <http://books.scielo.org>.

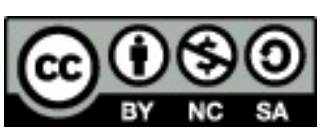

All the contents of this chapter, except where otherwise noted, is licensed under a Creative Commons Attribution-Non Commercial-ShareAlike 3.0 Unported.

Todo o conteúdo deste capítulo, exceto quando houver ressalva, é publicado sob a licença Creative Commons Atribuição Uso Não Comercial - Partilha nos Mesmos Termos 3.0 Não adaptada.

Todo el contenido de este capítulo, excepto donde se indique lo contrario, está bajo licencia de la licencia Creative Commons Reconocimento-NoComercial-CompartirIgual 3.0 Unported. 


\title{
A EVOLUÇÃO AECENTE DO SETOR BANCARIO NO BRASIL

PATRÍcIA OLGA CAMARGO

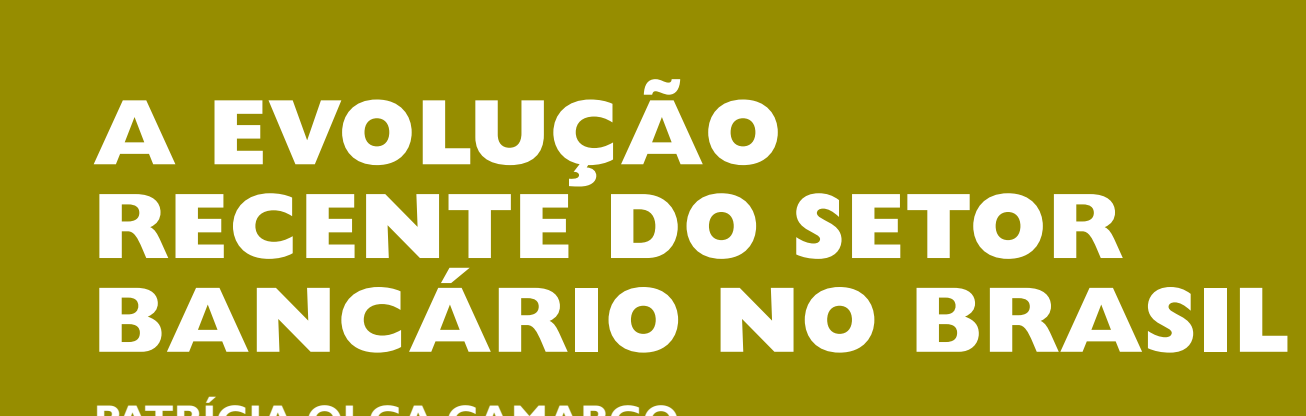

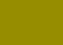

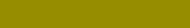 \\ \begin{tabular}{l} 
CULTURA \\
ACADÊMICA \\
\hline dito a
\end{tabular}
}

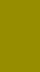

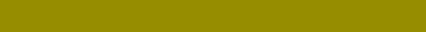

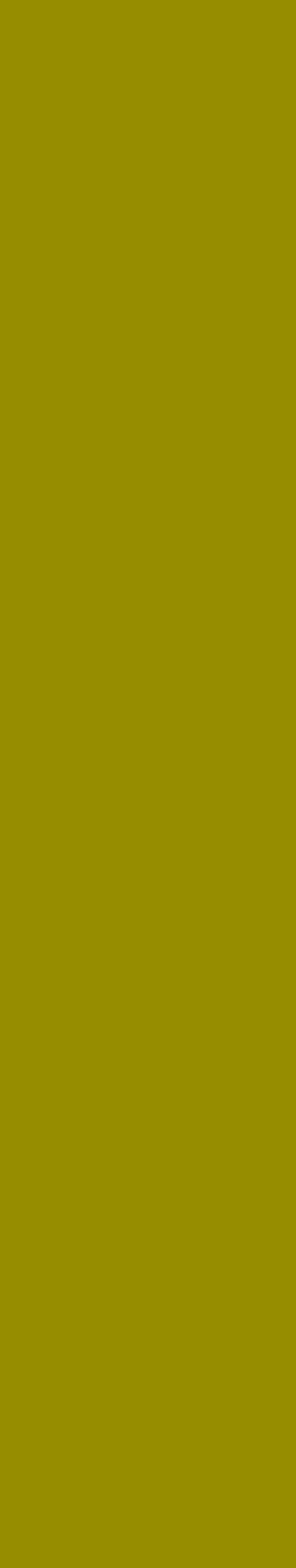

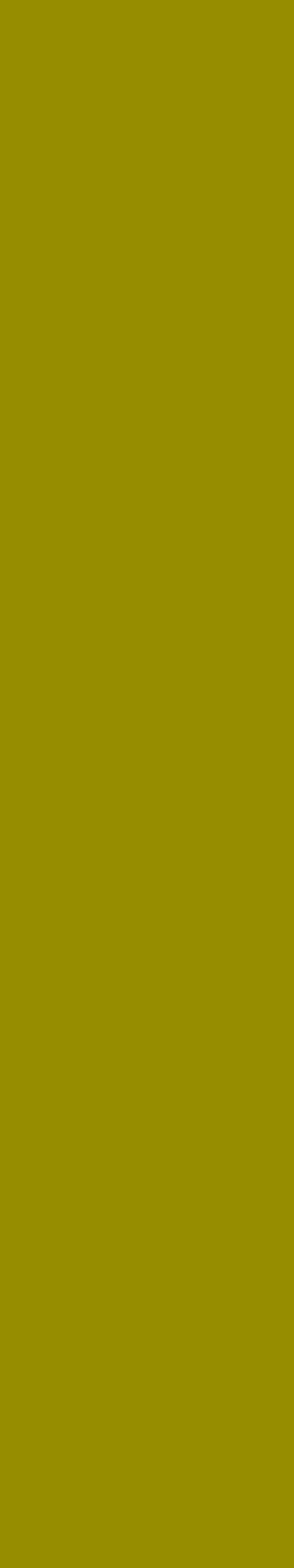

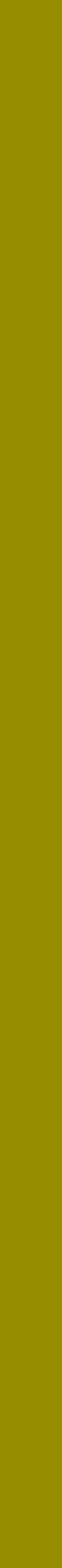

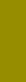




\section{A EVOLUÇÃo RECENTE DO SETOR BANCÁRIO NO BRASIL}





\section{PATRÍCIA OLGA CAMARGO}

\section{A evolução Recente DO SETOR BANCÁRIO NO BRASIL}


(C) 2009 Editora UNESP

\section{Cultura Acadêmica}

Praça da Sé, 108

01001-900 - São Paulo - SP

Tel.: (0xx11) 3242-7171

Fax: (0xx11) 3242-7172

www.editoraunesp.com.br

feu@editora.unesp.br

CIP - Brasil. Catalogação na fonte

Sindicato Nacional dos Editores de Livros, RJ

C181e

Camargo, Patricia Olga

A evolução recente do setor bancário no Brasil / Patrícia Olga Camargo.

- São Paulo : Cultura Acadêmica, 2009.

Anexos

Inclui bibliografia

ISBN 978-85-7983-039-6

1. Bancos - Brasil. 2. Instituições financeiras - Brasil - Administração.

3. Desenvolvimento organizacional. I. Título.

09-6245.

CDD: 332.10981

CDU: 336.71(81)

Este livro é publicado pelo Programa de Publicações Digitais da Pró-Reitoria de Pós-Graduação da Universidade Estadual Paulista "Júlio de Mesquita Filho" (UNESP)

Editora afiliada:

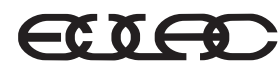

Asociación de Editoriales Universitarias de América Latina y el Caribe

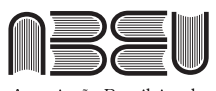

Associação Brasileira de Editoras Universitárias 


\section{SUMÁRIO}

Introdução 7

1 Evolução do sistema financeiro internacional eas especificidades do Brasil 11

2 A nálise de dados e resultados obtidos 75

Conclusão 123

R eferências bibliográficas 127

A nexos: A nálise individual dos mai ores bancos 141 



\section{INTRODUÇÃO}

N a década de 1990, ocorreram importantes mudanças na estrutura e nos padrões de concorrência do sistema bancário brasileiro. Seguindo a tendência mundial de liberalização em vários mercados, - Brasil iniciou um processo de abertura comercial efinanceira. A pós o processo de reestruturação bancária promovido pelo governo, os bancos estrangeiros ampliaram em muito sua participação no mercado bancário do país. H ouve uma intensificação no processo de fusões e aquisições, tanto por instituições estrangei ras como por instituições nacionais, o que aumentou consideravelmente a concentração bancária.

Q uando da abertura do mercado aos bancos estrangei ros, al gumas das expectativas eram de que haveria um acirramento da concorrência, com consequente redução do spread, uma maior qualidade e diversificação dos produtos e serviços financeiros, modernização tecnológica eum aumento na eficiência do sistema, principalmente pelo aumento da concessão de crédito. Entretanto, contrariando estas expectativas, os bancos estrangeiros adotaram uma postura conservadora, direcionada, principalmente, para os títulos públicos. D essa forma, apesar de terem ampliado sua atuação no mercado brasileiro, não provocaram mudanças significativas no sistema financeiro do país. Portanto, grande parte das mudanças ocorridas no setor, nesse 
período, provavel mente teria acontecido sem a entrada das instituições estrangeiras.

A situação do sistema bancário brasileiro após a abertura do mercado aos bancos estrangeiros, pelo lado dos ativos, foi de concentração das aplicações em aquisições de títulos públicos, com relativamente pouco apoio ao setor privado. D o lado dos passivos, o estímulo foi pela captação de recursos, principalmente junto ao grupo derenda média ealta. A ssim, os bancos dedicaram proporções semelhantes dos seus ativos a operações de crédito e títulos, principalmente títulos públicos. O s bancos públicos foram exceções, já que dedicam proporção maior de recursos a operações de crédito. Consequentemente, apesar da importância do setor bancário na economia, o coeficientecrédito/ PIB manteve-sebaixo, secomparado com outros países (C arvalho, 2005a).

Estetrabal ho buscará verificar seessas características do sistema bancário brasileiro se mantêm, analisando as atuais estratégias dos bancos brasileiros, comparando-as conforme o tipo de controle, se público, privado nacional ou privado estrangeiro. É objetivo deste trabal ho verificar as diferenças e semel hanças entre as instituições selecionadas eentreesses tipos de controle. A lém disso, pretende-se analisar as diferenças entre a atuação dos bancos estrangeiros no B rasil eno exterior, com o objetivo de verificar se estes últimos adotaram estratégias diferentes deatuação em local izações diversas. Para atendimento desses objetivos, será analisado o período de 1998, após a entrada dos bancos estrangeiros, até o primeiro semestre de 2008.

Para desenvolvimento destetrabal ho, foram sel ecionadas as oito maiores instituições, por val or deativos totais, exceto intermediações, conforme apresentado na Tabela 1.1.

D as instituições sel ecionadas, duas são bancos públicos federais (Banco do Brasil eC aixa E conômica F ederal), três são bancos privados nacionais (I taú, Bradesco eU nibanco) etrês são bancos privados com controle estrangeiro (A BN -A mro, Santander e H SBC). Para desenvolvimento destetrabalho, o U nibanco será considerado banco privado nacional, uma vez que, apesar de contar com participação estrangeira, esta é minoritária; portanto, seu controle énacional. 
T abela 1.1 - M aiores instituições por ativo total (exceto intermediações) em junho/ 2008 (em R \$ bilhões)

\begin{tabular}{|c|c|c|c|c|}
\hline R anking & Instituição & Controle & $\begin{array}{l}\text { A tivo T otal (-) } \\
\text { Intermediação }\end{array}$ & $\begin{array}{c}\text { Part. no A tivo } \\
\text { T otal (\%) }\end{array}$ \\
\hline 1 & $\begin{array}{c}\text { Banco do } \\
\text { Brasil }\end{array}$ & Público Federal & 361,0 & 15,8 \\
\hline 2 & Itaú & Privado $\mathrm{N}$ acional & 307,3 & 13,5 \\
\hline 3 & Bradesco & Privado $\mathrm{N}$ acional & 295,9 & 13,0 \\
\hline 4 & CEF & Público Federal & 250,6 & 11,0 \\
\hline 5 & $A B N$ & $\begin{array}{l}\text { Privado com } \\
\text { C ontrole } \\
\text { Estrangeiro }\end{array}$ & 158,5 & 6,9 \\
\hline 6 & U nibanco & $\begin{array}{l}\text { Privado com } \\
\text { Participação } \\
\text { Estrangeira }\end{array}$ & 143,4 & 6,3 \\
\hline 7 & Santander & $\begin{array}{c}\text { Privado com } \\
\text { Controle } \\
\text { Estrangeiro }\end{array}$ & 114,5 & 5,0 \\
\hline 8 & HSBC & $\begin{array}{l}\text { Privado com } \\
\text { C ontrole } \\
\text { Estrangeiro }\end{array}$ & 96,5 & 4,2 \\
\hline TOTAL & $\begin{array}{c}101 \\
\text { instituições }\end{array}$ & - & $2.281,7$ & 75,7 \\
\hline
\end{tabular}

Fonte: Elaboração própria a partir de dados extraídos do site do Banco C entral do Brasil.

A amostraérepresentativa, uma vez queas instituições selecionadas possuem 75,7\% do total de ativos detidos pelas 101 instituições existentes, classificadas pelo Banco Central como Consolidado Bancário I. ${ }^{1}$ A lém disso, são grandes bancos varejistas, que se destacam por seu tamanho, em termos de ativos, crédito, depósitos, redes de agências e quantidade de clientes.

Este trabalho foi organizado da seguinte maneira. 0 primeiro item do capítulo 1 trata do processo de consolidação bancária, que se iniciou na década de 1970, em vários países. N o segundo e ter-

1 Conglomerados em cuja composição se verifica pel o menos uma instituição do tipo Banco Comercial ou Banco M últiplo com Carteira Comercial, e as instituições financeiras do tipo Banco Comercial, Banco M últiplo com C arteira Comercial ou $\mathrm{C}$ aixa $\mathrm{E}$ conômica que não integrem conglomerado. 
ceiro itens foi desenvolvida uma breve discussão sobre eficiência e concorrência bancária. N o quarto item, foi traçada a evolução do sistema financeiro brasileiro. 0 quinto item faz uma análise da reestruturação bancária ocorrida no Brasil na década de 1990, destacando suas principais causas, características e consequências. N o sexto item, buscou-se caracterizar o sistema financei ro do país após a entrada dos bancos estrangeiros. N o sétimo item, é desenvolvida uma caracterização atual do sistema financeiro nacional, abordando aspectos de sua estrutura e regulamentação. No capítulo 2, foram destacadas as características etendências recentes do setor bancário, a partir daanáliseindividual das oito instituições. Por fim, os A nexos demonstram os resultados obtidos com as análises individuais dos bancos selecionados. 


\section{1 \\ EVOLUÇÃO DO SISTEMA FINANCEIRO INTERNACIONAL E AS ESPECIFICIDADES DO BRASIL}

\section{O processo de internacionalização, desregulamentação e liberalização bancária iniciado nos anos 1970}

A téos anos 1970, o setor financeiro era extremamenteregulado em todas as economias demercado. Essesistemaderegulação esupervisão, implantado nos anos 1930, após, portanto, vários dos efeitos da crise de1929, visava prevenir a ocorrência de crises sistêmicas, diminuindo, assim, o risco de colapso dos sistemas de pagamentos baseados no uso de depósitos à vista. A pesar de al guns episódios de instabilidade, a existência de tal aparato de supervisão financeira garantiu a aderência a essas regras, bem como a estabilidade do sistema financeiro por, no mínimo, cinco décadas. Entretanto, essemesmo aparato foi responsável por manter os sistemas financeiros essencialmenteestagnados. $\mathrm{N} 0$ caso do setor bancário, sujeito a regulação e supervisão mais rígidas devido ao temor deriscos sistêmicos, foram atenuados os incentivos às inovações financei ras eà concorrência- via preços ou via outro instrumento queaumentassea contestabilidade dos mercados bancários, estimulando a adoção decomportamentos inovadores (C arvalho, 2007).

A partir da década de 70 , iniciou-se, em vários países do mundo, um processo de liberalização e desregulamentação do setor de 
serviços financeiros. G radual mente, foram sendo eliminadas as restrições sobre operações financeiras, estabelecidas após a crise de 1929 e durante o regime de Bretton W oods. A presença do Estado é diminuída e surgem inovações tecnológicas e financeiras, como a securitização, os derivativos e as operações fora do balanço. E ssas mudanças al teram a forma de atuação desse setor, principiando um acentuado processo deconsolidação do setor deserviços financeiros, por meio de fusões e aquisições - envolvendo empresas bancárias de um mesmo país e também de países diferentes (T abela 1.2). E m um primeiro momento, observam-se grupos financeiros maiores incorporando instituições de menor porte, especialmente aquelas atuantes no mesmo mercado (local e setorial). Entretanto, a partir da segunda metade dos anos 90, o processo de fusões e aquisições começou a acontecer entre grandes instituições, envolvendo volume significativo de recursos.

Iniciou-se, dessa forma, um processo de concentração bancária em vários países, o que impôs desafios para as instituições reguladoras, como, por exemplo, o de proteger os pequenos demandantes de serviços financeiros. M uitos países, no entanto, não foram capazes de fornecer as condições necessárias para o pleno aproveitamento dos ganhos originados de economias de escala, escopo efinanceiras, resultantes dos menores custos de captação de recursos. C omo consequência, inicia-seum processo deinternacional ização das instituições bancárias e de desnacional ização de sistemas financeiros nacionais, principalmente no caso de países em desenvolvimento.

0 processo deinternacionalização das instituições financei ras de cada país também é considerado, tradicionalmente, como acompanhando a transnacional ização das empresas do setor produtivo desses mesmos países ea expansão do comércio internacional, intensificadas a partir de 1980. Esses processos levaram a uma expansão da demanda por serviços financeiros na esfera internacional (Strachman eVasconcelos, 2001).

Primeiramente, as instituições financeiras ofereciam serviços financeiros aos residentes de outros países, no seu próprio país de origem, por meio de uma moderna tecnologia de comunicações. Em 


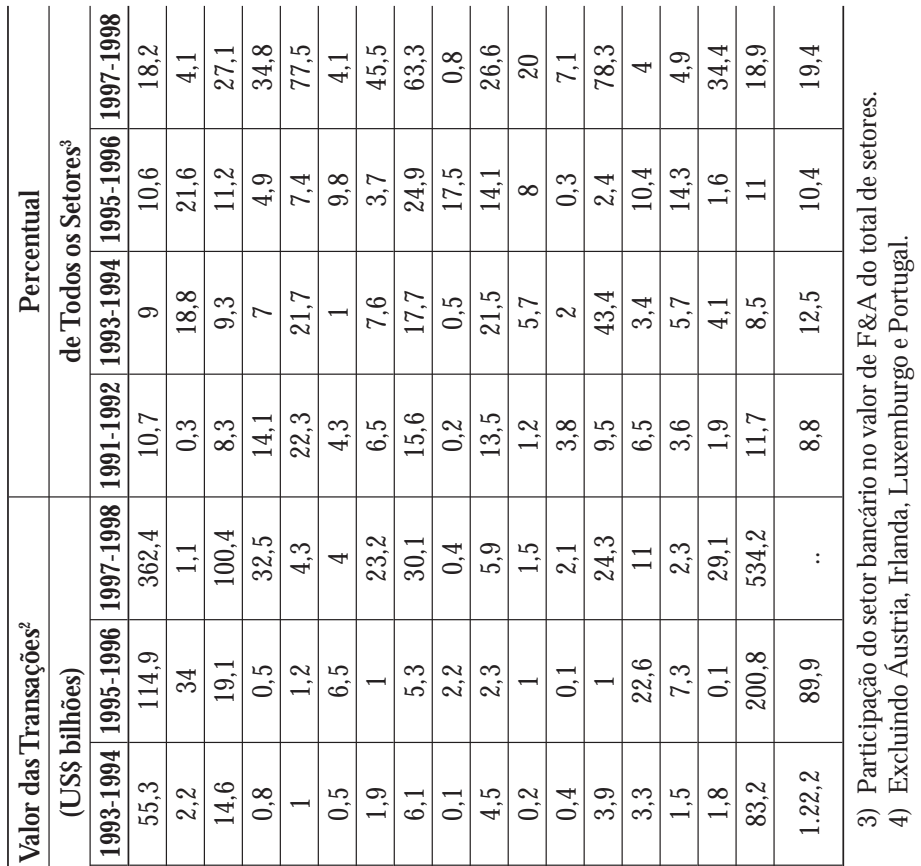

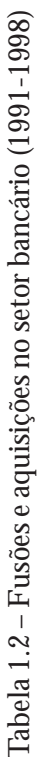

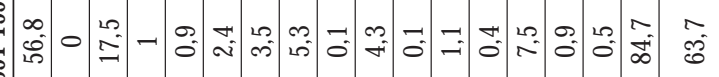
官

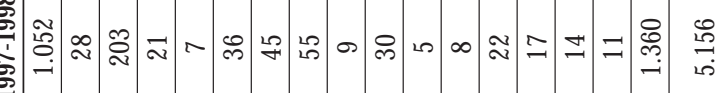

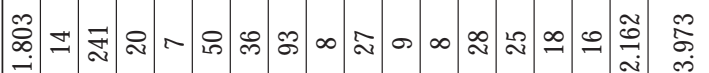

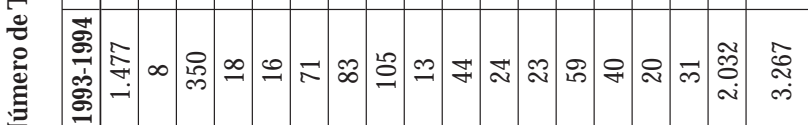

2

ริ

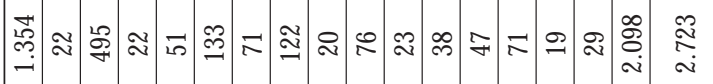

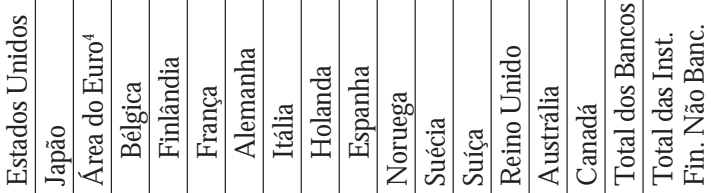

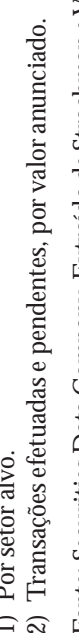


um segundo momento, passou a ser vantajoso o estabel ecimento de contato direto com os clientes, criando-se incentivos para que os bancos estabelecessem filiais, ao menos nas praças com maior concentração de clientes.

A lém disso, havia uma pressão das instituições financeiras multilaterais e de algumas instituições governamentais para que os governos nacionais aceitassem a presença de bancos estrangeiros. 0 argumento era que a entrada de bancos estrangeiros poderia aumentar a eficiência operacional do sistema financeiro doméstico e torná-lo mais sólido, podendo contribuir, adicionalmente, para tornar o mercado financeiro doméstico mais estável e para a estabilidade do balanço de pagamentos. Essa estabilidade seria resultado da possibilidade deos bancos contarem com ajuda financeira de seus países deorigem em momentos de dificul dade causada pela contração da liquidez internacional, auxiliando, dessa forma, os países onde essas filiais estivessem instaladas. A lém disso, haveria um acirramento da concorrência que traria benefícios aos clientes ( $C$ arval ho, 2002).

A s crises de bal anço de pagamentos dos países emergentes, no final dos anos 90, forneceram argumentos para queo $\mathrm{F} \mathrm{M} \mathrm{I} \mathrm{aumentasse}$ a pressão sobre os governos nacionais, a fim de que estes aceitassem a presença dos bancos estrangeiros. A reestruturação e a modernização dos sistemas bancários domésticos passaram a ser vistas como necessárias, e estas passavam pela abertura de mercados aos bancos estrangeiros.

A maioria dos países emergentes, principal mente da A mérica L atina e da E uropa, aceitou essa visão e, durante a década de 90 , as limitações legais eregulatórias foram sendo gradativamenterelaxadas ou eliminadas. D essa forma, alguns bancos conseguiram expandir suas atuações, atingindo novos tipos de clientes e aumentando sua escala de operações, por meio do aumento da participação de mercado em outros países. É importantesal ientar que, devido à crisefinanceira mexicana eà entrada de bancos estrangei ros na região, o processo de consolidação bancária foi mais intenso nos países da A mérica $L$ atina do que em outros países emergentes (C arvalho, 2002). 
Strachman eVasconcel os (2001) apontam algumas razões que podem levar os países, principalmente os mais atrasados, a permitir e incentivar a entrada de bancos estrangeiros no mercado nacional. Primeiramente, os bancos estrangeiros ampliariam a diversidade e qualidade dos produtos financeiros disponíveis no mercado, desenvolvendo habilidades e tecnologias para o sistema financeiro, já que os bancos nacionais seriam incentivados pela concorrência a se aprimorar. A lém disso, os bancos estrangeiros incentivariam a adoção, pelas autoridades governamentais, deum sistema deregulação e supervisão bancária mais sofisticado. A presença dos bancos estrangeiros tenderia, ainda, a ampliar o acesso do país aos fluxos de capital internacionais, podendo tornar a oferta de crédito menos sensível às oscilações dos ciclos macroeconômicos domésticos. Consequentemente, os empréstimos bancários adicionais disponíveis poderiam amenizar a contração de crédito ocorrida nas fases de depressão. P or último, um setor financeiro mais dinâmico e eficiente contribuiria para o crescimento econômico.

Contudo, estes mesmos autores (Strachman eVasconcel os, 2001) sublinham algumas potenciais desvantagens dessa mesma entrada de bancos estrangeiros, sobretudo nos países menos adiantados economicamente. $L$ iberalizações financeiras aceleradas poderiam estimular movimentos disruptivos nos mercados financeiros. $\mathrm{U} \mathrm{m}$ indício dessa possibilidade é o fato de que várias crises financeiras e bancárias, ocorridas durante a década de 90 , foram precedidas de liberação financeira. A lém disso, em países menos desenvolvidos, existe a possibilidade de que a entrada de instituições estrangeiras provoque concentração e desnacional ização bancárias, como ocorreu em países como A rgentina, ChileeM éxico. D essa forma, devem ser considerados, por exemplo, os impactos negativos da concentração bancária sobre os pequenos investidores etomadores decrédito, bem como da desnacionalização bancária sobre os balanços de serviços e de capitais.

Strachman eVasconcelos (2001) mencionam, ainda, queas instituições financeiras queatuam em diferentes países simultaneamente concentram-seem atender, principalmente, os grandesclientes. U ma 
das consequências desse comportamento éa possibilidade de redução dos canais de crédito para pequenas empresas. 0 utra questão que deve ser considerada é o impacto sobre o canal de transmissão da política monetária, uma vez que as instituições estrangeiras teriam maior acesso ao mercado de crédito internacional. O s autores também apontam para o fato de que o ingresso de instituições bancárias estrangei ras podetornar os países em desenvolvimento mais frágeis diante de choques externos, já que os canais para fuga de capitais são mais amplos.

Com relação aosfatores de repul são queimpul sionaram a internacionalização bancária, R ocha (2002) destaca a saturação dos mercados dos países desenvolvidos; a mudança ocorrida na estrutura bancária internacional, que passou a exigir atuação global dos grandes bancos e amplos canais de distribuição; e a busca de diversificação deaplicações, por meio da diminuição dos riscos e da ampliação das fontes - inclusive geográficas - de retorno sobre os ativos bancários. A diversificação permitiria, ainda, economias decusto, por meio dos ganhos de eficiência operacional, com melhor aproveitamento das economias de escopo e de escala. A explicação de que os bancos se internacional izam para preservar os clientes domésticos, ofertando, no exterior, os mesmos serviços bancários disponíveis no país de origem (follow the customer), é a mais citada pela literatura; entretanto, o autor considera que a expectativa de obtenção de maiores taxas de retorno no exterior é o fator básico de expansão dos bancos estrangeiros para fora dos seus países de origem.

R ocha (2002) cita ainda, como outro fator de repulsão, a regulamentação doméstica sobre o setor, dado que controles sobre as atividades empresariais e critérios prudenciais muito rígidos incentivariam a criação de subsidiárias em outros países, além de tornar o mercado doméstico menos atraente para os bancos estrangeiros. A tualmente, entretanto, analisando o ocorrido na Europa, esse motivo pode funcionar de forma contrária, uma vez que o excesso de competição causado pela desregulamentação pode diminuir a lucratividade dos bancos. 0 autor também cita a arbitragem entre diferentes taxas dejuros entre os países de origem e de destino como 
um fator de internacionalização bancária, uma vez que possibilita um maior resultado da intermediação financeira. 0 utras causas que podem ser apontadas são a reação de um banco à expansão internacional de um concorrente e a reação defensiva, relacionada com a manutenção do poder de mercado.

Portanto, a decisão de internacionalização depende de vários fatores, tornando-senecessário anal isar cada caso específico. N o caso brasileiro, todos os eventos recentes de ingresso de bancos estrangeiros envolveram bancos de origem europeia e o principal fator de expansão foi a perspectiva deconcorrência estrangeira nos mercados domésticos, já maduros e saturados.

Cabesalientar, entretanto, que os processos de consolidação dos países desenvolvidos (E stados U nidos, U nião E uropeia e J apão) e dos países em desenvolvimento (Á sia, A mérica $L$ atina e E uropa O riental) são distintos. N os primeiros, a consolidação bancária teve como objetivo principal o aumento da eficiência ou do poder de mercado, enquanto nos segundos representou, sobretudo, uma maneira de resolver crises financeiras. A ssim, nos países desenvolvidos, observa-se que a consolidação resultou em economias de escala, de escopo e de rendas e em um melhor posicionamento dos bancos nacionais no mercado doméstico ( $D$ e Paula e $M$ arques, 2006).

A lém disso, nos países em desenvolvimento as fusões eaquisições se deram, principalmente, entrefronteiras, ou seja, entreinstituições dediferentes países, o quenão ocorreu nos países desenvolvidos. Essa distinção se deve, em parte, ao fato deque, nos países desenvolvidos, a consolidação bancária representou uma resposta à desregulamentação e à maior competição nos mercados internos. N os mercados em desenvolvimento, por sua vez, foram frequentes os processos de fusão eaquisição com instituições estrangeiras, pois esse processo era entendido como um meio de estimular os canais deentrada de fluxos decapitais, fortalecendo o mercado financei ro doméstico. Por último, na maioria dos países em desenvol vimento a consolidação foi dirigida pelo governo, ao passo que em mercados maduros a consolidação foi dirigida, sobretudo, pelo mercado. 
F reitas e Prates (2003) destacam, ainda, que a pressão para a liberalização dos sistemas financeiros domésticos e para adesão ao princípio da livre mobilidade dos capitais teve origem distinta nos países desenvolvidos e em desenvolvimento. N os países desenvolvidos, essa pressão partiu da dinâmica concorrencial das instituições financeiras (como nos Estados U nidos) e/ ou da ação favorável dos governos (como no caso da F rança e do J apão). N o caso dos países em desenvolvimento, a pressão partiu dos organismos multilaterais, como o F undo M onetário I nternacional e o Banco M undial.

$\mathrm{N}$ o entanto, mesmo entreos países em desenvolvimento, existem distinções. N a Á sia, as consolidações se iniciaram após as crises financeiras de 1997-98, tendo sido comandadas pelo governo, com exceção de H ong K ong e C ingapura, que não foram tão afetados pela crise, passando por um tipo de consolidação mista. 0 processo também não gerou aumento na concentração bancária (pelo contrário), embora o número deinstituições bancárias tenha diminuído nos principais países emergentes da Á sia (D e Paula e M arques, 2006).

$\mathrm{N}$ a A mérica $L$ atina, por sua vez, o processo de consolidação foi mais avançado, devido à ocorrência de crises financeiras eà entrada de bancos estrangeiros. D essa forma, após a crise de 1994-95, os governos de países como A rgentina, Brasil, Chile e M éxico participaram ativamente no processo de consolidação bancária. E ntretanto, no final da década de 1990, esse processo passou a ser dirigido, principalmente, pelas forças de mercado. A o contrário do ocorrido nos demais países em desenvolvimento, a redução no número de instituições nos países da A mérica L atina foi acompanhada, em geral, de uma acentuada concentração bancária.

A s consequências desse intenso processo de concentração, que vem sendo observado em nível mundial, são variadas. Primeiramente, observa-se a compressão das margens (spreads), a maior volatilidade das taxas de juros e o aumento da liberdade de atuação em novos mercados. A redução dos spreads, entretanto, não ocorreu nos países em desenvolvimento, ou porque a liberalização do setor não foi tão intensa como nos países desenvolvidos ou porque essa liberalização não foi acompanhada de medidas que incentivassem 
a concorrência no setor e a contestabilidade no mercado doméstico (Strachman eVasconcelos, 2001).

A delino e D e Paula (2006) apontam para a queda no número de instituições bancárias, para o aumento da concentração bancária na maioria dos países (T abela 1.3) e para a queda no número de trabaIhadores no setor, principalmente devido aos avanços tecnológicos eao processo defusões eaquisições. Verifica-se, ainda, um aumento na participação das receitas não juros no total das receitas bancáriase uma queda nas margens líquidas dejuros das instituições financeiras, devido ao aumento da concorrência.

T abela 1.3 - Concentração bancária em países selecionados

\begin{tabular}{|c|c|c|c|c|c|c|c|}
\hline & \multicolumn{3}{|c|}{ Número de Instituições ${ }^{1}$} & \multirow{2}{*}{$\begin{array}{c}\begin{array}{c}\text { Taxa de } \\
\text { Variação } \\
\text { (\%) }\end{array} \\
1980-97\end{array}$} & \multicolumn{3}{|c|}{$\begin{array}{l}\text { Participação das } 5 \text { (10) } \\
\text { M aiores Instituições no } \\
\text { Total de A tivos (\%) }\end{array}$} \\
\hline & 1980 & 1990 & 1997 & & 1980 & 1990 & 1997 \\
\hline EUA & 36.103 & 27.897 & 22.140 & $-20,6$ & $9(14)$ & $9(15)$ & $17(26)$ \\
\hline J apão & 547 & 605 & 575 & $-5,0$ & $25(40)$ & $30(49)$ & $31(51)$ \\
\hline Á rea do Euro & 9.445 & 8.979 & 7.040 & $-21,6$ & & & \\
\hline Á ustria & 1.595 & 1.210 & 995 & $-17,8$ & $40(63)$ & $35(54)$ & $44(57)$ \\
\hline Bélgica & 176 & 157 & 136 & $-13,4$ & $53(69)$ & $48(65)$ & $57(74)$ \\
\hline Finlândia & 631 & 498 & 341 & $-31,5$ & $63(68)$ & $65(69)$ & $77(80)$ \\
\hline França & 1.033 & 786 & 567 & $-27,9$ & $56(69)$ & $52(66)$ & $57(73)$ \\
\hline A lemanha & 5.355 & 4.721 & 3.577 & $-24,2$ & & & $17(28)$ \\
\hline Itália & 1.071 & 1.067 & 909 & $-14,8$ & $26(42)$ & $24(39)$ & $25(38)$ \\
\hline Holanda & 200 & 180 & 169 & $-6,1$ & $69(81)$ & $73(84)$ & $79(88)$ \\
\hline Portugal & 17 & 33 & 39 & 18,2 & & & \\
\hline Espanha & 357 & 327 & 307 & $-6,1$ & $38(58)$ & $38(58)$ & $47(62)$ \\
\hline N oruega & 346 & 165 & 154 & $-6,7$ & $63(74)$ & $68(79)$ & $59(71)$ \\
\hline Suécia & 598 & 498 & 124 & $-75,1$ & $64(71)$ & $70(82)$ & $90(93)$ \\
\hline Suíça & 478 & 499 & 394 & $-21,0$ & $45(56)$ & $45(57)$ & $49(62)$ \\
\hline R eino U nido & 796 & 665 & 537 & $-19,2$ & & $49(66)$ & $47(68)$ \\
\hline A ustrália & 812 & 481 & 344 & $-28,5$ & $62(80)$ & $65(79)$ & $69(81)$ \\
\hline Canadá & 1.671 & 1.307 & 942 & $-27,9$ & & $55(78)$ & $78(93)$ \\
\hline
\end{tabular}

1) Instituições receptoras de depósitos, geralmente incluindo bancos comerciais, bancos de poupança e vários tipos de bancos mútuos e cooperativos.

Fonte: BIS (1999). 
Strachman eVasconcelos (2001) também destacam o aumento da concentração bancária, que, segundo al guns estudos, seria prejudicial aos pequenos clientes, já que os custos dos empréstimos para estes são maiores e as taxas pagas sobre as aplicações são menores. Se o mercado de capitais não for de fácil acesso aos pequenos agentes econômicos, se não houver canais alternativos de obtenção de crédito e se a redução do custo de capital para as grandes empresas não compensar a perda observada no caso das pequenas empresas, a concentração bancária poderia, prejudicar o crescimento econômico de um país. 0 s autores apontam, ainda, para a ampliação da tendência de aumento do poder de mercado das instituições financeiras e, portanto, da capacidade para determinar os valores de seus serviços.

Por outro lado, dada a possibilidade de economias deescala e de escopo nesse mercado, o aumento do tamanho dos bancos podelevar a ganhos de eficiência com consequente redução de custos operacionais. Essa redução, por sua vez, pode causar diminuição dos spreads bancários e melhoria nas condições de crédito e na remuneração de depósitos para os clientes. C aso os custos caiam significativamente, mesmo um aumento de spreads pode implicar diminuição dos juros finais pagos pelo cliente.

O utra possível consequência da concentração bancária é a redução dos riscos esperados nas operações financeiras, que também poderá levar a redução de custos, por meio da ampliação da diversificação setorial, geográfica e de produtos das instituições financeiras.

Portanto, para avaliar os resultados da concentração bancário- financeira, é preciso considerar dois fatores: primeiramente, se houve aumento de eficiência das novas instituições consolidadas; segundo, se esses ganhos de eficiência tendem a ser repassados, pela redução de preços ou de oferta de novos serviços, aos clientes potenciais. Para que essa segunda condição se verifique, énecessário que a concorrência no setor se intensifique, tanto em relação ao mercado de varejo quanto em relação ao mercado de atacado.

$\mathrm{N}$ o entanto, grande partedaliteratura corrente defende que, nos países desenvolvidos, os bancos estrangeiros são menos eficientes 
que os bancos nacionais e que, nos países em desenvolvimento, ocorre o contrário. A maior eficiência dos bancos estrangeiros nos países em desenvolvimento seria resultado, principalmente, do fato de operarem, originalmente, em ambientes mais competitivos, mais propícios à inovação emais sensíveis à eficiência operacional. Por esse motivo, tenderiam a adotar melhores métodos de gerenciamento, a desenvolver novos produtos e tecnologias e a influenciar a melhor preparação dos reguladores. A lém disso, o ambienteregulatório dos países desenvol vidosé, supostamente, mais rigoroso, com supervisão mais apertada, o que dá vantagens aos bancos provenientes desses países, pois sabem como atuar com requisitos mais estritos de desempenho (C arvalho, 2002).

N os países em queo sistema bancário possuía instituições basicamente voltadas para o mercado interno, de porte pequeno ou médio, e menos eficientes em relação aos padrões internacionais, a desregulamentação bancária e a liberalização resultaram em concentração e em desnacionalização bancárias. Esse tipo de processo ocorreu, na década de 90, em países como A rgentina, C hile e M éxico.

$\mathrm{N}$ o caso do Brasil, entretanto, grande parte dos estudos concluiu quea entrada de bancos estrangei ros não trouxenenhuma melhoria em termos de eficiência e de características operacionais. A demais, os avanços tecnológicos foram introduzidos mais intensamente por bancos nacionais do que por bancos estrangeiros. A s estruturas dos bal anços contábeis nos dois casos são muito semel hantes, sendo caracterizadas por uma maior importância das operações de curto prazo, das aplicações em títulos e dos investimentos em securitização (C arvalho, 2002). N os próximositens, o caso brasileiro será anal isado com mais detalhes.

\section{Eficiência bancária}

Carvalho (2004) aponta para a existência de um paradoxo no Sistema Financeiro B rasileiro em relação aos demais países em desenvolvimento, especialmente da A mérica $L$ atina. Por um lado, 
as instituições financeiras brasilei ras são extremamente sólidas e competitivas. D e fato, os bancos estrangeiros que se instalaram no país na década de 1990, em geral, não foram capazes de conquistar espaços significativos no mercado doméstico. Por outro lado, a funcionalidade do SF B é muito baixa, especialmente em termos macroeconômicos. A relação crédito privado/ PIB, por exemplo, continua muito abaixo da média internacional.

H á uma percepção general izada de queas instituições financei ras do país são incapazes deal ocar eficientementerecursos para investimentos produtivos, direcionando-os, preferencialmente, paratítulos públicos e para operações interfinanceiras. A demais, as linhas de crédito direcionadas para consumidores e investidores privados são extremamentecaras e escassas, principalmenteas delongo prazo. A preferência pelosempréstimos de curto prazo podeser explicada pela captação de recursos, feita, principalmente, pela emissão depassivos decurto prazo, como depósitosà vista ou a prazo. A utilização desses recursos no financiamento delongo prazo provocaria o descasamento de prazos nos balanços dos bancos, aumentando a vulnerabilidade dessas instituições perantequal quer choque dejuros. Essa preferência pel o curto prazo também é resultado da incerteza provocada pela longa convivência com a al ta inflação (Carvalho, 2004).

Entretanto, do ponto de vista microeconômico, as instituições financeiras queoperam no país não podem ser consideradas ineficientes, uma vez que uma instituição é considerada eficiente se é capaz de maximizar seus lucros com o menor risco possível, aproveitando as oportunidades de ganho que o mercado oferece. $\mathrm{N}$ a segunda metade da década de 1990, as mel hores oportunidades de ganho foram oferecidas pelo governo federal, ao colocar quantidades crescentes de títulos públicos com alta rentabilidade eliquidez, além de baixo risco. Portanto, do ponto de vista microeconômico, as instituições brasileiras podem ser consideradas eficientes.

Por outro lado, uma instituição pode ser considerada eficiente, porém disfuncional, se não contribui para o al cance de certos objetivos definidos como desejáveis pela sociedade. $\mathrm{N}$ o caso específico do Brasil, o mercado de capitais tem uma participação restrita no 
financiamento privado, e o crédito bancário desempenha um papel fundamental na viabilização de projetos de investimento eno apoio ao crescimento econômico. N essesentido, o sistema financeiro brasileiro écomumente considerado disfuncional ou de baixa eficiência macroeconômica. Essa disfuncionalidade, entretanto, é resultado mais da combinação perversa de incentivos existente, tanto do lado do ativo quanto do passivo, do que de al guma ineficiência intrínseca. Pelo lado do ativo, os bancos são estimulados a concentrar suas aplicações na aquisição de títulos públicos, ao passo que, pelo lado do passivo, o estímulo épara a captação de recursos junto aos grupos de renda média e alta (C arvalho, 2005a).

Carval ho (2004) argumenta que as características do setor que causam essa disfuncionalidade, impedindo o alcance da eficiência macroeconômica, são: a) a atuação dos bancos como intermediários financeiros, sendo que os mercados de títulos têm papel quase irrelevante no financiamento à atividade privada; b) 0 al to grau deconcentração existenteno setor bancário; c) a estrutura do setor bancário, queincentiva a emergência deuma forma decompetição oligopólica, naqual os bancos líderes fixam os preços básicos deserviços financeiros ecompetem entresi por meio da diferenciação deserviços, mais do que por preços; d) a atuação dos bancos não líderes em nichos não atraentes para os bancos líderes, devido às poucas condições para que esses primeiros exerçam pressões competitivas mais efetivas sobreos segundos nos mercados mais atraentes; ee) a situação permanente de instabilidadeeconômica e de déficits fiscais, que levou sucessivos governos a oferecer grandevolume detítul os públicos, em condições extremamente favoráveis de retorno eliquidez.

A tese de que as instituições financeiras brasileiras seriam ineficientes em relação às instituições estrangeiras foi utilizada como principal justificativa à proposta de abertura do setor aos bancos estrangeiros. Entretanto, como visto nos itens anteriores, as instituições financeiras que entraram no Brasil, a partir de 1995, adotaram padrões de comportamento si milares e até inferiores aos padrões das instituições nacionais. Esses bancos se adaptaram às condições de operação do mercado brasileiro, não representando uma ameaça 
competitiva aos líderes estabel ecidos. Também contrariando as expectativas, o custo do capital, que é determinado, entre outros fatores, pela taxa básica de juros, a taxa Selic, e pelo spread fixado pelos bancos, manteve- se excessivamente el evado.

\section{Concorrência bancária}

A maioria dos trabal hos sobre concorrência bancária utiliza conceitos de organização industrial, considerando o setor bancário como uma indústria e os bancos como firmas. Esses trabal hos, entretanto, não consideram as especificidades dos bancos, bem como a natureza dos serviços que produzem.

D entre essas especificidades, F reitas (1997) cita a instabilidade do setor bancário, que tem origem em sua própria atividade. A lém disso, não há limitações físicas - como custos tangíveis e limites de capacidade - para que ofereçam seu "produto" principal, moeda e crédito. Por isso, tendem, em momentos de expansão econômica, a conceder mais crédito do que seria prudente. A autora também relaciona a criação de novos instrumentos financeiros, já que os bancos não incorrem em grandes despesas no desenvolvimento de inovações. Como também não existe registro de patente, os demais concorrentes podem imitar o inovador rapidamente. D essa forma, os ganhos resultantes de inovações são temporários, apesar de contribuírem para a busca de novos produtos e serviços. Por último, a natureza dos lucros bancários também é diferente da dos lucros das empresas industriais, já que os bancos determinam as condições de liquidez da economia, regulando a taxa de juros. A ssim, como não existem limites naturais para a taxa de juros, os bancos podem dificultar ou facilitar o funcionamento do processo produtivo que demanda recursos financeiros.

Freitas (1997) busca contribuir para uma visão al ternativa, que considera o caráter dinâmico edesestabilizador dos bancos. A o mesmo tempo em queestão submetidos à lógica da valorização da riqueza, também ocupam papel central no processo de criação monetária 
na economia capital ista moderna, atuando, simultaneamente, como criadores de moeda e intermediários financeiros. C onsiderando essa posição diferenciada que os bancos ocupam no sistema monetário e de crédito, suas atividades devem ser estritamente reguladas.

Q uando a regulamentação bancária é mais rigorosa, as oportunidades de criação de vantagens competitivas pelos bancos são reduzidas, apesar de sempre existirem possibilidades de busca pela diferenciação. Por outro lado, a ausência de uma regulamentação eficaz podefazer com quea concorrência assuma formas destruidoras e ameace a estabilidade do sistema de crédito (F reitas, 1997).

Portanto, a atividade bancária é marcada por um permanente conflito entre os objetivos de estabilidade do sistema e busca pela valorização do capital. A ssim, a concorrência bancária se circunscreve, no geral, nos limites fixados pela regulamentação, quevariam conforme a estrutura institucional ejurídica existente em cada país. Porém, por meio da inovação, os bancos buscam escapar desses controles, criando uma tensão dinâmica entre o processo competitivo inovador e a necessidade de aperfeiçoamento contínuo da regulamentação (F reitas, 1997).

A concorrência no setor bancário pode ocorrer de várias formas. F reitas (1997) cita: construção de uma imagem de experiência, tradição e solidez; técnicas de marketing; qualidade de suas equipes operacionais; informações privilegiadas obtidas no relacionamento com seus clientes; desenvolvimento denovos instrumentos epráticas financeiras etc. A cooperação ou a formação de alianças também é uma estratégia concorrencial muito utilizada pel os bancos. Por meio dos correspondentes bancários, por exemplo, um banco podeampliar sua área de atuação, sem a necessidade de incorrer em custos para a abertura de novas agências.

H á vários trabalhos aplicad os que buscaram mensurar o grau de competição no sistema bancário brasileiro. G rande parte desses testes concluiu que a estrutura de mercado é imperfeita, com um grau razoável deconcorrência (R ocha, 2007). A ssim, os al tos spreads verificados poderiam ser explicados por al gumas especificidades do setor, sendo que as principais são informação assimétrica, fidelização 
declientes, custos detransferência (switching costs), rendas informacionais, risco moral e sel eção adversa (N akane, 2005).

A s assimetrias informacionais, devido à heterogeneidade dos clientes, criam nichos de atuação, que permitem que os bancos se protejam da concorrência e pratiquem políticas de preços distintas (Ferreira eFarina, 2005). Essa assimetria deinformações também eleva os custos detransferência para os clientes, criando efeitos lock-in ${ }^{1} \mathrm{e}$ possibilitando a obtenção de rendas informacionais ( $N$ akane, 2005).

A pesar de alguns avanços realizados no Brasil para minimizar esses efeitos, al guns entraves ainda permanecem, como a limitação da portabilidade de cadastro, as altas tarifas de encerramento de conta e outros fatores que ainda contribuem para aumentar o custo desaída ( $M$ artinez, 2008). D essa forma, medidas como portabilidade de informações, cadastro positivo e a criação da conta-salário são importantes para reduzir os ef eitos dos custos de transferência e de seleção adversa.

\section{Evolução do sistema financeiro brasileiro}

Esta seção buscará del inear a evolução do sistema financeiro brasileiro, desdeo período colonial atéas relevantesalterações ocorridas na década de 90.

D o período colonial até a criação do primeiro banco no Brasil, houve baixa entrada de capital estrangei ro e escassez monetária. $\mathrm{N}$ esse período, havia grande dificuldade de transformar a riqueza em moeda, devido à sua escassez, predominando o escambo. D essa forma, o sistema monetário brasileiro nesse período era composto, principalmente, de açúcar e escravos, em substituição à moeda metálica.

O período de 1808 até 1914 pode ser caracterizado como deabertura financeira e de grande endividamento externo, sendo marcado pela criação, em 12 deoutubro de 1808, do primeiro banco do país. 0

$1 \mathrm{D}$ evido aos altos custos em que incorrem os clientes para trocar de banco. 
Banco do Brasil foi viabilizado pela vinda de D. J oãoVI e da família real, que promoveram a abertura dos portos e acordos comerciais com a E uropa e as colônias. A s atividades do banco foram iniciadas em 1809; entretanto, a instituição foi fechada em 1829, devido ao prejuízo obtido com as exportações eà volta de D. J oão VI a Portugal, levando grande parte do lastro metálico depositado. 0 segundo Banco do Brasil foi criado em 1833, mas não conseguiu integralizar o capital para a sua instal ação.

Em 1836, foi criado o primeiro banco comercial privado, o Banco do Ceará, que encerrou suas atividades em 1839. Em 1851, foi fundado o terceiro Banco do Brasil, de controle privado, o qual, em 1853, uniu-se com o Banco C omercial do R io deJ aneiro, instituição criada em 1838. Essa fusão, a primeira do país, originou o quarto Banco do Brasil. ${ }^{2} \mathrm{Em} \mathrm{1863,} \mathrm{foram} \mathrm{instalados} \mathrm{no} \mathrm{país} \mathrm{os} \mathrm{primeiros}$ bancos estrangeiros: o L ondon \& Brazilian Bank e o T he Brazilian and Portuguese Bank, ambos sediados no R io deJ aneiro.

$N$ esse período, o sistema bancário ainda não estava plenamente constituído, contando com a presença de bancos isolados. Estavam ausentes no sistema bancário brasileiro uma rede de agências bancárias integradas, uma câmara de compensação que permitisse a expansão da emissão de cheques, bem como uma carteira de redesconto para amenizar as situações de crise deliquidez. D essaforma, a criação endógena de moeda bancária pelas forças de mercado estava prejudicada.

O s bancos estrangeiros eram predominantes, estando voltados principalmente para os empréstimos comerciais - com preferência pela manutenção de altos níveis de ativos de curto prazo - e para as operações cambiais - por meio do financiamento ao comércio exterior, da especulação cambial e da atuação desses bancos como agentes de empréstimos externos na emissão de dívida pública no mercado internacional. Esse posicionamento pode ser explicado

20 Banco do Brasil atual foi originado em 1906, resultado da fusão do Banco do Brasil de 1853 ao Banco da República do Brasil (D ecreto no 1.455, de 30/ 12/ 1905). 
pela maior lucratividade e segurança dos empréstimos comerciais e das operações cambiais, em relação às demais operações existentes na economia nesse período. Para o mercado interno ou para a agricultura, pouco capital era alocado, já que a rentabilidade era menor e o risco era muito maior. A s operações domésticas eram realizadas, principalmente, pelos bancos nacionais, públicos eprivados (R ocha, 2002). 0 encerramento dessa fase é caracterizado pel o fechamento da economia em âmbito internacional, devido à Primeira G uerra $M$ undial, e pela fuga das reservas em ouro.

A partir da década de 20 , inicia-seum processo denacionalização efortal ecimento do sistema bancário, que se estende até 1964. E sse período é caracterizado por uma queda nos empréstimos externos (exceto na década de 1920), por progressos importantes em relação ao desenvolvimento de mecanismos definanciamento interno epelo estabelecimento de um sistema bancário ef etivamente nacional. N o início desse período, havia uma relevante participação dos bancos estrangeiros, que eram responsáveis por cerca de $45 \%$ dos empréstimos e depósitos do sistema bancário, controlando, como vimos, 0 financiamento de curto prazo do comércio exterior e o mercado de câmbio. 0 crédito às atividades econômicas internas, entretanto, era relativamente baixo, dadas as condições favoráveis do crédito em nível internacional. No âmbito do processo de nacional ização do sistema bancário, a L ei Bancária de 1921 criou al nspetoria G eral dos Bancos e limitou as atividades dos bancos estrangeiros, cuja participação em depósitos e empréstimos decresceu ao longo do período 1920-1945, representando, em 1945, 7\% e 5\% respectivamente(C osta eD eD eos, 2002). N aquele mesmo ano foi aprovado o regulamento para a fiscal ização dos bancose das casas bancárias e, em 1934, foram criadas as $C$ aixas $E$ conômicas F ederais. A expansão da rede bancária doméstica e dos depósitos bancários, ocorrida no período, permitiu o retorno dos recursos emprestados ao sistema bancário.

A s C onstituições de 1934 e de 1937 determinaram a nacionalização dos bancos estrangeiros e proibiram a posse de bancos no B rasil por não residentes. A C onstituição de 1946, por sua vez, permitiu o livre acesso dos bancos estrangeiros ao sistema financeiro nacional, 
não fazendo distinção entre bancos nacionais e bancos estrangeiros. A participação estrangeira, entretanto, ficou muito reduzida até os anos 60. Efetivamente, no período 1946-60, apenas sete bancos estrangei ros ingressaram no país (C orazza, 2001).

Em 1945, foi criada a Superintendência da M oeda e do C rédito (Sumoc), que passou a ser responsável pelo controle do mercado monetário. A Sumoc recebeu do Banco do Brasil as atribuições da C arteira de R edesconto e da C arteira de M obilização eF iscalização Bancária.

Em 1952, foi criado o Banco $\mathrm{N}$ acional de D esenvolvimento E conômico (BNDE), instituição de fomento, com o objetivo de conceder financiamento de longo prazo aos empreendimentos que contribuíssem para o desenvolvimento do país. U ma vez que o sistema bancário privado não era capaz de prover crédito de longo prazo e não se possuía um mercado de capitais desenvolvido, a el evada expansão do setor urbano-industrial, a partir de meados da década de 50, foi possibilitada pelo setor financeiro estatal, incentivos fiscais, subsídios cambiais à importação de equipamentos, pelo setor externo - principalmente por meio de financiamento às importações - epelo autofinanciamento das empresas. A al ta inflação inibiu o desenvolvimento de um mercado financeiro de títulos de dívida de médio elongo prazo, ea ausência deadequação prévia dos esquemas de financiamento a termo contribuiu para reduzir a duração da expansão industrial intensiva em capital (Costa e D e D eos, 2002).

N o período de 1964 a 1979, hásignificativo crescimento econômico eexpansão do setor bancário brasileiro, podendo ser caracterizado, como um todo, por uma fase de abertura financeira e de facilidade de captações estrangeiras em âmbito internacional.

Em 1964, é promovida uma reforma financeira, na qual foram criados o Sistema F inanceiro da $\mathrm{H}$ abitação (SF H ); o Banco $\mathrm{N}$ acional de H abitação (BN H ); o C onsel ho $M$ onetário $\mathrm{N}$ acional (C M N ); e o Banco Central do Brasil em substituição à Sumoc. São instituídos, ainda, em 1966, os bancos de investimento e o F undo de $\mathrm{G}$ arantia do Tempo de Serviço (F G T S). 
Em 1967, o CM N facilitou a obtenção de recursos originários do mercado financeiro internacional - o que possibilitou, a partir de então, grande afluxo de capitais - , além de autorizar, via R esolução 63, os bancos a captarem empréstimos externos destinados a repasse às empresas no país. A reforma financeira impôs, ainda, controles à entrada de bancos estrangeiros, mas deixou livre a instalação de escritórios de representação de bancos estrangei ros. N o entanto, os acordos bilaterais ea aplicação do princípio da reciprocidadelevaram ao aumento da internacional ização do sistema bancário nacional . E ntre 1962 e 1981, quinze novos bancos estrangeiros se instalaram no Brasil (C orazza, 2001).

A demais, a reforma promoveu a especial ização setorial do sistema financeiro, conduzindo, posteriormente e ao contrário do que se esperava, à congl omeração e concentração do setor. F oi instituído um sistema inspirado no model o norte-americano, baseado no princípio de especial ização e segmentação do mercado financeiro, instituído por meio da especialização das funções das instituições financeiras, bem como da vinculação da captação com a aplicação de recursos (D e Paula, 1998).

Com a segmentação, os bancos comerciais passaram a realizar somente operações de crédito de curto prazo, captando depósitos à vista. O s bancos de investimento e desenvolvimento passaram a ser responsáveis pel os empréstimos delongo prazo, a partir da captação dedepósitos a prazo ederecursos no exterior. A ssociedades de crédito, financiamento einvestimento (financeiras) foram direcionadas ao crédito ao consumidor eaos empréstimos pessoais, captando letras de câmbio. A s instituições do Sistema F inanceiro da H abitação (SF H ), por sua vez, ficaram responsáveis pelo financiamento habitacional, para o qual eram utilizados recursos obtidos por meio de depósitos de poupança e de letras imobiliárias (Puga, 1999). ${ }^{3}$

3 Entretanto, asegmentação foi menor do quea indicada pelalegislação, uma vez que diferentes instituições financeiras, pertencentes ao mesmo conglomerado, podiam operar juntas utilizando o mesmo espaço físico, apenas com um plano contábil separado para se enquadrarem na legislação (Puga, 1999). 
Costa e D e D eos (2002) consideram, contudo, que os bancos de investimento não desempenharam o papel que Ihes foi atribuído pela reforma financeira, de financiar os investimentos, devido àfalta de funding adequado. O S CD Bs privados não conseguiam grande colocação no mercado para captação de depósitos a prazo, pois a preferência dos investidores, em uma situação de inflação e juros decrescentes, era aplicar em letras de câmbio com taxa de juros prefixadas.

A partir de 1968, com a redução da solicitação de fundos de financiamento pelos órgãos do setor público, devido à política monetária mais "frouxa" , e com retomada do crescimento econômico, foram ampliados os empréstimos aos diversos ramos da indústria detransformação.

O BN D E ampliou progressivamenteseus empréstimos em favor do setor privado. A Finame, subsidiária do BN DE em suas operações delongo prazo, além de recursos próprios edo BN DE, contava com recursos do PIS, medianteconvênio firmado com a $C$ aixa E conômica F ederal. O Pasep, instituído em 1971, era gerido, até 1974, pelo Banco do Brasil, quando, juntamentecom o PIS, foi transferido para a gestão do BN DE.

A partir do início de 1970, há uma reversão do observado até então, com um aumento da internacionalização financeira. A dinâmica do endividamento externo, com a captação de recursos no exterior sendo estimulada pela política econômica, foi um elemento determinante nesse processo. A presença do capital estrangeiro no setor aumentou devido à abertura de novos bancos comerciais, à participação minoritária em bancos de investimento eà maior participação nos empréstimos (principal menteem operações relacionadas ao repasse de capitais internacionais).

O utra característica desse período foi a maior rentabilidade das aplicações financeiras, em detrimento dos investimentos produtivos, o que distorceu a al ocação de recursos do setor privado, promovendo um círculo vicioso de acumulação do setor financeiro.

Pode-se resumir, então, que a reforma financeira de 1964 não conseguiu lograr seus objetivos iniciais, de desenvolvimento do 
mercado definanciamento a longo prazo por bancos deinvestimento privados. 0 crédito doméstico de longo prazo para o investimento industrial ficou restrito ao mercado externo eao sistema BN DE, ea diversificação dos títulos financei ros não atingiu formas de captação de longo prazo. A lém disso, a maior parte do capital captado pelo sistema bancário, nesse período, não foi direcionada para o setor produtivo, prejudicando o papel defomentador do desenvolvimento econômico do setor bancário (C osta e D e D eos, 2002).

Em 1976, foi criada a Comissão deValores M obiliários (CV M ), que passou a regulamentar o mercado de valores mobiliários. Em 1979, é implementado o Sistema Especial de L iquidação e de C ustódia(Selic), que passou a realizar a custódia ea liquidação financeira das operações envolvendo títulos públicos, além de eliminar o uso do cheque para a liquidação de operações com títulos públicos.

Em 1986, foi criadaa Central deC ustódia edeL iquidação Financeira deT ítulos (C etip), empresa que se constituiu em um mercado debal cão organizado para registro enegociação deval ores mobiliários derenda fixa. A criação da C etip permitiu a introdução dos $D$ epósitos I nterfinanceiros (D I ou CD I) e a eliminação do uso do cheque para a liquidação de operações com títulos privados.

A queda da taxa decrescimento da economia, a partir da primeira metade da década de 80, adicionada à política decontrole monetário edecrédito, que buscava auxiliar no ajusteexterno da economia (por meio do controle da demanda agregada) e no controle da inflação, levou à retração, em termos reais, dos empréstimos. A lém da quase completa interrupção do acesso voluntário a fontes externas, havia o problema dos al tos custos dos empréstimos internos, devido às elevadas taxas de juros domésticas e ao crescimento da correção monetária, consequência da mencionada aceleração inflacionária. Com o aprofundamento da recessão, o sistema BN D ES passou a cumprir a função deapoiador financei ro das empresas mais atingidas pela crise, o que levou à queda real dos desembolsos para ampliação da capacidade produtiva.

N esseperíodo, pode-sedestacar, ainda, o surgimento, em 1983, da C ompensação $\mathrm{N}$ acional, que permitiu a integração da compensação 
de todo o país, e a incorporação, em 1986, do BN H pela Caixa Econômica Federal (afunção normativa do SF H éassumida pelo CM N ).

Em setembro de 1988, por meio da Resolução do CM N o 1.524, foi realizada uma nova reforma bancária no Brasil, desregulamentando o sistema financeiro eextinguindo a exigência da carta-patente para a criação dos bancos múltiplos. Esta reforma possibilitou queo capital estrangeiro constituísse bancos com carteira comercial, ampliando sua presença no país - apesar de os grandes conglomerados financeiros já atuarem antes como instituições múltiplas, ainda que como uma empresa jurídica com contabilidade própria para cada carteira específica.

A Constituição Federal de 1988 impediu a instalação de instituições estrangei ras no Brasil, bem como a ampliação da participação percentual do capital estrangeiro em instituições bancárias no país, exceto nos casos de acordos internacionais, de reciprocidade, ou de interesse do governo brasileiro. Entretanto, o texto condicional não proibiu a expansão operacional do capital estrangeiro, o que permitiu a transformação de 26 instituições não bancárias estrangeiras em bancos múltiplos com carteira comercial (já que as carteiras comerciais criadas mantinham o mesmo percentual de participação estrangeirada instituição original). Por outro lado, havia forte pressão dos organismosinternacionais, como F M I eBanco M undial, edeacordos multilaterais (os acordos de formação do G AT S eda O M C , por exemplo, ao final da R odada U ruguai) pela abertura dos mercados bancários domésticos, principalmente dos países emergentes (R ocha, 2002).

$N$ a década de 1990, destacam-se: a instituição, em 1996, do Comitê de Política M onetária (Copom), criado com o objetivo de estabelecer as diretrizes da política monetária, definir a meta da taxa Selic e seu eventual viés e analisar o R elatório de Inflação; a criação, em 1997, do Sistema de Financiamento I mobiliário (SF I) e da $C$ entral de $R$ isco de C rédito, mantida pelo Banco Central do Brasil; a introdução, em julho de 1999, da sistemática de "metas para a inflação" como diretriz para a fixação do regime de política monetária; ea instituição, em 2001, da Cédula deC rédito Bancário, um "título de crédito emitido, por pessoafísica ou jurídica, em favor 
de instituição financeira ou de entidade a esta equiparada, representando promessa de pagamento em dinheiro, decorrente de operação decrédito dequalquer modalidade" (M edidaProvisória nํ⒉160-25, de23 deagosto de2001). Esse instrumento possibilitou o surgimento de um título de crédito que espel hasse as relações jurídicas entre as instituições financeiras eseus clientes, além detornar a formalização das diversas operações de crédito menos onerosa ecomplexa, uma vez querepresentou maior garantia na recuperação decrédito. Essa mai or garantia se deveà definição dessetítul o como executivo extrajudicial, ou seja, não é necessário o protesto para que o credor possa cobrar o endossante da C édula, seus aval istas e terceiros garantidores.

O período de 1980 a 1994 pode ser caracterizado por uma fasede crises, recessões einstabilidade monetária e financeira. N o entanto, essa situação não afetou consideravel mente o setor bancário, apesar da falência de al guns bancos e dos desajustes na rentabilidade e nas contas patrimoniais dos bancos estaduais. O s ganhos do setor bancário nesse período devem-se, principalmente, à alta inflação, que permitia que os bancos capturassem depósitos à vista para financiar a compra de títulos da dívida pública, os quais eram rolados diariamente, normalmente a taxas de juros nominalmente elevadas e, portanto, rentáveis.

U m estudo comparativo, realizado por economistas do Banco M undial sobre o sistema bancário de doze países latino-americanos, revel ou que, entre 1981 e 1987, os bancos brasileiros foram recordistas de rentabilidade. Esse resultado foi possível devido não somenteà inflação el evada, mas também devido às linhas básicas de política econômica adotadas para enfrentar a crise provocada pelo estrangulamento cambial do início dos anos 1980. U m dos fatores determinantes foi o compromisso do governo federal em manter a taxa de juros elevada, o que garantiu a atratividade de seus títulos, desestimulando a fuga de capitais para o exterior e a dolarização das transações domésticas. E sse compromisso evitou a combinação nociva de câmbio val orizado com desregulamentação financeira e abertura externa, como ocorreu em outros países da A mérica $L$ atina nesse período (C arvalho, 2003). 
N esse cenário, o crédito ao setor privado apresentava alto risco, não sendo tão atrativo quanto o mercado de títulos públicos ( $\mathrm{C}$ arvalho, 2002). 0 desestímulo ao crédito favoreceu a abertura de um spread considerável entre as taxas de captação e aplicação dos bancos. Como consequência, a oferta de crédito pelo sistema financeiro caiu de 35\% do PIB em 1978 para 11\% em 1991 (C arvalho, 2003).

Por outro lado, a eficácia dos instrumentos de neutralização de perdas inflacionárias também resultou na possibilidade de sobrevivência de bancos de baixa competitividade, denominados "T reasury B anks", ou seja, instituições criadas com o objetivo exclusivo de captar depósitos para financiar a aquisição de títulos públicos. I sso foi possibilitado pela facilidade de obtenção de ganhos proporcionada pela captação de depósitos para realização de aplicações em dívida pública. G rande parte desses bancos não sobreviveu quando o cenário se alterou (C arvalho, 1998). ${ }^{4}$

O s bancos trataram de buscar formas de proteger os lucros acumulados contra as incertezas futuras, principal mentecontra a inevitável perda dos ganhos inflacionários em al gum momento posterior. Para isso, desenvolveram estratégias de diversificação patrimonial, com investimentos e compra de participações em empresas do setor produtivo. A lém disso, ampliaram o número deagências einvestiram na informatização das operações ena introdução de inovações financeiras que permitissem maior extração de ganhos possibilitados por aquelemomento. Essecomportamento possibilitou um aumento na renda de serviços bancários euma diminuição relativa das despesas administrativas, devido à demissão de funcionários propiciada por aqueles ganhos de escala e informatização.

Carval ho (2004) cita dois exemplos relevantes do desenvolvimento de inovações, ocorrido no período. A al ta inflação levou à necessidade deaceleração da circulação da moeda, o quefez com que os bancos brasilei ros se tornassem extremamenteágeis na real ização

4 D o grupo de bancos que funcionava em dezembro de 1988 , cerca de $40 \%$ não chegou a 2000 e quase metade deles saiu do SF N por motivo de liquidação. (Fonte: Site do Banco Central do Brasil). 
de pagamentos e na movimentação de recursos. U ma pesquisa da consultoria M cK insey, realizada em 1994, apontou que os bancos brasileiros exibiam índices de eficiência superiores aos de muitas economias desenvolvidas, no que se refere à agilidade do sistema de pagamentos. O utro exemplo relevante foi o desenvolvimento de operações com mercados de títulos. A alta inflação ea indexação incentivaram o desenvolvimento detecnologias de contratação enegociação sofisticadas, que permitiram a neutral ização da inflação ea identificação deoportunidades deganhos com papéis, arbitrando, por exemplo, entrecontratos com diferentes indexadores ou com diferentes preços, determinados por diferenças em seus prêmios de liquidez.

O movimento ocorrido nos bancos nesse período acentuou, consequentemente, as características típicas devariações na “ preferência por flexibilidade" , a partir deuma ampla eágil capacidade deresposta a mudanças conjunturais. Essas características foram muito importantes para que as instituições pudessem, posteriormente, reagir ao Plano R eal com rapidez e eficácia, defendendo sua lucratividade (C arvalho, 2003).

O período decrise da dívida externa encerra-seno início dos anos 90, com a volta dos créditos voluntários, ainda durante o governo Collor, e com a destruição, a partir de 1994, do sistema de regras e contratos indexados, quevigorava desdea reforma de 1964. A década de90 é, assim, caracterizada por um período deampla abertura financeira, com inflexão do model o de desenvolvimento seguido atéentão, sustentado sobre o financiamento público e o autofinanciamento.

\section{A reestruturação bancária e a entrada dos bancos estrangeiros no Brasil}

A partir de 1990, ocorre um direcionamento da política econômica aos princípios consolidados no "Consenso de W ashington", ou seja, à abertura comercial e financeira, com menor participação do Estado na economia (por meio de medidas que incentivavam a liberalização, desregulamentação e privatizações). 
U ma das principais medidas adotadas para promover a abertura financeira foi a R esolução do Conselho $\mathrm{M}$ onetário $\mathrm{N}$ acional no 1.832, de 31 de maio de 1991, que regulamentou os investimentos estrangeiros em títul os eval ores mobiliários nas companhias abertas brasileiras, aumentando consideravelmente 0 ingresso de recursos externos. 0 governo manteve, entretanto, a proibição dedepósitos em moeda estrangeirano sistema bancário doméstico, ao contrário do que ocorreu em grande partedos países da A mérica L atina (R ocha, 2002).

$N$ esse período observa-se um aumento significativo na oferta de crédito, o que foi resultado, principalmente: a) da queda da receita dos bancos nas operações com títulos, após a forte redução da dívida pública em mercado promovida, em março de 1990, pelo Plano Collor; b) do fim das aplicações em overnight após o Plano Collor II, dejaneiro de 1991; c) do cenário econômico mais favorável, possibilitado pela volta dos recursos externos em 1992 e pela retomada do crescimento econômico; ed) da necessidade de os bancos se anteciparem frenteà perspectiva de queda da inflação (C arval ho, 2003).

A partir de 1994, com a implementação do Plano R eal, são eliminadas as receitas inflacionárias oriundas do float ${ }^{5}$ de recursos remunerados a taxas reais negativas ou inferiores às de aplicação. Estas receitas, queatingiram 4\% do PI B no período 1990-93, foram reduzidas a 2\%, em 1994, ea 0,1\%, em 1995 (T abela 1.4). Em termos do valor da produção bancária imputada, as receitas inflacionárias, que representavam $87,3 \%$ em 1993, reduziram-se para $49,5 \%$ em 1994, e 1,6\% em 1995 (C orazza, 2001).

T abela 1.4 - R eceita inflacionária como \% do PIB e do Valor da Produção I mputada

\begin{tabular}{l|c|c|c|c|c|c}
\hline & $\mathbf{1 9 9 0}$ & $\mathbf{1 9 9 1}$ & $\mathbf{1 9 9 2}$ & $\mathbf{1 9 9 3}$ & $\mathbf{1 9 9 4}$ & $\mathbf{1 9 9 5}$ \\
\hline R eceita I nflacionária/ PIB & 4,0 & 3,8 & 4,0 & 4,3 & 2,0 & 0,1 \\
\hline $\begin{array}{l}\text { Receita I nflacionária/ Valor Produção } \\
\text { Imputada }\end{array}$ & 70,0 & 81,2 & 86,8 & 87,3 & 49,5 & 1,6 \\
\hline
\end{tabular}

Fonte: IBGE/ A N DIM A (1997).

5 G anho inflacionário possibilitado pela detenção de recursos e depósitos não passíveis de correção monetária ou qual quer outra modalidadederemuneração. 
O s bancos buscaram compensar essa perda de receitas com um aumento na oferta de crédito, o que acentuou a expansão que já estava em andamento no início da década. Com a redução drástica das taxas deinflação e o expressivo crescimento da economia em 1994 e 1995, os depósitos bancários setornaram atrativos novamente, com um crescimento de $165 \%$ nos primeiros seis meses do Plano R eal. Esses depósitos constituíram o funding das operações de crédito, incentivando o direcionamento dos bancos ao crédito aos agentes privados, fossem el es firmas ou consumidores, efinanciando o primeiro miniciclo expansivo do Plano $\mathrm{R}$ eal (M aia, 2003). ${ }^{6} \mathrm{U}$ m dos principais atrativos para o aumento da oferta de crédito pelos bancos foram as elevadas taxas de juros e os respectivos spreads proporcionados. N o período de 1997 a 2002, a taxa de juros nominal do crédito pessoal atingiu o pico de $133 \%$ ao ano, em fevereiro de 1998 , eo piso de $68 \%$, em abril de 2000 (J acob, 2003).

0 crescimento da demanda por crédito, por sua vez, foi possibilitado pelo forte crescimento econômico, pela melhoria nos salários reais e pela diminuição nos juros nominais. Essemovimento fez com que o governo impusesse, a partir de outubro de 2004, restrições sobre a oferta de crédito, por meio do aumento nos requerimentos de reserva sobre os depósitos à vista ea prazo e da criação de um depósito compulsório sobre os empréstimos concedidos pel os bancos. 0 recolhimento compulsório sobre depósitos à vista passou de $48 \%$ para 100\%, enquanto o recol himento sobreos depósitos depoupança passou de 10\% para 30\%. Foi instituído, ainda, um recolhimento de $30 \%$ sobre o sal do dos depósitos a prazo. N este contexto, os efeitos da crise mexicana atingiram o país, fazendo com que o governo promovesse um significativo aumento nas taxas de juros domésticas, em março de 1995. Como consequência, verifica-se uma reversão no ritmo de crescimento econômico do país. 0 aumento da taxa dejuros provocou um aumento da taxa deinadimplência euma desacel eração no crescimento do crédito.

6 O s empréstimos ao setor privado aumentaram quase $60 \%$ no primeiro ano do Plano Real (M aia, 2003). 
O s bancos, entretanto, conseguiram manter as margens de lucro em 1995 e 1996, devido ao direcionamento para operações com títulos públicos, à manutenção de juros e spreads elevados e ao aumento da captação externa e da securitização de dívidas. Por outro lado, foram reduzidas as despesas administrativas e com pessoal, devido à informatização e ao e- banking (R ocha, 2002).

A manutenção das margens de lucro também foi possibilitada pelo aumento das receitas sobre serviços bancários, resultado do aumento dos custos operacionais embutidos na captação de recursos sem juros ou com juros abaixo da média do mercado. Com inflação alta, o custo destes recursos é compensado pelos altos rendimentos nominais obtidos; entretanto, com inflação baixa, os bancos procuram repassar esses custos para os clientes. A I guns bancos varejistas de portemédio conseguiram elevar de 10\% para 35\% a parcela desua receita bruta originada de cobrança de tarifas.

Também contribuíram para esse desempenho os ganhos em operações com moeda estrangeira, que refletiram o posicionamento acertado da maioria dos bancos de que a nova moeda seria implementada acompanhada de juros altos e val orização real do câmbio. Essa posição gerou lucros muito acima do esperado. A lém disso, o aumento das receitas com crédito também representou um papel relevante, ${ }^{7}$ apesar do grande esforço das autoridades para impedi- Io.

D essa forma, antes da estabilização de preços, a instabilidade inflacionária permitia ao setor bancário obter al tos lucros da operação com títulos da dívida pública. D epois da estabilização de preços, a instabilidade do balanço de pagamentos permitiu ao setor bancário continuar obtendo seus lucros exatamente da mesma forma. Essa peculiaridade do setor bancário brasileiro permitiu queas instituições mantivessem, durante toda a década, sua rentabilidade patrimonial histórica. A rentabilidademédia dos bancos brasileiros aumentou de 14,9\%, em 1993, para 16,8\%, em 1994, mantendo-seno patamar dos 13\% até 1998 (G ráfico 1.1). Em 1999, a mesma chegou a 23\%, em virtude dos ganhos com a desval orização cambial (C orazza, 2001).

70 crédito ao setor privado aumentou 58,7\% duranteo primeiro ano devigência do Plano R eal (Soares, 2001). 


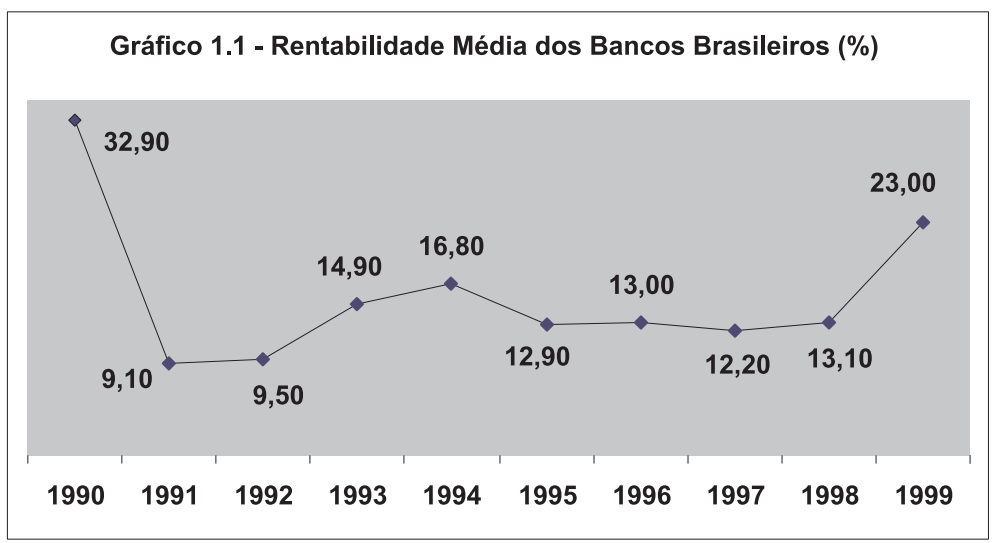

Fonte: IBGE/ A N D IM A (1997).

Portanto, o Plano R eal resultou, inicialmente, em um breve período de maior crescimento econômico, em relação aos anos 80, em ampliação da demanda agregada, em remonetização e em aumento das operações de crédito. N o entanto, esse processo foi rapidamente abortado, em 1995, devido às altas taxas de juros praticadas após a crise mexicana, que levariam a uma forte deterioração da qualidade dos empréstimos, devido às políticas econômicas restritivas necessárias para fazer frente a crises de balanço de pagamentos. I sso porque, nesses primeiros anos do Plano R eal, devido à abertura comercial excessiva e à apreciação real do câmbio, o país ficou dependente de fluxos de capital para sustentar o balanço de pagamentos. A ssim, durante a crise do M éxico, em 1995, essa forma de financiamento no mercado de capitais já sofre uma primeira ruptura significativa.

O sistema bancário, portanto, enfrentava alguns problemas, relacionados à eliminação do rendimento que era antes obtido com a inflação, às elevadas reservas compulsórias exigidas, ao aumento da inadimplência e ao "empoçamento da liquidez" . . A crise do

8 Situação em que o dinheiro disponível no mercado fica concentrado nas mãos das instituições financeiras de maior porte, não circulando entre as instituições de pequeno porte. 
M éxico provocou, ainda, aumento da volatilidade macroeconômica, implicando, via choque externo, uma política monetária restritiva. A lém disso, a prematura liberalização financeira, adicionada às fal has de gestão, fraudes contábeis e deficiências na supervisão e regulamentação prudencial conduzidas pela autoridade monetária, provocou diversas falências de pequenos bancos ea insolvência, em 1995, de duas grandes instituições privadas do país, levando o Brasil à iminência de uma crise bancária sistêmica. Com isso, a partir da intervenção nos bancos E conômico, em agosto de 1995, eN acional, em novembro de 1995 (sétimo e quarto maiores bancos privados, por ativos, respectivamente), a ameaça de crise bancária torna-se concreta (R ocha, 2002). A inda mais que, como vimos, a resposta do governo deu-se, sobretudo, via adoção de uma política monetária mais restritiva.

D essa forma, o processo dedesnacionalização bancária no B rasil iniciou-se no âmbito de um conjunto de reformas implementadas pelo governo, com o objetivo deevitar uma crise bancária sistêmica. D entre as medidas adotadas, podem ser citadas: a concessão de incentivos fiscais para a incorporação de instituições financeiras; a aprovação do estatuto e regulamento do $F$ undo de $G$ arantia de C réditos; a imposição demaiores dificuldades para criação de novas instituições financeiras; a criação de incentivos para processos de fusão, incorporação etransferência de controle acionário; 0 aumento do poder de intervenção do $B$ anco $C$ entral nas instituições financeiras; a responsabilização das empresas de auditoria contábil ou dos auditores contábeis independentes em casos de irregularidades em instituições financeiras; a alteração da legislação quetrata da abertura dedependências dos bancos no exterior; a consolidação das demonstrações financeiras dos bancos no Brasil com suas participações no exterior; a permissão de cobrança detarifas pela prestação deserviços por parte das instituições financeiras; a criação da Central de R isco de C rédito; e, por fim, a implementação do Programa de Incentivo à R edução do Setor Público Estadual naA tividade Bancária (Proes) e do Programa de Estímulo à R eestruturação eao Fortalecimento do Sistema Financeiro $\mathrm{N}$ acional (Proer) (Corazza, 2001). 
0 Proes financiou integralmente as despesas de reestruturação dos bancos estaduais, no caso de privatização ou transformação dos bancos em instituições não bancárias (se o Estado pretendesse continuar como controlador do banco, o financiamento federal seria limitado a 50\%). 0 resultado do Proes foi a acentuada redução do número de instituições públicas estaduais em atuação e a respectiva redução da participação relativa dos bancos estaduais no total do sistema financeiro nacional, sob qualquer critério de análise. Este espaço foi preenchido por bancos privados nacionais e pela entrada de instituições financeiras estrangeiras. D as 35 instituições bancárias estaduais existentes na época, 10 foram extintas, 7 foram privatizadas, 6 foram federalizadas, com posterior privatização, e 5 foram reestruturadas. A penas 3 bancos estaduais não aderiram ao programa. D as privatizações realizadas, duas significaram a entrada de bancos estrangeiros: a privatização do Banco do Estado dePernambuco (Bandepe), quefoi comprado em 17 denovembro de 1998 pelo A BN -A mro Bank, pelo valor de $\$$ 182,9 milhões, ea do Banespa, adquirido pelo Banco Santander C entro-H ispano, em 20 de novembro de 2000, pelo valor deR $\$ 7,05$ bilhões (R ocha, 2002).

O Proer, por sua vez, regulamentou a aquisição de bancos com problemas patrimoniais e de solvência, por meio da criação de linhas de crédito, de incentivos fiscais, de benefícios tributários e de isenção temporária do cumprimento de certas normas bancárias. O s principais resultados do Proer foram o incentivo às fusões, incorporações, transferências de controle acionário e aquisições, por bancos estrangeiros, dos bancos privados nacionais. Por meio desse programa, foram despendidos $\mathrm{R} \$ 20,4$ bilhões, o equival entea $2,7 \%$ do PIB médio de 1995-97 (M aia, 2003).

A lém disso, foram promovidosa modernização eo aprimoramento da regulamentação prudencial do Bacen, que passou a adotar os padrões internacionais estabelecidos pelos Comitês da Basileia. A regulamentação incorpora itens como requisitos para a constituição de bancos, capital mínimo ponderado pelo risco, supervisão consolidada, abertura de dependências no exterior e model os internos de avaliação derisco decrédito. D essa forma, a atuação discricionária do 
Bacen, adicionadaà existência de bancos grandes esaudáveis, evitou o contágio sistêmico. A atuação do Bacen também foi importante no sentido de excluir do mercado as instituições problemáticas, de estimular as privatizações com a autorização prévia para a desnacionalização, de reforçar os padrões de regulamentação prudencial ede capitalização, e deconsolidar a abertura do setor bancário brasileiro.

Também com o objetivo de combater a ameaça de crisesistêmica, em 1995, duas semanas após a intervenção no Banco E conômico, o $M$ inistério da Fazenda, utilizando a exceção prevista na Constituição, enviou duas Exposições de $M$ otivos (E M / M F) à Presidência da R epública, reconhecen do o interesse do governo brasileiro no ingresso de bancos estrangeiros. A justificativa era dequeos aportes de capitais externos eram necessários para suprir a escassez de capitais nacionais e, dessa forma, promover o desenvolvimento do Sistema Financeiro $\mathrm{N}$ acional. A partir dessa justificativa, os ingressos seriam permitidos, mesmo que não estivessem associados a instituições insolventes ou com dificuldades. D o ponto de vista microeconômico, a lógica dessas medidas era de que as instituições estrangeiras aumentariam a qualidade dos serviços prestados e introduziriam novas tecnologias e inovações em produtos eserviços (R ocha, 2002).

$\mathrm{N}$ o entanto, a primeira aquisição ocorreu apenas em março de 1997, com a venda do Bamerindus, um grandebanco nacional de varejo, ao H SBC. A operação foi intermediada pelo Banco Central do B rasil e obteve amparo dos recursos do Proer. Portanto, a primeira aquisição ocorreu após a reestruturação do setor efetuada pelo governo federal e pel o Bacen, ou seja, quando os riscos sistêmicos eram bem menores. D essa forma, o papel dos bancos estrangei ros na reestruturação bancária brasileira foi secundário e posterior à resolução da ameaça de crise sistêmica. No entanto, a participação destes foi importante na continuidade da reestruturação, contribuindo para minimizar os gastos públicos com o resgate deinstituições insolventes eparauma maior solidez do setor bancário no país (R ocha, 2002).

A pós essa transação, outras foram feitas, sendo que foram incluídas, exclusivamente, instituições insolventes ou ilíquidas, além das privatizações. Posteriormente, este movimento se estendeu, 
generalizadamente, para qualquer banco. $\mathrm{N}$ a realidade, as aquisições bancárias realizadas por bancos privados nacionais ou estrangeiros iniciaram uma acelerada consolidação bancária. D e 1995 até 1999, foram concedidas 87 autorizações para ingresso ou ampliação da participação do capital externo no mercado doméstico, incluindo compra debancos, privatizações, aumento departicipação acionária, constituição de participação minoritária e permissão para criação de novas instituições bancárias e não bancárias (R ocha, 2002).

D esse modo, assim como nos demais países da A mérica L atina, o processo de consolidação bancária no Brasil foi, em um primeiro momento, conduzido pelo governo. N o final da década, entretanto, esse processo passou a ser conduzido pelo mercado, por meio das fusões e aquisições lideradas por bancos privados nacionais e por bancos estrangeiros.

A entrada de instituições estrangeiras em outros países, principalmente da A mérica $L$ atina, também foi acelerada por problemas bancários. D essa forma, as crises da década de 1990 contribuíram para a liberal ização dos sistemas financeiros domésticos, na medida em que provocaram a venda de diversos bancos e modificaram a postura dos governos nacionais em relação à presença do capital estrangeiro. Esta mesma contribuição foi dada, no caso brasileiro, pelos problemas bancários dos primeiros anos após o Plano R eal.

U ma característica específica do Brasil foi a reação dos bancos privados nacionais à entrada dos bancos estrangeiros, participando, em um primeiro momento, ativamente do processo de fusões e aquisições e, posteriormente, passando a comandar esse processo, dada a retração dos bancos estrangeiros.

O s bancos estrangeiros que vieram para o Brasil eram principalmente europeus. Essa predominância se explica pelas mudanças ocorridas, a partir do final dos anos 80, no padrão de concorrência do setor naquelecontinente, com um aumento do nível deconcentração e queda das margens de lucro. A implantação do M ercado Ú nico, na E uropa, tornou inócua a necessidade de autorizações locais e restrições nacionais à atuação dos bancos. A dicionalmente, a perspectiva de unificação monetária, a partir de 1999, estimulou tanto a 
consolidação bancária nos mercados internos como a expansão para o exterior.

A demais, o mercado brasileiro mostrava-se atrativo, principalmente devido à estabilização inflacionária, às modificações ocorridas na legislação doméstica e à reestruturação que se seguiu à ameaça de crise bancária sistêmica de 1995-96. A lém disso, também foram considerad os fatores deatração importantes o tamanho eo potencial de expansão deste mercado, o da maior economia da A mérica $L$ atina, a qual está entre as maiores do mundo e tem um setor bancário operacional mente desenvolvido e diversificado. Por outro lado, a relação entre o tamanho dos bancos e o da economia é considerada menos relevante do que o potencial para uma economia do tamanho da brasileira. O s indicadores de população "bancarizada", crédito bancário/ PIB e depósitos/ PIB são baixos, se comparados aos países desenvolvidos, o que gerou expectativas externas al tamente positivas quanto ao potencial de crescimento do setor bancário brasileiro (Rocha, 2002).

O utro argumento para a abertura do mercado foi a sempre reputada (por al guns) escassez decapital nacional, portanto, a incapacidade deuma solução demercado para os problemas bancários, quetivesse origem nas instituições privadas nacionais. A demais, as falências que ocorreram originaram significativa quantidade debancos para serem vendidos, quejá contavam com rededeagências, clientes, funcionários e marca, gerando um forte atrativo para os bancos estrangeiros.

N o entanto, dados do período de 1994 a 2000 mostram que a operação que teve maior impacto na concentração bancária foi a compra do grupo BC N pelo Bradesco, a qual superou a privatização do Banespa. A dicionalmente, o I taú foi o banco queadquiriu o maior número de instituições privatizadas. Com isso, pode-se concluir que a desnacional ização foi mais uma opção de política governamental do que uma resposta à escassez de recursos dos bancos nacionais para a reestruturação do setor (R ocha, 2002).

Por último, questões relacionadas com a eficiência também são apontadas como fatores deatração. I sso porque os sistemas bancários dos países emergentes seriam menos eficientes, tornando-seatraentes 
para o capital externo, devido à possibilidade de aproveitamento da maior eficácia deste capital para obter el evados lucros e maior participação nesses mercados.

Portanto, a mudança estrutural observada no setor bancário a partir do Plano R eal não é resultado somente da participação estrangeira, mas também da estabilidadeinflacionária e da volatilidade macroeconômica, dos programas governamentais dereestruturação bancária e da agressividade dos bancos privados nacionais por meIhorias de eficiência e por maior participação nas fusões eaquisições (Rocha, 2002).

\section{O sistema financeiro brasileiro após a entrada dos bancos estrangeiros}

A o final da década de 90 , esse processo de reestruturação resultou em uma redução significativa do número de bancos públicos estaduais edos bancos privados nacionais, bem como em um crescimento expressivo dos bancos com controleestrangeiro (T abela 1.5). D entre as instituições adquiridas por grupos estrangeiros, no período de 1988 a 2000, apenas 35\% dos ativos pertenciam a instituições públicas estaduais privatizadas, ou seja, a maior parte das transferências de controle para o capital estrangeiro teve sua origem entre os capitais privados nacionais, que perderam uma parcela de sua participação no sistema (site do Banco Central do Brasil).

0 ingresso e as atividades de bancos estrangeiros no Brasil, até 1994, seguiam o padrão geral: operação com câmbio, comércio exterior efinanciamento de empresas multinacionais. N esse período, os bancos estrangei ros enfrentavam dificuldades para atuar em um ambientecom al ta inflação e penetrar em nichos de mercado dominados pelos grandes bancos nacionais de varejo. N o entanto, após o Plano $R$ eal, a entrada de bancos estrangei ros passou a ocorrer por meio da aquisição de bancos com posição estabelecida, ou potencial, junto aos mercados domésticos (banco a cuja aquisição, anteriormente, os bancos estrangei ros não tinham acesso - C orazza, 2001). 
T abela 1.5 - N úmero de bancos brasileiros por categorias selecionadas

\begin{tabular}{l|c|c|c}
\hline Tipo de Instituição & dez./ 88 & jun./ 94 & dez./ 98 \\
\hline Bancos Públicos & 43 & 40 & 30 \\
\hline Federais & 6 & 6 & 6 \\
\hline Estaduais & 37 & 34 & 24 \\
\hline Bancos Privados N acionais & 44 & 147 & 106 \\
\hline Bancos Estrangeiros & 40 & 69 & 75 \\
\hline Filiais & 18 & 19 & 16 \\
\hline Controle Estrangeiro & 7 & 19 & 36 \\
\hline Participação Estrangeira & 5 & 31 & 23 \\
\hline Bancos de Investimento & 49 & 17 & 22 \\
\hline T OT A L & 166 & 273 & 233 \\
\hline
\end{tabular}

Fonte: Elaborado a partir de C orazza (2001).

Esse novo cenário e a nova postura do governo implicaram alterações na estrutura e nos padrões de concorrência do mercado bancário brasileiro. A s principais mudanças foram: o incentivo ao processo de fusões privadas nacionais (no âmbito da reestruturação, das privatizações e das alterações nas normas prudenciais dos bancos); o aumento da concentração, principalmente bancária; um intenso processo de desnacional ização, entre 1997 e 2000; ea reação defensiva/ ofensiva dos bancos privados nacionais. O s bancos estrangeiros, por sua vez, passaram a atuar em todos os segmentos do mercado financeiro doméstico, deixando de ter uma atuação apenas complementar no setor bancário brasileiro.

Porém, ao contrário do ocorrido nos países da O CDE, o processo de consolidação bancária brasileiro foi caracterizado por altas margens de intermediação financeira, principalmente devido aos altos spreads bancários. A expectativa com relação à entrada dos bancos estrangei ros era de que haveria um acirramento da concorrência, o que levaria a menores spreads, a uma maior qualidade dos produtos e serviços e à modernização da tecnologia, beneficiando os clientes de serviços bancários (R ocha, 2002). A lém disso, esperava-se que essas instituições introduzissem no país práticas creditícias e técnicas apropriadas a uma economia com preços estáveis. 0 u seja, 0 
portfolio dos bancos estrangei ros seria direcionado, desdeo princípio, ao crédito a firmas e consumidores, enquanto os bancos domésticos continuariam direcionados à dívida pública, até que conseguissem se adaptar ao novo ambiente (C arvalho, 2002).

Contrariando essas expectativas, os bancos estrangeiros queentraram no Brasil (principalmente via fusões e aquisições) adotaram uma postura ainda mais conservadora, direcionada, principalmente, para os títulos públicos. D essa forma, enquanto a rentabilidade dos bancos estrangeiros era maior quea dos bancos nacionais, a relação crédito por ativo total era maior nos bancos nacionais.

U m estudo deA delino eD ePaula (2006) concluiu que, no Brasil, os bancos privados nacionais têm se revelado mais eficientes que os bancos estrangeiros, ao contrário do defendido pela literatura internacional. U ma das hipóteses de autores para explicar essa divergência éa possi bilidade de as fusões eaquisições brasileiras terem resultado em economias de escala e economias de escopo, tendo em vista que os bancos brasileiros que participaram do processo de fusões eaquisições constituem-se em bancos múltiplos, queatuam com diversos produtos e segmentos do mercado bancário (como intermediação financeira, previdência, seguros e gestão de fundos). A conclusão dos autores équeo processo de fusões eaquisições no setor bancário real menteproporcionou um aumento na eficiência deintermediação dos bancos compradores. Esse resultado pode ser explicado, possivelmente, pelo aprimoramento no gerenciamento operacional dos bancos e pelos cortes nos custos administrativos e de pessoal.

Foi observado, também, que a melhoria na eficiência foi mais significativa nos bancos privados nacionais do que nos bancos estrangeiros, já que os primeiros obtiveram maiores ganhos neste quesito, tanto com relação àintermediação quanto em relação aos resultados. I sto pode explicar o motivo pelo qual os bancos privados nacionais, principalmente Bradesco e I taú, lideraram o processo de fusões e aquisições ocorrido no período.

Carvalho (2002) também argumenta que a entrada de bancos estrangeiros no Brasil não trouxe nenhuma melhoria em termos de eficiência e de características operacionais. O s avanços tecnológicos 
foram introduzidos mais intensamente por bancos nacionais do que por bancos estrangeiros. A s estruturas dos balanços contábeis nos dois casos são muito semel hantes, sendo caracterizadas por uma maior importância das operações de curto prazo, das aplicações em títulos públicos e dos investimentos em securitização.

Rocha (2002) conclui quea participação dos bancos estrangeiros na reestruturação bancária, entre 1997 e2000, foi fundamental para a solidez do setor bancário brasileiro. N o entanto, a mai oria das expectativas com relação à presença desses bancos não foi atendida, como, por exemplo, nas questões de eficiência, gerenciamento, capacidade de emprestar, diversificação esistemas de controles de riscos. A expectativa de redução dos spreads edosjuros ativos, com consequente ampliação do crédito, também não foi observada. O s bancos estrangeiros têm atuado de forma semelhante aos bancos nacionais, com relação à intermediação financeira e à preferência por operações de tesouraria, sendo ainda mais dependentes das aplicações financeirase em títulos da dívida pública - principal mente aindexada ao câmbio, da qual são os principais compradores. A justificativa para essetipo de atuação é a necessidade de fazer hedge em moeda estrangeira de seus investimentos no país, além de considerarem essas operações altamente lucrativas, sobretudo frente ao baixo risco.

A s expectativas de modificações e modernizações na regulamentação prudencial ena supervisão bancária pelos bancos estrangeiros também não foram observadas, já que estas estão muito mais relacionadas ao mercado doméstico, principal mente após os problemas bancários de 1995-1996. Portanto, os bancos estrangei ros não causaram mudan ças significativas no sistema bancário brasileiro, quer com relação à competitividade e eficiência, quer com relação ao estímulo ao crescimento, pela ampliação da oferta de crédito.

Por último, o autor conclui que é altamente improvável que a liberalização do sistema financeiro brasileiro resulte em desnacionalização bancária quase total, como ocorreu nos demais países da A mérica L atina, principalmenteA rgentina, $M$ éxico eC hile. A razão paraessa diferençaéa especificidade do mercado bancário brasileiro, no qual as instituições domésticas, tanto públicas federais quanto 
privadas, atuam como bancos universais, com grandes redes nacionais de atendimento eal ta participação no mercado. 0 s dois maiores bancos públicos federais, Banco do Brasil eC aixaE conômica Federal, respondem por parcela significativa deempréstimose depósitos, além deatuarem como instrumentos deimplementação de política econômica. O s dois mai ores grupos bancários privados nacionais, B radesco el taú, estão bem capitalizados egerenciados, além de apresentarem altas lucratividades. A participação ativa desses bancos na consolidação do setor bancário do país resultou em ganhos significativos deescala e demarket share, fazendo com queficassem com valores de mercado muito acima deseus valores patrimoniais, o que, adicionado aos significativos tamanhos relativos dessas instituições, dificulta em muito o recebimento de propostas de compra. O sbancos estrangeiros, após 1997, também se tornaram relevantes, porém de importância secundária, se comparados aos bancos nacionais.

\section{Caracterização do sistema financeiro nacional}

\section{Estrutura}

A estrutura funcional do Sistema Financeiro N acional (SF N) é composta de dois subsistemas, o normativo e o operativo. 0 subsistema normativo é constituído por órgãos normativos, responsáveis pelo estabelecimento de políticas e normas aplicáveis ao SF N , e por entidades supervisoras, que são responsáveis pela execução das políticas enormas estabel ecidas pel os órgãos normativos, bem como pela fiscal ização das instituições participantes do SF N (site do Banco Central do Brasil).

O s órgãos normativos do SF N são: o C onsel ho M onetário N acional (CM N), responsável pelo estabelecimento das diretrizes da política monetária, creditícia e cambial; o C onselho $\mathrm{N}$ acional de Seguros Privados (CN SP), responsável por fixar as diretrizes e normas da política de seguros privados; e o Consel ho de G estão da Previdência C omplementar (CG PC), responsável pela regulação, 
normatização e coordenação das atividades das entidades fechadas de previdência complementar (fundos de pensão).

A cada órgão normativo estão vinculadas entidades supervisoras, que são responsáveis por executar e fiscalizar o cumprimento das normas e políticas determinadas por cada órgão normativo. A s entidades supervisoras vinculadas ao $\mathrm{C}$ onsel ho $\mathrm{M}$ onetário $\mathrm{N}$ acional são o Banco C entral do Brasil e a C omissão deValores M obiliários (CVM ), queé a autarquia responsável por regulamentar, desenvolver, controlar e fiscalizar o mercado de valores mobiliários do país.

O Banco Central do Brasil, por suavez, éresponsável por garantir o poder decompra da moeda nacional, tendo por objetivos zelar pela adequada liquidez da economia, manter as reservas internacionais em nível adequado, estimular a formação de poupança, zelar pela estabilidade e promover o permanente aperfeiçoamento do sistema financeiro. D entre suas atribuições estão: emitir papel-moeda e moeda metálica; executar os serviços do meio circulante; receber recol himentos compulsórios evoluntários das instituições financeiras e bancárias; realizar operações de redesconto e empréstimo às instituições financeiras; regular a execução dos serviços de compensação de cheques e outros papéis; efetuar operações de compra e venda de títulos públicos federais; exercer o controle de crédito; exercer a fiscalização das instituições financeiras; autorizar o funcionamento das instituições financeiras; estabel ecer as condições para o exercício de quaisquer cargos de direção nas instituições financeiras; vigiar a interferência de outras empresas nos mercados financeiros e de capitais; e controlar o fluxo de capitais estrangeiros no país.

Para operacional ização de al gumas de suas atribuições, o Banco C entral do Brasil disponibiliza às instituições bancárias eaos bancos de investimento contas denominadas "reservas bancárias", cuja titularidade é obrigatória para as instituições que recebem depósitos à vista e opcional para os bancos de investimento e para os bancos múltiplos sem cartei ra comercial. Por meio dessas contas, as instituições financeiras cumprem os recolhimentos compulsórios/ encaixes obrigatórios sobre recursos à vista, sendo que elas funcionam também como contas de liquidação. 
A s entidades supervisoras do Consel ho $\mathrm{N}$ acional de Seguros Privados são: a Susep, que é a autarquia responsável pel o controle e fiscalização do mercado deseguro, previdência privada aberta ecapitalização; o I R B, por sua vez, tem a atribuição de regular o cosseguro, o resseguro ea retrocessão, além de promover o desenvolvimento das operações de seguros no país.

A entidade supervisora vinculada ao Consel ho de $\mathrm{G}$ estão da Previdência Complementar é a Secretaria de Previdência Complementar (SPC), que éo órgão responsável por fiscalizar as atividades das Entidades Fechadas de Previdência Complementar (fundos de pensão). A SPC se relaciona com os órgãos normativos do sistema financeiro na observação das exigências legais deaplicação das reservas técnicas, fundos especiais e provisões, que as entidades sob sua jurisdição são obrigadas a constituir equetêm diretrizes estabel ecidas pelo C onsel ho M onetário $\mathrm{N}$ acional.

O subsistema operativo, por sua vez, éconstituído por operadores vinculados a cada entidade supervisora. O s operadores vinculados ao Banco C entral são as instituições financei ras captadoras de depósitos à vista, as demais instituições financei ras e outros intermediários financei ros e administradores de recursos de terceiros.

São considerados instituições financei ras captadoras de depósitos à vista os bancos múltiplos, bancos comerciais, Caixa Econômica Federal e cooperativas de crédito. Todas essas instituições, com exceção das últimas, são os objetos de estudo deste trabalho. O s bancos múltiplos são instituições financeiras privadas ou públicas que real izam operações ativas, passivas e acessórias das diversas instituições financeiras, por intermédio das carteiras comercial, de investimento e/ ou de desenvolvimento (somente pode ser operada por banco público), de crédito imobiliário, de arrendamento mercantil e de crédito, financiamento einvestimento. 0 banco múltiplo deve ser constituído com, no mínimo, duas carteiras, sendo uma delas, obrigatoriamente, comercial ou de investimento. D eve ser constituído sob a forma desociedadeanônima eem sua denominação social deve constar a expressão "Banco". 9

9 R esolução C M N 2.099, de 1994. 
O s bancos comerciais são instituições financeiras privadas ou públicas, que têm como objetivo principal ofertar recursos para financiar, a curto e médio prazos, o comércio, a indústria, as empresas prestadoras deserviços, as pessoas físicas eterceiros em geral. A captação de depósitos àvista, livrementemovimentáveis, éatividade típica do banco comercial, que pode também captar depósitos a prazo. D eve ser constituído sob a forma de sociedade anônima e na sua denominação social deve igual mente constar a expressão "Banco".

A Caixa Econômica Federal, empresa pública vinculada ao M inistério da F azenda, assemelha-se aos bancos comerciais, podendo captar depósitos à vista, realizar operações ativas, efetuar prestação deserviços, operar com crédito direto ao consumidor, financiar bens deconsumo duráveis eemprestar sob garantia de penhor industrial e caução detítul os. D iferentemente das demais instituições, entretanto, a C aixa prioriza a concessão de empréstimos e financiamentos a programas e projetos nas áreas deassistência social, saúde, educação, trabalho, transportes urbanos, habitação, saneamento e esporte, além de possuir os monopólios do empréstimo sob penhor de bens pessoais e sob consignação e da venda de bilhetes de loteria federal. A instituição é responsável, ainda, por centralizar o recolhimento e posterior aplicação de todos os recursos oriundos do $\mathrm{F}$ undo de G arantia do Tempo de Serviço (F G T S), integrando o Sistema Brasileiro de Poupança e Empréstimo (SBPE) e o Sistema Financeiro da $\mathrm{H}$ abitação (SF H).

A s cooperativas de crédito são originadas da associação depessoas de uma área determinada de atuação, sob certas condições, como, por exemplo, funcionários de uma mesma empresa ou grupo de empresas, profissionais de determinado segmento ou empresários. O s eventuais lucros auferidos com as operações de prestação de serviços e oferecimento de crédito aos cooperados são repartidos entre os associados. Para constituição, devem possuir o número mínimo de vinte cooperados e adequar sua área de ação às possibilidades de reunião, controle, operações e prestações de serviços. Estão autorizadas a aplicar recursos no mercado financeiro ea real izar operações de captação por meio de depósitos à vista ea prazo de associados, de 
empréstimos, repasses e refinanciamentos de outras entidades financeiras, e de doações. Podem conceder crédito somente a associados, por meio de desconto de títulos, empréstimos efinanciamentos. As cooperativas de crédito devem adotar, obrigatoriamente, em sua denominação social, a expressão "C ooperativa", sendo vedada a utilização da palavra "Banco".

A s demais instituições financei ras são: agências de fomento; associações de poupança e empréstimo; bancos de desenvolvimento; bancos de investimento; Banco $\mathrm{N}$ acional de D esenvolvimento E conômico e Social (BN DES); companhias hipotecárias; cooperativas centrais de crédito; sociedades de crédito, financiamento e investimento; sociedades de crédito imobiliário; esociedades de crédito ao microempreendedor.

São classificad os como outros intermediários financeiros eadministradores de recursos de tercei ros as administradoras de consórcio, as sociedades de arrendamento mercantil, as sociedades corretoras de câmbio, as sociedades corretoras de títulos evalores mobiliários, as sociedades de crédito imobiliário e as sociedades distribuidoras de títulos e valores mobiliários.

O s operadores vinculados à C V M são as bolsas de mercadorias e futuros e a Bolsa deV alores. O s operadores da Susep são o Instituto de R esseguros do Brasil (IRB), as sociedades seguradoras, as sociedades de capitalização e as entidades abertas de previdência complementar. O s operadores vinculados à SPC , por sua vez, são as entidades fechadas de previdência complementar (fundos de pensão).

D entreas instituições relacionadas, ocupam posição dedestaque, no âmbito do sistema de pagamentos, os bancos comerciais, os bancos múltiplos com carteira comercial, as caixas econômicas e, em plano inferior, os bancos cooperativos e as cooperativas de crédito. E ssas instituições captam depósitos à vista e, em contrapartida, oferecem aos seus clientes contas movimentáveis por cheque, muito utilizadas pelo público em geral, pessoas físicas ejurídicas, para fins de pagamentos e transferências de fundos.

O Sistema Financeiro N acional está dividido, ainda, em dois grandes segmentos: o mercado de crédito e o mercado de capitais. 
0 mercado de capitais restringe-se a apenas al gumas grandes empresas que conseguem realizar captações por meio da emissão de debêntures e notas promissórias, tanto no mercado interno quanto no externo. 0 mercado de crédito, por sua vez, é composto por recursos direcionados e recursos livres. O s recursos direcionados são aquel es utilizados em operações com taxas já estabel ecidas, por meio de programas ou repasses governamentais, geralmente destinados aos setores rural, habitacional edeinfraestrutura. O s recursos livres, por sua vez, estão associados às operações contempladas na C ircular no 2.957/ 1999 do Banco C entral, com taxas de juros livremente acordadas entre o credor e o tomador. E sses recursos podem ser destinados a diversas linhas definanciamentos, criadas pel o sistema financei ro para atender à demanda por crédito dos vários setores da economia, principalmente com relação à necessidade de capital de giro (Jacob, 2003).

Com relação à propriedade, as instituições podem ser classificadas em bancos públicos (federais ou estaduais), privados nacionais, privados com controle estrangeiro e privados com participação estrangeira. 0 s bancos públicos operam em segmentos de interesse estratégico para o desenvolvimento econômico, atuando, especialmente, no provimento de crédito direcionado de longo prazo. U ma das principais diferenças dessas instituições em relação às demais são as condições de captação de recursos, uma vez que grande parte dos seus passivos é formada por depósitos compulsórios com taxas administradas (J acob, 2003). A s instituições com maior participação no total de ativos do sistema financeiro, eque serão analisadas neste trabal ho, são o Banco do B rasil e a C aixa E conômica F ederal.

O s bancos privados atuam, principalmente, como provedores de capital de giro ou de recursos de curto prazo. E mbora tenham operações com recursos direcionados, por meio de repasses e da carteira do Sistema Financeiro da H abitação, suas estratégias estão voltadas, principalmente, para prover recursos livres (J acob, 2003). São considerados bancos privados nacionais aqueles em que a participação estrangeira no capital votante éinferior a 10\%. O s bancos com participação estrangeira são aqueles em que de 10\% a 49,9\% do 
capital votante pertence a estrangeiros. O s bancos com controle estrangeiro, por sua vez, são aqueles em que a participação estrangeira no capital votante é superior a $50 \%$.

R ecentemente, tem sido observada uma forte transformação no perfil do credor brasileiro, com o setor privado assumindo crescente parcela de mercado anteriormente ocupada pelo setor público. E sta inflexão das participações dos dois setores ocorre com maior intensidade após 1994, depois da estabilidade monetária, e no ano 2000, com a privatização do Banespa (T abela 1.6). Este processo deve-se à forte crise de liquidez enfrentada pelos bancos estaduais e ao consequente processo de privatização estimulado pelo Proes. A tualmente, a participação do crédito do setor público é sustentada pelo Banco do Brasil, Caixa E conômica Federal, Banco $\mathrm{N}$ acional de D esenvolvimento E conômico eSocial, $\mathrm{N}$ ossa Caixa ealguns bancos estaduais, como o Banrisul.

T abela 1.6 - Evolução da participação dos sistemas financeiros público eprivado nas operações de crédito do sistema financeiro

\begin{tabular}{c|c|c}
\hline Ano & Setor Público & Setor Privado \\
\hline 1988 & $65 \%$ & $35 \%$ \\
\hline 1989 & $68 \%$ & $32 \%$ \\
\hline 1990 & $67 \%$ & $33 \%$ \\
\hline 1991 & $65 \%$ & $35 \%$ \\
\hline 1992 & $64 \%$ & $36 \%$ \\
\hline 1993 & $62 \%$ & $38 \%$ \\
\hline 1994 & $58 \%$ & $42 \%$ \\
\hline 1995 & $56 \%$ & $44 \%$ \\
\hline 1996 & $56 \%$ & $44 \%$ \\
\hline 1997 & $56 \%$ & $44 \%$ \\
\hline 1998 & $53 \%$ & $47 \%$ \\
\hline 1999 & $52 \%$ & $48 \%$ \\
\hline 2000 & $49 \%$ & $51 \%$ \\
\hline 2001 & $38 \%$ & $62 \%$ \\
\hline 2002 & $37 \%$ & $63 \%$ \\
\hline
\end{tabular}

Fonte: Elaboração própria a partir de dados extraídos do site do Banco C entral do Brasil. 


\section{Regulamentação}

A s crises bancárias se mostraram recorrentes e quase inexoráveis ao longo da história dos bancos. 0 setor possui uma significativa vulnerabilidade, uma vez que participa da soberania monetária do Estado, na medida em quecria dinheiro de crédito, realiza os serviços decompensação eadministra os meios de pagamento. A lém disso, as instituições bancárias são altamente endividadas, por meio de uma "correntedeelos", demodo queuma criseem apenas umainstituição pode se transformar, facilmente, em crise geral do sistema. A relevância do setor também podeser explicada pelo papel estratégico que desempenha na economia, por meio da intermediação financeira edo financiamento das atividades econômicas. A scrises bancárias afetam a economia deforma mais profunda do queas crises deoutras empresas, já que afetam o crédito, juros, investimentos e o nível da atividade econômica, provocando, ainda, fugas de capital eo agravamento dos problemas de balanço de pagamentos. A demais, a solução de crises bancárias exigegrande volumederecursos públicos (C orazza, 2001).

D e modo geral, as crises são provocadas pela conjugação de fatores macroeconômicos, como um ambiente de instabilidade, e microeconômicos. A fragilidade microeconômica pode ser consequência de uma baixa qualidade dos ativos, decorrente de uma má administração ou de práticas fraudulentas, o que, por sua vez, écausado, principalmente, por deficiências do sistema de regulamentação e supervisão bancárias.

G eralmente, as crises bancárias têm início no auge dos ciclos econômicos, pois nesses períodos os bancos tendem a aumentar os empréstimos e a assumir maiores riscos. Essa tendência expressa a hipótese da fragilidadefinanceira formulada por M insky, em 1982. 0 auge cíclico depende crescentemente do endividamento para financiar gastos deexpansão; entretanto, os lucros não crescem na mesma taxa que o endividamento, fazendo com que as empresas se tornem incapazes de saldar seus compromissos financeiros. Esse processo resulta em aumento da inadimplência e, portanto, da fragilização dos bancos, provocando as crises (C orazza, 2001). 
D essa forma, devido à sua importância econômica eà existência de assimetrias de informação em suas operações, o que poderia levar ao surgimento de risco sistêmico e de sel eção adversa, o setor de serviços financeiros necessita de um conjunto de instituições governamentais e de mercado que seja capaz de fornecer um sólido arcabouço de regulamentação e de fiscalização de suas atividades (Strachman eVasconcelos, 2001).

Torna-se necessária até mesmo, em uma época de crescente integração internacional de comércio, finanças e fluxos de capitais, a homogeneização dos diferentes mercados nacionais, em direção a um padrão comum de ordenamento institucional. $V$ ários fóruns de discussão, como BIS, F M I, OECD e OM C, procuram definir esse ordenamento institucional. Entretanto, atualmente, vem sendo adotado o paradigma vigentenosEU A, direcionado, principalmente, aos interesses dos acionistas (Strachman eV asconcel os, 2001).

Para enfrentar os desafios da regulamentação prudencial, criados pelas transformações financeiras intensas ocorridas desdea década de 70, principal menterelacionadas à liberalização dos controles sobreas atividades dos bancos e das instituições financeiras não bancárias, à securitização, à proliferação dos instrumentos derivativos de crédito eà gl obal ização financeira, os bancos centrais dos países do chamado G rupo dos 10 (G 10) ${ }^{10}$ criou, em 1975, o B asle C ommittee. 0 chamado C omitê para Práticas de Supervisão e R egulamentação Bancária do Banco de C ompensações I nternacionais (BIS) tem procurado estabelecer eaperfeiçoar normas e princípios comuns de referência para o sistema bancário internacional. Em 1988, os bancos centrais do G 10 assinaram um acordo denominado I nternational C onvergence of C apital M easurement and Capital Standards, conhecido como A cordo da Basileia, que previu a harmonização internacional das regulamentações relativas à adequação de capital dos bancos internacionais. Seu principal objetivo era fortalecer o sistema financeiro internacional ereduzir uma fontededesigual dade competitiva entre

10 O s países-membros do G 10 são Bélgica, C anadá, França, A lemanha, I tália, J apão, H olanda, Suécia, R eino U nido, Estados U nidos e Suíça. 
os bancos internacionais. Para al cançar esses objetivos, foram especificados os recursos que podem ser considerados como capital dos bancos eestabel ecidos os requerimentos mínimos para a capital ização dessas instituições.

N essa nova sistemática, o montante de capital de um banco é determinado em função da razão capital-ativo, que corresponde ao inverso da alavancagem, e em função do risco diferenciado das operações ativas. A utilização desses dois conceitos pode ser justificada pelo fato de os bancos utilizarem, geralmente, muito mais alavancagem financeira do que a maioria das outras corporações comerciais, o que faz com que seja necessário o estabelecimento de um limite para essa al avancagem. A lém disso, os bancos assumem mais riscos operacionais do que as empresas produtivas, sendo necessário explicitar e ponderar esses riscos em relação ao patrimônio da instituição (Soares, 2001).

A adesão ao A cordo não éobrigatória, entretanto a não aderência sujeitaria o país a coerções de ordem política eeconômica. A o aderir ao A cordo, a autoridade monetária do país assume o compromisso de exigir dos bancos um nível de capital que seja compatível com o volume de suas operações ativas, ou seja, queo Patrimônio L íquido A justado (PLA) dos bancos seja igual ou superior ao Patrimônio L íquido Exigível (PLE). 0 A cordo definiu o PL A como o capital mínimo compatível com o grau de risco das operações ativas, sendo formado pela soma dos valores contidos em duas categorias de contas: principal (nível um), que deve compor, no mínimo, 50\% do capital, e suplementar (nível dois). A s contas de nível um, consideradas integral menteno PLA, incluem somenteações permanentes ereservas abertas, como o montante de capital social, reservas de capital, reservas de lucros livres de compromisso, dentre outras contas. As contas de nível dois, consideradas parcialmente no PLA, incluem reservas fechadas, reservas de reavaliação, reservas de contingências, reservas especiais delucros não distribuídos, dentre outras. O PLE, por sua vez, representa o capital que o banco deve ter eé obtido por meio da multiplicação do inverso da al avancagem - quecorresponde à razão capital-ativo - pelo total do ativo ponderado pelo risco. 0 
capital de um banco, portanto, deve ser função direta do risco dos seus ativos eindireta da al avancagem, o que representou a exigência de maior nível de capitalização às instituições mais propensas ao risco (Soares, 2001).

Cabeao Banco C entral do país, ainda, para cálculo do PL E, adefinição da al avancagem do sistema financei ro edo risco (ponderação) dos ativos bancários, bem como a determinação de quais recursos (contas do balancetepatrimonial) os bancos devem considerar como componentes do PLA.

O A cordo estabel ece que os países signatários devem possuir um valor mínimo de alavancagem de 12,5, o que corresponde a um capital mínimo de $8 \%$ em relação ao ativo total ponderado. A lém disso, foram definidas cinco categorias de risco para os ativos: disponibilidades, títulos federais, aplicações em ouro, títulos dos governos estaduais e municipais e créditos, que são classificados em risco nulo, reduzido e risco normal, com ponderação de 0\%, 10\%, 20\%, $50 \%$ e $100 \%$, respectivamente. Entretanto, as autoridades nacionais estariam livres para fixar exigências mais al tas que as contempladas no A cordo (Soares, 2001).

O Banco Central do Brasil aderiu ao A cordo da Basileia em agosto de 1994, ${ }^{11}$ mesmo ano da estabilização econômica, sujeitando os bancos brasileiros à manutenção deum Patrimônio L íquido Exigido (PLE ), em função do risco, de pelo menos 8\% das operações ativas. E m 1997, com o objetivo de contrair o crédito, esse percentual foi el evado para $10 \%{ }^{12}$ e, posteriormente, para $11 \%,{ }^{13}$ com consequente redução da al avancagem para 9,09\% (J acob, 2003). A lém disso, nesse mesmo ano, o Banco C entral el evou o risco do crédito tributário de $20 \%$ para $300 \%$ e incluiu as operações de swap, com ouro e as referidas em outras moedas na equação de cál culo do PL E , como soma de parcelas independentes (Soares, 2001).

11 R esolução nํ 2.099, de agosto de 1994.

12 R esolução nํ⒉399, de 1997.

13 Circular no 2.784, de 1997. 
Para estabelecer o PL E, foram criadas cinco classificações de risco dos ativos, com ponderação de $0 \%, 20 \%, 50 \%, 100 \%$ e $300 \%$, sendo: $0 \%$ (risco nulo) - atribuído a ativos como recursos em cai$x a$, reservas junto à autoridade monetária, títulos públicos federais e reservas em moeda estrangeira depositadas no Banco C entral; $20 \%$ (risco reduzido) - atribuído a depósitos bancários delivremovimentação mantidos em bancos, aplicações em ouro e disponibilidades em moeda estrangeira; 50\% (risco reduzido) - atribuído a títulos estaduais emunicipais, financiamentos habitacionais e aplicações no interbancário; 100\% (risco normal) - atribuído às aplicações em ações, debêntures, obrigações da Eletrobrás, T ítulos da D ívida A grária (T D A ), às operações vinculadas a bolsas devalores, de mercadorias e de futuros e às operações de empréstimos e financiamento, tais como financiamentos rurais, agroindustriais, a empreendimentos imobiliários, de infraestrutura, de desenvolvimento e à exportação (Soares, 2001); e 300\% - atribuído aos créditos tributários.

D essa forma, não há exigência de capital para deter títulos públicos, ao passo que, para cada $R \$ 100,00$ emprestados, a instituição deve deter $\mathrm{R} \$ 11,00$ em capital próprio (J acob, 2003). O u seja, a limitação para que os bancos comprem títulos do governo federal passa a ser a sua capacidade de captar recursos a um custo inferior ao rendimento desses títulos.

$\mathrm{N}$ ão foi estabelecido, entretanto, o procedimento para o cálculo do Patrimônio L íquido A justado (PLA), deforma queo Patrimônio $\mathrm{L}$ íquido (PL) acrescido do resultado entre receitas e despesas foi utilizado como proxy do PL A. Somente em agosto de 1998, com a R esolução no 2.543, o PL A foi definido em conformidade com o A cordo daBasileia, ou seja, pel o somatório dos doisníveis decapital, principal esuplementar (Banco Central do Brasil, 1998).

Essa mesma resolução normatizou, ainda, outras questões relacionadas ao capital das instituições bancárias, como um montante mínimo de capital para funcionamento dos bancos e o patrimônio mínimo necessário das pessoas físicas que controlam as instituições financeiras. Essas outras regulamentações, que não constavam no A cordo da Basileia, foram consideradas por alguns autores como 
responsáveis pela criação de dificuldades para os bancos pequenos, restringindo a concorrência no setor, em um momento em queessas instituições necessitavam de estímulo. U m desses críticos, R oberto T roster, argumentou que essas exigências contribuíram para a oligopolização do setor, ao fragilizar mais de cinquenta bancos. 0 aumento de capital para os bancos comerciais foi de $60 \%$. N o caso dos bancos múltiplos, o aumento foi diferenciado por carteira, sendo de $60 \%$ para as cartei ras comerciais e de investimento, de $722 \%$ para as de desenvolvimento, de $135 \%$ para as financeiras e de $174 \%$ para a carteira imobiliária (Soares, 2001).

Como a lucratividadeémedida pela razão lucro-capital, o banco postergará a ampliação do seu capital para maximizar sua taxa de Iucro. D essa forma, tenderá a aplicar percentual maior dos seus recursos em ativos quenão exigem correspondência com o capital, o quenão éo caso do crédito. Portanto, aumentar a razão capital- ativo (diminuir a alavancagem) é uma maneira de restringir os créditos, uma vez que, seos bancosnão puderem ou não acharem conveniente aumentar o capital, deverão reduzir as aplicações derisco, ou seja, os empréstimos. Por outro lado, o sistema ten de a aumentar a demanda por títulos do governo federal, considerados aplicações sem risco, mesmo que o volume de crédito do banco não supere o seu limite.

Em estudos, foi verificado que os bancos brasileiros possuem um perfil conservador no que diz respeito à exigência de capital mínimo em relação ao risco das operações ativas, uma vez queesse percentual, na maioria dos casos, supera os limites estipulados pelo Comitê da Basileia (D e Paula e M arques, 2006). Em dezembro de 2006, o I ndicede Basileia, no B rasil, foi $18,8 \%$, ou seja, 7,8 pontos percentuais maior do que o mínimo exigido no país. $\mathrm{N}$ os vinte e quatro meses anteriores, a variação foi muito pequena, sendo que o menor índice foi de $17,5 \%$ em maio de 2006 , enquanto o maior foi de $19,4 \%$ em setembro de 2006 (Banco C entral do Brasil, 2007). ${ }^{14}$

14 Em dezembro de2006, das 1.781 instituições existentes, estavam desenquadradas do L imite de Basileia 55 instituições de pequena representatividade sob a ótica do SF N (Banco Central, 2007). 
No intuito deaperfeiçoar egarantir um monitoramento das atividades bancárias, o C omitêda Basileia divulgou, em 1997, um estudo preliminar sobre "os princípios fundamentais para uma supervisão bancária ef etiva". Esse estudo sugeriu a adoção de 25 princípios como referência básica para as autoridades de supervisão em todos os países, membros ou não membros. Foi proposto, ainda, quefosse efetuado, juntamente com autoridades multilaterais (como o F M I), o monitoramento da implementação desses princípios nos diversos países (F reitas ePrates, 2003). Esses princípios buscavam assegurar que as instituições estabelecessem e cumprissem políticas, práticas e procedimentos adequados, possuíssem sistemas de informações gerenciais que permitissem identificar a eventual concentração de risco em suas carteiras eimplementassem políticas e procedimentos adequados para monitorar e controlar esses riscos. Em 1998, com a final idade de aprimorar ainda mais a supervisão dos riscos e controles, o Comitêpublicou os treze princípios que compõem os alicerces dos controles internos (M oraes, 2003).

A partir da crise asiática do final dos anos 90 , surge um esforço mundial no sentido de rediscutir as leis de insolvência, objetivando a criação de estruturas que pudessem minimizar os efeitos das crises sistêmicas financeiras sobre o setor real e que incentivassem esforços de recuperação eficientes (C osta, 2004). Esse reordenamento foi proposto com o objetivo de resolver três questões principais: a) o funcionamento inadequado e ineficiente do mercado financeiro internacional, bem como a insuficiência de transparência das informações sobre os países periféricos; b) a negligência dos bancos e investidores estrangeiros, resultado da expectativa de que o $\mathrm{FM} \mathrm{I}$ e os governos dos países centrais socorreriam os países em caso de crises de liquidez ou solvência (problema de moral hazard); ec) as deficiências verificadas na infraestrutura institucional dos sistemas financeiros dos países periféricos (F reitas e Prates, 2003).

N esse contexto, o Comitê divulgou, em 1999, uma proposta de revisão do A cordo de Capital de 1988 . 0 chamado $\mathrm{N}$ ovo A cordo de C apital da Basileia, N ovo A cordo ou Basileiall apresentou alternativas mais sofisticadas para o cál culo do capital mínimo regulamentar. 
D irecionado para os grandes bancos internacional mente ativos, 0 $\mathrm{N}$ ovo A cordo se baseia em três pilares complementares: a) requerimento mínimo de capital, no qual também foi incluída uma matriz de classificação de crédito externo, contra os quais certos níveis de capital precisam ser mantidos, bem como o risco operacional e 0 risco excessivo de taxa de juros; ${ }^{15}$ b) redefinição da supervisão da adequação de capital, pilar que está baseado no estilo de supervisão britânico de revisão contínua, no qual a instituição tem flexibilidade para exigir uma reserva de capital superior ao nível mínimo de 8\%, de acordo com o grau de sofisticação das relações e da capacidade de o banco estabelecer um padrão de controle interno; e c) disciplina demercado, queconsisteno fornecimento deinformações suficientes para viabilizar uma avaliação da gestão dos riscos e de seus níveis de adequação de capital (F reitas e Prates, 2003).

U ma das principais al terações verificada nesse $\mathrm{N}$ ovo A cordo éa incorporação do risco operacional em sua estrutura (requerimento a, acima), pois se verificou que, mesmo após a implementação do A cordo da Basileia I, os bancos continuaram a incorrer em perdas financeiras. Podem ser caracterizados como riscos operacionais os assaltos, violação de computadores, fal has em sistemas, processos inadequados e erros de funcionários. $\mathrm{N}$ esse sentido, 0 atendimento ao quesito transparência, terceiro pilar (c) do N ovo A cordo, é extremamente importante para expor ao mercado quais medidas são adotadas para mitigar tais riscos (Caldas e Carval ho, sem data).

Caldas e $C$ arvalho (sem data) destacam que as principais diferenças entre os A cordos da Basileial ell , na prática, são estruturais. $\mathrm{N}$ os dois $\mathrm{A}$ cordos, as instituições financei ras devem ter capital suficiente para fazer frenteaos riscos que reconhecem e resolvem correr em função de o trade- off risco/ retorno ser favorável; entretanto, o $\mathrm{N}$ ovo A cordo acrescenta quea adoção de boas práticas de gerenciamento de riscos pel os bancos deve ser verificada pelos reguladores. É adicionada também a necessidade de queas instituições demons-

15 Q uando os bancos utilizam como funding deoperações de médio prazo recursos de curto prazo sem efetuar hedge adequado. 
trem transparência e melhor comunicação com o mercado em que atuam.

O A cordo da Basileiall busca minimizar os problemas resultantes da padronização imposta por regras gerais. D essa forma, torna possível que as instituições adotem modelos mais próximos de seu ambiente particular, ou seja, mais compatíveis com o perfil de risco de cada uma, conforme a atividade que decidam realizar.

Posteriormente, na divulgação do N ovo A cordo, foram introduzidos, no primeiro pilar, novos critérios alternativos para a classificação dos riscos. Foi permitida a utilização dos ratings de crédito externo (credit external ratings) elaborados pelas agências privadas de classificação de risco, bem como a adoção de ratings internos (internal ratings based approach), elaborados pelos próprios bancos, desde que aprovados pelas autoridades domésticas de supervisão. Entretanto, inicial mente, a maioria dos bancos deveria adotar os ratings externos, pois somente os grandes bancos internacionais teriam condições de desenvolver internamente sistemas sofisticados de avaliação dos riscos.

F reitas eP rates (2003) argumentam, contudo, queas novas regras podem ter efeitos prejudiciais sobre as condições de financiamento dos países, por dois motivos. Primeiramente, poderão deteriorar as condições de acesso ao mercado internacional de crédito, tanto no segmento de empréstimos bancários quanto no de crédito securitizado, uma vez que os bancos internacionais são, ao lado dos investidores institucionais, os principais compradores de títulos de renda fixa (bônus, euronotes, commercial papers etc.). Por outrolado, as novas regras podem af etar negativamenteas condições domésticas definanciamento bancário.

A sautoras argumentam queo N ovo A cordo atribuiu importância significativa às agências de rating. T odavia, é importante salientar que essas agências desempenharam um papel fundamental na propagação da crise de desconfiança nos países asiáticos, reforçando o comportamento de manada característico do funcionamento dos mercados financeiros, além de terem se equivocado fortemente em seus ratings originais, pois, seassim não fosse, estes não precisariam 
ser revistos deformatão abrupta. Para um país em desenvolvimento, o anúncio deum rebaixamento na classificação das agências derating podeter implicação sistêmica, uma vez que podeoriginar uma fuga de capitais, o que conduziria a um novo rebaixamento, reforçando o pânico e criando um círculo vicioso que dificultaria ainda mais o acesso aos mercad os internacionais. A s novas regras poderiam, ainda, deteriorar as condições de acesso dos países em desenvolvimento ao mercado de crédito bancário nas situações de normalidade, uma vez queos critérios utilizados na anál isee classificação do risco soberano não são claros. G eralmente, essas agências se baseiam na análise de variáveis de difícil mensuração.

O utros problemas podem ser gerados devido à utilização dos

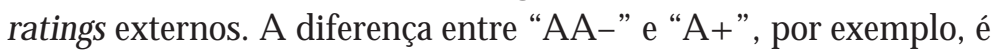
insignificante em termos de risco de falência, mas implica um salto de $20 \%$ a 100\% no aprovisionamento de capital, no caso de uma corporação. A lém disso, somente as corporações e bancos americanos são amplamente avaliados (mesmo assim, apenas se emitem títulos dedívida). N a E uropa essesistema está começando a se desenvolver, enquanto nos países periféricos a atuação destas agências éainda mais limitada. Por último, empresas que recorrem a agências de rating e forem classificadas abaixo de "B-" serão penalizadas com $150 \%$ de aprovisionamento, enquanto que as empresas sem avaliação devem ter uma provisão de 100\%. Esse critério incentivará as empresas com maiores dificuldades a não procurar obter uma avaliação. ${ }^{16}$

N o caso do Brasil, a implementação desseN ovo A cordo está sendo feita de forma gradual, sendo que o cronograma de implantação para os diferentes métodos, estabelecido pel o Banco C entral, abrange o período de 2006 a 2011 (Caldas e Carvalho, sem data). E m 2011, será iniciado o processo de autorização para uso de modelos internos, que deverão ser implementados em 2013, em substituição aos model os padronizados. Em julho de 2008, grandepartedas medidas do $\mathrm{N}$ ovo A cordo foram implementadas, dentre as quais podemos

16 A única agência que divulga ratings não solicitados éa M oody's. 
destacar: exigência de alocação de capital para cobertura do risco operacional edos riscos demercado dejuros pós-fixados, commodities eações; redução do percentual de al ocação de capital para operações devarej ${ }^{17}$ de $100 \%$ para $75 \%$, uma vez quesão de menor val or etêm risco diluído; aumento da alocação de capital para linhas em que o banco não pode suspender o crédito de forma unilateral, como é o caso das contas garantidas e do cheque especial (nesses casos, 0 banco deverá al ocar capital para todo o limite de crédito disponível ao cliente, mesmo queestenão tenha sido utilizado); a denominação do capital mínimo exigido dos bancos para cobrir perdas inesperadas nas suas atividades foi alterada dePatrimônio $L$ íquido Exigido (PL E) para Patrimônio de R eferência Exigido (PRE), queconsiderará seis tipos de risco - operacional, variação de ações, taxas dejuros e preços demercadorias ecommodities, exposição em ouro, moeda estrangeira evariação cambial. N o caso do crédito imobiliário, a ponderação foi vinculadaà rel ação entreo val or emprestado eo val or do imóvel. C aso o banco financieaté $50 \%$ do valor do imóvel com garantia dealienação fiduciária ou hipoteca, a exigência de capital será $30 \%$ menor do que na regraanterior; sefinanciar entre $50 \%$ e $80 \%$, a exigência permanece a mesma; e, se o financiamento superar $80 \%$, o capital exigido será $100 \%$ maior do que na regra anterior.

Tendo em vista que al gumas medidas implicam redução do capital alocado, enquanto outras levarão ao aumento desse capital, o Banco Central estima que o efeito dessas alterações no sistema será nulo. Individualmente, porém, as instituições financei ras poderão ter al gum impacto, aumentando ou diminuindo a exigência de capital próprio (Valor E conômico, 5/ 5/ 2008).

A lém da adesão ao A cordo da Basileia, também foram criados, no Brasil, alguns instrumentos que exigiram maior transparência na gestão de risco dos bancos e proporcionaram melhores condições para a concessão de crédito (J acob, 2003).

17 São consideradas operações devarejo os empréstimos até $\mathrm{\$} \$ 400$ mil, concedidos a pessoas físicas ou pequenas empresas com faturamento anual deatéR $\$ 2,4$ milhões. 
Em de agosto de 1995, foi criado, pelo Banco Central, o F undo

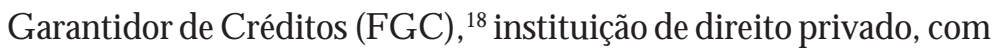
capital formado, principalmente, por contribuições efetuadas pelas próprias instituições financeiras, da qual participam as instituiçõesfinanceiras eas associações de pou pança e empréstimos. Por meio desse fundo, são garantidos os créditos de cada cliente contra a mesma instituição, ou contra todas as instituições do mesmo conglomerado financeiro. Q uando foi criado, o val or máximo garantido pelo F G C era de $\$ 20$ mil; entretanto, a partir de setembro de 2006, ${ }^{19}$ esseval or passou a ser deR \$ 60 mil. A lém disso, a contribuição mensal devida pelas instituições associadas passou de 0,3\% a.a. para 0,15\% a.a.

Em novembro de $1995,{ }^{20}$ foi estabelecido um limiteinicial maior de capital para a constituição de novos bancos, o que incentivou os processos de incorporação e transferência de controle acionário. Passou a ser exigido, ainda, que os controladores comprovassem ter uma situação econômica compatível com o empreendimento e correspondentea no mínimo 220\% do maior dos seguintes parâmetros: valor patrimonial contábil, capital mínimo paraa instituição previsto na regulamentação vigente e preço de aquisição (Puga, 1999).

E m março de 1996, ${ }^{21}$ foi ampliada a responsabilidade das empresas de auditoria contábil e dos auditores contábeis independentes em casos de irregularidades na instituição financeira analisada. D essa forma, criou-se um incentivo para que esses agentes informem ao Banco C entral sempre que forem identificados problemas ou que houver recusa do banco em divulgar as informações.

A dicionalmente, a R esolução № 2.302, de 25 de julho de 1996, determinou a consolidação das demonstrações financei ras das atividades no Brasil com as demonstrações financeiras do banco em outros países, para efeitos decál culo dos limites operacionais do A cordo da

18 R esolução nำ 2.211/ 95, do C onselho M onetário N acional, e C ircular Bacen $\mathrm{n}=3.270 / 04$.

19 R esolução no 3.400, de 6 de setembro de 2006.

20 R esolução nำ2.212, de novembro de 1995.

21 M edida Provisória ํo 1.334, de 13 de março de 1996. 
Basileia, aumentando, dessa forma, as exigências de capital mínimo para a constituição de bancos com dependências no exterior. Essa mesma resolução instituiu a I nspeção G lobal C onsolidada (IG C), que permitiu o aprimoramento dos procedimentos de fiscal ização do Banco C entral. A I G C passou a verificar os tipos deatividade da instituição e do grupo econômico do qual ela faz parte e a analisar a política operacional da instituição, com o objetivo de avaliar sua situação econômico-financeira e o risco global do grupo econômico.

Em 2001, foi realizada umal G C para adequação patrimonial dos quatro principais bancos federais, Banco do Brasil, Caixa E conômica Federal, Banco do N ordeste e Banco da A mazônia, no âmbito do Programa de Fortalecimento das I nstituições F inanceiras Federais (Proef). N esseprocedimento, foi identificadaa presença significativa de créditos de baixa remuneração e/ ou de difícil recuperação, além de elevados subsídios, vinculados, principalmente, às operações de crédito nas áreas de saneamento, habitação, agricultura, pequenos e médios produtores e financiamentos de programas de desenvolvimento regional.

Para adaptar o patrimônio dos bancos às exigências da regulamentação, o governo adotou as seguintes medidas: transferência do risco desses créditos para o T esouro $\mathrm{N}$ acional ou para uma empresa não financeira, denominada Empresa $\mathrm{G}$ estora de A tivos (E mgea); troca deativos de pouca liquidez ebaixa remuneração por ativos líquidos, remunerados à taxa de mercado; aumento de capital, realizado na CEF, no Banco do N ordeste eno Banco da A mazônia.

A inda em julho de 1996, a R esolução no 2.303 permitiu que as instituições financei ras cobrassem tarifas pela prestação deserviços. E ssa medida buscou amenizar a perda de receita pel os bancos com a queda da inflação (Puga, 1999).

Em maio de 1998, ${ }^{22}$ os bancos passaram a ter a possibilidade de vender parte ou toda a carteira de crédito a sociedades anônimas de objeto exclusivo, a partir das Companhias Securitizadoras de C réditos Financeiros (C SC F ). Essa medida facilitou a recuperação do capi-

22 R esolução no 2.493, de maio de 1998. 
tal emprestado, estimulando as instituições financeiras a ampliarem a oferta de crédito. A lém disso, a medida possi bilitou a agilização do processo de saneamento dos bancos, uma vez que permitiu o repasse dos créditos das instituições sob intervenção (Puga, 1999).

A lém dessa medida, o Banco C entral determinou, em 1999,, ${ }^{23}$ que as instituições financeiras classifiquem suas operações de crédito em níveis de risco, em ordem decrescente. Para isso, foram criados nove níveis de classificação de risco, de A A a H , que devem ser revistos periodicamente, bem como o provisionamento que deverá ser realizado em cada caso. E ssa medida tem como objetivo oferecer maior transparência com relação à qualidade da carteira de crédito dos bancos, possibilitando que o Banco C entral fiscalize as instituições financeiras, além deconstranger a displicência por partedos gestores de crédito. Espera-se, com essa medida, a mudança no comportamento dos bancos com relação à concessão de crédito (J acob, 2003).

A Central de Risco de C rédito foi criada em maio de 2000, pelo Banco $C$ entral, ${ }^{24}$ com o propósito de oferecer umaferramenta depesquisa para as instituições anal isarem o risco de crédito dos tomadores. E sse sistema pode simular dados contábeis para angariar crédito no sistema financeiro. A C entral de R isco de C rédito está instalada no Banco Central e recebe informações de todos os bancos sobre seus clientes com saldos devedores superiores a um determinado valor. E ssas informações são utilizadas pela autoridade fiscalizadora para aprimorar sua capacidade deaval iação da concentração dos empréstimos por devedor/ conglomerado, mensuração do risco e análise da qualidade do portfolio bancário.

O Banco Central patrocinou uma série de medidas objetivando o fortal ecimento do sistema de pagamentos, sendo que o principal marco legal da reforma foi instituído pela L ei no 10.214 , de março de 2001, que determinou: a definição do Sistema de Pagamentos B rasileiro (SPB) e dos sistemas que o integram; a atribuição ao Banco C entral da definição dos sistemas considerados sistemicamente

23 R esolução no 2.682, de dezembro de 1999.

24 R esolução nํ⒉390, de maio de 1997. 
importantes, ${ }^{25}$ o reconhecimento da compensação multilateral nos sistemas de compensação e deliquidação; a definição deque, em todo sistema de compensação multilateral considerado sistemicamente importante, a correspondente entidade operadora deve atuar como contrapartecentral eassegurar a liquidação detodas as operações cursadas; o estabelecimento da impenhorabilidade dos bens oferecidos em garantia no âmbito dos sistemas de compensação edeliquidação; e a disposição de que os regimes de insolvência civil, concordata, falência ou liquidação extrajudicial, a que seja submetido qualquer participante, não afetam o adimplemento de suas obrigações no âmbito de um sistema de compensação e de liquidação, as quais serão ultimadas eliquidadas na forma do regulamento desse sistema (site do Banco Central do Brasil).

E m agosto de2001, o Banco C entral estabeleceu os princípios básicos defuncionamento do SPB, seguindo recomendações feitas pelo BIS e pela I nternational O rganization of Securities Commissions (I osco) nos relatórios denominados C ore $P$ rinciples for Systemically I mportant Payment Systems e R ecommendations for Securities $S$ ettlement Systems. U ma das principais recomendações éa observação do princípio da Entrega Contra Pagamento (ECP) nos sistemas de liquidação de operações com títulos, valores mobiliários e moeda estrangeira. O u seja, os sistemas de liquidação devem contar com um mecanismo que assegureque a entrega ocorra somente seo pagamento ocorrer, contribuindo, assim, para reduzir o risco deliquidez.

Também foi implementado, em 22 de abril de2002, o novo Sistema dePagamentos Brasileiro, quetevecomo foco principal a questão do gerenciamento de riscos no âmbito dos sistemas de compensação e de liquidação. U ma das medidas adotadas foi a implantação do

25 São considerados sistemicamente importantes os sistemas de compen sação e de liquidação, cuja fal ha pode colocar em risco a solidez e o funcionamento adequado do sistema financeiro. No Brasil, são considerados sistemas sistemicamente importantes todos aqueles que liquidam operações com ativos e derivativos financeiros, bem como os sistemas de transferência de fundos que apresentam giro diário ou que liquidam pagamentos acima de um determinado valor (Fonte: Site do Banco Central do Brasil). 
Sistema de T ransferência de R eservas (ST R ), que possibilitou a transferência de fundos interbancários em tempo real e em caráter irrevogável eincondicional, reduzindo os riscos deliquidação (risco de perda definitiva do valor total ou parcial de uma operação e o risco de a liquidação de uma operação somente ocorrer em data posterior à acordada) e, consequentemente, o risco sistêmico - ou seja, o risco de que a quebra de um banco provoque a quebra em cadeia de outros bancos. A s operações com títulos públicos federais cursadas no Sistema E special de L iquidação e de C ustódia (Selic) também passaram a ser liquidadas em tempo real, o que foi possibilitado pela interconexão entre esse sistema e o ST R .

A lém disso, foi al terado o regime deoperação das contas dereservas bancárias. A partir de junho de 2002, qualquer transferência de fundos entre contas passou a ser condicionada à existência de sal do suficiente de recursos na conta do participante emitente da correspondente ordem. Essa medida permitiu uma redução significativa no risco de crédito incorrido pelo Banco Central do Brasil.

A inda no âmbito da reestruturação do SP B, foram autorizados novos sistemas decompensação e deliquidação: a Câmara de C âmbio da BM \& F, a Central clearing de C ompensação e L iquidação S.A ., a T ecban e a Câmara I nterbancária de Pagamentos (CIP).

Também foi estimulada, pelo Banco C entral, a efetivação de transferências defundos de maior val or (antes efetuadas por cheque ou D O C ecursadas na $C$ entral izadora da C ompensação de C heques e $\mathrm{O}$ utros Papéis - Compe) por meio de outros instrumentos mais seguros e modernos, como a T ransferência Eletrônica D isponível (TED ), com liquidação no ST R ou em outro sistema detransferência defundos.

Em 6 de dezembro de 2006, foi editada a R esolução no 3.402, que garantiu o direito de escolha dos beneficiários de salários, aposentadorias, pensões e similares quanto à instituição financeira em que desejam manter sua conta de depósitos para recebimento dos referidos recursos. Essa resolução permitequeos beneficiários transfiram, sem ônus de qual quer espécie, os referidos recursos para uma conta de depósitos mantida em outra instituição de sua preferência. 
Para os beneficiários que assinaram contrato de pagamento após 5 de setembro de 2006, as contas-salários, isentas de tarifas, foram abertas a partir de 2 de abril de 2007. Para os que assinaram contrato de pagamento antes de 5 de setembro de 2006, as novas regras deverão entrar em vigor até 2 de janeiro de 2009 (Banco C entral do Brasil, 2007). A expectativa é que essa medida leve ao acirramento da concorrência è queda da taxa de juros cobrada dos clientes.

Também devido a essa medida, atualmente o SPB pode ser considerado um sistema com al to grau de automação e com crescente utilização de meios el etrônicos para transferência de fundos eliquidação de obrigações. 



\section{2 \\ ANÁLISE DE DADOS \\ E RESULTADOS OBTIDOS}

\section{Ambiente econômico}

A partir da análise individual dos maiores bancos, efetuada no A nexo I deste trabal ho, destacaremos, neste capítulo, as principais características do setor bancário brasileiro no período de 1998 ao primeiro semestre de 2008. Para isso, serão consideradas, primeiramente, as mudanças recentes ocorridas no ambiente econômico do país e que influenciaram os dados obtidos.

Entre o final de 1997 eo início de 1999, o Brasil sofreu osimpactos das crises asiática erussa. E m seguida, ocorreu a crisecambial doméstica - janeiro de 1999 - , quelevou ao fim do controleda taxa decâmbio pelo Banco C entral. Em 2001, o Brasil passou por vários choques externos, como a crise da A rgentina, da T urquia e a desacel eração da economia americana. Em 2002, a estabilidade de preços do Plano R eal sofreu um abalo, com a inflação atingindo índices recordes, no mês de outubro. Em 2003, primeiro ano do governo L ula, a nova equipe econômica optou por manter uma política econômica austera, dejuros altos e medidas conservadoras. 0 nível de crescimento manteve-se baixo, enquanto, por outro lado, a inflação foi controlada. 0 sprimeiros sinais de retomada do crescimento apareceram no final de2003, com o PIB do penúltimo trimestreapontando paraum crescimento de $0,4 \%$. 
O período de 2003 a 2007 foi de expressivo crescimento da economia brasileira e mundial. A economia mundial atingiu um crescimento de cerca de $5 \%$ ao ano, em termos reais, com o volume do comércio global aumentando mais de $7 \%$ ao ano e a liquidez internacional expandindo-se em ritmo recorde. $\mathrm{N}$ o Brasil, o crescimento real do PIB atingiu 5,7\%, em 2004 (G ráfico 2.1).

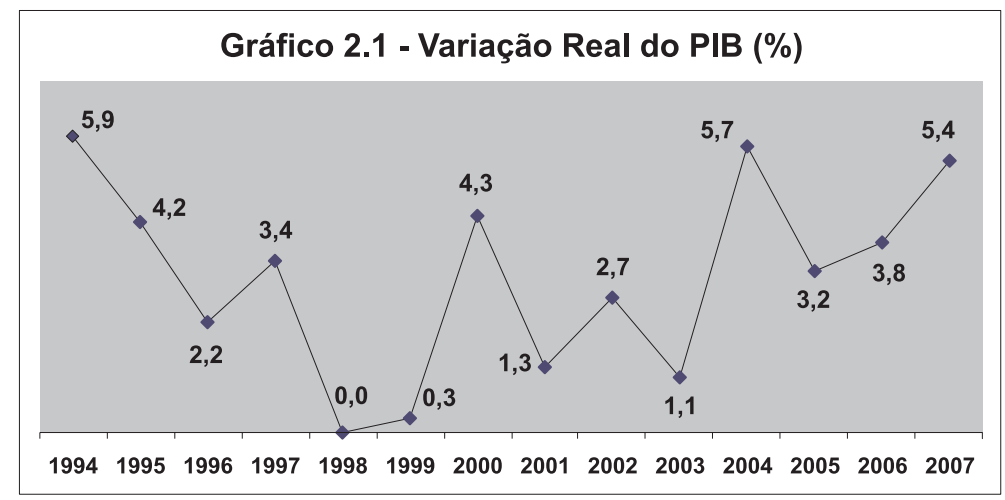

Fonte: Elaboração própria a partir de dados extraídos do site do Banco C entral do Brasil.

0 ambiente de crescimento da renda e do emprego permitiu a expansão do crédito, principalmente aquele direcionado a Pessoas F ísicas. Esse crescimento foi favorecido pela queda gradual na taxa de juros, ampliação dos prazos de amortização, recuperação do mercado de trabal ho e avanço no ambiente regulatório, com regras mais claras e processos mais ágeis para execução de garantias. T ais condições favoreceram o aumento do consumo das famílias e dos investimentos das empresas.

D entre as medidas tomadas pel o governo, com o objetivo de expandir a concessão decrédito e diminuir o spread bancário, podem ser destacadas a regulamentação do crédito consignado, em 2003, ea implementação do novo Sistema del nformações de C rédito (SCR ). Foram adotadas, ainda, medidas de incentivo ao crédito habitacional, à criação de cooperativas decrédito, à bancarização da população de menor renda eà ampliação da transparência na cobrança de tarifas e de taxas dejuros. 
O SCR éum banco de dados que entrou em operação em junho de 2005, ${ }^{1}$ alimentado mensal mente pelas instituições financeiras, mediante coleta de informações sobre as operações concedidas. A tualmente, são armazenadas nessebanco de dados as operações dos clientes com responsabilidade total igual ou superior a $R \$ 5 \mathrm{mil}$, a vencer evencidas, eos val ores referentes às finanças e aos avais prestados pelas instituições financeiras a seus clientes. 0 sistema pode ser acessado por áreas especial izadas do $B$ anco $C$ entral, pelos clientes e pelas instituições financeiras, mediante autorização dos clientes.

0 acesso do Banco Central tem como objetivo tornar mais eficaz o diagnóstico e a prevenção de crises bancárias, dotando a área de Supervisão do BC de instrumento de identificação de instituições com problemas potenciais em sua carteira de crédito. A lém disso, a amplitudedeinformações do SCR permiteaumentar o conhecimento sobre o mercado de crédito, facil itando a adoção de políticas que visem à expansão da oferta de crédito.

A s instituições financeiras, por sua vez, são auxiliadas na gestão de suas carteiras de crédito, uma vez que o sistema permitea obtenção de informações sobre as características, perfil e capacidade de pagamento dos clientes. Com base nessas informações, os bancos poderão oferecer produtos com melhores condições de taxa ou de prazo adequadas a cada tipo de cliente, com impactos positivos na diminuição dos índices de inadimplência. 0 s clientes também terão acesso às informações cadastradas no sistema, o que aumentará seu poder de barganha na negociação por mel hores taxas e condições.

O principal objetivo do SCR é ampliar a transparência e reduzir a assimetria de informações do sistema financeiro brasileiro. Espera-se que o uso continuado do sistema gere um aumento da

1 A primeira experiência de central de risco de crédito foi implantada pela A lemanha em 1934, sendo que, atualmente, diversos países, como Bél gica, Chile, E spanha, França e I tália, desenvolveram sistemas semelhantes. N o Brasil, 0 primeiro sistema com essas características, chamado de Central de R isco de C rédito, foi implementado em junho de 1997. N o novo sistema, abasededados foi ampliada e o acesso ficou mais fácil e rápido. 
competitividade do mercado de crédito e uma mel hor avaliação de risco, contribuindo para a expansão da oferta de crédito e redução dos spreads bancários.

T ambém contribuiu para a ampliação do crédito a al teração, pelo B anco C entral, das regras para recolhimento compulsório sobre os recursos a prazo, que passou a ser exigido somente para a parcela que exceder $\mathrm{R} \$ 300$ milhões. Esse afrouxamento na regra do recoIhimento, implementado em 19 de novembro de 2004, aumentou a liquidez dos bancos.

Em 2006, foi criada a conta-salário, que permite que os trabaI hadores escolham o banco no qual desejam receber o salário. Da conta-salário, o dinheiro pode ser automaticamente enviado para uma conta-corrente do trabalhador em outro banco, sem cobrança de qualquer encargo ou tarifa. Para os funcionários de empresas privadas, a medida entrou em vigor em janeiro de2009, eserá estendida para os funcionários públicos em 2012. 0 utra medida adotada recentemente foi a R esolução no 3.401, de 6 de setembro de 2006, que garantiu a portabilidade do crédito e do cadastro dos clientes bancários. N este caso, o cliente pode transferir um empréstimo de um banco para outro que ofereça melhores condições de pagamento.

A expansão do crédito também foi resultado do posicionamento do governo, que incentivou principalmente as classes C, D e E a aumentarem o consumo. Esse posicionamento incluiu medidas como aumento do gasto público, ampliação dos programas sociais, reajustes do salário mínimo acima da inflação e implantação, em 22 de janeiro de 2007, do Programa de A celeração do C rescimento (PA C ). O PAC tem como objetivo recuperar a infraestrutura, estimular o crédito e o financiamento e aumentar o ritmo de expansão da economia, entre os anos de 2007 e2010. N esse período, o governo pretende direcionar $\mathrm{R} \$ 503,9$ bilhões para a ampliação do crédito para infraestrutura e habitação.

N essecontexto, o Banco C entral reduziu a taxa Selic para $11,25 \%$ ao ano em dezembro de 2007 (G ráfico 2.2), o menor nível desdeque foi criada, em 1986. Essa queda incentivou ainda mais o aumento do crédito. 


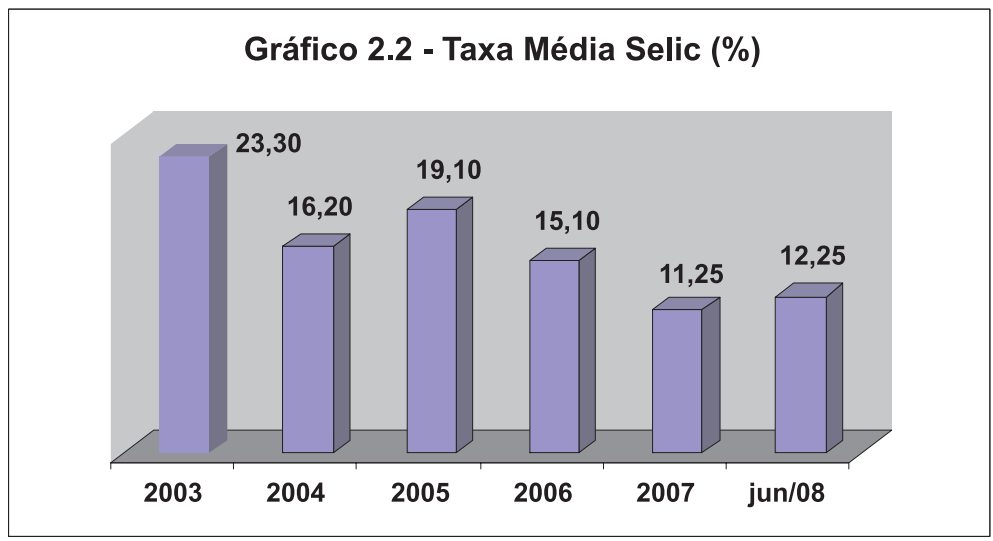

Fonte: Elaboração própria a partir de dados extraídos do site do Banco C entral do Brasil.

N o primeiro semestre de 2008, o mercado de crédito apresentou crescimento, apesar da crise iniciada no segundo semestre de 2007, originada no mercado imobiliário norte-americano, e das medidas restritivas implementadas pelo governo no começo do ano, como: aumento do I mposto sobre $O$ perações F inanceiras (I OF ) sobre operações de crédito, de 1,5\% para 3,38\%, em janeiro de 2008; instituição de uma alíquota de compulsório sobre captações feitas pelos bancos por meio de suas empresas de leasing, válida a partir de maio de 2008; e aumento da taxa de juros a partir de abril de 2008. Esses fatores atuaram para que os juros médios dos empréstimos subissem em relação a 2007 (Valor E conômico, 30/ 4/ 2008).

No primeiro semestre do ano, duas das três principais agências internacionais de avaliação de risco concederam o grau de investimento ao Brasil, o queconfirmou amelhora nos fundamentos do país, nos últimos anos. Esse ambiente positivo permitiu a continuidade do avanço do crédito, embora em menor ritmo. Também devido a essa expansão, o B anco $\mathrm{C}$ entral considerou propício el evar a taxa básica de juros de $11,25 \%$, em dezembro de 2007 , para $12,25 \%$, em junho de 2008. 


\section{Aumento da concentração}

0 grau deconcentração no sistema bancário brasileiro éuma questão constantementedebatida. O s elevadosjuros etarifas cobrados pelas instituições bancárias levaram à suspeita da existência do queC arvalho (2007) chama de "déficit de concorrência" no setor. Entretanto, o grau de concentração no Brasil continua não sendo muito distinto do observado em outros países, conformeVasconcelos e Strachman (2002) jáhaviam apontado, o quepodeindicar queessa sejaumacaracterística estrutural do setor. Essa concentração sugere uma estrutura oligopolística de mercado, com concorrência pela diferenciação de produtos, mais do queem preços (C arvalho, 2007). N os anos recentes, tem se verificado, no Brasil, uma tendência de ampliação da concentração e e existência de um novo processo de consolidação bancária.

No primeiro semestre de 2008 , as oito maiores instituições representavam $75,7 \%$ do total de ativos, exceto intermediações, ${ }^{2}$ do Sistema Financeiro $\mathrm{N}$ acional. Essa partici pação vem crescen do desde dezembro de 1998 (G ráfico 2.3). 0 número de instituições, por sua vez, caiu de128, em dezembro de 1998, para 101, em junho de2008.

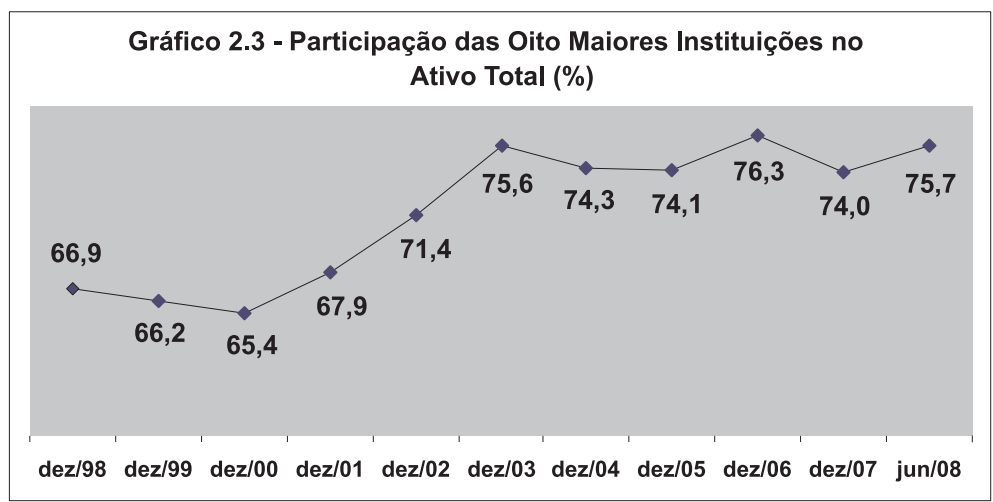

Fonte: Elaboração própria a partir de dados extraídos do site do Banco C entral do Brasil.

2 O s dados divulgados pelo Banco Central consideram o bal anço operacional dos bancos, que inclui somente as operações financeiras, não contabilizando operações como as de seguros, previdência e capitalização. 
Essa concentração foi acompanhada pela queda da participação dos bancos públicos no ativo total e 0 aumento da participação dos bancos privados nacionais eestrangeiros. E m dezembro de 1996, os bancos públicos federais eestaduais dentre os 50 maiores eram quinzeerepresentavam $55,3 \%$ dos ativos totais do C onsolidado Bancário I. N o primeiro semestre de 2008 , a quantidade de instituições caiu para nove, com participação de $31,9 \%$. A s instituições privadas nacionais diminuíram de 25 para 22; entretanto, a participação no total de ativos cresceu de $33,5 \%$ para $43,4 \%$. A s instituições com controle estrangeiro, por sua vez, eram dez, em dezembro de 1996, com participação de $6,7 \%$ no ativo, mas, no primeiro semestre de 2008 , o número aumentou para 19 , passando a representar $23,2 \%$ dos ativos.

A pesar do crescimento da participação dos bancos com controle estrangeiro, essa partici pação ainda é inferior à dos bancos nacionais e à verificada em outros países da região. Essa peculiaridade do Brasil, de baixa participação dos bancos estrangeiros e forte atuação dos bancos públicos, contribuiu para que o país não fosse tão afetado pela crise internacional iniciada em 2007, ao contrário do previsto em boa parte da literatura sobre bancos (Vasconcel os e Strachman, 2002). N o M éxico, por exemplo, 90\% dos bancos são de capital estrangeiro, o quecontribuiu para o aprofundamento da crise no país.

Recentemente, um novo processo de concentração foi iniciado no setor, destacando-se a aquisição do A BN pelo Santander, da $N$ ossa C aixa pelo Banco do B rasil e a fusão entre I taú e U nibanco. Esseprocesso, em conjunto com a necessidade de prover liquidez ao sistema em um período de crise, impulsionou a edição, em outubro de 2008, da M edida Provisória no 443, que permitiu que os bancos públicos adquirissem instituições financeiras privadas. ${ }^{3}$

Todos os bancos privados anal isados, tanto estrangeiros como nacionais, cresceram, principalmente, pelas fusões e aquisições,

3 A M edida Provisória é válida até junho de 2011, podendo ser prorrogada por doze meses. 
enquanto a C aixa e o Banco do Brasil cresceram de forma orgânica, por meio da abertura de agências e ampliação da base de clientes. D essa forma, a aquisição de instituições financeiras é vista como estratégica para os bancos públicos e, principalmente, para o Banco do Brasil, que busca recuperar a liderança de mercado, perdida, no segundo semestre de 2008, para a nova instituição I taú-U nibanco (IU ). A ssim, essa nova medida tende a impulsionar o processo de consolidação em andamento.

O utro fator que tende a aprofundar o novo processo de consolidação éa crise internacional iniciada em 2007, quetendea provocar fuga de depósitos para os maiores bancos, bem como a compra de instituições menores pelos grandes bancos. Os movimentos dos principais bancos também tendem a desencadear novas fusões e aquisições, lideradas, principal mente, pelos grandes bancos, que deverão buscar potenciais sinergias e ganhos de escala para enfrentar o ambiente com concorrência mais acirrada.

\section{Redução das taxas de juros e dos spreads ${ }^{4}$ e ampliação dos prazos de amortização}

A s taxas de juros cobradas pel os bancos nas operações de crédito vêm decrescendo desde2003 (Tabela 2.1). Essemovimento foi mais acentuado no segmento de pessoas físicas, o que pode ser explicado pela expansão de operações de menor risco, como financiamento de veículos, crédito consignado e crédito imobiliário. A redução da taxa Selic, nesse período, também impulsionou a queda das taxas de juros. 0 aumento, verificado no primeiro semestre de 2008, já refleteos efeitos da criseinternacional, dentreeles, o aumento da taxa Selic.

$4 \mathrm{~N}$ a definição do Banco $\mathrm{C}$ entral do Brasil, o spread bancário é a diferença entre a taxa de empréstimo e a taxa de captação de CD B - Certificado de D epósito Bancário. 
A redução das taxas de juros foi acompanhada por um aumento dos prazos de amortização. 0 prazo médio das operações totais foi de 374 dias, em junho de 2008, um crescimento de 70\% em relação a dezembro de 2003. 0 prazo para pessoas físicas atingiu 466 dias, enquanto o prazo para pessoas jurídicas foi de 303 dias (Tabela 2.2).

T abela 2.1 - Taxa de aplicação (\%) - Taxas prefixadas

\begin{tabular}{l|c|c|c|c|c|c|c|c|c}
\hline & dez./ 00 & dez./ 01 & dez./ 02 & dez./ 03 & dez./ 04 & dez./ 05 & dez./ 06 & dez./ 07 & jun./ 08 \\
\hline Geral & 52,56 & 60,21 & 70,13 & 57,34 & 53,11 & 53,33 & 47,31 & 40,18 & 45,04 \\
\hline $\begin{array}{l}\text { Pessoa } \\
\text { Jurídica }\end{array}$ & 37,59 & 43,77 & 50,46 & 42,30 & 40,65 & 41,55 & 36,90 & 32,22 & 36,74 \\
\hline $\begin{array}{l}\text { Pessoa } \\
\text { Física }\end{array}$ & 66,49 & 71,82 & 83,52 & 66,64 & 60,54 & 59,26 & 52,13 & 43,94 & 49,10 \\
\hline
\end{tabular}

Fonte: Elaboração própria a partir de dados extraídos do site do Banco C entral do Brasil.

T abela 2.2 - Prazo médio das operações de crédito (em dias corridos)

\begin{tabular}{l|c|c|c}
\hline & Pessoa Jurídica & Pessoa Física & C onsolidado \\
\hline dez./ 03 & 170 & 296 & 220 \\
\hline dez./ 04 & 189 & 296 & 234 \\
\hline dez./ 05 & 218 & 319 & 264 \\
\hline dez./ 06 & 234 & 368 & 296 \\
\hline dez./ 07 & 275 & 439 & 350 \\
\hline jun./ 08 & 303 & 466 & 374 \\
\hline Cresc. (\%) & 78,2 & 57,4 & 70,0 \\
\hline
\end{tabular}

Fonte: Elaboração própria a partir de dados extraídos do site do Banco Central do Brasil.

O spread bancário, por sua vez, apresentou tendência de queda no período de 1995, após o Plano R eal, até2000. N o início de 1995, o índice atingiu $150 \%$ ao ano, devido às políticas monetárias contracionistas implementadas pelo Banco C entral. A partir de 1996, esse índice começou a decrescer em consequência do relaxamento das medidas contracionistas e da diminuição da desconfiança dos agentes em relação ao processo decontágio da crisemexicana ( $D$ ePaula, 0 no, $O$ reiro e Silva, 2005). A pós aumento no período de dezembro de 2000 a dezembro de 2002, os spreads voltaram a decrescer em 2003, atingindo seu menor nível em 2007 (Tabela 2.3). 
Tabela 2.3 - Spread (\%) - Taxas prefixadas

\begin{tabular}{l|c|c|c|c|c|c|c|c|c}
\hline & dez./ 00 & dez./ 01 & dez./ 02 & dez./ 03 & dez./ 04 & dez./ 05 & dez./ 06 & dez./ 07 & jun./ 08 \\
\hline Geral & 36,11 & 39,95 & 42,46 & 41,52 & 35,56 & 36,40 & 34,78 & 28,40 & 31,12 \\
\hline $\begin{array}{l}\text { Pessoa } \\
\text { Jurídica }\end{array}$ & 21,57 & 24,38 & 24,97 & 26,44 & 23,19 & 24,07 & 24,30 & 20,97 & 23,78 \\
\hline $\begin{array}{l}\text { Pessoa } \\
\text { Física }\end{array}$ & 49,68 & 50,99 & 54,51 & 50,85 & 42,94 & 42,60 & 39,63 & 31,92 & 34,74 \\
\hline
\end{tabular}

Fonte: Elaboração própria a partir de dados extraídos do site do Banco C entral do Brasil.

N o período de dezembro de 2002 a dezembro de 2007 , a queda do spread foi de $33 \%$, provocada, principalmente, pela queda do spread de pessoa física, que foi de $41 \%$, contra um decréscimo de $16 \%$ do spread depessoajurídica. Essa queda foi impulsionada pela redução das taxas de juros; entretanto, nesse mesmo período, a taxa de captação sofreu uma redução de 50\%, o que possibilitou uma redução menos acentuada dos spreads.

A pesar do decréscimo verificado a partir de 2003, o spread bancário do Brasil ainda é o mais al to do mundo e é onze vezes maior do que o praticado nos países desenvolvidos, segundo estudo do I nstituto de Estudos para o D esenvolvimento Industrial (I edi). E m 2008, o spread médio do Brasil foi de 34,88\%, contra 3,16\% dos países desenvolvidos. A média simples das taxas de 62 países em desenvolvimento, que integram o relatório do I edi, ficou em $6,55 \%$ em 2008. O s dados foram obtidos por meio da razão entre 0 custo de capital para os bancos de 86 países e os juros que cobram, informados ao F undo M onetário I nternacional (F M I) (Folha de S. Paulo, 1/2/2009).

D esde 1999, o Banco Central divulga um amplo diagnóstico anual do mercado de crédito, que inclui uma investigação sobre as causas das al tas taxas de juros cobradas no Brasil. N essediagnóstico, é cal culado o peso dos fatores que compõem o spread. D esde 2001, verifica-se que o maior componente do spread é a inadimplência, seguida pelo resíduo líquido, querepresenta a margem efetivamente apropriada pelos bancos (Tabela 2.4).

0 recenteaumento das taxas dejuros foi justificado pel os bancos, pelo aumento na expectativa de ampliação da inadimplência, devi- 
Tabela 2.4 - D ecomposição do spread bancário (\%)

\begin{tabular}{l|c|c|c|c|c|c|c}
\hline & $\mathbf{2 0 0 1}$ & $\mathbf{2 0 0 2}$ & $\mathbf{2 0 0 3}$ & $\mathbf{2 0 0 4}$ & $\mathbf{2 0 0 5}$ & $\mathbf{2 0 0 6}$ & $\mathbf{2 0 0 7}$ \\
\hline Spread Total & 39,95 & 42,46 & 41,52 & 35,56 & 36,4 & 34,76 & 28,4 \\
\hline Inadimplência & 32,4 & 32,2 & 31,9 & 34,7 & 36,1 & 38,3 & 37,4 \\
\hline Resíduo L íquido & 28,1 & 18,4 & 31,0 & 26,1 & 25,4 & 28,2 & 26,9 \\
\hline Custo A dministrativo & 13,2 & 15,0 & 11,8 & 14,2 & 15,5 & 12,4 & 13,5 \\
\hline Impostos D iretos & 14,1 & 11,5 & 13,4 & 11,0 & 9,9 & 10,0 & 10,5 \\
\hline Tributos eT axas & 6,9 & 7,8 & 7,1 & 7,6 & 8,1 & 7,7 & 8,1 \\
\hline Custo do Compulsório & 5,3 & 15,1 & 4,8 & 6,4 & 5,0 & 3,4 & 3,6 \\
\hline Inadimplência + Res. Líquido & 60,5 & 50,6 & 62,9 & 60,8 & 61,5 & 66,5 & 64,3 \\
\hline
\end{tabular}

Fonte: Elaboração própria a partir de dados extraídos do site do Banco C entral do Brasil.

do à deterioração do cenário econômico e à possibilidade de queda de emprego e de renda. Entretanto, a parcela do spread referente à inadimplência destina-se a cobrir perdas ainda não real izadas, uma vez que se trata apenas deuma projeção do risco de perdas nas novas operações. D essa forma, o percentual do spread que é apropriado pel os bancos equivale à soma das parcelas de inadimplência e de resíduo líquido, que atingiu $64,3 \% \mathrm{em} 2007$. Tendo em vista que, conforme constatado no A nexo I, os índices de inadimplência dos bancos analisados têm se mantido em níveis baixos, esse el evado percentual que os bancos destinam para cobrir a inadimplência pode ser questionado.

O s bancos vêm sendo muito pressionados pelo governo para que reduzam as taxas de juros e o spread. A lém das medidas adotadas para acirrar a concorrência, já relacionadas no item "A mbiente econômico" (capítulo 2), o governo vem, recentemente, pressionando os bancos públicos, principalmentea CEF eo BB, paraquereduzam suas taxas, o quepoderia forçar os bancos privados a fazer o mesmo. Em janeiro de2009, verificou-sequeas menores taxas dejuros foram as cobradas pelos dois bancos públicos, principalmente pela $\mathrm{C}$ aixa E conômica Federal. A s taxas mais altas foram as do H SBC e do Santander, ou seja, dois bancos estrangeiros. D estaca-se, também, o A BN - A mro, cuja taxa foi menor do que a dos bancos privados nacionais ( $G$ ráfico 2.4). 


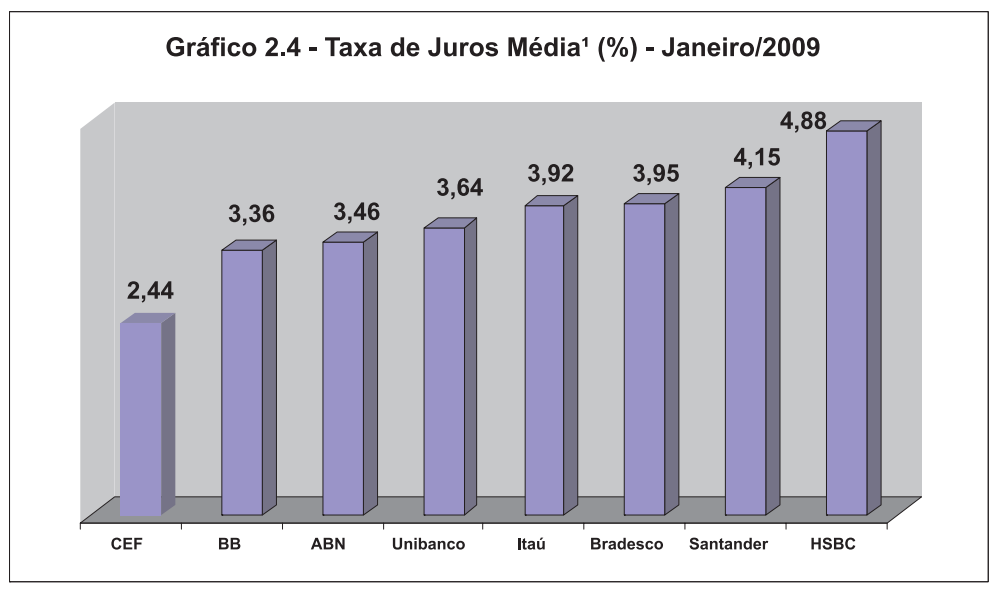

1) O btida por meio da média simples das taxas de juros das modalidades Cheque Especial, C rédito Pessoal, A quisição deVeículos, A quisição de Bens, D esconto de D uplicatas, Capital de Giro - Prefixado, Capital de G iro - Flutuante, Conta G arantida, A quisição de Bens - PJ.

Fonte: Elaboração própria a partir de dados extraídos do site do Banco Central do Brasil.

\section{Retomada da importância dos bancos públicos}

$N$ as décadas de 1980 e 1990, inexistia a orientação para que os bancos públicos desenvolvessem ações de inclusão bancária e disseminação do crédito. A o contrário, essas instituições não tinham papel relevantena execução das políticas governamentais ehavia um forte movimento para que fossem privatizadas ( $M$ attoso eVasconcelos, 2006). D efato, muitas delas, principalmenteestaduais, foram privatizadas na década de 1990, conforme visto no capítulo 1. No caso das instituições públicas federais, al gumas foram privatizadas, enquanto outras perderam importância ou foram reestruturadas, visando à futura privatização. N esse último caso, enquadram-se o Banco do Brasil e, principalmente, a Caixa Econômica Federal.

A pós as medidas adotadas pelo Proef, a CEF perdeu espaço no mercado bancário, concentrando suas operações em títulos públicos. A soperações decrédito comercial foram consideradas secundárias, 0 que fez com quea $C$ aixa e outras instituições públicas diminuíssem 
sua participação no total da carteira decrédito do Sistema Financeiro $\mathrm{N}$ acional.

O governo L ula buscou reverter essa situação de desmonte dos bancos públicos, tornando-os principais agentes de execução da sua política de governo. A ssim, esses bancos recuperaram seu papel de fomentar o desenvolvimento econômico esocial brasileiro, ofertando crédito e serviços financeiros em melhores condições para toda a população. Esse papel significa, muitas vezes, a atuação em regiões e segmentos menos interessantes aos bancos privados ( $M$ attoso eVasconcelos, 2006). Como exemplos, podem ser citados a forte atuação do Banco do Brasil no crédito agrícola, segmento em que a participação dos bancos privados é pequena, apesar da importância econômica do setor, devido ao alto risco de quebra de safra; o segmento de crédito imobiliário, em que a C aixa élíder, eque também não era atrativo para os bancos privados, devido ao al to risco e às altas taxas de inadimplência - os bancos privados passaram a atuar nesse segmento somente após a implementação de medidas que diminuíram o risco do setor; 0 atendimento da população de menor renda; ea oferta definanciamento delongo prazo - em queo BN DES équase exclusivo. A Caixa E conômica F ederal também éa principal agente do governo na execução do PA C - Programa de A celeração do Crescimento.

O s bancos públicos, principalmente a CEF e o Banco do Brasil, também passaram a investir, recentemente, em segmentos em queos bancos privados eram mais atuantes. A partir de 2005, o BB adotou a estratégia de ampliar sua atuação com não correntistas, segmento em que os bancos privados mais crescem. I niciou suas operações em financiamento de veículos e crédito imobiliário e passou a buscar o estabel ecimento de parcerias com grandes redes varejistas. A C aixa, por sua vez, pretende ampliar sua atuação no segmento de pessoas jurídicas.

E ssa importância dos bancos públicos se acentuou a partir de 2007, quando o governo atribuiu a essas instituições o papel de evitar a escassez de crédito e uma consequente redução da atividade econômica, devido à crise internacional iniciada nesse mesmo ano. 
0 governo determinou que o BB incrementasse o crédito rural, facilitasse as exportações e os empréstimos efinanciamentos a pessoas físicas. À Caixa, foi designada a responsabilidadedeampliar a oferta de recursos para os segmentos de habitação, saneamento básico e micro e pequenas empresas. Como resultado, em 2008 a carteira de crédito dos bancos públicos foi a que mais cresceu. D e março de 2008 a março de 2009 , esse crescimento foi de $37,1 \%$, contra uma expansão de $19,1 \%$ das instituições privadas nacionais e de $17,8 \%$ das instituições estrangeiras, conforme dados do Banco Central do Brasil. C omo já visto, aos bancos públicos também caberá o papel de reduzir as taxas de juros eas tarifas bancárias e deampliar a liquidez no sistema financei ro nacional, por meio da aquisição de instituições privadas, possibilitada pela M edida Provisória 443.

D entre os argumentos dos defensores da forte presença dos bancos públicos no país, destacavam-se aqueles que defendiam a necessidade de levar agências às local idades mais distantes e economicamente inviáveis (Caval cante, C rocco e J aime J r., 2004), bem como a crença de que banco do governo não quebra. A tualmente, entretanto, esses argumentos não são mais tão fortes, já que, com o avanço da tecnologia e com a inclusão de novas formas de atendimento, como o correspondentebancário, os grandes bancos privados também conseguem atender grande parte dos municípios. A lém disso, não há perspectiva de quebra para esses bancos, que estão bem sólidos e registram lucros recordes, a despeito da frequente desconfiança - no Brasil e no resto do mundo - quanto à fidelidade dos balanços bancários em relação à realidade de cada uma dessas instituições.

A principal importância dos bancos públicos, hojeem dia, estána execução depolíticas governamentaisena promoção da concorrência no setor. Carvalho (2000) destaca a garantia de oferta de serviços financeiros ao governo a custos razoáveis, a moderação das práticas oligopolistas dos bancos privados no crédito ea ampliação da eficácia das políticas de estabilização e defesa da moeda e do sistema financeiro. 0 autor cita as turbulências ocorridas nos anos de 1996 e 1997, 
em que o Banco do Brasil eaCEF foram extremamenteimportantes para que uma crise bancária fosse evitada. 0 aumento da desconfiança do público provocou a transferência de depósitos eoperações para os dois bancos públicos, que, por sua vez, repassaram esses recursos no interbancário. Essa atuação manteve o financiamento do sistema privado e, principalmente, dos bancos mais ameaçados pela crise de desconfiança.

D essa forma, a redução da atuação dos bancos públicos poderia enfraquecer os instrumentos de política econômica, bem como ampliar o poder de mercado e o lucro dos bancos privados. D e acordo com estudos divulgados, em abril de2009, pelo I nstituto de Pesquisa E conômica A plicada (I pea), a redução dos bancos públicos, a partir de 1996, levou à concentração do sistema financeiro, à menor oferta deserviços bancários à população de baixa renda eà manuten ção de ambiente favorável à cobrança de al tos juros.

\section{Concentração dos pontos de atendimento em regiões mais desenvolvidas}

A s instituições analisadas possuem presença mais significativano Sudeste, Sul e N ordeste, sendo quetodos os bancos estão mais concentrados naregião Sudeste. 0 banco onde essa concentração émaior é o Santander. Isso se deve ao fato de a instituição ter ampliado sua atuação no Brasil por meio da aquisição do Banespa, banco estadual paulista, bem como ao fato de estar mais direcionada para regiões de renda mais alta. 0 s bancos onde a concentração na região Sudesteé menor são Banco do Brasil e C aixa E conômica Federal, o que pode ser explicado pelo fato de setratar de bancos públicos, quebuscam a bancarização da população situada em regiões menos desenvolvidas.

O Bradesco éo banco com maior participação naquantidadetotal depontos deatendimento, seguido pelo Banco do Brasil. A pesar deo $B$ anco do Brasil ser líder nas regiões $C$ entro- $O$ este, $N$ ordeste, $N$ orte e Sul, o Bradesco lidera na região Sudeste (T abela 2.5). 
Tabela 2.5 - D istribuição dos pontos de atendimento (\%) em janeiro/ 2009

\begin{tabular}{l|c|c|c|c|c|c}
\hline & Centro-0 este & Nordeste & Norte & Sudeste & Sul & Total \\
\hline Bradesco & 26,3 & 33,0 & 32,2 & 28,8 & 20,3 & 27,9 \\
\hline Banco do Brasil & 35,3 & 40,8 & 35,8 & 17,5 & 32,1 & 26,3 \\
\hline I taú & 9,5 & 4,7 & 5,3 & 15,1 & 10,6 & 11,6 \\
\hline A BN & 5,7 & 6,0 & 6,1 & 8,0 & 3,4 & 6,5 \\
\hline CEF & 7,8 & 6,8 & 4,8 & 5,0 & 7,7 & 6,0 \\
\hline Santander & 1,3 & 0,6 & 0,6 & 7,2 & 4,2 & 4,7 \\
\hline H SBC & 5,0 & 1,9 & 4,5 & 3,6 & 7,1 & 4,1 \\
\hline U nibanco & 2,0 & 1,9 & 0,8 & 4,3 & 3,2 & 3,3 \\
\hline T OTAL & 4.958 & 9.784 & 3.294 & 31.761 & 10.989 & 60.786 \\
\hline
\end{tabular}

Fonte: Elaboração própria a partir de dados extraídos do site da Febraban.

É importantedestacar que, apesar deaCEF não ter uma participação significativa no total de pontos de atendimento, éa instituição com mel hor cobertura geográfica, ${ }^{5}$ estando presente em todos os municípios do país. Em muitos municípios, entretanto, o banco não disponibiliza agências ou pontos de atendimento bancário, contando, somente, com os correspondentes bancários - não considerados pontos de atendimento pela Febraban.

Também severificou umatendência deampliação da participação dos grandes bancos no total de pontos de atendimento do país. $\mathrm{N} 0$ final de 2008, após a recente onda de fusões ocorridas no setor bancário, as dez maiores instituições passaram a deter $94 \%$ das agências bancárias do Brasil. Em 1999, esse percentual era de 76\%.

Verifica-se, ainda, que os bancos brasileiros ainda não buscam a internacionalização. I sso se deve ao fato de o mercado doméstico ainda não estar saturado, como ocorreu com os países desenvolvidos, apresentando, ainda, grande oportunidade de crescimento eampliação da rentabilidade. ${ }^{6} \mathrm{U}$ ma exceção, dentre os bancos analisados, é o I taú, que sempre foi mais voltado para o mercado externo do

5 Segundo o Prêmio R elatório Bancário 2007.

6 A baixa internacionalização dos bancos brasileiros foi um fator importantepara dificultar a propagação, no Brasil, da crise internacional iniciada em 2007. 
que as demais instituições. ${ }^{7}$ A pós a aquisição do U nibanco, a nova instituição adotou a internacional ização como principal estratégia.

\section{Crescimento de formas alternativas de atendimento}

Com o objetivo de reduzir os custos de operação, todas as instituições analisadas vêm buscando ampliar as formas de atendimento diferenciadas, como internet banking e caixas eletrônicos. A pesar da importância ainda significativa das agências bancárias, o processo de automação dos serviços bancários cresce de forma acelerada, com expressiva ampliação da parcela de serviços efetuados por meio do internet banking e dos canais de autoatendimento.

T ambém se destacaram as associações com estabel ecimentos comerciais, chamados de "correspondentes bancários", queatingiram 84 mil em 2007. N esse sistema, os bancos instalam equipamentos em lojas, supermercados e outros estabelecimentos comerciais, com a finalidadede oferecer serviços aos clientes, como saques, depósitos, pagamento de contas, dentre outros. U ma variante desse sistema é o Banco Postal, resultado de acordo entre o Bradesco e os Correios para prestação desses serviços.

Verificou-se, também, uma forte tendência de estabelecimento de parcerias com redes varejistas, para financiamento do consumo e fornecimento de cartões de crédito. Essa tendência é verificada, principalmente, no Bradesco, I taú, U nibanco, H SBC e, mais recentemente, Banco do Brasil. O utrafortetendênciano setor foi a criação de financeiras, por todos os bancos privados anal isados, para atendimento da população demenor renda. São oferecidos, principalmente, cartões de crédito, financiamento a veículos e crédito ao consumo.

Em 2006, as agências representaram somente $10,4 \%$ do total de atendimentos, sendo que os correspondentes foram responsáveis por $8 \%$ dos atendimentos. A s transações foram efetuadas, principal-

7 Em junho de 2008, o I taú possuía ativos no C hile, A rgentina e U ruguai. 
mente, por meio do autoatendimento, débito automático e internet banking, que responderam por $32,4 \%, 24,5 \%$ e $16,8 \%$, respectivamente (G ráfico 2.5).

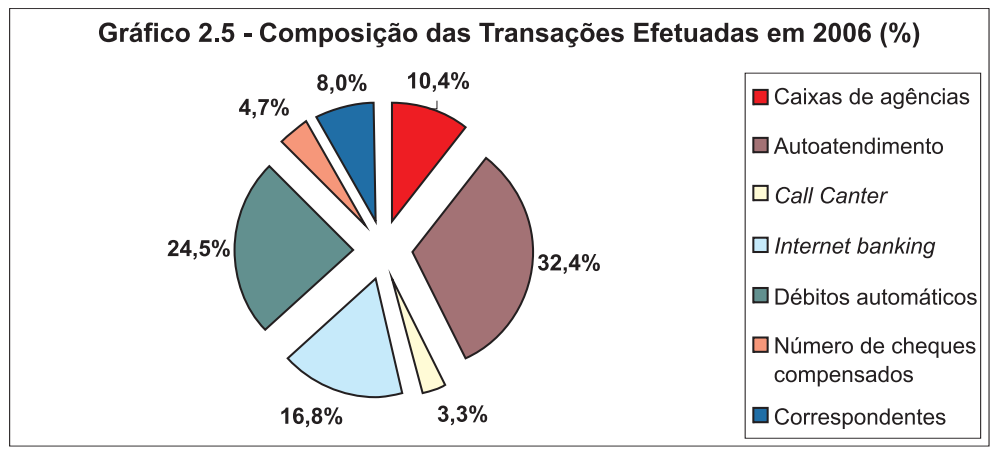

Fonte: Elaboração própria a partir de dados extraídos do site da F ebraban.

A tual mente, a maior parte do crescimento da inserção do sistema bancário na economia se dá por meio de correspondentes bancários, que, cada vez mais, seassemel ham às tradicionais agências bancárias, pelagrandeamplitude deatividades eserviços prestados. N o período de2000 a 2007, foi a forma deatendimento quemais cresceu, seguida pelo autoatendimento. A quantidade de agências, por sua vez, não sofreu alteração significativa (G ráfico 2.6).

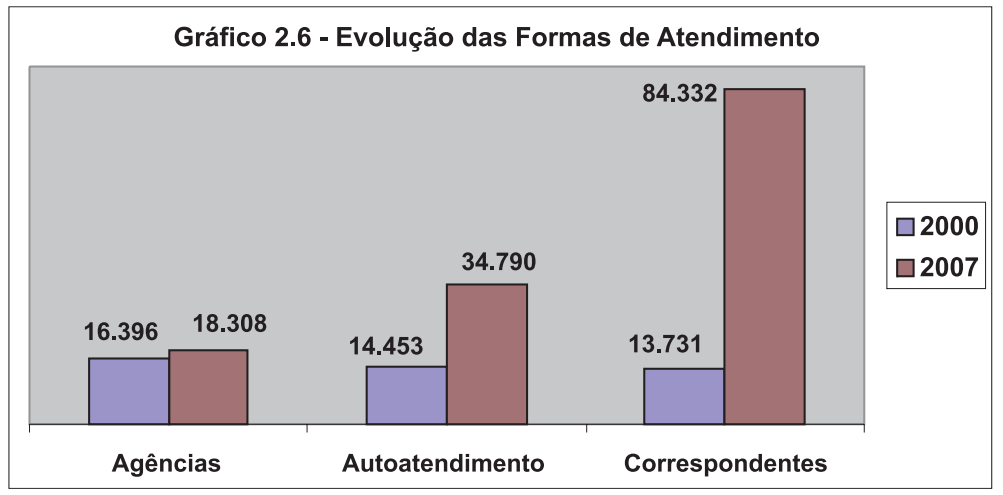

Fonte: Elaboração própria a partir de dados extraídos do site da Febraban. 


\section{Alta quantidade de pontos de atendimento}

A pesar da tendência de crescimento de formas al ternativas de atendimento, conforme visto no item anterior, verificou-se que os bancos brasileiros ainda têm, relativamente, mais pontos de atendimento dos que os bancos situados em países mais desenvolvidos. E $m$ todos os grupos estrangeiros analisados, a quantidade de pontos de atendimento instalados na filial brasileira era alta em relação aos demais países. $\mathrm{N}$ o caso do A BN , por exemplo, a A mérica L atina representa somente $5,1 \%$ dos ativos totais do grupo; entretanto, concentra $51,5 \%$ dos pontos de atendimento.

A alta quantidade depontos deatendimento era uma das críticas que os bancos estrangeiros fizeram ao sistema bancário nacional quando da sua entrada no país; entretanto, verifica-se que esses bancos mantiveram essa mesmaestratégia, atuando, assim, deforma diferente de como atuavam em seus países de origem.

I sso se deve ao fato de que a presença da agência ainda é um fator importante para atrair novos clientes, dado o baixo nível de bancarização da população. D esse modo, os bancos, tanto estrangeiros como nacionais, mantêm extensa rede de atendimento, com o objetivo de ampliar o número declientes. Essecomportamento podeser comprovado pelo recente processo de fusões e aquisições ocorrido no país, já que, atéo momento, não houve fechamento significativo de agências, ao contrário do queocorreu no processo de consolidação dos anos 1990.

\section{Segmentação de clientes}

A substituição dos lucros provenientes de al tas taxas de inflação por receitas provenientes de serviços levou a uma val orização da figura do cliente. Como consequência, no período estudado, todas as instituições analisadas adotaram a estratégia de segmentação de clientes por renda, perfil, investimentos e relacionamento com 0 banco. Baseados nesse modelo, os bancos criam produtos e pacotes de serviços diferenciados, adequados a cada perfil de cliente. 
R ecentemente, o A BN tem buscado alterar sua estratégia com relação à segmentação, ampliando o fluxo de produtos padronizados, com o objetivo dereduzir os custos transacionais e promover ganhos deeficiência eescala. Essa estratégia, entretanto, érecenteecontrária à tendência verificada no setor bancário brasileiro.

\section{Aumento da bancarização}

A diversificação dos pontos de atendimento, com a ampliação da atuação dos correspondentes bancários, do Banco Postal, das redes varejistas parceiras das instituições bancárias e das financeiras, contribuiu para a aceleração do processo de bancarização da população de menor renda.

O s bancos públicos tiveram participação importante nesse processo, por meio do Banco Popular do Brasil, do Banco do Brasil e da Conta Caixa F ácil, da C aixa E conômica Federal. A conta simplificada foi criada pelo Banco C entral, em 2003, com o objetivo de incluir os consumidores da baixa renda no setor bancário, facilitando a abertura de conta-corrente ea concessão de empréstimos. M ais da metade desse tipo de conta foi aberta na $\mathrm{C}$ aixa E conômica F ederal e no Banco do Brasil.

0 número de contas bancárias atingiu 112,1 milhões em 2007, um crescimento de $76 \%$ em relação a 2000 . Esse crescimento foi impulsionado pelo crescimento do emprego e pela ascensão de mais famílias à classe $C$. A lém disso, o país conta com 77 milhões de contas-poupança e 7,6 milhões de contas simplificadas.

D estaca-se, ainda, o crescimento da quantidade de cartões de crédito, de 28 milhões, em 2000, para 93 milhões, em 2007. G rande partedessecrescimento se deu entreas classes mais baixas, sendo que as financei ras eas redes varejistas parcei ras deinstituições financei ras foram as principais responsáveis por essa expansão.

A instituição com maior número de clientes éa $C$ aixa E conômica Federal, queatingiu 40 milhões declientes em 2007, sendo quecerca de $80 \%$ são em conta-poupança. E m seguida vêm o Banco do Brasil, com 24,6 milhões de clientes, o Bradesco, com 18 milhões, eo I taú, 
com 13 milhões. Em outro patamar estão U nibanco, com 7,7 milhões, Santander, com 7,2 milhões, A BN , com 6 milhões, e H SBC, com 4 milhões. $\mathrm{O}$ u seja, os bancos públicos são os que possuem maior quantidade de clientes, seguidos pel os bancos privados nacionais.

\section{Alteração da composição das formas de captação}

H á uma tendência de queda da participação dos depósitos à vista ${ }^{8}$ e de poupança em todas as instituições, com exceção da C aixa, que vêm sendo substituídos por captações de mercado aberto e por depósitos a prazo, principal menteC ertificados de D epósitos B ancários (CD Bs). 0 aumento da participação das captações de mercado aberto é uma tendência verificada em todos os bancos, com exceção do H SBC , em que essa forma de captação não é significativa. E ssa tendência pode ser explicada pela recente queda das taxas de juros, que diminuiu o custo desse tipo de captação.

O s bancos estrangeiros analisados captam recursos, principalmente, por meio de depósitos a prazo. Verifica-se que, no momento de aquisição dos grandes bancos nacionais, houve um aumento na participação dos depósitos à vista e de poupança; entretanto, essa participação foi decrescendo, e esses depósitos foram sendo gradativamente substituídos por depósitos a prazo.

N o caso dos três bancos privados nacionais, há uma maior participação das captações de mercado aberto, acima de 40\%. N o caso do U nibanco, entretanto, os depósitos a prazo têm maior participação na captação total. Também se verifica, nos três bancos, uma queda departicipação dos depósitos à vistae, principal mente, depoupança.

O Banco do Brasil capta recursos, principalmente, por meio do mercado aberto; entretanto, os depósitos a prazo também têm participação significativa. A s captações por meio da poupança também vêm decrescendo, porém em ritmo mais lento do que nos demais bancos.

8 A queda mais acentuada dos depósitos à vista, no primeiro semestre de 2008, verificada em todos os bancos, deve-se ao fim daCPM F, queresultou em maior mobilidade de recursos. 
A Caixa éa instituição que mais se diferencia dos outros bancos, pois capta recursos, principalmente, por meio da poupança, e essa participação, ao contrário do que ocorreu com os demais, vem crescendo. A captação em poupança éuma vantagem da CE F em relação aos outros bancos, porquetem custo menor do queas outras formas decaptação. A lém disso, essa forma decaptação évista como estratégica porqueal avanca recursos para a expansão do crédito imobiliário e, na faixa livre, para a expansão da carteira de crédito comercial. A CEF conta, ainda, com os recursos federais queadministra, como 0 F undo de G arantia do Tempo de Serviço (F G T S), quetambém têm baixo custo. A s captações de mercado aberto começaram a crescer a partir de 2002, devido ao Proef. Entretanto, a captação por meio de depósitos ainda é predominante.

O Banco do Brasil élíder em depósitos à vista, interfinanceirose a prazo, enquanto a Caixa é líder em depósitos de poupança. O BB também é líder em depósitos totais, seguido pela CEF. Em seguida vêm Bradesco, I taú, A BN , H SBC, U nibanco e Santander. Com relação à captação de mercado aberto, o líder é o Bradesco, seguido por I taú, BB, CEF, U nibanco, A BN , Santander eH SBC (T abela 2.6).

T abela 2.6 - C aptações - Participação de M ercado (\%)

\begin{tabular}{|c|c|c|c|c|c|c|c|c|c|c|c|c|}
\hline \multirow[b]{2}{*}{$\frac{5}{70}$} & \multicolumn{2}{|c|}{ À Vista } & \multicolumn{2}{|c|}{ Poupança } & \multicolumn{2}{|c|}{ Interfin. } & \multicolumn{2}{|c|}{ A Prazo } & \multicolumn{2}{|c|}{ Total } & \multicolumn{2}{|c|}{$\begin{array}{c}\text { C ap. } \\
\text { M ercado } \\
\text { A berto }\end{array}$} \\
\hline & $\frac{5}{8}$ & $\frac{8}{\frac{8}{3}}$ & $\frac{5}{\frac{0}{0}}$ & $\frac{8}{5}$ & $\frac{5}{8}$ & $\frac{8}{5}$ & $\frac{5}{8}$ & $\frac{8}{2}$ & $\frac{5}{8}$ & $\overrightarrow{\mathrm{E}}$ & $\frac{5}{8}$ & $\frac{8}{2}$ \\
\hline BB & 28,3 & 30,9 & 17,3 & 19,8 & 21,2 & 17,5 & 22,3 & 15,5 & 20,2 & 20,3 & 5,8 & 17,6 \\
\hline I taú & 0,3 & 3,9 & , & 7 & 3 & 4 & 1 & 71 & 68 & 9,0 &, 9 & 18,5 \\
\hline Brade & 15,0 & 19,1 & 14,4 & 13,8 & 0,9 & 1,5 & 2,0 & 12,1 & 7,8 & 12, & 4,8 & 19,2 \\
\hline CEF & 8,1 & 8,2 & 24,3 & 33,3 & 0,0 & 0,0 & 19,0 & 8,8 & 22,1 & 15,4 & 1,9 & 7,9 \\
\hline$A B N$ & 0,0 & 6,2 & 0,0 & 4,4 & 1,9 & 3,6 & 0,5 & 9,6 & 0,3 & 1,3 & 0,2 & 3,7 \\
\hline Uniba & 3,2 & 2,6 & 2,9 & 3,4 & 0,2 & 4,4 & 2,3 & 7,6 & 2,5 & 5,5 & 3,0 & 7,1 \\
\hline Santander & 0,2 & 3,1 & 0,0 & 2,9 & 0,0 & 2 & 0,7 & 6,8 & 0,3 & 4 & 0,2 & 3,3 \\
\hline H SBC & 2,7 & 4,8 & 3,7 & 0,9 & 6,4 & 2,9 & 1,4 & 8,5 & 2,4 & 5,6 & 2,5 & 0,2 \\
\hline Total & 67,8 & 88,9 & 75,8 & 90,3 & 33,8 & 36,2 & 50,0 & 76,1 & 62,4 & 80,9 & 23,3 & 77,5 \\
\hline
\end{tabular}

Fonte: Elaboração própria a partir de dados extraídos do site do Banco C entral do Brasil. 
D esta análise, destaca-se, uma vez mais, a liderança das instituições públicas em depósitos ea liderança das instituições privadas nacionais, com exceção do U nibanco, em captações de mercado aberto.

\section{Ampliação das operações de crédito}

Verificou-se, principalmente a partir de 2003, uma elevação da carteira de crédito de todas as instituições. Esse crescimento foi possibilitado pelo bom desempenho da economia, pelas condições positivas de renda e emprego, pela redução das taxas de juros e pela ampliação dos prazos de amortização. A participação do crédito no PIB al cançou 36,5\% em junho de2008, contra 27,9\% em dezembro de 1998 (G ráfico 2.7). E m dezembro de2008, essa participação atingiu 41,3\%, o maior percentual da sérieiniciada, pelo Banco Central, em julho de $1994 .{ }^{9}$

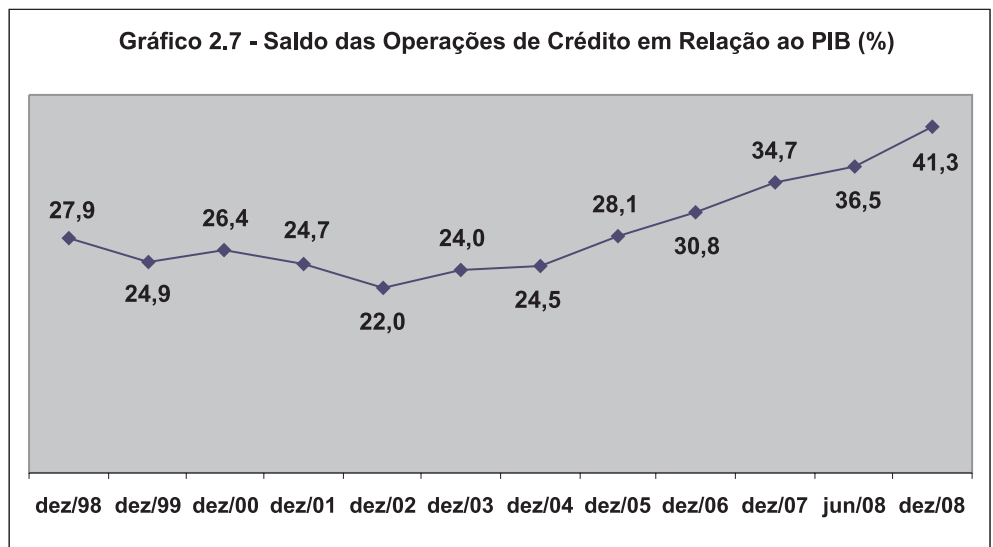

Fonte: Elaboração própria a partir de dados extraídos do site do Banco Central do Brasil.

90 percentual recorde era de 36,8\% do PIB, em janeiro de 1995. 
O segmento de varejo foi o que mais cresceu, com destaque para o financiamento de veículos, crédito consignado, financiamento imobiliário e cartões de crédito. Em 2007, o crescimento dessas modalidades em relação a 2006 foi de $34,3 \%$, 28,4\%, 87,5\% e 28,7\%, respectivamente.

O s principais destaques, entretanto, foram para os segmentos de financiamento de veículos e crédito consignado, o que indica que o crescimento do crédito foi acompanhado de um aumento da participação de financiamentos com garantias reais. E m agosto de 2007, a participação dessetipo de crédito foi de 65,5\%, contra 43\% em 2003, ou seja, antes do início das operações com crédito consignado (V alor E conômico, 8/ 8/ 2007).

E ssecrescimento do crédito protegeu as margens delucro dos bancos contra a queda dos juros. A pesar de os custos de captação terem permanecido altos, em 2007, a taxa de aplicação do crédito mostrou- sesuficiente para absorver esses custos, em especial a de pessoa física.

O Banco do Brasil é líder em operações de crédito, seguido pelo Bradesco, I taú, CEF, A BN , U nibanco, Santander e H SBC. D esde dezembro de 1998, os bancos estrangeiros foram os que mais apresentaram crescimento na participação de mercado. Se for considerado o período de 2003 a junho de 2008, de maior crescimento das operações de crédito, os bancos que apresentaram maior expansão em sua carteira foram Santander, Bradesco, I taú e H SBC, seguidos pelos bancos A BN , Banco do Brasil, CEF e U nibanco. Verifica-se queos bancos estrangeiros foram os que apresentaram maior crescimento, pois, juntos, representaram uma ampliação de $171 \%$, contra um crescimento de $161 \%$ dos bancos privados e de $153 \%$ dos bancos públicos (Tabela 2.7).

A participação no crédito conforme o tipo de controle (T abela 2.8) demonstra que as instituições privadas nacionais detêm maior parcela da carteira de crédito total do SF N , seguidas pelas instituições públicas. Essa maior participação se acentuou em 2005, o que indica que recentecrescimento das operações decrédito foi liderado pelos bancos privados nacionais, apesar deos demais também terem apresentado crescimento expressivo. 
Tabela 2.7 - C arteira de C rédito - Participação de M ercado (\%)

\begin{tabular}{|c|c|c|c|c|c|c|c|c|c|c|c|c|}
\hline & $\frac{8}{8}$ & $\frac{8}{8}$ & $\frac{8}{\frac{8}{8}}$ & $\frac{\sqrt{0}}{\frac{d}{0}}$ & $\frac{8}{8}$ & $\frac{8}{\frac{8}{8}}$ & $\frac{\delta}{d}$ & $\frac{\frac{1}{8}}{\frac{d}{8}}$ & $\frac{8}{8}$ & $\frac{\delta}{d}$ & $\stackrel{8}{\frac{8}{3}}$ & $\frac{8}{\dot{y}}$ \\
\hline BB &, 0 & 3,9 & 4,8 & 16,0 & 8,2 & 1,4 & 1,0 & 19,9 & 1,2 & 20,3 & 21,3 & 2,5 \\
\hline Itaú & 55 & 61 & 3 & 9,1 & 172 & 10,4 & 0,0 & 10,1 & 0,5 & 10,6 & 10,8 & 6,8 \\
\hline Brad & 0,3 & 0,4 & 12,5 & 14,3 & 14,4 & 14,1 & 14,7 & 15,8 & 14,9 & 15,8 & 15,2 & 47,8 \\
\hline CEF & 5 & 6,3 & 1,6 & 7, & 76 & 7 & 7,6 & 8,0 & 79 & 7 & 77 & $-74,8$ \\
\hline$A B N$ & 0,5 & 3,6 & 3,6 & 4,5 & 5, & 7,1 & 7,0 & 7,9 & 8,0 & 8,0 & 7,3 & $1.390,8$ \\
\hline Uni & 5,0 & 5 & 6,0 & 7, & 72 & 7,3 & 7, & 7, & 6,8 & 6 & 6,7 & 0 \\
\hline Sant & 1,7 & 1,6 & 1,9 & 4, & 4, & 3,5 & 5,0 & 5,4 & 5,9 & 5,4 & 5,1 & 195,6 \\
\hline $\mathrm{SB}$ & 1 & 1,5 & 2,4 & 2 & 2,5 & 4, & 3,8 & 3,9 & 3,8 & 3,7 & 3,7 & 190,5 \\
\hline
\end{tabular}

Fonte: Elaboração própria a partir de dados extraídos do site do Banco Central do Brasil.

T abela 2.8 - Participação dos Bancos na C arteira de C rédito (\%)

\begin{tabular}{c|c|c|c}
\hline D ata & Públicos & Privados Nacionais & Privados E strangeiros \\
\hline dez./ 98 & 55,0 & 29,1 & 15,9 \\
\hline dez./ 99 & 50,2 & 29,8 & 20,0 \\
\hline dez./ 00 & 44,0 & 33,8 & 22,2 \\
\hline dez./ 01 & 34,5 & 38,8 & 26,7 \\
\hline dez./ 02 & 37,5 & 37,4 & 25,1 \\
\hline dez./ 03 & 39,9 & 38,6 & 21,5 \\
\hline dez./ 04 & 38,5 & 39,6 & 21,9 \\
\hline dez./ 05 & 36,8 & 40,8 & 22,4 \\
\hline dez./ 06 & 36,7 & 41,2 & 22,1 \\
\hline dez./ 07 & 34,0 & 43,8 & 22,2 \\
\hline
\end{tabular}

Fonte: Elaboração própria a partir de dados extraídos do site do Banco C entral do Brasil.

O segmento definanciamento deveícul os está entre os mais representativos na carteira de crédito do sistema financeiro nacional. D e acordo com dados do Banco C entral, essa modalidade representou $34 \%$ dos créditos direcionados às pessoas físicas, em 2007, e uma expansão de 423\%, em relação a 2000. Esse bom desempenho pode ser explicado pelo aumento da demanda e pel o baixo risco dessas operações, tendo em vista queas garantias são os próprios veículos 
financiados. A lém disso, os veículos têm el evadaliquidez no mercado secundário, no caso de necessidade de apreensão.

A principal estratégia dos bancos anal isados édeestabelecimento deparcerias com redes deconcessionárias, o quecontribuiu para que esse segmento apresentasse a maior participação na carteira de crédito total, na maioria dos bancos anal isados, com exceção da C aixa e do Banco do Brasil, em que essa participação não é significativa. N o Banco do Brasil, essa modalidade passou a ser incluída como prioritária somente a partir de 2006, enquanto a C aixa passou a investir mais nessemercado a partir de2008. 0 banco líder em financiamento de veículos é o I taú, que atingiu uma participação de mercado de $26,5 \%$ em junho de 2008, seguido pelo Bradesco, com participação de $25,6 \%$. O u seja, os dois grandes bancos privados nacionais detêm mais de $50 \%$ do mercado, sendo que, em conjunto com o A BN -A mro e a BV Financeira, essa participação atinge $76 \%$ do mercado.

O crédito consignado, por sua vez, era permitido desde 1990 para servidores públicos; entretanto, somente após a regularização dessa modalidade para trabal hadores do setor privado, em setembro de 2003, e, principalmente, para aposentados e pensionistas do I N SS, em abril de 2004, é que o setor ganhou importância. E m 2004, foram feitas alterações significativas na legislação que trata do produto. ${ }^{10} \mathrm{O}$ D ecreto $\mathrm{n}-5.180$ e a L ei no 10.953 trouxeram a possibilidade de contratação com aposentados e pensionistas do I N SS, sem a necessidade de transferência de domicílio bancário e de vinculação do benefício ao banco concessor de empréstimos e financiamentos.

$\mathrm{N}$ essa modalidade, o pagamento é descontado diretamente da conta dos tomadores, que são, principalmente, servidores públicos, ou seja, têm maior estabilidade de emprego. Essa característica faz com o risco seja baixo. A lém disso, a qualidade da carteira de crédito de aposentados e pensionistas do I N SS é classificada como

10 A modalidade de crédito consignado já havia sido amplamente utilizada anteriormente, tendo sido eliminada por ser considerada uma violação do direito do assal ariado de decidir sobre a alocação de sua renda (C arvalho, 2007). 
"A". D essaforma, essetipo deempréstimo possibilita que os bancos mel horem a qualidade do crédito para pessoas físicas, diminuindo a exigência decapital próprio para as provisões eaumentando o Í ndice de Basileia (Bader eT akeda, 2005).

Todos os bancos analisados têm forte atuação nesse segmento e o consideram estratégico, sendo que o líder é o Banco do Brasil, com uma participação demercado de $21,6 \%$ em junho de 2008 . U ma das estratégias dos bancos analisados nesse segmento éa compra de carteira de crédito de instituições financeiras de pequeno e médio porte. Essas instituições são mais eficientes na captação de clientes e, muitas vezes, optam por vender parte das operações contratadas para os grandes bancos.

D esde 2004, a participação desse segmento no total de crédito do Sistema Financeiro $\mathrm{N}$ acional (SF N), bem como em cada instituição analisada, cresceu significativamente. N o período de 2004 a 2007, o crescimento dessa modalidade foi de $258 \%$, sendo que, em 2007, representava $27 \%$ do total do saldo da carteira de pessoas físicas do SF N e 56,3\% da carteira de crédito pessoal.

Recentemente, entretanto, esse crescimento se desacelerou, devido a uma saturação do mercado, principal mente nas linhas de empréstimos para o IN SS, que respondiam por $52,5 \%$ do total em 2006. Essa redução nos empréstimos direcionados a aposentados e pensionistas do IN SS também pode ser explicada pelas medidas adotadas recentemente pelo governo, dentre as quais destacam-se: redução do limite da parcela mensal do financiamento de $30 \%$ para $20 \%$ do benefício mensal; redução da taxa de juros máxima de cobrança, de $2,64 \%$ para $2,5 \%$ nos empréstimose de $3,7 \%$ para $3,5 \%$ nas operações com cartão de crédito; proibição da emissão de cartão de crédito sem autorização por escrito do segurado; proibição desaques com cartões de crédito, de efetivação de operações de arrendamento mercantil e de acúmulo de sete empréstimos concomitantes vinculados ao mesmo benefício; proibição para operações em Estados diferentes do quetem a inscrição do segurado; eredução do limite de crédito no cartão de três para duas vezes o valor do benefício (Valor E conômico, 6/3/2008). Essas medidas foram tomadas para evitar 
que os aposentados e pensionistas do IN SS fossem induzidos ao endividamento irresponsável e para evitar fraudes.

Com o mercado próximo do limite, a tendência é que os bancos se voltem para os funcionários do setor privado. Entretanto, a alta rotatividadee a possibilidade de crise nas empresas privadas tornam essa operação mais difícil. N esse caso, os juros são maiores para compensar o maior risco, já que a taxa de inadimplência do setor privado é de $7 \%$, contra $2 \%$ do setor público.

O segmento de crédito habitacional também ganhou importância recentemente, apresentando crescimento significativo nos últimos anos. Essa expansão foi possibilitada pela estabilidade econômica e pel o crescimento do emprego e renda, al iados às mudanças legais implementadas no setor. Essas mudanças possi bilitaram queas garantias das operações fossem equival entes às de países com mercados mais desenvolvidos. $D$ entre as alterações, destaca-se a lei do patrimônio de afetação, que separou a figura jurídica da obra e da construtora, protegendo o empreendimento de débitos do empreendedor. D essa forma, os bancos concederão crédito diretamente para uma obra específica, reduzindo o risco em caso de quebra das empresas. A lei do incontroverso, por sua vez, obrigou o pagamento do principal da dívida nos casos em que o mutuário contestar, najustiça, os val ores do financiamento. A possibilidadedecontratação com taxas prefixadase dedesconto da prestação em fol ha de pagamento também ampliou as contratações. A principal al teração, entretanto, foi a criação daalienação fiduciária, quegarantea recuperação do imóvel em caso deinadimplência, mesmo instrumento utilizado no financiamento de veículos. A alienação fiduciária para os empréstimos imobiliários foi criada em 1997, mas não começou a ser usada deimediato, devido ao receio dos bancos quanto ao comportamento do J udiciário, sendo quea CEF foi a pioneira, em 2000. A pós sua disseminação, o tempo deretomada do imóvel caiu de oito anos para menos dedozemeses (Valor E conômico, $25 / 7 / 2008)$. Essas medidas resultaram em queda da inadimplência do Sistema Financeiro de 11,2\%, em 2003, para 3,6\%, em 2008.

A lém disso, o próprio governo tem incentivado o financiamento de imóveis, por meio do Programa de A celeração do C rescimento (PAC), 
do F G T S e da CEF, reduzindo os juros e aumentando os prazos de amortização, quechegam atrintaanos. A pesar dessecrescimento, o cré dito imobiliário representa $2 \%$ do PIB, percentual baixo secomparado a outros países. N o C hile, essa participação éde 14\%, no Panamáéde 24\%enaA lemanhaédemais de 50\%(V alor E conômico, 29/ 11/2007).

A carteira de crédito habitacional atingiu $R \$ 52,8$ bilhões em junho de 2008 , um crescimento de $121 \%$ em relação a dezembro de 2001. A pesar da obrigatoriedade de direcionamento de $65 \%$ dos volumes captados em depósito em caderneta de poupança a financiamentosimobiliários, o setor permaneceu estagnado no período de 1999 a 2003, voltando a apresentar crescimento expressivo a partir de2004 (Valor E conômico, 20/ 3/ 2007). Em 2007, foram financiados 196 mil imóveis, entre novos e usados, aproximando-se do recorde histórico de 1981, quando os bancos financiaram 267 mil unidades.

O s bancos anal isados adotaram como estratégia o financiamento direto a construtoras e incorporadoras e o estabel ecimento de parcerias com imobiliárias. 0 interesseprincipal, entretanto, énas pessoas físicas, que se manterão clientes dos bancos durante todo o período de amortização, ou seja, por, aproximadamente, vinte anos.

A C aixaélíder demercado desde 1997, quando detinha $72 \%$ dos val ores contratados nesse segmento e era aúnica instituição habilitada a operar com recursos do F G T S. R ecentemente, devido ao maior interesse dos demais bancos, essa participação vem decrescendo, atingindo $68 \%$, em 2006 , pois os outros bancos se habilitaram para operar com o F undo. Todos os bancos analisados têm apresentado crescimento expressivo da carteira habitacional, dadas as mudanças ocorridas nessa modalidade, já relacionadas, que reduziram o risco de inadimplência e facilitaram a execução das garantias.

É importante ressaltar, entretanto, a diferença entre a atuação da C aixa ea das outras instituições. $\mathrm{Na}$ C EF, 85\% das unidades financiadas em 2006 foram destinadas a famílias com renda de até cinco salários mínimos. ${ }^{11}$ O s outros bancos, por sua vez, vêm ampliando

110 percentual destinado afamílias com renda de atétrês salários mínimos foi de $59 \%$ em 2006, segundo o site da C aixa E conômica Federal. 
sua participação no crédito para as classes média e alta, enquanto nas classes de renda média baixa e renda baixa, cuja atratividade é menor, a CEF continua dominando grandeparte do mercado. A lém disso, na Caixa, os Estados deSão Paulo e R io de J anei ro concentram $35 \%$ dos empréstimos concedidos, enquanto no Sistema Financeiro N acional esse percentual é de 65\% (Valor E conômico, 1/ 4/ 2008).

Com relação ao segmento de cartões de crédito, apesar de não possuir garantias demel hor qualidade como os segmentos anteriores, também tem sido verificado crescimento significativo na maioria das instituições. N o Sistema Financeiro N acional, o crescimento no período de 2000 a 2007 foi de 514\%. U ma das explicações para essa expansão é, como visto, a estratégia recente de oferecer cartões a não correntistas, por meio das financeiras e do estabel ecimento de parcerias com grandes lojas varejistas.

0 mercado de cartões de crédito ainda tem muito potencial de crescimento, uma vez que se estima que 70 milhões de brasileiros, que teriam condições de possuir um cartão, ainda não o possuem. D esse total, 96\% pertencem às classes C, D e E (Valor E conômico, 10/4/2007). Esse alto potencial, aliado aos altos spreads cobrados, fez com que todos os bancos anal isados investissem no segmento de cartões de crédito, buscando o crescimento, principalmente, nas classes C e D . 0 I taú é líder em faturamento - R \$22,7 bilhões - e em emissão de cartões de crédito - 16,2 milhões em 2007.

O segmento de micro epequenas empresas, por sua vez, também vem apresentando bom desempenho, embora este seja inferior ao verificado no segmento de Pessoas F ísicas. O s produtos que mais têm se destacado, entretanto, são os relacionados ao capital de giro, de curto prazo, como veículos, antecipação de recebíveis e conta garantida. O u seja, são produtos em que a qualidade da garantia é maior, não estando, entretanto, direcionados ao investimento. U ma consequência desse comportamento, destacada por J acob (2003), éa redução da capacidade de endividamento das empresas, já que esta fica condicionada à disponibilidade de geração de contas a receber. Como resultado, a alavancagem com capital de terceiros é baixa e a cobertura do endividamento é feita por empréstimos decurto prazo. 
$\mathrm{N}$ os últimos anos, algumas medidas também foram tomadas para impulsionar o segmento demicro e pequenas empresas, como a criação do Simples - Sistema I ntegrado dePagamento del mpostose Contribuiç̧ões - ea mudança na L ei de F alências, que dá prioridade de pagamento aos créditos garantidos em relação aos tributários, 0 que criou um ambiente mais favorável à concessão de crédito.

Em 2006, o Bradesco foi líder de mercado, com uma participação de $29 \%$, seguido pelo A BN , com $22 \%$, I taú, com $20 \%$, e Banco do Brasil, também com $20 \%$ de participação. E m 2007, o Bradesco também se manteve na liderança no repasse destinado às micro, pequenas e médias empresas.

Por outro lado, desde 2003, o bom desempenho da economia nacional e a maior liquidez nos mercados internacionais possibilitaram um mais fácil acesso das grandes empresas ao mercado de capitais. D essa forma, essas empresas optaram pela diversificação das suas fontes de financiamento, o que também contribuiu para 0 direcionamento da concessão de crédito dos bancos para o varejo.

D estaca-se, uma vez mais, a peculiaridade do Banco do Brasil quanto à alta participação do financiamento à agricultura em sua carteira (partici pação demercado de 58\% em 2007) e, principalmente, da C aixa E conômica Federal, que possui uma carteira de crédito bem distinta das demais instituições. $\mathrm{N} \mathrm{a} \mathrm{CEF}$, a participação do crédito habitacional émuito elevada, destacando-se, também, a alta participação do penhor, linha não existentenos outros bancos. Essas peculiaridades devem-se ao fato de se tratar de bancos públicos, 0 que faz com que tenham de atuar conforme os setores prioritários definidos pelo governo federal, como é o caso do crédito agrícola, habitação e crédito às micro e pequenas empresas.

Com relação aos grupos estrangeiros, apesar de o Brasil ea A mérica $L$ atina não serem as regiões com maior participação no crédito, são as que apresentaram maior crescimento nos últimos anos. Esse crescimento pode ser explicado, principalmente, pelo aumento das operações de crédito e pela apreciação do real em relação ao euro.

$\mathrm{N}$ o Brasil, as instituições com controle estrangeiro buscam ampliar as operações de crédito, com destaque para o varejo, principal- 
menteem operações com maiores garantias ou maiores retornos. Essa estratégia, entretanto, se diferencia daquela adotada em seus países de origem, em que o crescimento do crédito não é tão acentuado nem tão direcionado para o varejo. A lém disso, nesses países, os principais componentes da cartei ra de crédito de Pessoas F ísicas são as hipotecas residenciais, modal idade pouco desenvolvida no Brasil. A expectativa dos grupos estrangei ros com relação ao Brasil eoutros países em desenvolvimento éotimista, pois el es consideram queesses países estão crescendo acima da média dos países desenvolvidos e ainda possuem baixo nível de bancarização.

Por último, é importante destacar que, apesar do crescimento do percentual das operações de crédito em relação ao PIB, este permanece baixo em relação a outros países (T abela 2.9). Esse baixo percentual, portanto, indica que o país ainda possui um forte potencial de bancarização e penetração de crédito e outros produtos financeiros.

T abela 2.9 - Saldo das 0 perações de C rédito como Percentual do PIB em D iversos Países - 2005 (\%)

\begin{tabular}{c|c|c|c}
\hline País & C rédito / PIB (\%) & País & C rédito / PIB (\%) \\
\hline Estados U nidos & 194,8 & Coreia do Sul & 102,1 \\
\hline Japão & 186,9 & França & 93,1 \\
\hline Canadá & 181,4 & Itália & 90,2 \\
\hline H olanda & 173,4 & Chile & 82,3 \\
\hline Suíça & 166,8 & Bélgica & 75,1 \\
\hline Reino Unido & 165,5 & Irã & 40,9 \\
\hline Portugal & 147,3 & Brasil & 28,1 \\
\hline H ong Kong & 146,2 & Indonésia & 26,9 \\
\hline Espanha & 146,1 & Turquia & 26,1 \\
\hline Á frica do Sul & 143,5 & Rússia & 25,7 \\
\hline China & 114,4 & Colômbia & 23,9 \\
\hline Á ustria & 112,9 & Peru & 19,4 \\
\hline A lemanha & 111,4 & M éxico & 18,2 \\
\hline A ustrália & 104,6 & & \\
\hline
\end{tabular}

Fonte: The B anker 1000 - julho de 2007. Extraído do site da Febraban. 


\section{Manutenção dos índices de inadimplência}

A pesar do crescimento verificado na carteira decrédito, o índice de inadimplência do setor bancário não sofreu al terações significativas, ao contrário do que ocorreu em outros períodos. Em 1994, início do Plano R eal eda estabilidadeeconômica, os bancos ampliaram a oferta decrédito eainadimplência seel evou. N o crescimento recente, entretanto, verificou-se uma queda do índice de inadimplência do Sistema Financeiro $\mathrm{N}$ acional $\mathrm{O}$ atraso acima de noventa dias passou a representar 3,1\% em junho de 2008, contra 3,7\% em 2006 (G ráfico 2.8). Foi observada redução/ manutenção do índice de inadimplência em todos os segmentos do sistema financeiro, tanto nos bancos públicos como nos privados estrangeiros ou nacionais. O s bancos analisados acompanharam essa tendência.

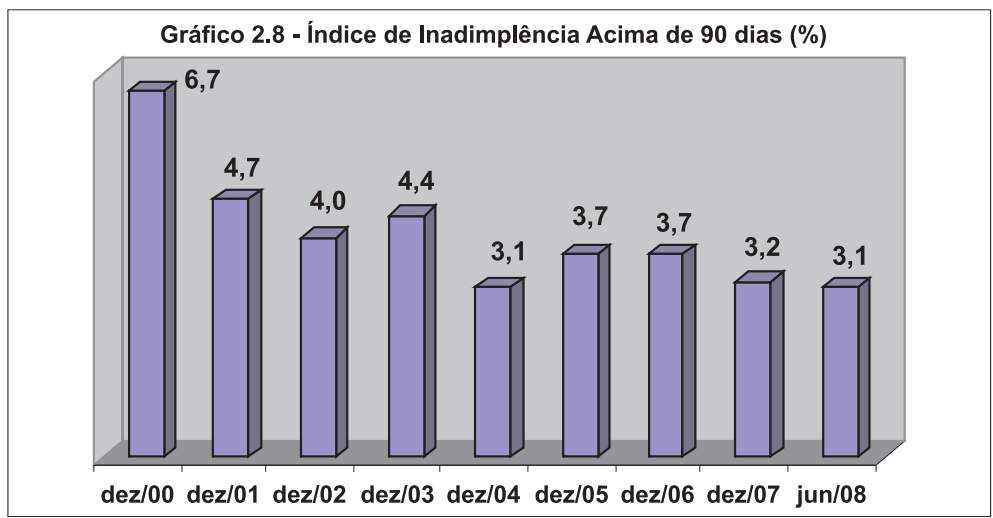

Fonte: Elaboração própria a partir de dados extraídos do site do Banco C entral do Brasil.

Esse comportamento pode ser explicado pelo fato de os bancos terem concentrado o crescimento do crédito em modalidades com menores taxas de juros e menor risco, caso do crédito consignado, financiamento deveículos ecrédito imobiliário. Também contribuíram a estabilidadeeconômica, o crescimento econômico com melhoria da renda da população, a ampliação dos prazos de amortização e a redução das taxas de juros. 


\section{Maior Índice de Solvabilidade dos bancos brasileiros}

O Índice de Solvabilidade, ou Índice de Basileia, mede a capacidade de alavancagem das instituições financeiras. Conforme estabelecido pela R esolução no 2.099, de 17 de agosto de 1994, do C onsel ho M onetário $\mathrm{N}$ acional, as instituições brasileiras devem ter um índice mínimo de $11 \%$.

Todos os bancos analisados mantiveram-se acima do índice mínimo durante o período de dezembro de 2001, quando o Banco C entral começou a divulgar esseíndice, a junho de 2008. N o final de dezembro de 2007, o Índice de Solvabilidade médio dos 50 maiores bancos brasileiros, conforme critérios do Banco C entral, foi de 17,3\%, bem acima do mínimo exigido. O sbancos públicos atingiram o maior índice, de $18,8 \%$, contra $17 \%$ dos bancos privados nacionais e $15,8 \%$ dos bancos privados estrangeiros.

A s instituições que apresentaram o Í ndice de Solvabilidade mais elevado foram C aixa E conômica Federal, I taú e Bradesco. O H SBC e o Banco do Brasil são os bancos em que o índice está em nível mais baixo, sendo que a queda se acentuou em 2007 e no primeiro semestre de 2008. O Índice de Solvabilidade do A BN , U nibanco e Santander vêm apresentando tendência de queda desde dezembro de2004 (Tabela 2.10).

Tabela 2.10 - Índicede Basileia (\%)

\begin{tabular}{l|c|c|c|c|c|c|c|c}
\hline & dez./ 01 & dez./ 02 & dez./ 03 & dez./ 04 & dez./ 05 & dez./ 06 & dez./ 07 & jun./ 08 \\
\hline CEF & 13,56 & 14,68 & 19,24 & 20,27 & 27,87 & 25,29 & 28,88 & 22,36 \\
\hline I taú & 18,27 & 17,05 & 20,22 & 20,06 & 16,66 & 18,30 & 18,74 & 17,07 \\
\hline Bradesco & 15,22 & 17,89 & 19,85 & 18,75 & 17,26 & 18,76 & 15,65 & 14,35 \\
\hline U nibanco & 13,72 & 15,71 & 18,60 & 16,27 & 15,64 & 15,99 & 14,72 & 13,71 \\
\hline A BN & 16,75 & 15,73 & 19,55 & 19,34 & 15,19 & 13,76 & 13,46 & 13,62 \\
\hline Santander & 14,66 & 15,09 & 18,08 & 16,96 & 14,13 & 15,37 & 14,24 & 13,57 \\
\hline H SBC & 12,23 & 12,93 & 14,39 & 13,95 & 14,33 & 14,23 & 13,40 & 13,11 \\
\hline BB & 12,61 & 12,16 & 13,65 & 15,14 & 17,06 & 17,25 & 15,58 & 13,08 \\
\hline
\end{tabular}

Fonte: Elaboração própria a partir de dados extraídos do site do Banco C entral do Brasil. 
Essa queda, bem como os mais recentes decréscimos verificados nos outros bancos, pode ser explicada pela elevação do crédito em todas as instituições, com consequente aumento da alavancagem. C onforme visto no capítulo 1, a carteira de crédito está entre os ativos de maior risco e que exigem maior alocação de recursos. Por outro lado, os títulos públicos são considerados de risco nulo, o que explica os altos índices de solvabilidade da C aixa. $\mathrm{O}$ baixo índice do Banco do Brasil, por sua vez, pode ser explicado pelo crescimento dos créditos tributários, que exigem al ocação de capital de $300 \%$.

E mbora o $\mathrm{C}$ onselho $\mathrm{M}$ onetário $\mathrm{N}$ acional tenha definido um Índice de Solvabilidade mínimo de $11 \%$, os países de origem dos bancos estrangeiros analisad os mantiveram o índice mínimo de 8\% definido pelo Comitê da Basileia. Esta deve ser a principal razão pela qual os grupos estrangeiros analisados mantêm índices menores do que os bancos que atuam no Brasil (Tabela 2.11). Verifica-se, portanto, conformeapontado no capítulo 1, queos bancos brasilei ros possuem um perfil mais conservador no que diz respeito à exigência de capital mínimo em relação ao risco das operações ativas, mesmo após a recente queda do Í ndice de Solvência. O s bancos estrangeiros que entraram no Brasil mantiveram esseperfil conservador, com Í ndices de Solvência mais al tos do que em outras praças.

Tabela 2.11 - Índice de Basileia (\%) - G rupos Estrangeiros

\begin{tabular}{l|c|c|c|c|c|c|c|c}
\hline & dez./ 01 & dez./ 02 & dez./ 03 & dez./ 04 & dez./ 05 & dez./ 06 & dez./ 07 & jun./ 08 \\
\hline A BN & 10,91 & 11,54 & 11,73 & 11,06 & 13,14 & 11,14 & 14,61 & - \\
\hline Santander & 12,00 & 12,64 & 12,43 & 13,01 & 12,94 & 12,49 & 12,66 & 11,43 \\
\hline H SBC & 13,00 & 13,30 & 12,00 & 12,00 & 12,80 & 13,50 & 13,60 & 11,40 \\
\hline
\end{tabular}

Fonte: Elaboração própria a partir de dados extraídos dos sites dos grupos A BN , Santander e $\mathrm{HSBC}$.

Com a entrada em vigor das novas regras de capital mínimo dos bancos, em julho de 2008, o Banco Central estima que o efeito sobre o sistema bancário seja nulo, com aumento de exigência de capital para al guns bancos e diminuição para outros. Com relação aos grandes bancos com forte atuação no crédito ao varejo, que é o caso das instituições anal isadas nestetrabal ho, a expectativa édeque 
a exigência de capital diminua eque sejam liberados recursos para a expansão do crédito. I sso se deve à redução do capital exigido para operações de crédito de varejo.

Tendo em vista que o Brasil permanece com altos Í ndices de Solvência em relação aos bancos de outros países (G ráfico 2.9), verifica-se que há espaço para que o Banco Central reduza o Índice de Solvabilidade mínimo exigido. A Iguns dos bancos analisados já chegaram ao nível de 13\% no primeiro semestre de 2008 (T abela 2.10), o que pode levar a uma maior restrição à concessão de crédito. U m I ndice de Solvabilidademínimo de $8 \%$, queé o índice pactuado no A cordo da Basileia e praticado pela maioria dos países, poderia, neste sentido, expandir a oferta de crédito.

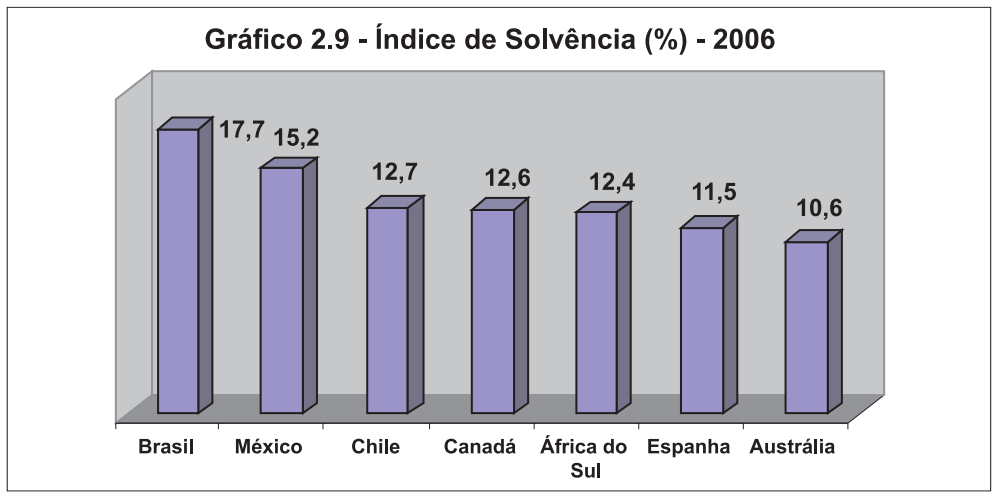

Fonte: Bacen e G lobal Financial Stability R eport - F M I.

\section{Aumento da qualidade da carteira de crédito}

N os bancos analisados, as cartei ras com melhor qualidade são as degrandes empresas ecomércio exterior, seguidas pelas carteiras de micro e pequenas empresas. A s cartei ras de qual idade menor são as de pessoas físicas e de financiamento à agricultura.

Todos os bancos analisados, com exceção da Caixa E conômica Federal, concentram mais de $90 \%$ das suas operações de crédito nos 
níveis derisco A A , A, B eC, considerados níveis normais derisco. ${ }^{12}$ $\mathrm{N}$ a Caixa, esse percentual atingiu 87,52\% em junho de 2008; entretanto, até 2004 era de menos de $70 \%$.

O s dois bancos públicos são as instituições que possuem mais créditos de menor qualidade. I sso se deve ao fato de sofrerem interferência do governo para direcionar seus empréstimos a setores como agricultura e o segmento de renda mais baixa, considerados créditos de menor qualidade. ${ }^{13} \mathrm{C}$ onforme já verificado em Vasconcel os e Strachman (2002), ainda não há evidências de que os bancos com controle estrangeiro sejam mais conservadores quanto ao risco dos empréstimos concedidos do que os bancos privados nacionais.

Verifica-seuma tendência de mel hora na qualidade da carteira de crédito, o que pode ser explicado pelo direcionamento a operações de crédito com menores riscos, como crédito consignado efinanciamento deveículos. $\mathrm{N}$ a carteira decrédito total do SistemaFinanceiro, $92,2 \%$ das operações estavam concentradas nos níveis derisco A A - C , em junho de2008, contra 90,8\%, em janeiro de 2007.

\section{Ampliação do Índice de Cobertura}

O Índice de Cobertura expressa a capacidade de cobertura das despesas de pessoal somente com as receitas de prestação deserviços.

12 O s créditos classificados deA A atéC são considerados derisco normal eincluem 0 atraso até 60 dias, bem como o risco que seria percebido através da análise econômico-financeira; os créditos classificados de D até G são considerados de risco ampliado 1 e captam o atraso de 60 a 180 dias, com garantias suficientes, e o risco que seria percebido através da análise econômico-financeira; os créditos classificados como H , por sua vez, são considerados de risco ampliado 2 ecaptam os créditos em liquidação, deduzidas as rendas apropriadas, com atraso demais de 60 dias, sem garantias suficientes, ou de mais de 180 dias, bem como o risco percebido através da análiseeconômico-financeira (Vasconcel os eStrachman, 2002).

13 Conforme destacado por Vasconcelos e Strachman (2002), deve-se considerar a possibilidade de essa classificação estar refletindo também, ou somente, a capacidadedeos bancos anal isarem as demandas por crédito através desistemas mais eficientes. 
E sseíndice apresentou crescimento significativo em todos os bancos analisados, destacando-seno I taú eno Santander. A C aixa éo banco com o menor Í ndice de C obertura (Tabela 2.12).

Tabela 2.12 - Índices de C obertura (\%)

\begin{tabular}{l|c|c|c|c|c|c|c|c|c|c|c}
\hline & $\mathbf{1 9 9 8}$ & $\mathbf{1 9 9 9}$ & $\mathbf{2 0 0 0}$ & $\mathbf{2 0 0 1}$ & $\mathbf{2 0 0 2}$ & $\mathbf{2 0 0 3}$ & $\mathbf{2 0 0 4}$ & $\mathbf{2 0 0 5}$ & $\mathbf{2 0 0 6}$ & $\mathbf{2 0 0 7}$ & $\mathbf{1 0 S ~ 2 0 0 8}$ \\
\hline Santander & 53,3 & 44,5 & 45,0 & 38,7 & 72,8 & 80,9 & 102,0 & 108,2 & 147,5 & 185,2 & 198,3 \\
\hline I taú & 100,8 & 133,1 & 126,8 & 123,2 & 136,3 & 173,5 & 197,3 & 224,3 & 212,6 & 200,0 & 190,1 \\
\hline U nibanco & 101,5 & 123,6 & 115,7 & 107,2 & 121,5 & 125,4 & 119,2 & 136,5 & 134,4 & 149,6 & 140,1 \\
\hline H SBC & 92,9 & 82,5 & 79,3 & 94,3 & 84,6 & 95,2 & 105,7 & 133,8 & 142,5 & 132,4 & 131,1 \\
\hline BB & 44,3 & 49,4 & 56,0 & 67,4 & 80,4 & 80,6 & 93,0 & 102,3 & 112,9 & 108,1 & 130,9 \\
\hline Bradesco & 73,6 & 82,7 & 89,4 & 99,2 & 87,8 & 85,2 & 101,7 & 115,6 & 114,2 & 122,0 & 124,5 \\
\hline A BN & 20,3 & 69,4 & 67,9 & 75,1 & 70,1 & 80,8 & 87,4 & 92,3 & 113,3 & 118,0 & 113,7 \\
\hline CEF & 65,6 & 69,9 & 73,4 & 80,6 & 108,1 & 114,0 & 98,1 & 92,5 & 89,6 & 95,9 & 90,6 \\
\hline
\end{tabular}

Fonte: Elaboração própria a partir de dados extraídos do site do Banco C entral do Brasil.

0 aumento verificado foi impulsionado pela ampliação das receitas deprestação deserviços, destacando-seas receitas originadas pelas operações com cartões decrédito e débito, com exceção do Banco do Brasil, Caixa eSantander. N o BB, as receitas de prestação de serviços são compostas, principalmente, por tarifas de conta-corrente. I sso pode ser explicado pelo el evado número deconta-correntes que o banco possui. $\mathrm{N}$ a C aixa, destacam-se as receitas deadministração do F G T S, enquanto no Santander a maior contribuição vem das operações de crédito.

Essa ampliação das receitas de prestação de serviços contribuiu para a continuidade dos al tos lucros obtidos pel os bancos após o término dos expressivos ganhos com as receitas advindas da inflação. Segundo estudos da A ustin R ating, a participação das receitas de prestação de serviços nas receitas totais cresceu de 7,6\%, em dezembro de 1994, para 21,2\%, em setembro de 2007. A ampliação dessas receitas, de 1994 a 2006, foi de 734,7\%, contra um crescimento de $74 \%$ das despesas com pessoal, enquanto a inflação do período foi de $157 \%$. Esse desempenho permitiu um expressivo crescimento do Í ndice de C obertura do Sistema Financeiro, que atingiu 129,8\% em 2007, contra 93,3\% em 2003 (Valor E conômico, 29/ 11/ 2007). 
A recente redução ou o menor crescimento das receitas de prestação de serviços, verificados em todas as instituições, podem ser explicados pela antecipação dos bancos à R esolução no 3.518/ 07, do Conselho $\mathrm{M}$ onetário $\mathrm{N}$ acional, que disciplinou a cobrança de tarifas para pessoas físicas. A novaregulamentação entrou em vigor em abril de 2008. A s principais medidas adotadas foram: redução de 55 para 20 do número de serviços quepodem ser cobrados; maior padronização das tarifas; inclusão de mais serviços como essenciais, ou seja, que não podem ser cobrados pelos bancos; prazo mínimo de seis meses entre reajustes de tarifas; obrigatoriedade na divulgação do custo total de financiamentos; e extinção da taxa de antecipação de liquidação, cobrada quando o cliente quita o empréstimo antes do prazo, da tarifa de manutenção de contas-correntes inativas e da tarifa de processamento de cheques de baixo valor.

A s novas medidas têm como objetivo aumentar a transparência e padronizar os serviços prestados pelos bancos e, dessa forma, ampliar a concorrência no setor. A pós a adoção dessas medidas e padronização dos pacotes de tarifas, verificou-se que as menores tarifas eram cobradas por bancos públicos, com liderança da C aixa E conômica F ederal. $N$ a média, a diferença entreos pacotes oferecidos aos correntistas do Banco do Brasil e da Caixa E conômica Federal em relação aos bancos privados éde $49,62 \%$. 0 s bancos estrangeiros são os que registraram tarifas mais altas (Extra - RJ , 2/4/ 2008).

\section{Redução do Índice de Eficiência}

0 Índice de E ficiência expressa a relação entreas despesas administrativas eas receitas operacionais; portanto, quanto menor, maior é a eficiência da instituição. $N$ esse caso, o desempenho dos bancos privados nacionais foi melhor do queo dos bancos estrangeiros. Entre os bancos nacionais, somentea CEF apresentou Índice deEficiência mais elevado, de 74,8\% em 2007 (G ráfico 2.10). Entretanto, conformedetal hado no $\mathrm{A}$ nexo I , a tendência verificada em todos os bancos é de queda dos Índices de E ficiência. 


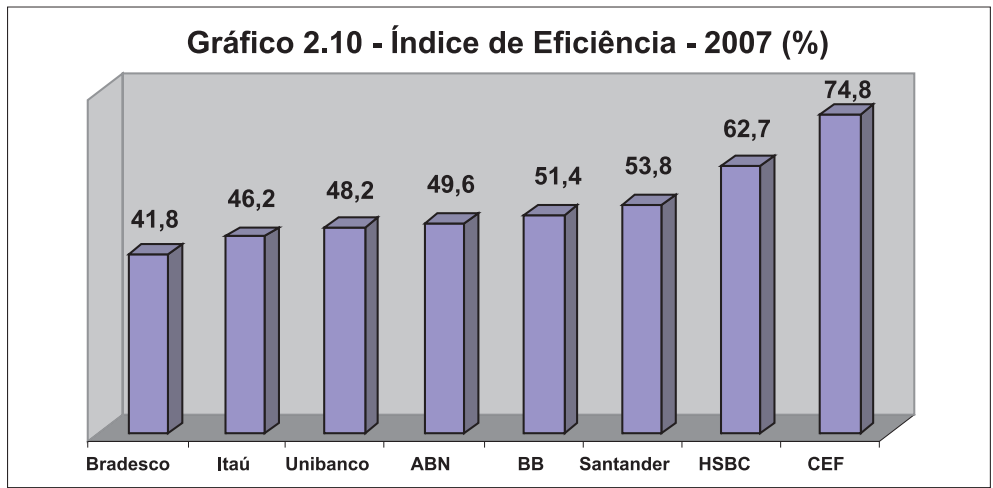

Fonte: Elaboração própria a partir de dados extraídos dos balanços dos bancos anal isados.

O Grupo A BN possui Í ndice deE ficiência superior ao detodos os bancos brasileiros, inclusiveao desua unidadeno Brasil. 0 G rupo Santander possui índicemais próximo ao dos bancos privados nacionais, entretanto inferior ao de sua unidade brasileira. As unidades com menores Í ndices deEficiência do Santander estão local izadas na E uropa continental. N o caso do H SBC, o índice do grupo é menor do que o índice da sua unidade brasileira (Tabela 2.13).

Tabela 2.13 - Índice de eficiência dos grupos estrangeiros (\%)

\begin{tabular}{l|c|c|c|c}
\hline & dez./ 04 & dez./ 05 & dez./ 06 & dez./ 07 \\
\hline A BN & 77,9 & 74,9 & 79,1 & 83,5 \\
\hline Santander & 52,0 & 52,6 & 48,6 & 44,2 \\
\hline Europa Continental & - & 37,7 & 40,8 & 38,8 \\
\hline R eino U nido & - & 60,1 & 55,1 & 50,1 \\
\hline A mérica L atina & - & 47,4 & 47,0 & 41,8 \\
\hline H SBC & 51,6 & 51,2 & 51,3 & 49,4 \\
\hline Europa & 64,0 & 60,8 & 60,1 & 59,9 \\
\hline H ong K ong & 35,8 & 38,2 & 38,0 & 33,4 \\
\hline Á sia & 54,8 & 55,1 & 52,8 & 47,4 \\
\hline A mérica do N orte & 43,4 & 44,8 & 47,1 & 46,3 \\
\hline A mérica L atina & 62,9 & 60,0 & 61,0 & 58,3 \\
\hline
\end{tabular}

Fonte: Elaboração própria a partir de dados extraídos dos sites dos grupos A BN, Santander e $\mathrm{HSBC}$. 
D essa forma, verifica-se que, com exceção do A BN , as unidades brasileiras dos grupos estrangei ros são menos eficientes do que suas matrizes. Entretanto, os Í ndices deE ficiência dos bancos localizados no Brasil estão bem próximos aos dos bancos localizados no exterior, sendo em al guns casos, como visto, menores. 0 Í ndicedeE ficiência do SistemaF inanceiro $\mathrm{N}$ acional também vem decrescendo, passando de 56,3\%, em 2003, para 50,7\%, em 2007.

A busca por menores Í ndices de E ficiência adquiriu maior relevância na década de 1990, com a entrada dos bancos estrangeiros, que já tinham a cultura da busca pela maior eficiência. Conforme visto no capítulo 1, quando os bancos estrangeiros entraram no Brasil, os bancos nacionais eram menos eficientes. Segundo estudo realizad o pel o Banco $C$ entral, suas despesas operacionais equivaliam a 9,6\% dos ativos administrados, acima do índice de $6,8 \%$ exibido pelos bancos estrangeiros. A tualmente, esses índices se inverteram (G ráfico 2.11), o que pode ser explicado, principalmente, pela busca por maior eficiência dos bancos nacionais, devido à ameaça de concorrência das instituições estrangeiras (Valor E conômico, 30/ 7 ( 2008).

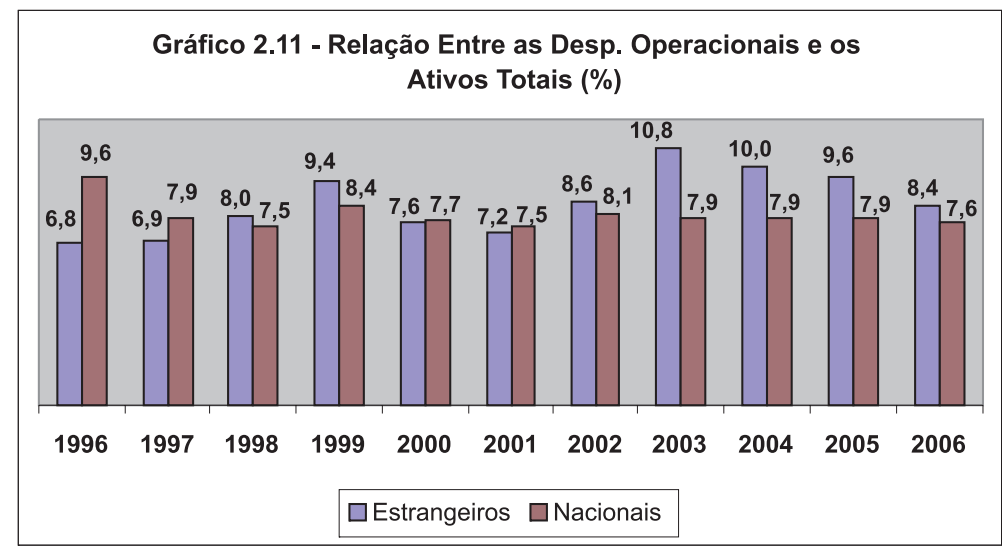

Fonte: Elaboração própria a partir de dados extraídos do site do Banco C entral do Brasil. 


\section{Ampliação da participação da carteira de crédito no total de ativos}

Em todas as instituições analisadas, com exceção da C aixa, a carteira decrédito éo principal componentedo ativo. No caso daCEF, o ativo écomposto, principalmente, porT ítulos eValores M obiliários (T V M ); entretanto, a participação da carteira de crédito vem apresentando crescimento, principalmentea partir de2004 (T abela 2.14).

T abela 2.14 - Participação das 0 perações de C rédito no A tivo T otal (\%)

\begin{tabular}{c|c|c|c|c|c|c|c|c}
\hline & B B & Itaú & B radesco & C E F & A B N & U nibanco & Santander & H SBC \\
\hline dez./ 97 & 27,9 & 25,4 & 39,2 & 52,1 & 40,2 & 33,5 & 23,4 & 15,4 \\
\hline dez./ 98 & 23,4 & 24,3 & 34,0 & 53,9 & 11,5 & 34,3 & 30,5 & 18,4 \\
\hline dez./ 99 & 23,6 & 28,7 & 31,5 & 46,2 & 30,3 & 34,8 & 26,1 & 25,1 \\
\hline dez./ 00 & 28,0 & 29,1 & 39,1 & 44,7 & 32,6 & 32,4 & 19,6 & 28,9 \\
\hline dez./ 01 & 25,7 & 30,9 & 39,9 & 19,4 & 37,6 & 39,9 & 20,5 & 27,8 \\
\hline dez./ 02 & 26,7 & 31,2 & 36,3 & 17,7 & 41,1 & 30,5 & 23,3 & 30,2 \\
\hline dez./ 03 & 30,2 & 30,7 & 31,3 & 16,8 & 42,5 & 37,5 & 24,9 & 43,5 \\
\hline dez./ 04 & 33,5 & 30,9 & 37,7 & 19,6 & 45,0 & 39,0 & 28,3 & 42,4 \\
\hline dez./ 05 & 36,5 & 31,9 & 44,1 & 19,7 & 49,1 & 40,8 & 29,7 & 37,6 \\
\hline dez./ 06 & 41,3 & 29,6 & 40,3 & 21,8 & 38,5 & 40,3 & 33,4 & 37,2 \\
\hline dez./ 07 & 41,6 & 27,1 & 40,8 & 22,4 & 36,9 & 34,0 & 33,8 & 38,0 \\
\hline jun./ 08 & 43,7 & 26,4 & 36,0 & 24,0 & 36,6 & 32,8 & 32,9 & 31,1 \\
\hline Fonte: Elabry
\end{tabular}

Fonte: Elaboração própria a partir de dados extraídos do site do Banco C entral do Brasil.

Em todos os bancos tem severificado uma tendência de queda da participação dos títulos públicos no total de ativos. A s instituições com maior participação detítulos públicos são a Caixa e o BB, ou seja, os bancos públicos. Em 2008, a CEF assumiu uma estratégia de diminuir a importância dos títulos e val ores mobiliários em seu balanço e transferir essas cartei ras para operações decrédito. A participação dos títulos públicos na carteira de títulos do SF N foi de $70,2 \%$, em dezembro de 2006, contra 84,1\%, em dezembro de2003 - trajetória compatível com o crescimento da emissão deinstrumentos privados, com destaque para as debêntures. 
O s bancos com maior participação das operações de crédito são Banco do Brasil, A BN e Bradesco. N os casos do Banco do Brasil, H SBC e, principalmente, do Santander, a carteira de crédito ganhou importância mais recentemente. Com relação aos grupos estrangeiros, A BN e HSBC vêm apresentando, no mundo, tendência de queda da participação das operações de crédito no ativo total, ao contrário das suas unidades situadas no B rasil. A s participações são bem menores do que os níveis das unidades brasileiras: $38,7 \%$ no A BN e 36,9\% no H SBC.

Com o Santander ocorre o oposto. Enquanto sua unidade brasileira tinha as operações deT VM como principais componentes do ativo até 2006, atingindo uma participação de 32,9\% em junho de 2008, o grupo tem al ta participação do crédito nos ativos totais, de $62,4 \%$ em junho de 2008.

\section{Aumento do lucro líquido e da rentabilidade sobre o patrimônio líquido médio}

D urante o período analisado, de dezembro de 1998 a junho de 2008, os maiores lucros líquidos foram obtidos pelo I taú, seguido pelo Bradesco e Banco do Brasil. O s menores lucros foram obtidos pelo H SBC, seguido pelo A BN e Santander, ou seja, pelos bancos estrangeiros. E ntretanto, os bancos estrangeiros foram os que apresentaram o maior crescimento do lucro no período.

E $m$ todos os bancos analisados, há uma tendência de crescimento do lucro líquido, a qual se intensificou, especialmente, a partir de 2004. Esse maior crescimento pode ser explicado, principalmente, pel o fato de os bancos terem conseguido obter resultados positivos com a expansão do crédito, com destaque para os segmentos de crédito consignado e de financiamento de veículos.

N o caso dos bancos públicos, o maior crescimento do lucro líquido foi verificado desde 2002, devido às medidas implementadas pelo Proef, tendo seintensificado, posteriormente, devido à ampliação das operações de crédito, principalmente do crédito consignado. 
O R etorno sobre o Patrimônio L íquido M édio, por sua vez, representa o lucro deuma instituição em relação ao seu patrimônio, ou seja, a relação entre o ganho obtido pelos sócios e os investimentos que realizaram nainstituição. O s bancos com mai or retorno em 2007 foram I taú, U nibanco e Bradesco. N a média dos retornos obtidos entre 2003 e 2007, os bancos mais rentáveis foram I taú, B radesco, BB e CEF (Tabela 2.15).

T abela 2.15 - Rentabilidade sobre o patrimônio líquido médio (\%)

\begin{tabular}{l|c|c|c|c|c|c}
\hline & $\mathbf{2 0 0 3}$ & $\mathbf{2 0 0 4}$ & $\mathbf{2 0 0 5}$ & $\mathbf{2 0 0 6}$ & $\mathbf{2 0 0 7}$ & M édia \\
\hline I taú & 29,70 & 29,20 & 35,30 & 28,80 & 32,10 & 31,02 \\
\hline Bradesco & 19,20 & 22,50 & 32,70 & 31,20 & 28,30 & 26,78 \\
\hline BB & 22,30 & 23,00 & 26,80 & 32,10 & 22,50 & 25,34 \\
\hline CEF & 28,00 & 21,31 & 26,07 & 25,99 & 23,71 & 25,02 \\
\hline A BN & 22,30 & 18,40 & 20,30 & 25,00 & 24,50 & 22,10 \\
\hline H SBC & 11,60 & 20,45 & 24,75 & 26,30 & 26,89 & 22,00 \\
\hline Unibanco & 15,30 & 16,80 & 21,10 & 18,20 & 31,70 & 20,62 \\
\hline Santander & 21,80 & 20,20 & 21,60 & 16,10 & 21,30 & 20,20 \\
\hline
\end{tabular}

Fonte: Elaboração própria a partir de dados extraídos dos sites dos bancos analisados.

D essa forma, verifica-se que os bancos mais rentáveis foram os privados nacionais, seguidos pelos bancos públicos. Os bancos estrangei ros foram as instituições que apresentaram menor retorno sobreo patrimônio líquido médio. A maior taxamédia derentabilidadepatrimonial dos bancos privados nacionais também foi constatada no período de 1995 a junho de 2001, em Vasconcel os e Strachman (2002). Esse resultado foi obtido, principalmente, devido ao bom desempenho do Bradesco, do U nibanco e, especialmente, do I taú.

Com relação aos grupos estrangei ros, verifica-se que, no caso do Santander edo H SBC, a unidadebrasileira apresenta retornos maiores do que a média do grupo, principalmente no caso do H SBC. 0 retorno do G rupo A BN tem sido levemente maior do que o retorno da sua unidade brasileira.

A rentabilidademédia do setor financeiro no Brasil foi de $25,34 \% \mathrm{em}$ 2007, contra 16,16\% em 2003, segundo o Banco Central (G ráfico 2.12). N o mercado internacional, o retorno ficou entre 18\% e 20\% em 2006. 


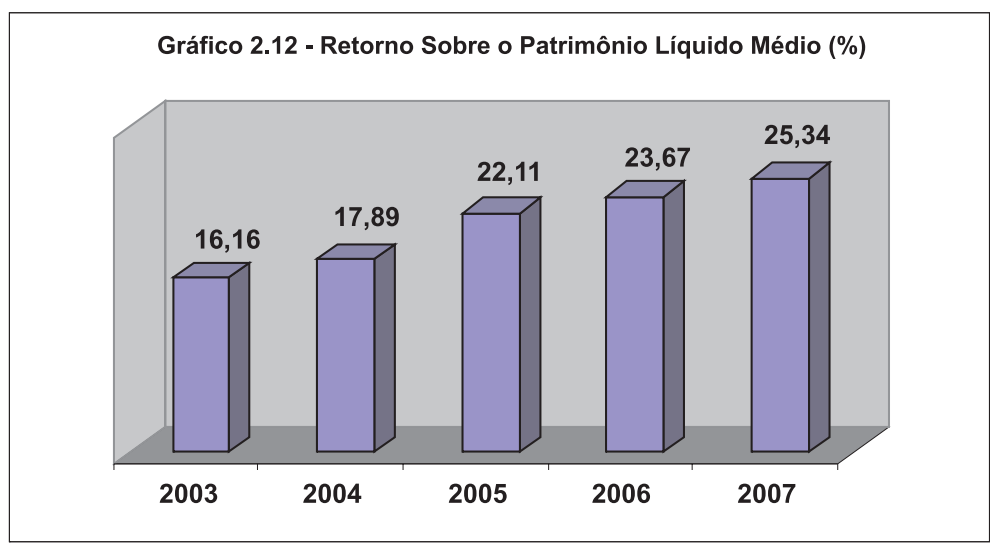

Fonte: Elaboração própria a partir de dados extraídos do site do Banco C entral do Brasil.

O s índices de rentabilidade dos bancos brasileiros são considerados al tos em relação aos dos bancos estrangeiros. Em 2008, três bancos nacionais estavam entre as cinco instituições com maior rentabilidade da A mérica $L$ atina, segundo levantamento da consultoria E conomática: o Banco do Brasil (1ํ lugar), o Bradesco (2ㅇ lugar) e o I taú-U nibanco (5lugar) (Folha de S. Paulo, 21/3/ 2009).

Sefor considerado outro índice derentabilidade, o retorno médio sobre os ativos, verifica-seque, no período de 1996 a 2006, o retorno dos bancos nacionais foi superior ao dos bancos estrangeiros. A s instituições estrangeiras somente obtiveram retornos maiores em 1999 e 2002, devido à política de proteger, por meio de operações dehedge, o capital aplicado no Brasil contra desval orizações do real. E ssa política resultou em ganhos com as fortes dep reciações cambiais observadas nesses dois anos (Valor E conômico, 30/ 7/ 2008).

\section{Substituição dos ganhos com títulos e valores mobiliários}

A pós o fim dos altos ganhos proporcionados pela alta inflação, os bancos direcionaram-se para os títulos públicos, que ofereciam alta rentabilidadee baixo risco. R ecentemente, entretanto, devido à 
queda da taxa dejuros, esses títulos perderam um pouco da atratividade, apesar de ainda serem importantes fontes de receita.

$\mathrm{N}$ os últimos anos, os al tos lucros do setor bancário foram resultado, principal mente, das operações de crédito e, em menor medida, das receitas de prestação de serviços, que substituíram os ganhos obtidos com títulos públicos. A receita obtida com operações de crédito éo principal componente das receitas operacionais dos bancos analisados. Essa participação vem apresentando tendência de crescimento, principalmentea partir de2003. Somenteno A BN eno U nibanco ela se manteve constante. Entretanto, estes dois bancos, principal menteo $A B N$, já possuíam al ta participação dessas receitas no total de suas receitas operacionais (T abela 2.16).

O s bancos em que a participação das receitas com operação de crédito é maior são A BN eH SBC, seguidos por I taú e Bradesco. A C aixa éo único banco em queas receitas com operações deT V M são os principais componentes das receitas totais. I sso se deve à grande quantidade de títulos públicos detida pela instituição.

A s receitas com prestação de serviços também ganharam importância no período anal isado, sendo que, no sistema financeiro nacional, sua participação cresceu de 9,2\%, em 1997, para 13\%, no primeiro semestre de2008. E ntretanto, tendo em vista a nova regulamentação sobretarifas ea maior pressão da sociedadee do governo, não há mais muito espaço para crescimento. 0 s bancos em queessas receitas têm maior participação são os bancos públicos, seguidos pelo Santander.

Como consequência da ampliação da participação das receitas com operações de crédito e de prestação de serviços, as receitas com títulos e valores mobiliários vêm perdendo participação nos últimos anos em todas as instituições analisadas. A pesar de as operações de crédito apresentarem maior risco do que os títulos públicos, o retorno é maior, dadas as altas taxas de juros. D essa forma, os al tos ganhos al cançados mais do que compensam o maior risco. Como resultado, os lucros líquidos obtidos pelas instituições analisadas vêm apresentando expressivo crescimento, conformejá visto no item anterior. 
Tabela 2.16 - Composição das receitas operacionais (\%)

\begin{tabular}{|c|c|c|c|c|c|c|c|c|c|c|c|c|c|}
\hline o & Receita & 1997 & 1998 & 1999 & 2000 & 2001 & 2002 & 2003 & 2004 & 2005 & 2006 & 2007 & 10508 \\
\hline \multirow{3}{*}{ Ш } & Crédito & 39,5 & 42,4 & 31,6 & 34,6 & 37,4 & 31,1 & 35,5 & 40,2 & 40,3 & 43,0 & 46,5 & 6,2 \\
\hline & TVM & 21,9 & 35,3 & 34,8 & 30,6 & 24,7 & 34,1 & 34,0 & 26,1 & 25,5 & 26,2 & 22,6 &, 9 \\
\hline & RPS & 10,9 & 8,5 & 7,7 & 13,0 & 12,8 & 9,9 & 11,9 & 15,3 & 15,7 & 17,2 & 17,7 & 16,8 \\
\hline \multirow{3}{*}{$\overrightarrow{0}$} & Crédito & 46,8 & 36,6 & 32,3 & 35,7 & 38,7 & 40,7 & 37,8 & 41,6 & 48,9 & 50,9 & 53,5 & 7,1 \\
\hline & TVM & 14,6 & 32,5 & 30,0 & 24,4 & 23,0 & 19,3 & 22,7 & 16,5 & 13,4 & 15,2 & 16,2 & 13,2 \\
\hline & RPS & 21,5 & 15,3 & 17,0 & 20,6 & 17,1 & 16,0 & 16,9 & 18,9 & 19,2 & 18,2 & 15,8 & 12,6 \\
\hline \multirow{3}{*}{$\begin{array}{l}\frac{8}{8} \\
\frac{8}{0}\end{array}$} & Crédito & 52,0 & 54,8 & 55,3 & 49,7 & 51,0 & 50,4 & 46,1 & 47,2 & 48,7 & 53,5 & 50,0 & 53,3 \\
\hline & TVM & 16,1 & 19,6 & 19,3 & 20,9 & 19,7 & 24,2 & 24,6 & 19,2 & 17,4 & 14,8 & 12,6 & 12,5 \\
\hline & RPS & 14,6 & 12,0 & 9,5 & 13,9 & 12,4 & 9,4 & 11,2 & 14,5 & 14,1 & 14,4 & 13,4 & 11,5 \\
\hline \multirow{3}{*}{ 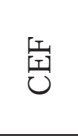 } & Crédito & 48,1 & 52,6 & 63,2 & 52,1 & 26,6 & 15,2 & 16,4 & 20,6 & 21,6 & 24,6 & 24,5 & $-4,2$ \\
\hline & TVM & 19,1 & 13,6 & 12,3 & 14,0 & 21,0 & 42,6 & 45,4 & 44,0 & 43,6 & 42,5 & 36,0 & 37,1 \\
\hline & RPS & 9,9 & 9,5 & 10,1 & 14,2 & 15,2 & 17,1 & 14,1 & 16,9 & 14,9 & 15,4 & 18,3 & 17,9 \\
\hline \multirow{3}{*}{$\frac{m}{4}$} & Crédito & 85,8 & 70,4 & 48,5 & 58,8 & 57,6 & 44,4 & 58,3 & 56,5 & 59,6 & 61,1 & 57,3 & 61,5 \\
\hline & TVM & 4,8 & 20,7 & 19,9 & 17,1 & 18,3 & 28,1 & 13,7 & 13,9 & 13,8 & 15,3 & 15,7 & 12,5 \\
\hline & RPS & 1,2 & 1,7 & 6,9 & 11,0 & 10,6 & 8,4 & 12,6 & 13,2 & 13,2 & 12,9 & 12,3 & 11,1 \\
\hline \multirow{3}{*}{ 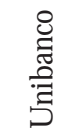 } & Crédito & 52,8 & 51,7 & 54,5 & 3,9 & 54,5 & 46,0 & 56,3 & 46,8 & 53,5 & 52,3 & 50,6 & 51,4 \\
\hline & TVM & 16,7 & 22,5 & 15,5 & 18,6 & 17,8 & 33,1 & 14,9 & 18,2 & 16,4 & 18,4 & 17,9 & 18,1 \\
\hline & RPS & 11,3 & 10,6 & 7,3 & 10,7 & 9,0 & 8,7 & 11,7 & 11,1 & 10,6 & 10,7 & 10,8 & 9,2 \\
\hline \multirow{3}{*}{$\begin{array}{l}\frac{d}{0} \\
\frac{0}{0} \\
\stackrel{0}{0} \\
\text { N }\end{array}$} & Crédito & - & 49,1 & 36,8 & 17,3 & 56,8 & 23,6 & 32,9 & 34,1 & 35,1 & 40,5 & 38,8 & 39,7 \\
\hline & TVM & - & 29,0 & 50,0 & 23,8 & 95,6 & 57,5 & 27,5 & 32,6 & 31,4 & 29,7 & 28,9 & 30,4 \\
\hline & RPS & - & 8,4 & 4,2 & 2,4 & 13,7 & 7,0 & 10,6 & 14,2 & 12,7 & 14,8 & 15,8 & 16,1 \\
\hline \multirow{3}{*}{ ñ } & Crédito & 26,3 & 24,6 & 31,0 & 40,6 & 39,5 & 45,2 & 46,4 & 53,1 & 52,1 & 53,6 & 55,9 & 58,3 \\
\hline & TVM & 34,4 & 41,9 & 40,0 & 31,8 & 35,5 & 36,3 & 13,2 & 14,9 & 19,2 & 18,8 & 16,8 & 15,2 \\
\hline & RPS & 18,8 & 20,8 & 17,8 & 17,3 & 16,7 & 16,8 & 16,0 & 15,6 & 15,2 & 16,4 & 16,2 & 13,6 \\
\hline \multirow{3}{*}{$\frac{\pi}{6}$} & Crédito & 47,8 & 44,0 & 42,2 & 41,6 & 42,6 & 36,9 & 37,9 & 40,8 & 42,9 & 45,5 & 46,0 & 48,6 \\
\hline & TVM & 26,2 & 32,0 & 32,7 & 29,4 & 30,7 & 34,9 & 32,0 & 27,6 & 26,9 & 26,2 & 23,4 & 20,8 \\
\hline & RPS & 9,2 & 9,0 & 7,6 & 11,1 & 10,7 & 8,8 & 11,3 & 13,7 & 13,4 & 14,2 & 14,4 & 13,0 \\
\hline
\end{tabular}

Fonte: Elaboração própria a partir de dados do site do Banco C entral do Brasil. 



\section{CONCLUSÃo}

N este trabalho, verificou-se que, mais de dez anos após o processo de consolidação do setor bancário, este continua mantendo características bem específicas em relação aos de outros países. $0 \mathrm{~s}$ bancos estrangeiros vêm ampliando sua participação no mercado; entretanto, os bancos nacionais continuam na liderança do setor, com, em geral, mai or participação no crédito enos depósitos, maiores lucros e menores índices de eficiência.

Como quaisquer outras empresas em uma economia demercado, os bancos buscam maximizar sua rentabilidade e a valorização de seu capital com o menor risco possível, voltando-separa as mel hores oportunidades. Por isso, os bancos estrangeiros, após sua entrada no país, acomodaram-se às altas margens de lucro internas, sem grandes inovações. A ssim, a contribuição dessas instituições para o fortalecimento do sistema bancário do Brasil foi mínima, o que indica que as principais mudanças ocorridas no setor, no período analisado, não foram resultado do ingresso desses bancos no país. Provavel mente, essas mudanças teriam acontecido mesmo sem a entrada das instituições estrangeiras.

Como visto, essa característica do setor difere daquela encontrada em grande parte dos países da A mérica L atina, onde os bancos estrangeiros dominam o mercado. A ssim, concluiu-se que as insti- 
tuições estrangeiras que entraram no Brasil vêm atuando de forma muito semel hanteà dos bancos privados nacionais, distanciando-se das estratégias adotadas por suas matrizes.

O utra peculiaridade do Brasil é a forte presença de bancos públicos, os quais, recentemente, tiveram sua importância retomada. A pós a implementação do Proef, o Banco do Brasil passou a atuar de forma cada vez mais semel hante à dos bancos privados. Entretanto, no governo L ula e, principalmente, nos últimos dois anos, aquela instituição, a C aixa E conômica Federal e o BN DES tiveram seu papel de banco público retomado. Esses bancos foram convocados a alavancar crédito e a liderar a redução de tarifas bancárias e taxas de juros, tendo sido fundamentais para a execução das políticas de governo.

Como visto, essas peculiaridades do setor bancário brasileiro, de baixa participação dos bancos estrangeiros, baixo grau de internacional ização das instituições residentes no país e forte atuação contracíclica dos bancos públicos, contribuíram para que o Brasil não fosse tão afetado pela crise internacional iniciada no segundo semestre de 2007, já que os bancos privados, tanto nacionais como estrangeiros, se retraíram.

Verificou-se, também, queas instituições brasileiras têm uma alta capacidade de adaptação, mantendo uma alta lucratividade, independentemente das condições impostas pelo ambiente econômico e político, as quais, por outro lado, têm sido bastantefavoráveisa esses ganhos. N a década de 1980, os resultados dependiam, majoritariamente, de receitas advindas da inflação, passando por um período, que vai de meados dos anos 1990 a 2002, de forte dependência dos ganhos com títulos públicos e, em menor intensidade, de receitas de prestação de serviços, com baixos volumes de crédito e spreads extremamente altos. A partir de 2003, com a trajetória declinante da taxa dejuros, que provocou a redução da atratividade dos títulos públicos, eo ambientemais favorável ao crescimento econômico, os bancos direcionaram-se para as operações decrédito, quesetornaram as principais responsáveis pelos al tos lucros do período. A s receitas de prestação deserviços, apesar deainda terem participação importante 
nos resultados das instituições, não têm muito espaço para crescimento, devido à intensa pressão do governo e da sociedade, bem como à nova regulamentação sobre tarifas bancárias. Portanto, a tendência é que os bancos se voltem ainda mais para operações de crédito.

O s bancos nacionais lideraram a expansão do crédito, porém, recentemente, esse papel foi repassado aos bancos públicos, como visto. D estacaram-se os financiamentos com garantias reais, principalmentefinanciamento imobiliário, a veículos ecrédito consignado, o que permitiu que o crédito seexpandisse, sem quea inadimplência sofresse alterações significativas, ao contrário dos movimentos de expansão do crédito ocorridos em outros períodos. Por outro lado, esse crescimento se deu deforma conservadora, direcionado ao consumo e não ao investimento, e concentrado em operações de curto prazo. A s operações de longo prazo continuam concentradas nos três maiores bancos públicos: Banco do Brasil, CaixaE conômica F ederal e, principalmente, BN DES. Esperava-sequeos bancos estrangeiros mudassem essa situação, entretanto isso não ocorreu.

D essa forma, com relação à eficiência bancária, concluiu-se que houve um significativo avanço em termos microeconômicos, com tendência de melhora dos índices de eficiência, de cobertura, de solvabilidade e de rentabilidade. A eficiência microeconômica dos bancos brasileiros podeser considerada, em muitos casos, superior à verificada em instituições instaladas em outros países. A partir deste trabal ho, constatou-setambém que, no período analisado, os bancos privados nacionais mantiveram, em geral, a maior rentabilidade dentre as instituições bancárias, seguidos pelos bancos públicos.

Com relação à eficiência macroeconômica, os bancos brasileiros ainda não são capazes de suprir a demanda por crédito de longo prazo, direcionado aos investimentos. Entretanto, a contribuição dos bancos ao desenvolvimento econômico do país evoluiu muito nos últimos anos, sendo queesse processo tende a continuar. A ssim, a participação do crédito no PIB alcançou níveis recordes, apesar de ainda ser baixa em relação à de outros países.

A questão que secoloca équanto à possibilidade decontinuidade da expansão do crédito. 0 limitedas modalidades mais atraentes, de 
financiamento de veículos, crédito consignado e cartões de crédito, está, principalmente, na capacidade de endividamento dos clientes. Como visto, a modal idade de crédito consignado já apresenta sinais desaturação. A recenteredução dos spreads também évista como um desafio para os bancos, que deverão atuar com volumes de crédito maiores e buscar, continuamente, a redução dos custos.

Para que esses desafios sejam vencidos e para que as instituições setornem mais eficientes, em termos macroeconômicos, ampliando sua atuação em outras linhas de financiamento, éimprescindível que os bancos invistam em sistemas mais eficientes de gestão de risco, sendo igualmente importante que o país busque, continuamente, a criação de um ambiente mais favorável à concessão de crédito, com garantias cada vez mais eficientes. Como visto, o sistema bancário responde positivamente quando há um aprimoramento das garantias, como ocorreu, por exemplo, no caso do crédito imobiliário. E ssa modal idade ganhou um expressivo impulso após medidas que, dentre outras alterações, facilitaram a retomada do imóvel em caso deinadimplência. 


\section{REFERÊNCIAS BIBLIOGRÁFICAS}

ADELINO DE FARIA JÚ NIOR, J. eDE PAULA, L. F. "Eficiência no Setor Bancário Brasileiro: A Experiência R ecente das $F$ usões e A quisições". In: XXX IV Encontro N acional de E conomia (A npec), 2006, Salvador. A nais do XXXIV Encontro N acional deE conomia, 2006, p.20. AFANASIEFF, T. S.; L H ACER, P. M .V.; eNAKANE, M . I. "TheDeterminants of Bank Interest Spread in Brazil". B anco $C$ entral do B rasil - W orking Paper S eries n. 46, agosto de 2002.

BADER, F. L. C. e CH U, V.Y. T. "R esenha sobre o Spread Bancário". $N$ otas T écnicas do $B$ anco $C$ entral do B rasil n. 21, maio de 2002.

BA DER , F. L . C . eT A K ED A , T. "Consignação em Folha dePagamentoFatores da I mpulsão do C rédito". D epartamento deE studos ePesquisas do Banco Central do Brasil - DEPEP/SP, 2005.

BA N CO CEN T RA L D O BRASI L. "Boletim do Banco Central do Brasil" - R elatório 1998 - I tem 2 - M oeda e C rédito, 1998.

"R elatório de A tividades - 1999 a 2002". D iretoria de Política M onetária. D ezembro de 2002.

"R elatório de Estabilidade Financeira". Volume 6 - N úmero 1. $M$ aio de 2007.

BECKER, J. L .; LU NARDI, G. L.; e M A ÇADA, A . C. G . "A nálise de E ficiência dos Bancos Brasileiros: U m E nfoquenos I nvestimentos $R$ ealizados em T ecnologia de I nformação (T I )". R evista P rodução, volume 13, n. 2 - São Paulo, 2003.

BENEGAS, M.; CHABALGOITY, L.; MARINHO, E.; eNETO, P. “EficiênciaT écnica, Produtividadee L iderançaT ecnológica nal ndús- 
tria Bancária Brasileira". Pesquisa e P lanejamento E conômico - P PE - volume 37, n. 1, abril de 2007.

BIG NOTTO , F. G. eRODRIGUES, E. A. de S. "Fatores de R isco e o Spread Bancário no Brasil". B anco C entral do B rasil - Trabalhos para D iscussão n. 110, julho de 2006.

CALDA S, M. P. eCA RVA L H O, D. B. "Basileia II : A bordagem Prática para A companhamento de R isco O peracional em Instituições Financeiras". R esenha BM \& F (artigo técnico), s/ d.

CÂNDIDO JR., J. O . e M AT OSFILHO, J. C. "Poupança Privada e Sistema Financeiro: Possibilidades e L imitações". I pea - Texto para D iscussão n. 488. Brasília, junho de 1997.

CA RVA L H O , C. E. "Bancos Privados não Substituem Bancos Públicos". G azeta M ercantil, p.A 3, 19/11/2000.

"Bancos e Inflação no Brasil: D a C rise dos A nos 1980 ao Plano R eal". A BPHE - A ssociação Brasileira de Pesquisadores em H istória E conômica - A nais do V Congresso Brasileiro de $\mathrm{H}$ istória E conômica e 6a $\mathrm{C}$ onferência I nternacional de $\mathrm{H}$ istória de $\mathrm{E}$ mpresas.

CARVA L H O, F. J. C. de. "T he R eal Stabilization Plan and the Banking Sector in Brazil". Banca N azionale del L avoro. Q uarterly R eview, setembro de 1998, 51, 206; A BI / I N F O R M G lobal, p.291.

"T heR ecent Expansion of Foreign Banks in Brazil: F irst R esults". L atin A merican B usiness R eview, N ovaYork, v. 3, n. 4, p.93-119, 2002.

"O SistemaFinanceiro Brasileiro: A M odernização N ecessária". In: J. Sicsú; L .F. dePaula; R. M ichel. (O rg.). "N ovo-D esenvolvimentismo. U m projeto nacional de crescimento com equidade social". 1 ed. São Paulo: M anole, 2004, p.329-346.

"Investimento, Poupança e Financiamento: Financiando o C rescimento com Inclusão Social". T exto para D iscussão do G rupo M oeda e Sistema Financeiro, IE / U F R J, 2005a.

"Sistema Financeiro, C rescimento el nclusão". In: C astro, A . C.; L icha, A .; Pinto J r., H . Q .; Saboia, J. (O rg.). B rasil em D esenvolvimento. 1 ed. R io deJ aneiro: Civilização Brasileira (R ecord), 2005b, v. 1, p.23-50.

"Estrutura ePadrões de Competição no Sistema Bancário Brasileiro: U ma H ipótese para I nvestigação e A Iguma E vidência Preliminar". In: Paula, L . F.; O reiro, J. L . (O rg.). "SistemaFinanceiro. U maA nálise do Setor Bancário Brasileiro" . 1 ed. R io de J aneiro: C ampus/ Elsevier, 2007, p.103-123.

CAVALCANTE, A.; CROCCO, M .; eJAIME JR., F. G. "Preferência pela $L$ iquidez, Sistema Bancário e D isponibilidade de C rédito R egio- 
nal". Texto para D iscussão, CEDEPLA R/ U F M G , Belo H orizonte, n. 237, agosto/ 2004.

CORA ZZA, G . "C rise e R eestruturação Bancária no Brasil". R evista A nálise, Porto A legre, v. 12, n. 2, p.21-42, 2001.

C O ST A, A . C. A . "Ensaios em M icroeconomia Bancária”. Tese de D outoramento apresentada ao $D$ epartamento de E conomia da Faculdade de E conomia, A dministração e C ontabilidade da U niversidade de São Paulo, 2004.

COST A, F. N. da. "C aça ao (T ítulo do) Tesouro". A rtigo publicado no jornal Folha de S. Paulo em 6/ 12/ 2001.

COST A, F. N . e DE DEOS, S. S. "R eflexões sobre o Financiamento na E conomia Brasileira". Texto para D iscussão. IE/ U N ICA M P n. 109, abril/ 2002.

DE PAU L A, L . F. R. "Tamanho, D imensão e C oncentração do Sistema Bancário no C ontexto de A Ita eBaixa I nflação no Brasil". N ova E conomia, v. 8, n. 1, p.87-116, jul./ dez. 1998.

DE PAU L A , L uiz Fernando eM A R Q UES, M aria Beatriz L . (2006) “Tendências R ecentes da Consolidação Bancária no M undo e no Brasil". A nálise E conômica, Porto A legre, v. 24, n. 45, p.235-263, 2006.

DE PAU L A , L uiz Fernando; O N O , Fábio H ideki; O REIR O, J osé L uís; e SI LVA G uilherme Jonas C osta da (2005) "D eterminantes M acroeconômicos do Spread Bancário no Brasil: T eoria eE vidência R ecente". Programa de Seminários em D esenvolvimento E conômico - D epartamento de E conomia da U niversidade Federal do Paraná - Centro de Ciências Sociais A plicadas - 17/ 3/ 2005.

FA CH A DA, Pedro; FIG U EIRED O, L uiz Fernando; e L U N DBERG, Eduardo (2003) "Sistema Judicial e M ercado de C rédito no Brasil". $\mathrm{N}$ otas T écnicas do Banco Central do Brasil n. 35 - M aio de 2003.

FERREIRA , C aio Fonseca eFA R IN A , Elizabeth M . M . Q . (2005) “C oncorrência e Performance do Setor Bancário em um M ercado $\mathrm{H}$ eterogêneo". R evista A N PE C, v. 6, p.157-189, 2005.

FREITAS, M aria Cristina Penido (1997) "A N atureza Particular da Concorrência Bancária e seus E feitos sobre a Estabilidade Financeira". E conomia e Sociedade (U N I C A M P), C ampinas, v. 8, p.51-83, 1997.

FREITAS, M aria Cristina Penido de e PRATES, D aniela $M$ agalhães (2002) "R eestruturação do Sistema Financeiro I nternacional e Países Periféricos". R evista de E conomia Política, volume 22, n. 2 (86), abril-junho de 2002.

FREIT A S, M ariaC ristinaPenido deePR AT ES, D aniela M agal hães (2003) "Sistema Financeiro e D esenvolvimento: A s R estrições das N ovas 
R egras do C omitê da B asileia Sobre os Países Periféricos". In: J oão C arlosF erraz; M arco C rocco; L uis A ntonio Elias (O rg.). " L iberalização E conômica e D esenvolvimento: M odelos, Políticas e R estrições". São Paulo: Editora F utura, 2003, p.234-261.

FU CIDJI, J. R.; ST RACH M A N , E.; eVA SCO N CEL O S, M . R . (2003) "L iberalização e D esregulamentação Bancária: M otivações, Consequências e A daptações". N ova E conomia, Belo H orizonte/ M G , v. 13, n. 1, p.101-140, 2003.

G O L DFA JN , I.; H EN N I N GS, K .; e M O RI, H. "Sistema Financeiro no B rasil: R esistente a Choques e à $\mathrm{D}$ olarização, mas em Busca da Promoção do Crescimento". S eminário de E stabilidade Financeira. R io de Janeiro, novembro de 2002.

IBG E / A N DI M A. "Sistema Financeiro, uma A nálise a partir das Contas N acionais 1990 - 1995". Rio de J aneiro, IBGE, D epartamento de C ontas N acionais, 1997.

J A CO B , C . A . "C rédito Bancário no Brasil: U mal nterpretação H eterodo$x a "$. Tese de D outoramento apresentada no Instituto de E conomia da U niversidade E stadual de C ampinas. D ezembro de 2003.

K OYA M A , S. M . eN A K A N E, M . I. “O Spread Bancário Segundo Fatores de Persistência e Conjuntura". N otas T écnicas do Banco Central do Brasil n. 18, abril de2002a.

"O sD eterminantes do S pread Bancário no Brasil". N otasT écnicas do Banco Central do Brasil n. 19, abril de 2002b.

KOYAM A, S. M . eT ON O OKA, E. K. "T axa de Juros e Concentração Bancária no Brasil". Banco C entral do Brasil - Trabalhos paraD iscussão n. 62. Fevereiro, 2003.

L U N D BE R G , E. "Política M onetária eSupervisão do Sistema Financeiro $N$ acional no Banco C entral do Brasil". Banco Central do Brasil - Trabalhos para D iscussão n. 2. Julho, 2000.

M A CA R IN I, J. P. "A Política E conômica do G overno C osta eSilva 1967- 1969". R evista de E conomia Contemporânea, volume 10, n. 3. Rio de Janeiro, setembro/ dezembro 2006.

M ACARIN I, J. P. "A Política Bancária do Regime M ilitar: O Projeto de C ongl omerado (1967-1973)". Texto para D iscussão n. 124 - J aneiro de 2007. IE/ U N ICAMP.

M A IA, G. V. S. "R eestruturação Bancária no Brasil: O C aso do Proer". N otasT écnicas do Banco C entral do Brasil, número 38, junho de2003, D epec/ Copec.

M A RT IN EZ, A . P. "A Concorrência no Setor Bancário no Brasil". Valor E conômico, 22/ 10/ 2008. 
M AT T O SO , J. eVA SC O N CEL O S, M . "Para que Banco Público" em "R egulação Bancária e D inâmica Financeira: Evolução e Perspectivas a Partir dos A cordos de Basileia" - O rganizadores: A na R osa R ibeiro de $M$ endonça eR ogério $P$. de A ndrade - Instituto deE conomia - IE da U niversidade E stadual de C ampinas (U nicamp), 2006.

M O L IN A , W . deS. L . "A R eestruturação do Sistema Bancário Brasileiro nos A nos 90: $M$ enos $C$ oncorrência e $M$ ais $C$ ompetitividade". I N TELLECTUS - Revista A cadêmica Digital das Faculdades U nopec. U niversidade São F rancisco, ano 2, n. 3, agosto/ dezembro de 2004.

M ORA ES, J. C. F. de. "A nálise da Eficácia da D isseminação de Conhecimentos sobre $C$ ontroles I nternos A pós sua I mplementação no B anco do Brasil". D issertação de M estrado apresentada ao Programa de Pós- G raduação em Engenharia de Produção da U niversidade Federal de Santa C atarina, 2003.

NAKA NE, M . I. "A Test of Competition in Brazilian Banking". Banco C entral do Brasil, W orking Paper Series n. 12, março de 2001.

"C oncorrência no Setor Bancário: R esumo da Evidência para o Brasil". BA CEN \& U SP - 2a jornada de Estudos de R egulação - I pea - novembro/ 2005.

PU G A , F. P. "Sistema Financeiro Brasileiro: R eestruturação R ecente, C omparações I nternacionais eVulnerabilidadeà C rise C ambial". BN DES - T exto para D iscussão n. 68. M arço/ 1999.

RO CH A, B. de P. "Concorrência no Setor Bancário". 8o SEM AT - Seminário de $A$ tendimento Bancário. São Paulo, 18 de setembro de 2007.

R O CH A , F. A . S. "Evolução da Concentração Bancária no Brasil (1994-2000)". N otas T écnicas do Banco C entral do Brasil n. 11, novembro de 2001.

“D esnacional ização Bancáriano Brasil (1997-2000)". Tese(M estrado) - Instituto deE conomia, U niversidade Estadual deCampinas, 2002.

SITE DO BAN CO A BN -A mro BRA SI L : www.bancoreal.com.br

SITE DO BANCO BRADESCO: www.bradesco.com.br

SITE DO BANCO CENTRAL DO BRASIL: www.bcb.gov.br

SITE DO BANCO DO BRASIL: www.bb.com.br

SITE DO BANCO HSBC: www.hsbc.com.br

SITE DO BANCO ITAÚ - www.itau.com.br

SITE DO BANCO SANTANDER: www.santander.com.br

SITE DA CAIXA ECON ÔMICA FEDERAL: www.caixa.gov.br

SITE DA FEBRABAN : www.febraban.org.br

SITE DO GRUPO ABN - A mro: www.abnamro.com 
SITE DO GRUPO HSBC: www.hsbc.com

SITE DO GRUPO SANTANDER: www.santander.com

SITE DO UNIBANCO: www.unibanco.com.br

SO A RES, R. P. "Ev volução do C rédito de 1994 a 1999: U ma Explicação".

T exto para D iscussão n. 808 - I pea. Julho de 2001.

ST RA CH M A N , E. eVA SC O N CEL O S, M . R. "Reestruturação do Setor de Serviços Financeiros em N ível M undial: Caracterização, R egularização eC onsequências para as D iscussões junto ao G AT S" . In T ironi, L uís F. (O rg.). A spectos Estratégicos da Política Comercial Brasileira. Brasília: I pea/ IPRI. 2001, p.17-99.

VA SC O N CEL O S, M . R. eST RA CH M A N , E. "R eorganização M undial do Setor deServiços $F$ inanceiros eR eestruturação R ecente do $M$ ercado Bancário Brasileiro". Relatório de Pesquisa, fevereiro de 2002.

VERSIA N I, F. R. "A D ívida Pública Interna e suaT rajetória R ecente" U niversidade de Brasília, D epartamento deE conomia - SériedeT extos para D iscussão - T exto n. 284 - M arço/ 2003.

\section{Artigos utilizados}

A GÊ N CIA E STAD 0 , 24/ 1/2007 - "Bradesco A nuncia Compra do Banco $B M C "$.

A GE N CIA ESTAD 0, 6/ 8/ 2008 - "L ucro do Bradesco C resce 27,9\% no Semestre".

AGORA SÃO PAULO 0, 16/8/2008 - "Banco do Brasil Deve Financiar I móvel com F G T S em Setembro".

CARTA CAPITAL , 20/7/ 2008 - "O Crédito Continua a Bombar".

CORREIO BRASILIEN SE, 24/ 11/ 2007 - "CaixaL ucra M enos 89,4\%". DCI - SP, 23/ 4/ 2007 - "C aixa D estina R \$ 35,4 bi a Pequenas e M édias". DCI - SP, 9/ 11/2007 - "Banco R etoma C aptação Externa com Juro M aior".

DCI - SP, 31/3/2008 - "C rédito para I móveis Terá N ovo Salto".

$D C I$ - SP, 2/ 4/ 2008 (1) - "Banco do Brasil Prevê R \$ 10 bi para C rédito I mobiliário em 4 A nos".

DCI - SP, 2/ 4/ 2008 (2) - "C aixa Fecha C ontrato com T itton Brugger". DCI - SP, 16/5/ 2008 - "Construtoras Fazem Parcerias com Bancos". DCI - SP, 17/ 9/ 2008 - "Santander L ança L inhas para Pequena e M édia Empresa". 
DCI - SP, 22/ 9/ 2008 - “Bancos Públicos T êm a M issão de Evitar Falta deE mpréstimos".

DESTAK JOR N A L , 24/3/2008 - "Parceria de Construtoras e Bancos Cresce".

DIA, 0 - RJ , 8/ 8/ 2008 - "I móvel N ovo R epresenta 52\% dos C ontratos".

DIÁRIO DE S. PAU L 0, 27/ 5/ 2008 - "Com Procura M aior, C resce O ferta del móveis na Faixa de $\mathrm{R} \$ 80$ mil" - Cibele $\mathrm{G}$ andolpho.

DIÁRIO DE S. PAU L 0 , 18/8/2008 - "Casa Própria" - A ncelmo Góis.

DIÁRIO DE S. PAU L 0, 28/8/2008 - "ClasseC A gora tem Carro Zero, M ostra Pesquisa".

DIN H EIR 0 - SP, 6/ 4/ 2008 - "L ar, Rico L ar" - M árcio K roehn.

ESTAD O DE S. PAU L 0, 0, 27/6/2008 (1) - "Símbolo da Recuperação do Setor, G oldfarb Volta ao Topo".

ESTAD O DE S. PAU L 0, 0, 27/6/2008 (2) - "Especializada em E conômicos, I taplan Comemora R ecuperação do Segmento".

ESTAD O DE S. PAU L 0, 0, 8/ 11/2008 - "BB Cresce, mas N ão R etoma a $L$ iderança" - R enée Pereira.

EX TRA - RJ , 2/ 4/ 2008 - "Pacote de Bancos Públicos é 50\% M ais Barato que o dos Privados".

F O L H A DE S.PAU L 0, 24/ 11/2007 - "Inadimplência D erruba L ucro da C aixa em 89\% no 3T ri".

F O L H A DE S.PAU L 0, 26/3/2008 - "BaixaR enda tem 61\% dos C artões, mas $\mathrm{G}$ asta $70 \% \mathrm{M}$ enos".

F O L H A DE S. PAU L 0 , 15/ 5/ 2008 - "C rédito paraH abitaçãoTem Início em Julho".

F O L H A D E S. PAU L 0 , 23/ 5/ 2008 - "G overno Paulista já Sofre Pressão de Bancos Privados".

F O L H A D E S. PAU L 0 , 28/ 8/ 2008 - "I taú Saltou do 52 para o 2으 ugar entre Bancos Privados" - Toni Sciarreta.

F OLHA DE S. PAU L 0, 22/9/2008 - "Governo A inda T enta Cobrar a Conta do Proer".

FOLHA DE S. PAU L 0, 9/11/2008 - “BB DevePagar atéR \$ 13 Bilhões pelo Banco Votorantim".

F O L H A DE S. PAU L 0 , 25/ 11/ 2008 - "C riseElevaI nteressepor O peração do Citi no Brasil" - Toni Sciarreta.

F OLHA DE S. PAU L 0, 1/2/2009 - "Ganho de Banco no País éo M ais A Ito do M undo".

F OLHA DE S. PAU L 0, 21/3/2009 - "Banco do País é M ais R entável quedosEUA". 
GAZETA M ER CAN TIL , 26/9/2007 - "Santander A mplia Prazo deFinanciamento para $30 \mathrm{~A}$ nos".

GAZETA M ER CAN TIL , 24/3/ 2008 (1) - "R \$ 1 Bilhão para R ossi".

GAZETA M ERCAN TIL , 24/3/2008 (2) - "H SBC Q uer L ucro 20\% M aior em 2008".

GAZETA M ER CAN TIL , 26/3/2008 - "RiwendaeCEF".

GAZETA M ER CAN TIL , 31/3/ 2008 (1) - "Estána BaixaR enda a M aior O portunidade para os Bancos".

GAZETA M ER CANTIL , 31/3/2008 (2) - "ExperiênciaT Teve Início em Bangladesh".

GAZETA M ER CAN TIL , 16/5/2008 - "BB Incorpora as O perações do Banco Popular" - Viviane M onteiro.

GAZE TA M ER CAN TIL , 19/ 8/ 2008 - "CréditoT ributário A judao L ucro do H SBC no Semestre".

GAZETA M ER CANTIL , 28/ 11/2008 - "Sem A IG, U nibanco D everá A celerar I ntegração com I taú" - L uciano M áximo.

GL OB 0, 0,1/ 11/ 2006 - "Itaú L ucrou R \$3,02 bi entreJ aneiro eSetembro".

GL OB 0, 0, 24/ 11/ 2007 - "C al ote de M icroempresa D erruba o L ucro da Caixa".

G L O B 0, 0,8/ 4/ 2008 - "H SBC G astará com AltaR endaR \$ 70 M ilhões". RE U TE RS , 3/ 11/ 2008 - "I taú eU nibanco C riarão G igantedo H emisfério Sul" - A lberto A lerigi J $r$.

VALOR ECON ÔM IC 0,11/4/2006 - "DisputaparaFinanciarVé́culos". VAL OR E CON ÔM IC 0, 16/ 1/2007 - "Caixa A presenta R esultado H istórico em $\mathrm{H}$ abitação, Saneamento e Infra-estrutura".

VALOR ECON ÔM IC 0, 23/ 1/2007 - "PAC PrevêQ uase R \$ 504 bi em Investimentos até 2010".

VAL OR EC O N ÔM IC 0, 20/3/2007 - “C rédito Imobiliário Cresce 67\% no A no" - Fernando Travaglini.

VALOR E C ON ÔM IC O,21/3/2007 - "A umento do C onsumo Surpreende eE leva C oncessão de C rédito nos Bancos" - Fernando T ravaglini.

VALOR ECON ÔM IC 0, 22/3/2007 - "Imóveis M antêm F ôlego eL ideram" - A Itamiro Silva Júnior.

VALOR ECON ÔM IC 0, 5/ 4/2007 - “N ãoTem Banco àVenda, Diz Setúbal" - Ivana M oreira.

VALOR E CON ÔM IC O 10/ 4/ 2007 - "Cartão PodeC hegar a M ais de 70 M ilhões, D iz Pesquisa" - A Itamiro Silva Júnior.

VAL OR E C O N ÔM IC O , 17/ 4/ 2007 - "Santander C obraráT axa deA dministração D ecrescente" - J osé Sérgio 0 sse e A ngelo Pavini. 
VAL O R E C O N Ô M IC O , 18/4/2007 (1) - “I taú Compra as 0 perações do A BN em M iami e M ontevidéu" - M aria C hristina C arvalho.

VALOR E C O N ÔM IC O , 18/4/ 2007 (2) - "Bancos el mobiliárias Facilitam o Crédito" - Chico Santos.

VALOR ECON ÔM IC 0, 19/4/ 2007 - “Varejo A juda a Reduzir R isco de Bancos no Empréstimo Popular" - Tatiana Bautzer.

VALOR ECON ÔM IC O , 24/ 4/ 2007 (1) - "Besc Reforça C rédito I mobiliário do BB" - A lex Ribeiro.

VAL OR E C ON ÔM IC 0, 24/ 4/ 2007 (2) - "Santander Pretende L imitar a

C oncessão de C rédito para C ana" - M ônica Scaramuzzo.

VAL OR E C O N Ô M IC 0, 30/4/ 2007 - "Santander Banespa A mplia L ucro em $22 \%$ e R eforça o C apital em R \$ 1,5 bi" - M aria C hristina C arvalho.

VALOR ECON ÔM ICO, 1/6/2007 - "BB Resolve'Pisar no A celerador'" - M aria Christina C arvalho.

VALOR ECON ÔM IC O , 14/6/ 2007 - “Penhor Bate R ecorde H istórico em Maio".

VA L O R E C O N Ô M I C O 15/ 6/ 2007 - "A gência Bancária Será D entro do C elular" - A Itamiro Silva Júnior.

VAL OR EC ON ÔM IC O , 27/ 6/ 2007 - "Banco M édio PoderáT er até 45\% del nvestimento Estrangeiro" - A lex R ibeiro.

VALOR ECON ÔM IC O,28/6/2007- "Banco Eleva Crédito àsEmpresas" - Fernando Travaglini.

VALOR ECON ÔM IC 0, 2/ 7/ 2007 - "Consignado já A tingeR $\$ 56,3$ bi"

- Fernando Travaglini.

VALOR ECON ÔM IC 0, 3/7/2007 (1) - "BC M ostra Q ueda de 10,5\% no

L ucro dos Bancos e Expansão de 23,1\% no C rédito" - M aria C hristina Carvalho.

VALOR ECON ÔM IC 0, 3/ 7/2007 (2) - "Santander A posta em Ciclo Virtuoso na A mérica L atina" - C atherineVieira.

VAL OR E C ON Ô M IC 0, 4/ 7/ 2007 (1) - “E missão deCartões de C rédito

C resce entre a Baixa R enda" - A Itamiro Silva únior.

VALOR ECON ÔM IC 0, 4/ 7/ 2007 (2) - "R eceitas M aiores de C rédito e

Serviços Compensam G anho M enor com T ítulos" - M aria C hristina Carvalho.

VALOR E CON ÔM IC 0, 6/7/2007 - "Santander Investirá US\$800 M iIhões no Brasil em Três A nos" - C atherineV ieira.

VALOR E C ON ÔM IC O , 26/7/2007- "G randesEmpresasVoltam aTomar Empréstimos nos Bancos" - A lex Ribeiro.

VALOR ECON ÔM IC 0, 31/ 7/ 2007 - "L ucro do Real C resce 84\%, para R \$1,261 bi" - Fernando T ravaglini. 
VALOR E CON ÔM IC 0, 7/ 8/ 2007 - "Bradesco L ucra R \$ 4 Bilhões com

Serviços, C rédito, A rcelor eSerasa" - A Itamiro Silva Júnior.

VALOR E CON ÔM IC 0, 8/8/2007 (1) - “C rédito ao Consumo M antém

Força" - Fernando T ravaglini.

VAL O R E C O N Ô M IC 0,8/8/2007 (2) - "L ucro do I taú Sobe35,8\%, para

$\mathrm{R} \$ 4,016$ bi, Puxado pelo C rédito" - Fernando T ravaglini.

VALOR ECON ÔM IC O, 23/ 8/2007 - "Banco do Brasil Faz A cordo com

Saraiva" - A Itamiro SilvaJúnior.

VALOR E CON ÔM IC 0, 3/ 9/2007 (1) - “Crédito para Construtoras Chega

a D obrar nos Bancos" - Fernando T ravaglini.

VALOR E CON ÔM ICO, 3/9/2007 (2) - "Cresce C rédito para C onstrutoras" - Fernando Travaglini.

VALOR ECON ÔM IC 0, 3/9/2007 (3) - "H SBC Pagará U S\$6,3 Bilhões por Participação M ajoritária no Korea Exchange Bank".

VAL OR E C O N Ô M IC O , 13/9/2007 - "I taú Faz Proposta deR \$2 Bilhões para Comprar 50\% do Banco BM G" - R aquel Balarin eT atianaBautzer. VALOR ECON ÔM IC O , 17/9/2007 (1) - "Eventuais Compras do BB

T erão de Passar pelo C ade" - Juliano Basilee A lex R ibeiro.

VALOR ECON ÔM IC 0, 17/ 9/2007 (2) - "Cresce o U so de G arantias

R eais" - FernandoT ravaglini.

VAL OR E C ON ÔM ICO, 19/9/2007 - "Bradesco Prepara-se para a C oncorrência" - Sérgio Bueno.

VAL OR E CON ÔM ICO, 20/9/2007 - "BB Foca O portunidades deC rescimento no N ordeste" - A lex Ribeiro.

VALOR ECON ÔM ICO , 21/9/2007 - "Escritório nos EUA Põea Caixa no M ercado Externo" - A lex Ribeiro.

VAL OR E CO N ÔM IC O , 1/ 10/2007 - "Fusão deSantander eA BN M udará M apa do M ercado" - M aria C hristina C arvalho.

VAL OR E C O N Ô M IC O , 8/ 10/2007 - "Com o R eal, Santander Passa aSer o M aior Banco de São Paulo".

VALOR E CON ÔM IC 0, 22/ 10/ 2007 - "Cresce D isputa entre os Bancos Federais" - Alex Ribeiro.

VAL OR E C O N ÔM IC O, 25/ 10/2007 - “L ucro do Santander Cresce 53\% em $N$ ove M eses, para R \$1,358 Bilhão".

VALOR ECON ÔM ICO , 30/ 10/2007 - "D isputa A mplia Prazo do Crédito" - Fernando T ravaglini.

VAL OR E C O N O M IC 0, 31/ 10/2007 - "I taú C omeça a R epassar R \$ 200 M ilhões do F GT S" - Fernando T ravaglini.

VAL OR E C ON ÔM IC 0, 9/ 11/2007 - "U nibanco G anhaR \$2,6 bi eEntra no Consignado". 
VAL OR E C ON Ô M IC O ,29/11/2007 - "R eceitas com Tarifasjá Superam A ntigos $G$ anhos com a I nflação" - Fernando T ravaglini.

VALOR ECON ÔM I C 0 , 5/ 12/2007 (1) - "I taú Transfere M il C lientes para o BBA" - Cristiane Perini L ucchesi.

VALOR ECON ÔM IC 0, 5/ 12/2007 (2) - "Bancos Financiam I móveis Comerciais" - Fernando Travaglini.

VAL OR E C ON ÔM IC O, 11/ 12/2007 - "H SBC PrevêR etraçãonos EUA eE feitos sobre Brasil" - M arli L ima.

VALOR ECON ÔM IC O , 4/ 1/2008 - "H SBC Emite3 M ilhões deC artões e Bate Recorde" - A Itamiro Silva únior.

VAL OR E C ON ÔM IC $0,7 / 1 / 2008$ - "Cartão C orporativo Tem Forte Expansão" - Altamiro Silvajúnior.

VALOR ECON ÔM IC 0, 15/ 1/ 2008 (1) - "Recurso para I móvel N ovo D eve C rescer $M$ ais em 2008" - Fernando T ravaglini.

VALOR E C ON ÔM IC 0, 15/1/2008 (2) - “Bancos E mprestam R \$ 10 bi para O bras" - Fernando Travaglini.

VALOR ECON Ô M IC 0, 24/ 1/ 2008 - "Santander Prevê Crescimento de $50 \%$ na Á rea de C rédito I mobiliário" - Fernando T ravaglini.

VALOR ECON ÔM IC 0, 8/2/2008 - "Santander R eforçaA postano Brasil" - M aria Christina Carvalho.

VAL OR E C O N Ô M IC O, 13/2/2008 - "I taú D obra L ucro com Expansão do C rédito" - $M$ aria C hristina Carvalho.

VALOR ECON ÔM I C 0, 27/2/2008 - "BB D ecepciona eM acula o Setor". VALOR ECON ÔM IC 0, 4/3/2008 (1) - "BB já Q uer Comprar Bancos Privados" - $M$ aria C hristina C arvalho.

VALOR ECON ÔM IC 0, 4/ 3/2008 (2) - "Brasil A mplia Participação no Resultado do HSBC" - A lex R ibeiro.

VALOR ECON ÔM IC 0,6/3/2008 - "Juro do Consignado Cai para 2,5\% e R egra de C oncessão F ica M ais R ígida" - A rnaldo G alvão.

VALOR E C ON ÔM IC O 13/3/2008 - "C rédito C onsignado eparaVeículos

$M$ antém Inadimplência sob C ontrole" - Fernando T ravaglini.

VALOR E CON ÔM IC O, 17/3/2008 - "BB A vança no C rédito com A juda de Bancos Estaduais" - A lex R ibeiro.

VALOR E C ON ÔM IC O , 1/ 4/ 2008 (1) - “C rédito I mobiliário A vança em Todo País" - Fernando T ravaglini.

VALOR E CON ÔM IC 0, 1/4/2008 (2) - “U nibanco C ria 'I nvestment B ank'" - Vanessa A dachi.

VAL OR E C O N ÔM IC 0, 15/4/2008 - "Governo A nuncia Pacote M unicipalista e Busca A poio à R eformaT ributária" - Ruy Baron. 
VALOR ECON ÔMICO, 18/4/2008 - "HSBC Quer Dobrar A tivose

L ucros na A L" - M aria C hristina C arvalho.

VALOR E C ON ÔM IC 0, 25/4/2008 - "Santander Fecha Parceria com a

A gra de $R$ \$2,2 Bilhões" - FernandoT ravaglini.

VAL OR E C O N Ô M IC O , 30/ 4/ 2008 - "M edidas deC ontenção N ão Surtem

E feito aT empo e C rédito A celera $M$ ais" - A lex R ibeiro.

VALOR ECON ÔM IC 0,5/5/2008 - "BC Exige Reserva deC apital para o Risco O peracional" - A lex R ibeiro.

VALOR E CON ÔM IC 0, 20/5/2008 - "Para H SBC Private, I nvestidores

D evem R eforçar a $L$ iquidez".

VALOR ECON ÔM IC O,23/5/2008 - "Venda do Banco PodeR ender até

R \$ 6 Bilhões" - Fernando T ravaglini, A driana Cotias, D aniele C amba eA ngelo Pavini.

VALOR ECON ÔMIC 0, 4/ 6/ 2008 - "Comércio Exterior do H SBC no

País Vira M odelo para A L" - A Itamiro Silva Júnior.

VALOR E C O N ÔM IC 0, 11/6/2008- "CaixaC ontrariao M ercado eCapta $M$ ais em Poupança" - A lex Ribeiro.

VAL OR E C ON ÔM IC O , 20/6/ 2008 - "L osango Q uer D obrar o N úmero dePontos-de-Venda em 2008" - C atherineVieira.

VAL O R E C O N O M IC O , 4/ 7/ 2008- "Santander Sai naFrentecom 'H ome Equity'” - Fernando Travaglini.

VAL OR E CON ÔM IC 0,8/7/2008- "Brasil G anhaVulto para Santander"

- $D$ enise $N$ eumann.

VALOR ECON ÔM IC O, 14/7/2008- "R edeEletro A breSuas L ojas para Produtos da L osango" - D anilo J orge.

VAL O R E CO N ÔM IC O ,25/7/ 2008 - "FacilidadeparaR etomar o I móvel A juda Expansão" - A na Paula Paiva.

VAL OR E CON ÔM IC 0, 30/7/ 2008 - "Banco L ocal éM ais Eficiente, Diz $B C "$ - A lex Ribeiro.

VALOR E CON ÔM IC 0, 4/ 8/2008 - "Brasil G anha D estaque em Integração G lobal" - Fernando Travaglini.

VAL OR E C O N Ô M IC 0 , 11/ 8/ 2008 - "Grandes BancosPrivados Saem-se Bem no PrimeiroT este de Basileia 2".

VALOR ECON ÔM IC O, 14/8/2008- "Bradesco eBBVA Fazem Parceria" - Cristiane Perini L ucchesi.

VAL OR ECON Ô M IC O , 19/8/2008 - "Instituições D emonstram M enor Interesse pelo C rédito Consignado".

VALOR E CON ÔM IC 0 , 4/ 9/2008 - "Juro não I nibe C rédito a E mpresa". VALOR E CON Ô M IC 0, 9/9/2008 - "Banco R eal A mplia A tuação entre Pequenas E mpresas". 
VAL OR E CON ÔM IC O, 17/ 9/2008 - "Bradesco faz A cordo com a R ede C onnector" - Altamiro Silva únior.

VAL OR E CON ÔM IC 0, 14/ 10/2008 - "Bradesco eU nibanco Compram Carteiras de Crédito".

VALOR E C ON ÔM IC O, 20/ 10/2008 - "Itaú Firma Parceria com L ojas $M$ arisa paraVender C artões de C rédito" - J osé Sérgio 0 sse.

VALOR ECON ÔM IC O, 23/ 10/2008 - "BB eC aixa A gora Podem Comprar Bancos Privados" - Cláudia Safatlee A rnaldo G alvão.

VAL OR E C O N Ô M IC O ,28/ 10/2008 - "L ucro do G rupo Santander Brasil Sobe $1,3 \%$ no A no, para $\$ 2,23$ bi".

VALOR E C ON ÔM IC 0,29/10/2008 - "CaixaseC omprometeaC omprar

$\mathrm{R} \$ 11$ bi em Carteiras até 2010".

VALOR ECON ÔM IC 0, 30/10/2008 - "Unibanco Tira A IG da M arca da Seguradora e E spera Sinal do Fed" - M aria Christina Carvalho e A Itamiro Silva Júnior.

VALOR E CON ÔM IC 0, 3/ 11/2008 (1) - "I taú eU nibanco D ecidem U nir O perações Financeiras".

VAL O R E C O N Ô M IC O , 3/ 11/2008 (2) - "Santander R eforça R edeno Sul eSudeste" - M aria Christina C arvalho.

VALOR E C ON ÔM IC 0, 7/ 11/2008 - "A vançam as N egociações para 0

BB Comprar Fatia do Votorantim" - Vanessa A dachi.

VALOR ECON ÔM IC 0, 21/11/2008 - "BB Compra N ossa Caixa por $\mathrm{R} \$ 5,4$ bi" - A Itamiro Silva Júnior.

VALOR ECON ÔMIC 0, 26/11/2008 - "Bradesco D escarta Corrida a A quisições" - M urillo C amarotto.

VAL OR E C O N Ô M IC O , 10/ 12/2008 - "I taú-U nibancojáM iraA quisições". 


\section{Anexos \\ ANÁLISE INDIVIDUAL DOS MAIORES \\ BANCOS}

\section{Banco do Brasil}

\section{Histórico e estrutura}

O Banco do Brasil é uma sociedade de economia mista, criada em 12 de outubro de 1808, com ações negociadas em bolsa desde 1906. D esde que suas atividades foram iniciadas, no $R$ io deJ aneiro, em 11 de dezembro de 1809, o banco exerceu papel de autoridade monetária, desenvolvendo atividadesfundamentais para dinamizar o capital epromover a indústria nacional. A partir de 1945, o controle monetário e a preparação da organização de um banco central, até então exercidos pelo Banco do B rasil, passaram a ser de responsabilidade da Superintendência da M oeda e do C rédito (Sumoc).

A partir de 1986, quando deixou de ser autarquia de crédito passando a ter, então, uma atuação mais similar à de outros bancos públicos e privados - , a instituição ampliou sua atuação como banco comercial, conquistando a liderança em vários segmentos do mercado financeiro nacional.

Em 3 de abril de 2001, o Banco do Brasil adotou a configuração deBanco M últiplo, o que o habilitou a operar as carteiras comercial, financeira edeleasing. Também foi adotada nova estrutura, com foco 
no cliente, caracterizada pela segmentação em três pilares negociais: A tacado, Varejo e G overno, além do pilar R ecursos deT erceiros.

A inda em 2001, o governo federal anunciou o Programa deF ortalecimento das I nstituições F inancei rasF ederais (P roef), cujas medidas provocaram efeitos relevantes para o Banco do Brasil, como, por exemplo, a permuta dos títulos emitidos pela R epública Federativa do Brasil no exterior (brady bonds) por títulos da dívidainterna deemissão doT esouro. T ambém foi efetuada a troca deativos depouca liquidez e baixa qualidade (principalmente da carteira de crédito) por ativos mais líquidos e remunerados a taxas de mercado (principalmente títulos públicos) (Versiani, 2003; Folha de S. Paulo, 22/ 9/2008).

Em 2002, o Estatuto Social do Banco foi adequado ao objetivo de garantir maior transparência e melhores práticas de $G$ overnança C orporativa, o que culminou na entrada da instituição no N ovo M ercado da Bolsa deValores de São Paulo (Bovespa), em 2006.

Por meio do BB Banco de Investimentos, subsidiária integral, o Banco do Brasil participa de empresas nos ramos de seguros (Brasil Veículos Cia. de Seguros, Cia. de Seguros A liança do Brasil e B rasilsaúde), previdência (Brasilprev) e capitalização (Brasilcap), disponibilizando um amplo portfolio de produtos não bancários.

A gente financeiro da U nião, o Banco do Brasil tem o T esouro $\mathrm{N}$ acional como seu principal acionista, com $65,3 \%$ do capital, seguido pela C aixa de Previdência dos F uncionários do Banco do Brasil (Previ), com 10,5\% das ações, e pel o BN D E Spar - empresa de participações do Banco $\mathrm{N}$ acional de $\mathrm{D}$ esenvolvimento E conômico e Social -, com 2,5\% das ações. 0 restante das ações, $21,7 \%$, está alocado em F ree- $\mathrm{F}$ loat, ${ }^{1}$ distribuído entre Pessoas F ísicas, J urídicas e Capital Estrangeiro (Tabela I.1.1).

N os últimos anos vem crescendo a participação do free-float no capital do Banco do Brasil, sendo que, quando a instituição aderiu ao $\mathrm{N}$ ovo M ercado, em 2006, comprometeu-se a atingir 25\% dessetipo de ação até 2009. A inda em 2006, o C onselho M onetário N acional (CM N) aprovou proposta de el evação da participação estrangeira no

1 A ções do banco que estão pulverizadas no mercado. 
Tabela I.1.1 - Composição A cionária (\%)

\begin{tabular}{l|r|c|c|c|c}
\hline \multicolumn{1}{c|}{ A cionistas } & $\mathbf{2 0 0 4}$ & $\mathbf{2 0 0 5}$ & $\mathbf{2 0 0 6}$ & $\mathbf{2 0 0 7}$ & jun./ 08 \\
\hline Tesouro N acional & 72,1 & 72,1 & 68,7 & 67,1 & 65,3 \\
\hline PREVI & 13,9 & 13,9 & 11,4 & 10,7 & 10,5 \\
\hline BN DESPar & 5,8 & 5,7 & 5,1 & 2,6 & 2,5 \\
\hline A ções em T esouraria & 1,4 & 1,4 & - & - & - \\
\hline Free-F loat & 6,8 & 6,9 & 14,8 & 19,6 & 21,7 \\
\hline Pessoas Físicas & 2,9 & 2,6 & 4,2 & 5,4 & 5,8 \\
\hline Pessoas Jurídicas & 1,1 & 0,9 & 3,4 & 4,3 & 4,0 \\
\hline Capital Estrangeiro & 2,8 & 3,4 & 7,2 & 9,9 & 11,9 \\
\hline T OTAL & 100 & 100 & 100 & 100 & 100 \\
\hline
\end{tabular}

Fonte: Elaboração própria a partir de dados extraídos do site do Banco do Brasil.

capital social da instituição de 5,6\% para 12,5\%. Em junho de 2008, - CM N autorizou o aumento da participação estrangeira no capital social para $25 \%$.

D esde 2002, tem sido observado um expressivo aumento da participação de investidores estrangeiros no capital do Banco. Essa participação, queera de 0,9\% em 2002, passou para 11,9\% em junho de 2008, representando 55\% do free-float (G ráfico I.1.1).

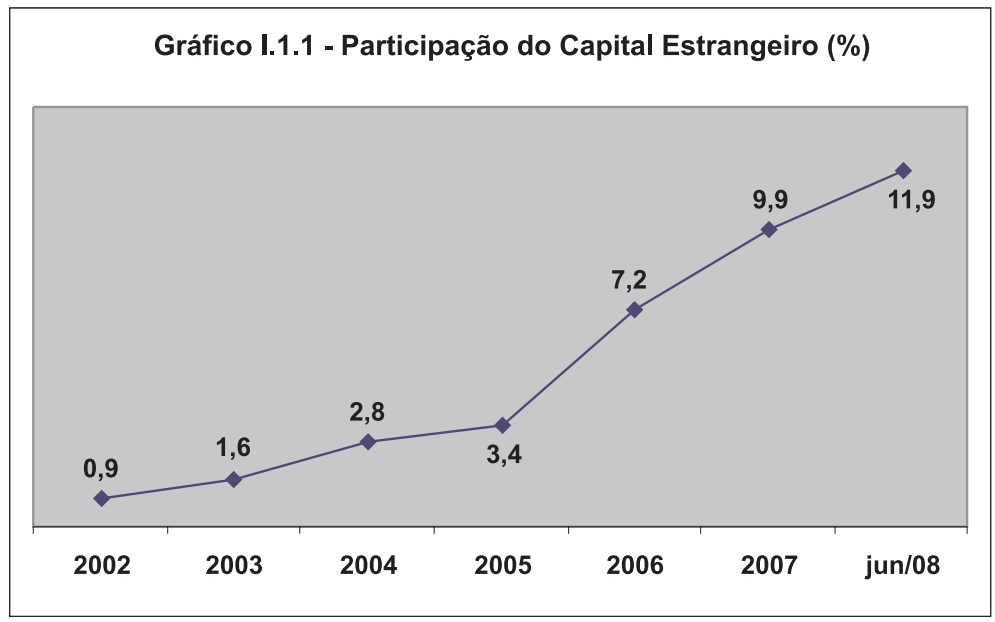

Fonte: Elaboração própria a partir de dados extraídos do site do Banco do Brasil. 


\section{Rede de atendimento}

O Banco do Brasil está presenteem 3.274 municípios brasileiros, encerrando o primeiro semestre de 2008 com 84,3 mil funcionários, 9,5 mil estagiários, 15,6 mil pontos de atendimento e4,3 mil correspondentes da rede "A qui tem BB", com destaque para o correspondente BB-Visanet. $O$ banco disponibiliza, ainda, 38,8 mil terminais de autoatendimento, além de canais al ternativos, como o internet banking, a C entral de A tendimento, o Portal BB e a prestação de serviços pelo celular. O s clientes do Banco do Brasil também podem utilizar os terminais de autoatendimento da Caixa E conômica Federal, do Banco do N ordeste do Brasil (BN B) e do Banco do Estado de Santa C atarina (Besc), que são compartilhados com o BB. Por meio do Banco Popular do Brasil (BPB), o BB disponibiliza, ainda, serviços para a população de baixa renda. O BPB encerrou o primeiro semestre de 2008 com uma rede de 2.795 correspondentes bancários presentes em 1.378 municípios.

N o Brasil, o banco tem mai or presença na região Sudeste, seguido pelas regiões N ordeste, Sul, C entro- $O$ este e N orte (G ráfico I.1.2). E ssa participação não sofreu alterações significativas nos últimos anos. O bserva-se um pequeno aumento da participação das regiões $\mathrm{N}$ orte e N ordeste, desde 2004, acompanhado de diminuição da participação da região Sudeste.

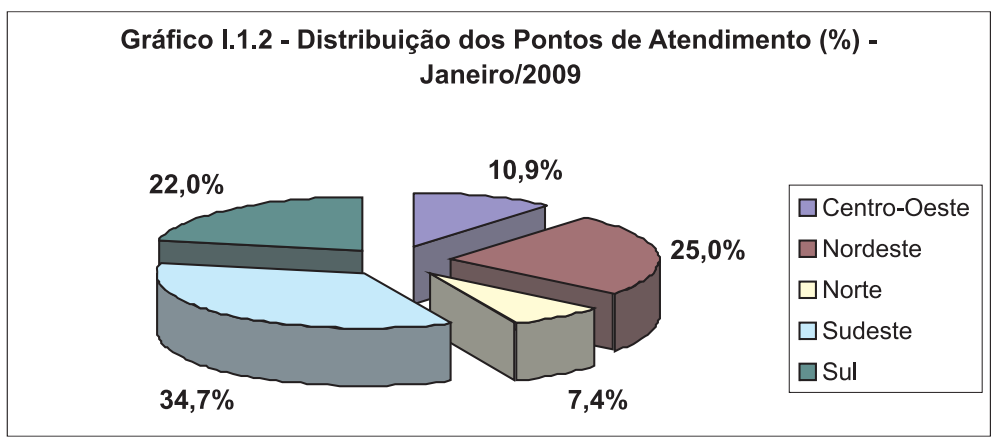

Fonte: Elaboração própria a partir de dados extraídos do site da Febraban. 
Em 2007, o BB anunciou o lançamento do Projeto N ordeste, em queprocura seaproximar dos governos da região (V alor E conômico, 22/ 10/2007). A instituição considera a região $N$ ordeste como um mercado com fortepotencial decrescimento e, com exceção dealguns segmentos, como o de cartão de crédito, essepotencial não tem sido bem aproveitado pelo setor bancário. O BB pretende ocupar essa lacuna, por meio, por exemplo, da sua experiência com agricultura e no atendimento de governos. Essa maior aproximação com os governos locais também aumenta a possibilidade de o banco firmar novos contratos no mercado de fol has de pagamento dos Estados (Valor E conômico, 20/ 9/2007).

$\mathrm{N}$ o exterior, a rede do Banco do Brasil é formada por 42 pontos de atendimento (15 agências, 10 subagências, 12 escritórios de representação e 5 subsidiárias), distribuídos em 23 países. A lém desua redeprópria no exterior, o banco mantinha, em junho de 2008, uma rede complementar de 1.426 bancos correspondentes, distribuídos em 151 países.

\section{Base de clientes}

O Banco do Brasil conta com 27,4 milhões declientes correntistas, sendo que $93,5 \%$ são pessoas físicas e $6,5 \%$ são pessoas jurídicas. A instituição possui, ainda, 14,7 milhões de clientes não correntistas, dentre poupadores, beneficiários do IN SS e consumidores deoutros produtos eserviços.

O s clientes são segmentados por renda, perfil, investimentos e relacionamento com a instituição. O s segmentos nos quais eles são alocados são: varejo, que inclui pessoas físicas e micro e pequenas empresas; ${ }^{2}$ atacado, que inclui empresas médias e grandes e o segmento corporate; governo, que atende entidades da administração pública; e agronegócio.

2 A s microempresas eempresas de pequeno porte representam 94,3\% dos clientes pessoa jurídica do Banco do Brasil (posição junho/ 2008). 
O s serviços disponíveis para a população demenor renda, principalmentetrabal hadores do setor informal, são oferecidos por meio da subsidiária integral Banco Popular do Brasil (BPB), criada em 2003. D esde sua criação, o BPB já concedeu mais de $R$ \$424,6 milhões em crédito.

Em maio de 2008, foi criada a D iretoria $M$ enor R enda, com o intuito de ampliar o foco estratégico em clientes com renda de até um salário mínimo, que correspondem a cerca de 8,3 milhões de correntistas do BB, 1,4 milhão de correntistas do Banco Popular do B rasil e 15 milhões de clientes não correntistas que mantêm al gum tipo de relacionamento com o BB. A nova diretoria absorveu as operações do Banco Popular e centralizou a gestão dos Correspondentes Bancários e as ações relativas ao D esenvolvimento R egional Sustentável (G azeta M ercantil, 16/ 5/ 2008).

$\mathrm{N}$ o relacionamento com o governo, o Banco do Brasil atua nasesferas dos poderes Executivo, L egislativo e J udiciário, apresentando- se como um dos principais parceiros do governo na implementação de políticas, programas e projetos voltados para o desenvolvimento nacional. N esse segmento, podem ser destacados os contratos para administração das folhas de pagamento das esferas de poder. E m dezembro de 2007, o BB tinha sob sua responsabilidade o processamento de $45 \mathrm{mil}$ folhas de pagamento, um importante instrumento de fidelização de clientes pessoa física.

\section{Captações}

O saldo de recursos captados pelo Banco do Brasil atingiu, em junho de 2008, R $\$ 288$, 8 bilhões, um crescimento de $366,7 \%$, em relação a dezembro de 1997. M erecem destaque as captações de mercado aberto e os depósitos a prazo, que correspondem a $60 \%$ do total de recursos captados (Tabela I.1.2).

N o segmento de depósitos a prazo, a principal forma decaptação são os depósitos judiciais, que totalizaram $\mathrm{R} \$ 31,3$ bilhões, em junho de2008, um crescimento de 18,3\% em relação a junho de 2007. 
Tabela I.1.2 - Composição das C aptações (em \%)

\begin{tabular}{|c|c|c|c|c|c|c|c|c|}
\hline Data & $\begin{array}{c}\text { À } \\
\text { Vista }\end{array}$ & Poupança & Interfin. & $\begin{array}{c}\text { A } \\
\text { Prazo }\end{array}$ & Outros & $\begin{array}{c}\text { D epósitos } \\
\text { Totais }\end{array}$ & $\begin{array}{c}\text { Cap. } \\
\text { M ercado } \\
\text { A berto }\end{array}$ & \begin{tabular}{|c|} 
Total \\
(em R \$ \\
bilhões)
\end{tabular} \\
\hline dez./ 97 & 14,8 & 26,9 & 2,8 & 44,6 & 0,3 & 89,4 & 10,6 & 61,9 \\
\hline dez./ 98 & 13,6 & 23,7 & 1,6 & 38,2 & 0,4 & 77,5 & 22,5 & 78,7 \\
\hline dez./ 99 & 13,7 & 23,0 & 2,9 & 42,1 & 1,3 & 83,0 & 17,0 & 87,0 \\
\hline dez./ 00 & 16,5 & 21,3 & 3,5 & 27,9 & 0,9 & 70,1 & 29,9 & 93,8 \\
\hline dez./ 01 & 15,5 & 18,1 & 3,6 & 21,7 & 3,8 & 62,7 & 37,3 & 117,2 \\
\hline dez./ 02 & 16,2 & 18,5 & 2,7 & 25,7 & 3,7 & 66,8 & 33,2 & 145,6 \\
\hline dez./ 03 & 17,6 & 18,3 & 4,9 & 27,6 & 4,9 & 73,3 & 26,7 & 150,1 \\
\hline dez./ 04 & 17,5 & 19,4 & 3,6 & 25,3 & 6,4 & 72,2 & 27,8 & 160,0 \\
\hline dez./ 05 & 19,5 & 19,5 & 3,2 & 30,5 & 9,2 & 81,9 & 18,1 & 168,2 \\
\hline dez./ 06 & 18,2 & 17,6 & 2,3 & 28,0 & 10,2 & 76,3 & 23,7 & 208,1 \\
\hline dez./ 07 & 18,9 & 17,6 & 2,0 & 25,8 & 8,0 & 72,3 & 27,7 & 260,6 \\
\hline jun./ 08 & 14,5 & 17,0 & 1,9 & 27,7 & 6,6 & 67,7 & 32,3 & 288,8 \\
\hline Cresc. & 357,0 & 195,5 & 218,0 & 189,7 & $10.450,0$ & 253,5 & $1.320,2$ & 366,7 \\
\hline
\end{tabular}

Fonte: Elaboração própria a partir de dados extraídos do site do Banco C entral do Brasil.

N o período de dezembro de 1997 a junho de 2008, as C aptações no $\mathrm{M}$ ercado $\mathrm{A}$ berto foram a forma de captação que mais cresceu. U ma das explicações para o crescimento de $1.320,2 \%$, nesse período, foi a intensificação das operações compromissadas, ${ }^{3}$ que atingiram $R \$ 46,4$ bilhões, em junho de 2008 , um crescimento de $42,7 \%$, em dozemeses.

\section{Carteira de crédito}

A carteira de crédito do Banco do Brasil, queinclui os segmentos deVarejo, Comercial, A gronegócios, Comércio Exterior, Exterior e D emais, atingiu $\mathrm{R} \$ 176,4$ bilhões, em junho de 2008 (G ráfico I.1.3).

3 C arteira deTerceiros. 


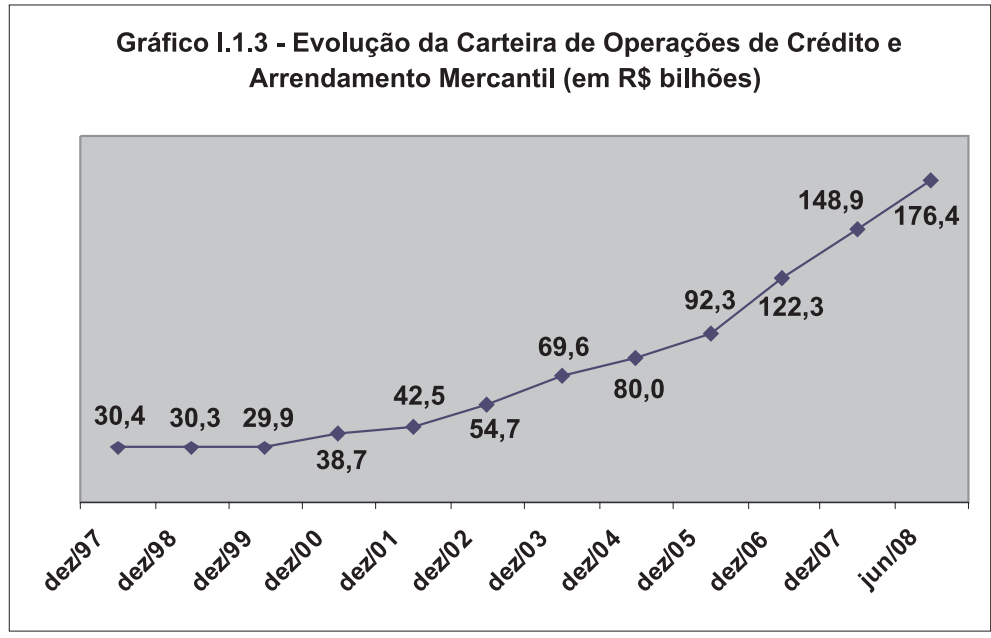

Fonte: Elaboração própria a partir de dados extraídos do site do Banco C entral do Brasil.

N os últimos anos, observa-se um aumento na participação do segmento de varejo na carteira total. Essa participação, que era de $20 \%$ em 2002 , alcançou $34,2 \%$ em junho de 2008 . N o período de 2002 a junho de2008, a carteira de varejo foi a quemais cresceu, com uma ampliação de 417\% (Tabela I.1.3).

A participação da carteira comercial estava em queda até 2005, quando atingiu 13,6\% da carteira total. A partir de2006, entretanto, essa cartei ra vem apresentando tendência decrescimento, atingindo 21,3\% da carteira total do banco em junho de 2008 (Tabela I.1.3).

A carteira de agronegócios também apresentou crescimento expressivo nos últimos anos, com uma participação de 32,4\% em junho de 2008 eum crescimento de $266,7 \%$ de dezembro de 2002 a junho de 2008. A té2006, essa carteira era a quetinha maior participação na carteir ratotal decrédito, sendo substituída pela carteira devarejo em 2007. A participação das carteiras deC omércio Exterior eExterior apresenta tendência de queda nos últimos anos (Tabelal .1.3).

A C arteira de C rédito deVarejo engloba os produtos destinados, principalmente, às Pessoas F ísicas e às M icro e Pequenas Empresas. A carteira de crédito de Pessoas Físicas, por sua vez, inclui as 
Tabelal 1.1.3 - Composição da Carteira de C rédito (em \%)

\begin{tabular}{l|c|c|c|c|c|c|c|c|c}
\hline & dez./ 02 & dez./ 03 & dez./ 04 & dez./ 05 & dez./ 06 & dez./ 07 & jun./ 08 & C resc. \\
\hline Varejo & 20,0 & 20,1 & 23,1 & 30,4 & 30,4 & 33,2 & 34,2 & 417,0 \\
\hline Comercial & 22,3 & 21,2 & 21,8 & 13,6 & 16,3 & 18,4 & 21,3 & 188,7 \\
\hline A gronegócios & 26,7 & 34,5 & 33,9 & 35,1 & 33,8 & 32,3 & 32,4 & 266,7 \\
\hline $\begin{array}{l}\text { Comércio } \\
\text { Exterior }\end{array}$ & 12,1 & 9,4 & 9,0 & 9,5 & 8,3 & 7,4 & 5,7 & 42,4 \\
\hline Exterior & 16,4 & 12,2 & 10,2 & 9,0 & 9,1 & 7,1 & 5,1 & $-5,8$ \\
\hline Demais & 2,5 & 2,6 & 2,0 & 2,4 & 2,1 & 1,6 & 1,3 & 56,1 \\
\hline
\end{tabular}

Fonte: Elaboração própria a partir de dados extraídos do site do Banco do Brasil.

operações de C rédito $D$ ireto ao C onsumidor (CD C), operações com cartão de crédito e o segmento de cheque especial.

0 segmento de maior destaque é o $C$ rédito $C$ onsignado, que responde por $21,6 \%$ do total desta carteira. D e dezembro de 2003 a junho de 2008, o crescimento da cartei ra de crédito consignado foi de 2.437\%. A carteira deF inanciamento aVeículos também apresentou crescimento significativo, passando a representar 7,25\% da carteira de varejo em junho de 2008 (T abela I.1.4).

Tabela I.1.4 - Composição da C arteira de C rédito deVarejo (\%)

\begin{tabular}{l|c|c|c|c|c|c|c}
\hline & dez./ 03 & dez./ 04 & dez./ 05 & dez./ 06 & dez./ 07 & jun./ 08 & C resc. $^{\mathbf{1}}$ \\
\hline CD C & 35,5 & 35,2 & 38,7 & 41,8 & 44,7 & 44,3 & 275,2 \\
\hline $\begin{array}{l}\text { CD C Crédito em } \\
\text { Consignação }\end{array}$ & 2,6 & 5,4 & 12,3 & 20,5 & 22,3 & 21,6 & $2.436,7$ \\
\hline $\begin{array}{l}\text { Financiamento } \\
\text { aVeículos }\end{array}$ & - & - & 0,6 & 2,2 & 5,5 & 7,3 & $2.404,8$ \\
\hline $\begin{array}{l}\text { Financiamento } \\
\text { Imobiliário }\end{array}$ & - & - & - & - & - & 0,0 & - \\
\hline Recebíveis & 26,2 & 24,6 & 0,0 & 17,9 & 15,1 & 13,2 & 51,5 \\
\hline BB G iro R ápido & 12,5 & 12,5 & 12,6 & 10,7 & 9,3 & 8,2 & 98,3 \\
\hline Cartão deC rédito & 7,5 & 7,3 & 8,0 & 7,6 & 8,1 & 10,9 & 336,4 \\
\hline Cheque Especial & 10,1 & 8,5 & 7,2 & 5,5 & 4,5 & 4,4 & 30,6 \\
\hline \begin{tabular}{l} 
D emais \\
\hline
\end{tabular}
\end{tabular}


O s empréstimos na modal idade de C rédito Consignado estão concentrados nos servidores públicos, que representaram, no final do primeiro semestre de $2008,82,2 \%$ do volume da carteira. O s aposentados e pensionistas do I N SS representaram 7,5\% da carteira e os trabalhadores da iniciativa privada, 10,3\%.

Jáa carteira definanciamento deveículos, reestruturada em 2006, apresentou um crescimento expressivo devido à estratégia de firmar parcerias com concessionárias e multimarcas, para oferecimento de financiamentos. Essas parcerias foram responsáveis por 33,5\% do volume contratado no primeiro semestre de 2008, representando $25,3 \%$ do total da carteira de financiamento de veículos.

N o segmento de crédito imobiliário, o Banco do Brasil começou a atuar em fevereiro de2007, por meio de uma parceria com a A ssociação dePoupança eE mpréstimo do Exército (Poupex), para oferta do produto, enquanto aguardava autorização para operar com carteira própria (Valor E conômico, 1/ 6/2007). Por meio desse convênio, foram concedidos $R \$ 252,8$ milhões em cartas de crédito eliberados $\mathrm{R} \$ 88,8$ milhões em financiamentos imobiliários.

Em dezembro de 2007, o BB começou a operar com sua carteira própria decrédito imobiliário, atendendo, inicialmente, os clientes do E stado deSão Paulo. Em março de2008, o Banco Central autorizou o BB a direcionar $10 \%$ de seus depósitos em conta-poupança ao crédito imobiliário, por meio do Sistema Financeiro de H abitacão (SF H) (DCI - SP, 2/ 4/ 2008). O banco enfrentava restrições legais para atuar nesse segmento porque os recursos captados nas cadernetas de poupança deveriam ser direcionados, obrigatoriamente, para o crédito rural (Valor E conômico, 24/ 4/ 2007; Folha de S. Paulo, 15/ 5/ 2008).

$\mathrm{N}$ o segmento de microcrédito, por meio do Banco Popular do Brasil (BPB), o Banco do Brasil viabilizou, em 2007, R \$1,9 milhão em operações para o público demenor renda emicroempreendedores. 0 BPB encerrou o primeiro semestre de 2008 com R \$11,1 milhões, em créditos concedidosno período, esaldo em carteira de $\$ 25,1$ milhões.

N o segmento de cartões, o Banco do Brasil atingiu uma base de 75 milhões de cartões, em junho de 2008, sendo 23,7 milhões de cartões de crédito e 51,2 milhões de cartões de débito. D estaca-se a 
base de 1,4 milhão decartões emitidos, em parceriacom 21 empresas de diversos segmentos.

$O$ segmento de $M$ icro eP equenas $E$ mpresas, queengloba operações de G iro, operações com base em recebíveis, o BB G iro R ápido, as operações de Proger U rbano E mpresarial eO utros, representava, em dezembro de 2007, 42,8\% da Carteira deVarejo, contra 45,3\% em dezembro de 2006. Essa redução deve-se, principalmente, à estratégia do banco de concentrar esforços em produtos voltados às pessoas físicas, como $C D C$ Veícul os, Consignação e $C$ artão de $C$ rédito. $D$ essa forma, as carteiras de crédito destinadas às $M$ icro $\mathrm{e}$ Pequenas E mpresas vêm diminuindo sua participação na $C$ arteira deVarejo do Banco do Brasil.

A $C$ arteira de $C$ rédito $C$ omercial engloba os produtos destinados, principalmente, às médias e grandes empresas e aos clientes corporate, incluindo operações de C apital de G iro, Investimento, Recebíveis, $\mathrm{C}$ onta $\mathrm{G}$ arantida e $\mathrm{O}$ utros. A linha com maior participação nessa carteira éa de $C$ apital de $\mathrm{G}$ iro, querepresentou $62 \%$ do total da carteira, em junho de 2008. Esta modalidade também foi a que cresceu mais rapidamente nos últimos anos.

A linha de Investimento, destinada, principal mente, à ampliação ou modernização da produção via aquisição de máquinas e equipamentos, também tem participação significativa, de $21 \%$ da carteira comercial. D estacam-se as operações com repasses de recursos do BN D ES eF iname, queatingiram saldo de $R \$ 5,2$ bilhões no primeiro semestre de 2008.

0 aumento da partici pação da carteira comercial na carteira total do Banco do Brasil, nosúltimosanos (Tabelal .1.3), foi consequência, principalmente, do incremento de operações com grandes grupos empresariais. Essecrescimento, por suavez, deveu-se, principalmente, à queda da taxa de juros, que fez com que as grandes empresas voltassem a tomar empréstimos em bancos, retomando uma alternativa de financiamento que vinha sendo substituída, desde 2005, por operações no mercado de capitais (Valor E conômico, 26/ 7/ 2007).

Com relação à carteira de crédito de agronegócio, o B anco do B rasil élíder entre as instituições financeiras integrantes do Sistema 
N acional do C rédito R ural, com participação de $62,6 \%$ em junho de 2008. N o final do primeiro semestre de 2008 , a carteira de agronegócios representava 32,4\% da carteira de crédito total do BB (T abela I.1.3), sendo composta por $35,9 \%$ de operações de investimento, $34,7 \%$ de operações de custeio, $27,8 \%$ de comercialização e $1,5 \%$ de crédito agroindustrial.

0 crescimento dessa carteira nos últimos anos, entretanto, foi inferior ao verificado nas carteiras dePessoa F ísica e Jurídica, devido ao processo derecuperação da renda em curso no setor produtivo rural e à busca por empréstimos demenor risco, como o crédito consignado e o financiamento de veículos. Por sua rel evância na carteira do BB, o menor crescimento do crédito rural, em 2007, contribuiu para que a instituição perdesse participação no mercado de crédito.

Como principal financiador do A gronegócio no País, o BB éresponsável pela execução dos programas do governo para esse segmento. O s recursos disponibilizados são obtidos por meio dos depósitos depoupança eà vista, Programa de G eração deE mprego eR enda da Á rea $\mathrm{R}$ ural (Proger R ural), Programa $\mathrm{N}$ acional de Fortalecimento da A gricultura Familiar do $M$ inistério do $D$ esenvolvimento $A$ grário (Pronaf), F undo Constitucional de $D$ esenvolvimento do C entro- O este (F C O ) e Banco N acional de D esenvolvimento E conômico eSocial (BN DES).

Para financiamentos a taxas controladas, com os recursos captados por meio da poupança e do $\mathrm{F}$ undo de A mparo ao T rabal hador (FAT ), o BB recebe do T esouro $\mathrm{N}$ acional, na forma de equalização, a diferença entre os custos da captação, os riscos, os custos administrativos e tributários e o valor cobrado do tomador do crédito para tornar essaintermediação viável. A título deequalização, ainstituição recebeu $\mathrm{R} \$ 562$ milhões no primeiro semestre de 2008.

A carteira decomércio exterior do Banco do Brasil écomposta por operações de financiamento à exportação nas modalidades A diantamento sobre Contratos de Câmbio (A C C), A diantamento sobre Cambiais E ntregues (A CE ), Financiamento à I mportação eBN DES-Exim. Essa carteira é composta, principalmente, por operações de financiamento à exportação, nas modalidades A diantamento sobre 
Contratos de Câmbio ( $\mathrm{ACC}$ ) e A diantamento sobre Cambiais Entregues (ACE), que respondem por $59,2 \%$ do total de empréstimos da carteira de crédito para o comércio exterior. E m seguida, a linha BN DES-Exim responde por 30,9\% da carteira.

Como agente financeiro exclusivo da U nião no Programa de Financiamento às Exportações (Proex), que oferece crédito em condições compatíveis com as praticadas no mercado internacional para os exportadores brasileiros, o banco desembolsou, no primeiro semestre de 2008, U S\$115,8 mil hões na modalidadeF inanciamento eU S\$ 81,5 milhões na modalidade Equalização.

Com relação ao Í ndice de I nadimplência da carteira de crédito da instituição, verifica-seuma redução, apesar da expansão da carteira. 0 índice para operações vencidas há mais de 60 dias al cançou 2,8\%, no segundo trimestre de 2008, contra 3,3\%, no quarto trimestre de 2007 (G ráfico I.1.4). 0 índice de atraso até 90 dias atingiu 2,5\%, no segundo trimestre de 2008 , contra $2,4 \%$ registrado no mesmo período de 2007.

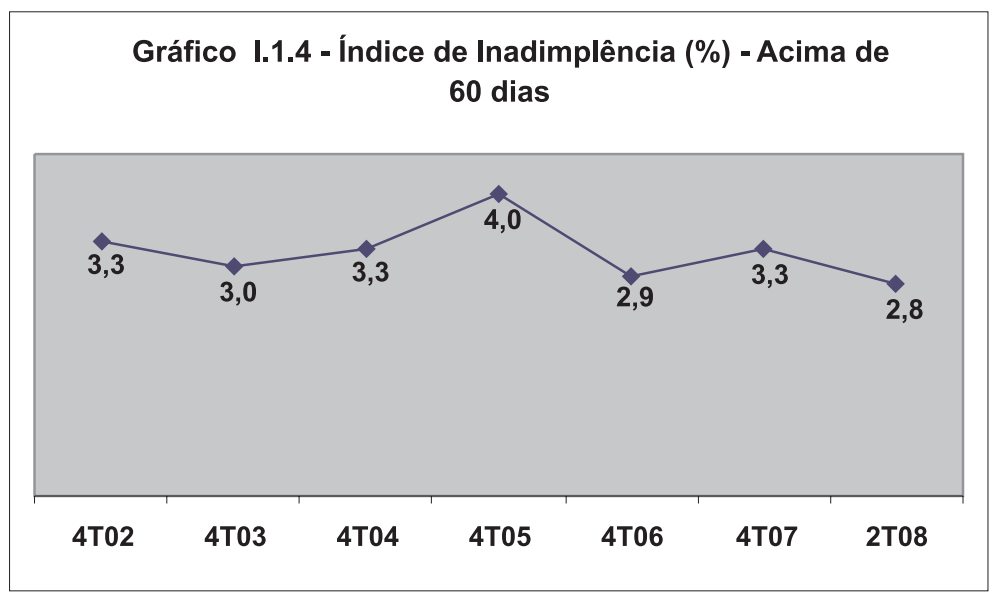

Fonte: Elaboração própria a partir de dados extraídos do site do Banco do Brasil.

A elevação nosíndices de atraso da C arteira de C rédito verificada em 2007, em relação a 2006, deve-se, principalmente, ao processo de renegociação de operações rurais ocorrido no final de 2007. 


\section{Gestão de riscos}

O s riscos de mercado, liquidez, crédito e operacional são gerenciados pelo Banco do Brasil de acordo com as melhores práticas adotadas no mercado internacional. Todas as decisões rel acionadas à gestão de riscos são tomadas deforma colegiada, por meio deprocesso decisório estabelecido. $\mathrm{N}$ o intuito de atender às exigências do N ovo A cordo de C apitais - Basileia II e alinhado às melhores práticas de gestão deriscos, o Banco do Brasil desenvolveu metodologia própria para apuração dos componentes de risco. 0 banco direciona seus esforços para a adoção de modelos internos de avaliação dos riscos para cálculo da exigência de capital.

0 índice de adequação de capital do banco - Índice de Basileia - apresentava tendência de crescimento até dezembro de 2006. Entretanto, em 2007, esse índice atingiu 15,6\%, chegando a 13,1\% em junho de 2008 (G ráfico I .1.5). Essa redução pode ser explicada pela ampliação das operações de crédito e pelo crescimento dos créditos tributários, que exigem al ocação de capital da ordem de 300\%.

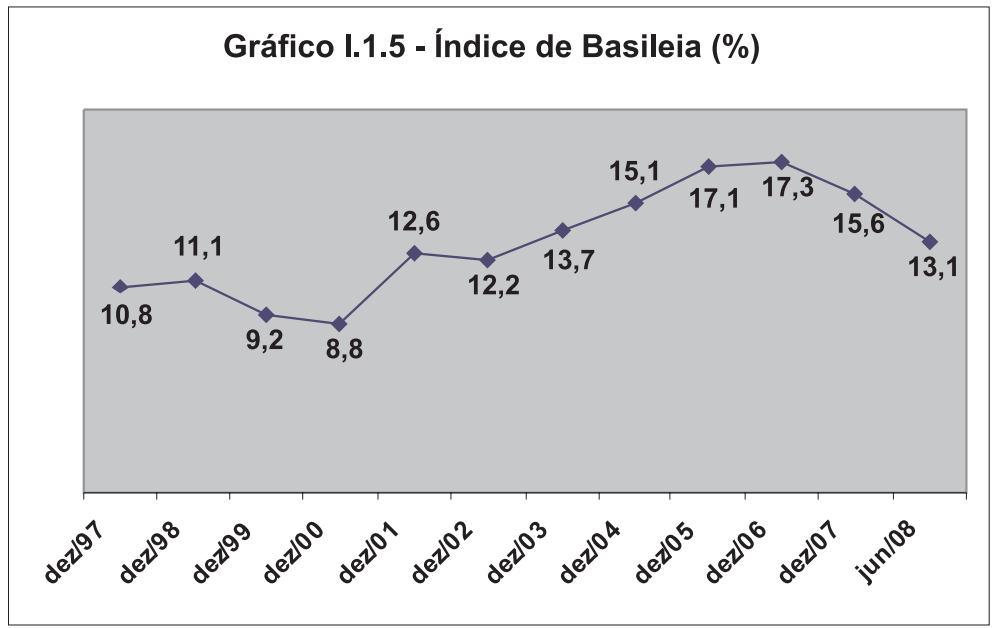

Fonte: Elaboração própria a partir de dados extraídos do site do Banco do Brasil. 
Com relação à distribuição da carteira de crédito, 90,4\% das operações está concentrada nos níveis de risco A A, A, B e C ${ }^{4}$ (Tabela I.1.5).

Tabela I.1.5 - Composição da C arteira de C rédito por $\mathrm{N}$ ível de R isco (\%)

\begin{tabular}{c|c|c|c|c|c|c|c}
\hline & dez./ 02 & dez./ 03 & dez./ 04 & dez./ 05 & dez./ 06 & dez./ 07 & jun./ 08 \\
\hline A A & 24,9 & 20,7 & 19,3 & 18,1 & 24,8 & 26,6 & 28,3 \\
\hline A & 41,8 & 44,5 & 28,4 & 28,7 & 24,0 & 19,5 & 19,8 \\
\hline B & 18,1 & 20,0 & 31,6 & 30,8 & 30,6 & 33,3 & 30,7 \\
\hline C & 7,2 & 6,9 & 12,8 & 13,1 & 11,6 & 11,5 & 11,6 \\
\hline D & 2,5 & 3,3 & 2,8 & 3,4 & 3,2 & 3,4 & 4,0 \\
\hline E & 1,4 & 0,7 & 0,9 & 1,2 & 1,5 & 1,4 & 1,1 \\
\hline F & 0,5 & 0,4 & 0,6 & 0,7 & 0,5 & 0,5 & 0,6 \\
\hline G & 0,4 & 0,4 & 0,5 & 0,8 & 0,7 & 0,7 & 0,7 \\
\hline H & 3,2 & 3,0 & 3,1 & 3,4 & 3,1 & 3,2 & 3,2 \\
\hline AA-C & 92,0 & 92,1 & 92,1 & 90,6 & 91,0 & 90,9 & 90,4 \\
\hline D-H & 8,0 & 7,9 & 7,9 & 9,4 & 9,0 & 9,1 & 9,6 \\
\hline
\end{tabular}

Fonte: Elaboração própria a partir de dados extraídos do site do Banco do Brasil.

A C arteira de Crédito de menor qualidade do Banco do Brasil é a de $A$ gronegócios, ${ }^{5}$ em que, em junho de 2008 , somente $85,5 \%$ das operações estavam concentradas nos níveis de risco A A, A, B e C. N o caso das operações de varejo, esse percentual era de $89,8 \%$. A s demais carteiras, C omercial, C omércio Exterior e Exterior, podem ser consideradas demel hor qualidade, uma vez que mais de $98 \%$ das operações estavam concentradas nos quatro primeiros níveis derisco.

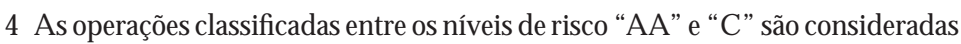
como de curso normal. A s operações no nível " $D$ " são consideradas como em estágio de administração de risco, devendo-se buscar sua redução ou a agregação de garantias de maior liquidez. Já as operações classificadas nos níveis de risco entre " $\mathrm{E}$ " $\mathrm{e}$ " $\mathrm{H}$ " são consideradas como decurso anormal, podendo resultar em perdas parciais, depois deesgotados os métodos de cobrança cabíveis.

50 risco médio dessa carteira está fortemente influenciado pelas operações das safras de 2005 a 2007, prorrogadas com saldo total de $R \$ 16,5$ bilhões. 
N os últimos anos, tem severificado uma mel hora derisco, devido ao crescimento na carteira deoperações delinhas de crédito com menores taxas de juros e mel hores garantias, como crédito consignado e financiamento a veículos.

\section{Índices de cobertura e de eficiência}

0 Í ndice de Cobertura ${ }^{6}$ tem apresentad o tendência de crescimento, atingindo $130,9 \%$ no primeiro semestre de 2008 , contra $44,3 \%$ em 1998 (Tabela I.1.6). Esse crescimento pode ser explicado pelo controle dos custos administrativos e pel o aumento das R eceitas de Prestação deServiços (R PS). N o período de 1998 a 2007, as R eceitas dePrestação deServiços cresceram 294,5\%, enquanto as D espesas de Pessoal aumentaram 61,9\%.

Tabela I.1.6 - Índice deC obertura (em \%)

\begin{tabular}{l|c|c|c|c|c|c|c|c|c|c|c}
\hline & $\mathbf{1 9 9 8}$ & $\mathbf{1 9 9 9}$ & $\mathbf{2 0 0 0}$ & $\mathbf{2 0 0 1}$ & $\mathbf{2 0 0 2}$ & $\mathbf{2 0 0 3}$ & $\mathbf{2 0 0 4}$ & $\mathbf{2 0 0 5}$ & $\mathbf{2 0 0 6}$ & $\mathbf{2 0 0 7}$ & $\begin{array}{c}\mathbf{1 0 S} \\
\mathbf{2 0 0 8}\end{array}$ \\
\hline $\begin{array}{l}\text { Rec. Prest. } \\
\text { Serviços } \\
\text { (em R \$ milhões) }\end{array}$ & 2.510 & 2.802 & 3.149 & 3.767 & 4.452 & 5.489 & 6.614 & 7.649 & 8.888 & 9.903 & 5.201 \\
\hline $\begin{array}{l}\text { Despesas de } \\
\begin{array}{l}\text { Pessoal } \\
\text { (em R \$ milhões) }\end{array}\end{array}$ & 5.662 & 5.668 & 5.628 & 5.586 & 5.534 & 6.807 & 7.111 & 7.475 & 7.871 & 9.164 & 3.973 \\
$\begin{array}{l}\text { Indice de } \\
\text { Cobertura }\end{array}$ & 44,3 & 49,4 & 56,0 & 67,4 & 80,4 & 80,6 & 93,0 & 102,3 & 112,9 & 108,1 & 130,9 \\
\hline
\end{tabular}

Fonte: Elaboração própria a partir de dados extraídos do site do Banco C entral do Brasil.

As R eceitas de Prestação de Serviços são compostas, principalmente, porT arifas deC onta-C orrentee porT arifas deA dministração de F undos, que representaram $48,2 \%$ do total das R PS, no primeiro semestre de 2008 (G ráfico I.1.6). A sT arifas de C onta-C orrente, entretanto, vêm reduzindo sua partici pação, enquanto as receitas deA dministração de F undos e de C artão vêm apresentando crescimento.

6 Expressa a capacidade de cobertura das D espesas de Pessoal apenas com as R eceitas de Prestação de Serviços (RPS). 


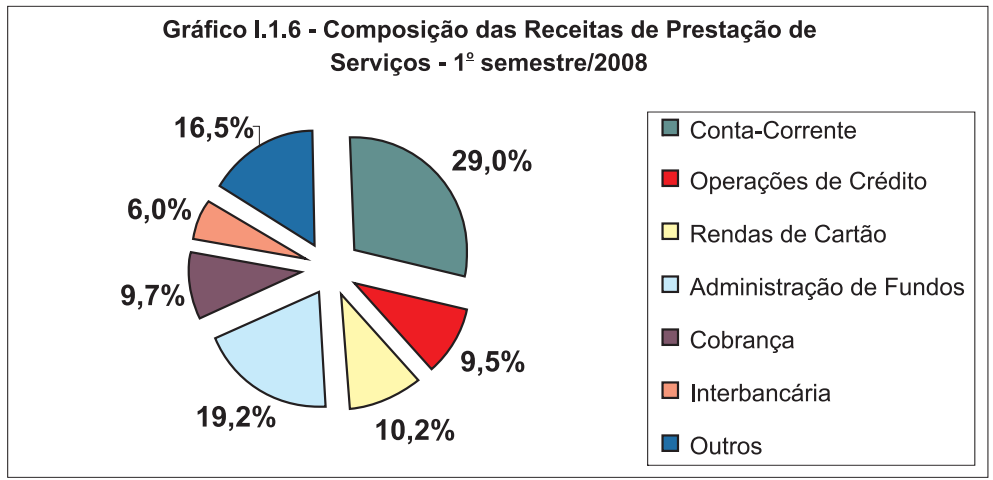

Fonte: Elaboração própria a partir de dados extraídos do site do Banco do Brasil.

A recente retração das R eceitas com $T$ arifas de C onta-C orrente reflete a mudança de política do banco na cobrança de tarifas, antecipando-se à R esolução C M N 3.518/ 07, que disciplina a cobrança de tarifas para pessoas físicas.

O Í ndice de E ficiência ${ }^{7}$ caiu significativamente no período, passando de 92,2\% em 1999 para 44,5\% no primeiro semestre de 2008 (G ráfico I.1.7).

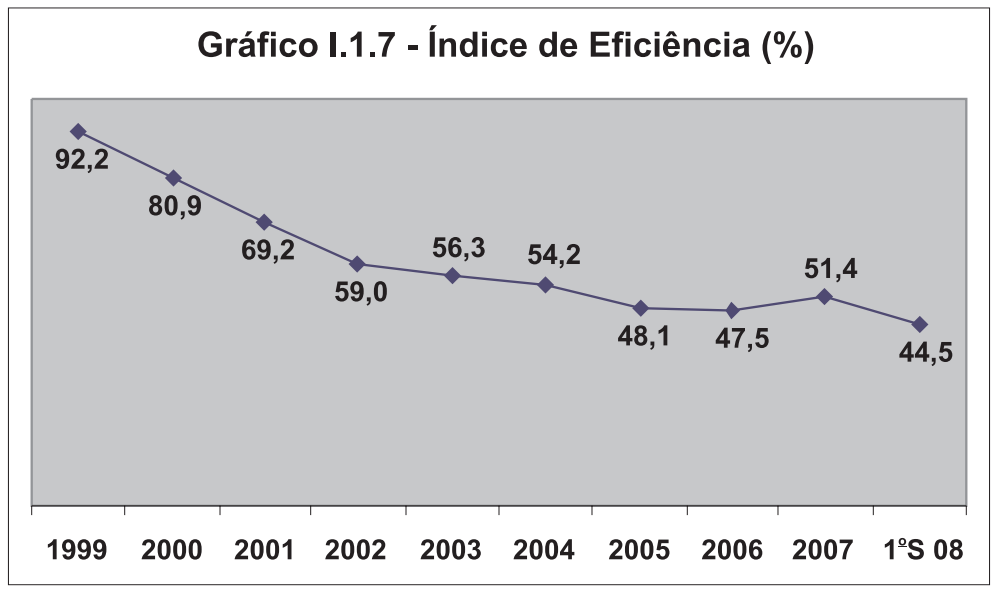

Fonte: Elaboração própria a partir de dados extraídos do site do Banco do Brasil.

7 Expressa a relação entre as despesas administrativas eas receitas operacionais. 


\section{Composição dos ativos e das receitas de intermediação financeira}

Os ativos do Banco do Brasil são compostos, principalmente, por T ítulos eValores M obiliários e Instrumentos F inanceiros D erivativos, além de 0 perações de $C$ rédito e $A$ rrendamento $M$ ercantil. D esde 2003, a composição desses ativos vem se invertendo, com ampliação da participação das 0 perações de C rédito, frente aos T ítulos eValores M obiliários (T V M ). Enquanto, em dezembro de 2002 , os ativos totais eram compostos por $34,7 \%$ deT VM e26,7\% de 0 perações de C rédito, em junho de 2008 esses percentuais atingiram 17,4\% e 43,7\%, respectivamente. No período de dezembro de 1997 a junho de 2008, o sal do das 0 perações de C rédito cresceu 480,8\%, contra 143,6\% dos T ítulos eValores M obiliários (T abela I.1.7). A carteira deT VM é composta, principalmente, por títulos públicos, que representaram 94,4\% da carteira em junho de 2008.

Tabelal I.1.7 - Composição dos A tivos (em \%)

\begin{tabular}{|c|c|c|c|c|c|c|}
\hline D ata & $\begin{array}{l}\text { A plicações } \\
\text { Interfin. }\end{array}$ & $\begin{array}{l}\text { T V M e } \\
\text { Instrum. } \\
\text { Financ. } \\
\text { D eriv. }\end{array}$ & $\begin{array}{c}\text { Op. de } \\
\text { Crédito e } \\
\text { Arrend. } \\
\text { M erc. }\end{array}$ & $\begin{array}{l}\text { O utros } \\
\text { C réditos }\end{array}$ & 0 utros $^{1}$ & $\begin{array}{l}\text { A tivo T otal } \\
\quad \text { (em } \\
\text { R \$ bilhões) }\end{array}$ \\
\hline dez./ 97 & 13,0 & 26,5 & 27,9 & 24,4 & 8,2 & 108,9 \\
\hline dez./98 & 14,9 & 31,3 & 23,4 & 21,4 & 9,0 & 129,6 \\
\hline dez./ 99 & 10,8 & 32,7 & 23,6 & 23,1 & 9,7 & 126,5 \\
\hline dez./ 00 & 3,7 & 36,9 & 28,0 & 23,1 & 8,3 & 138,4 \\
\hline dez./ 01 & 7,6 & 37,8 & 25,7 & 18,6 & 10,1 & 165,1 \\
\hline dez./ 02 & 8,7 & 34,7 & 26,7 & 14,6 & 15,4 & 204,6 \\
\hline dez./ 03 & 14,5 & 30,2 & 30,2 & 11,9 & 13,1 & 230,1 \\
\hline dez./ 04 & 6,9 & 30,7 & 33,5 & 13,1 & 15,9 & 239,0 \\
\hline dez./ 05 & 11,4 & 26,3 & 36,5 & 13,9 & 11,9 & 253,0 \\
\hline dez./ 06 & 9,8 & 24,6 & 41,3 & 13,7 & 10,6 & 296,4 \\
\hline dez./ 07 & 14,3 & 21,0 & 41,6 & 12,7 & 10,4 & 357,8 \\
\hline jun./ 08 & 13,4 & 17,4 & 43,7 & 14,2 & 11,3 & 403,5 \\
\hline Cresc. (\%) & 282,3 & 143,6 & 480,8 & 115,3 & 406,6 & 270,4 \\
\hline
\end{tabular}

1) Inclui D isponibilidades, Relações Interfinanceiras, R elações de I nterdependências, Provisão para C réditos de L iquidação D uvidosa, $\mathrm{O}$ utrosValores e Bens, I mobilizado de A rrendamento ePermanente.

Fonte: Elaboração própria a partir de dados extraídos do site do Banco C entral do Brasil. 
A composição das $R$ eceitas del ntermediação financei ra também vem apresentando comportamento semelhante. A receita com operações de crédito vem ampliando sua participação no total de receitas nos últimos anos. N o primeiro semestre de 2008, essa participação foi de $65,5 \%$, contra $38,2 \%$ em 2002 . A s receitas com operações de T V M , por sua vez, representavam $42 \%$ da receita total em 2002, contra 31\% no primeiro semestre de 2008 (Tabela I.1.8).

T abela I .1.8 - C omposição das R eceitas de I ntermediação Financeira (em \%)

\begin{tabular}{l|c|c|c|c}
\hline D ata & $\begin{array}{c}\text { O p. C rédito e } \\
\text { A rrend. M erc. }\end{array}$ & $\begin{array}{c}\text { O perações com } \\
\text { T V M }\end{array}$ & O utros $^{\mathbf{1}}$ & $\begin{array}{c}\text { Total (em } \\
\text { R \$ bilhões) }\end{array}$ \\
\hline 1997 & 62,0 & 34,3 & 3,7 & 15,2 \\
\hline 1998 & 54,1 & 45,1 & 0,8 & 23,2 \\
\hline 1999 & 43,3 & 47,7 & 9,0 & 26,7 \\
\hline 2000 & 50,9 & 44,9 & 4,2 & 16,5 \\
\hline 2001 & 55,8 & 36,9 & 7,3 & 19,6 \\
\hline 2002 & 38,2 & 42,0 & 19,8 & 36,6 \\
\hline 2003 & 47,2 & 45,1 & 7,7 & 34,8 \\
\hline 2004 & 56,5 & 36,7 & 6,8 & 30,9 \\
\hline 2005 & 58,6 & 37,2 & 4,2 & 33,4 \\
\hline 2006 & 59,5 & 36,2 & 4,3 & 37,2 \\
\hline 2007 & 63,6 & 31,0 & 5,4 & 40,8 \\
\hline $10 S 2008$ & 65,5 & 31,0 & 3,5 & 21,9 \\
\hline Cresc. (\%) & 176,0 & 142,3 & 292,2 & 168,4 \\
\hline
\end{tabular}

1) Inclui $O$ perações com Instrumentos Financeiros D erivativos, 0 perações de $C$ âmbio e A plicações Compulsórias.

Fonte: Elaboração própria a partir de dados extraídos do site do Banco C entral do Brasil.

A alteração nas composições dos ativos edas receitas deintermediação financeira a partir de 2002 podeser explicada, principalmente, pelos efeitos das medidas implementadas pelo Programa de Fortalecimento das I nstituições F inanceiras F ederais (Proef).

\section{Resultados}

N o ano de2007, o Banco do Brasil al cançou um lucro líquido de R \$ 5,1 bilhões, um crescimento de 750\% em relação a 1997. 0 lucro 
da instituição tem crescido significativamente nos últimos anos, principalmente a partir de 2002 (G ráfico I.1.8). 0 lucro acumulado no primeiro semestre de 2008 atingiu $\mathrm{R} \$ 4$ bilhões; entretanto, esse resultado foi impactado extraordinariamente em $\mathrm{R} \$ 970$ milhões, em decorrência, principalmente, da venda da participação da Visa I nternacional e da venda de ações daT el emar Participações.

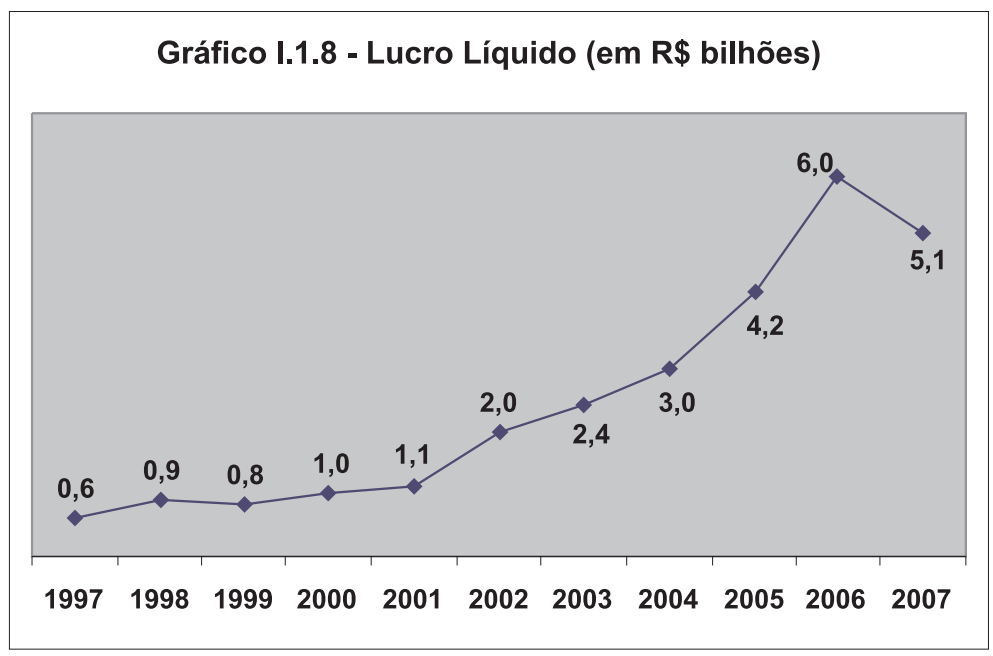

Fonte: Elaboração própria a partir de dados extraídos do site do Banco C entral do Brasil.

A queda do lucro líquido em 2007, em relação a 2006, foi resultado do aumento das despesas de investimento em reorganização das atividades do banco e do menor crescimento da carteira de crédito. Esse menor crescimento foi provocado pela redução do ritmo de crescimento do crédito para o agronegócio eo comércio exterior, além da queda das operações realizadas no exterior devido à valorização do real (Valor E conômico, 27/ 2/ 2008).

D evido ao foco dado pela administração do banco ao crescimento da carteira de crédito, o resultado financei ro oriundo das operações de crédito foi o que mais contribuiu para o desempenho do Banco do B rasil, com destaque para o resultado das operações com pessoas físicas. Entretanto, ressal te-se que o resultado adicionado pelas ope- 
rações direcionadas a pessoas jurídicas vem crescendo em ritmo ainda superior ao das pessoas físicas. 0 resultado originado no crédito ao agronegócio registrou retração em relação a junho de 2007, em razão do menor volume de receitas de equalização.

A companhando o lucro líquido, o R etorno sobre o Patrimônio L íquido M édio mel horou significativamentea partir de2002 (apesar da queda em 2007), atingindo $25,4 \%$ no primeiro semestre de 2008 (G ráfico l.1.9).

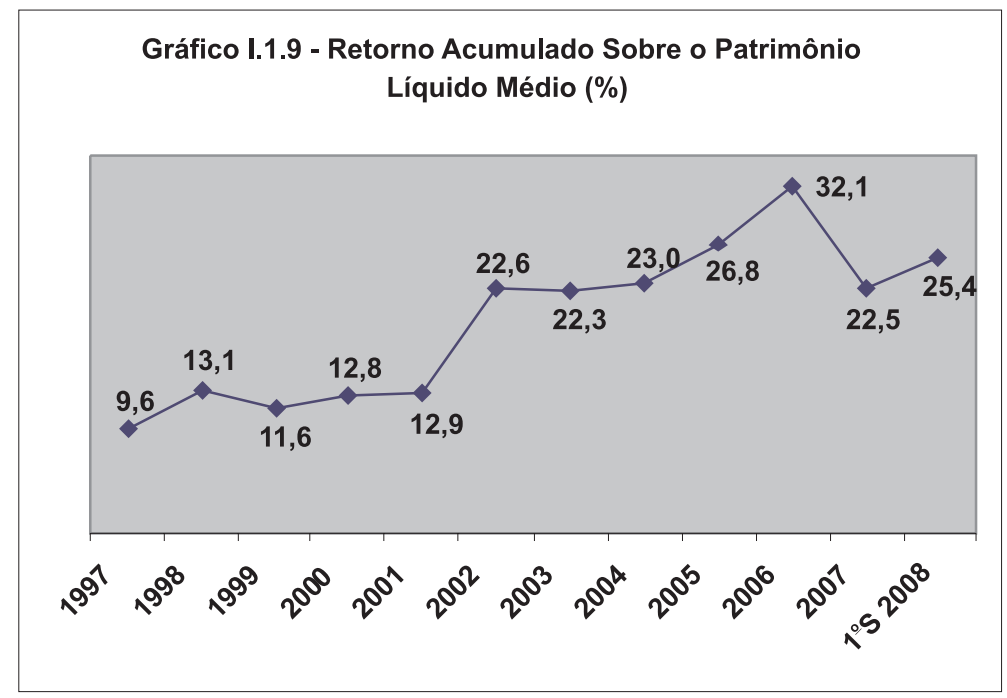

Fonte: Elaboração própria a partir de dados extraídos do site do Banco do Brasil.

\section{Tendências recentes}

R ecentemente, o Banco do Brasil vem adotando medidas de fortal ecimento e ampliação dos produtos ofertados, com o objetivo de se preparar para o crescente acirramento da concorrência no setor bancário, devido, principalmente, ao acesso dos funcionários públicos à conta-salário a partir dejaneiro de2012 - grande partedos clientes do BB recebe salário pelo banco - à compra do A BN - A mro pelo Santander e à recente fusão do I taú com o U nibanco. 
Para enfrentar esse acirramento da concorrência, o Banco do Brasil aposta na expansão dos negócios com o segmento varejo, ofertando novos produtos de crédito e, em especial, dos negócios com clientes não correntistas. C rédito consignado, financiamento a veículos, crédito imobiliário e cartões terão importante papel nessa estratégia de crescimento.

Financiamento de veículos e crédito imobiliário são dois novos segmentos que o BB pretende desenvolver para recuperar a posição de liderança entre as instituições financeiras. 0 banco pretende firmar parcerias com construtoras e concessionárias para ampliar sua atuação nesses segmentos. A carteira de financiamento de veículos fechou o balanço de 2007 com um saldo equival ente a somente $10 \%$ do saldo dos principais concorrentes (Valor E conômico, 4/ 3/ 2008; DCI - SP, 2/ 4/ 2008).

A instituição pretende ampliar sua atuação no segmento de crédito imobiliário, que, além de crescer rapidamente, proporciona maior fidelização de clientes. 0 Banco do Brasil começou a operar com recursos da poupança em junho de 2008 e também está aguardando autorização para operar com financiamento habitacional, com recursos do F G T S (A gora São Paulo, 16/ 8/ 2008).

Para fortalecer a estratégia de negócios com não correntistas, 0 banco se concentrará na formação de novas parcerias varejistas para financiamento do consumo, por meio decartões eempréstimos, epara oferta de produtos de seguridade. Em 2007, foram firmadas 13 novas parcerias eemitidos 1,1 milhão de cartões de parcerias. E ssa estratégia foi adotada tardiamente em relação aos concorrentes Bradesco el taú, quejá tinham conquistado grandes clientes, como C asas Bahia ePão de A çúcar. Por isso, o BB se concentrou, primeiramente, em acordos regionais, conquistando clientes nacionais, como a Saraiva (Valor E conômico, 23/ 8/ 2007).

Com o objetivo defazer frenteao recentemovimento deaquisição de instituições financeiras por seus principais concorrentes, o B anco do Brasil também tem buscado a aquisição de outras instituições. E ssa estratégia foi favorecida pela M edida Provisória no 443, que autorizou o BB e a Caixa E conômica Federal a comprarem outras instituições financeiras. 
Foi iniciado o processo de incorporação do Banco do Estado do Piauí (BEP), já federalizado, do Banco do E stado de Santa C atarina (Besc) edo Banco $\mathrm{N}$ ossa $\mathrm{C}$ aixa. A inda está sendo negociada a incorporação do Banco Regional de Brasília (BRB).

Essas operações são vistas como estratégicas para o Banco do $B$ rasil manter a liderança de mercado. T radicional mente, os bancos privados cresceram por meio de fusões eaquisições, enquanto o BB se expandiu deforma orgânica, pela abertura de agências eaumento da base de clientes (Valor E conômico, 17/ 9/2007).

0 movimento de incorporação debancos estaduais também tem papel estratégico na conquista de folhas de pagamento de órgãos públicos, no aumento da participação do banco no mercado de empréstimos consignados para funcionários públicos estaduais, e na expansão da capilaridade da instituição. A aquisição do Besc e do $B E P$, por exemplo, permitirá o avanço do Banco do Brasil no crédito consignado ea ampliação da sua base de clientes (V alor E conômico, $17 / 3 / 2008$ ).

A incorporação do Besc, quefoi federalizado após receber socorro financeiro do T esouro, também dariaum novo impulso ao segmento de crédito imobiliário, uma vez que a Besc C rédito I mobiliário é a décima maior instituição na captação de caderneta de poupança vinculada à habitação, com uma carteira de crédito imobiliário de $R \$ 73$ milhões. A instituição, entretanto, tem atuado de forma limitada devido às restrições impostas pelo contrato que prevê sua privatização. A aquisição, portanto, disponibilizaria fundos para que o BB expandisse suas operações com maior velocidade (Valor E conômico, 24/ 4/ 2007).

Em maio de 2008, foram iniciadas as negociações com o governo do Estado deSão Paulo paraincorporação do Banco N ossa Caixa pelo Banco do Brasil. $O$ processo de aquisição foi concluído em novembro de 2008, com a aquisição, pelo BB, de $71 \%$ do capital do Banco $\mathrm{N}$ ossa C aixa, sendo que a intenção é que ocorra, ainda em 2009, uma oferta pública para compra das demais ações (Valor E conômico, 21/ 11/ 2008). A fusão possibilitará o fortal ecimento do BB no Estado deSão Paulo, além detrazer 800 mil funcionários públicos da carteira 
da N ossa Caixa eos depósitos judiciais, considerados de baixo custo, que somam R \$14,9 bilhões (Valor E conômico, 23/ 5/ 2008).

A decisão de fusão também foi incentivada pela presença vulnerável do Banco do Brasil no agronegócio paulista, que, por sua vez, começou a atrair o interesse de outros bancos, como o Santander. A N ossa C aixa agregaria uma carteira importante, principalmente de pequenos e médios agricultores (F ol ha de S. Paul0, 23/5/2008).

O BB também pretende investir em aquisições de instituições financeiras privadas. A scarteiras demai or interesse são a definanciamento deveículos ecrédito imobiliário (Valor E conômico, 4/ 3/ 2008).

Em 2009, a instituição anunciou a aquisição de 49\% do capital do Banco Votorantim. 0 principal atrativo do Votorantim éa BV Financeira, especializada em financiamento de veículos, que é um segmento no qual o BB tem grande interesse. 0 utro negócio atrativo do Votorantim para o BB é a carteira de clientes de atacado (Valor E conômico, 7/ 11/2008). A vantagem da participação minoritária para o BB é o ganho de agilidade na tomada de decisões, como, por exemplo, no pagamento de salários mais competitivos. A tualmente, o banco tem limites por ser uma instituição pública (Folha de $S$. Paulo, 9/ 11/2008).

\section{Banco Itaú}

\section{Histórico e estrutura}

O Banco I taú H olding Financeira S.A . éuma sociedadeanônima decapital aberto que, em conjunto com empresas coligadas e controladas, atua no Brasil e no exterior, por meio das carteiras comercial, de investimento, de crédito imobiliário, de crédito, financiamento e investimento e de arrendamento mercantil. 0 banco também atua nas operações de câmbio e em atividades complementares, como as de Seguros, Previdência Privada, C apitalização, Corretagem deT ítulos eValores M obiliários e A dministração de C artões de C rédito, C onsórcios, $\mathrm{F}$ undos de I nvestimentos e $\mathrm{C}$ arteiras $\mathrm{A}$ dministradas. 
A instituição começou a operar no Brasil em 30 de dezembro de 1943, com o nome de Banco C entral de Crédito S.A. Em 1964, a instituição se fundiu com o mineiro Banco I taú S.A ., passando a adotar o nome de Banco Federal I taú.

O grandesal to do I taú ocorreu após 1965, com a reforma da L ei Bancária, quando o banco pôdeconstituir seu banco de investimento e abrir agências nas principais capitais brasileiras.

Para possibilitar seu crescimento, o banco passou a buscar as fusões e aquisições. Comprou o Banco Sul-A mericano do Brasil, em 1966, o Banco A mérica, em 1969, o Banco A liança, em 1970, o Banco Português do Brasil, em 1973, e o Banco U nião Comercial, em 1974, quando se tornou o segundo maior banco privado do país (Folha de S. Paulo, 28/8/2008).

Em 1976, o I taú criou a segmentação de clientes, a partir da atribuição de estrelas aos melhores correntistas, sendo o "cliente cinco estrelas" aquele quenunca tinha o seu cheque devolvido. Em 1980, iniciou-se a internacionalização do Banco I taú, com a inauguração de uma agência em $\mathrm{N}$ ovaY ork, a primeira da instituição no exterior.

E m 1988, o I taú organizou-se como banco múltiplo, centralizando, em carteiras, as operações queantes eram real izadas por empresas distintas no grupo. $N$ a década de 90 tem início um processo de reformulação do sistema deatuação no mercado devarejo. A ampliação da segmentação iniciou-se com a criação do P rivate B ank, para atender pessoas físicas de alta renda.

Com o fim da inflação alta no país, o I taú voltou a fazer aquisições. Em 1995, assumiu o controle acionário do Banco Francês e Brasileiro S.A ., reforçando sua posição no segmento de clientes de alta renda, tesouraria e corporate banking. Surgiu, dessa forma, o I taú P ersonnalité.

Em 1997, no primeiro leilão de privatização de bancos estaduais, o I taú adquiriu o Banco Banerj S.A ., fortalecendo sua atuação no mercado do R io de Janeiro. E $m$ 1998, foi adquirido o controleacionário do Banco do Estado de M inas G erais S.A . (Bemge). E m novo leilão de privatização, em 2000, o Banco I taú adquiriu o controle 
acionário do Banco do Estado do Paraná S.A . (Banestado), passando a deter a maior participação de mercado no Paraná. N o final de2001, o I taú adquiriu o Banco do E stado de G oiás S.A. (BE G ). Em 2002, o Banco I taú iniciou suas operações na Bolsa de N ovaY ork (N Y SE ). $\mathrm{N}$ o final desse mesmo ano, o I taú anunciou a associação com o BBA $C$ reditanstalt, originando o I taú $B B A$, um dos principais bancos de atacado do país.

Em 2003, o Banco I taú S.A . iniciou uma reorganização societária, que culminou na criação do Banco I taú H olding Financeira S.A . A nova instituição passou a controlar as empresas financeiras do conglomerado. A inda em 2003, foi adquirido o controle acionário do Banco F iat, com o objetivo de ampliar a atuação do I taú no mercado de financiamento de bens de consumo.

N o final de 2006, o I taú adquiriu a carteira deU S\$3,7 bilhões de clientes do private banking do BankBoston na $A$ mérica $L$ atina, que pertencia ao Bank of A merica (BA C). 0 banco americano assumiu uma participação de 7,44\% no I taú (Valor E conômico, 18/ 4/ 2007).

E m abril de2007, o grupo I taú adquiriu a carteira do A BN -A mro em M iami e $M$ ontevidéu, passando a ser o terceiro maior private banking da $A$ mérica $L$ atina, atrás apenas dos bancos internacionais U BS e Citigroup (Valor E conômico, 18/4/2007). N esse mesmo ano, foram aprovadas as aquisições das operações do BankBoston no C hile e no U ruguai, além da aquisição integral do BankBoston I nternational, com sedeem M iami, edo BankBoston T rust Company $\mathrm{L}$ imited, com sede em $\mathrm{N}$ assau. O s dois últimos foram adquiridos por meio do Banco I taú E uropa e da sua subsidiária Banco I taú E uropa $L$ uxembourg.

Em abril de 2008, o Banco I taú adquiriu a totalidade das ações da U nión Capital A FA P S.A ., empresa administradora de fundo previdenciário, que detém $20 \%$ dos ativos dos fundos de pensão do U ruguai. A efetivação da operação foi aprovada pelos órgãos reguladores em julho de 2008. Com relação à estrutura acionária da instituição, pouco mais da metade das ações está pulverizada no mercado - F ree-F loat (G ráfico I.2.1). 


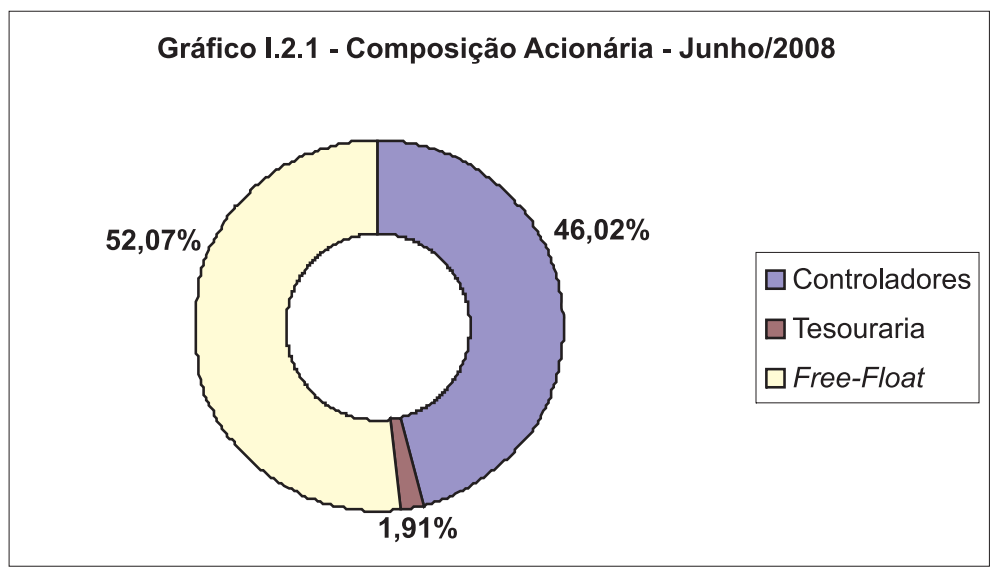

Fonte: Elaboração própria a partir de dados extraídos do site do Banco I taú.

\section{Rede de atendimento}

O I taú está presente em todo o país, por meio de uma rede de 3,6 mil agências e postos de atendimento bancário e mais de 24 mil caixas eletrônicos e pontos de aten dimento el etrônico em empresas. 0 s pontos deatendimento apresentam forte concentração no Sudeste do Brasil, que detém $67,9 \%$ do total da rede (G ráfico I.2.2).

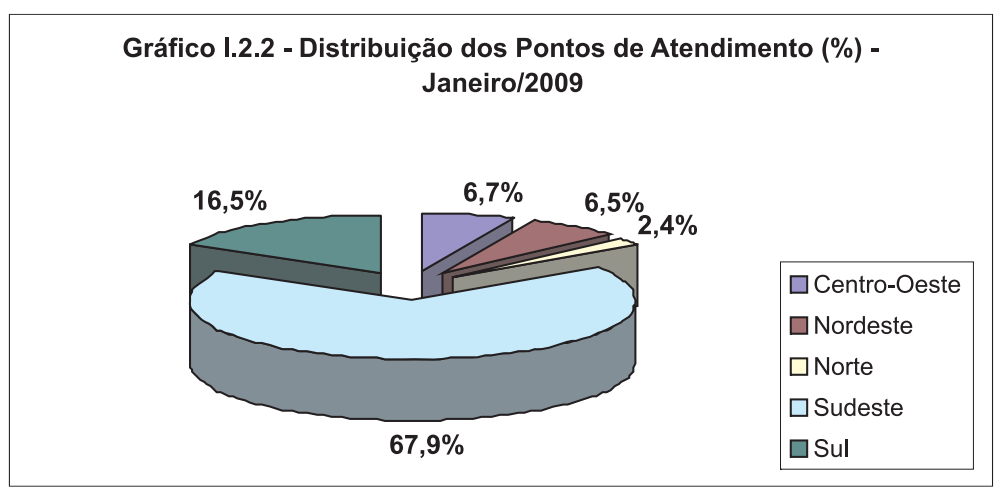

Fonte: Elaboração própria a partir de dados extraídos do site da Febraban. 
A instituição disponibiliza amplo atendimento por meio do internet banking e do telefone celular, pelo qual é possível realizar transferências, pagamentos de títulos, consulta de saldos, consulta de dados de fundos de investimento, consulta desal do de aplicações em ações, dentre outros (Valor E conômico, 15/ 6/ 2007).

O segmento decrédito ao consumo do I taú éatendido por meio da rededelojas T aií - Financeira I taú (T rishop Promoções e Serviços), criada em 2004, queconta com 736 lojas e 344 pontos deatendimento el etrônico. Por meio das três financeiras I taú - FIT, I taú CBD - FIC e A mericanas I taú-FA I - , a redeT aií disponibiliza financiamento e cartões de crédito, principalmente para clientes sem acesso aos serviços financeiros tradicionais.

A rede de lojas próprias da Taií-FIT atua nos Estados de São Paulo, R io de J aneiro, M inas G erais, Paraná, Espírito Santo, Bahia, Pernambuco, G oiás e C eará. A Financeira I taú CBD -FIC oferece produtos e serviços para clientes das unidades de negócios $P$ ão de A çúcar, Extra, Extra-Eletro, Compre Bem e Sendas. A I taú. FA I, por sua vez, atua por meio dos pontos de venda das $L$ ojas A mericanas (L A SA ) eA mericanas Express, bem como dos sites de venda de produtos A mericanas.com eShoptime.

Também fazem parte do Banco I taú H olding Financeira S.A . os bancos I taú C hile, I taú U ruguai, I taú A rgentina, I taú e I taú BBA. O I taú BBA éresponsável pelas atividades de corporate einvestment banking, atendendo, aproximadamente, 2 mil gruposeconômicos entreos maiores do País. São ofertadas desdeoperações típicas debanco comercial atéoperações demercado de capitais eassessoramento em fusões e aquisições. N o exterior, o I taú BBA atua, principalmente, com operações de câmbio, estruturação de operações delongo prazo, em formato bilateral e/ ou em regime de sindicato com outras instituições, e no financiamento ao comércio exterior.

A rededo I taú $\mathrm{H}$ olding no exterior conta com agências em $\mathrm{N}$ ova York el Ihas Cayman, do Banco I taú Buen A yre, com a subsidiária I taubank, do Banco I taú E uropa, e com o Banco I taú E uropa L uxemburgo, além das unidades do I taú BBA . A instituição possui unidades e realiza operações no J apão, C hina, Estados U nidos, I lhas 
Cayman, $\mathrm{N}$ assau, Portugal, I nglaterra, A rgentina, ChileeU ruguai. E $m$ 2007, consolidou-seo processo de fortal ecimento das operações corporate no C hile, por meio do I taú C hile. A aquisição das operações do BankBoston no Chile e no U ruguai, aprovadas em 2007 pelas autoridades reguladoras desses países, aumentou consideravelmente a participação internacional do I taú no varejo.

A I taú $\mathrm{H}$ olding também tem uma atuação significativa no financiamento ao comércio exterior, na colocação de eurobonds ena oferta de operações financeiras mais sofisticadas no exterior, por meio de suas subsidiárias localizadas na A mérica do N orte, Europa e Á sia.

\section{Base de clientes}

O s clientes do I taú são segmentados em não correntistas, pessoas físicas, pessoas físicas dealta renda (I taú P ersonnalité), clientes com el evado patrimônio financeiro (I taú P rivate B ank), microempresas, pequenas empresas, médias empresas, grandes corporações, investidores institucionais e poder público. A I taú H olding alcançou cerca de 24 milhões de clientes em dezembro de 2007, sendo que quase metade deles são não correntistas.

O segmento de clientes não correntistas é atendido dentro da estrutura da I taucred e tem crescido rapidamente nos últimos anos. Esses clientes utilizam, principalmente, os serviços de cartões de crédito, financiamento deveículos ecrédito ao consumo. Somente a financeira Taií possui 6,7 milhões de clientes.

A s aquisições de oper ações de private bank do BankBoston I nternational (BBI), com sedeem $M$ iami, do BankBoston T rust Company L imited (BBT ), com sede em N assau, e do A BN -A mro Bank N .V. (M iami eM ontevidéu) ampliaram a atuação do I taú junto aos clientes do segmento $P$ rivate $B$ ank. A integração com o BankBoston também possibilitou um expressivo crescimento da carteira de clientes Pequenas e M édias E mpresas, durante 0 ano de 2007.

Em setembro de 2007, os clientes com faturamento anual entre $R$ \$ 150 milhões e $R$ \$ 250 milhões foram transferidos do Banco 
I taú para o Banco I taú BBA, que passou a atender as 2 mil maiores empresas clientes da holding, com serviços de banco de atacado, de investimento, além de outros mais identificados com o varejo, como folhas de pagamento para funcionários. Por meio do I taú BBA , essas empresas podem acessar o mercado de capitais, realizar emissão pública inicial deações (IPO ), obter empréstimos mais estruturados ou utilizar derivativos financeiros mais complexos (Valor E conômico, 5/ 12/ 2007).

N o segmento C orporate, o I taú ocupa a liderança em fundos de investimento para clientes pessoa jurídica, com uma participação de $15,5 \%$ do mercado. N o segmento de I nvestidores I nstitucionais, que abrange a administração de recursos de clientes, o I taú manteve-se na liderança como o maior gestor privado de recursos de Entidades de Previdência Complementar Privadas, com uma participação de mercado de 20,2\%, segundo o ranking A nbid de dezembro de 2007. N o segmento Poder Público, o I taú atendia, no final de 2007, 902 órgãos públicos, sendo responsável pela fol ha de pagamento decerca de 1,78 milhão de servidores.

\section{Captações}

O perfil das captações do Banco I taú está intimamente ligado à gestão de liquidez, em que o fluxo de caixa éadministrado de forma que as captações efetuadas dos clientes sustentem suas operações de crédito. Em junho de 2008, o total de recursos captados atingiu R \$ 185 bilhões, sendo que, até março de 2008, as captações eram feitas, principalmente, por meio de depósitos, que representaram $55 \%$ do total de recursos captados. Entretanto, em junho de 2008, essa participação foi de $47 \%$, contra $53 \%$ das Captações de M ercado A berto. Por outro lado, observa-se uma tendência de queda da participação dos depósitos de poupança e de aumento de participação dos $\mathrm{D}$ epósitos a Prazo, principais componentes dos D epósitos (Tabela I.2.1). 
Tabelal .2.1 - Composição das C aptações (em \%)

\begin{tabular}{c|c|c|c|c|c|c|c|c}
\hline D ata & $\begin{array}{c}\mathbf{A} \\
\text { Vista }\end{array}$ & Poupança & Interfin. & $\begin{array}{c}\text { A } \\
\text { Prazo }\end{array}$ & O utros & $\begin{array}{c}\text { D epósitos } \\
\text { Totais }\end{array}$ & $\begin{array}{c}\text { C ap. } \\
\text { M ercado } \\
\text { A berto }\end{array}$ & $\begin{array}{c}\text { Total } \\
\text { (em R \$ } \\
\text { bilhóes) }\end{array}$ \\
\hline dez./ 97 & 14,0 & 52,5 & 1,1 & 9,2 & 0,1 & 76,9 & 23,1 & 24,0 \\
\hline dez./ 98 & 14,2 & 61,5 & 0,6 & 13,0 & 0,1 & 89,4 & 10,6 & 23,8 \\
\hline dez./ 99 & 16,1 & 52,3 & 1,1 & 12,5 & 0,1 & 82,1 & 17,9 & 28,3 \\
\hline dez./ 00 & 16,4 & 41,1 & 0,6 & 13,3 & 0,1 & 71,5 & 28,5 & 39,2 \\
\hline dez./ 01 & 17,3 & 39,5 & 1,2 & 11,4 & 0,0 & 69,4 & 30,6 & 41,0 \\
\hline dez./ 02 & 20,3 & 34,7 & 1,0 & 20,8 & 0,1 & 76,9 & 23,1 & 51,4 \\
\hline dez./ 03 & 17,7 & 32,5 & 2,2 & 16,3 & 0,3 & 69,0 & 31,0 & 54,3 \\
\hline dez./ 04 & 18,8 & 32,7 & 1,1 & 18,9 & 0,3 & 71,8 & 28,2 & 58,8 \\
\hline dez./ 05 & 17,0 & 26,4 & 0,9 & 24,2 & 0,6 & 69,1 & 30,9 & 74,8 \\
\hline dez./ 06 & 17,6 & 22,3 & 2,1 & 16,6 & 2,0 & 60,6 & 39,4 & 102,7 \\
\hline dez./ 07 & 18,2 & 18,6 & 1,1 & 16,0 & 1,0 & 54,9 & 45,1 & 150,5 \\
\hline jun./ 08 & 10,2 & 15,6 & 0,7 & 19,8 & 0,7 & 47,0 & 53,0 & 185,0 \\
\hline Cresc. & 462,4 & 128,8 & 392,8 & $1.563,5$ & $7.366,7$ & 371,3 & $1.661,4$ & 669,9 \\
\hline
\end{tabular}

Fonte: Elaboração própria a partir de dados extraídos do site do Banco Central do Brasil.

0 expressivo crescimento das $C$ aptações de $M$ ercado $A$ berto deve-se à maior demanda por ativos de crédito, que fez com que 0 I taú suprisse sua necessidade marginal de funding com captações no mercado.

\section{Carteira de crédito}

A carteira de crédito do Banco I taú, quealcançou $\mathrm{R} \$ 89,8$ bilhões em junho de 2008 (G ráfico I.2.3), éformada pelas carteiras de Pessoa F ísica - cartão de crédito, crédito pessoal e veículos -, Pessoas Jurídicas - micro, pequenas, médias egrandes empresas -, C réditos $D$ irecionados e pelas carteiras da A rgentina, Chile e U ruguai. A estratégia do I taú para a carteira de empréstimos e financiamentos tem sido privilegiar aqueles capazes de oferecer mel hor relação entre risco e retorno nas operações. 


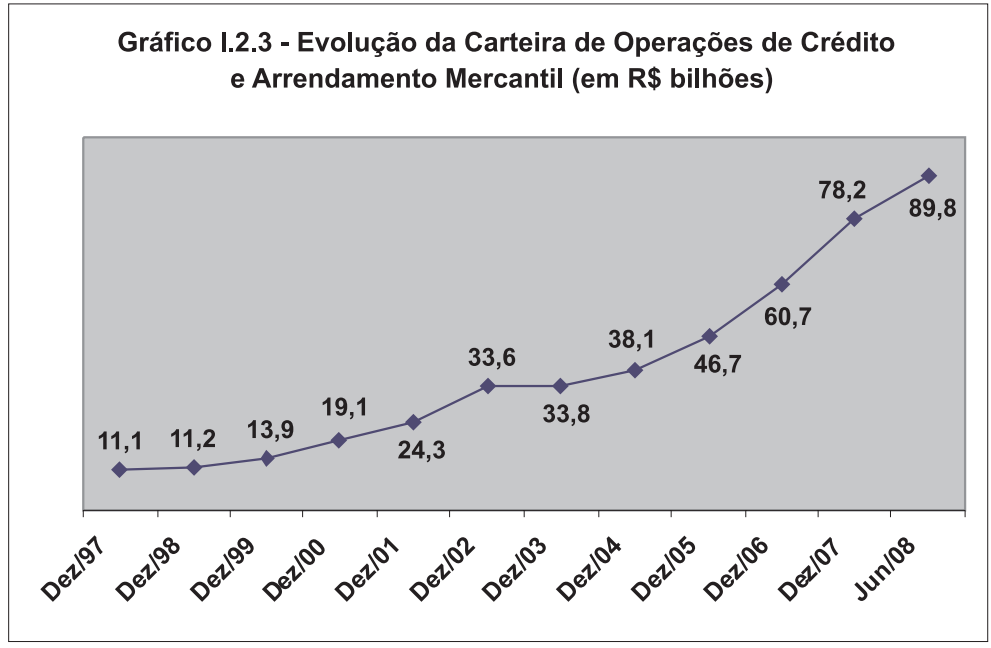

Fonte: Elaboração própria a partir de dados extraídos do site do Banco C entral do Brasil.

N osúltimosanos, os segmentos quemais têm contribuído para o crescimento da carteira de crédito são o definanciamento deveículos e o de crédito às micros, pequenas e médias empresas. A carteira de empréstimos deempresas éa quetem maior participação na carteira total, atingindo $46,8 \%$, em junho de 2008; entretanto, nos últimos anos essa participação vem caindo. A participação da carteira de pessoas físicas, por suavez, tem apresentado tendência de crescimento, passando de $28,7 \%$ em dezembro de 2003 para $42,1 \%$ em junho de 2008 (T abela I.2.2).

A soperações deempréstimo efinanciamento das micro, pequenas emédias empresas também vêm se destacando, com um crescimento de quase $500 \%$, no período de dezembro de 2003 a junho de 2008. Esse crescimento foi superior à média do mercado, destacando-se os produtos decurto prazo. A ampliação da atuação do banco entreesses clientes foi possibilitada pela aquisição do BankBoston, que era um dos líderes nessenicho demercado (V alor E conômico, 8/ 8/ 2007 [2]). $\mathrm{N}$ o momento da aquisição do banco estrangeiro, a participação desses clientes no total de empréstimos do I taú passou de $18,7 \%$ para $22 \%$ (0 Globo, 1/ 11/2006). 
Tabela I.2.2 - C omposição da Carteira de C rédito (\%)

\begin{tabular}{l|c|c|c|c|c|c|c}
\hline & dez./ 03 & dez./ 04 & dez./ 05 & dez./ 06 & dez./ 07 & jun./ 08 & $\begin{array}{c}\text { C resc. } \\
\text { (\%) }\end{array}$ \\
\hline Pessoas Físicas & 28,7 & 34,3 & 41,9 & 43,1 & 42,6 & 42,1 & 387,4 \\
\hline Empréstimos Empresas & 62,3 & 57,3 & 50,3 & 49,7 & 45,1 & 46,8 & 149,6 \\
\hline G randes & 51,1 & 39,0 & 35,0 & 32,4 & 28,0 & 26,7 & 73,8 \\
\hline $\begin{array}{l}\text { M icro, Peq. e } \\
\text { M édias }\end{array}$ & 11,2 & 18,3 & 15,3 & 17,3 & 17,1 & 20,1 & 493,8 \\
\hline Créditos Direcionados & 9 & 8,4 & 6,7 & 6,3 & 5,0 & 4,9 & 79,2 \\
\hline$\quad$ Crédito Rural & 4,4 & 5,0 & 3,9 & 3,7 & 2,9 & 2,7 & 105,7 \\
\hline$\quad$ Crédito Imobiliário & 4,6 & 3,4 & 2,8 & 2,6 & 2,1 & 2,1 & 53,9 \\
\hline $\begin{array}{l}\text { Argentina/ Chile/ } \\
\text { U ruguai }\end{array}$ & - & - & 1,1 & 0,9 & 7,3 & 6,2 & $1.136,0^{1}$ \\
\hline
\end{tabular}

1) Crescimento verificado de dezembro/ 2005 a junho/ 2008.

Fonte: Elaboração própria a partir de dados extraídos do site do Banco I taú.

A expansão da carteira de $G$ randes E mpresas foi provocada pela intensificação do relacionamento com clientes e pela crescente demanda por crédito por parte das empresas de grande porte, mesmo considerando a facilidade de acesso que esses clientes têm a fontes de financiamento al ternativas no mercado de capitais. A aquisição do BankBoston também contribuiu significativamente para o bom desempenho dessesegmento. 0 expressivo aumento da participação dessa cartei ra ocorrido em dezembro de2007, em relação a dezembro de2006, deve-seao início, no primeiro semestre de2007, das operações do banco no C hileenoU ruguai (Valor E conômico, 8/ 8/ 2007 (2)).

A soperações de crédito das unidades do I taú no exterior - A rgentina, Chile e U ruguai - também tiveram uma expansão expressiva, impulsionadas, principalmente, pelas operações com clientes pessoa jurídica. A redução da participação na carteira total verificada no primeiro semestre de2008, em relação a2007, deve-se, principalmente, à desval orização cambial do peso chileno em relação ao real, o que afetou o valor da carteira do I taú naquele país.

$\mathrm{N}$ a carteira decrédito pessoas físicas, o segmento definanciamento de veículos é o que tem apresentando melhor desempenho, com um crescimento de $717 \%$ no período de dezembro de 2003 a junho de 2008, impulsionado, principalmente, pelas operações do Banco F iat 
(Valor E conômico, 5/ 4/ 2007). A lém do Banco Fiat, o I taú adquiriu as carteiras da Fináustria e do Banco Intercap. Em junho de 2008, a carteira de veículos representou $24,4 \%$ da carteira total do I taú, contra 9,9\% em dezembro de 2003 (T abela I .2.3).

T abelal .2.3- Participação da C arteiradeC rédito Pessoa F ísica naC arteiraT otal (em \%)

\begin{tabular}{l|c|c|c|c|c|c|c}
\hline & dez./ 03 & dez./ 04 & dez./ 05 & dez./ 06 & dez./ 07 & jun./ 08 & $\begin{array}{c}\text { C resc. } \\
\text { (\%) }\end{array}$ \\
\hline Cartão de Crédito & 7,1 & 9,7 & 10,7 & 9,8 & 8,5 & 7,5 & 249,3 \\
\hline Crédito Pessoal & 11,7 & 13,0 & 13,3 & 12,1 & 8,6 & 8,1 & 191,7 \\
\hline Crédito Consignado & - & - & 1,8 & 2,0 & 2,3 & 2,1 & $160,2^{1}$ \\
\hline Veículos & 9,9 & 11,6 & 16,1 & 19,2 & 23,2 & 24,4 & 717,4 \\
\hline Total Pessoas Físicas & 28,7 & 34,3 & 41,9 & 43,1 & 42,6 & 42,1 & 387,4 \\
\hline
\end{tabular}

1) Crescimento verificado de dezembro/ 2005 a junho/ 2008.

Fonte: Elaboração própria a partir de dados extraídos do site do Banco I taú.

A soperações decartão de crédito também tiveram um crescimento significativo em 2007 eno primeiro semestre de2008, resultado da crescentepopularização desse instrumento como meio de pagamento efinanciamento. 0 banco encerrou o primei ro semestre de 2008 com 16,2 milhões de cartões e faturamento de $R$ \$22,7 bilhões. A conquista de clientes de menor poder aquisitivo vem impulsionando as emissões de cartões, enquanto a expansão do faturamento tem sido consequência, principalmente, do aumento dos gastos dos clientes de renda mais alta (Valor E conômico, 4/ 7/ 2007 [1]).

O segmento de crédito para consumo, administrado pela Taií, destaca-se pela venda de crédito pessoal, cartões de uso restrito (private label), cartões de crédito I taucard VISA e M asterC ard (cobranded), além de outros produtos de crédito voltados ao consumo. O s produtos são oferecidos por meio de lojas próprias ou por meio de parcerias com grandes varejistas brasileiros. A carteira de crédito da Taií, excluindo o crédito consignado, atingiu a marca de $\mathrm{R} \$ 2$ bilhões em junho de 2008 .

A carteira de crédito consignado do I taú al cançou a marca de R \$ 3,3 bilhões em 2007, uma evolução de 45,8\% em relação a 2006. E $m$ 2007, as operações desse segmento resultaram, principalmente, 
deum acordo entreo I taú eo Banco BM G para a distribuição do produto nos canais devendal taú. 0 BM G élíder em empréstimos consignados, principalmente para aposentados e pensionistas do I N SS, sendo um dos bancos quemais geram créditos de varejo no país (Valor E conômico, 13/ 9/ 2007). G randepartedos empréstimos para não correntistas real izados pelaT aí foi feita por meio do crédito consignado. $\mathrm{N}$ o primeiro semestrede2007, por exemplo, o total deempréstimos para não correntistas foi de $R \$ 3,8$ bilhões, sendo que $R \$ 2,5$ biIhões foram decrédito consignado (Valor E conômico, 8/ 8/ 2007 [2]).

$\mathrm{N}$ o primeiro semestre de 2008 , o saldo dessa carteira atingiu $R \$ 3,2$ bilhões. Enquanto a carteira composta pelas operações com clientes correntistas cresceu $11,9 \%$ em relação ao trimestreanterior, al cançando $\mathrm{R} \$ 959$ mil hões, o sal do das operações decrédito consignado dos clientes não correntistas apresentou redução de 6,2\%, no mesmo período. Essaredução foi resultado, basicamente, do término do acordo estabelecido com o Banco BM G para a aquisição denovas operações de crédito consignado.

A pesar dessecrescimento verificado na carteira de crédito, o índice deinadimplência não sofreu grandes alterações. A pós atingir 5,3\%em 2006, o índice caiu para 4,3\%no primeiro semestrede2008. 0 índice referente aos clientes pessoa física atingiu 6,6\%, enquanto o índice associado aos clientes pessoa jurídica al cançou 1,5\% (G ráfico I.2.4).

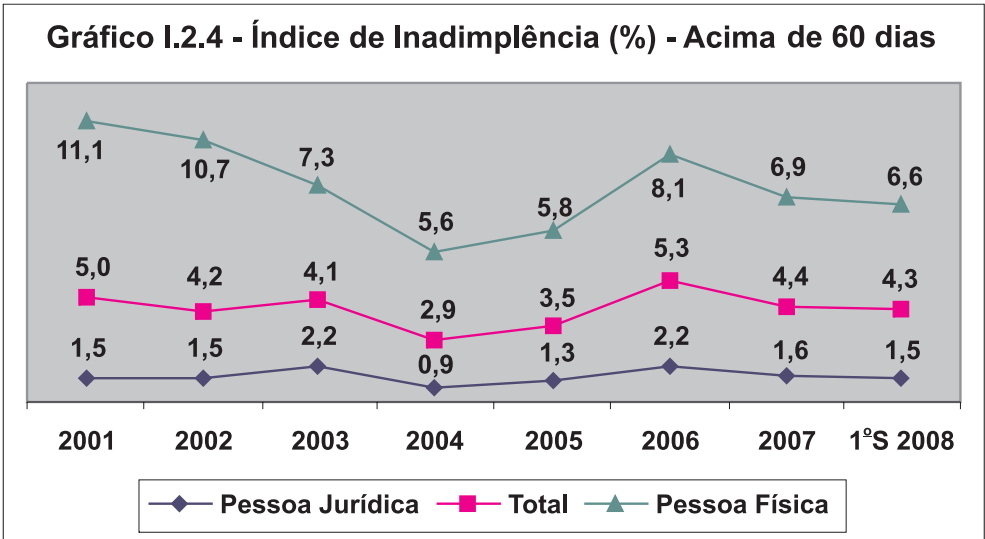

Fonte: Elaboração própria a partir de dados extraídos do site do Banco I taú. 


\section{Gestão de riscos}

O I taú criou uma estrutura específica para o Basileia II, em forma de comitês, com a participação de todas as áreas que, de alguma forma, estejam envolvidas com a adequação dos controles de risco aos padrões exigidos pelo $\mathrm{N}$ ovo A cordo. $\mathrm{O}$ Índice de Basileia atingiu 17,1\% em junho de 2008, contra 18,7\% em dezembro de 2007 (G ráfico I.2.5). E ssa redução ocorreu, principalmente, devido à recompra deações pela tesouraria do banco, durante o período. N os últimos anos, esse índice não tem sofrido al terações significativas, mantendo-se elevado em relação ao mínimo exigido.

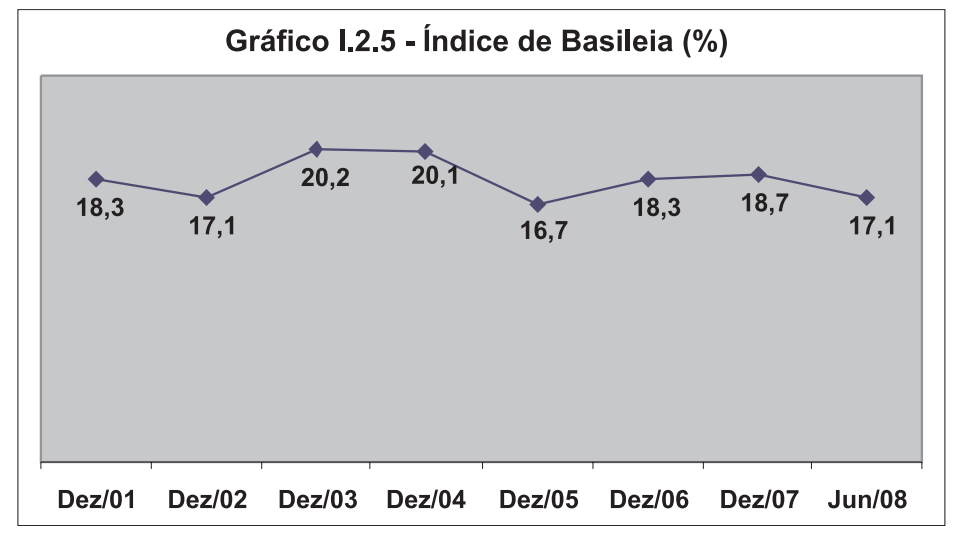

Fonte: Elaboração própria a partir de dados extraídos do site do Banco I taú.

Com relação à qual idade da cartei ra de crédito, a participação dos créditos classificados entre os níveis "A A" e "C" atingiu 91,9\% da carteira. A pós redução, em 2006, essa participação voltou a crescer em 2007 e no primeiro semestre de 2008 (T abela I.2.4). A carteira de maior qualidade é a de grandes empresas, enquanto a de menor qualidade é a de crédito pessoal.

Tabela I .2.4 - Composição da C arteira de Crédito por N ível de R isco (\%)

\begin{tabular}{c|c|c|c|c}
\hline & dez./ 05 & dez./ 06 & dez./ 07 & jun./ 08 \\
\hline A A-C & 90,2 & 87,5 & 91,7 & 91,9 \\
\hline D-H & 9,8 & 12,5 & 8,3 & 8,1 \\
\hline
\end{tabular}

Fonte: Elaboração própria a partir de dados extraídos do site do Banco I taú. 


\section{Índices de cobertura e de eficiência}

N o primeiro semestre de 2008 , as receitas de prestação de serviços totalizaram $R$ \$ 4,5 bilhões, enquanto as despesas de pessoal atingiram $\mathrm{R} \$ 2,4$ bilhões. Esses resultados levaram a um Índice de Cobertura de 190,1\% (Tabela I.2.5).

Tabela I.2.5 - Índice deC obertura (em \%)

\begin{tabular}{l|c|c|c|c|c|c|c|c|c|c|c|c}
\hline & $\mathbf{1 9 9 7}$ & $\mathbf{1 9 9 8}$ & $\mathbf{1 9 9 9}$ & $\mathbf{2 0 0 0}$ & $\mathbf{2 0 0 1}$ & $\mathbf{2 0 0 2}$ & $\mathbf{2 0 0 3}$ & $\mathbf{2 0 0 4}$ & $\mathbf{2 0 0 5}$ & $\mathbf{2 0 0 6}$ & $\mathbf{2 0 0 7}$ & $\begin{array}{c}\mathbf{1 0 S} \\
\mathbf{2 0 0 8}\end{array}$ \\
\hline $\begin{array}{l}\text { Rec. Prest. } \\
\begin{array}{l}\text { Serviços } \\
\text { (em } \\
\text { R \$ milhões) }\end{array}\end{array}$ & 1.775 & 1.695 & 2.495 & 2.586 & 2.984 & 3.666 & 4.464 & 5.286 & 7.006 & 8.217 & 8.985 & 4.473 \\
\hline $\begin{array}{l}\text { D espesas } \\
\text { dePessoal } \\
\text { (em } \\
\text { R \$ milhões) }\end{array}$ & 1.460 & 1.682 & 1.875 & 2.039 & 2.422 & 2.690 & 2.573 & 2.679 & 3.124 & 3.865 & 4.493 & 2.353 \\
\hline $\begin{array}{l}\text { Índice de } \\
\text { Cobertura }\end{array}$ & 121,6 & 100,8 & 133,1 & 126,8 & 123,2 & 136,3 & 173,5 & 197,3 & 224,3 & 212,6 & 200,0 & 190,1 \\
\hline
\end{tabular}

Fonte: Elaboração própria a partir de dados extraídos do site do Banco C entral do Brasil.

A recenteredução do Í ndice de Cobertura foi consequência, principalmente, do menor crescimento da receita de prestação deserviços. Esse menor crescimento foi provocado, basicamente, pelacampanha deredução detarifas parafidelização de clientes, anunciada em agosto de2007, em antecipação à R esolução CM N 3.518/ 07, quedisciplina a cobrança detarifas para pessoas físicas. Foram verificadas reduções das receitas de serviç̧os deconta-correntee das receitas de operações de crédito e garantias prestadas.

A pesar da recente redução, o I ndice de Cobertura apresentou crescimento significativo no período anal isado, passando de $121,6 \%$ em 1997 para 190,1\%no primeiro semestre de 2008. Essecrescimento foi resultado da ampliação de $406,2 \%$ das receitas de prestação de serviços, contra um crescimento desomente $207,7 \%$ das despesas de pessoal verificado no período. 
O s principais componentes das R eceitas deP restação de Serviços são as receitas de A dministração deR ecursos eas receitas de C artões de C rédito. N o primeiro semestre de 2008, esses dois segmentos foram responsáveis por $58,7 \%$ do total das receitas (G ráfico I.2.6).

0 Índice de Eficiência, por sua vez, atingiu $43,6 \%$ no primeiro semestre de 2008, contra 46,2\% em 2007. D esde 2001, quando era de $62,1 \%$, esse índice vem decrescendo (G ráfico I.2.7).

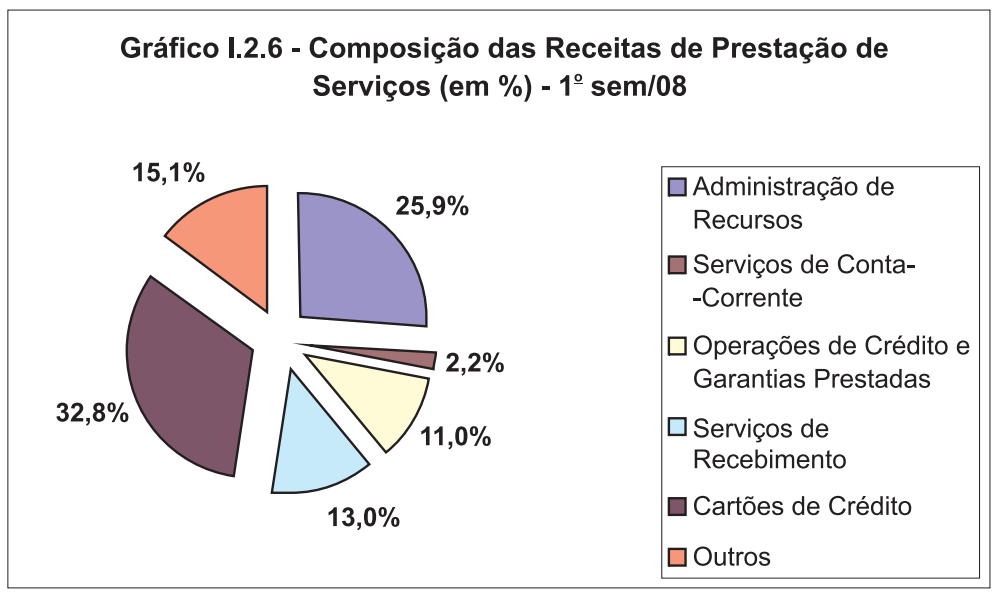

Fonte: Elaboração própria a partir de dados extraídos do site do Banco I taú.

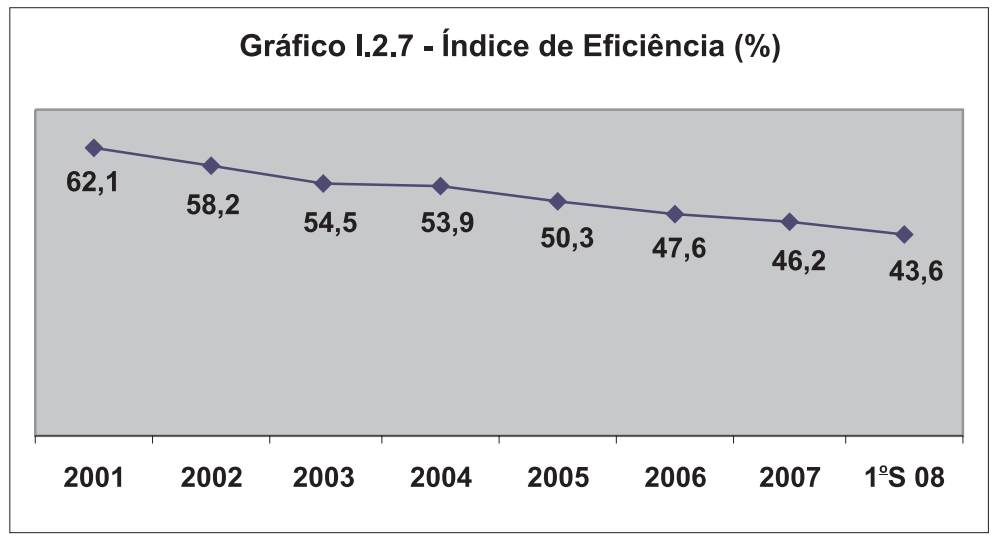

Fonte: Elaboração própria a partir de dados extraídos do site do Banco I taú. 


\section{Composição dos ativos e das receitas de intermediação financeira}

O s principais componentes da carteira de ativos do I taú são as $O$ perações de $C$ rédito e $G$ arantias, que, no primeiro semestre de 2008, alcançaram uma participação de $26,4 \%$ no total de ativos. A carteira deT ítulos eV alores M obiliários, por sua vez, tem apresentado tendência de queda, atingindo uma participação de 12,9\% em junho de 2008 (Tabela I.2.6).

Tabelal .2.6 - Composição dos A tivos (em \%)

\begin{tabular}{|c|c|c|c|c|c|c|}
\hline D ata & $\begin{array}{l}\text { A plicações } \\
\text { Interfin. }\end{array}$ & $\begin{array}{l}\text { T VM } \\
\text { elnstr. } \\
\text { Financ. } \\
\text { D eriv. }\end{array}$ & $\begin{array}{l}\text { Op.de } \\
\text { Crédito e } \\
\text { Arrend. } \\
\text { M erc. }\end{array}$ & $\begin{array}{l}\text { O utros } \\
\text { C réditos }\end{array}$ & O utros 1 & $\begin{array}{l}\text { A tivo T otal } \\
\quad \text { (em } \\
\text { R \$ bilhões) }\end{array}$ \\
\hline dez./ 97 & 25,2 & 12,0 & 25,4 & 12,4 & 25,0 & 43,8 \\
\hline dez./ 98 & 12,6 & 24,3 & 24,3 & 16,2 & 22,6 & 45,9 \\
\hline dez./ 99 & 15,0 & 21,9 & 28,7 & 11,8 & 22,6 & 48,4 \\
\hline dez./ 00 & 13,3 & 24,1 & 29,1 & 13,4 & 20,1 & 65,4 \\
\hline dez./ 01 & 12,8 & 19,0 & 30,9 & 17,0 & 20,3 & 78,6 \\
\hline dez./ 02 & 15,8 & 18,6 & 31,2 & 16,5 & 17,9 & 107,7 \\
\hline dez./ 03 & 18,9 & 17,0 & 30,7 & 16,9 & 16,5 & 110,0 \\
\hline dez./ 04 & 15,5 & 13,4 & 30,9 & 18,8 & 21,4 & 123,4 \\
\hline dez./ 05 & 15,4 & 12,3 & 31,9 & 15,4 & 25,0 & 146,0 \\
\hline dez./ 06 & 14,9 & 13,3 & 29,6 & 16,1 & 26,1 & 205,2 \\
\hline dez./ 07 & 19,1 & 13,0 & 27,1 & 15,2 & 25,6 & 288,8 \\
\hline jun./ 08 & 19,8 & 12,9 & 26,4 & 13,7 & 27,2 & 339,6 \\
\hline Cresc. (\%) & 508,5 & 733,6 & 706,7 & 761,4 & 740,0 & 675,3 \\
\hline
\end{tabular}

1) Inclui D isponibilidades, R elações I nterfinanceiras, R elações deI nterdependências, Provisão para $C$ réditos de L iquidação $D$ uvidosa, $O$ utros $V$ al ores e Bens, I mobilizado de $A$ rrendamento ePermanente.

Fonte: Elaboração própria a partir de dados extraídos do site do Banco Central do Brasil.

O s títulos públicos são os principais componentes da carteira de T ítulos eValores M obiliários, com uma participação de 41,6\% (G ráfico I .2.8), sendo que $61,5 \%$ desses títulos são nacionais. 


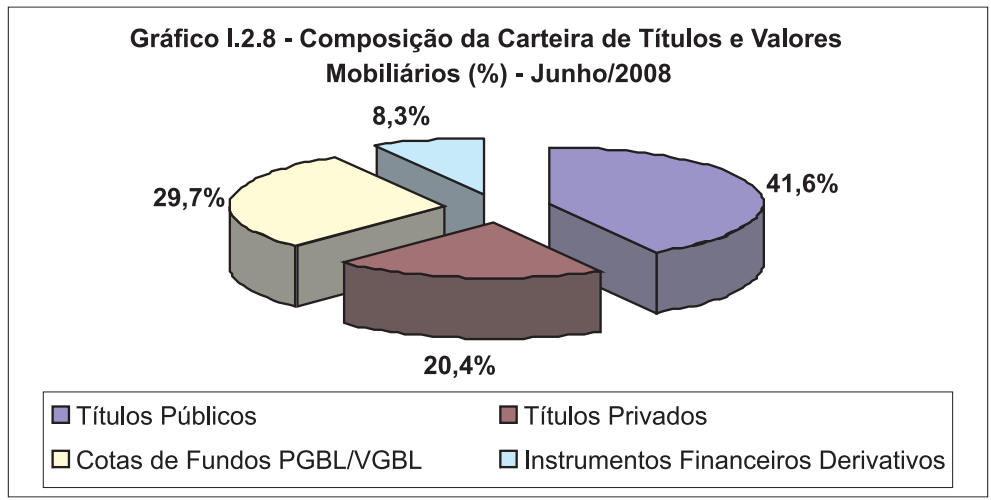

Fonte: Elaboração própria a partir de dados extraídos do site do Banco I taú.

Em junho de 2008, as operações de crédito representaram 73,4\% do total das receitas de intermediação financeira, enquanto o resultado de títulos e valores mobiliários contribuiu com 17\%. A participação das operações de crédito tem crescido, principalmente a partir de 2004, enquanto a participação do resultado deT VM vem apresentando tendência de queda (Tabela I .2.7).

Tabela I.2.7 - Composição das R eceitas de Intermediação Financeira (em \%)

\begin{tabular}{l|c|c|c|c}
\hline \multicolumn{1}{c|}{ D ata } & $\begin{array}{c}\text { O p. C rédito e } \\
\text { A rrend. M erc. }\end{array}$ & $\begin{array}{c}\text { O perações com } \\
\text { T V M }\end{array}$ & O utros $^{\mathbf{1}}$ & $\begin{array}{c}\text { Total } \\
\text { (em R \$ bilhões) }\end{array}$ \\
\hline 1997 & 69,0 & 21,5 & 9,5 & 5,6 \\
\hline 1998 & 49,9 & 44,4 & 5,7 & 8,1 \\
\hline 1999 & 49,2 & 45,8 & 5,0 & 9,6 \\
\hline 2000 & 56,3 & 38,5 & 5,2 & 8,0 \\
\hline 2001 & 61,7 & 36,7 & 1,6 & 11,0 \\
\hline 2002 & 61,8 & 29,3 & 8,9 & 15,1 \\
\hline 2003 & 56,9 & 34,2 & 8,9 & 17,5 \\
\hline 2004 & 61,7 & 24,5 & 13,8 & 18,9 \\
\hline 2005 & 68,0 & 18,7 & 13,3 & 26,3 \\
\hline 2006 & 69,9 & 20,9 & 9,2 & 33,0 \\
\hline 2007 & 71,9 & 21,8 & 6,3 & 42,4 \\
\hline 1052008 & 73,4 & 17,0 & 9,6 & 27,6 \\
\hline Cresc. (\%) & 686,3 & 663,6 & 406,2 & 657,1 \\
\hline
\end{tabular}

1) Inclui $O$ perações com Instrumentos Financeiros D erivativos, 0 perações de $C$ âmbio e A plicações Compulsórias.

Fonte: Elaboração própria a partir de dados extraídos do site do Banco C entral do Brasil. 


\section{Resultados}

N o primei ro semestre de 2008, o lucro líquido consolidado do I taú foi de $\mathrm{R} \$ 4,1$ bilhões. $\mathrm{N}$ o ano de 2007, o lucro líquido foi de $\mathrm{R} \$ 5,1$ bilhões, contra $\mathrm{R} \$ 6,9$ bilhões em 2006 ( $G$ ráfico I .2.9). 0 resultado da instituição tem sido impulsionado, principalmente, pelas operações de crédito.

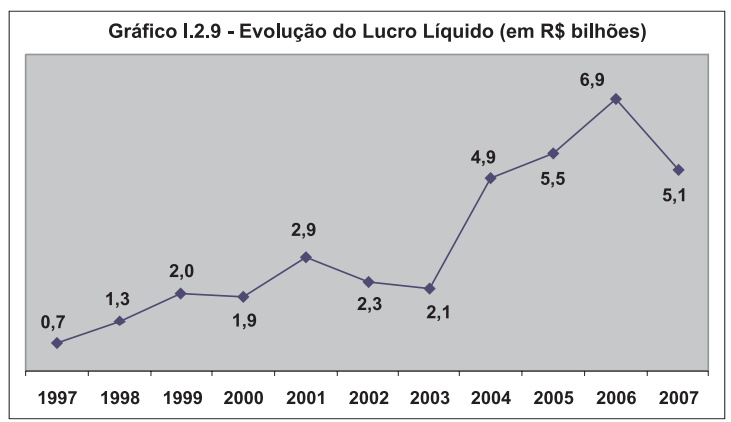

Fonte: Elaboração própria a partir de dados extraídos do site do Banco C entral do Brasil.

0 menor lucro da instituição, apontado em 2007 pelo Banco C entral, foi decorrente da amortização, no período, de todo o ágio de $R$ \$ 4,435 bilhões pago na aquisição do BankBoston (Valor E conômico, 4/ $7 / 2007$ [2]).

0 R etorno A nualizado sobre o Patrimônio L íquido $M$ édio R O E A nualizado atingiu $27,7 \%$ em junho de 2008, índice abaixo das taxas anuais registradas a partir de 2000. Em 2007, esse índice foi de 32,1\%, contra 28,8\% em 2006 (G ráfico I.2.10).

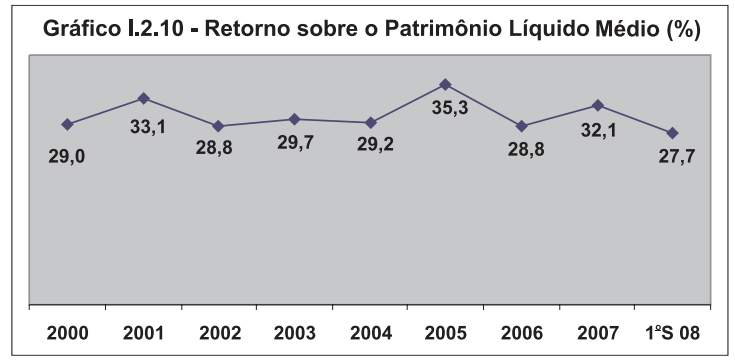

Fonte: Elaboração própria a partir de dados extraídos do site do Banco I taú. 


\section{Tendências recentes}

A té2004, o I taú manteve uma política de crédito conservadora, pautada em rígido controle de riscos, com elevados níveis de aplicações em T ítulos eValores M obiliários. Entretanto, nos últimos anos observa-se uma redução dessas aplicações, devido a um maior redirecionamento dos ativos para operações de crédito. C om isso, o I taú deverá competir no mercado de forma mais agressiva na obtenção de funding para fazer face à expansão de sua carteira de crédito, queé o foco atual da instituição.

O I taú vem apostando, também, no potencial de crescimento do crédito imobiliário, financiamento de veículos, crédito consignado e empréstimos a pequenas e médias empresas (Valor E conômico, 13/2/2008). 0 crédito imobiliário é considerado um segmento importante para o banco, uma vez que estabelece um relacionamento de longo prazo com o cliente, podendo gerar vínculos contratuais de até 25 anos. 0 I taú vem investindo, principalmente, no crédito direcionado para as construtoras eincorporadoras (Valor E conômico, 28/ 6/ 2007; Valor E conômico, 3/ 9/ 2007). Em 2008, por exemplo, o banco celebrou um contrato de abertura de linha de crédito com a A gra E mpreendimentos I mobiliários, para aquisição de terrenos e financiamento da construção de seus empreendimento (DCI - SP, 16/5/2008). O banco tem, ainda, uma parceria com a H M Engenharia para financiamento de empreendimentos ( $D$ estak J ornal, 24/3/2008).

O I taú também tem como estratégia o estabel ecimento de parcerias com imobiliárias, como, por exemplo, o acordo firmado com a $L$ opes C onsultoria de Imóveis, em dezembro de 2007, para agilizar as concessões. 0 acordo tem validade de vinte anos e garante exclusividade ao I taú para promover o financiamento dentro das lojas da corretora (D inheiro - SP, 6/ 4/ 2008). 0 principal objetivo dessa parceria é a ampliação do financiamento de imóveis usados (DCI - SP, 31/3/ 2008).

A instituição também tem investido na melhoria dos processos, expandindo os canais de atuação comercial e buscando ampliar 
sua participação de mercado. Foram lançados, ainda, novos produtos com taxas de juros reduzi das e prazos de financiamento de até 25 anos. A instituição também passou a operar, desde outubro de 2007, com recursos do F undo de G arantia do Tempo de Serviço (F G T S) para repasse de recursos para o financiamento imobiliário. O objetivo é atrair clientes de renda mais baixa (Valor E conômico, 31/ 10/ 2007).

A s operações de financiamento e leasing de veículos também são importantes para o banco, uma vez que se enquadram em sua estratégia deampliação da carteira com manutenção de uma adequada relação entre risco e retorno. Já que as garantias são os próprios veículos financiados, essas operações representam riscos relativamente baixos. 0 mesmo ocorre com o crédito consignado, carteira de baixo risco. 0 I taú busca ampliar sua atuação nesse segmento por meio da aquisição de carteiras de crédito (Valor E conômico, 13/2/ 2008).

N o segmento decrédito ao consumidor, a instituição busca crescer por meio do estabel ecimento de parcerias, como as estabelecidas com $G$ rupo Pão de A çúcar ecom as L ojas A mericanas S.A . Em outubro de2008, o banco firmou um acordo válido por dez anos com as L ojas M arisa para distribuir produtos de sua subsidiária financeira, al taú $\mathrm{H}$ olding Financeira, diretamentea clientes varejistas, em suas lojas. 0 acordo prevê a criação de um novo cartão de crédito, com ambas as marcas, para ser distribuído ecomercializado nas unidades das L ojas M arisa (Valor E conômico, 20/ 10/ 2008).

O segmento decartões também émuito lucrativo para o banco. 0 I taú é uma das instituições líderes nesse segmento epretendeexpandi-lo, principalmente, por meio da ampliação do número de cartões para a população de baixa renda (Folha de S. Paulo, 26/3/ 2008).

0 segmento de pequenas e médias empresas é uma área para a qual al taú H olding tem ambiciosos planos deexpansão. A instituição acredita que esse segmento tem um forte potencial de crescimento para os próximos anos, devido, principalmente, ao aumento do universo de clientes potenciais eà base de clientes incorporada com a aquisição do BankBoston. A expectativa do banco é de que, nos 
próximos anos, grande parte da expansão de crédito para pessoa jurídica venha do segmento de pequenas e médias empresas, uma vez que as grandes empresas têm a opção de recorrer aos instrumentos do mercado de capitais para a captação de seus recursos.

A sações implementadas pela instituição nosúltimos anos buscam capturar negócios além das frontei ras da atividade bancária tradicional, por meio de parcerias, incorporações de carteiras específicas ou aquisições. Podem ser citados, como casos recentes, o BankBoston, o A BN -A mro em M iami, Banco Fiat, R edecard, O rbitall, Credicard, G rupo Pão de A çúcar, L ojas A mericanas S.A ., BM G , L opes I mobiliária, L ojas M arisa, dentre outros.

A s aquisições são consideradas importantes pelo I taú para enfrentar a concorrência acirrada, principal mente após a aquisição do holandês A BN pelo consórcio formado por R BS eSantander. N esse sentido, em 30 de outubro de 2008, o I taú anunciou sua fusão com o U nibanco. A nova empresa, I taú-U nibanco H olding (IU ), será uma das vinte maiores instituições financeiras do mundo, a maior do Brasil e o maior conglomerado financeiro privado do $\mathrm{H}$ emisfério Sul, deacordo com dados do final do terceiro trimestre de 2008 (V al or E conômico, 3/ 11/2008). A pós a operação, a I taú S.A . deterá $66 \%$ da IU Participações, enquanto o restanteserá detido pelos controladores do U nibanco (R euters, 3/ 11/ 2008).

O I taú-U nibanco pretenderecorrer a novas aquisições para crescer no crédito consignado eno exterior. 0 I taú entrou com atraso no crédito consignado. T entou comprar o Banco BM G , mas a transação não foi concluída. 0 U nibanco, por sua vez, tem uma atuação mais significativa nessa área.

Com relação à atuação internacional, a nova instituição pretende ampliar sua atuação por meio de aquisições de bancos no exterior. A penas de $5 \%$ a $6 \%$ dos resultados vêm das operações internacionais, que estão relacionadas, principalmente, a operações de apoio a empresas brasileiras no exterior, com exceção dos negócios na A rgentina, Chile, Paraguai e U ruguai, onde o banco possui redes locais, com operações de varejo. 0 objetivo do novo banco é elevar esse percentual (Valor E conômico, 10/ 12/ 2008). 


\section{Bradesco}

\section{Histórico e estrutura}

O Banco Bradesco S.A . é uma companhia aberta de direito privado que opera como Banco M últiplo, desenvolvendo atividades bancárias por meio desuas carteiras comerciais, de operações de câmbio, de crédito ao consumidor, de crédito imobiliário e de cartões de crédito. Por intermédio de suas controladas, atua em diversas outras atividades, como A rrendamento $\mathrm{M}$ ercantil, Banco del nvestimentos, A dministração de Consórcios, Seguros, Previdênciae C apitalização.

O Bradesco foi fundado em 1943, em M arília, no interior deSão Paulo, com o nome de Banco Brasileiro de D escontos. Em 1951, a instituição tornou-se o maior banco privado do Brasil. N essa mesma década, o Bradesco chegou ao norte rural do Paraná e criou a F undação B radesco, que tinha como objetivo oferecer educação gratuita a crianças, jovens e adultos carentes.

$\mathrm{N}$ a década de 70 , as al tas taxas de crescimento do Brasil favoreceram a expansão do banco, que passou a ter uma atuação significativa no segmento de crédito, principalmente no financiamento de veículos. A instituição incorporou 17 outros bancos, atingindo, em 1978, um total demil agências. N a década de80, o Bradesco formou 0 G rupo Bradesco Seguros, passand o a atuar nos segmentos de seguro, de previdência privada aberta e de capitalização.

Em janeiro de 2007, o Bradesco anunciou a compra do banco BM C , instituição fundada em 1939, com forteatuação no segmento de crédito consignado, com agências em São Paulo, R io de J aneiro, Belo H orizonte, Curitiba, Porto A legre, Fortaleza, R ecife, Salvador, C ampinas, São J osé do R io P reto e J oinville (A gência Estado, 24/ 1/ 2007).

Q uanto à estrutura societária da instituição, a maior acionista é a empresa holding Cidade de D eus - Companhia C omercial de Participações, que detém $24,51 \%$ do capital total, seguida pela F undação Bradesco, com 8,58\%. A maior parte das ações, 59,94\%, está pulverizada no mercado (G ráfico I.3.1). 


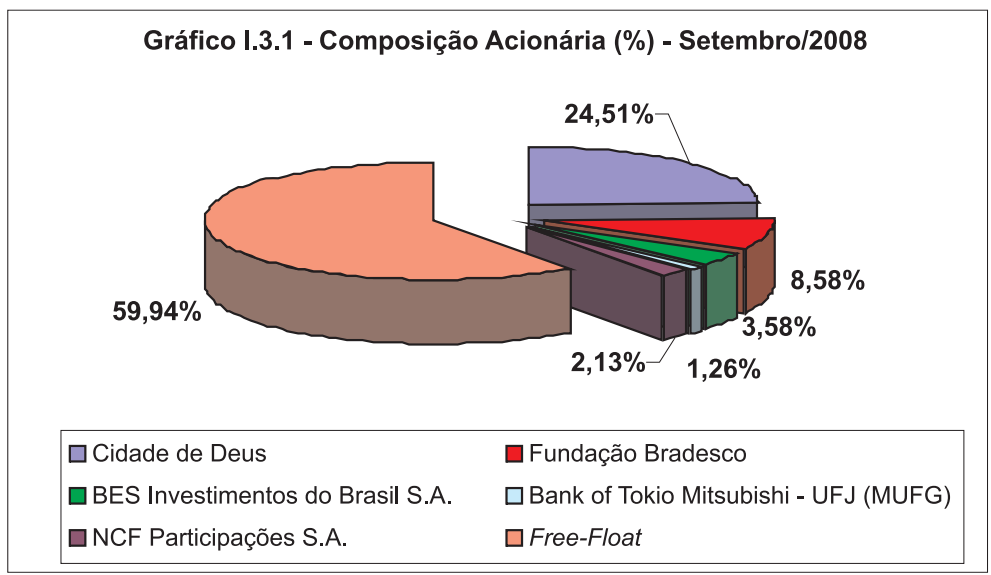

Fonte: Elaboração própria a partir de dados extraídos do site do Bradesco.

\section{Rede de atendimento}

O Bradesco conta com mais de 83 mil trabal hadores e uma ampla rede de atendimento, composta por $3.193 \mathrm{~A}$ gências (3.176 do Bradesco, 16 do Banco Finasa BM C e 1 do Bradesco BBI ), 27,4 mil máquinas da R ede de $A$ utoatendimento Bradesco $D i a \& N$ oite, 4,6 mil máquinas da R ede Banco24H oras, 13,4 mil Pontos Bradesco Expresso (Correspondentes), 5,9 mil A gências do Banco Postal, 3,3 mil Postos e Pontos de A tendimento Bancário em E mpresas, 1,6 mil Correspondentes Bancários do Banco Finasa BM C, para atendimento nos segmentos consignados e veículos, e 268 Filiais da Finasa Promotora deVendas. $0 \mathrm{~s}$ clientes também contam com o compartilhamento da rede com o Banco do Brasil e com o atendimento por meio do tel efone (fixo e celular) e do internet banking.

A maior parte dos pontos de atendimento do Bradesco está localizada no Sudeste, com uma participação de $53,9 \%$, seguido pelo N ordeste, que tem uma participação de $19 \%$ do total de pontos de atendimento (G ráfico I.3.2). N os últimos anos, a distribuição dos pontos de atendimento pelo país não tem se alterado consideravelmente, destacando-se um pequeno aumento da participação da 


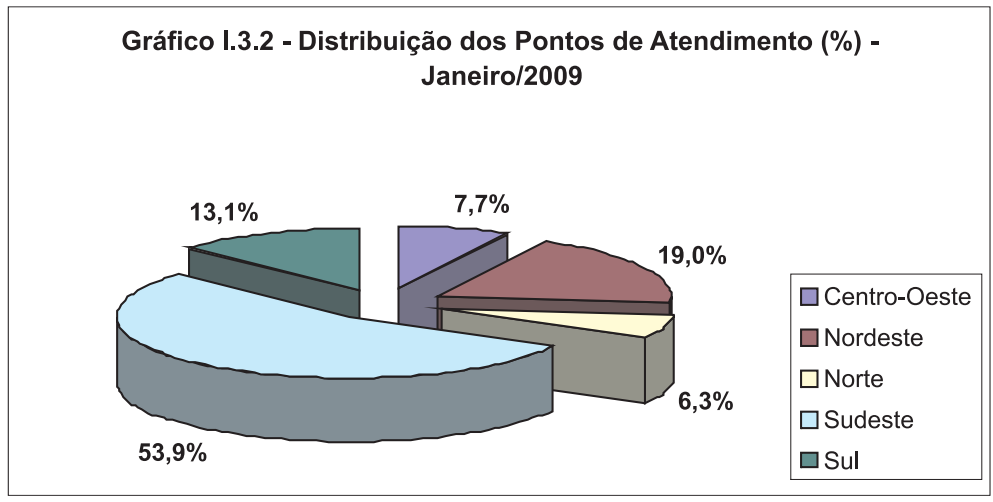

Fonte: Elaboração própria a partir de dados extraídos do site do Bradesco.

região N orte, acompanhado de pequena redução na participação da região Sudeste.

A lém do Banco deVarejo, a O rganização Bradesco possui as empresas dearrendamento mercantil Bradesco L easing S.A. A rrendamento M ercantil, Zogbi L easing S.A . A rrendamento M ercantil e Bankpar A rrendamento M ercantil S.A ., além da carteira de arrendamento mercantil do Banco Finasa S.A .

O Banco Finasa disponibiliza financiamento de crédito direto ao consumidor para aquisição de bens e serviços, além de operações deleasing ecrédito pessoal, sendo que sua carteira dearrendamento mercantil é composta, basicamente, por operações de financiamento de veículos destinadas às pessoas físicas. $A$ instituição atua principalmente por meio de parcerias com grandes montadoras e revendas de veículos, caminhões e implementos, e com importantes redes de lojas de comércio varejista, contando com 33.816 L ojas eR evendas C onveniadas, sendo 21.151 pontos de revenda de veículos.

O Banco Bradesco BBI S.A. é o Banco de Investimento da O rganização Bradesco, responsável pelo desenvolvimento de operações nos segmentos de R enda Variável, R enda Fixa, O perações Estruturadas, F usões e A quisições, Financiamento de Projetos e Tesouraria. 
O Banco Postal atua em todos os municípios brasileiros, buscando a inclusão da população não bancarizada, por meio de serviços como recepção eencaminhamento de propostas de abertura decontas ede propostas de crédito, saques e depósitos em conta-corrente e poupança, recebimento de títulos de cobrança bancária e de contas de consumo, pagamento de benefícios do I N SS e empréstimos on-line para clientes com limite disponível, dentre outros.

O Banco Postal foi criado em 2001, por meio deum acordo, válido até2011, com a E mpresa deC orreios eT el égrafos (E CT ) para oferta de produtos e serviços (Valor E conômico, 19/ 9/2007). A parceria contribui para a ampliação do atendimento das comunidades locais, especialmentenas localidades não assistidas pela R edeB ancária, além de se constituir em um ponto de apoio aos clientes do Bradesco que transacionam em todo o Brasil.

N o segmento de correspondente, a instituição atua por meio da R ede Bradesco Expresso, firmando parcerias com supermercados, farmácias, magazines, lojas de departamentos e outras redes varejistas. Para o Bradesco, essa éa melhor forma de chegar aos clientes de baixa renda, em especial à população não bancarizada. O s principais serviços prestados são de recebimento de contas de consumo, tributos e boletos de cobrança, recarga de celular pré-pago esaques em conta-corrente, poupança eI N SS.

$A$ rede do Bradesco no exterior éformada por 12 unidades, sendo uma agência em $\mathrm{N}$ ovaYork, três em $\mathrm{G}$ rand $\mathrm{C}$ ayman (sendo uma do BM C) e uma em N assau, além de 7 subsidiárias: Banco Bradesco A rgentina S.A ., em Buenos A ires; Banco Bradesco L uxembourg S.A ., em L uxemburgo; Bradesco Securities, I nc., em N ovaYork; Bradesco Securities U K L imited, em L ondres; Bradesco Services C o., L td., em T óquio; Cidade C apital $M$ arkets $L$ td., em $G$ rand C ayman; eBradescoT radeService $L$ td., em $H$ ong K ong. A principal atividade dessas unidades no exterior é de apoio ao financiamento do comércio exterior brasileiro, bem como de captação de recursos na comunidade financeira internacional e nas empresas brasileiras com unidades no exterior. 
Em setembro de 2008, o Bradesco assinou um acordo para fazer parte da R ede Connector, uma aliança internacional composta por 13 instituições financeiras de mais de 30 países da Europa, Estados U nidos, $O$ ceania e, com a entrada do Bradesco, da A mérica $L$ atina. Pelo acordo, as companhias brasileiras clientes do Bradesco terão acesso a uma rede de mais de 20 mil agências dos bancos que fazem parte da associação, especializada na prestação de serviços de cash management. O s serviços incluem o gerenciamento de todo o fluxo financeiro das empresas, como pagamentos, arrecadação detributos, importação, exportação, maior facilidade na abertura de contas em outros países ena gestão detesouraria internacional. 0 utra vantagem éa indicação de clientes corporativos em cada país para os bancos que fazem parteda rede. 0 Bradesco também deverá atender os clientes que fazem parte da associação (Valor E conômico, 17/ 9/2008).

A cordo semel hantefoi firmado com o BBVA, em agosto de 2008. A estratégia do Bradesco ao firmar esse tipo de acordo teve como objetivo principal responder à ameaça de concorrência representada pela unificação do Santander com o A BN - A mro, instituições que têm forte atuação no gerenciamento de caixa para clientes (Valor E conômico, 14/ 8/ 2008).

A área de cash management vem ganhando importância para o Bradesco, nos últimos anos, e a associação vem em um momento importante em quevárias empresas brasileiras estão em processo de internacionalização (Valor E conômico, 17/ 9/ 2008).

\section{Base de clientes}

Em junho de 2008, a base de clientes do Bradesco alcançou 37 milhões (incluindo seguros e capital ização), sendo 20 milhões de correntistas. D os correntistas, 95\% são clientes Pessoa F ísica e 5\% são clientes Pessoa J urídica. 0 processo de segmentação de clientes do Bradesco alinha-se à tendência de mercado, que consiste em reunir grupos de clientes de um mesmo perfil, permitindo, assim, atendimento diferenciado e crescentes ganhos de produtividade. 
Em sua estratégia desegmentação, o Bradesco classifica os clientes nos segmentos Varejo, Prime, Private, Empresas e C orporate. O Bradesco Varejo atende pessoas físicas, sendo considerado um segmento estratégico e prioritário pelo banco. E m dezembro de 2007, eram atendidos mais de 18 milhões declientes correntistas. 0 B radesco Prime atua no segmento de pessoas físicas de alta renda, atendendo 389 mil clientes, por meio deuma rede deatendimento de 228 agências. $O$ Bradesco Private Banking atendepessoas físicas de elevado patrimônio. Em dezembro de 2007, essa divisão gerenciava $\mathrm{R} \$ 33,7$ bilhões, de um total de 5.109 clientes.

O Bradesco E mpresas - M iddle $M$ arket atendegrupos econômicos com faturamento anual entreR $\$ 30$ milhões eR \$ 350 milhões, por meio de 68 A gências exclusivas, presentes nas principais capitais brasileiras, sendo que 57 estão local izadas nas regiões Sul eSudeste. Esse segmento atende 24.771 empresas em diversos setores da economia.

O Bradesco Corporate atende grandes grupos econômicos, com faturamento anual superior a R \$350 milhões. Em março de 2008, eram atendidos 1.204 grandes grupos econômicos, distribuídos nos Estados de São Paulo, R io de J aneiro, M inas G erais, Paraná, R io $\mathrm{G}$ rande do Sul, Santa C atarina, G oiás, Pernambuco e Bahia.

O Bradesco também atende o Poder Público, incluindo Entes e Ó rgãos dos Poderes Executivo, L egislativo e Judiciário, nos âmbitos federal, estadual e municipal, além das A utarquias, F undações Públicas, E mpresas Públicas e de E conomia $\mathrm{M}$ ista, Forças $\mathrm{A}$ rmadas (Exército, $M$ arinha e A eronáutica) e Forças A uxiliares (Polícias Federal, M ilitar e Civil), N otários e R egistradores.

\section{Captações}

A captação de recursos do Bradesco éfeita, principalmente, por meio de depósitos, que representaram $54,9 \%$ do total captado, em junho de 2008. D entre os recursos captados por meio de depósitos, os depósitos a prazo são os que têm maior participação no total de recursos captados pelo banco (Tabela I.3.1). 
Tabelal I.3.1 - Composição das C aptações (em \%)

\begin{tabular}{|c|c|c|c|c|c|c|c|c|}
\hline D ata & $\begin{array}{c}\text { À } \\
\text { Vista }\end{array}$ & Poupança & Interfin. & $\begin{array}{c}\text { A } \\
\text { Prazo }\end{array}$ & O utros & $\begin{array}{c}\text { D epósitos } \\
\text { Totais }\end{array}$ & \begin{tabular}{|c|} 
Cap. \\
M ercado \\
A berto \\
\end{tabular} & $\begin{array}{c}\text { Total (em } \\
\text { R \$ } \\
\text { bilhões) }\end{array}$ \\
\hline dez./ 97 & 18,3 & 51,8 & 0,3 & 9,4 & 0,0 & 79,8 & 20,2 & 26,6 \\
\hline dez./ 98 & 12,9 & 41,8 & 0,4 & 20,9 & 0,0 & 76,0 & 24,0 & 38,7 \\
\hline dez./ 99 & 15,0 & 38,0 & 1,0 & 28,8 & 0,0 & 82,8 & 17,2 & 45,4 \\
\hline dez./ 00 & 15,4 & 36,6 & 1,2 & 22,0 & 0,0 & 75,2 & 24,8 & 48,8 \\
\hline dez./ 01 & 14,6 & 33,1 & 0,1 & 26,8 & 0,0 & 74,6 & 25,4 & 55,4 \\
\hline dez./ 02 & 19,2 & 29,7 & 0,0 & 32,3 & 0,0 & 81,2 & 18,8 & 69,8 \\
\hline dez./ 03 & 14,2 & 24,4 & 0,0 & 25,4 & 0,0 & 64,0 & 36,0 & 91,1 \\
\hline dez./ 04 & 16,7 & 27,1 & 0,1 & 31,1 & 0,0 & 75,0 & 25,0 & 91,6 \\
\hline dez./ 05 & 15,9 & 26,1 & 0,1 & 32,7 & 0,3 & 75,1 & 24,9 & 100,5 \\
\hline dez./ 06 & 15,6 & 20,9 & 0,2 & 26,5 & 0,4 & 63,6 & 36,4 & 132,1 \\
\hline dez./ 07 & 16,3 & 18,7 & 0,2 & 21,6 & 0,5 & 57,3 & 42,7 & 175,9 \\
\hline jun./ 08 & 11,5 & 15,2 & 0,2 & 27,6 & 0,4 & 54,9 & 45,1 & 225,5 \\
\hline Cresc. & 434,0 & 148,0 & 552,6 & $2.385,4$ & - & 483,7 & $1.794,6$ & 747,7 \\
\hline
\end{tabular}

Fonte: Elaboração própria a partir de dados extraídos do site do Banco Central do Brasil.

N os últimos anos, observa-se, entretanto, uma tendência de queda da participação dos depósitos, acompanhado do aumento da participação das captações no mercado aberto, queatingiu 45,1\% em junho de2008. A principal causa desseresultado tem sido a quedada participação dos depósitos de poupança, que representavam 15,2\% do total captado em junho de 2008, contra 51,8\% em dezembro de 1997.

\section{Carteira de crédito}

N os últimos anos, a carteira de crédito do Bradesco vem crescendo consideravelmente, atingindo $R \$ 125,5$ bilhões em junho de 2008, um crescimento de 651,5\% em relação a dezembro de 1997 (G ráfico I.3.3). 


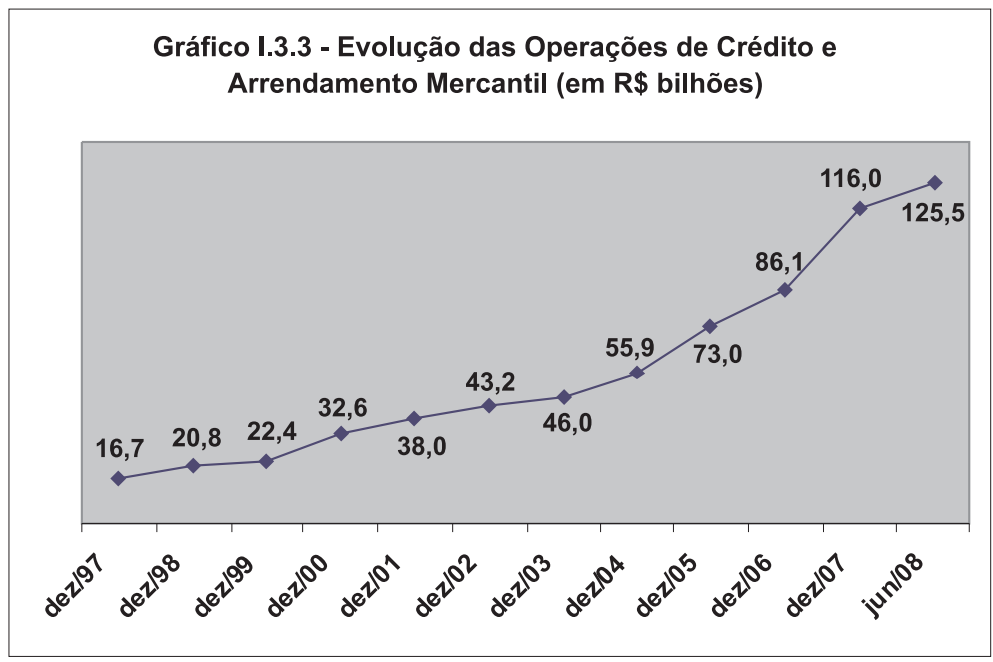

Fonte: Elaboração própria a partir de dados extraídos do site do Banco C entral do Brasil.

Em junho de 2008, 59,6\% da carteira foram direcionados para 0 segmento Pessoas Jurídicas, sendo queas $G$ randes E mpresastiveram uma participação de $28 \%$, enquanto o segmento deM icro, Pequenas eM édias E mpresas representou 31,6\% do total da carteira. 0 crédito para pessoas físicas respondeu por 40,4\% da carteira da instituição (Tabela I.3.2).

T abela I.3.2 - Composição da Carteira de C rédito por T ipo de C liente (\%)

\begin{tabular}{|c|c|c|c|c|c|c|}
\hline & dez./ 03 & dez./ 04 & dez./ 05 & dez./ 06 & dez./ 07 & mar./ 08 \\
\hline Grandes Empresas & 45,3 & 36,5 & 30,3 & 28,8 & 27,3 & 27,7 \\
\hline $\begin{array}{l}\text { M icro, Pequenas e } \\
\text { M édias Empresas }\end{array}$ & 25,9 & 29,7 & 28,8 & 30,0 & 32,0 & 31,3 \\
\hline Pessoas Físicas & 28,8 & 33,8 & 40,9 & 41,2 & 40,7 & 41,0 \\
\hline T otal (em R \$ bilhões) & 54,3 & 62,8 & 81,1 & 96,2 & 131,3 & 139,0 \\
\hline
\end{tabular}

Fonte: Elaboração própria a partir de dados extraídos do site do Bradesco.

N os últimos anos, verifica-se um crescimento da participação da carteira de $\mathrm{M}$ icro, Pequenas e M édias $\mathrm{E}$ mpresas e, principalmente, da carteira de pessoas físicas. A participação da carteira de G randes 
E mpresas, por sua vez, vem apresentando tendência de queda. $\mathrm{N} \mathrm{a}$ carteira Pessoa J urídica destacam-se os produtos R epasse BN DES, Financiamento à Exportação, C apital deG iro eL easing. $O$ produto "C apital de G iro" éo quetem maior participação da carteira Pessoa Jurídica, representando 16,5\% em junho de 2008.

A evolução das operações decrédito destinadas às pessoas físicas foi o fator fundamental para o crescimento recente da carteira de crédito. A carteira de financiamento de veículos é a que tem maior participação na cartei ra deP essoa F ísica do B radesco, representando 47,9\% em junho de 2008, sendo queessa participação vem crescendo nos últimos anos (Tabela I.3.3).

Tabela I.3.3 - Composição da C arteira de C rédito Pessoa F ísica (\%)

\begin{tabular}{l|c|c|c|c}
\hline & dez./ 05 & dez./ 06 & dez./ 07 & mar./ 08 \\
\hline CDC - Veículos/ L easing & 41,2 & 41,1 & 45,8 & 46,6 \\
\hline Crédito Pessoal & 25,5 & 25,7 & 24,6 & 24,0 \\
\hline Cartões de C rédito & 9,0 & 14,2 & 15,5 & 14,4 \\
\hline Financiamento de Bens & 8,1 & 8,0 & 10,2 & 3,2 \\
\hline O utros & 16,2 & 11,0 & 3,9 & 11,8 \\
\hline Total (em R \$ bilhões) & 33,2 & 39,6 & 53,5 & 57,0 \\
\hline
\end{tabular}

Fonte: Elaboração própria a partir de dados extraídos do site do Bradesco.

$\mathrm{N}$ a modalidade C rédito Pessoal, destaca-se o C rédito C onsignado, que representou $11,1 \%$ da carteira de Pessoas F ísicas em junho de 2008. A s modalidades de financiamento de veículos e de crédito consignado têm grande importância para o banco, uma vez que, por suas garantias e características, proporcionam à carteira um nível mais adequado de risco de crédito. 0 financiamento de veículos é oferecido, principalmente, por meio da Finasa e do Banco Ford, adquirido em 2002.

N o segmento de cartões de crédito, o Bradesco vem ampliando a sua participação de mercado. A aquisição da bandeira A merican Express, em maio de 2006, contribuiu significativamente para essa expansão, principalmente com relação aos clientes de maior nível derenda. Em junho de 2008, a base de C artões de C rédito do banco 
alcançou 32,3 milhões, um crescimento de 45,5\% nos últimos doze meses. 0 faturamento, por sua vez, atingiu R \$ 21 bilhões, o que representou um crescimento de $25,4 \%$ em doze meses.

A s operações com cartões $P$ rivate $L$ abel, sobretudo, na linha de crédito rotativo, também contribuíram para a expansão da carteira decrédito. A instituição atua por meio deacordos operacionais com redes de lojas varejistas dos segmentos de eletrodomésticos, supermercados, lojas de departamento, vestuário, farmácia e cosméticos. D estacam-seos acordos com as C asas B ahia, C omper, Carone, D ois I rmãos, G. Barbosa, C oop, L eaderC ard, L ojas Esplanada (G rupo D eib $O$ toch), L uigi Bertolli, Panvel, D rogasil, L ojas H ering e $O$ Boticário. Por meio desses acordos, o Bradesco busca val orizar efidelizar clientes, facilitando o acesso aos produtos eserviços bancários.

O B radesco começou a atuar com os cartões $P$ rivate $L$ abel em 2005 e, desde então, a base desse tipo de cartão é a que mais tem crescido. Em 2006, 2007 ejunho de 2008, o crescimento em relação aosúltimos dozemeses foi de $206,3 \%$, 98\% e85,3\%, respectivamente. Só com a rede de supermercados nordestina G . Barbosa, o B radesco tem 2 milhões de cartões em operação. A tualmente, o grupo ocupa o quarto lugar no ranking nacional desupermercados (V alor E conômico, 19/4/2007).

$\mathrm{N}$ a carteira $\mathrm{O}$ utros, destaca- se a carteira de $\mathrm{C}$ rédito I mobiliário, que representou, em junho de 2008, 3,4\% da carteira de Pessoas Físicas do banco. 0 bom desempenho dessa carteira éresultado, principalmente, do aumento da demanda (Valor E conômico, 22/ 3/ 2007), do aumento do prazo de amortização para 25 anos e da criação de um site voltado à prestação de serviços para auxiliar os interessados na aquisição da casa própria.

A instituição vem ampliando, principal mente, o crédito imobiliário destinado às construtoras e incorporadoras, sendo que essa estratégia resultou em um aumento de $100 \%$ no saldo do crédito para empresas, contra 30\% observado no segmento de pessoas físicas (Valor E conômico, 28/ 6/ 2007; Valor E conômico, 3/ 9/2007).

0 índice de inadimplência aumentou em 2006, devido ao crescimento verificado na inadimplência das carteiras Pessoas F ísicas e 
M icro, Pequenase M édiasE mpresas. D e2006 ajunho de2008, entretanto, esseíndicesemantevepraticamenteconstante, com uma melhora na inadimplência apenas da carteira de $M$ icro, Pequenas e M édias Empresas (Tabela I.3.4). O Bradesco, como vimos, busca reduzir a inadimplência por meio da estratégia de privilegiar operações com menor risco decrédito, como consignados efinanciamento deveículos.

Tabela I.3.4 - Índice del nadimplência - A cima de 90 dias (\%)

\begin{tabular}{l|c|c|c|c}
\hline & mar./ 08 & dez./ 07 & dez./ 06 & dez./ 05 \\
\hline Pessoas Físicas & 6,4 & 6,4 & 6,6 & 4,4 \\
\hline M icro, Pequenas e M édias Empresas & 2,5 & 2,6 & 3,6 & 2,6 \\
\hline G randes Empresas & 0,3 & 0,4 & 0,1 & 0,5 \\
\hline Total & 3,5 & 3,5 & 3,8 & 2,7 \\
\hline
\end{tabular}

Fonte: Elaboração própria a partir de dados extraídos do site do Bradesco.

\section{Gestão de riscos}

O Bradesco aborda o gerenciamento de todos os riscos inerentes às suas atividades - de $C$ rédito, $M$ ercado, $L$ iquidez e 0 peracional - de modo integrado, permitindo que sejam efetivamente identificados, avaliados, monitorados, controlados e mitigados de modo centralizado.

D esde 2003, o Bradesco vem se preparando para atender às exigências de Basileia II, sendo que, em 2004, com a publicação do documento definitivo sobreo $\mathrm{N}$ ovo $\mathrm{A}$ cordo de Capital - I nternational $\mathrm{C}$ onvergence of $\mathrm{C}$ apital $\mathrm{M}$ easurement and $\mathrm{C}$ apital $\mathrm{S}$ tandards -, a instituição estabeleceu um plano de implementação interno. D entre as atividades estabelecidas para adequação, podem ser destacadas a revisão e atualização dos modelos de concessão e de recuperação de crédito, 0 armazenamento de dados históricos sobre default, recuperações e perdas operacionais, a revisão dos processos de gestão de limites e garantias, a avaliação dos dados e modelos de riscos de mercado e deliquidez ea certificação, pelaauditoriainterna, detodos os processos e model os relacionados a Basileia II . 
0 Índice deBasileia do Bradesco no consolidado financeiro atingiu 14,35\% em junho de2008, superior, portanto, ao mínimo de $11 \%$ estabelecido pelo Conselho M onetário $\mathrm{N}$ acional. Entretanto, em dezembro de2007 ejunho de2008 esseíndice ficou abaixo da média alcançada pelo Bradesco no período de 2002 a 2006 (G ráfico I.3.4).

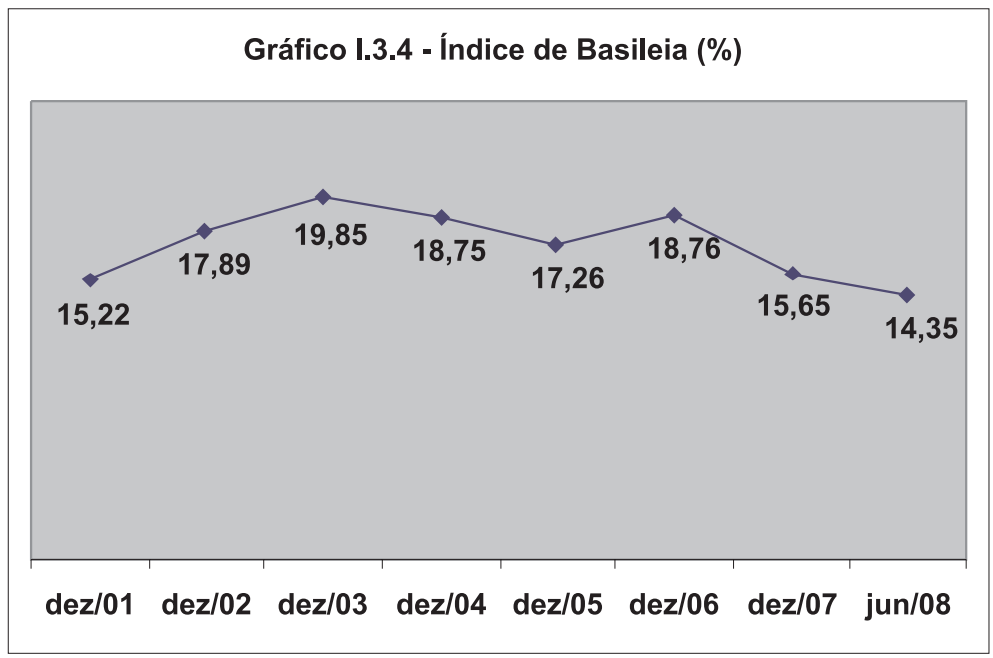

Fonte: Elaboração própria a partir de dados extraídos do site do Banco C entral do Brasil.

Essa redução foi provocada pela ampliação das operações de crédito, o que aumentou a al avancagem (Valor E conômico, 11/ 8/ 2008). $\mathrm{N}$ os últimos anos, tem se verificado uma tendência de aumento da participação das operações de crédito classificadas nos níveis " $A$ A", "A", "B" e "C", que passou de $90 \%$ em 2000 para 93,4\% em junho de2008 (Tabela I.3.5).

Tabela I .3.5 - C omposição da C arteira de C rédito (\%)

\begin{tabular}{l|c|c|c|c|c|c|c|c|c}
\hline & $\mathbf{2 0 0 0}$ & $\mathbf{2 0 0 1}$ & $\mathbf{2 0 0 2}$ & $\mathbf{2 0 0 3}$ & $\mathbf{2 0 0 4}$ & $\mathbf{2 0 0 5}$ & $\mathbf{2 0 0 6}$ & $\mathbf{2 0 0 7}$ & jun./ 08 \\
\hline A A-C & 90,0 & 90,6 & 90,9 & 91,2 & 92,3 & 93,2 & 92,1 & 93,3 & 93,4 \\
\hline D-H & 10,0 & 10,4 & 9,1 & 8,8 & 7,7 & 6,8 & 7,9 & 6,7 & 6,6 \\
\hline
\end{tabular}

Fonte: Elaboração própria a partir de dados extraídos do site do Bradesco. 
A carteira de melhor qualidade do Bradesco éa de $G$ randes $E$ mpresas, em que $98,8 \%$ das operações estão classificadas entreos níveis de risco "A A " e "C", contra 94\% da carteira de M icro, Pequenas e $M$ édias E mpresas e 89,4\% da carteira de Pessoas F ísicas. Em todas as carteiras, entretanto, tem severificado uma mel hora da qualidade do crédito.

\section{Índices de cobertura e de eficiência}

N o primeiro semestre de2008, as R eceitas de Prestação de serviços atingiram $R \$ 3,6$ bilhões, enquanto que as $D$ espesas de Pessoal al cançaram $\mathrm{R} \$ 2,9$ bilhões. Como resultado, o I ndice de C obertura das $D$ espesas de Pessoal pela R eceita de Prestação de Serviços, foi de $124,5 \%$ (Tabelal.3.6).

Tabela I.3.6 - Í ndice de C obertura (em R \$ milhões)

\begin{tabular}{l|c|c|c|c|c|c|c|c|c|c|c|c}
\hline & $\mathbf{1 9 9 7}$ & $\mathbf{1 9 9 8}$ & $\mathbf{1 9 9 9}$ & $\mathbf{2 0 0 0}$ & $\mathbf{2 0 0 1}$ & $\mathbf{2 0 0 2}$ & $\mathbf{2 0 0 3}$ & $\mathbf{2 0 0 4}$ & $\mathbf{2 0 0 5}$ & $\mathbf{2 0 0 6}$ & $\mathbf{2 0 0 7}$ & $\begin{array}{c}\mathbf{1 0 S} \\
\mathbf{2 0 0 8}\end{array}$ \\
\hline $\begin{array}{l}\text { Rec. } \\
\text { Prest. } \\
\text { Serviços }\end{array}$ & 1.317 & 1.679 & 1.974 & 2.536 & 2.946 & 3.036 & 3.490 & 4.367 & 5.359 & 6.041 & 7.024 & 3.591 \\
\hline $\begin{array}{l}\text { Despesas } \\
\text { dePessoal }\end{array}$ & 1.711 & 2.281 & 2.386 & 2836 & 2.971 & 3.458 & 4.098 & 4.293 & 4.635 & 5.289 & 5.757 & 2.884 \\
\hline $\begin{array}{l}\text { Indice de } \\
\text { Cobertura } \\
\text { (\%) }\end{array}$ & 77,0 & 73,6 & 82,7 & 89,4 & 99,2 & 87,8 & 85,2 & 101,7 & 115,6 & 114,2 & 122,0 & 124,5 \\
\hline
\end{tabular}

Fonte: Elaboração própria a partir de dados extraídos do site do Banco C entral do Brasil.

0 crescimento verificado no Í ndice de C obertura deve-se à ampliação de 433,3\% das R eceitas de Prestação de Serviços, no período de 1997 a 2007, contra uma ampliação de somente $236,5 \%$ nas D espesas de Pessoal, nesse mesmo período. Os principais itens que contribuíram para o crescimento das R eceitas de Prestação de Serviços foram as rendas de cartão e as tarifas de conta-corrente, que representaram, respectivamente, $24,9 \%$ e $20,7 \%$ das receitas em junho de 2008 (G ráfico I.3.5). 


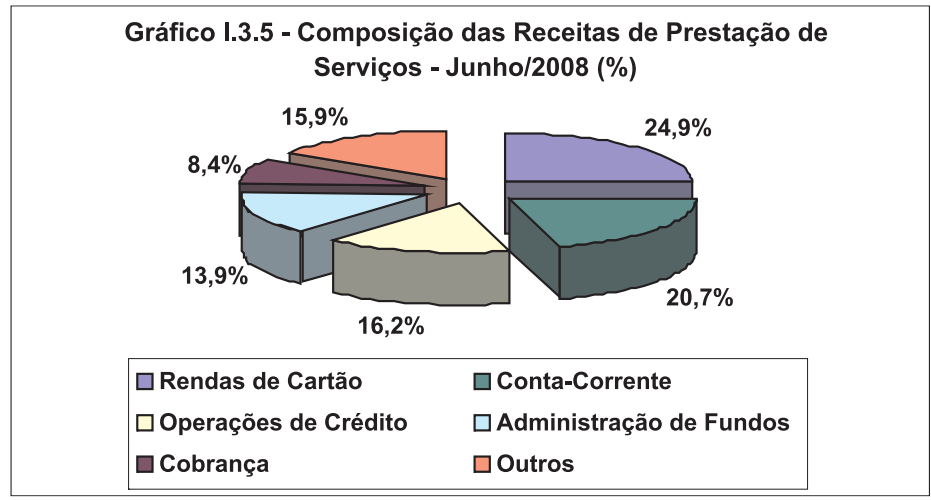

Fonte: Elaboração própria a partir de dados extraídos do site do Bradesco.

0 menor crescimento das R eceitas de Prestação de Serviços, verificado em 2008, deve-se, principalmente, ao realinhamento de tarifas relativas à conta-corrente cobradas das pessoas físicas e da menor receita de operações de crédito em decorrência da redução na cobrança deT axa de A bertura de C rédito (TAC).

$O$ Índice de E ficiência $O$ peracional tem apresentando tendência dequedanosúltimos anos. 0 índicefoi de 41,3\% em junho de2008, contra 60,5\% em 2000 (G ráfico I .3.6). E sseresultad o foi consequência, principalmente, da combinação do controle das despesas com o esforço para o aumento das receitas.

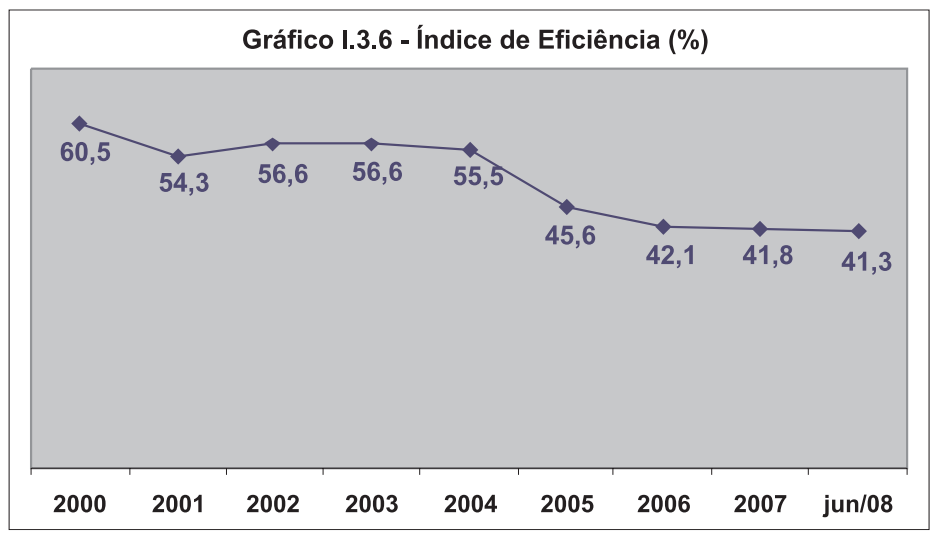

Fonte: Elaboração própria a partir de dados extraídos do site do Bradesco. 


\section{Composição dos ativos e das receitas de intermediação financeira}

O s ativos do Bradesco al cançaram um total de $R$ \$348,4 bilhões em junho de 2008, conforme critérios adotados pelo Banco Central, queconsideram o bal anço operacional dos bancos, incluindo somente as operações financeiras, não contabilizando operações como as de seguros, previdência e capitalização, segmentos em quea atuação do Bradesco é significativa (Valor E conômico, 3/ 7/ 2007). 0 principal componente da carteira de ativos do Bradesco éa carteira de 0 perações de Crédito e A rrendamento $M$ ercantil, com uma participação de 36\% em junho de 2008 (Tabelal .3.7).

T abelal .3.7 - C omposição dos A tivos (em \%)

\begin{tabular}{l|c|c|c|c|c|c}
\hline D ata & $\begin{array}{c}\text { A plicações } \\
\text { Interfin. }\end{array}$ & $\begin{array}{c}\text { T V M } \\
\text { e Instr. } \\
\text { Financ. } \\
\text { D eriv. }\end{array}$ & $\begin{array}{c}\text { O p. de } \\
\text { C rédito e } \\
\text { A rrend. } \\
\text { M erc. }\end{array}$ & $\begin{array}{c}\text { O utros } \\
\text { C réditos }\end{array}$ & O utros & $\begin{array}{c}\text { A tivoT otal } \\
\text { (em } \\
\text { R \$ bilhões) }\end{array}$ \\
\hline dez./ 97 & 10,7 & 15,2 & 39,2 & 9,8 & 25,1 & 42,7 \\
\hline dez./ 98 & 9,1 & 21,9 & 34,0 & 12,3 & 22,7 & 61,1 \\
\hline dez./ 99 & 3,6 & 28,5 & 31,5 & 15,0 & 21,4 & 71,2 \\
\hline dez./ 00 & 2,8 & 26,2 & 39,1 & 17,0 & 14,9 & 83,4 \\
\hline dez./ 01 & 4,1 & 26,0 & 39,9 & 15,0 & 15,0 & 95,1 \\
\hline dez./ 02 & 15,6 & 13,8 & 36,3 & 15,3 & 19,0 & 119,0 \\
\hline dez./ 03 & 21,5 & 16,6 & 31,3 & 14,7 & 15,9 & 147,2 \\
\hline dez./ 04 & 15,1 & 16,8 & 37,7 & 12,9 & 17,5 & 148,2 \\
\hline dez./ 05 & 15,1 & 9,9 & 44,1 & 11,7 & 19,2 & 165,8 \\
\hline dez./ 06 & 12,2 & 16,3 & 40,3 & 11,8 & 19,4 & 213,3 \\
\hline dez./ 07 & 13,2 & 14,6 & 40,8 & 11,7 & 19,7 & 284,4 \\
\hline jun./ 08 & 21,2 & 12,2 & 36,0 & 10,4 & 20,2 & 348,4 \\
\hline Cresc. (\%) & $1.512,6$ & 552,6 & 649,2 & 764,2 & 558,3 & 715,9 \\
\hline
\end{tabular}

1) Inclui D isponibilidades, R elações I nterfinanceiras, R elações del nterdependências, Provisão para C réditos de L iquidação D uvidosa, $\mathrm{O}$ utros Valores e Bens, I mobilizado de A rrendamento ePermanente.

Fonte: Elaboração própria a partir de dados extraídos do site do Banco C entral do Brasil.

A s 0 perações de T ítulos eV alores M obiliários representaram $12,2 \%$ do total deativos contra $26 \%$ em dezembro de 2001 . A partir de 2002, essa carteira começou a perder participação, devido, principal- 
mente, à ampliação da carteira deA plicações I nterfinanceirase, a partir de 2005, à ampliação da cartei ra de 0 perações de C rédito e A rrendamento $\mathrm{M}$ ercantil. A carteira deT ítulos eValores M obiliários é composta, principalmente, por títulos públicos, querepresentaram $53,6 \%$ em junho de 2008, contra 64,5\% em dezembro de 2004; portanto, verifica-seuma ten dência de queda nessa participação (Tabelal .3.8).

Tabela I.3.8 - Composição da Carteira deT VM (\%)

\begin{tabular}{l|c|c|c|c|c}
\hline & dez./ 04 & dez./ 05 & dez// 06 & dez $/$ 07 & jun./ 08 \\
\hline Títulos Públicos & 64,5 & 48,6 & 58,2 & 55,9 & 53,6 \\
\hline T ítulos Privados & 16,0 & 23,8 & 16,8 & 16,8 & 19,1 \\
\hline Cotas deF undos de "PG L B" e“VG BL" & 19,5 & 27,6 & 25,0 & 27,3 & 27,3 \\
\hline
\end{tabular}

Fonte: Elaboração própria a partir de dados extraídos do site do Bradesco.

A s R eceitas de I ntermediação Financeira al cançaram R \$ 24,1 bilhões no primeiro semestre de 2008, sendo que, no ano de 2007, esse montantefoi deR $\$ 38$ bilhões. Com exceção dos anos de 2000, 2003 e2004, essas receitas têm apresentado crescimento, desde 1997 (Tabela I.3.9).

T abela I .3.9 - C omposição das R eceitas de I ntermediação Financeira (em \%)

\begin{tabular}{|c|c|c|c|c|}
\hline D ata & $\begin{array}{l}\text { Op. C rédito e } \\
\text { A rrend. M erc. }\end{array}$ & $\begin{array}{c}\text { O perações com } \\
\text { TVM } \\
\end{array}$ & 0 utros $^{1}$ & $\begin{array}{c}\text { T otal (em } \\
\mathbf{R} \$ \text { bilhões) }\end{array}$ \\
\hline 1997 & 69,7 & 21,6 & 8,7 & 6,7 \\
\hline 1998 & 68,1 & 24,4 & 7,5 & 11.3 \\
\hline 1999 & 67,4 & 23,6 & 9,0 & 17,1 \\
\hline 2000 & 66,3 & 28,0 & 5,7 & 13,7 \\
\hline 2001 & 64,4 & 24,9 & 10,7 & 18,8 \\
\hline 2002 & 60,1 & 28,9 & 11,0 & 27,2 \\
\hline 2003 & 58,1 & 30,9 & 11,0 & 24,8 \\
\hline 2004 & 61,0 & 24,8 & 14,2 & 23,3 \\
\hline 2005 & 62,1 & 22,2 & 15,7 & 29,8 \\
\hline 2006 & 67,7 & 18,8 & 13,5 & 33,2 \\
\hline 2007 & 69,0 & 17,4 & 13,6 & 38,0 \\
\hline 1ㅇ 2008 & 69,2 & 16,2 & 14,6 & 24,1 \\
\hline Cresc. (\%) & 460,1 & 356,4 & 788,0 & 467,2 \\
\hline
\end{tabular}

1) Inclui O perações com Instrumentos Financeiros D erivativos, 0 perações de $C$ âmbio e A plicações Compulsórias.

Fonte: Elaboração própria a partir de dados extraídos do site do Banco C entral do Brasil. 
N o primeiro semestre de 2008, a participação das receitas com $O$ perações de $C$ rédito e A rrendamento $M$ ercantil foi de $69,2 \%$ do total das receitas, contra uma participação de $16,2 \%$ das receitas de O perações com T ítulos eV alores M obiliários. A pesar de ser o item com maior participação nas receitas totais, desde 1998, a participação das receitas de $O$ perações de $C$ rédito e $A$ rrendamento $M$ ercantil decresceu até2003, quando atingiu 58,1\%. A partir de2004, entretanto, sua participação tem aumentado.

\section{Resultados}

N o primeiro semestre de 2008, o L ucro L íquido do Bradesco atingiu $\mathrm{R} \$ 4,1$ bilhões, sendo que, em 2007, a instituição atingiu um L ucro L íquido de R \$ 8,1 bilhões, o maior da sua história. O L ucro $\mathrm{L}$ íquido tem apresentado tendência de crescimento nos últimos anos, passando de R \$ 800 milhões em 1997 para R \$ 8,1 bilhões em 2007 (G ráfico I.3.7).

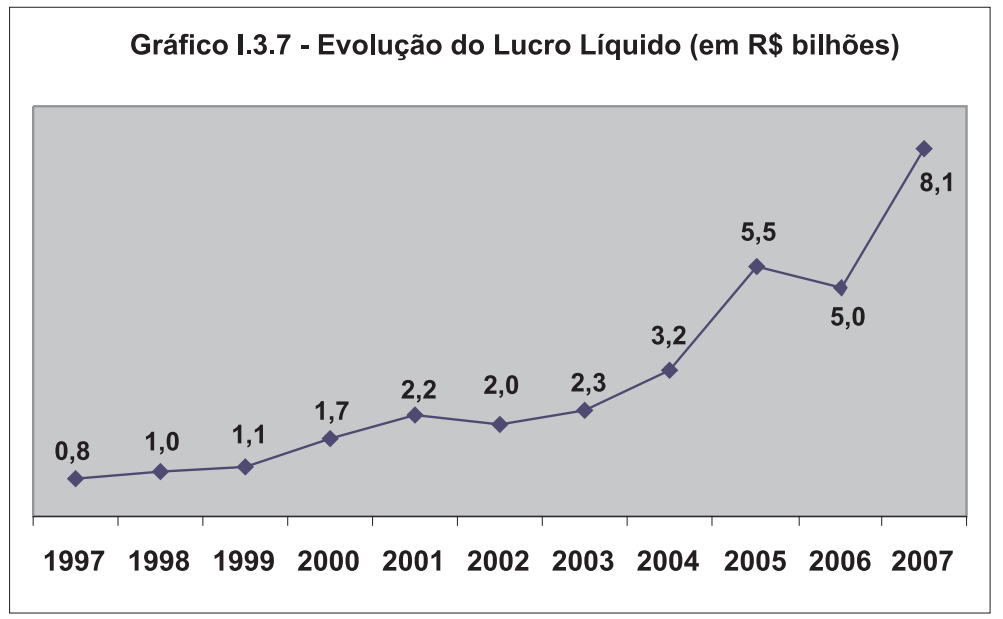

Fonte: Elaboração própria a partir de dados extraídos do site do Banco C entral do Brasil. 
O sitens que mais têm contribuído para o resultado do B radesco são o Segmento Segurador (operações de seguros, previdência e capital ização), seguido pelas $R$ eceitas de Prestação de Serviços epelas O perações de C rédito. N o primeiro semestre de $2008,69 \%$ do lucro total foram originados das atividades financeiras, enquanto $31 \%$ resultaram das atividades de seguros, previdência e capital ização (A gência E stado, 6/ 8/ 2008).

O s produtos que mais contribuíram para a significativa participação das 0 perações de $C$ rédito no resultado do banco foram as operações de crédito consignado, de financiamento de veículos e as operações com cartões $P$ rivate $L$ abel .

$O$ retorno sobreo Patrimônio L íquido $M$ édio $A$ nualizado atingiu $28,6 \%$ em junho de 2008 , maior do que os retornos al cançados em 2003, 2004 e 2007, porém, menor do que os resultados verificados em 2005 e 2006 (G ráfico I.3.8).

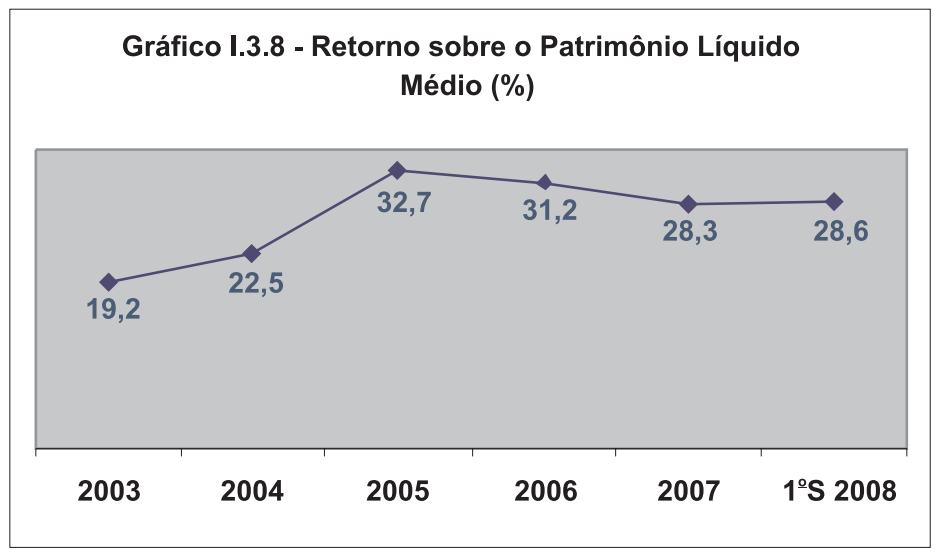

Fonte: Elaboração própria a partir de dados extraídos do site do Bradesco.

\section{Tendências recentes}

A expectativa do Bradesco é que ocorra um crescimento da demanda por seus produtos e serviços, principalmente por operações de crédito. N este contexto, a instituição buscará manter o foco no 
mercado doméstico, principalmenteno crédito imobiliário, financiamento de veículos, crédito consignado e crédito ao consumo.

Para atingir essas metas, o banco buscará expandir, continuamente, a base de clientes, em especial no Varejo, cujo potencial de crescimento é expressivo entre a população não bancarizada, principalmentepor meio do Banco Postal e de outros Correspondentes.

N o segmento decrédito imobiliário, a instituição tem se concentrado, principalmente, no crédito para construtoras eincorporadoras, financiando, inclusive, osterrenos (Valor E conômico, 3/ 9/ 2007). Em 2007 , cerca de $77 \%$ das concessões foram dirigidas às construtoras (Valor E conômico, 5/ 12/ 2007 [2]). E m 2008, por exemplo, o Bradesco concedeu uma linha de crédito para produção à R ossi R esidencial, no valor deR \$ 1 bilhão (G azeta M ercantil, 24/3/ 2008). O Bradesco também vem investindo em consórcios imobiliários, queconstituem a linha que resulta em maior receita para o banco em relação a outros consórcios (Valor E conômico, 22/ 3/ 2007).

O banco também aposta no financiamento de imóveis usados, que, em 2008, representava $26 \%$ da cartei ra total de crédito imobiliário. Para ganhar espaço nesse segmento, o Bradesco vem buscando se associar às imobiliárias, para queo cliente não precise ir à agência (Valor E conômico, 18/ 4/ 2007 [2]). N o primeiro trimestre de 2008, a instituição possuía 130 contratos fechados com imobiliárias e 450 com construtoras (DCI - SP, 31/3/2008).

A expectativa quanto ao segmento definanciamento de veículos é de crescimento expressivo. Entretanto, devido ao aumento da inadimplência verificada no primeiro semestre de 2008, a F inasa reduziu o prazo deamortização para 60 meses, operando com 72 meses apenas em casos excepcionais de modelos novos. O s juros também aumentaram ea financeira ficou mais rigorosa no momento deavaliar a ficha cadastral de novos clientes (D iário de S. Paulo, 28/8/2008).

Com relação ao crédito consignado, o Bradesco pretende ampliar suas operações. Com a compra do BM C , aprovada em agosto de 2007 pelo Banco C entral, a instituição pretende chegar à liderança do segmento de crédito consignado no país. D esde que o BM C foi adquirido, em janeiro de2007, o volume de empréstimos aumentou 
de R \$ 115 milhões para R \$ 250 milhões por mês. ${ }^{8} 0$ objetivo da instituição éultrapassar o líder BM G , que, em junho de2007, apresentava uma carteira de $\mathrm{R} \$ 3,5$ bilhões (Valor E conômico, 7/ 8/ 2007; Valor E conômico, 19/ 9/2007).

N o crédito ao consumo, o Bradesco buscará aumentar os empréstimos para a classe $C$, sem aumentar a inadimplência. Por meio da Finasa, os bons pagadores da classe $C$ recebem ofertas de cartões de crédito com bandeira, crédito pessoal parcelado e financiamento de veículos (Valor E conômico, 19/ 4/ 2007; Valor E conômico, 30/ 10/ 2007).

O Bradesco considera que a experiência do varejo na concessão de crédito em períodos nos quais os bancos estavam fora do mercado (antes da década de 90, por exemplo) éextremamenteimportante. A instituição concedemais crédito por meio das parcerias daF inasa com as redes varejistas, como Casas Bahia eG . Barbosa, do quepor meio das contas-correntes no Banco Postal (Valor E conômico, 19/ 4/ 2007).

O Bradesco já se prepara para enfrentar o aumento da concorrência no setor financeiro, com a compra do A BN - A mro pelo Santander e com a fusão do I taú e do U nibanco. Sua estratégia, entretanto, se concentraráno crescimento no mercado interno. A o contrário do seu concorrentel taú-U nibanco, o Bradesco não pretende, no momento, investir no mercado externo (Valor E conômico, 26/ 11/ 2008).

$\mathrm{N}$ a atual fase deexpansão das instituições financeiras brasileiras, - Bradesco pode ser considerado o banco mais agressivo na política deaquisições. Serão continuamenteavaliadas as al ianças estratégicas em potencial e oportunidades de consolidação, inclusive propostas de privatizações e aquisições ou outras formas que possibilitem a ampliação da participação de mercado ou da eficiência do banco. A instituição já demonstrou interesse pela N ossa Caixa (já adquirida pelo Banco do Brasil), Votorantim, Safra (0 Estado de S. Paulo, $8 / 11 / 2008$ ) e pelas operações do Citibank no Brasil (Folha de $S$. Paulo, 25/ 11/ 2008).

8 Somente com o fornecimento de funding ao BM C, pois, até a aprovação da compra pelo Banco Central, o Bradesco não tinha a gestão do BM C. 
Em outubro de 2008, o Bradesco anunciou a compra decarteiras de crédito de financiamento de veículos e de consignado de bancos de menor porte. A compra foi estimulada pela medida tomada pelo Banco C entral que ampliou de $40 \%$ para $70 \%$ o percentual do compulsório sobre depósitos a prazo que pode ser destinado à compra decarteiras de crédito (Valor E conômico, 14/ 10/ 2008). A instituição ainda anal isará a compra de outras carteiras de crédito.

\section{Caixa Econômica Federal}

\section{Histórico e estrutura}

A C aixa E conômica F ederal é uma instituição financeira sob a forma de empresa pública, com personalidade jurídica de direito privado, criada em 12 dejaneiro de1861, com o objetivo deincentivar a poupança e conceder empréstimos sob penhor. Em 1934, por determinação do governo federal, a instituição assumiu a exclusividade dos empréstimos sob penhor, com a consequente extinção das casas de prego operadas por particulares. A partir de 1961, a instituição passou a deter o monopólio das $L$ oterias Federais.

Em 1986, a CEF incorporou o Banco $\mathrm{N}$ acional de $\mathrm{H}$ abitação (BN H ), passand o a atuar como agenteoperador do $F$ undo de $G$ arantia do T empo deServiço (F G T S), antes gerido pelo BN H . Em 1989, todas as contas recolhedoras do F G T S existentes na rede bancária foram central izadas na C aixa, que passou a administrar a arrecadação desse fundo e o pagamento dos valores aos trabal hadores.

Em 2001, o governo federal implementou o Programa de Fortalecimento das I nstituições Financeiras Federais (Proef), com o objetivo deadequar os bancos federais aos padrões decapital ização e deprovisão deriscos decrédito estabel ecidos pelo A cordo da Basileia. C omo resultado desse programa, a CE F teveseu capital aumentado e procedeu-se, também, à troca de ativos de pouca liquidez e baixa qualidade (principalmente empréstimos imobiliários) por ativos mais líquidos e remunerados a taxas de mercado (principalmente 
títulos públicos). 0 risco de crédito foi transferido para o T esouro $\mathrm{N}$ acional, no caso de operações ligadas a programas de governo, eà E mpresa G estora de A tivos (E mgea), uma empresa especialmente criada para esse fim (Versiani, 2003; Folha de S. Paulo, 22/ 9/2008). Por essemotivo, observaremos quegrande partedos dados analisados apresentam alteração a partir de 2002, principalmente as operações de crédito, já que grande parte da carteira de crédito da Caixa foi cedida à E mgea, durante a execução do Proef.

O capital daCaixa pertenceintegralmenteàU nião. D essaforma, a instituição auxilia na execução da política de crédito do governo federal, atuando, prioritariamente, no fomento ao desenvol vimento urbano, por meio dos segmentos dehabitação, saneamento einfraestrutura, ena administração defundos, programas e serviços de caráter social.

D entre os serviços deapoio ao governo federal, podem ser citados o financiamento à produção de habitações para famílias de baixa renda, acompanhado de ações técnicas sociais destinadas ao fortalecimento, organização eapropriação dos bens produzidos, deforma a dar sustentabilidadeaos empreendimentosefixar as famílias nas áreas deintervenção; transferência de recursos e acompanhamento das obras executadas por meio do O rçamento G eral da U nião (O G U ); pagamento de benefícios dos programas sociais de transferências de renda do governo federal, ${ }^{9}$ tais como Bolsa Família, A gente J ovem, A uxílio A luno, Programa de E rradicação doT rabalho I nfantil (Peti), G arantia Safra, D eV olta para Casa, Pró-J ovem, Bolsa A tleta, E scola de F ábrica, A ção G riô, Chapéu de Palha ePlano de Formação eValorização do Pescador; coleta e gestão de dados contábeis e gerenciais de todos os entes da Federação, auxiliando na aplicação da $L$ ei de R esponsabilidade Fiscal no país; execução do Programa de Financiamento Estudantil (FIES), destinado ao financiamento da graduação em ensino superior de estudantes que não tenham

9 A fim de assegurar uma execução mais eficiente das políticas sociais, a Caixa desenvolveu o C adastro Ú nico, ferramenta capaz de apresentar informações sobre o perfil socioeconômico de aproximadamente 53,5 milhões de pessoas situadas abaixo da linha de pobreza. 
condições de arcar com os custos de sua formação; ea atuação como patrocinadora oficial do atletismo brasileiro, da ginástica artística brasileirae, por meio das loterias, do ComitêParaolímpico Brasileiro (CPB) e dos atletas do paradesporto.

A lém do segmento de habitação, a C aixa é o principal agente do governo federal na operacional ização dos programas desaneamento einfraestrutura e de transferência de recursos aos Estados e municípios, referentes aos convênios com o $F$ undo N acional deSaúde(F N S) e $\mathrm{F}$ undação $\mathrm{N}$ acional de Saúde (F unasa). A instituição também é agenteadministrador do F undo del nvestimento F G T S (FI-FGT S), criado em 2007, para financiar segmentos como construção, reforma, ampliação ou implantação de empreendimentos de infraestrutura em rodovias, portos, hidrovias, ferrovias, além de obras de energiae saneamento. O peracional iza, ainda, o P rograma $\mathrm{N}$ acional de $\mathrm{A}$ poio à $M$ odernização da $G$ estão edo Planejamento dos Estados edo $D$ istrito Federal (PN AGE), além de financiar e operacionalizar o Programa $\mathrm{N}$ acional deA poio à $\mathrm{G}$ estão $\mathrm{A}$ dministrativa eFiscal dos $\mathrm{M}$ unicípios Brasileiros (PN A FM).

A CEF também é responsável pela administração de fundos de investimentos eloterias, bem como pela administração etransferência do Seguro-D esemprego, $F$ undo de G arantia doT empo deServiço (F G T S), F undo de Compensação de Variações Salariais (F CVS), Programa de I ntegração Social (PIS), F undo de D esenvolvimento Social (FDS), F undo deA rrendamento R esidencial (FA R ) eF undo $\mathrm{N}$ acional deH abitação del nteresseSocial (F N H IS). N a qualidadede agenteoperador do F G T S, a C aixaé responsável pela administração de 62 milhões de contas ativas e 6,8 milhões de contas inativas, totalizando um sal do de $\mathrm{R} \$ 137,8$ bilhões. A instituição também atua nos segmentos de Seguros, Previdência, $C$ apital ização e C onsórcio.

\section{Rede de atendimento}

A rede de atendimento da Caixa abrange todos os $5.561 \mathrm{mu}$ nicípios brasileiros, contando com mais de 100 mil empregados, 
sendo quase 75 mil destes concursados, ${ }^{10}$ e com 22.628 pontos de atendimento entre agências, lotéricas e correspondentes CA IXA A Q U I , postos deatendimento bancário e el etrônico esal as de autoatendimento. A instituição disponibiliza, ainda, terminais eletrônicos, Banco 24h, CAIXA Rápido, débito automático, atendimento tel efônico, internet banking e serviços de mobile banking - serviços financeiros para celular e computador de mão - PDA.

Para ampliar as possibilidades deatendimento ereduzir os custos, a C aixa e o Banco do Brasil firmaram um acordo para compartilhamento de canais de atendimento al ternativos. A s C asas L otéricas destacam-se como importantes canais para pagamento de contas de energia elétrica, água e tel efone, bem como para o recebimento dos benefícios do governo federal. E $m$ 2007, a arrecadação das lotéricas foi recorde, al cançando $R$ \$ 5,2 bilhões, sendo queR $\$ 2,4$ bilhões foram repassados ao governo federal ea entidades não governamentais para aplicação em programas na área da educação, cultura, esporte e segurança.

O s pontos de atendimento estão localizados, principalmente, na região Sudeste, que concentra $43,7 \%$ das unidades, seguida pelas regiões Sul, N ordeste, C entro-O este e N orte (G ráfico I.4.1). R ecentemente, o $\mathrm{N}$ ordeste tem sido o mercado em que a $\mathrm{C}$ aixa cresce de forma mais acelerada.

Gráfico I.4.1 - Distribuição dos Pontos de Atendimento (\%) - Janeiro/2009

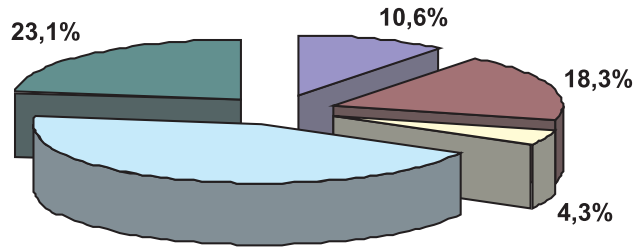

$\square$ Centro-Oeste
$\square$ Nordeste
$\square$ Norte
$\square$ Sudeste
$\square$ Sul

$43,7 \%$

Fonte: Elaboração própria a partir de dados extraídos do site da Febraban.

10 O s demais colaboradores são estagiários, adolescentes aprendizes eprestadores de serviços. 
N o mercado externo, a atuação da C aixa está baseada no relacionamento com emigrantes brasileiros, os quais utilizam os canais de atendimento do banco para envio derecursos ao Brasil; nos acordos de cooperação técnica assinados com diversos países; ena identificação de oportunidades de negócios em âmbitos nacional einternacional.

E m 2007, foram inaugurados os dois primeiros Escritórios de Representação I nternacional, local izados no J apão, na cidade de H amamatsu, enos Estados U nidos, nacidadedeJ ersey. Por meio desses escritórios, aC aixa pretendeatrair brasileiros quevivem no exterior efechar parcerias com outras instituições financeiras, ampliando as remessas deemigrantes brasileiros, consideradas importantesfontes derecursos paralastrear suas operações de financiamento decomércio exterior. $0 \mathrm{~s}$ escritórios também funcionam como ponto de apoio para empresas brasileiras que fazem negócios no exterior. A unidade nos Estados U nidos será responsável, ainda, pelo relacionamento com organismos multilaterais de crédito, como o Banco M undial (Bird) eo Banco Interamericano deD esenvolvimento (BID ) (Valor E conômico, 21/ 9/ 2007).

A CEF também opera em Portugal, por meio de parceria com 0 M illennium BCP, firmada em 2005, e negocia com outros bancos acordos semelhantes para atuar em países com presença significativa de brasileiros, como F rança, I tália, Espanha e Inglaterra. Esse convênio facilitou as remessas de emigrados brasileiros ao país, possibilitadas desde 2004 por meio do C aixa Internacional.

\section{Base de clientes}

A CEF éo maior banco público daA mérica L atina, atingindo uma base de 33,6 milhões de clientes em junho de 2008, uma expansão de $42 \%$ em relação a 2006. D esses clientes, $85 \%$ são caracterizados no segmento essencial. 0 banco encerrou o primeiro semestre de 2008 com 11,5 milhões decontas-correntes de pessoas físicas e 973,2 mil de pessoas jurídicas, representando umaevolução de $16,8 \%$ no número de contas em relação ao mesmo período de2007. Por meio daC ontaC aixa Fácil, foram incluídos no sistema bancário 5,5 milhões de brasileiros, 
atéjunho de2008. O sclientes da contadispõem delimites rotativos, que variam deR $\$ 200,00$ aR $\$ 1.000,00$, por meio do C rédito CA IXA F ácil.

A C aixa possui, também, forte atuação junto ao poder público. A lém de disponibilizar recursos e firmar acordos para administração das folhas de pagamento, a instituição auxilia as prefeituras e governos estaduais a projetarem eacompanharem obras promotoras de desenvolvimento urbano, contribuindo, também, para a adoção de soluções mais eficientes para a gestão financeira dos municípios.

\section{Captações}

A Caixa capta recursos principalmente por meio de depósitos, sendo que, em junho de 2008 , estes representaram $77,8 \%$ dos recursos captados. D esde 2002, entretanto, observa-seuma tendência de aumento nas $\mathrm{C}$ aptações de $\mathrm{M}$ ercado $\mathrm{A}$ berto, em relação à captação por meio dedepósitos. Em junho de 2008, 22,2\% dos recursos foram captados por meio do M ercado A berto, contra 3,5\% em dezembro de 1997 (Tabela I.4.1).

T abela I .4.1 - Composição das C aptações (em \%)

\begin{tabular}{c|c|c|c|c|c|c|c|c}
\hline D ata & $\begin{array}{c}\text { À } \\
\text { V ista }\end{array}$ & Poupança & Interfin. & $\begin{array}{c}\text { A } \\
\text { Prazo }\end{array}$ & O utros & $\begin{array}{c}\text { D epósitos } \\
\text { Totais }\end{array}$ & $\begin{array}{c}\text { Cap. } \\
\text { M ercado } \\
\text { A berto }\end{array}$ & $\begin{array}{c}\text { Total (em } \\
\text { R \$ bilhões) }\end{array}$ \\
\hline dez./ 97 & 4,2 & 37,3 & 0,0 & 37,7 & 17,3 & 96,5 & 3,5 & 62,5 \\
\hline dez./ 98 & 4,7 & 43,9 & 0,0 & 45,5 & 4,4 & 98,5 & 1,5 & 61,3 \\
\hline dez./ 99 & 5,2 & 46,3 & 0,0 & 44,4 & 2,6 & 98,5 & 1,5 & 62,5 \\
\hline dez./ 00 & 5,9 & 47,6 & 0,0 & 40,8 & 3,7 & 98,0 & 2,0 & 64,4 \\
\hline dez./ 01 & 6,2 & 49,3 & 0,0 & 36,3 & 4,6 & 96,4 & 3,6 & 71,8 \\
\hline dez./ 02 & 5,4 & 44,4 & 0,0 & 26,4 & 4,0 & 80,2 & 19,8 & 95,5 \\
\hline dez./ 03 & 4,4 & 38,1 & 0,0 & 22,7 & 5,2 & 70,4 & 29,6 & 115,1 \\
\hline dez./ 04 & 5,6 & 46,3 & 0,0 & 28,5 & 6,3 & 86,7 & 13,3 & 105,8 \\
\hline dez./ 05 & 5,0 & 38,3 & 0,0 & 27,8 & 5,7 & 76,8 & 23,2 & 139,2 \\
\hline dez./ 06 & 5,6 & 38,7 & 0,0 & 27,2 & 6,8 & 78,3 & 21,7 & 155,0 \\
\hline dez./ 07 & 6,3 & 41,2 & 0,0 & 22,5 & 7,2 & 77,2 & 22,8 & 183,8 \\
\hline jun./ 08 & 5,8 & 43,4 & 0,0 & 23,9 & 4,7 & 77,8 & 22,2 & 190,2 \\
\hline Cresc. & 325,5 & 253,5 & 0,0 & 93,1 & $-18,1$ & 145,2 & $1.849,4$ & 204,1 \\
\hline
\end{tabular}

Fonte: Elaboração própria a partir de dados extraídos do site do Banco C entral do Brasil. 
A principal mudança ocorreu a partir de 2002, decorrente das medidas adotadas pelo Proef. A queda nas taxas dejuros eo aumento na renda proporcionaram uma marca histórica para a caderneta de poupança, que, em junho de 2008, registrou 25 meses seguidos de captação positiva. $0 \mathrm{~s}$ recursos depositados em poupança representaram, em junho de 2008, 43,4\% do total de recursos captados.

A captação em poupança éimportante para a C aixa porque tem baixo custo ${ }^{11}$ eal avanca recursos para a expansão do crédito imobiliário e, na faixalivre, paraa expansão da carteira decrédito comercial. $\mathrm{N}$ o primeiro semestre de 2008, o banco contava com 35,5 milhões de cadernetas de poupança (Valor E conômico, 11/ 6/ 2008).

A forma de captação que mais cresceu no período de 1997 a junho de 2008 foi a de $D$ epósitos à Vista, com um crescimento de $325,5 \%$, seguido pelos D epósitos de Poupança, que apresentaram uma expansão de 253,5\% (T abela I .4.1).

\section{Carteira de crédito}

A pós uma significativa redução em dezembro de2001 (devido às medidas implementadas por meio do Proef), a Carteira de C rédito e A rrendamento $M$ ercantil da $C$ aixa apresentou expressivo crescimento, partindo de $R \$ 19,7$ bilhões em dezembro de 2001 para $R \$ 63,6$ bilhões em junho de 2008, uma ampliação de $223 \%$ (G ráfico I.4.2).

Em junho de 2008, 75,4\% do saldo de operações de crédito eram constituídos por operações das carteiras deH abitação (pessoas físicas e pessoas jurídicas) e de Pessoas F ísicas. A participação do Setor Público foi de $6,7 \%$, enquanto a carteira de Pessoas Jurídicas teve uma participação de 4\% (T abela I.4.2).

$11 \mathrm{G}$ rande parte dos bancos privados capta através de Certificados de $D$ epósitos Bancários - CD Bs, que têm maior custo. 
Gráfico I.4.2 - Operações de Crédito e Arrendamento Mercantil (em R \$ bilhões)

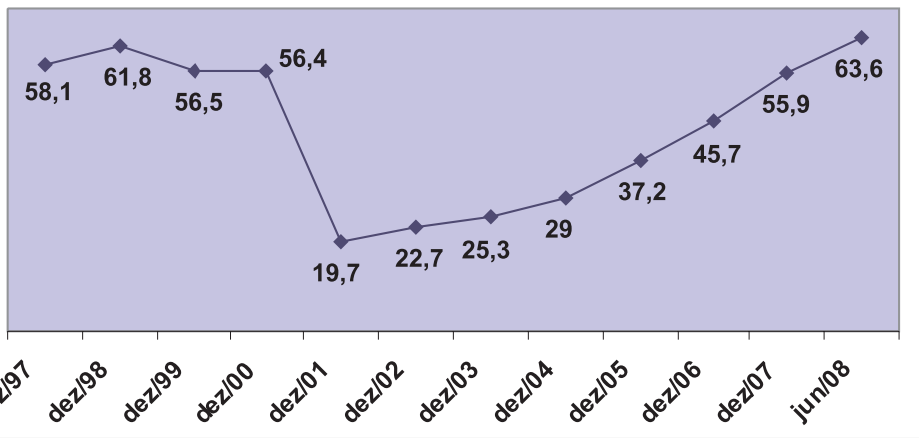

Fonte: Elaboração própria a partir de dados extraídos do site do Banco Central do Brasil.

Tabela I .4.2 - Composição da Carteira de C rédito por C liente (em \%)

\begin{tabular}{l|c|c|c|c|c|c|c|c|c}
\hline & $\mathbf{2 0 0 1}$ & $\mathbf{2 0 0 2}$ & $\mathbf{2 0 0 3}$ & $\mathbf{2 0 0 4}$ & $\mathbf{2 0 0 5}$ & $\mathbf{2 0 0 6}$ & $\mathbf{2 0 0 7}$ & jun./ 08 & C resc. \\
\hline Setor Público & 8,4 & 5,0 & 5,4 & 6,4 & 6,6 & 7,1 & 6,8 & 6,7 & 146,8 \\
\hline Setor Privado & 91,6 & 95,0 & 94,6 & 93,6 & 93,4 & 92,9 & 93,2 & 93,3 & 216,5 \\
\hline Pessoas Jurídicas & 2,9 & 3,3 & 2,2 & 3,1 & 4,3 & 4,6 & 3,9 & 4,0 & 322,4 \\
\hline Pessoas Físicas & 20,8 & 25,6 & 19,6 & 22,7 & 24,9 & 21,9 & 21,2 & 20,7 & 208,8 \\
\hline H abitação - PF/PJ & 64,4 & 62,6 & 60,0 & 54,3 & 49,8 & 53,0 & 54,8 & 54,7 & 164,0 \\
\hline O utros & 3,5 & 3,5 & 12,8 & 13,5 & 14,4 & 13,4 & 13,3 & 13,9 & $1.147,2$ \\
\hline
\end{tabular}

Fonte: Elaboração própria a partir de dados extraídos do site da C aixa E conômica Federal.

Em junho de 2008 o saldo da carteira de crédito apresentou ampliação de 26,7\%. 0 segmento quemais tem apresentado crescimento éo dePessoas J urídicas, entretanto sua participação na carteira total não é significativa (T abela I.4.2). N a carteira de Pessoas F ísicas destacam-se as operações de crédito rotativo, o crédito à habitação, o crédito consignado e o penhor.

R ecentemente, o segmento de $\mathrm{H}$ abitação vem obtendo recordes históricos. Em junho de 2008, a contratação por intermédio dos diversos programas habitacionais al cançou $\mathrm{R} \$ 35,6$ bilhões. $\mathrm{N}$ o ano de2007, esse bom desempenho garantiu ao banco a participação em quase um quarto no mercado de financiamento habitacional (Valor E conômico, 15/ 1/ 2008 [1]). 
A CEF encerrou o ano de 2007 com recorde de contratação em habitação, saneamento e infraestrutura. Foi contratada a quantia de $R \$ 37,2$ bilhões, dos quais $R \$ 21,5$ bilhões foram destinados à habitação, sen do que $R \$ 31,6$ bilhões referem-sea recursos destinados a obras do PAC.

Por meio dos Feirões da C asa Própria, realizados anualmente desde 2005, a Caixa se aproxima do mutuário final, ampliando as contratações (Valor E conômico, 16/ 1/ 2007). Em 2007, os Feirões foram responsáveis pela realização de negócios no valor de $\mathrm{R} \$ 349$ milhões. 0 aumento do prazo de amortização para 30 anos, a partir de outubro de 2007, também contribuiu para a ampliação das contratações (Valor E conômico, 3/ 9/ 2007).

A grande participação da C aixa no segmento habitacional também éconsequência do fato dea instituição ser o principal banco na execução dos programas habitacionais do governo federal. D entre esses programas, que atendem famílias de baixa renda, principalmente aquelas com renda mensal de até três salários mínimos, podem ser citados o C rédito Solidário, que utiliza recursos do $\mathrm{F}$ undo de D esenvolvimento Social (FDS), o Programa de A rrendamento R esidencial (PA R) e os programas habitacionais subsidiados com recursos do O rçamento G eral da U nião - O GU. G rande parte dos recursos utilizados para contratação dos financiamentos habitacionais, entretanto, é originária do $\mathrm{F}$ undo de $\mathrm{G}$ arantia do $\mathrm{T}$ empo de Serviço (F G T S).

N o segmento de Pessoas Físicas, as linhas que mais têm apresentado crescimento são a de crédito direto ao consumidor (Valor E conômico, 21/3/2007) ea de crédito consignado. D esde2004, com uma al teração na legisl ação que permitiu a contratação com aposentados epensionistas sem a necessidade detransferência de domicílio bancário e devinculação do ben efício ao banco concessor deempréstimos e financiamentos, o segmento de consignação consolidou-se como a linha de crédito de maior procura pela população, com um crescimento de 135,3\% em relação a 2003.

Recentemente, o crescimento do crédito consignado foi impulsionado pela transferência para a $\mathrm{C}$ aixa das carteiras dessa moda- 
lidade dos bancos BM G e Banco M ercantil do Brasil (BM B), em 2005 (Valor E conômico, 27/ 6/ 2007). Em 2007, 60\% da carteira era formada por aposentados epensionistas do IN SS (Valor E conômico, 2/ 7/ 2007). A carteira decrédito consignado representou, no primeiro semestre de 2008, 25\% da carteira total de pessoas físicas.

N o segmento de cartões de crédito e débito, cuja carteira passou a ser diretamente administrada pela Caixa em 2002, foram realizadas, no primeiro trimestre de 2008, 77,5 milhões de transações, total izando $R$ \$ 4,5 bilhões. A basedecartões al cançou 47 milhões de unidades, sendo que os cartões de débito atingiram uma base de 43,2 milhões, um crescimento de $11,55 \%$ em relação ao primeiro trimestre de 2007.

A linha de penhor vem apresentando expressivo crescimento nos últimos anos, atingindo uma participação de $17 \%$ da carteira dePessoas F ísicas em junho de2008. A C aixa éo único banco que oferece essetipo de empréstimo, que continua atrativo pela facilidadeepela pouca burocracia. N o primeiro semestre de 2007 , foram emprestados $\mathrm{R} \$ 2$ bilhões em penhor, sendo queR \$ 187 milhões foram destinad os à linha de $\mathrm{M}$ icropenhor - penhor para baixa renda. O s E stados de São Paulo, Rio de Janeiro, M inas G erais, Paraná e Pará responderam por $61 \%$ do total de aplicação realizada em maio de 2007 (V alor E conômico, 14/ 6/ 2007). O M icropenhor foi lançado em agosto de 2004, como alternativa de crédito facilitado e com juros baixos para a população de baixa renda, contribuindo para a consolidação do $M$ icrocrédito no Brasil.

N o segmento Pessoas J urídicas, destaca-se ampliação da atuação da C aixajunto às micro e pequenas empresas. $\mathrm{N}$ o primeiro semestre de 2008, esse segmento representou $90 \%$ do total da C arteira Pessoa J urídica. A s principais linhas são as operações de C apital de G iro D esconto, Cheque Empresa C A IXA, G I M eC onta Garantida. N a linha de I nvestimento, destacam-se o PROGER, linha de crédito instituída pelo $\mathrm{M}$ inistério do T rabal ho para empreendimentos que visem a geração de emprego e renda, e as operações com recursos do BN DES. Em 2007, a instituição destinou R \$ 35,4 bilhões para 
micro, pequenas emédias empresas, o que representou um aumento de 51,92\% em comparação aos R \$23,3 bilhões desembolsados em 2006 (DCI - SP, 23/ 4/ 2007).

$\mathrm{O}$ direcionamento ao segmento de $\mathrm{M}$ icro e Pequenas $\mathrm{E}$ mpresas foi incentivado pela política governamental de expansão do acesso ao crédito, reforçada pela aprovação da nova lei das M icro ePequenas E mpresas. Entretanto, a al ta inadimplência desse segmento, que al cançou $8 \%$ no início de 2007, contra 5,3\% no início de 2006, impactou negativamente no resultado da instituição em 2007 (F ol ha de S. Paulo, 24/ 11/2007). Essa estratégia já foi revista pelo banco, inclusive com mudanças na diretoria; entretanto, o segmento deM icro ePequenas E mpresas continua sendo um dos focos da instituição (0 Globo, 24/ 11/ 2007).

\section{Gestão de riscos}

$\mathrm{N}$ os últimos anos, a C aixa vem buscando al inhar-seàs melhores práticas de gestão deriscos eao cumprimento das exigências do N ovo A cordo de C apitais da Basileia, conforme cronograma ecritérios de implementação estabel ecidos pelo Banco C entral do Brasil. V isando refletir a priorização estratégica e a decisão de implantar os modelos avançados previstos no $\mathrm{N}$ ovo A cordo, o C onsel ho D iretor da Caixa aprovou a criação do Projeto Estratégico Basileia II, que passou a gerenciar todas as ações em andamento nainstituição para adequação aos requisitos desse $\mathrm{N}$ ovo $\mathrm{A}$ cordo.

0 Índice de Solvabilidade- Basileia - manteve-se, desde 2001, acima dos $11 \%$ exigidos pelo Banco C entral. N esseperíodo, o índice apresentou crescimento, partindo de 13,56\% em 2001 para 20,35\% em junho de2008 (Gráfico I.4.3).

$\mathrm{N}$ os últimos anos, verificou-se uma melhora significativa na carteira de crédito. A s operações classificadas nos níveis A A, A, B e $C$ representaram $87,52 \%$ do total da carteira de crédito em junho de 2008, contra 63,45\% em dezembro de 2001 (Tabela I .4.3). 


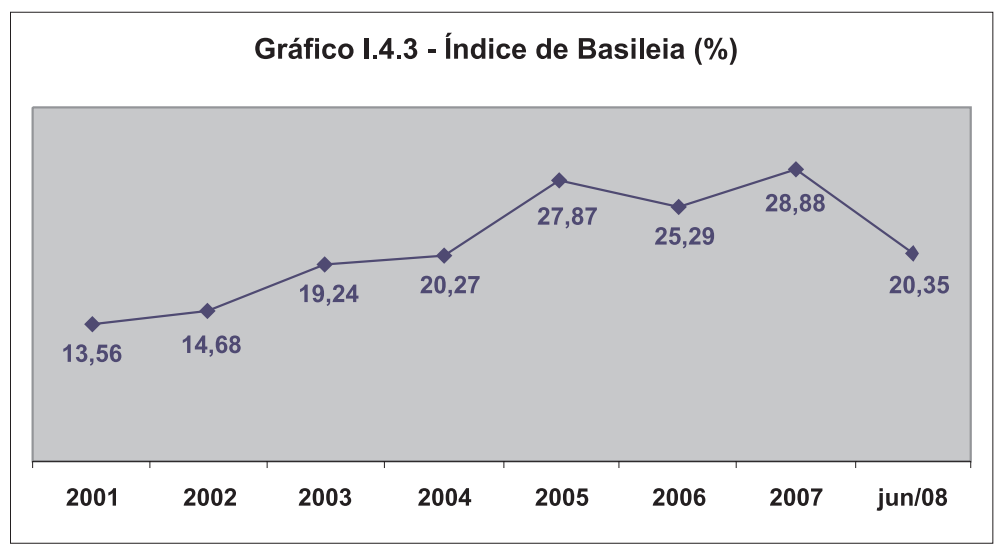

Fonte: Elaboração própria a partir de dados extraídos do site do Banco C entral do Brasil.

Tabela I .4.3 - Composição da C arteira de Crédito por N ível de R isco (\%)

\begin{tabular}{c|c|c|c|c|c|c|c|c}
\hline & $\mathbf{2 0 0 1}$ & $\mathbf{2 0 0 2}$ & $\mathbf{2 0 0 3}$ & $\mathbf{2 0 0 4}$ & $\mathbf{2 0 0 5}$ & $\mathbf{2 0 0 6}$ & $\mathbf{2 0 0 7}$ & jun./ 08 \\
\hline A A & 5,99 & 5,67 & 6,62 & 6,35 & 5,44 & 4,98 & 6,35 & 6,08 \\
\hline A & 24,32 & 26,47 & 31,31 & 28,85 & 39,30 & 43,55 & 40,17 & 38,67 \\
\hline B & 12,78 & 12,67 & 13,69 & 13,91 & 14,28 & 15,82 & 20,58 & 23,60 \\
\hline C & 20,36 & 16,64 & 14,53 & 16,98 & 16,73 & 19,21 & 19,44 & 19,17 \\
\hline D & 17,79 & 26,18 & 20,69 & 21,73 & 13,29 & 6,03 & 4,55 & 4,10 \\
\hline E & 1,86 & 1,93 & 2,08 & 2,01 & 2,20 & 1,35 & 0,90 & 0,75 \\
\hline F & 4,93 & 1,52 & 1,58 & 1,41 & 1,08 & 0,77 & 0,76 & 0,94 \\
\hline G & 1,56 & 0,85 & 0,94 & 1,04 & 0,84 & 1,06 & 1,08 & 1,00 \\
\hline H & 10,41 & 8,07 & 8,56 & 7,72 & 6,84 & 7,23 & 6,17 & 5,69 \\
\hline AA-C & 63,45 & 61,45 & 66,15 & 66,09 & 75,75 & 83,56 & 86,54 & 87,52 \\
\hline D-H & 36,55 & 38,55 & 33,85 & 33,91 & 24,25 & 16,44 & 13,46 & 12,48 \\
\hline
\end{tabular}

Fonte: Elaboração própria a partir de dados extraídos do site da C aixa E conômica F ederal.

\section{Índices de cobertura e de eficiência}

0 Índice de C obertura, que representa a razão entre as R eceitas de Prestação de Serviços e as D espesas de Pessoal, cresceu significativamente de 1997 a 2003, quando al cançou 114\%. D e 2004 a 2006, esseíndice sofreu pequena queda, voltando a crescer em 2007 (Tabela I.4.4). 
Tabelal .4.4 - Índice de C obertura (em R \$ milhões)

\begin{tabular}{l|c|c|c|c|c|c|c|c|c|c|c|c}
\hline & $\mathbf{1 9 9 7}$ & $\mathbf{1 9 9 8}$ & $\mathbf{1 9 9 9}$ & $\mathbf{2 0 0 0}$ & $\mathbf{2 0 0 1}$ & $\mathbf{2 0 0 2}$ & $\mathbf{2 0 0 3}$ & $\mathbf{2 0 0 4}$ & $\mathbf{2 0 0 5}$ & $\mathbf{2 0 0 6}$ & $\mathbf{2 0 0 7}$ & $\begin{array}{c}\mathbf{1 0 S} \\
\mathbf{2 0 0 8}\end{array}$ \\
\hline $\begin{array}{l}\text { Rec. Prest. } \\
\text { Serviços }\end{array}$ & 2.123 & 2.124 & 2.433 & 2.663 & 3.230 & 4.234 & 4.594 & 4.648 & 5.166 & 5.595 & 6.865 & 3.630 \\
\hline $\begin{array}{l}\text { D espesas } \\
\text { dePessoal }\end{array}$ & 3.445 & 3.240 & 3.480 & 3.628 & 4.007 & 3.916 & 4.030 & 4.740 & 5.585 & 6.244 & 7.159 & 4.005 \\
\hline $\begin{array}{l}\text { Índicede } \\
\text { Cobertura } \\
\text { \%) }\end{array}$ & 61,6 & 65,6 & 69,9 & 73,4 & 80,6 & 108,1 & 114,0 & 98,1 & 92,5 & 89,6 & 95,9 & 90,6 \\
\hline
\end{tabular}

Fonte: Elaboração própria a partir de dados extraídos do site do Banco C entral do Brasil.

Esse comportamento pode ser explicado pelas maiores despesas depessoal a partir de2003, em relação ao período anterior. Em 2007, esse aumento foi compensado por um aumento expressivo nas Receitas de Prestação de Serviços (R PS). D e1997 a 2007, o crescimento das R PS foi de $223,4 \%$, enquanto as D espesas de Pessoal cresceram $107,8 \%$.

A s R PS são compostas, principalmente, por receitas deadministração do F G T S, de administração de fundos de investimento e de tarifas de convênio. Em junho de 2008, essas receitas representaram $33,1 \%, 11,5 \%$ e10,2\% do total deR PS, respectivamente(G ráfico I.4.4).

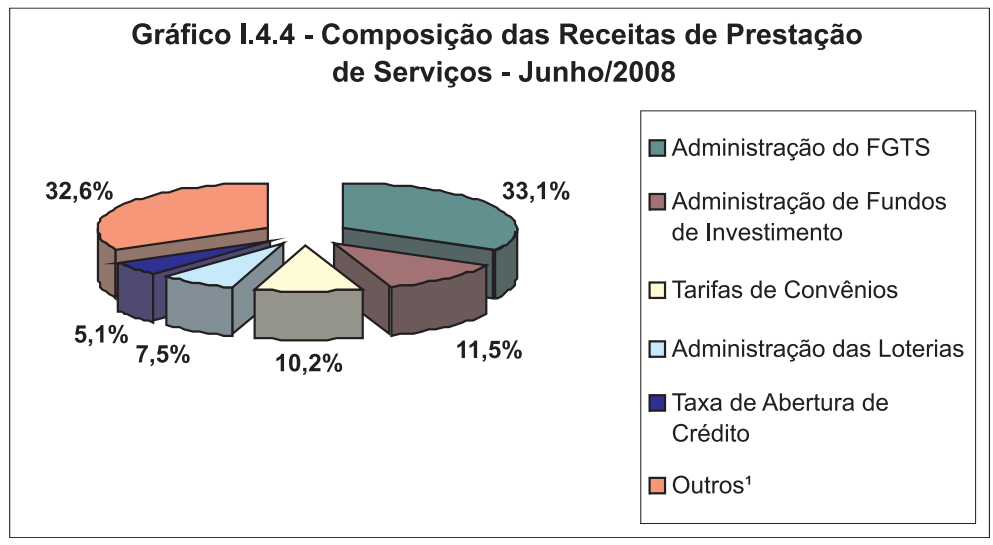

1) Todas as outras receitas representam menos de $5 \%$ na R PS total.

Fonte: Elaboração própria a partir de dados extraídos do site da C aixa E conômica F ederal. 
O Índice de Eficiência, por sua vez, tem se mantido constante nos últimos anos, com exceção o ano de 2007, quando sofreu um significativo aumento. Em junho de2008, o Índice de Eficiência da Caixa atingiu 65,30\% (G ráfico I.4.5).

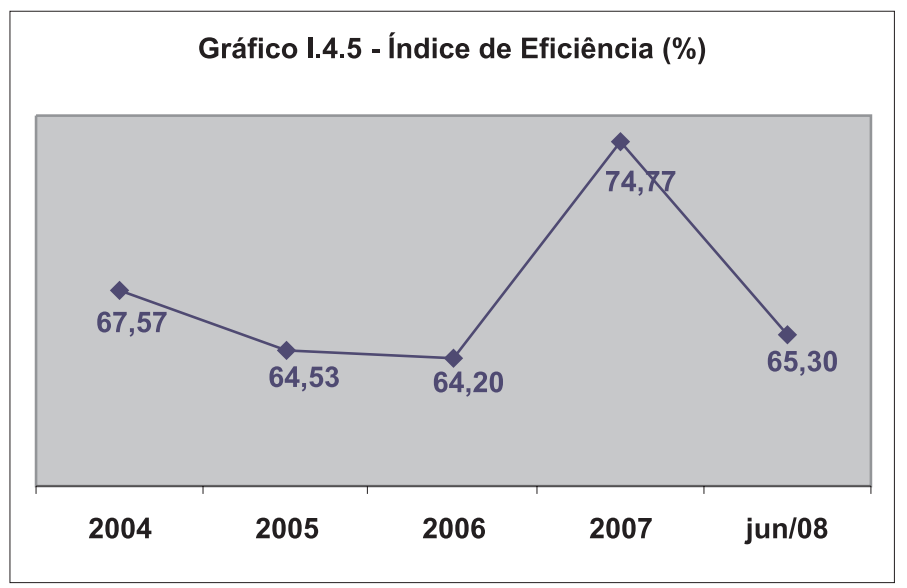

Fonte: Elaboração própria a partir de dados extraídos do site da C aixa E conômica Federal.

\section{Composição dos ativos e das receitas de intermediação financeira}

O s ativos da C aixa são compostos, principalmente, por T ítulos eValores M obiliários e I nstrumentos Financeiros D erivativos, os quais, em junho de 2008, representavam $44 \%$ dos A tivos T otais, contra $24 \%$ das $O$ perações de C rédito e A rrendamento $M$ ercantil. E ssa distribuição não sofreu alterações significativas desde 2001. N 0 período de 1997 a 2000, entretanto, essa composição erainversa, com as $O$ perações de $C$ rédito e $A$ rrendamento $M$ ercantil representando $44,7 \%$ dos A tivos T otais em 2000 , contra 7,4\% de participação dos T ítulos eValores M obiliários e I nstrumentos F inanceiros D erivativos (T abela I.4.5). Essa mudança decomportamento a partir de2001 foi resultado das medidas adotadas pelo Proef. 
Tabelal I.4.5 - Composição dos A tivos (em \%)

\begin{tabular}{|c|c|c|c|c|c|c|}
\hline D ata & $\begin{array}{l}\text { A plicações } \\
\text { Interfin. }\end{array}$ & $\begin{array}{l}\text { T VM } \\
\text { elnstr. } \\
\text { Financ. } \\
\text { D eriv. }\end{array}$ & $\begin{array}{l}\text { Op. de } \\
\text { C rédito e } \\
\text { A rrend. } \\
\text { M erc. }\end{array}$ & $\begin{array}{c}\text { O utros } \\
\text { C réditos }\end{array}$ & O utros ${ }^{1}$ & $\begin{array}{l}\text { A tivo Total } \\
\text { (em } \\
\text { R \$ bilhões) }\end{array}$ \\
\hline $\begin{array}{l}\text { dez./ } 97 \\
\end{array}$ & 5,3 & 9,5 & 52,1 & 14,1 & 19,0 & 111,6 \\
\hline dez./ 98 & 5,8 & 7,9 & 53,9 & 16,3 & 16,1 & 114,7 \\
\hline dez./ 99 & 0,7 & 14,6 & 46,2 & 15,9 & 22,6 & 122,4 \\
\hline dez./ 00 & 2,6 & 7,4 & 44,7 & 17,8 & 27,5 & 126,1 \\
\hline dez./ 01 & 4,8 & 42,1 & 19,4 & 6,4 & 27,3 & 101,3 \\
\hline dez./ 02 & 5,1 & 44,7 & 17,7 & 4,0 & 28,5 & 128,4 \\
\hline dez./ 03 & 3,3 & 51,5 & 16,8 & 3,8 & 24,6 & 150,5 \\
\hline dez./ 04 & 2,9 & 49,3 & 19,6 & 4,6 & 23,6 & 147,8 \\
\hline dez./ 05 & 5,2 & 49,5 & 19,7 & 4,5 & 21,1 & 188,7 \\
\hline dez./ 06 & 8,1 & 44,7 & 21,8 & 4,3 & 21,1 & 209,5 \\
\hline dez./ 07 & 4,7 & 49,0 & 22,4 & 3,7 & 20,2 & 249,6 \\
\hline jun./ 08 & 6,4 & 44,0 & 24,0 & 5,3 & 20,3 & 264,4 \\
\hline Cresc. (\%) & 184,2 & 995,1 & 9,5 & $-11,7$ & 153,1 & 136,9 \\
\hline
\end{tabular}

1) Inclui D isponibilidades, R elações I nterfinanceiras, R elações deI nterdependências, Provisão para C réditos de L iquidação D uvidosa, $\mathrm{O}$ utrosValores e Bens, I mobilizado de A rrendamento ePermanente.

Fonte: Elaboração própria a partir de dados extraídos do site do Banco C entral do Brasil.

A carteiradeT ítulos eValores M obiliários também foi aquemais cresceu no período, com uma expansão de $995,1 \%$, contra somentede 9,5\% dacarteira de 0 perações de $C$ rédito eA rrendamento $M$ ercantil. G rande parte da carteira deT ítulos eV alores M obiliários da Caixa é formada por títulos públicos, cujacarteiraal cançou, no final de2007, um sal do demais de $R$ \$100 bilhões (C orreio B rasiliense, 24/ 11/ 2007). Em dezembro de2006, essesal do era de $R \$ 92,43$ bil hões, al cançando $\mathrm{R} \$ 112,4$ bilhões em setembro de 2008 . O u seja, a participação dos títulos públicos nos ativos totais da CEF ésignificativa, caindo, entretanto, de $44 \%$ em dezembro de 2006 para $41 \%$ em setembro de 2008 .

D esde2002, as R eceitas del ntermediação F inanceira são compostas, principalmente, por 0 perações com T ítulos eV alores M obiliários, seguidas pelas 0 perações de $C$ rédito eA rrendamento $M$ ercantil. A ssim como ocorreu com os A tivos Totais, a composição das R eceitas de Intermediação Financeira era inversa até 2001 (T abela I 4.6). 
Tabela I .4.6 - Composição das R eceitas de Intermediação Financeira (em \%)

\begin{tabular}{c|c|c|c|c}
\hline D ata & $\begin{array}{c}\text { O p. C rédito e } \\
\text { Arrend. M erc. }\end{array}$ & $\begin{array}{c}\text { O perações com } \\
\text { T V M }\end{array}$ & O utros $^{\mathbf{1}}$ & $\begin{array}{c}\text { T otal } \\
\text { (em R \$ bilhões) }\end{array}$ \\
\hline 1997 & 62,3 & 24,7 & 13,0 & 16,6 \\
\hline 1998 & 70,5 & 18,2 & 11,3 & 16,7 \\
\hline 1999 & 77,5 & 15,1 & 7,4 & 19,7 \\
\hline 2000 & 69,8 & 18,7 & 11,5 & 14,0 \\
\hline 2001 & 44,4 & 35,0 & 20,6 & 12,7 \\
\hline 2002 & 21,8 & 61,2 & 17,0 & 17,3 \\
\hline 2003 & 21,3 & 58,8 & 19,9 & 25,1 \\
\hline 2004 & 26,6 & 56,9 & 16,5 & 21,3 \\
\hline 2005 & 28,8 & 58,0 & 13,2 & 26,0 \\
\hline 2006 & 31,9 & 55,0 & 13,1 & 28,0 \\
\hline 2007 & 34,3 & 50,5 & 15,2 & 26,8 \\
\hline 1 -S 2008 & 33,1 & 50,7 & 16,2 & 14,8 \\
\hline Cresc. (\%) & $-10,7$ & 230,7 & 90,0 & 61,4 \\
\hline
\end{tabular}

1) Inclui $O$ perações com Instrumentos Financeiros D erivativos, $O$ perações de $C$ âmbio e A plicações Compulsórias.

Fonte: Elaboração própria a partir de dados extraídos do site do Banco C entral do Brasil.

A s receitas com 0 perações com T ítulos eValores M obiliários, principais componentes das R eceitas de I ntermediação F inanceira, atingiram uma participação de 50,7\%, no primeiro semestrede 2008 (T abela I.4.6). A pesar do crescimento verificado desde 2001, essas receitas sofreram redução nos anos de 2004 e 2007, o que pode ser explicado, principal mente, pela redução da taxa dejuros promovida pelo Banco Central, uma vez que a quase totalidade da carteira de títulos da instituição é composta por títulos públicos.

\section{Resultados}

A Caixa encerrou o primeiro semestre de 2008 com um lucro de R \$ 2.543 milhões, um crescimento de $48 \%$ em relação ao mesmo período de 2007 (G ráfico I .4.6). D esde 2005, o banco vem obtendo lucros recordes, devido, principalmente, à significativa expansão das receitas com operações de crédito, especialmente no segmento de crédito consignado (0 G lobo, 24/ 11/ 2007). 


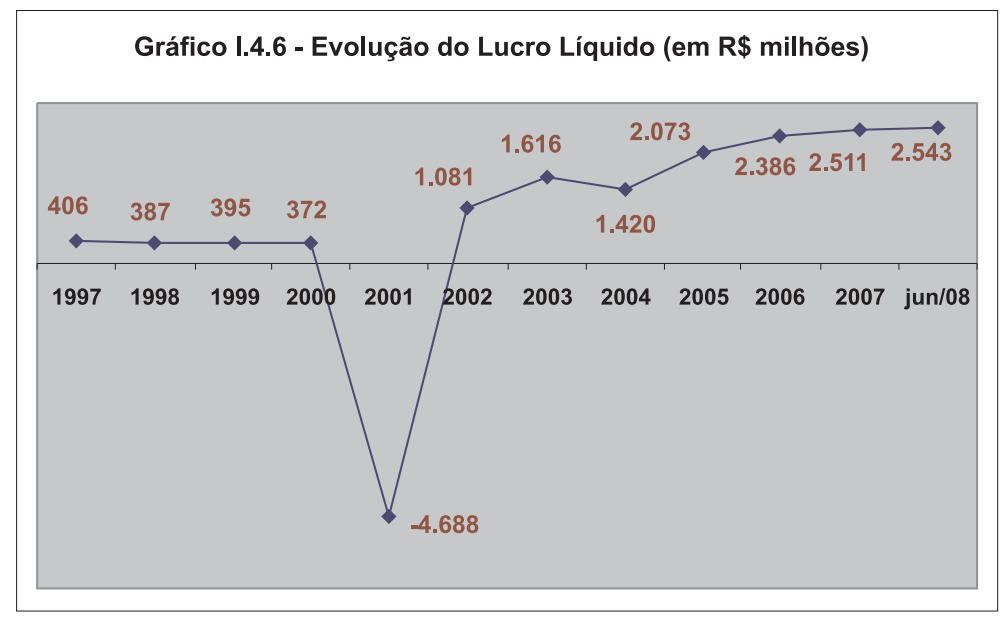

Fonte: Elaboração própria a partir de dados extraídos do site do Banco C entral do Brasil.

Em 2007, entretanto, o lucro da instituição não foi muito significativo, se comparado ao lucro obtido por outros bancos. Esse desempenho deveu-se, principalmente, ao aumento da inadimplência nas operações de crédito, especial mente no segmento de micro e pequenas empresas.

Para al guns especial istas do sistema financeiro, a estratégia adotada, voltada para a pequena em resa, foi incentivada pelo governo, que buscou atender esse segmento por meio, por exemplo, do incentivo à ampliação da facilidade de bancarização, da criação da L ei $G$ eral das $\mathrm{M}$ icro eP equenas Empresas edo estímulo aos consórcios. Esse direcionamento também foi resultado da busca da instituição por novos clientes, após perder mercado no segmento de crédito consignado, modalidade de baixo risco que passou a atrair outros bancos (0 G lobo, 24/ 11/2007).

O Retorno sobre o Patrimônio L íquido da CEF atingiu 44,9\% no primeiro semestre de 2008 , contra $40,7 \%$ no primeiro semestre de 2007. Em 2007, esse índice foi de $23,71 \%$ contra $25,99 \%$ em 2006 (G ráfico I.4.7). Essa redução acompanhou a queda do lucro líquido. 


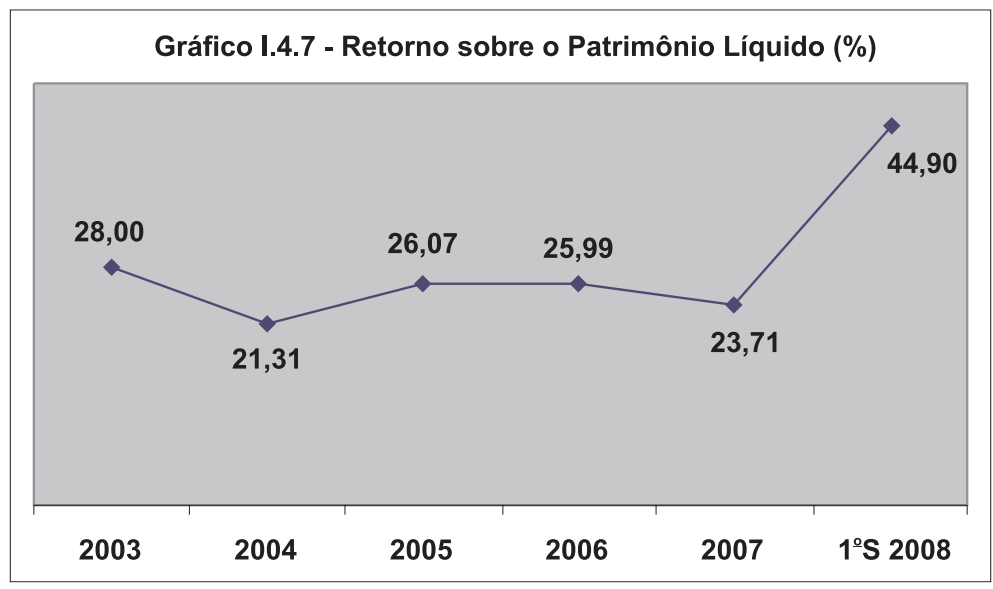

Fonte: Elaboração própria a partir de dados extraídos do site da C aixa E conômica F ederal.

\section{Tendências recentes}

A principal estratégia da C aixa tem sido ampliar a concessão de crédito. A orientação recente do governo é para que a CEF atue, principalmente, nos segmentos de habitação, saneamento básico e micro e pequenas empresas (DCI - SP, 22/ 9/2008). A instituição tem atuação significativa no segmento habitacional, principalmente junto às famílias de baixa renda (Valor E conômico, 16/ 1/ 2007). $\mathrm{N}$ esse segmento, a atuação da C aixa éfortementeinfluenciada pelas estratégias do governo, as quais priorizam as famílias com renda de até cinco salários mínimos, que é a faixa onde se concentra a maior parte do déficit habitacional.

N o primeiro semestre de $2008,62 \%$ dos créditos habitacionais foram direcionados parafamílias com renda deatécinco salários mínimos. A pesar derepresentar a maioria, essa partici pação decresceu em relação a 2007, quando atingiu 86\% (D iário de S. Paulo, 18/ 8/ 2008).

Recentemente, principalmente a partir de 2008, o governo (por meio da C aixa) vem tomando várias medidas para impulsionar o crédito habitacional, o que resultou em contratações recordes no 
primeiro semestre de2008. Essas medidas preveem redução de juros, ampliação do prazo de amortização, redução da parcela de entrada do financiamento, ampliação da disponibilização de recursos e flexibilização das regras do F G T S, dentre outras.

O M inistério das C idades e o C onsel ho C urador do F G T S também determinaram queno mínimo $50 \%$ dos financiamentos fossem direcionados para a aquisição de imóveis novos ou na planta, com o objetivo decriar novos postos detrabal ho egerar renda. N o primeiro semestre de 2008, os imóveis novos representaram $52 \%$ dos contratos definanciamento (0 Dia - R J, 8/8/2008).

0 banco também pretendeinvestir no financiamento às construtoras de imóveis novos, criando áreas específicas dentro deal gumas agências para atender as empresas (Valor E conômico, 15/ 1/ 2008 [2]). $\mathrm{N}$ esse sentido, a CEF assinou convênios habitacionais com grandes construtoras, para financiamento da produção e comercial ização de unidades habitacionais. $D$ entre as empresas que firmaram esse convênio com a Caixa, podem ser citadas a T ecnisa, a F it R esidencial (empresa criada pela G afisa), T enda, Camargo C orrêa, H M Engenharia, M RV, R iwenda, T itton Brugger, A byara, T risul, A sa I ncorporadora e G oldfarb. N o total, foram assinados treze convênios com construtoras desde 2007 (D estak J ornal, 24/ 3/ 2008; G azeta M ercantil, 26/3/2008; DCI - SP, 2/ 4/ 2008 (2); DCI - SP, 16/ 5/ 2008; D iário de S. Paulo, 27/ 5/ 2008; 0 Estado de S. Paulo, 27/6/2008).

A pesar dos problemas enfrentados com a inadimplência em 2007, a Caixa pretende continuar investindo fortemente no segmento de micro e pequenas empresas. 0 regime de gestão foi revisado e foi criada uma vice-presidência exclusiva para pessoas jurídicas.

Para apoiar e incentivar o uso adequado dos recursos, a CEF assinou, em junho de 2008, um convênio com o Serviço Brasileiro de $A$ poio às $M$ icro e Pequenas E mpresas (Sebrae), com o objetivo defortal ecer a capacidade empresarial do empreendedor eaumentar a sua competitividade. 0 Sebrae entrará com os instrumentos de capacitação e a C aixa, com o apoio financeiro às empresas ( $C$ arta C apital, 20/ 7/ 2008). 
À medida que os outros bancos tentam acessar mercados tradicionalmente ocupados pela $C$ aixa, como o crédito consignado e o crédito habitacional direcionado à baixa renda, a instituição avança em segmentos em que sua atuação não era tão expressiva, como as classes média e alta. Essa estratégia foi favorecida pela medida adotada pelo Consel ho C urador do F G TS, que retirou, em outubro de 2007, o limite superior de renda de $\mathrm{R} \$ 4,9$ mil mensais, abrindo a possibilidade de detentores decontas no F G T S há mais de três anos financiarem imóveis de até $\mathrm{R} \$ 350$ mil (Valor E conômico, $31 / 10 / 2007)$. N o segmento derenda mais alta atendido com recursos do F G T S, o chamado Pró-C otista, o fundo decidiu direcionar $70 \%$ dos R \$909 milhões, previstos para 2008, para a Caixa, contrariando os demais bancos (Valor E conômico, 24/ 1/ 2008).

A CEF também pretendeinvestir no crédito consignado, segmento quecresceu com a transferência das operações do Banco BM G . D e junho de 2006 a maio de 2007, o crescimento foi de 46\%. A pesar do aumento do interesse dos demais bancos nesse segmento, ainda há espaço para crescimento dessas operações na C aixa, devido à grande quantidade de clientes aposentados e pensionistas do IN SS (Valor E conômico, 2/ 7/ 2007).

Também faz parte das estratégias da Caixa um programa de internacionalização, que tem como objetivo ampliar a atuação da instituição no segmento de pessoas jurídicas. C om a ampliação das exportações, grande partedos clientes dainstituição passou a buscar outros bancos para fechar operações de câmbio. A ssim, em 2006, a instituição obteve autorização do Banco C entral para operar com câmbio para pessoas jurídicas. 0 banco pretende concentrar sua atuação no segmento de micro e pequenas empresas, que não é o foco da maioria dos outros bancos (Valor E conômico, 21/ 9/2007).

A instituição também passou a disponibilizar financiamentos com A diantamento sobre Contrato de C âmbio (A C C) (Valor E conômico, 21/ 9/2007), com o objetivo deampliar sua participação no financiamento ao comércio exterior. A pretensão da CEF éatingir, em atéseis anos, de 5\% a 6\% departicipação nas operações definanciamento a empresas brasileiras no mercado internacional (DCI - SP, 9/ 11/2007). 
A C aixa ainda tem papel fundamental no Programa de A celeração do C rescimento (PA C), lançado pelo governo federal em 22 de janeiro de 2007, que pretende investir, nos próximos quatro anos, $\mathrm{R} \$ 503,9$ bilhões em infraestrutura. A instituição éa principal responsável pelo financiamento dos investimentos em infraestrutura, habitação e saneamento ambiental, respondendo por $20 \%$ do total de investimentos programados. N o primeiro semestre de 2008, 5.048 municípios, deum total de 5.562, tinham obras federais financiadas pela Caixa. E ssetotal não inclui obras dos M inistérios da Saúdee da Educação (Valor E conômico, 15/ 4/ 2008).

Com o lançamento do Programa, a expectativa é que o crédito oferecido pela instituição cresça consideravelmente. Em 2007, 0 governo disponibilizou $\mathrm{R} \$ 8,8$ bilhões para operações de saneamento e infraestrutura. Para dar vazão a esses valores, oT esouro concedeu crédito especial de $\mathrm{R} \$ 5,2$ bilhões à C aixa, o que permite a elevação do limite de financiamento da empresa. $A$ estimativa é que, no período de 2007 a 2010, cerca de R \$ 106, 3 bilhões passem pela C aixa, com destino ao setor habitacional. D essetotal, $R$ \$55, 9 bil hões serão aplicados em programas e financiamentos para a compra da casa própria para famílias com renda deatécinco salários mínimos (Valor E conômico, 23/ 1/ 2007).

E $m$ 2008, a CEF assumiu uma estratégia de diminuir a importância dos títulos evalores mobiliários em seu bal anço etransferir essas carteiras para operações de crédito. A alta capacidade de ampliar a carteira de crédito pode ser explicada pela forma de captação, de custo menor em relação à dos outros bancos. A lém de contar com uma caderneta de poupança que cresce a taxas recordes, a CEF controla recursos federais, como o $\mathrm{F}$ undo de $\mathrm{G}$ arantia do Tempo de Serviço (F G T S).

Em 21 de outubro de2008, foi editada a M edidaProvisória no 443, que possibilitou ${ }^{12}$ que os bancos públicos comprassem instituições financeiras privadas - inclusive os segmentos de seguros, previdência e capital ização - , além de permitir à C aixa a constituição de um

12 Essa M edida é válida por dois anos, prorrogável por mais dois anos. 
banco de investimento ea aquisição de participação minoritária em empresas da construção civil ou outras que julgar atrativas (Valor E conômico, 23/ 10/2008). A M edida Provisória ainda precisa ser aprovada pela Câmara. A edição dessa medida foi estimulada pelas recentes fusões e aquisições ocorridas no setor, principalmente do U nibanco e I taú, e pela necessidade de ampliação da liquidez do sistema em um período de crise.

A CEF pretendeinvestir na aquisição de cartei ras nos segmentos deleasing, financeiras, corretoras devalores, crédito imobiliário, infraestrutura esaneamento. Em 29 de outubro de 2008, a instituição informou játer adquirido cartei ras decrédito deseis bancos pequenos e médios, concentradas, principalmente, nos segmentos de crédito consignado e debêntures (Valor E conômico, 29/ 10/ 2008).

\section{ABN-Amro}

\section{Histórico e estrutura}

O A BN - A mro é um banco internacional, criado em 1824, na H olanda. A instituição iniciou suas operações no Brasil em 1917, com o nome de Banco H olandês da A mérica do Sul, com escritórios no R io de J aneiro e Santos, e atuação limitada ao financiamento ao comércio exterior.

O banco se expandiu com a combinação de aquisições e crescimento orgânico. Em 1963, adquiriu 50\% do controle da A ymoré de C rédito, Financiamento e I nvestimento, adquirindo o restante da participação em 1970 etornando-se importantefinanciador do consumo. E m 1993, o nome da instituição foi alterado paraA BN - A mro Bank e, em julho de 1998, foi anunciada a compra do Banco R eal, ${ }^{13}$ instituição fundada em 1925. 0 A BN adquiriu, ainda, o Banco de Pernambuco (Bandepe), em 1998, o Banco da Paraíba (Paraiban), em 2001, e o Banco Sudameris, em 2003.

13 A integração das duas instituições foi concluída em 2000. 
A aquisição do Sudameris, queatua no Brasil desde 1910, adicionou mais de 700 mil clientes concentrados nos segmentos demais alta renda, além de ampliar a participação do banco na região Sudeste, principalmenteno E stado deSão Paulo. 0 Banco Sudameristambém adicionou ao $A B N$ serviços de alta qualidade direcionados para os segmentos de pequenas empresas e pessoas físicas premium, além de uma ampla experiência nas operações voltadas para o comércio internacional ena administração de recursos de terceiros.

Em 2007, o A BN - A mro foi adquirido pelo consórcio de bancos formado pelo espanhol Santander, o britânico R oyal Bank of Scotland (RBS) e pelo belgo-holandês Fortis. 0 consórcio dividiu o A BN conforme os interesses geográficos de cada membro do grupo. A divisão envolveu 4.500 agências distribuídas em 53 países. 0 belga F ortis ficou com as operações da $\mathrm{H}$ olanda e com as operações de administração de ativos. 0 britânico R BS ficou com as operações deatacado edebanco de investimento ecom atividades naÁ sia enos EU A . A s operações brasileiras ficaram com o Santander, criando um dos líderes do setor bancário brasileiro. 0 Santander ficou, também, com a unidade italiana do A BN (Valor E conômico, 1/ 10/ 2007).

Em 24 de julho de 2008, o Banco Santander S.A ., com sede na Espanha, passou a exercer efetivamenteo controle societário indireto das empresas do Conglomerado A BN - A mro R eal no Brasil, após a obten ção da aprovação dos Bancos $\mathrm{C}$ entrais da $\mathrm{H}$ oland $\mathrm{a}^{14} \mathrm{edo}$ Brasil. O Banco Santander será a instituição líder dos Conglomerados F inanceiro eE conômico-Financeiro peranteo $\mathrm{Banco} C$ entral do Brasil.

O Banco A BN - A mro R eal S.A. está organizado sob a forma de banco múltiplo autorizado a operar com as carteiras comerciais, inclusive as de operações de câmbio, de investimento, de crédito, financiamento einvestimentos ecrédito imobiliário. $O$ Banco $A B N$ - A mro R eal S.A . éuma subsidiária do A BN -A mro Bank N.V., com sede em A msterdã.

Em 30 dejunho de 2008, o Banco A BN -A mro R eal S.A . detinha $98,6 \%$ do total do capital social da instituição. A s demais ações es-

14 D eN ederlandsche Bank. 
tavam distribuídas entre o A BN - A mro A sset $M$ anagement $(0,3 \%)$, R eal C apitalização S.A . (0,5\%) eR eal T okio $M$ arineV ida ePrevidênciaS.A . (0,6\%). 0 conjunto de instituições que conduz as operações do banco faz parte da estrutura do Conglomerado e atua de forma integrada no mercado financei ro, de previdência e capitalização.

\section{Rede de atendimento}

Em junho de 2008, o A BN contava com 34 mil funcionários e 8,6 mil pontos de vendas, sendo 1.148 agências, além de pontos de atendimento bancário, $129 \mathrm{~L}$ ojas C onsumer (A ymoré) erede Banco-24H oras. A instituição disponibiliza, ainda, 10 mil caixas eletrônicos e 1,4 mil correspondentes bancários, além do R eal I nternet Banking, o D isque R eal (atendimento telefônico) e o Real W A P Banking (atendimento via celular). 0 atendimento por canais el etrônicos éo que mais vem crescendo nos últimos anos. ${ }^{15}$

A s agências estão local izadas, principalmente, na região sudeste, seguida pelas regiões $\mathrm{N}$ ordesteeSul, com uma participação de $63,6 \%$, $14,7 \%$ e 9,5\%, respectivamente. (G ráfico I.5.1).

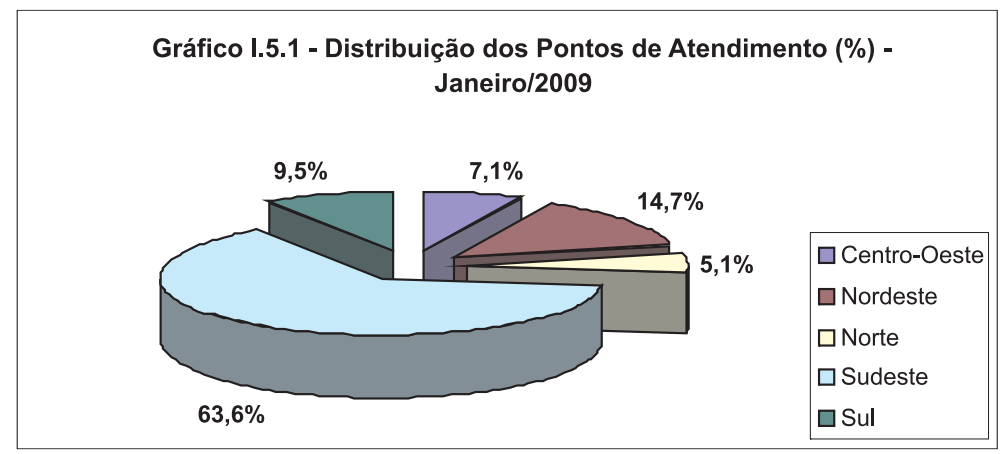

Fonte: Elaboração própria a partir de dados extraídos do site da Febraban.

15 Em 2006, através dos canais R eal I nternet Banking, D isque R eal eAT M s, foram captados pela instituição $\mathrm{R}$ \$ 6,5 bilhões em depósitos e fundos, e concedidos quase $R$ \$,7 bilhões em empréstimos. 
A s parcerias com correspondentes bancários constituem importante canal de distribuição dos produtos. Em 2006, o volume de processamento por intermédio de correspondentes respondeu por $29,3 \%$ de todos os recebimentos do banco, contribuindo para a el evação da capilaridade da rede.

O A BN - A mro R eal oferece, ainda, um portfolio completo de produtos de seguro, vida e previdência. $\mathrm{N}$ a área internacional, a instituição oferece financiamentos e serviços de comércio exterior, câmbio egarantias internacionais. São disponibilizados, por meio da internet, dados completos, em tempo real, sobre o fluxo de câmbio e a documentação pertinente às operações de comércio exterior do cliente.

\section{Base de clientes}

O A BN possui 13,1 milhões de clientes (Valor E conômico, 1/ 10/ 2007), sendo 4,2 milhões decorrentistas. A atuação do A BN - A mro R eal segueuma estratégia de segmentação, sendo quea gestão do relacionamento com clientes se organiza em três grandes áreas de negócios: Varejo, A ymorée E mpresas.

$\mathrm{N}$ o Varejo, o banco atende pessoas físicas e pequenas empresas. O s correntistas pessoas físicas são agru pados em três segmentos, de acordo com a renda pessoal eo nível de relacionamento que mantêm com o A BN -A mro R eal: Clássico, Especial e Van G ogh. ${ }^{16}$ Pessoas físicas de alta renda têm também à disposição a divisão de $P$ rivate B anking.

A instituição vem aumentando sua atuação junto ao segmento de pequenas empresas, o quevem sendo acompanhado pela introdução de melhorias de produtos e processos e pela adoção de ferramentas refinadas de avaliação de risco e de conceitos de cadeia de valor e gestão de carteira. A instituição também se propõe a oferecer a esse

160 serviço preferencial Van G ogh foi lançado em 2003, adaptando para o Brasil uma experiência bem-sucedida do A BN -A mro na Á sia. 
segmento produtos que, tradicionalmente, sedestinavam apenas às grandes corporações, como lançamento de debêntures, eurobonds e ações.

Por meio da A ymoré, o A BN oferece produtos definanciamento ao consumo, principalmente para a aquisição de veículos. Posicionada como uma das líderes entre as financeiras do país, a A ymoré também oferece as linhas de C rédito $D$ ireto ao Consumidor (CD C), empréstimos pessoais (Club C ard), consórcio de veículos eimóveise financiamento deveículos pesados (caminhões emáquinas agrícolas). A financeira identifica grande potencial de crescimento em veículos pesados e iniciou a atuação nesse segmento firmando acordos com as principais montadoras do país.

0 processo desolidificação da A ymorédeu-sea partir da estratégia de foco no relacionamento com os revendedores independentes, aqueles que trabalham com variadas marcas e não estão atrelados às redes de concessionárias das montadoras. Essa parceria trouxe vantagens para todos os participantes. A financeira encontrava espaço para crescimento em um mercado de baixa concorrência, os revendedores passavam a ter meios formais de financiar suas vendas e os clientes tinham mais opções para a compra de veículos a prazo.

A o identificar a tendência de consolidação do mercado, a A ymoré revisou sua estratégia para contemplar, também, as concessionárias das montadoras. D essa forma, foram firmadas parcerias com diversas redes deconcessionárias, sobretudo dos fabricantes que chegaram ao B rasil a partir do final dos anos 90 . $N$ esse segmento, a A ymoréatua também por meio daW ebM otors, maior portal brasilei ro da indústria automotiva, adquirida pelo banco em 2002. 0 portal engloba toda a cadeia desse setor, desde montadoras e fábricas de autopeças até anunciantes, revendedores e clientes finais, que têm à disposição os produtos de financiamento da A ymoré.

U tilizando essa experiência adquirida no mercado automotivo, o A BN passou a oferecer financiamento para aquisição de outros bens. A dotou, então, al gumas premissas quesustentaram o crescimento da A ymoré: a distribuição por revendedores e a opção por produtos de 
maior valor agregado e, portanto, passíveis de pagamento parcelado de longo prazo. T otal mente alinhados a essas características, três segmentos acabaram se solidificando nos últimos anos: móveis de alto padrão, pacotes turísticos e computadores.

N o segmento deE mpresas, por sua vez, o banco atende médiase grandes empresas, oferecendo uma gama de soluções financeiras, de banco comercial e banco de investimento. N o segmento de grandes corporações, o A BN -A mro Brasil atende multinacionais brasileiras e estrangeiras, desenvolvendo soluções específicas ecustomizadas para atender às necessidades das estratégias de negócios de seus clientes corporativos, incluindo assessoria em operações de fusão e aquisição e operações de project finance. ${ }^{17}$

Como parte de um grandegrupo financeiro internacional, o banco também permite aos clientes acesso global e experiência de atuação nos mais importantes mercados financeiros e de capitais, participando de transações estratégicas e da consolidação de grandes empresas dos principais setores econômicos no país.

D esde maio de 2005 a instituição retomou as atividades no mercado de capitais de renda variável, atuando em joint venture com o R othschild, o que permitiu que o A BN passasse a atuar em dez países. Presta serviços de assessoria, orientando empresas na abertura de capital eoferta secundária deações, ena organização e no preparo para exposição a um novo ambiente operacional. Em 2006, o banco participou de 16 ofertas iniciais deações I PO seliderou uma operação no setor de construção civil.

Por meio do A BN - A mro A sset M anagement, a instituição oferece fundos e carteiras administradas para atender às diferentes necessidades deinvestimentos dos clientes dos segmentos devarejo, private banking, empresas, investidores institucionais eseguradoras. O A BN -A mro A sset M anagement está presenteem 24 países e, em 2006, administrava global mente 193 bilhões de euros.

17 Financiamento de projetos em que a estrutura financeira e de garantias é assegurada exclusivamente pelo próprio projeto em desenvolvimento. 


\section{Captações}

A principal forma de captação do A BN são os D epósitos a Prazo, modalidade responsável por $55,1 \%$ do total de recursos captados (Tabela I.5.1). A redução dessa forma de captação em 2006 e 2007 foi resultado da oferta de novos produtos de investimento na rede de atendimento.

Tabela I.5.1 - Composição das C aptações (em \%)

\begin{tabular}{c|c|c|c|c|c|c|c|c}
\hline D ata & À V ista & Poupança & Interfin. & $\begin{array}{c}\text { A } \\
\text { Prazo }\end{array}$ & O utros & $\begin{array}{c}\text { D epósitos } \\
\text { Totais }\end{array}$ & $\begin{array}{c}\text { C ap. } \\
\text { M ercado } \\
\text { A berto }\end{array}$ & $\begin{array}{c}\text { Total } \\
\text { (em R \$ } \\
\text { bilhões) }\end{array}$ \\
\hline dez./ 97 & 1,6 & 0,0 & 16,7 & 61,8 & 0,0 & 80,1 & 19,9 & 0,9 \\
\hline dez./ 98 & 1,7 & 0,0 & 7,8 & 73,3 & 0,0 & 82,8 & 17,2 & 1,6 \\
\hline dez./ 99 & 16,0 & 42,8 & 1,3 & 22,4 & 0,0 & 82,5 & 17,5 & 10,3 \\
\hline dez./ 00 & 18,1 & 39,3 & 1,1 & 17,3 & 0,0 & 75,8 & 24,2 & 11,1 \\
\hline dez./ 01 & 23,0 & 39,4 & 0,8 & 19,5 & 0,0 & 82,7 & 17,3 & 11,4 \\
\hline dez./ 02 & 20,5 & 32,7 & 0,5 & 43,1 & 0,0 & 96,8 & 3,2 & 16,3 \\
\hline dez./ 03 & 13,3 & 21,7 & 1,7 & 54,5 & 0,4 & 91,6 & 8,4 & 29,2 \\
\hline dez./ 04 & 12,6 & 19,9 & 1,3 & 58,7 & 0,3 & 92,8 & 7,2 & 34,9 \\
\hline dez./ 05 & 11,4 & 15,1 & 1,1 & 66,1 & 0,3 & 94,0 & 6,0 & 48,2 \\
\hline dez./ 06 & 10,6 & 12,6 & 1,0 & 58,8 & 0,3 & 83,3 & 16,7 & 66,2 \\
\hline dez./ 07 & 13,1 & 15,0 & 1,3 & 45,7 & 0,4 & 75,5 & 24,5 & 70,9 \\
\hline jun./ 08 & 9,3 & 12,2 & 1,3 & 55,1 & 0,2 & 78,1 & 21,9 & 90,1 \\
\hline $\begin{array}{l}\text { C resc. } \\
\text { (em \%) }\end{array}$ & $56.885,7$ & $151,3^{1}$ & 630,0 & $8.429,6$ & $58.896,0$ & $9.211,0$ & $10.491,6$ & $9.464,6$ \\
\hline
\end{tabular}

1) Crescimento de dezembro/ 1999 a junho/ 2008.

Fonte: Elaboração própria a partir de dados extraídos do site do Banco C entral do Brasil.

A s C aptações de M ercado A berto, por sua vez, respondem por $21,9 \%$ do total de recursos captados pelo banco, sendo que essa participação vem apresentando crescimento significativo desde 2006.

O sD epósitos à $V$ ista e os $D$ epósitos de Poupança passaram a ter uma maior participação a partir de 1999, principalmente devido à aquisição do Banco R eal. A tualmente, essas modalidades representam, respectivamente, 9,3\% e $12,2 \%$ do total de recursos captados. 


\section{Carteira de crédito}

A carteira de $C$ rédito e A rrendamento $M$ ercantil atingiu $R \$ 60$ bilhões em junho de 2008, um crescimento significativo em relação a dezembro de 2007 , de $62,6 \%$ em apenas seis meses. $N$ o período de 1999 a 2005, a carteira apresentou crescimento, decrescendo nos anos de 2006 e 2007 (G ráfico I.5.2).

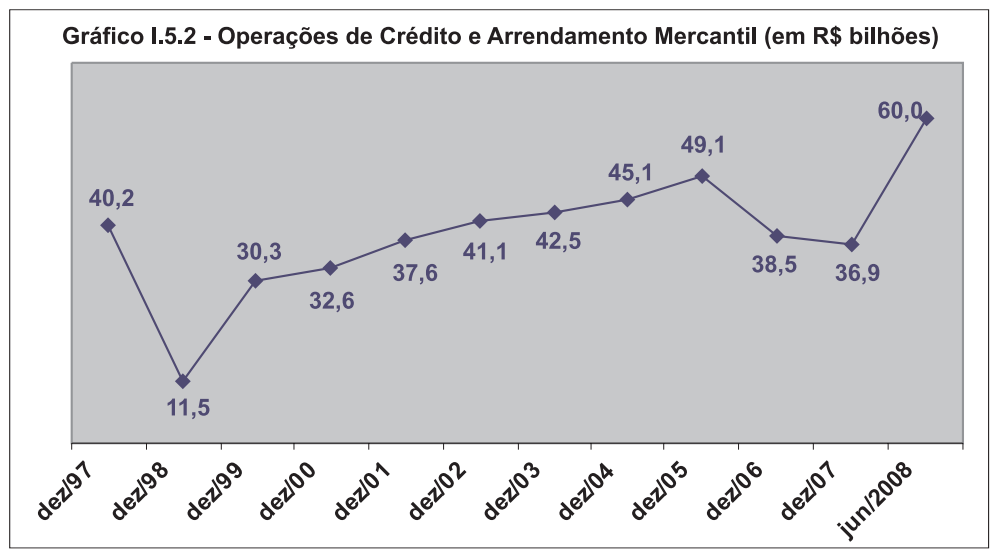

Fonte: Elaboração própria a partir de dados extraídos do site do Banco C entral do Brasil.

O s segmentos em que a instituição mais atua são Pequenas E mpresas eV eículos, que responderam por $27,2 \%$ e $26 \%$ do sal do da carteira de crédito em 2007. A participação do segmento de G randes E mpresas, por sua vez, vem diminuindo nos últimos anos, atingindo, em 2007, 4,4\% do saldo da carteira de crédito (Tabela I.5.2). Essa redução pode ser explicada, principalmente, pela maior liquidez observada no mercado decapitais, que possibilitou queessas empresas optassem pela diversificação das suas fontes de financiamento. Como consequência, a carteira de grandes empresas registrou uma retração de 33,8\% em relação a 2005.

O segmento deM édias $E$ mpresas também tem uma participação relevante, sendo o segmento quemais cresceu desde2005. E m 2007, esse grupo respondeu por $20,3 \%$ do saldo da carteira de crédito, contra 18,8\% em 2006 e 16,5\% em 2005 (Tabela I.5.2). 
Tabela I.5.2 - Composição da C arteira de C rédito (\%)

\begin{tabular}{l|c|c|c|c}
\hline & $\mathbf{2 0 0 5}$ & $\mathbf{2 0 0 6}$ & $\mathbf{2 0 0 7}$ & C resc. \\
\hline Pessoa Jurídica & 51,6 & 52,2 & 51,9 & 68,2 \\
\hline G randes Empresas & 11,0 & 8,4 & 4,4 & $-33,8$ \\
\hline M édias Empresas & 16,5 & 18,8 & 20,3 & 106,2 \\
\hline Pequenas Empresas & 24,1 & 25,0 & 27,2 & 8,8 \\
\hline Pessoa Física & 44,4 & 43,7 & 43,7 & 64,9 \\
\hline Cartões & 1,2 & 1,1 & 1,1 & 53,4 \\
\hline Veículos & 24,7 & 25,8 & 26,0 & 76,1 \\
\hline Varejo Bancário & 14,7 & 13,2 & 12,3 & 40,0 \\
\hline Financiamento ao Consumo & 3,8 & 3,6 & 4,3 & 89,3 \\
\hline Crédito Imobiliário & 4,0 & 4,1 & 4,4 & 81,9 \\
\hline Fote Elabráno proria
\end{tabular}

Fonte: Elaboração própria a partir de dados extraídos do site do Banco A BN - A mro R eal.

E $m$ 2007, o segmento dePessoas F ísicas respondeu por 43,7\% do total da carteira de crédito. A maioria dos financiamentos é direcionada para aquisição deveículos, por meio da financeira A ymoré. A s modalidades que vêm apresentando maior crescimento são crédito pessoal, crédito consignado, financiamento debens duráveis, financiamento de veículos e crédito habitacional.

0 crédito consignado começou a ser trabal hado pelo Banco R eal nos anos 90, a partir da forte presença que possuía no setor público. A tualmente, a estratégia do banco nesse segmento é focar os funcionários públicos e deempresas privadas. Em 2007, a participação desse segmento na carteira de crédito total atingiu $6 \%$.

Seguindo uma tendência do setor bancário, a base de cartões da instituição vem crescendo consideravel mente. Esseaumento decorre deuma oferta ampliada para todos os segmentos, incluindo pequenas emédias empresas enão correntistas. Essa modalidaderepresentou, em 2007, 1,1\% do total da carteira de crédito da instituição.

O setor imobiliário, por sua vez, respondeu por 4,4\% do saldo da carteira de crédito do A BN em 2007. A instituição considera que 0 mercado imobiliário possui potencial de crescimento e posiciona-se nesse setor com uma proposta completa, visando atender toda a cadeia defornecimento, oferecendo desde produtos de financiamento 
imobiliário para pessoas físicas e empresas até soluções de desintermediação da indústria por meio de estruturas de securitização de recebíveis imobiliários. 0 banco vem investindo no atendimento personalizado a construtoras eimobiliárias eem linhas diferenciadas para os clientes.

O crescimento da carteira Pessoa Jurídica, por sua vez, foi impulsionado, principalmente, pelo crédito a pequenas e médias empresas, as quais foram ampliadas devido à maior disponibilidade de produtos de financiamento e ao acesso a novos mercados e novas formas de financiamento. Essa ampliação foi acompanhada pela adoção de ferramentas mais refinadas de avaliação de risco e de conceitos de cadeia de valor e gestão de carteira. A lém disso, a introdução de melhorias de produtos e processos e a ampliação de investimentos em tecnologia vêm permitindo ao banco aumentar a rentabilidade dessas operações, por meio da ampliação do escopo dos produtos oferecidos, do incremento no número de clientes e, consequentemente, do fluxo financeiro transacionado.

0 crédito para empresas médias, por sua vez, foi impulsionado pela elevada oferta definanciamento ao comércio exterior, pela maior oferta de produtos e pela maior demanda por parte desses clientes, com destaque para operações del easing, financiamento de máquinas e equipamentos e capital de giro. O A BN disponibilizou operações mais sofisticadas, como reestruturação de passivos e de mercado de capitais. A instituição apoiou empresas brasileiras em seu processo de internacionalização, estruturou bonds ${ }^{18}$ com prazos de até dez anos, e coordenou eliderou operações de mercado de capitais.

O A BN -A mro Brasil também tem forte atuação no mercado de financiamento ao comércio exterior. São tomadoras desses recursos tanto as grandes corporações quanto as médias e pequenas empresas exportadoras e, em menor proporção, importadoras. No âmbito interno, o A BN -A mro Brasil também é um importante agente repassador de recursos do BN DES.

18 T ítulos de renda fixa distribuídos no mercado internacional. 
Com relação ao índice de inadimplência, este tem se mantido baixo, apesar do crescimento da carteira de crédito. E m dezembro de 2007, esse índice atingiu 2,8\%, contra 3,2\% em dezembro de 2006. 0 aumento de 2006 foi provocado, principalmente, pela maior inadimplência da carteira de crédito de Pessoas Físicas (Tabela I.5.3).

T abela I .5.3 - Índice del nadimplência - A cima de 90 dias (\%)

\begin{tabular}{l|c|c|c|c}
\hline & dez./ 04 & dez./ 05 & dez./ 06 & dez./ 07 \\
\hline Total & 2,8 & 2,8 & 3,2 & 2,8 \\
\hline Recursos L ivres - Pessoa Física & 4,0 & 3,8 & 4,7 & 4,4 \\
\hline Recursos L ivres - Pessoa Jurídica & 1,6 & 1,8 & 1,9 & 1,5 \\
\hline
\end{tabular}

Fonte: Elaboração própria a partir de dados extraídos do site do Banco A BN -A mro R eal.

\section{Gestão de riscos}

A gestão deriscos do A BN -A mro R eal abrange a gestão dos riscos de crédito, mercado, liquidez, operacional, socioambiental e de reputação, eocorre demaneira integrada, por meio deuma estrutura de comitês, envolvendo a alta e média administração e as diversas áreas de negócios e infraestrutura.

A s políticas decrédito estabel ecem comitês eal çadas deaprovação para clientes pessoa física e empresas, com modelos e ferramentas de gestão desenvolvidos de forma a capturar a realidade brasileira. O s comitês têm responsabilidade de monitorar e agir sobre a concentração de riscos em segmentos, produtos e setores econômicos.

O gerenciamento de risco de capital busca otimizar a relação risco/ retorno, de forma a minimizar perdas, por meio de estratégias de negócios bem definidas, procurando maior eficiência na composição dos fatores que impactam no Í ndice de Solvência - Basileia. A instituição administra o risco de mercado, bem como a liquidez e o risco operacional, de forma alinhada com o modelo internacional adotado pelo G rupo A BN -A mro N .V. 
0 Índice de Solvabilidade atingiu 13,62\% em junho de 2008. A pesar de ter se mantido acima do mínimo exigido pelo Banco C entral, de $11 \%$, o índicetem apresentado tendência de queda desde 2005 (G ráfico l.5.3).

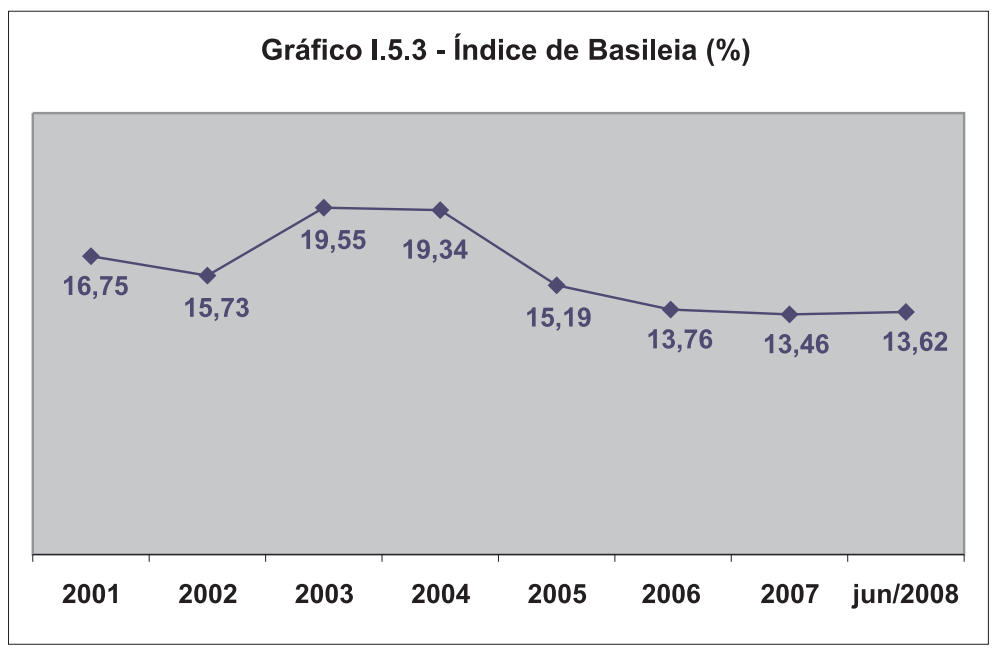

Fonte: Elaboração própria a partir de dados extraídos do site do Banco C entral do Brasil.

D evido ao aumento da concessão de crédito eao direcionamento para segmentos de maior risco ocorridos nos últimosanos, a instituição tem adotado a estratégia de elevar as reservas de provisão para créditos de liquidação duvidosa, com o objetivo de minimizar os impactos da inadimplência.

0 crescimento da oferta decrédito para pessoas físicas foi baseado na abordagem do $C$ rédito $C$ erto, adotado como alicerceem ferramentas de avaliação do risco comportamental do cliente. 0 incremento da carteira de pequenas e médias empresas dá-se a partir da análise de toda a cadeia de empresas efornecedores que envolvem o cliente.

Em junho de 2008, 92,6\% das operações estavam concentradas nos níveis A A , A , B eC , não sofrendo alterações significativas desde 2000. D estaca-se o significativo crescimento das operações classificadas no nível de risco "A A", que atingiu 41,3\% em junho de 2008, contra 7,5\% em dezembro de 2000 (T abela I.5.4). 
Tabelal .5.4 - Composição da Carteira de C rédito por N ível de R isco (\%)

\begin{tabular}{c|c|c|c|c|c|c|c|c|c}
\hline & $\mathbf{2 0 0 0}$ & $\mathbf{2 0 0 1}$ & $\mathbf{2 0 0 2}$ & $\mathbf{2 0 0 3}$ & $\mathbf{2 0 0 4}$ & $\mathbf{2 0 0 5}$ & $\mathbf{2 0 0 6}$ & $\mathbf{2 0 0 7}$ & jun./ 08 \\
\hline A A & 7,5 & 12,3 & 15,1 & 18,1 & 15,5 & 46,3 & 44,3 & 40,8 & 41,3 \\
\hline A & 70,9 & 46,8 & 41,1 & 43,8 & 40,2 & 34,7 & 35,2 & 35,0 & 34,2 \\
\hline B & 12,8 & 27,3 & 30,1 & 21,2 & 29,9 & 6,4 & 7,1 & 11,4 & 10,9 \\
\hline C & 2,6 & 5,2 & 7,0 & 7,4 & 7,9 & 5,9 & 5,7 & 5,8 & 6,1 \\
\hline D & 0,8 & 1,8 & 2,0 & 2,9 & 1,7 & 1,6 & 1,8 & 1,4 & 1,6 \\
\hline E & 0,6 & 0,8 & 0,6 & 1,4 & 0,8 & 1,1 & 1,3 & 1,4 & 1,5 \\
\hline F & 0,7 & 0,7 & 0,5 & 0,9 & 0,5 & 0,7 & 0,7 & 0,6 & 0,8 \\
\hline G & 0,4 & 1,0 & 0,4 & 0,9 & 0,6 & 0,6 & 0,6 & 0,6 & 0,6 \\
\hline H & 3,7 & 4,1 & 3,1 & 3,4 & 2,9 & 2,9 & 3,3 & 3,0 & 3,0 \\
\hline A A - C & 93,8 & 91,6 & 93,3 & 90,6 & 93,5 & 93,2 & 92,3 & 93,0 & 92,6 \\
\hline
\end{tabular}

Fonte: Elaboração própria a partir de dados extraídos do site do Banco A BN -A mro R eal.

\section{Índices de cobertura e de eficiência}

O ÍndicedeC obertura das D espesas dePessoal cresceu significativamente nos últimos anos, seguindo uma tendência observada em todo o setor bancário. Em junho de2008, esseíndiceatingiu 113,7\%, contra 9,6\% em 1997 (Tabela I.5.5).

Essecrescimento foi resultado deum aumento dequase $22.000 \%$ daR eceita dePrestação deServiços, contrauma ampliação de $1.700 \%$ nas D espesas de Pessoal. 0 crescimento das R eceitas de Prestação de Serviços foi impulsionado, principalmente, pela ampliação da base de clientes, do número de transações financeiras, dos serviços de cobrança, da concessão de crédito, das atividades de banco de investimento e das receitas com cartões. A s receitas com cartões, por sua vez, foram impulsionadas pelo aumento da base de cartões emitidos, do número de estabelecimentos credenciados, da oferta segmentada, atingindo um grupo maior declientes, edo uso demeios eletrônicos de pagamento.

Em 2007, a receita com cartões representou 20,3\% da R eceita de Prestação deServiços total, sendo queas T arifas Bancárias e 0 utras Tarifas e C omissões representaram $68 \%$ (G ráfico I.5.4). 
Tabelal .5 .5 - Í ndice de C obertura (em R \$ milhões)

\begin{tabular}{l|c|c|c|c|c|c|c|c|c|c|c|c}
\hline & $\mathbf{1 9 9 7}$ & $\mathbf{1 9 9 8}$ & $\mathbf{1 9 9 9}$ & $\mathbf{2 0 0 0}$ & $\mathbf{2 0 0 1}$ & $\mathbf{2 0 0 2}$ & $\mathbf{2 0 0 3}$ & $\mathbf{2 0 0 4}$ & $\mathbf{2 0 0 5}$ & $\mathbf{2 0 0 6}$ & $\mathbf{2 0 0 7}$ & jun./ 08 \\
\hline $\begin{array}{l}\text { Rec. } \\
\begin{array}{l}\text { Prestação } \\
\text { Serviços }\end{array}\end{array}$ & 15 & 37 & 650 & 849 & 960 & 1.111 & 1.586 & 1.974 & 2.299 & 2.742 & 3.311 & 1.647 \\
\hline $\begin{array}{l}\text { Despesa } \\
\text { de } \\
\text { Pessoal }\end{array}$ & 156 & 182 & 937 & 1.251 & 1.278 & 1.586 & 1.962 & 2.259 & 2.492 & 2.421 & 2.806 & 1.449 \\
\hline $\begin{array}{l}\text { Indice de } \\
\begin{array}{l}\text { Cobertura } \\
\text { (\%) }\end{array}\end{array}$ & 9,6 & 20,3 & 69,4 & 67,9 & 75,1 & 70,1 & 80,8 & 87,4 & 92,3 & 113,3 & 118,0 & 113,7 \\
\hline
\end{tabular}

Fonte: Elaboração própria a partir de dados extraídos do site do Banco A BN -A mro R eal.

Gráfico I.5.4 - Composição das Receitas de Prestação de Serviços (em \%)

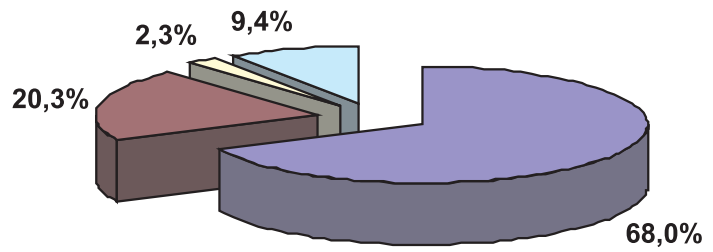

$\square$ Tarifas Bancárias e Outras Tarifas e Comissões

$\square$ Cartões

$\square$ Corretagem de Seguros

$\square$ Administração de Recursos de Terceiros

Fonte: Elaboração própria a partir de dados extraídos do site do Banco A BN - A mro R eal.

O ÍndicedeEficiênciavem melhorando continuamente, com exceção do ano de 2004, em queesseíndiceaumentou, ou seja, piorou. E m 2007, o A BN atingiu um Índice de E ficiência de 49,6\% contra $67,6 \%$ em 2000 (G ráfico 1.5 .5 ).

0 maior índice em 2004 foi resultado de dispêndios mais elevados em tecnologia, da depreciação de novos investimentos e do treinamento e comunicação que visaram à equiparação de sistemas e equal ização de processos, padrões de atendimento e canais de distribuição do Banco R eal e do Banco Sudameris. 


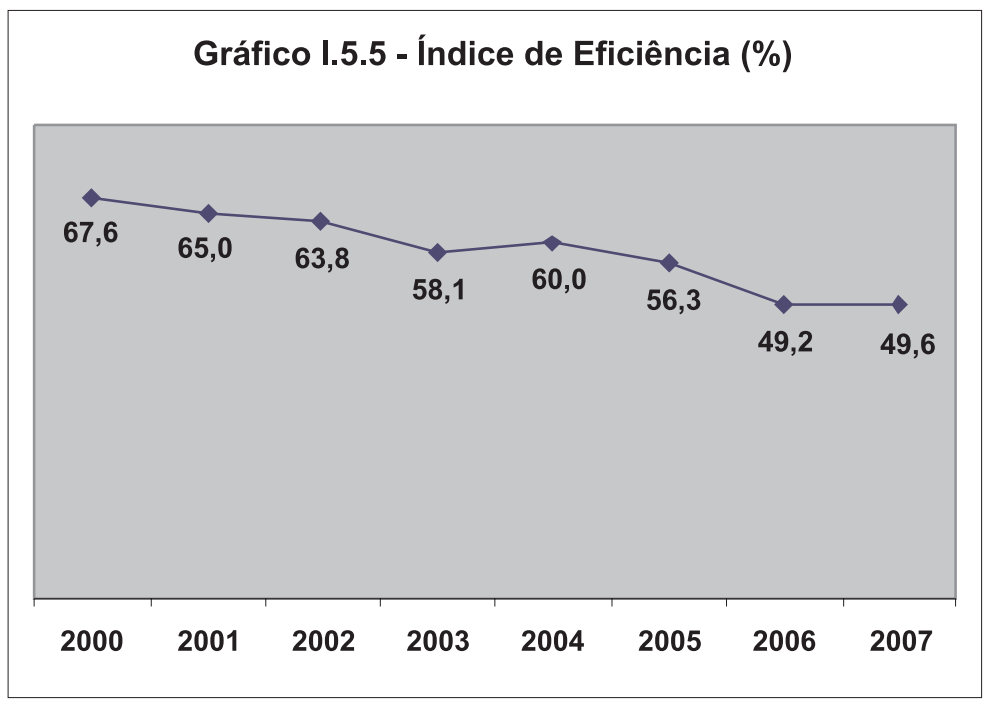

Fonte: Elaboração própria a partir de dados extraídos do site do Banco A BN -A mro R eal.

A melhoria do Índice de E ficiência em todos os outros anos foi resultado deuma combinação da expansão das atividades decrédito e do incremento das receitas de prestação de serviços gerados por uma base maior de clientes e pelo aprofundamento do relacionamento com clientes.

Composição dos ativos e das receitas de intermediação financeira

Em junho de2008, a instituição al cançou um total deativos deR \$ 164,2 bilhões. D essetotal, 36,6\% representam 0 perações de C rédito e A rrendamento $\mathrm{M}$ ercantil e 14,3\% representam T ítulos eValores M obiliários (TVM ) el nstrumentos Financeiros D erivativos. A participação das 0 perações de C rédito vinha crescendo desde 1999 - ano em que o A BN adquiriu o Banco R eal -, mas a partir de 2006 essa participação começou a decrescer. A carteira deT V M el nstrumentos Financei ros D erivativos começou a decrescer em 2005 (T abelal .5.6). 
Tabela I .5.6 - Composição dos A tivos (em \%)

\begin{tabular}{|c|c|c|c|c|c|c|}
\hline D ata & $\begin{array}{l}\text { A plicações } \\
\text { Interfin. }\end{array}$ & $\begin{array}{l}\text { TVM } \\
\text { elnstr. } \\
\text { Financ. } \\
\text { D eriv. }\end{array}$ & $\begin{array}{l}\text { Op. de } \\
\text { Crédito e } \\
\text { Arrend. } \\
\text { M erc. }\end{array}$ & $\begin{array}{l}\text { O utros } \\
\text { C réditos }\end{array}$ & O utros ${ }^{1}$ & $\begin{array}{l}\text { A tivo T otal } \\
\text { (em } \\
\mathrm{R} \$ \text { bilhões) }\end{array}$ \\
\hline dez./ 97 & 4,0 & 16,7 & 40,2 & 16,8 & 22,3 & 4,6 \\
\hline dez./ 98 & 14,9 & 10,9 & 11,5 & 8,5 & 54,2 & 8,6 \\
\hline dez./ 99 & 5,4 & 16,8 & 30,3 & 13,1 & 34,4 & 25,4 \\
\hline dez./ 00 & 7,9 & 19,7 & 32,6 & 14,8 & 25,0 & 28,9 \\
\hline dez./ 01 & 4,0 & 30,4 & 37,6 & 13,9 & 14,1 & 32,1 \\
\hline dez./ 02 & 1,0 & 23,6 & 41,1 & 16,4 & 17,9 & 36,4 \\
\hline dez./ 03 & 2,0 & 24,1 & 42,5 & 15,3 & 16,1 & 54,5 \\
\hline dez./ 04 & 2,3 & 23,9 & 45,0 & 12,8 & 16,0 & 59,2 \\
\hline dez./ 05 & 4,2 & 19,7 & 49,1 & 12,2 & 14,8 & 74,6 \\
\hline dez./ 06 & 7,6 & 17,6 & 38,5 & 24,9 & 11,4 & 119,2 \\
\hline dez./ 07 & 5,7 & 10,3 & 36,9 & 34,3 & 12,8 & 158,7 \\
\hline jun./ 08 & 9,6 & 14,3 & 36,6 & 22,7 & 16,8 & 164,2 \\
\hline Cresc. (\%) & $8.552,7$ & $2.930,8$ & $3.136,2$ & $4.710,3$ & $2.574,6$ & 3469,6 \\
\hline
\end{tabular}

1) Inclui D isponibilidades, Relações Interfinanceiras, R elações de Interdependências, Provisão para C réditos de L iquidação $\mathrm{D}$ uvidosa, $\mathrm{O}$ utrosValores e Bens, I mobilizado de A rrendamento ePermanente.

Fonte: Elaboração própria a partir de dados extraídos do site do Banco C entral do Brasil.

$O$ valor total deativos do A BN vem crescendo significativamente nos últimos anos. As principais causas deste crescimento foram a expansão da carteira de crédito, da carteira de câmbio, do saldo das operações com T V M edas aplicações interfinanceiras (Tabelal .5.6). Essas ampliações foram possibilitadas pel as aquisições efetuadas no período, com destaque para a aquisição do B anco R eal em 1998 e do Banco Sudameris em 2003.

Em junho de 2008, a carteira de Títulos eValores M obiliários atingiu $R \$ 23,4$ bilhões, sendo composta, principalmente, por títulos públicos. Em dezembro de 2007, os títul os públicos representavam $60,8 \%$ do total da carteira, contra $24,2 \%$ dos títulos privados e $15 \%$ dos derivativos (Tabela I.5.7). 
Tabela I .5.7 - Composição da C arteira deT ítulos eValores M obiliários (em \%)

\begin{tabular}{l|c|c|c}
\hline & $\mathbf{2 0 0 5}$ & $\mathbf{2 0 0 6}$ & $\mathbf{2 0 0 7}$ \\
\hline Títulos Públicos & 73,0 & 67,6 & 60,8 \\
\hline Títulos Privados & 15,5 & 22,7 & 24,2 \\
\hline Derivativos & 11,5 & 9,7 & 15,0 \\
\hline
\end{tabular}

Fonte: Elaboração própria a partir de dados extraídos do site do Banco A BN -A mro R eal.

N osúltimosanos, entretanto, a carteira deT V M vem apresentando mudanças em sua composição. A carteira detítulos privados vem aumentando sua partici pação em relação à carteira detítulos públicos.

Com relação às R eceitas de Intermediação Financeira, as 0 perações de $C$ rédito eA rrendamento $M$ ercantil são as que apresentam maior participação. E m junho de 2008, essas operações representaram $76,1 \%$ do total das receitas, contra $15,4 \%$ das 0 perações com T ítulos eValores M obiliários (T abela I.5.8).

T abela I .5.8 - C omposição das R eceitas de Intermediação Financeira (\%)

\begin{tabular}{l|c|c|c|c}
\hline & $\begin{array}{c}\text { O p. de C réd. e } \\
\text { Arrend. M ercantil }\end{array}$ & $\begin{array}{c}\text { O perações com } \\
\text { T V M }\end{array}$ & O utros $^{\mathbf{1}}$ & $\begin{array}{c}\text { T otal } \\
\text { (em R \$ bilhões) }\end{array}$ \\
\hline 1997 & 91,2 & 5,1 & 3,7 & 1,2 \\
\hline 1998 & 76,4 & 22,4 & 1,2 & 2,0 \\
\hline 1999 & 61,6 & 25,2 & 13,2 & 7,4 \\
\hline 2000 & 74,2 & 21,5 & 4,3 & 6,1 \\
\hline 2001 & 72,3 & 22,9 & 4,8 & 7,2 \\
\hline 2002 & 55,3 & 35,1 & 9,6 & 10,6 \\
\hline 2003 & 80,6 & 19,0 & 0,4 & 9,1 \\
\hline 2004 & 77,9 & 19,1 & 3,0 & 10,9 \\
\hline 2005 & 74,3 & 17,2 & 8,5 & 14,0 \\
\hline 2006 & 73,4 & 18,4 & 8,2 & 17,7 \\
\hline 2007 & 73,2 & 20,0 & 6,8 & 21,1 \\
\hline 1 -5 2008 & 76,1 & 15,4 & 8,5 & 12,0 \\
\hline Cresc. (\%) & $1.367,3$ & $7.076,1$ & $3.260,4$ & $1.658,3$ \\
\hline 1 In & & &
\end{tabular}

1) Inclui O perações com Instrumentos Financeiros D erivativos, 0 perações de Câmbio e A plicações Compulsórias.

Fonte: Elaboração própria a partir de dados extraídos do site do Banco Central do Brasil.

N o período de 1997 a 2007, as receitas originadas das 0 perações com T V M foram as que mais cresceram, com uma ampliação de $7.076,1 \%$, contra $1.367,3 \%$ das 0 perações de C rédito e A rrendamento $\mathrm{M}$ ercantil. 
N os últimos anos, o crescimento das R eceitas de Intermediação Financeira vem sendo impulsionado, principalmente, pelos resultados nas operações de seguros, previdência e capitalização e pela expansão do crédito, especial mentenos segmentos de pessoas físicas e de pequenas empresas. Essecrescimento também está associado à estratégia orientada para o desenvolvimento denegócios com clientes e as aquisições e investimentos na expansão orgânica, que resultaram em uma ampliação da base de clientes, de contas-correntes e da capilaridade e disponibilidade da rede de distribuição (por meio da introdução de novas formas de acesso aos serviços bancários, como os serviços via celular e internet).

\section{Resultados}

No primeiro semestre de 2008, o lucro do Banco A BN -A mro foi deR $\$ 900$ milhões. $A$ instituição fechou o ano de2007 com um lucro líquido de $R \$ 2,6$ bilhões ( $G$ ráfico I .5.6), o maior já registrado desde a instalação do banco no Brasil.

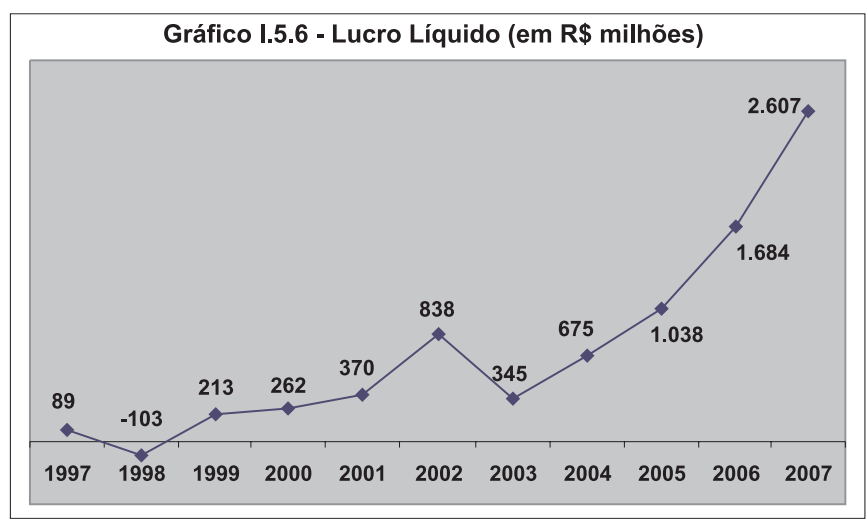

Fonte: Elaboração própria a partir de dados extraídos do site do Banco C entral do Brasil.

Contribuíram para esse resultado o forte crescimento dos negócios, investimentos em infraestrutura, expansão da rede de atendimento e expansão das operações de crédito, principalmente de 
operações de financiamento imobiliário, de cartões e de leasing para pessoas físicas. Também se destacou o segmento de pequenas e médias empresas. A lém do aumento da oferta decrédito, as empresas de menor porte estão, igual mente, demandando mais recursos para investimentos, enquanto as grandes empresas encontram outras fontes definanciamento. Com isso, a carteira para pessoas jurídicas caminha para uma combinação mais rentável, já que o retorno do segmento de pequenas emédias empresas émaior (Valor E conômico, 31/ 7/ 2007).

Desde 1996, o lucro do A BN vem crescendo, com exceção dos anos de 1998 e2003, em que houve decréscimo (G ráfico I .5.6). E ssa redução podeser explicada pela desval orização do dólar, queimpactou a posição dehedge, causando um aumento na linha deimpostos. ${ }^{19}$ O impacto positivo ou negativo dessa estrutura de proteção é resultante da tributação/ dedutibilidade da variação cambial em momentos de apreciação ou depreciação, respectivamente, do real frente às moedas estrangeiras, o que gera um impacto direto no lucro líquido.

O R etorno Sobre Patrimônio L íquido M édio atingiu 16,2\% no primeiro semestre de2008, uma quedasignificativa em relação aosanos anteriores, em queesseíndicesemanteveacima de $20 \%$ em todo o período, com exceção do ano de 2004, em queatingiu 18,4\% (G ráfico l .5.7).

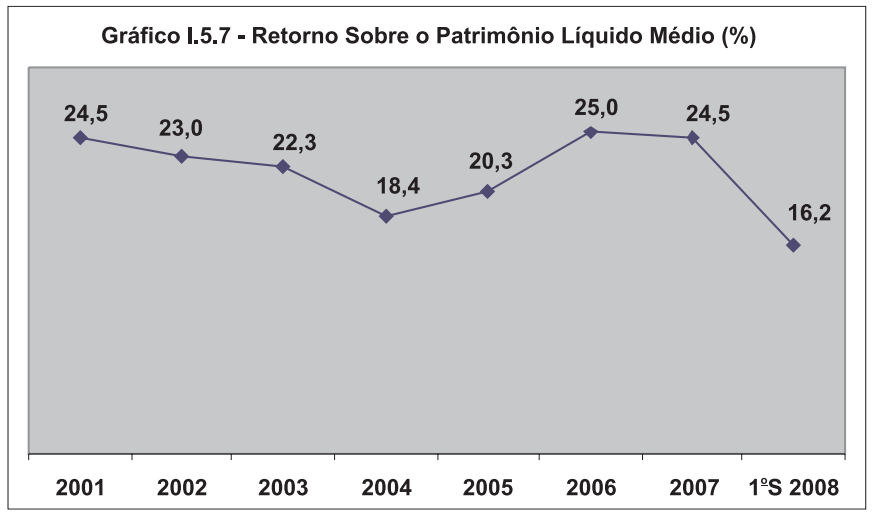

Fonte: Elaboração própria a partir de dados extraídos do site do Banco A BN -A mro R eal.

19 A s perdas derivadas de variação cambial em investimentos no exterior não são dedutíveis para fins de impostos. 


\section{Tendências recentes}

O A BN vem ampliando sua carteira de crédito, com destaque para as operações deleasing, por meio de uma estratégia departicipar ativamente dos projetos de expansão de seus clientes, e não apenas com recursos financeiros. A estratégia está centrada no desenvolvimento ena ampliação da atuação junto a pessoas físicas e pequenas e médias empresas, segmentos identificados globalmentepelo grupo como importantes para o crescimento orgânico dos próximos anos.

0 crédito consignado também éconsiderado, pelo A BN , estraté gico e com forte potencial de expansão. R ecentemente, a instituição iniciou parcerias com sete fabricantes de el etroel etrônicos e com uma rede de varejo de móveis para oferecer produtos financiados aos clientes consignados do banco, em uma espécie de oferta fechada (Valor E conômico, 2/ 7/ 2007). 0 banco vem direcionando sua atuação para o setor privado, devido ao aumento da demanda nessesegmento eà al teração das regras do I N SS, o quedificultou os empréstimos ao setor público (Valor E conômico, 19/ 8/ 2008).

O A BN também vem investindo no crédito para pequenas e médias empresas. R ecentemente, o banco iniciou a inauguração de plataformas de atendimento personalizado dentro das agências. 0 A BN pretende elevar a participação desse segmento na sua receita líquida, quefoi de $25 \%$ no primeiro semestre de 2008 (Valor E conômico, 9/9/2008).

N o setor imobiliário, acompanhando os outros grandes bancos, 0 $A B N$ ampliou o volumedecrédito destinado às construtoras eincorporadoras e passou a operar com recursos do F G T S. 0 interesseprincipal da instituição énas pessoas físicas, queirão adquirir os imóveis prontos, pois, além de serem mais rentáveis, se manterão clientes do banco por vinteanos (Valor E conômico, 28/ 6/ 2007; Valor E conômico, 15/ 1/ 2008 [1]). Para possibilitar essa estratégia, a instituição iniciou um programa deavaliação sustentável dos projetos financiados (V alor E conômico, 3/ 9/ 2007 [2]). Esse tipo de parceria com construtoras e incorporadoras parafinanciamento deempreendimentosjáfoi firmado com a G afisa ea R odobens (D estak Jornal, 24/3/2008). 
O banco também vem procurando se associar aos corretores, a fim de agilizar o crédito imobiliário, sem que o cliente precise ir à agência. O A BN fechou parceria com a imobiliária carioca Ética, especializada no mercado de imóveis usados, para facilitar a concessão de crédito para a compra da casa própria. 0 foco da parceria são os imóveis usados de até $\mathrm{R} \$ 120$ mil, destinados à classe $C$. O acordo com a Ética permite que a corretora indique a fonte de financiamento no ato da negociação da venda e o cliente pode saber em 24 horas se tem ou não condições de ser financiado. A operação de crédito, que antes era concluída em, no mínimo, 45 dias, passou a ter a possibilidade de ser concluída em 20 dias. 0 A BN pretende firmar parcerias semelhantes em São Paulo, Salvador, Curitiba e Recife (Valor E conômico, 18/ 4/ 2007 [2]).

A instituição também retomou os financiamentos de imóveis comerciais, com foco nas ampliações de redes varejistas, hospitais e universidades, além de financiamento da construção e expansão de plantas industriais (Valor E conômico, 5/ 12/ 2007 [2]).

R ecentemente, o A BN tem buscado alterar sua estratégia com relação à segmentação. Como o custo transacional decresce quando há um aumento de escala, o A BN considera que ampliar o fluxo de produtos padronizados é essencial para o crescimento dos resultados. N esse contexto, o banco inovou e integrou, ao final de 2005, a gestão de produtos que atendem pessoas físicas e empresas. Foram excluídas as operações feitas sob medida para grandes empresas e clientes pessoa física de alta renda, atendidos em private banking, assim como operações de cartões, setor imobiliário e de gestão de recursos de terceiros. Como resultado dessa estratégia, foi ampliada a oferta de produtos padronizados, reduzind o os custos transacionais e promovendo ganhos de eficiência e escala.

A recente aquisição do A BN pelo Santander permitirá que o A BN reforce o Santander em mercados em queo banco espanhol não possui alta participação, como éo caso do crédito para pessoa física e do financiamento de veículos. 0 banco também fortal ecerá o Santander em regiões onde sua participação émenor, como o N ordeste. A tual mente, o Santander concentra suas operações majoritariamente 
no eixo Sudeste-Sul, enquanto o A BN possui uma maior cobertura nacional. A pesar da eventual superposição deagências em São Paulo, as instituições consideram que a base de clientes é distinta, uma vez queo $A B N$ - A mro R eal atua, principalmente, na faixa de renda mais alta (Valor E conômico, 1/ 10/ 2007).

\section{Atuação externa ${ }^{20}$}

O A BN - A mro foi criado em 1824, na H olanda. A tualmente, possui representações em 55 países, com mais de 100 mil funcionários e 4.700 agências, proporcionando aos seus clientes acesso aos principais mercados financeiros internacionais.

Em 17 de outubro de 2007, a maior parte do capital do A BN foi adquirida pelo consórcio formado pelos bancos T he R oyal Bank of Scotland (RBS), Fortis e Santander. 0 processo de transferência das atividades e dos clientes do A BN para os bancos do consórcio teve início no primeiro semestre de 2008; portanto, grande parte da anál ise estendeu-seapenas até2007, com o objetivo de desconsiderar as significativas al terações ocorridas no primei ro semestre de 2008.

Por meio da estrutura organizacional adotada em janeiro de 2006, o A BN divide suas atividades em sete unidades de negócios: Países Baixos, Europa, A mérica do N orte, A mérica $L$ atina, Á sia, $P$ rivate $C$ lients ${ }^{21}$ e $G$ lobal $C$ lients. ${ }^{22} A$ A mérica $L$ atina, que abrange A rgentina, Brasil, Chile, Colômbia, M éxico, Paraguai, U ruguai e Venezuela, éa região com mai or participação na rededeatendimento da instituição, seguida pela Europa (G ráfico I.5.8).

20 As regras contábeis holandesas se diferenciam, em al guns pontos, das regras brasileiras; entretanto, essa diferença não irá interferir nesta análise, uma vez que, para possibilitar a comparação, neste item, serão adotados os critérios holandeses também para o Brasil.

21 A tende Pessoas Físicas e Pessoas J urídicas com mais de 1 milhão de euros disponível para investimento.

22 Inclui administração de ativos e passivos. 


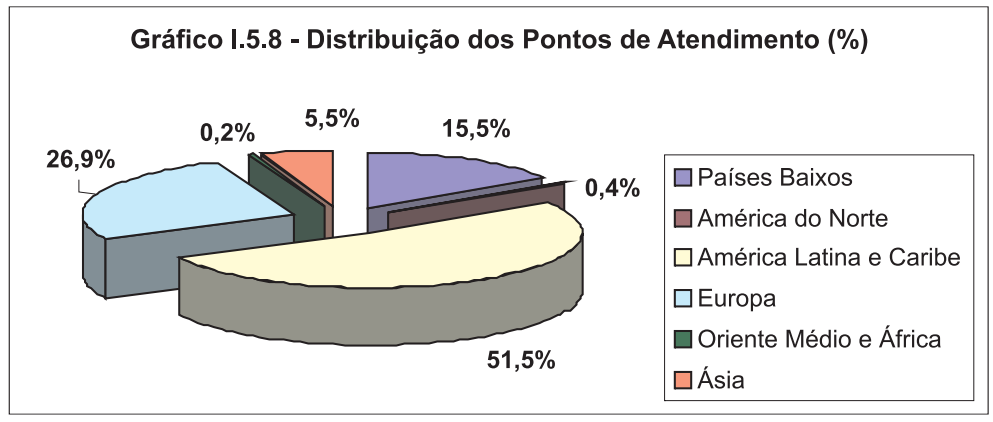

Fonte: Elaboração própria a partir de dados extraídos do site do G rupo A BN .

A U nidade de $\mathrm{N}$ egócio da Europa é composta por 23 países na E uropa, exceto osPaíses Baixos, além do C azaquistão, U zbequistão, E gito eÁ frica do Sul. A U nidade da Á sia é composta por 16 países, incluindo Indonésia, C hina, C ingapura e J apão. $\mathrm{N}$ a U nidade da A mérica $L$ atina, o Brasil, por meio do Banco R eal, representa a maioria das operações.

A Europa é a região com maior participação no ativo total do G rupo A BN . Essa participação atingiu 48,8\% em 2007 e vem apresentando crescimento nos últimos anos. $A$ A mérica $L$ atina, por sua vez, foi a região que mais cresceu desde 2004 (T abela I.5.9).

T abela I .5.9 - Participação das U nidades de N egócio no A tivo Total (\%)

\begin{tabular}{l|c|c|c|c|c}
\hline & dez./ 04 & dez./ 05 & dez./ 06 & dez./ 07 & C resc. \\
\hline Europa & 35,0 & 37,8 & 41,3 & 48,8 & 96,6 \\
\hline A mérica do N orte & 18,4 & 19,0 & 16,9 & 7,7 & $-40,7$ \\
\hline A mérica L atina & 2,5 & 3,2 & 4,0 & 5,1 & 188,2 \\
\hline Á sia & 7,4 & 7,6 & 7,1 & 7,5 & 41,8 \\
\hline Países Baixos & 36,7 & 32,4 & 20,9 & 21,8 & $-16,5$ \\
\hline Private Clients & - & - & 1,9 & 2,0 & $5,8^{1}$ \\
\hline G roup Functions & - & - & 7,9 & 7,1 & $-6,8^{1}$ \\
\hline Total (em milhões de euros) & 727.454 & 880.804 & 987.064 & 1.025 .213 & 40,9 \\
\hline Cr rescima
\end{tabular}

1) C rescimento verificado de dezembro/ 2006 a dezembro/ 2007.

Fonte: Elaboração própria a partir de dados extraídos do site do G rupo A BN . 
Em dezembro de 2007, a C arteira de C rédito representou 38,7\% dos A tivos T otais. E ssa participação vem decrescendo desde 2001 (G ráfico I.5.9).

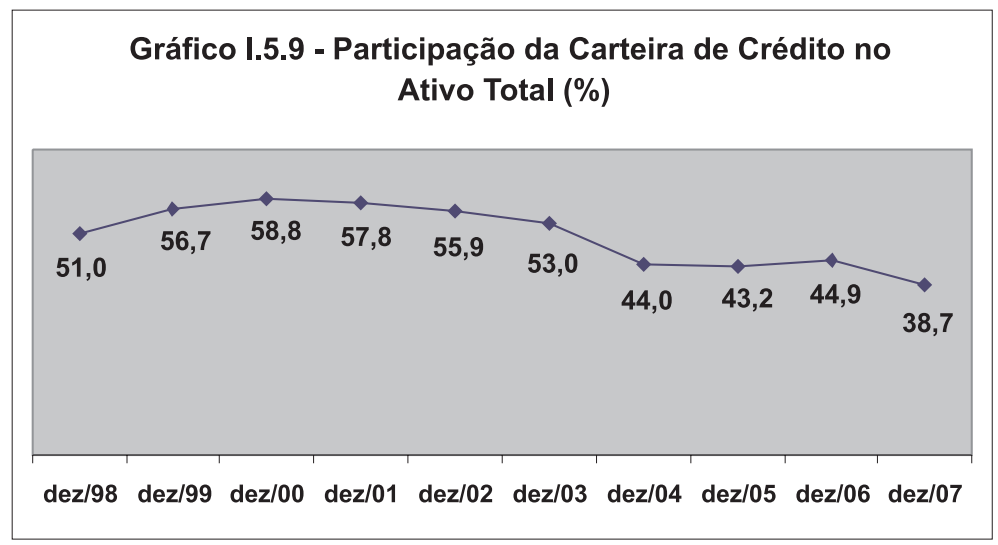

Fonte: Elaboração própria a partir de dados extraídos do site do G rupo $A B N$.

A redução verificada em dezembro de 2007 foi consequência das vendas da A ntonveneta (U nidade de N egócio Europa) e do L aSalle (U nidade de $\mathrm{N}$ egócio A mérica do N orte), ocorridas nesse ano.

O segmento de Pessoas J urídicas é o quetem maior participação na carteira decrédito, com uma contribuição de 53,1\% em dezembro de2007, contra 44,8\% do segmento dePessoas F ísicas. D edezembro de 2003 a dezembro de 2007, a carteira de Pessoas F ísicas cresceu 13,1\%, contra 10,3\% da carteira de Pessoas Jurídicas (T abelal .5.10). O s principais componentes da carteira de Pessoas F ísicas são as hipotecas, com uma participação de 78,4\% em dezembro de 2007.

Tabela I.5.10 - Composição da C arteira de C rédito (\%)

\begin{tabular}{l|c|c|c|c|c|c}
\hline & dez./ 03 & dez./ 04 & dez./ 05 & dez./ 06 & dez./ 07 & C resc. \\
\hline Setor Público & 2,3 & 2,5 & 2,7 & 3,5 & 2,1 & 4,5 \\
\hline Pessoas Jurídicas & 53,6 & 52,9 & 53,9 & 55,1 & 53,1 & 10,3 \\
\hline Pessoas Físicas & 44,1 & 44,6 & 43,4 & 41,4 & 44,8 & 13,1 \\
\hline
\end{tabular}

Fonte: Elaboração própria a partir de dados extraídos do site do G rupo A BN . 
A unidade de negócio com maior participação na carteira de crédito do A BN éa Países Baixos, seguida pela Europa e A mérica $L$ atina. $A$ unidade que apresentou maior crescimento desde dezembro de 2004 foi a A mérica L atina, com uma ampliação de 199\% (Tabela I.5.11). Esse crescimento foi resultado, principalmente, do aumento das operações de crédito no Brasil e da apreciação do real em relação ao euro.

T abela I.5.11 - Participação das U nidades de $\mathrm{N}$ egócio na Carteira de C rédito (\%)

\begin{tabular}{l|c|c|c|c|c}
\hline & dez./ 04 & dez./ 05 & dez./ 06 & dez./ 07 & C resc. \\
\hline Países Baixos & 59,7 & 54,2 & 47,9 & 60,3 & 14,4 \\
\hline Europa & 10,9 & 12,0 & 21,8 & 16,8 & 74,2 \\
\hline A mérica do N orte & 19,1 & 21,5 & 17,1 & 3,5 & $-79,1$ \\
\hline A mérica L atina & 3,8 & 5,6 & 5,8 & 10,0 & 199,0 \\
\hline Á sia & 6,5 & 6,7 & 7,4 & 9,4 & 64,5 \\
\hline
\end{tabular}

Fonte: Elaboração própria a partir de dados extraídos do site do G rupo $\mathrm{ABN}$.

O crescimento verificado na Á sia, por sua vez, foi resultado da ampliação dos empréstimos direcionados ao consumo edas operações com cartões de crédito.

$\mathrm{N}$ as U nidades de $\mathrm{N}$ egócio daE uropa, A mérica do $\mathrm{N}$ ortee Á sia a carteira decrédito dePessoas J urídicas épredominante, ao passo que nos Países Baixos e na A mérica $L$ atina a carteira de Pessoas $F$ ísicas também tem participação significativa (Tabela I .5.12).

Tabela I.5.12 - Composição da C arteira de C rédito das U nidades de $\mathrm{N}$ egócio em $2007(\%)$

\begin{tabular}{l|c|c|c}
\hline & Setor Público & PessoasJurídicas & PessoasF ísicas \\
\hline Países Baixos & 0,9 & 36,7 & 62,4 \\
\hline Europa & 2,2 & 92,6 & 5,2 \\
\hline A mérica do N orte & 0,8 & 99,2 & 0,0 \\
\hline A mérica L atina & 1,3 & 52,1 & 46,6 \\
\hline Á sia & 10,8 & 71,9 & 17,3 \\
\hline
\end{tabular}

Fonte: Elaboração própria a partir de dados extraídos do site do G rupo A BN . 
Com relação à gestão deriscos, o grupo tem sua atuação regulada pelas legislações holandesa e norte-americana, al ém da regulação local dos países eterritórios onde desenvolve suas operações. 0 bedece também aos requerimentos introduzidos, mais recentemente, pela L ei Sarbanes-O xley, da U S Securities and Exchange Commission, criada para garantir a integridade da administração, das auditorias e dos empregados. Essa regulação permitiu que a instituição atingisse um Índice de Basileia de 14,61\% em 2007, acima, portanto, do mínimo exigido pelo Comitêda Basileia, de 8\% (G ráfico I.5.10).

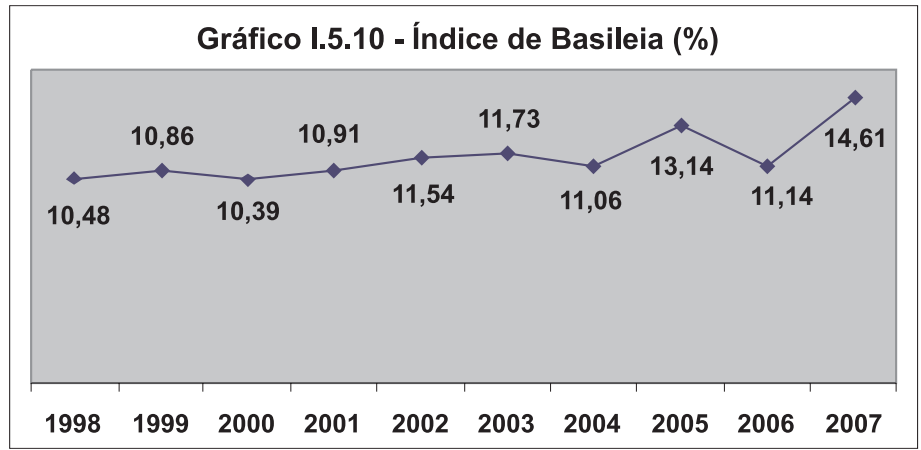

Fonte: Elaboração própria a partir de dados extraídos do site do G rupo A BN .

Com relação ao Í ndice deE ficiência, verifica-seuma tendência de crescimento nos últimos anos. Em 2007, esseíndice atingiu 83,5\%, o maior já al cançado desde 1998 (G ráfico I.5.11).

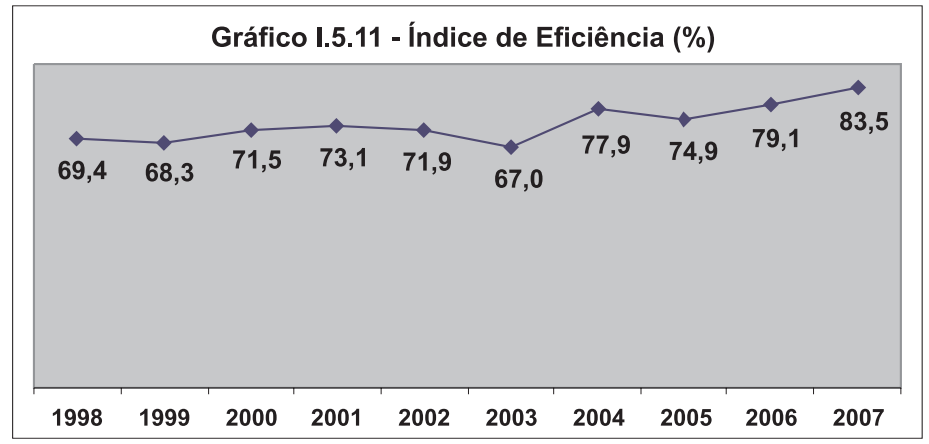

Fonte: Elaboração própria a partir de dados extraídos do site do G rupo A BN . 
Esseal to Í ndicedeEficiência éresultado, principalmente, dos altos índices verificados naE uropa ena $\mathrm{A}$ mérica do $\mathrm{N}$ orte. A A mérica $\mathrm{L}$ atina é a $\mathrm{U}$ nidade de $\mathrm{N}$ egócio com o menor Índice de Eficiência (Tabela I.5.13).

Tabela I .5.13 - Índice de Eficiência das U nidades de N egócio (\%)

\begin{tabular}{l|c|c|c|c}
\hline & dez./ 04 & dez./ 05 & dez./ 06 & dez./ 07 \\
\hline Europa & 190,7 & 95,8 & 99,0 & 215,6 \\
\hline A mérica do N orte & 67,1 & 95,8 & 140,8 & 122,4 \\
\hline A mérica L atina & 68,2 & 60,6 & 59,6 & 56,3 \\
\hline Ásia & 66,4 & 71,2 & 75,9 & 74,3 \\
\hline Países Baixos & 83,4 & 70,9 & 69,0 & 64,3 \\
\hline
\end{tabular}

Fonte: Elaboração própria a partir de dados extraídos do site do G rupo $A B N$.

O G rupo A BN atingiu um lucro líquido de 9.975 milhões de euros em 2007, o maior já al cançado pela instituição desde 1998. A U nidade de $\mathrm{N}$ egócio que mais contribuiu para esse resultado foi a A mérica do $\mathrm{N}$ orte, seguida pelos $\mathrm{P}$ aíses Baixos, com participação de $80,1 \%$ e 13,5\%, respectivamente (Tabela I.5.14). 0 al to lucro al cançado pela A mérica do N orte em 2007 foi resultado da venda da instituição L aSalle.

T abela I .5.14 - Participação das U nidades de N egócio no L ucro L íquido (\%)

\begin{tabular}{l|c|c|c|c}
\hline & $\mathbf{2 0 0 4}$ & $\mathbf{2 0 0 5}$ & $\mathbf{2 0 0 6}$ & $\mathbf{2 0 0 7}$ \\
\hline Europa & $-10,8$ & 2,3 & 3,0 & $-11,7$ \\
\hline A mérica do N orte & 20,3 & 25,9 & 25,3 & 80,1 \\
\hline A mérica L atina & 6,1 & 14,3 & 14,6 & 8,1 \\
\hline Á sia & 13,1 & 7,2 & 2,7 & 2,8 \\
\hline Países Baixos & 13,0 & 22,8 & 30,6 & 13,5 \\
\hline Outros & 58,3 & 27,5 & 23,8 & 7,2 \\
\hline Total (em milhões de euros) & 3.940 & 4.443 & 4.780 & 9.975 \\
\hline
\end{tabular}

Fonte: Elaboração própria a partir de dados extraídos do site do G rupo A BN .

O R etorno sobre o Patrimônio L íquido, por sua vez, atingiu 38,4\% em 2007, o maior desde 1998. N esseperíodo, o índice variou; entretanto, permaneceu acima de 20\% desde 1999 (G ráfico I .5.12). 


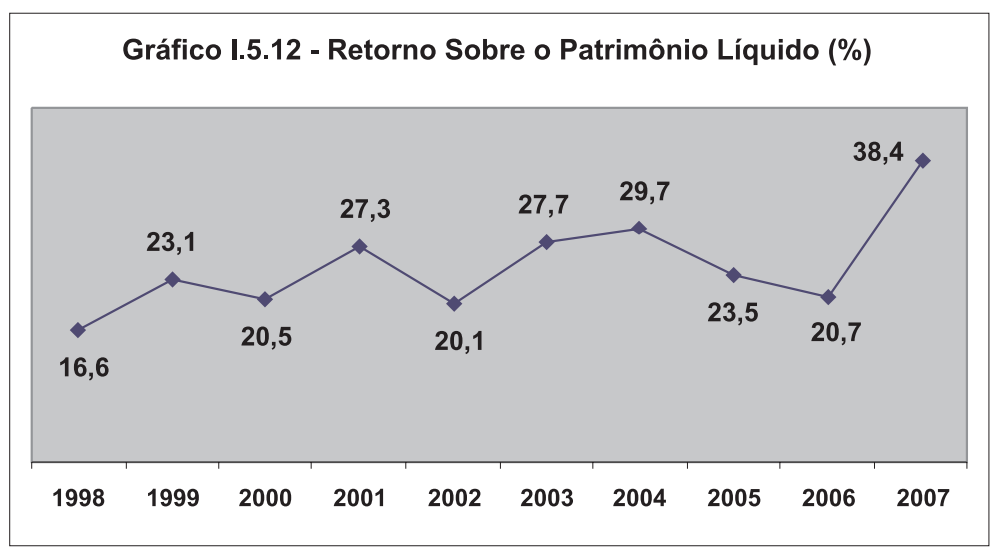

Fonte: Elaboração própria a partir de dados extraídos do site do G rupo A BN .

\section{Unibanco}

\section{Histórico e estrutura}

O U nibanco originou-se da C asa M oreira Salles, uma das mais importantes lojas de comércio de Poços de $\mathrm{C}$ aldas, $\mathrm{M}$ inas $\mathrm{G}$ erais, fundada por J oão M oreira Salles em 1918, cuja seção bancária recebeu autorização de funcionamento do governo federal em 27 de setembro de 1924. E m 1931, a seção bancária da C asa M oreiraSalles foi transformada em uma instituição independente, a Casa Bancária M oreiraSalles, passando a ter significativa importância no financiamento de empreendimentos da região.

Em julho de 1940, surge o Banco M oreira Salles, resultado da fusão entre a Casa Bancária M oreira Salles, o Banco M achadense e a C asa B ancária de Botelhos. Iniciou-se, então, a expansão da instituição, que deixou deser um banco regional do sul deM inas $G$ erais. Foram inauguradas a agência do R io de J aneiro, em abril de 1941, e a agência de São Paulo, em julho de 1942.

O banco se associou com o Commerzbank A G, em 1968, e com o Crédit Suisse, em 1969. Em 1970, a instituição absorveu o Banco 
Predial do Estado do R io de J aneiro, iniciando um novo perfil institucional, depopularização como banco devarejo. A ssociou-se, ainda, com o D ai- I chi K angyo Bank e com o Philadelphia I nternational I nvestment Corporation, em 1972, e com o H arris Bankcorp, I nc. eo W hiteW eld, em 1973. Em 1975, o grupo era constituído por quinze empresas, quepassaram a ter umaúnica denominação: U nibanco. Em 1983, a U nibanco Seguradoraassociou-seà Sul A mérica, líder do setor deseguro naquelemomento, por meio deuma troca de participações. D essa associação, foi criada a Sul A mérica U nibanco Seguradora.

A década de 1990 foi um marco na trajetória do U nibanco. 0 banco chegou às primeiras posições entre as maiores instituições financeiras do país e seu valor de mercado cresceu 69 vezes.

Em 1995, foi criado o U nibanco A sset M anagement, primeira instituição especializada na administração de recursos de terceiros no país. A instituição era controlada pelo U nibanco, mas tinha existência jurídica independente do controlador. A inda em 1995, 0 U nibanco adquiriu parte dos ativos do Banco $\mathrm{N}$ acional S.A., passando a contar com uma rede de 1.446 dependências no Brasil, cerca de 2,1 milhões de clientes e uma base de 1,4 milhões de portadores de cartão de crédito. E m 1996, o banco adquiriu 50\% da Fininvest, financeira com grande experiência no segmento de crédito direto ao consumidor e pertencente ao grupo I catu. E m 2000, o U nibanco adquiriu o controle integral da Fininvest e do C redibanco.

E m 1997, a instituição lançou suas ações na N Y SE, tornando-se o primeiro banco brasileiro a negociar seus títulos na bolsa de $\mathrm{N}$ ova York, mediante a maior oferta registrada no mercado internacional já realizada por uma instituição financeira latino-americana. N esse mesmo ano, associou-se com o grupo financeiro A I G , A merican I nternational G roup, naárea deseguros. Com a A I G , mantém também associação na U nibanco AIG Previdência.

Em 1999, o U nibanco adquiriu, por meio de uma emissão de ações, o Banco Bandeirantes, passando a contar com um novo sócio estrangeiro: a C aixa G eral de D epósitos. A aquisição permitiu um aumento da participação em mercados estratégicos, como São Paulo ea região N ordestedo Brasil. Essa operação também possibilitou um 
avanço significativo das atividades da seguradora do U nibanco. 0 maior grupo financeiro dePortugal, que controlava o Bandeirantes, passou a deter $12,3 \%$ do capital total do U nibanco, integrando o bloco de acionistas estrangei ros, junto com o al emão Commerzbank AG e o japonês M izuho Financial G roup.

E $m$ 2003, o banco passou por importantes mudanças societárias. U ma oferta de permuta deu o direito a todos os acionistas preferenciais de converter suas ações em U nits (certificados de depósito de ações representativos deuma ação preferencial daU nibanco H oldings e uma ação preferencial do U nibanco). 0 acionista $\mathrm{M}$ izuho vendeu toda a sua partici pação eo Commerzbank disponi bilizou uma parcela de suas ações ao mercado, permitindo um aumento significativo de liquidez das ações do U nibanco no mercado brasileiro.

Em junho de 2004, o U nibanco adquiriu a totalidade das ações do Banco BN L do Brasil S.A ., de titularidade da Banca N azionale del $L$ avoro, assumindo a operação brasileira do banco. A inda em 2004, o U nibanco foi o primeiro banco brasileiro a aderir aos Princípios do E quador, conjunto de medidas socioambientais utilizadas na avaliação e na concessão de crédito a projetos de infraestrutura.

N o início de 2008, o U nibanco anunciou a criação de um banco de investimento para se beneficiar das oportunidades existentes no mercado deações, principal mentepelas operações de ofertas iniciais de ações, modalidade que cresceu significativamente nos últimos anos. A pesar de chegar atrasado em relação aos seus concorrentes I taú e Bradesco, que constituíram suas unidades independentes há mais tempo, o U nibanco tinha sua origem no Banco de I nvestimento B rasil (BIB), sendo que, até $2001,70 \%$ dos seus ativos estavam no banco de atacado. Somente nos últimos anos o varejo se tornou predominante na instituição (Valor E conômico, 1/ 4/ 2008 [2]).

A tual mente, a $\mathrm{U}$ nibanco $\mathrm{H}$ oldings é controladora do $\mathrm{U}$ nibanco e seusativos consistem unicamentedaparticipação no U nibanco. 0 G rupo M oreira Salles é detentor de $67,6 \%$ das ações. A s demais são, principalmente, U nits, ${ }^{23}$ e estão pulverizadas no mercado (G ráfico I .6.1).

23 Certificados de D epósitos de A ções - são os ativos mais líquidos do U nibanco. 
Gráfico I.6.1 - Composição Acionária em 31 de julho de 2008 (\%)

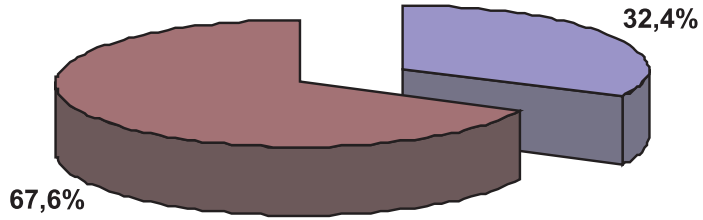

$\square$ Grupo Moreira Salles $\square$ Ações Pulverizadas no Mercado

Fonte: Elaboração própria a partir de dados extraídos do site do U nibanco.

\section{Rede de atendimento}

A rede de atendimento do U nibanco é constituída por 35 mil funcionários e 1.828 pontos de venda, sendo 954 agências, 280 Pontos deA tendimento Bancário e 594 lojas, quiosques eminilojas Fininvest. A instituição disponibiliza, ainda, terminais de autoatendimento, internet banking eatendimento pelo celular. Em janeiro de $2009,67,7 \%$ dos pontos de atendimento estavam concentrados na região Sudeste (G ráfico I .6.2). N os últimos anos, a distribuição dos pontos deatendimento pel o território brasileiro não sofreu al terações significativas.

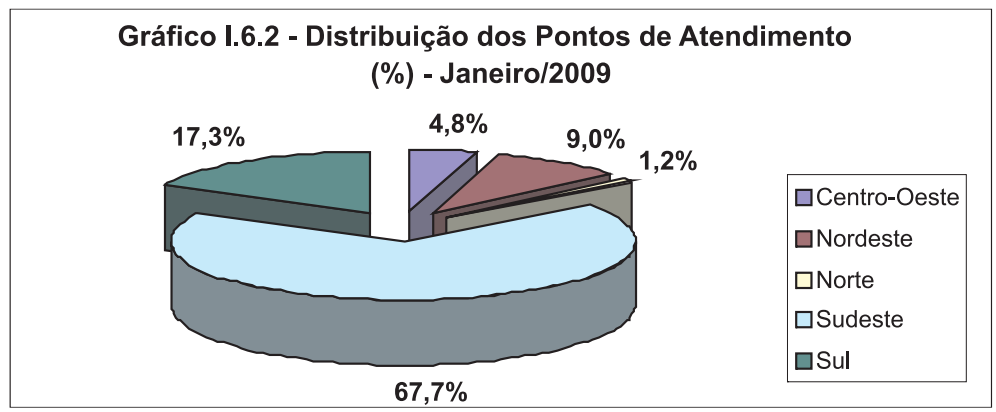

Fonte: Elaboração própria a partir de dados extraídos do site da Febraban. 
$\mathrm{N}$ os últimos anos, foram firmadas diversas parcerias com redes de varejo. Em agosto de 2001, o U nibanco estabeleceu uma aliança estratégica com a G lobex S.A ., proprietária da rede de lojas de eletrodomésticos Ponto F rio, presenteem todo o país. N essatransação, foram adquiridos $50 \%$ de participação na PontoC red, subsidiária da G lobex, empresa responsável pelos financiamentos aos clientes do Ponto Frio.

Em setembro de2001, a Fininvest estabeleceu uma parceria com o M agazine L uiza, redebrasileira delojas de departamentos queatua no Estado de São Paulo, no sul do país e no sul de M inas G erais. A parceria gerou uma nova empresa, a $L$ uizaC red, para oferecer financiamento aos clientes do $M$ agazine $L$ uiza.

Em novembro de 2003 , o U nibanco adquiriu $100 \%$ do capital da $C$ reditec, empresa com importante atuação no segmento de crédito pessoal e de financiamento de bens e serviços para as classes $B, C$ e D. Com noveanos de mercado, a $C$ reditec possuía cerca de 600 mil clientes cadastrados na época de sua aquisição. Em 2004, todas as lojas $\mathrm{Cr}$ reditec foram convertidas em lojas $\mathrm{F}$ ininvest.

Em março de 2004, o U nibanco adquiriu a totalidade das cotas da $\mathrm{H}$ iperC $\operatorname{ard} \mathrm{A}$ dministradora de $\mathrm{C}$ artão de $\mathrm{C}$ rédito $\mathrm{L}$ tda. A H iperC ard surgiu como empresa de cartões de crédito "private label" do Supermercado Bompreço, em 1982. 0 cartão da redeé, atualmente, o principal meio depagamento utilizado nas lojas da rede Bompreço eW al- $M$ art, sendo aceito em mais de 80 mil pontos de venda no $\mathrm{N}$ ordeste do Brasil.

Em agosto de 2004, o U nibanco eo Sonaefirmaram parceria para a criação de uma financeira. 0 Sonaeatua no segmento dehipermercados edesupermercados, com lojas nas regiões Sul eSudestedo país.

Em junho de 2005, o U nibanco, que já possuía $51 \%$ das ações do Banco $D$ ibens, passou a deter $100 \%$. A nova estrutura permitiu a consolidação das operações daU nibanco F inanceirae do Banco D ibens. A marca $D$ ibens passou a ser utilizada para financiamento de veículos pesados ea $U$ nibanco Financeira, para veículos leves emotos.

Em agosto de 2006, o U nibanco e o grupo I piranga anunciaram a constituição de uma sociedade de crédito, financiamento einvesti- 
mento. A lém dos cartões decrédito, foram disponibilizados produtos financeiros, como crédito pessoal e crédito direto ao consumidor. A tualmente, a rede conta com aproximadamente 4.200 postos.

A inda em 2006, o U nibanco firmou parceria com o grupo VR, distribuidora de benefícios da área derecursos humanos, para a concessão decrédito efinanciamento deprodutos, capital degiro, seguro de vida em grupo e previdência. 0 grupo VR possui mais de 20 mil acordos com empresas e seus produtos são aceitos em mais de 200 mil estabelecimentos comerciais. $\mathrm{N}$ essemesmo ano, foi estabelecida uma associação com o Banco C ruzeiro do Sul, para desenvolvimento de negócios na área de crédito consignado, por meio da constituição de uma empresa financeira em sociedade. Todas essas parcerias permitiram queo U nibanco ocupasse posição de destaque na oferta de produtos eserviços, principalmente ao segmento de baixa renda, com baixo grau de bancarização.

O segmento de cartões de crédito do U nibanco é constituído pelas empresas U nicard (emissora e administradora de cartões Visa e M asterC ard, e líder no segmento de cartões cobranded no país), $\mathrm{H}$ iperC ard (principal meio de pagamento utilizado nas lojas da redeBompreço eW al- $M$ art) e R edeC ard (empresa responsável pela captura e transmissão de transações dos cartões de crédito e débito das bandei ras $\mathrm{M}$ asterC ard, M asterC ard M aestro, R edeShop, M asterC ard E lectronic, M aestro e D iners C lub I nternational ).

A redeinternacional do U nibanco, por sua vez, éconstituída por agências em $\mathrm{N}$ assau e nas IIhas Cayman, escritórios de representação em N ovaY ork, subsidiárias bancárias em L uxemburgo, nas I Ihas C ayman e no Paraguai, e por uma corretora em N ovaYork, a U nibanco Securities Inc.

Por meio dessa rede, o U nibanco busca atender clientes estrangeiros interessados no Brasil, bem como oferecer à base de clientes no Brasil acesso eficaz epermanente, direto ou via balanço, a recursos disponíveis no mercado internacional. A s subsidiárias e agências da instituição no exterior também captam recursos para o financiamento do comércio internacional e para a concessão de empréstimos a clientes. 


\section{Base de clientes}

Em junho de 2008, o U nibanco atingiu 29,6 milhões de clientes, distribuídos nos quatro principais segmentos de atuação do banco: Varejo, A tacado, Seguros e Previdência e G estão dePatrimônios. 0 U nibanco atendeseus clientes demaneira segmentada desdeo início da década de 90, com uma oferta de produtos e serviços diferenciados e sob medida para aumentar sua competitividade no mercado. O crescimento da base de clientes verificado nos últimos anos é decorrente, principalmente, da expansão do número de folhas de pagamento, declientes decartões decrédito, do número de parcerias firmadas com varejistas e de aquisições.

N o segmento de varejo, o U nibanco atende as pequenas e médias empresas e as pessoas físicas de todos os níveis de renda e com investimentos financeiros abaixo de R \$ 3 milhões.

$\mathrm{N}$ o financiamento ao consumidor e no segmento de cartões de crédito o U nibanco opera também por meio de parcerias com redes varejistas, atacadistas, supermercados, lojas demateriais de construção, dentreoutras. N o total, são cerca de 250 parcerias, que têm como objetivo a obtenção de ganhos de escala e decapilaridade geográfica, fundamentais para o crescimento dos negócios do banco. Podem ser citadas as redesW al- $M$ art, L eroy $M$ erlin, R ede $M$ uffato, T umelero, B retãs, R ede N ordestão, grupo I piranga e Banco C ruzeiro do Sul.

O U nibanco também atua por meio das Financeiras de $C$ rédito ao Consumidor Fininvest, Banco D ibens (responsável pelo financiamento deveículos), PontoC red (disponibiliza financiamentos aos clientes da rede de lojas deeletrodomésticos $P$ onto $F$ rio) eL uizaC red (disponibiliza financiamento aos clientes do M agazine L uiza). Por meio das marcas populares, são atingidas as camadas da população de baixa renda. 0 U nibanco considera que tal estratégia evita 0 atendimento do mercado de massa dentro das agências e protege assim o padrão de qualidade oferecido pelo U nibanco aos clientes de maior renda.

N o segmento de M icrocrédito, o banco atua desde 1998, com a $\mathrm{R}$ ioC red. Em 2002, a instituição consolidou sua posição no micro- 
crédito com a U nibanco $\mathrm{M}$ icroinvest, resultado de uma parceria entre o Banco F ininvest, que detém 82\% do capital, e o I nternational Finance Corporation (IFC), braço financeiro do Banco M undial. 0 principal objetivo da empresa éa oferta de produtos financei ros para microempreendedores por meio de um modelo de distribuição com mais de 200 pontos de atendimento e 51 agentes de microcrédito. D esde o lançamento do programa até o ano de 2007, foram concedidos aproximadamente $\mathrm{R} \$ 38$ milhões em créditos destinados à aquisição de máquinas e equipamentos, capital de giro ou reformas. $M$ ais de 10 mil clientes jáforam beneficiados com essetipo decrédito. A tualmente, a empresa atende, principalmente, o setor de comércio e serviços.

O s produtos para M icro, Pequenas e M édias Empresas, por sua vez, são constituídos por transações com garantia de recebíveis, crédito rotativo, financiamento de veículos, cheque especial, conta garantida, capital degiro erepasses BN DES/ Finame, dentreoutros. E sses produtos possibilitam as ações de vendas cruzadas, como a conquista de fol has de pagamento e afiliação de lojistas/ varejistas e parceiros das empresas de cartão de crédito.

No atacado, o atendimento é feito por meio da estratégia de cobertura regional econhecimento setorial, voltada para o relacionamento delongo prazo. $\mathrm{N}$ esse segmento, o banco se destaca nas áreas de fusões e aquisições, project finance, renda fixa e renda variável, derivativos e operações estruturadas.

N o segmento deSeguroseP revidência, o U nibanco atua por meio da U nibanco A IG Seguros \& Previdência, que oferece, a pessoas físicas ejurídicas, seguro devida, deautomóvel, debens eacidentes, planos de pensão e aposentadoria, bem como produtos e serviços correlatos.

N o segmento de G estão de Patrimônios, o banco oferece produtos de investimentos via U nibanco A sset $M$ anagement (UA M ) para grandes investidores pessoas física ejurídica, eatende clientes com investimentos acima de $\mathrm{R} \$ 3$ milhões, por meio do segmento $P$ rivate $B$ anking. 


\section{Captações}

O U nibanco capta recursos principalmentepor meio dedepósitos a prazo, que representavam, em junho de $2008,43,4 \%$ do total de recursos captados. A participação das captações no mercado aberto, por sua vez, também é significativa evem apresentando crescimento expressivo, passando de 33,3\% em dezembro de 1997 para 41,6\% em junho de 2008 (Tabelal .6.1).

T abela I .6.1 - Composição das C aptações (em \%)

\begin{tabular}{|c|c|c|c|c|c|c|c|c|}
\hline & $\begin{array}{c}\text { À } \\
\text { Vista }\end{array}$ & Poupança & Interfin. & $\begin{array}{c}\text { A } \\
\text { Prazo }\end{array}$ & O utros & $\begin{array}{c}\text { Depósitos } \\
\text { Totais }\end{array}$ & $\begin{array}{c}\text { C ap. } \\
\text { M ercado } \\
\text { A berto }\end{array}$ & $\begin{array}{l}\text { Total (em } \\
\text { R \$ bilhões) }\end{array}$ \\
\hline dez./ 97 & 10,4 & 27,9 & 0,2 & 28,2 & 0,0 & 6 & 33,3 & 10,1 \\
\hline dez./ 98 & 10,2 & 28,1 & 0,2 & 35,2 & 0,0 & 73,7 & 26,3 & 10,6 \\
\hline dez./ 99 & 10,1 & 21,5 & 0,2 & 36,9 & 0,0 & 68,7 & 31,3 & 13,4 \\
\hline dez./ 00 & 10,3 & 16,6 & 0,2 & 29,4 & 0,0 & 56,5 & 43,5 & 23,5 \\
\hline dez./ 01 & 8,8 & 18,0 & 0,5 & 43,3 & 0,0 & 70,6 & 29,4 & 27,5 \\
\hline dez./ 02 & 8,1 & 14,3 & 0,2 & 43,0 & 0,0 & 65,6 & 34,4 & 40,1 \\
\hline dez./ 03 & 8,3 & 17,8 & 0,8 & 51,5 & 0,0 & 78,4 & 21,6 & 33,3 \\
\hline dez./ 04 & 7,9 & 14,3 & 0,3 & 59,3 & 0,0 & 81,8 & 18,2 & 41,5 \\
\hline dez./ 05 & 8,2 & 11,7 & 0,0 & 56,3 & 0,0 & 76,2 & 23,8 & 48,2 \\
\hline dez./ 06 & 7,3 & 12,2 & 0,1 & 45,6 & 0,2 & 65,4 & 34,6 & 55,6 \\
\hline dez./ 07 & 12,9 & 13,0 & 1,1 & 32,0 & 0,2 & 59,2 & 40,8 & 80,8 \\
\hline jun./ 08 & 3,9 & 9,4 & 1,6 & 43,4 & 0,1 & 58,4 & 41,6 & 90,3 \\
\hline Cresc. & 242,2 & 203,9 & $7.851,2$ & $1.280,1$ & 7.319,4 & 687,6 & $1.021,7$ & 794,1 \\
\hline
\end{tabular}

Fonte: Elaboração própria a partir de dados extraídos do site do Banco C entral do Brasil.

Como partedesua estratégia, o U nibanco tem seconcentrado em captações de CD Bs de baixo custo. A lém disso, com o recente ciclo de aumento da taxa de juros, houve maior demanda por produtos indexados à taxa interfinanceira (CDI) em relação a depósitos de poupança e fundos de investimento.

O fim daC PM F afetou negativamenteos depósitos àvista, já que trouxe muito mais mobilidade aos recursos. Essa maior mobilidade adicionada à nova regulamentação do Banco Central sobre depósitos compulsórios eà maior demanda do mercado por aplicações de menor risco provocaram o crescimento do sal do dedepósitos a prazo e interfinanceiros. 


\section{Carteira de crédito}

A carteira de crédito do U nibanco vem crescendo significativamente nos últimos anos, passando de $\mathrm{R} \$ 8,5$ bilhões, em dezembro de 1997, para R \$ 55,6 bilhões, em junho de 2008 (G ráfico I.6.3).

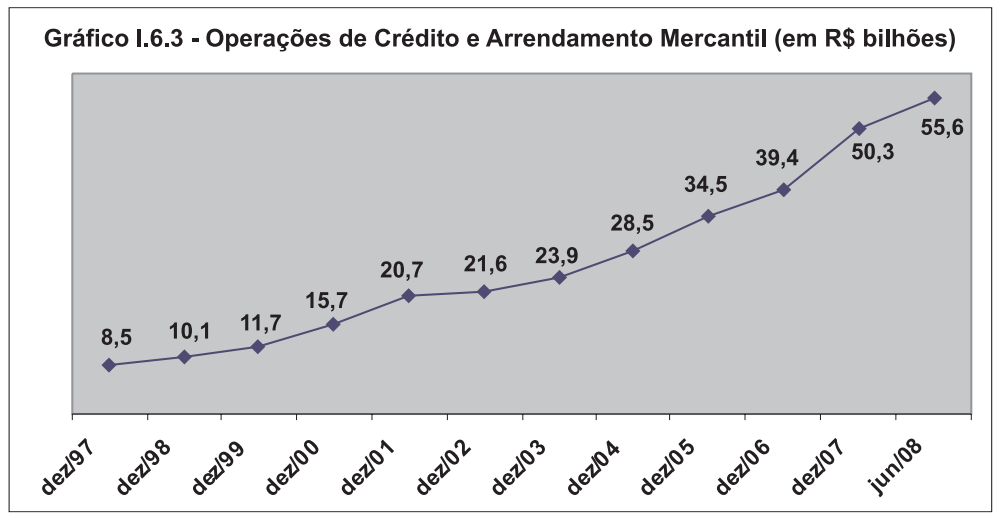

Fonte: Elaboração própria a partir de dados extraídos do site do Banco C entral do Brasil.

A té março de 2008, a carteira de crédito do U nibanco vinha crescendo a taxas superiores às do Sistema Financeiro $\mathrm{N}$ acional. N o segundo trimestre de 2008, a taxa de crescimento do U nibanco foi inferior.

A carteira de crédito que tem maior participação éa de $G$ randes E mpresas, que representou, em junho de 2008, 37,5\% da carteira total. Essa participação, entretanto, vem apresentando tendência de queda, com exceção do primeiro semestre de 2008, em que essa participação cresceu. 0 crescimento pode ser explicado pela maior procura por recursos no sistema financeiro local, devido à redução da liquidez nos mercados internacionais eàs grandes operações sindicalizadas, degrandes multinacionais brasileiras em seus planos de expansão (Tabela l.6.2).

A participação da carteira de $M$ icro, Pequenas eM édias empresas também vem decrescendo. O s segmentos quevêm aumentando sua participação na carteira decrédito total são, principalmente, Veículos e Cartões de C rédito (T abela I.6.2). 
Tabelal .6.2 - Composição da Carteira de C rédito (em \%)

\begin{tabular}{|c|c|c|c|c|c|c|c|}
\hline & dez./ 03 & dez./ 04 & dez./ 05 & dez./ 06 & dez./ 07 & jun./ 08 & C resc. ${ }^{1}$ \\
\hline G randes Empresas & 50,1 & 44,0 & 44,0 & 42,1 & 36,2 & 37,5 & 86,5 \\
\hline $\begin{array}{l}\text { M icro, Pequenas e } \\
\text { M édias Empresas }\end{array}$ & 16,0 & 19,6 & 18,0 & 13,9 & 14,7 & 14,9 & 131,8 \\
\hline Veículos & 10,1 & 11,6 & 11,0 & 10,1 & 14,3 & 15,6 & 283,5 \\
\hline Cartões de C rédito & 7,6 & 8,8 & 10,0 & 11,2 & 11,2 & 10,7 & 248,7 \\
\hline Crédito Consignado & - & - & - & 4,5 & 8,1 & 6,5 & 121,0 \\
\hline $\begin{array}{l}\text { Financiamento } \\
\text { Imobiliário }\end{array}$ & 3,3 & 3,6 & 3,5 & 3,3 & 2,8 & 3,0 & 123,4 \\
\hline $\begin{array}{l}\text { Financeiras } \\
\text { deC rédito ao } \\
\text { Consumidor }\end{array}$ & 6,1 & 7,0 & 8,0 & 5,9 & 5,0 & 4,6 & 85,5 \\
\hline Outros & 6,8 & 5,4 & 5,5 & 9,0 & 7,7 & 7,2 & 167,1 \\
\hline
\end{tabular}

1) $\mathrm{N}$ a carteira de crédito consignado, o crescimento informado abrange o período de dezembro/ 2006 a junho/ 2008.

Fonte: Elaboração própria a partir de dados extraídos do site do U nibanco.

O s destaques da carteira de varejo, nos últimos anos, foram os segmentos de automóveis, pequenas e médias empresas, cartões de crédito e crédito consignado. N o segmento de automóveis, a instituição atua no financiamento de veículos leves e pesados, em todo o território nacional. O s veículos são financiados, principalmente, por meio de concessionárias, o que reduz significativamente o risco de crédito nessa carteira. 0 U nibanco também optou por não estender os prazos definanciamento além do plano de 48 meses. Essas características resultaram em um índice de inadimplência de aproximadamente $3 \%$, abaixo do índice médio do mercado, que foi de 3,7\%.

A evolução da carteira de crédito consignado foi resultado da intensificação da oferta deste produto aos clientes. 0 U nibanco atua neste segmento com correspondentes bancários, incluindo a Fininvest, no banco múltiplo eem parcerias. D esdeo último trimestre de 2007, o U nibanco decidiu se concentrar em sua carteira de originação própria, evitando adquirir créditos consignados originados por terceiros. Como esses créditos ad quiridos anteriormente começam a se maturar, a chegar aos seus prazos de vencimento, essa carteira de 
créditos consignados adquirid os está em queda e será gradual mente substituída pelos créditos consignados de originação própria. A carteira própria de crédito consignado da instituição é composta, principal mente, por operações com aposentados, que representaram $41 \%$ destas, seguidas pelo setor privado, com $30 \%$, e pelo setor público, com $29 \%$.

O crédito imobiliário, que atende toda a cadeia de construção, desde o financiamento para pessoas físicas e jurídicas atéa incorporação deempreendimentos, também vem apresentando crescimento, atingindo, em junho de 2008, participação de $3 \%$ da carteira total de ativos do banco.

A s financeiras de crédito ao consumidor apresentaram um crescimento modesto, queo $U$ nibanco atribui a uma menor atratividade para esse tipo de financiamento, uma vez que, atualmente, existem opções mais baratas para o tomador e de menor risco para o sistema, como é o caso do crédito consignado.

A partir de meados de 2005, o U nibanco tomou a decisão de restringir o crédito em al gumas modalidades, sobretudo em al gumas carteiras das financei ras de crédito ao consumidor eem al gumas modalidades na rededeagências. A adoção desta política se deu em razão do aumento da inadimplência então detectada no Sistema F inanceiro $\mathrm{N}$ acional eda al teração na qual idade do crédito dessas modalidades, devido à mudança estrutural ocorrida no mercado brasileiro com a introdução do crédito consignado. Já no quarto trimestre de 2006, as operações de crédito das financeiras de crédito ao consumidor retomaram o crescimento, devido, principalmente, à melhora da qualidade de crédito e à reformatação da oferta da instituição para o segmento de crédito consignado.

Com relação ao Í ndice de I nadimplência, verificou-se redução de 5,4\%, em 2006, para 3,9\%, no final de 2007, como resultado de uma política conservadora de administração de riscos da carteira. E m junho de2008, o índiceficou praticamente estável, atingindo 4\% (G ráfico I.6.4). O segmento de maior risco, responsável por grande parteda despesa de provisão para perdas com créditos, éo decrédito direto ao consumidor em parcerias com lojistas. 


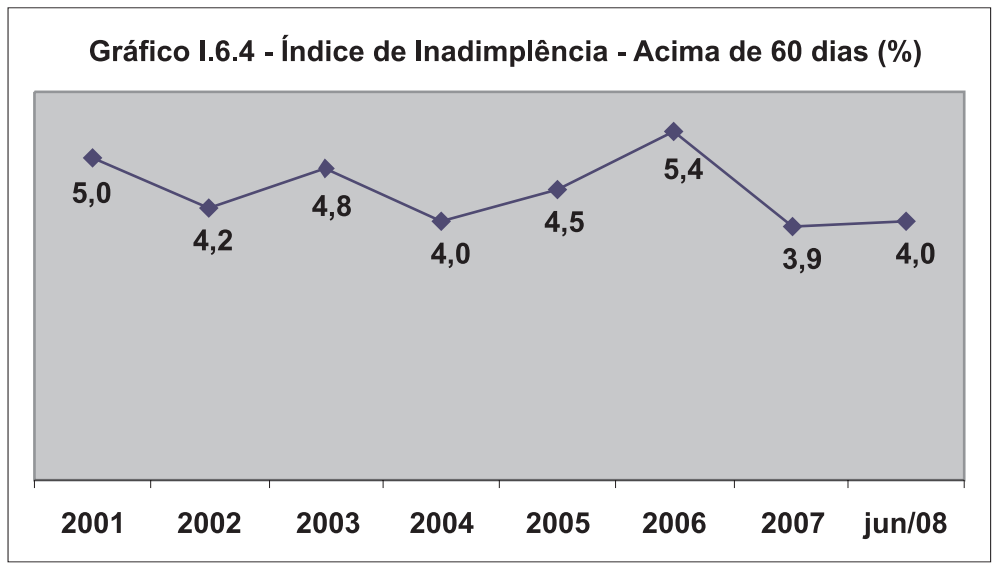

Fonte: Elaboração própria a partir de dados extraídos do site do U nibanco.

\section{Gestão de riscos}

O Í ndice de Basileia do U nibanco alcançou 13,71\% em junho de 2008 , acima do mínimo exigido pelo Banco Central, de $11 \%$. A té 2003, esse índice apresentava trajetória de crescimento, porém essa trajetória se reverteu a partir de 2004 (G ráfico I.6.5).

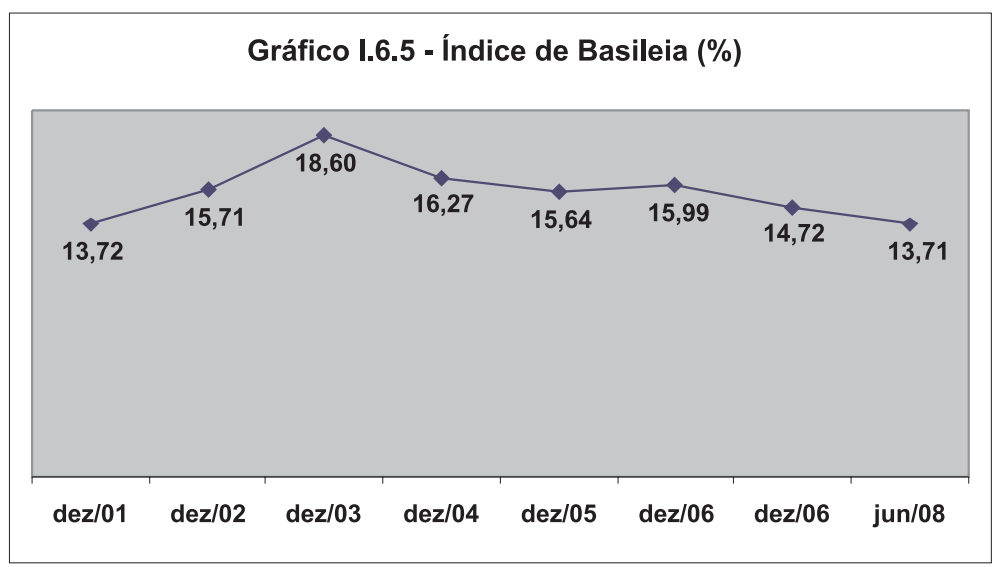

Fonte: Elaboração própria a partir de dados extraídos do site do Banco C entral do Brasil. 
A composição da carteira de crédito apresentou melhoria, com aumento dos créditos concentrados nos níveis de risco $A$ A, A, B e C, de $90,8 \%$ em dezembro de 2000 para 95,3\% em junho de 2008 (Tabela I.6.3).

T abela I .6.3 - Composição da C arteira de Crédito por N ível de R isco (\%)

\begin{tabular}{c|c|c|c|c|c|c|c|c|c}
\hline & dez./ 00 & dez./ 01 & dez./ 02 & dez./ 03 & dez./ 04 & dez./ 05 & dez./ 06 & dez./ 07 & jun./ 08 \\
\hline AA & 40,8 & 41,3 & 34,9 & 39,0 & 39,9 & 41,2 & 42,8 & 42,7 & 41,6 \\
\hline A & 29,9 & 28,6 & 29,0 & 34,5 & 37,2 & 38,1 & 38,7 & 42,7 & 43,3 \\
\hline B & 9,8 & 9,8 & 10,1 & 9,8 & 8,4 & 7,9 & 7,9 & 7,8 & 8,3 \\
\hline C & 10,3 & 11,7 & 17,0 & 7,9 & 5,5 & 5,1 & 4,2 & 2,2 & 2,1 \\
\hline D & 2,4 & 2,3 & 2,9 & 2,8 & 4,1 & 3,1 & 1,3 & 0,9 & 1,0 \\
\hline E & 1,1 & 1,3 & 1,7 & 2,0 & 1,5 & 0,9 & 0,8 & 0,6 & 0,6 \\
\hline F & 1,1 & 1,1 & 0,8 & 0,9 & 0,6 & 0,8 & 0,7 & 0,5 & 0,6 \\
\hline G & 1,2 & 1,2 & 1,3 & 0,7 & 0,9 & 0,8 & 0,6 & 0,4 & 0,5 \\
\hline H & 3,4 & 2,7 & 2,3 & 2,4 & 1,9 & 2,1 & 3,0 & 2,2 & 2,0 \\
\hline A A-C & 90,8 & 91,4 & 91,0 & 91,2 & 91,0 & 92,3 & 93,6 & 95,4 & 95,3 \\
\hline D-H & 9,2 & 8,6 & 9,0 & 8,8 & 9,0 & 7,7 & 6,4 & 4,6 & 4,7 \\
\hline
\end{tabular}

Fonte: Elaboração própria a partir de dados extraídos do site do U nibanco.

A política de administração de riscos do U nibanco, aliada ao crescimento de carteiras demenor risco, como consignado eveículos, possibilitou a contínua melhora na qual idade da carteira de crédito. E ssas mudanças refletiram-se na queda da margem financeira e da despesa deprovisão para perdas com créditos deliquidação duvidosa.

A administração do risco de crédito érealizada por meio da aplicação de políticas deavaliação, concessão, monitoramento econtrole do crédito. A s políticas compõem-se de definições delimites de crédito, buscando evitar concentração em clientes e setores específicos que possuam alto fator de risco. A decisão sobre crédito a empresas é embasada em fatores como histórico financeiro, fluxos de caixa, qualidade da administração, histórico de relacionamento, situação de mercado e outros fatores relacionados a risco de crédito.

A administração de crédito no segmento de varejo, por sua vez, exigesistema eprocessos especializados, dado o considerável volume 
de solicitações. São utilizados vários instrumentos estatísticos para avaliação eimpostos rigorosos padrões deoriginação eadministração da carteira de crédito, incluindo restrições aos aumentos de limites de crédito e às renovações de limites de cheque especial.

É realizado acompanhamento e monitoramento da carteira de crédito, com análises individuais das maiores exposições e concentrações, e cál culos de perdas esperadas e inesperadas por meio de modelos matemáticos e estatísticos.

\section{Índices de cobertura e de eficiência}

0 Í ndice deC obertura, querepresenta a razão entra as R eceitas de Prestação de Serviços eas D espesas de Pessoal, vem crescendo significativamenteno U nibanco, passando de 91,5\% em 1997 para 140,1\% no primeiro semestre de 2008. Esse crescimento pode ser explicado pela ampliação das R eceitas de P restação de Serviços em 242,7\%, no período de 1997 a 2007, contra um crescimento de somente $109,6 \%$ nas D espesas de Pessoal, nesse mesmo período (T abela I .6.4).

Tabela I.6.4 - Índice de C obertura (em R \$ milhões)

\begin{tabular}{l|l|l|l|l|l|l|l|l|l|l|l|l}
\hline & $\mathbf{1 9 9 7}$ & $\mathbf{1 9 9 8}$ & $\mathbf{1 9 9 9}$ & $\mathbf{2 0 0 0}$ & $\mathbf{2 0 0 1}$ & $\mathbf{2 0 0 2}$ & $\mathbf{2 0 0 3}$ & $\mathbf{2 0 0 4}$ & $\mathbf{2 0 0 5}$ & $\mathbf{2 0 0 6}$ & $\mathbf{2 0 0 7}$ & $\mathbf{1 0 S 0 8}$ \\
\hline $\begin{array}{l}\text { Receitas de } \\
\begin{array}{l}\text { Prest. de } \\
\text { Serviços }\end{array}\end{array}$ & 839 & 882 & 996 & 1.022 & 1.347 & 1.595 & 1.832 & 1.953 & 2.196 & 2.459 & 2.875 & 1.472 \\
\hline $\begin{array}{l}\text { Despesas } \\
\text { dePessoal }\end{array}$ & 917 & 869 & 806 & 883 & 1.256 & 1.313 & 1.461 & 1.639 & 1.609 & 1.829 & 1.922 & 1.051 \\
\hline $\begin{array}{l}\text { Indice de } \\
\begin{array}{l}\text { obertura } \\
\text { (\%) }\end{array}\end{array}$ & 91,5 & 101,5 & 123,6 & 115,7 & 107,2 & 121,5 & 125,4 & 119,2 & 136,5 & 134,4 & 149,6 & 140,1 \\
\hline
\end{tabular}

Fonte: Elaboração própria a partir de dados extraídos do site do Banco C entral do Brasil.

0 menor crescimento das receitas de prestação de serviços no primeiro semestre de 2008 se deve à queda nas receitas com tarifas cobradas declientes eà estratégia de crescimento da base de clientes 
por meio da isenção de al gumas tarifas. $G$ rande parte dos produtos ofertados está focada na baixa renda, como os cartões sem anuidade. E ssas receitas também foram impactadas pela al teração da regulamentação de tarifas bancárias estabel ecida pelo Banco C entral, que entrou em vigor em abril de 2008.

Por outro lado, contribuíram positivamente para o resultado das receitas de prestação de serviços aquelas advindas das operações de cartões de crédito (U nicard e H iperC ard), devido ao crescimento do faturamento da base de cartões, e as provenientes de transações estruturadas de mercado de capitais.

Em junho de2008, as linhas quemais contribuíram para a geração de R eceitas de Prestação de Serviços foram os Cartões de $C$ rédito e Conta-C orrente, que tiveram participação de $27,8 \%$ e $21,5 \%$, respectivamente (G ráfico I.6.6).

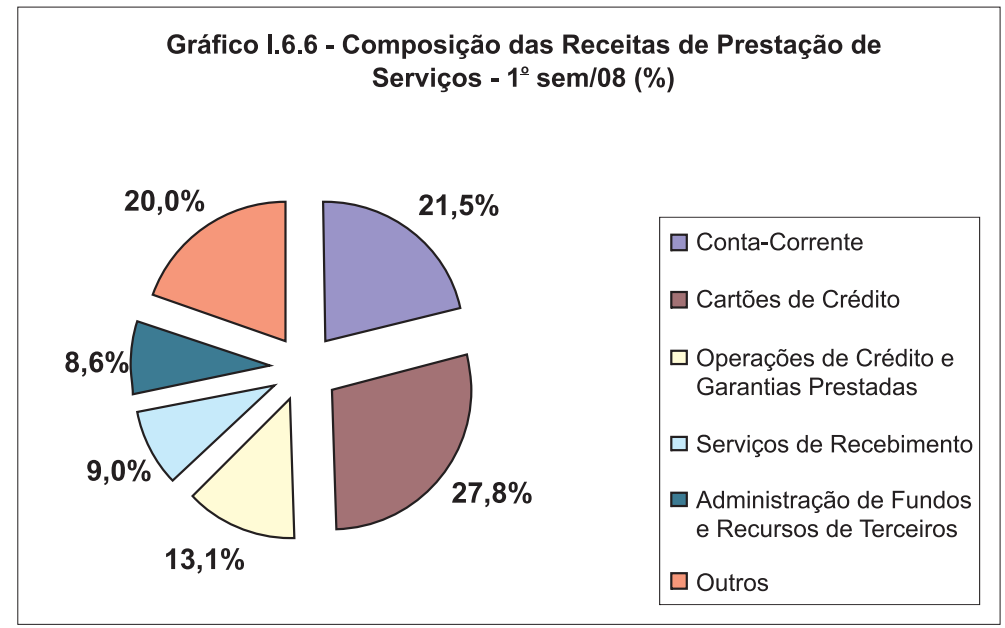

Fonte: Elaboração própria a partir de dados extraídos do site do U nibanco.

0 ÍndicedeE ficiência apresentou-se praticamenteconstanteaté 2004 , quando então passou a decrescer, atingindo $42 \%$ no primeiro semestre de 2008 (G ráfico I.6.7). 


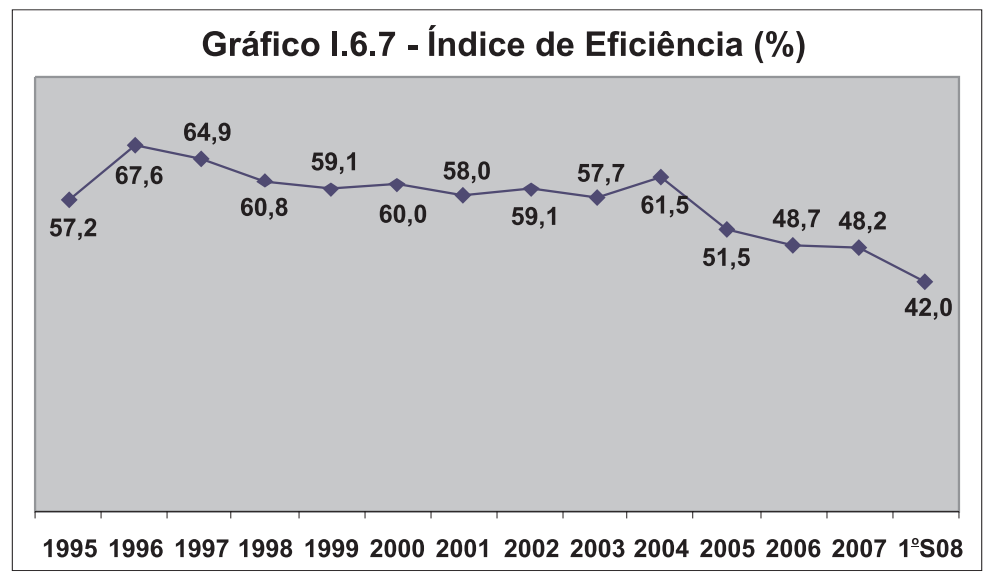

Fonte: Elaboração própria a partir de dados extraídos do site do U nibanco.

\section{Composição dos ativos e das receitas de intermediação financeira}

O U nibanco atingiu um total de ativos de $R \$ 169,7$ bilhões em junho de 2008, sendo queas 0 perações de C rédito eA rrendamento M ercantil representaram $32,8 \%$ dessevalor, contra $15,6 \%$ da carteira deT ítulos eV alores M obiliários el nstrumentos F inanceiros e D erivativos. 0 comportamento da participação dessas carteiras no total de ativos nos últimos anos não apresentou uma tendência específica; entretanto, a carteira de 0 perações de C rédito mantém-se, desde 1997, como o ativo de maior participação na carteira total deA tivos (Tabelal.6.5).

O s segmentos da carteira de crédito que mais vêm contribuindo para o crescimento dos ativos são o de financiamento de automóveis, pequenas e médias empresas, cartões de crédito e carteira de originação própria de crédito consignado.

A C arteiradeT ítulos eValores M obiliáriosécomposta, principalmente, por T ítulos Públicos, que, em junho de 2008, responderam por $76,7 \%$ do total da carteira, contra 50,7\% em dezembro de 1998 (Tabelal.6.6). 
Tabelal .6.5 - Composição dos A tivos (em \%)

\begin{tabular}{c|c|c|c|c|c|c}
\hline D ata & $\begin{array}{c}\text { A plicações } \\
\text { Interfin. }\end{array}$ & $\begin{array}{c}\text { T V M } \\
\text { elnstr. } \\
\text { Financ. } \\
\text { D eriv. }\end{array}$ & $\begin{array}{c}\text { O p. de } \\
\text { Crédito e } \\
\text { A rrend. } \\
\text { M erc. }\end{array}$ & $\begin{array}{c}\text { O utros } \\
\text { Créditos }\end{array}$ & O utros $^{\mathbf{1}}$ & $\begin{array}{c}\text { A tivo Total } \\
\text { (em } \\
\text { R \$ bilhões) }\end{array}$ \\
\hline dez./ 97 & 23,2 & 12,8 & 33,5 & 11,1 & 19,4 & 25,4 \\
\hline dez./ 98 & 19,3 & 13,0 & 34,3 & 13,4 & 20,0 & 29,4 \\
\hline dez./ 99 & 16,6 & 19,5 & 34,8 & 11,6 & 17,5 & 33,5 \\
\hline dez./ 00 & 13,8 & 21,0 & 32,4 & 14,2 & 18,6 & 48,5 \\
\hline dez./ 01 & 8,6 & 24,5 & 39,9 & 12,3 & 14,7 & 51,8 \\
\hline dez./ 02 & 22,2 & 21,7 & 30,5 & 13,0 & 12,6 & 70,9 \\
\hline dez./ 03 & 16,8 & 16,9 & 37,5 & 15,0 & 13,8 & 63,6 \\
\hline dez./ 04 & 19,1 & 13,4 & 39,0 & 14,6 & 13,9 & 72,9 \\
\hline dez./ 05 & 15,6 & 15,8 & 40,8 & 15,0 & 12,8 & 84,5 \\
\hline dez./ 06 & 19,9 & 12,1 & 40,3 & 13,8 & 13,9 & 97,8 \\
\hline dez./ 07 & 24,8 & 13,3 & 34,0 & 12,4 & 15,5 & 148,0 \\
\hline jun./ 08 & 23,3 & 15,6 & 32,8 & 11,7 & 16,6 & 169,7 \\
\hline Cresc. (\%) & 567,3 & 717,5 & 551,8 & 607,6 & 469,8 & 568,1 \\
\hline
\end{tabular}

1) Inclui D isponibilidades, Relações Interfinanceiras, R elações de Interdependências, Provisão para C réditos de L iquidação D uvidosa, O utrosValores e Bens, I mobilizado de A rrendamento ePermanente.

Fonte: Elaboração própria a partir de dados extraídos do site do Banco C entral do Brasil.

T abelal .6.6 - Composição da C arteira deT ítulos eValores M obiliários (em \%)

\begin{tabular}{|c|c|c|c|c|c|c|c|c|c|c|c|}
\hline & $\frac{8}{80}$ & $\frac{8}{8}$ & $\frac{8}{8}$ & $\frac{\delta}{d}$ & $\frac{8}{d}$ & $\frac{8}{\frac{8}{8}}$ & $\frac{8}{\frac{8}{8}}$ & $\frac{8}{8}$ & $\frac{8}{8}$ & $\frac{\delta}{d}$ & 8 \\
\hline Tít. Públicos & 50,7 & 54,6 & 66,9 & 62,9 & 67,0 & 61,5 & 46,6 & 75,6 & 73,7 & 73,5 & 76,7 \\
\hline T ít. Privados & 49,3 & 45,4 & 33,1 & 37,1 & 33,0 & 38,5 & 53,4 & 24,4 & 26,3 & 26,5 & 23,3 \\
\hline
\end{tabular}

Fonte: Elaboração própria a partir de dados extraídos do site do U nibanco.

A s R eceitas de I ntermediação Financeira al cançaram R \$12,8 bilhões no primeiro semestre de 2008, sendo que as 0 perações de C rédito e A rrendamento $M$ ercantil foram responsáveis por $64,5 \%$ dessas receitas, percentual que não sofreu alterações significativas nos últimos anos. A s O perações com T ítulos eValores M obiliários responderam por $22,7 \%$ do total das receitas no primeiro semestre de2008 (Tabela I.6.7). 
Tabela I.6.7 - Composição das R eceitas de Intermediação Financeira (em \%)

\begin{tabular}{l|c|c|c|c}
\hline D ata & $\begin{array}{c}\text { O p. C rédito e } \\
\text { A rrend. M erc. }\end{array}$ & $\begin{array}{c}\text { O perações com } \\
\text { T V M }\end{array}$ & O utros $^{1}$ & $\begin{array}{c}\text { Total } \\
\text { (em R \$ bilhões) }\end{array}$ \\
\hline 1997 & 68,6 & 21,7 & 9,7 & 5,7 \\
\hline 1998 & 64,8 & 28,2 & 7,0 & 6,6 \\
\hline 1999 & 64,9 & 18,5 & 16,6 & 11,4 \\
\hline 2000 & 63,7 & 24,2 & 12,1 & 7,3 \\
\hline 2001 & 66,5 & 21,7 & 11,8 & 12,2 \\
\hline 2002 & 60,4 & 43,3 & $-3,7$ & 14,0 \\
\hline 2003 & 69,0 & 18,3 & 12,7 & 12,8 \\
\hline 2004 & 65,7 & 25,5 & 8,8 & 12,6 \\
\hline 2005 & 70,0 & 21,5 & 8,5 & 15,8 \\
\hline 2006 & 68,2 & 24,0 & 7,8 & 17,6 \\
\hline 2007 & 70,0 & 24,8 & 5,2 & 19,2 \\
\hline 1052008 & 64,5 & 22,7 & 12,8 & 12,8 \\
\hline Cresc. (\%) & 243,3 & 283,9 & 81,9 & 236,8 \\
\hline
\end{tabular}

1) Inclui O perações com Instrumentos Financeiros D erivativos, $O$ perações de $C$ âmbio $e$ A plicações Compulsórias.

Fonte: Elaboração própria a partir de dados extraídos do site do Banco C entral do Brasil.

\section{Resultados}

O L ucro L íquido do U nibanco vem apresentando tendência de crescimento. Em 2007, foi alcançado o resultado de $\mathrm{R} \$ 3.499 \mathrm{mi}$ Ihões, o maior da história da instituição (G ráfico l .6.8).

$\mathrm{N}$ o primeiro semestre de 2008 , o lucro líquido atingiu $\mathrm{R} \$ 1,5$ biIhão. A satividades quemais contribuíram para esse resultad o foram as deintermediação financeira. T ambém apresentaram contribuição significativa as T arifas Bancárias e os C artões de C rédito.

0 crescimento do resultado da intermediação financeira podeser explicado, principal mente, pelo aumento do volume de crédito epela el evação das taxas de juros em al gumas carteiras.

0 R etorno A nualizado sobre o Patrimônio L íquido M édio foi de $26,6 \%$ no segundo trimestre de 2008 . A pesar de não ter sofrido al terações significativas de 1995 a 2004, esse índice apresentou tendência de crescimento a partir de 2005 (G ráfico I.6.9). 


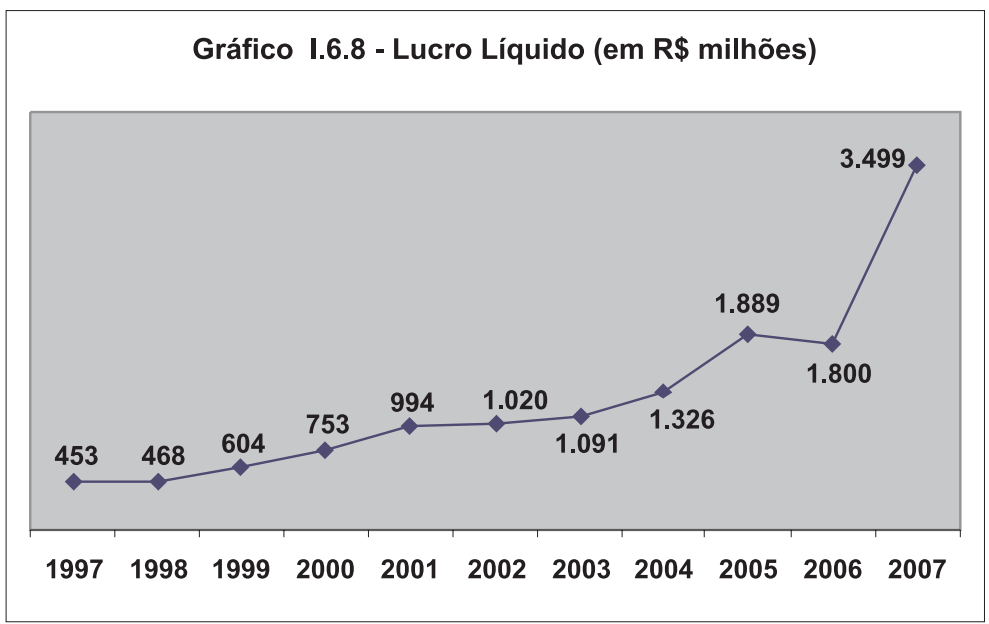

Fonte: Elaboração própria a partir de dados extraídos do site do Banco Central do Brasil.

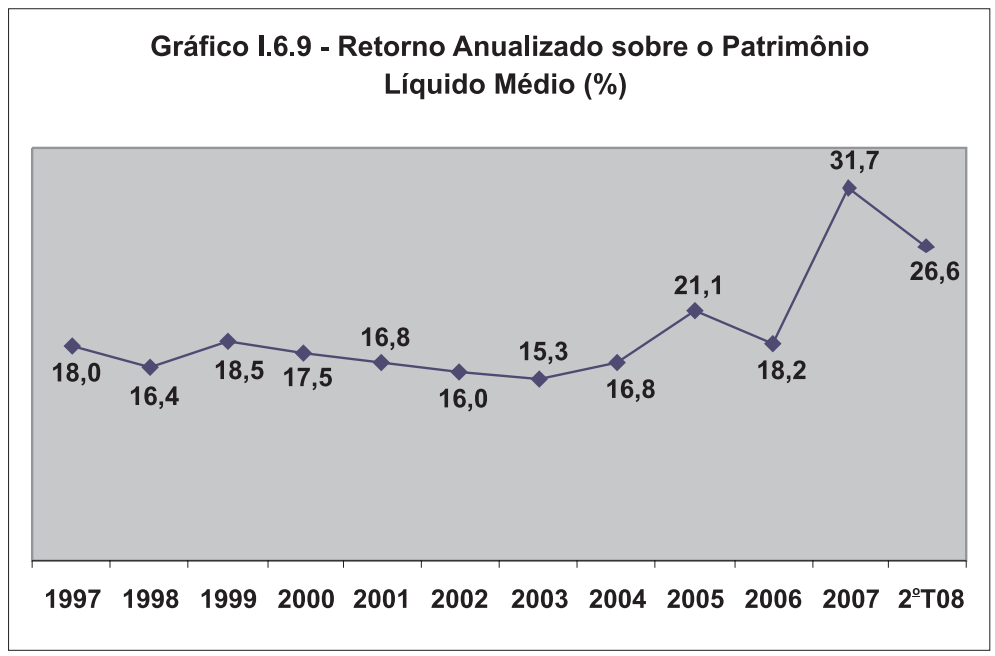

Fonte: Elaboração própria a partir de dados extraídos do site do U nibanco. 


\section{Tendências recentes}

O U nibanco vem acompanhando o ritmo do mercado na expansão do crédito, destacando-se na carteira de pessoas físicas. 0 significativo avanço dessesegmento vem sendo impulsionado pelas operações de crédito consignado e definanciamento de veículos. A o contrário do ocorrido em 2006, o U nibanco não hesitou em entrar no disputado mercado de crédito consignado em 2007. A pesar de adotar como estratégia preferencial o desenvolvimento de carteira própria, a instituição também vem buscando a aquisição decarteiras de outras instituições, focando as operações com empresas privadas e beneficiários do IN SS (Valor E conômico, 9/ 11/ 2007).

A pesar da expansão verificada na carteira de crédito, a qual idade do crédito melhorou. A inadimplência, medida pelos atrasos acima de 60 dias, não sofreu alterações significativas (Valor E conômico, 9/ 11/ 2007).

Isso porque as carteiras que vêm apresentando maior expansão são aquelas com maior garantia, como financiamento de veículos, crédito consignado e crédito imobiliário. ${ }^{24} \mathrm{C}$ aso fossem excluídas essas operações, a inadimplência teria aumentado em 2006 eteria se mantido em nível el evado. Sem o crédito consignado, a inadimplência do crédito pessoal (acima de 90 dias), no final de 2007, passaria de 5,3\% para 14,7\% (Valor E conômico, 13/3/ 2008).

Com a expectativa de crescimento do crédito imobiliário nos próximos anos, o U nibanco aumentou o foco neste segmento. A estrutura de atendimento foi reforçada e os processos de documentação e aprovação de crédito foram agilizados. V isando ampliar a originação de negócios, o U nibanco intensificou o relacionamento com as principais incorporadoras, construtoras eimobiliárias do país.

A expansão do crédito direcionado às construtoras se acelerou e avança em uma velocidade quase semel hante à dos empréstimos bancários destinados à habitação para as pessoas físicas. 0 U nibanco

24 A s novas operações de crédito imobiliário são contratadas com alienação fiduciária, o que reduz as taxas médias de inadimplência. 
também tem feito parcerias com imobiliárias para o financiamento de imóveis usados. A instituição fechou parceria com o Sindicato das E mpresas de Compra, Venda eL ocação de I móveis de São Paulo (Secovi-SP), com a R ede São J osé dos Campos, formada por 11 imobiliárias, e com a Júlio Bogoricin, do Rio de J aneiro. 0 objetivo principal dessas parcerias éatrair as classes $\mathrm{B}$ eC , devido à expectativa de crescimento nesses segmentos (Valor E conômico, 18/ 4/ 2007; Valor E conômico, 3/ 9/2007).

U ma importante tendência verificada nos últimos anos é de mudança do mix da carteira de crédito da instituição. Em 2003, a distribuição era de 50\%-50\%, entreo varejo eo atacado. A tualmente, o varejo representa $63 \%$ da carteira, demonstrando a evolução da estratégia, anunciada em 2004, de migrar para aquelas carteiras que tivessem maior margem, maior taxa decrescimento e maior capacidade de rentabilizar a operação.

A estratégia de segmentação do banco também foi direcionada para os segmentos com maior margem e maiores taxas de crescimento, especialmente os segmentos de financiamento ao consumo e cartões de crédito, voltados principal mente para classes mais baixas.

Para o banco, o setor definanciamento ao consumo éum dos segmentos que apresentam maior crescimento e maior rentabilidade no mercado brasileiro deserviços financeiros. A tingir uma fortepresença nesse mercado éparte central da estratégia de ganhar escala no negócio de varejo eatingir o segmento de renda mais baixa do mercado.

Em 30 de outubro de 2008, foi anunciada a fusão do U nibanco com o I taú, queoriginará a instituição I taú-U nibanco H olding (IU ), uma das vinte maiores instituições financeiras do mundo, a maior do B rasil e o maior congl omerado financeiro privado do H emisfério Sul, de acordo com dados do final do terceiro trimestre de 2008 (Valor E conômico, 3/ 11/2008). O U nibanco possuirá 34\% da nova instituição, enquanto o restanteserá detido pelo I taú (R euters, 3/ 11/ 2008).

E m novembro de2008, o U nibanco anunciou a compra da participação de 48\% da americana A IG , naU nibanco A I G , impulsionado, principalmente, pela crise internacional, que afetou severamente a A IG . D essa forma, o U nibanco pôs fim a uma parceria de onze 
anos e assumiu o controle majoritário da (agora) U nibanco Seguros e Previdência (Valor E conômico, 30/ 10/ 2008).

0 encerramento da sociedade poderá abrir caminho para a integração das áreas de seguros, previdência privada e capitalização do U nibanco e do I taú, que foi um dos motivos que impulsionaram a operação de fusão (G azeta M ercantil, 28/ 11/ 2008).

\section{Santander}

\section{Histórico e estrutura}

O Banco de Santander foi fundado em 15 de maio de 1857, na E spanha, por iniciativa de um grupo de comerciantes vinculados à economia da região eao comércio colonial 0 banco éo maior da zona do euro por capital ização em bolsa eestá entreas mai ores instituições financeiras do mundo.

O primeiro escritório de representação do Santander no Brasil foi instalado em 1970 e, em 1982, foi inaugurada a primeira agência para o público. Em 1991, começaram as operações do banco de investimento Santander I nvestment no B rasil. A partir da segunda metade da década de 1990, o G rupo Santander decidiu ampliar seus investimentos no Brasil e, impulsionado pelo momento de consolidação do setor financeiro no país, executou um plano deaquisição de instituições com perfis distintos e públicos-alvo estratégicos.

Essa estratégia, que correspondeu a um investimento no país de U S\$ 7,2 bilhões, foi iniciada com a aquisição do Banco $G$ eral do Comércio S.A ., em 1997, e do Banco N oroesteS.A ., em 1998, ambos com concentração no varejo no E stado de São Paulo. E m janeiro de 2000, a instituição adquiriu o C onglomerado Financeiro M eridional, formado pelos bancos $\mathrm{M}$ eridional, um importante banco regional de varejo do $\mathrm{R}$ io G rande do Sul, e Bozano-Simonsen, um banco de atacado com experiência em atividades de mercado de capitais. 0 projeto de aquisições culminou em 2000 na compra, por meio de leilão deprivatização, do Banespa, banco estadual com forteatuação 
no varejo euma expressiva rede de agências eclientes. E $m$ 2001, foi instituído o conglomerado financeiro Santander Banespa, quepassou a ser um dos principais bancos privados do país.

A pós esses investimentos, a instituição passou deum banco concentrado em atividades deA tacado para um banco universal. Entre dezembro de 2000 e dezembro de 2003, o banco dedicou-sea consolidar as operações brasileiras, com ênfase para a tecnologia. Em agosto de2006, as diretorias executivas do Banco Santander M eridional S.A . (BSM ), do Banco Santander Brasil S.A . (BSB), do Banco Santander S.A . (BSSA ) e do Banco do E stado de São Paulo S.A . (Banespa) e o Consel ho de A dministração do Banespa aprovaram a proposta de reestruturação societária constituída pelas incorporações do BSB, do BSSA edo Banespa pelo BSM . A instituição passou a denominar-se Banco Santander Banespa S.A ., permanecendo vinculada societariamente ao Banco Santander Central H ispano.

E $m$ 2007, como parte da estratégia denegócios em todas as nações ondeatua, o G rupo Santander promoveu a unificação da marca para simbolizar o fortalecimento dos negócios nos mercados gl obais. N o Brasil, a instituição passou a denominar-se Banco Santander S.A ., assim como todas as outras instituições do mundo pertencentes ao grupo. A lém dessa unificação, foram aprovados vários procedimentos da reestruturação societária, objetivando a racional ização operacional. D essa forma, a comparação dos dados dos anos de 2007 e2008 com os dados dos anos anteriores deve considerar essas alterações (Valor E conômico, 30/ 4/ 2007). Em março de 2007, a C omissão de Valores M obiliários (CV M ) aprovou a abertura decapital do banco.

A instituição opera como banco múltiplo e desenvolve suas operações por meio das cartei ras comercial, decâmbio, deinvestimento, decrédito efinanciamento, decrédito imobiliário e de arrendamento mercantil. Por meio de empresas ligadas, atua também nos mercados de seguros, previdência privada, capitalização, arrendamento mercantil, administração defundos deterceiros e corretagem devalores mobiliários e de seguros. T odas essas operações são conduzidas em conjunto no mercado financeiro, por meio do Banco Santander S.A ., daSantander Seguros S.A . edesuas respectivas controladas. O Banco 
Santander S.A . é a instituição-líder do conglomerado econômico financeiro perante o Banco Central do Brasil, sendo integrante do $G$ rupo Santander Central H ispano, controlado pelo Banco Santander, S.A ., com sedena Espanha.

Em outubro de 2007, como vimos, o A BN - A mro foi adquirido pelo consórcio formado pelo Santander, o britânico R oyal Bank of Scotland (RBS) e pelo belgo-holandês F ortis. 0 consórcio dividiu 0 A BN conformeos interesses geográficos decada membro do grupo. A divisão envolveu 4.500 agências distribuídas em 53 países, sendo que o F ortis ficou com as operações da $\mathrm{H}$ olanda e com as operações de administração de ativos e o RBS ficou com as operações de atacado e de banco de investimento e com as atividades na Á sia e nos EU A. O Santander, por sua vez, ficou com a unidade italiana ecom as operações brasileiras.

A aquisição do A BN permitiu que o Santander ampliasse, no B rasil, sua atuação no crédito para pessoa física eno financiamento deveículos, segmentos nos quais o banco espanhol não tinha participação significativa. No caso do financiamento de veículos, por meio da financeira A ymoré, o A BN detinha $16 \%$ do mercado, enquanto 0 Santander possuía 7\% (Valor E conômico, 1/ 10/ 2007). Os dois bancos também secomplementam nos negócios, uma vez que o A BN tinha forte concentração no Varejo, enquanto o Santander émais especializado nos negócios com $\mathrm{G}$ randes Empresas.

Em 24 de julho de 2008, o Banco Santander Espanha passou a exercer efetivamente o controle societário indireto das empresas do Conglomerado A BN - A mro R eal no Brasil, após o cumprimento de todas as condições para a transferência do controle, especialmente a obtenção da aprovação do D e N ederlandsche Bank (Banco Central da H olanda) e do Banco Central do Brasil.

A partir de 29 deagosto de 2008, o Banco A BN -A mro R eal S.A . e o A BN - A mro B rasil D ois Participações S.A. erespectivas empresas controladas passaram a integrar os conglomerados financeiro e econômico-financeiro Santander. D essa forma, como os números apresentados neste trabalho vão atéjunho de 2008, a análisenão foi afetada por essa aquisição. 


\section{Rede de atendimento}

O Santander atua em todos os segmentos do mercado financeiro, por meio deuma redecom 22.141 funcionários, 2.121 agências epostos de atendimento e 7.558 caixas eletrônicos. 0 banco atende todo o país com produtos de atacado e concentra suas operações de varejo nas regiões Sul eSudeste, ondeestão localizados $95,2 \%$ dos pontos de atendimento (G ráfico I.7.1), sendo que o Estado de São Paulo concentra a maioria deles. 0 R io de Janeiro, por sua vez, é o Estado no qual a instituição mais vem crescendo (Valor E conômico, 6/ 7/ 2007).

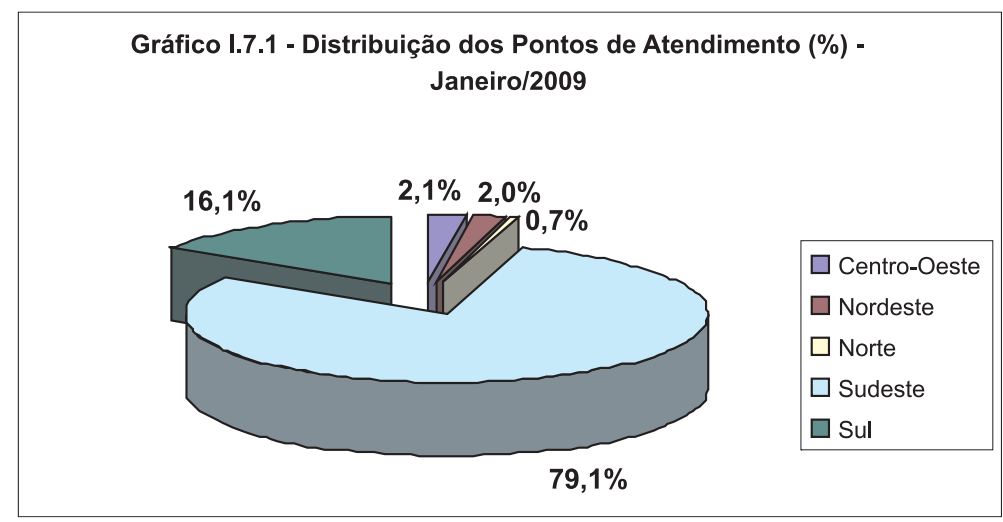

Fonte: Elaboração própria a partir de dados extraídos do site da Febraban.

Com a aquisição do banco A BN , a instituição passou a contar com 3.551 pontos de atendimento e17.978 terminais deautoatendimento, localizados principal mentenas regiões Sul eSudeste. O A BN também fortal eceu o Santander em regiões onde sua participação era menor, como o N ordeste (Valor E conômico, 1/ 10/ 2007).

Por meio de uma parceria com a R edeVerde-A marela (RVA ), o Santander detém 10 mil pontos de atendimento e 22.342 terminais e caixas interligados, distribuídos por todo o país. 0 banco também integra a R edeBanco24H oras, quedisponibiliza 30.067 equipamentos, epossui, ainda, o A utoatendimento $\mathrm{M}$ óvel, instalado em eventos sazonais. O s clientes também podem ser atendidos 24 horas por 
meio dos canais diferenciados deacesso, como telefone fixo, telefone celular einternet banking.

O Santander Banespa conta, ainda, com uma financeira própria, a O lé, criada em dezembro de 2005 com o objetivo de financiar o

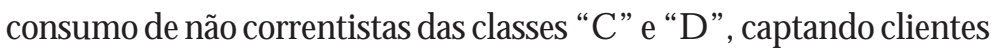
exclusivamente fora da rede do banco.

\section{Base de clientes}

O Banco Santander no Brasil possuía, em junho de 2008, 8,5 milhões de clientes, sendo 4,5 milhões de correntistas. Parte desses clientes foi herdada do Banespa, que administrava a folha de pagamento dos funcionários do governo de São Paulo. M esmo após a transferência da folha para a N ossa C aixa, no início de 2007, os depósitos do banco cresceram, o que pode ter sido resultado de retenção de parte dos correntistas e da aquisição de novos clientes, inclusive com a conquista da folha do governo do R io de Janeiro (Valor E conômico, 1/ 10/ 2007). Em 2008, a instituição adquiriu os clientes globais do A BN (Valor E conômico, 8/ 2/ 2008).

A estratégia da instituição contempla uma segmentação dessa basedeclientes, com modelos diferenciados deatendimento, em quatro grandes áreas de negócios: Varejo, Empresas, Santander G lobal Banking \& $M$ arkets e $G$ estão de R ecursos deT erceiros.

O Varejo atende aos segmentos Pessoa F ísica e Business - empresas com faturamento de até $\mathrm{R} \$ 20$ milhões. $O$ segmento Pessoa Física vem apresentando crescimento significativo nos últimos anos, alcançando 7,4 milhões declientes em 2007 (Valor E conômico, 1/ 10/2007). Cada cliente dispõe de uma oferta de, pelo menos, quatro produtos ou serviços diferenciados. 0 Santander vem ampliando sua participação de mercado nos produtos para essesegmento, principal menteem cartões de crédito, financiamento deveículos ecrédito consignado. Já o segmento de empresas de pequeno e médio porte, com faturamento anual até $\mathrm{R} \$ 20$ milhões, atingiu 300 mil clientes em 2007 (Valor E conômico, 1/ 10/ 2007). 
O segmento E mpresas tem como foco deatuação as companhiase grupos econômicos com faturamento anual superior a R \$20 milhões. O segmento conta, ainda, com uma célula exclusiva denominada R eal Estate, para o aten dimento a empresas egrupos econômicos nacionais ou multinacionais ligados à área de construção e incorporação imobiliária. A atuação do segmento Empresas abrange todo o território nacional, com 36 escritórios localizados nas principais regiões do país. 0 banco vem buscando fortalecer sua presença comercial no segmento $\mathrm{C}$ orporate nas regiões $\mathrm{N}$ orte, $\mathrm{N}$ ordeste e $\mathrm{C}$ entro- $\mathrm{O}$ este.

0 segmento Santander G lobal Banking \& M arkets atende os grupos econômicos egrandes corporações nacionais einternacionais, efechou o ano de 2007 com, aproximadamente, 400 clientes corporativos e institucionais. $\mathrm{N}$ esse segmento, a estratégia é fortalecer a posição como um banco de relacionamento global, em linha com os modelos adotados pelo grupo no exterior.

O segmento de G estão de R ecursos de Terceiros é responsável pela gestão defundos de investimento direcionados a pessoas físicas ejurídicas e pela administração de recursos de tercei ros do segmento Private. ${ }^{25}$

A instituição também atua no segmento de governos e instituições, queédirecionado ao atendimento de entidades e empresas dos governosfederal, estadual emunicipal, além deinstituições privadas com faturamento acima de $\mathrm{R} \$ 20$ milhões, ligadas, principalmente, às áreas desaúdee associações. N o segmento deagronegócios, o Santander ocupa posi ção de destaque. Em dezembro de2007, era a mai or instituição privada no E stado de São Paulo ea terceira no Brasil.

O Santander considera que o modelo de segmentação adotado permiteo desenvolvimento de produtos eserviços queseenquadrem no perfil de cada segmento, favorecendo a eficácia da equipe comercial. Com base nesse modelo, foram criados cartões diferenciados, diversos planos deinvestimento epacotes de serviços que consideram o potencial e o perfil de cada segmento.

25 Pessoas físicas com investimentos acima de R \$ 3 milhões. 


\section{Captações}

O Santander capta recursos principal mente por meio de depósitos a prazo; entretanto, a participação dessa forma de captação vem decrescendo, passando de 78,3\% em dezembro de 1997 para 54\%em junho de2008. A s C aptações no M ercado A berto, por sua vez, vêm aumentando sua participação, atingindo 27,1\%, em junho de 2008, contra 16,7\%, em dezembro de 1997 (Tabela I.7.1).

Tabela I .7.1 - Composição das C aptações (em \%)

\begin{tabular}{|c|c|c|c|c|c|c|c|c|}
\hline & $\begin{array}{c}\text { À } \\
\text { Vista }\end{array}$ & Poupança & Interfin. & $\begin{array}{c}\text { A } \\
\text { Prazo }\end{array}$ & O utros & $\begin{array}{c}\text { D epósitos } \\
\text { Totais }\end{array}$ & $\begin{array}{l}\text { Cap. } \\
\text { M erc. } \\
\text { A berto }\end{array}$ & $\begin{array}{c}\text { Total } \\
\text { (em R \$ } \\
\text { bilhões) }\end{array}$ \\
\hline dez./ 97 & 4,7 & 0,0 & 0,3 & 78,3 & 0,0 & 83,3 & 16,7 & 1,10 \\
\hline dez./ 98 & 3,1 & 4,9 & 0,3 & 68,4 & 0,0 & 76,7 & 23,3 & 4,90 \\
\hline dez./ 99 & 6,6 & 6,3 & 0,9 & 61,3 & 0,0 & 75,1 & 24,9 & 5,00 \\
\hline dez./ 00 & 4,5 & 8,2 & 0,5 & 31,5 & 0,0 & 44,7 & 55,3 & 11,20 \\
\hline dez./ 01 & 13,3 & 14,5 & 0,2 & 39,4 & 0,0 & 67,4 & 32,6 & 23,50 \\
\hline dez./ 02 & 13,7 & 16,8 & 0,3 & 46,2 & 0,0 & 77,0 & 23,0 & 25,20 \\
\hline dez./ 03 & 14,2 & 16,2 & 0,0 & 39,8 & 0,0 & 70,2 & 29,8 & 25,90 \\
\hline dez./ 04 & 11,7 & 13,7 & 0,3 & 41,9 & 0,1 & 67,7 & 32,3 & 33,90 \\
\hline dez./ 05 & 8,5 & 9,6 & 0,5 & 41,2 & 0,2 & 60,0 & 40,0 & 50,00 \\
\hline dez./ 06 & 8,2 & 8,8 & 0,4 & 37,6 & 0,6 & 55,6 & 44,4 & 57,40 \\
\hline dez./ 07 & 10,0 & 10,1 & 0,5 & 41,6 & 0,7 & 62,9 & 37,1 & 62,30 \\
\hline jun./ 08 & 6,4 & 11,1 & 1,0 & 54,0 & 0,4 & 72,9 & 27,1 & 65,20 \\
\hline Cresc. $^{1}$ & $7.880,1$ & $7.871,6$ & $19.617,3$ & $3.971,5$ & $2.611 .306,3$ & $5.065,7$ & $9.514,8$ & $5.827,3$ \\
\hline
\end{tabular}

1) $\mathrm{N}$ os segmentos de Poupança e O utros o crescimento informado refere-se ao período de dezembro/ 1998 a junho/ 2008.

Fonte: Elaboração própria a partir de dados extraídos do site do Banco Central do Brasil.

\section{Carteira de crédito}

A carteira de 0 perações de C rédito e A rrendamento $M$ ercantil do Santander atingiu R $\$ 41,9$ bilhões em junho de 2008, o que representou um crescimento de 660\% em relação a dezembro de 1997 (G ráfico I.7.2). 


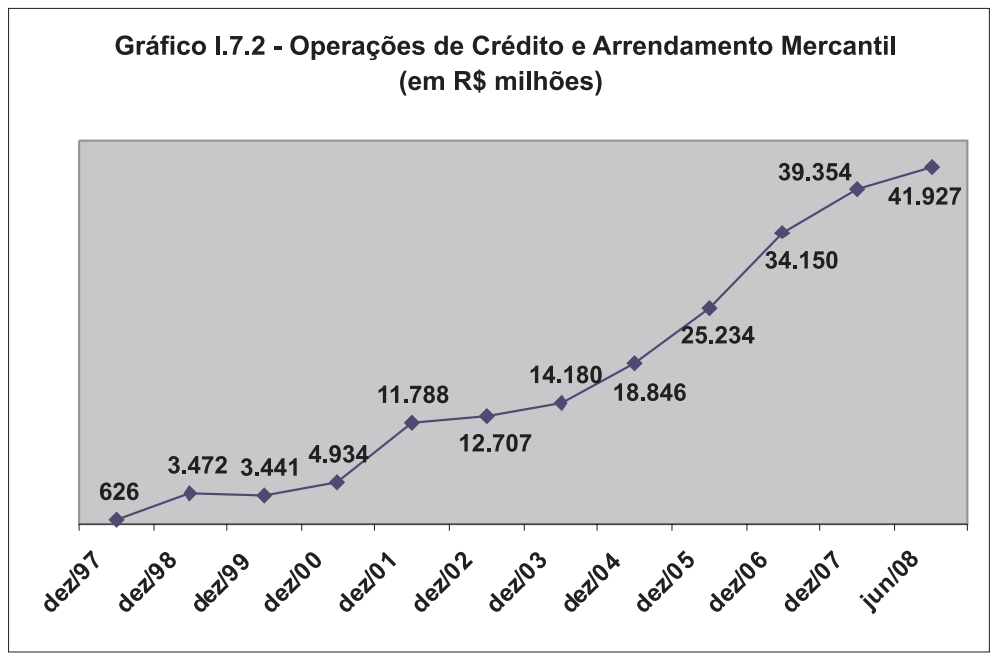

Fonte: Elaboração própria a partir de dados extraídos do site do Banco Central do Brasil.

O segmento com maior participação na carteira de crédito do Santander éo de Pessoas J urídicas, querepresentou 52,7\% da carteira total em junho de 2008. Essa participação, entretanto, vem decrescendo, enquanto a participação da carteira de Pessoas F ísicas vem aumentando (Tabela I.7.2).

Tabela I .7.2 - Composição da Carteira de C rédito por C liente (em \%)

\begin{tabular}{l|c|c|c|c|c|c|c|c|c}
\hline & $\mathbf{2 0 0 0}$ & $\mathbf{2 0 0 1}$ & $\mathbf{2 0 0 2}$ & $\mathbf{2 0 0 3}$ & $\mathbf{2 0 0 4}$ & $\mathbf{2 0 0 5}$ & $\mathbf{2 0 0 6}$ & jun./ 08 & C resc. \\
\hline Pessoas Jurídicas & 61,9 & 54,7 & 58,4 & 54,7 & 54,7 & 56,4 & 56,6 & 52,7 & 222,2 \\
\hline Pessoas Físicas & 22,4 & 29,5 & 26,4 & 29,9 & 31,2 & 32,1 & 32,8 & 35,8 & 505,9 \\
\hline H abitacional & 5,8 & 5,9 & 4,9 & 4,4 & 3,9 & 3,5 & 3,3 & 4,1 & 168,6 \\
\hline A gricultura & 8,1 & 9,0 & 8,9 & 9,4 & 9,4 & 7,0 & 6,9 & 7,0 & 226,7 \\
\hline Setor Público & 1,8 & 0,9 & 1,4 & 1,6 & 0,8 & 1,0 & 0,4 & 0,4 & $-19,1$ \\
\hline
\end{tabular}

Fonte: Elaboração própria a partir de dados extraídos do site do Banco Santander.

Considerando o período de dezembro de 2000 a junho de 2008, o segmento que mais cresceu foi o de Pessoas Físicas, com um desempenho positivo acumulado de 505,9\%. As linhas que mais têm contribuído para essecrescimento são as definanciamento deveículos 
e crédito consignado, que representaram $12,8 \%$ e 5,7\% em 2007 , com crescimento de $234,4 \%$ e $449,4 \%$ no período de 2003 a 2007 , respectivamente (Tabela I.7.3).

Tabela I.7.3 - Composição da Carteira de C rédito - Pessoa Física (\%)

\begin{tabular}{l|c|c|c|c|c|c}
\hline & $\mathbf{2 0 0 3}$ & $\mathbf{2 0 0 4}$ & $\mathbf{2 0 0 5}$ & $\mathbf{2 0 0 6}$ & $\mathbf{2 0 0 7}$ & C resc. \\
\hline Crédito Consignado & 0,9 & 1,8 & 3,5 & 4,7 & 5,7 & 449,4 \\
\hline Cartões de Crédito & 3,5 & 4,1 & 3,8 & 4,4 & 5,8 & 180,0 \\
\hline Crédito H abitacional & 4,4 & 3,9 & 3,5 & 3,3 & 4,6 & 117,1 \\
\hline Financiamento aV é́culos & 5,6 & 6,6 & 8,0 & 11,8 & 12,8 & 234,4 \\
\hline
\end{tabular}

Fonte: Elaboração própria a partir de dados extraídos do site do Banco Santander.

N o segmento de crédito consignado, em que o banco atua desde 2003, o destaque são as operações com o setor público, que representam mais de $60 \%$ do total. No final de 2007 , o banco mantinha 1.500 convênios de crédito consignado, num total de mais de 500 mil clientes.

$\mathrm{N}$ o segmento de financiamento de veículos, o destaque tem sido o C anal Externo, ou seja, o crédito concedido diretamente por lojas e concessionárias. 0 Santander começou a atuar nesse segmento em 2003, principalmente por meio da sua financeira O lé (V alor E conômico, 11/ 4/ 2006).

O s segmentos de cartões e crédito habitacional também são considerados relevantes para o Santander. U m dos motivos para o bom desempenho do segmento de cartões, em 2007 e 2008, foi o lançamento, em meados de 2007, do Cartão Santander Free, isento detarifas eanuidades. A té o final de2007, o produto já contava com mais de 650 mil adesões. 0 utro destaque desse segmento éa Conta PagaSantander, lançada no terceiro trimestre de 2007, que possibilita ao cliente concentrar o pagamento de suas contas em dataúnica, com prazo de até 40 dias para o pagamento, sem juros emulta. Esse produto já representa $3 \%$ do faturamento total do segmento de cartões.

$\mathrm{N}$ o segmento de crédito habitacional, o crescimento deve-se, principal mente, à oferta de novas opções de prazos eà simplificação do processo deobten ção de crédito. 0 Santander foi o primeiro banco 
a estender, em outubro de2007, o prazo deamortização para 30 anos (G azeta M ercantil, 26/ 9/2007) ea realizar empréstimos prefixados, que, em 2007, representaram 44\% das operações da instituição. Em parte, esse comportamento se deve à própria estratégia mundial do banco, que considera o crédito imobiliário uma excelenteferramenta de fidelização e captação de clientes. Em 2007, 60\% da produção do banco atendeu não correntistas (Valor E conômico, 24/ 1/ 2008). A pesar do aumento do crédito para o segmento habitacional, a inadimplência não aumentou. $\mathrm{N}$ o primeiro semestre de 2008, o índice de inadimplência acima de 90 dias foi de $0,2 \%$ (Valor E conômico, 25/ $7 / 2008$ ).

N o segmento de pessoas jurídicas, destaca-sea carteira de pequenas e médias empresas, que, em 2007, representou $23 \%$ da carteira de crédito total, contra 9,4\% em 2002. A evolução é decorrente da ampla oferta delinhas decrédito para automóveis, veículos pesados, máquinas e equipamentos. T ambém se destacaram os produtos C onta-C orrente G arantida com Cartões e o C apital de G iro Premium, com isenção da última parcela.

O desempenho do segmento de G randes E mpresas, por sua vez, tem sido prejudicado pela maior acessibilidade dessas empresas ao mercado decapitais, o que possibilitou uma maior diversificação das fontes de financiamento. Também contribuiu para o baixo desempenho desse segmento a apreciação do real, até 2007, que impactou a carteira de crédito indexada e denominada em moeda estrangeira.

N a área de crédito rural, o Santander tem participação rel evante, sendo uma das maiores instituições financeiras do Estado de São Paulo, com destaque para o financiamento da agropecuária. E m 2007, o banco al cançou o quarto lugar no ranking dos maiores financiadores agrícolas do país. A significativa participação da instituição no financiamento agrícola foi herdada do Banespa, que tinha forte tradição na agricultura paulista (Valor E conômico, 24/ 4/ 2007 [2]).

A pesar do crescimento da carteira de crédito, o Í ndice del nadimplência não sofreu grandes alterações até2007. N o primeiro semestre de2008, esseíndiceatingiu 5,8\%, maior do que o verificado nos anos anteriores (G ráfico I.7.3). 


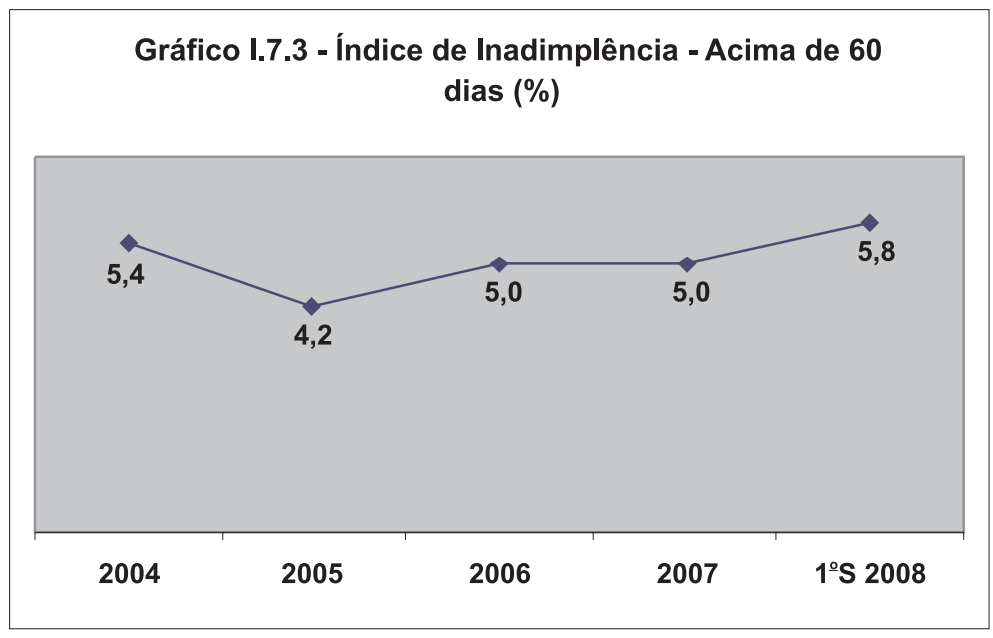

Fonte: Elaboração própria a partir de dados extraídos do site do Banco Santander.

\section{Gestão de riscos}

0 modelo de gestão de riscos de crédito e mercado adotado pelo Santander para proteger o capital e garantir a rentabilidade dosnegócios está sintonizado com os princípios gl obais do G rupo Santander, dentre os quais se destacam a independência e as decisões colegiadas. A área de gestão de riscos é composta pelo Comitê Executivo de $\mathrm{R}$ iscos e por vários comitês de crédito, estruturados por região e frentes de negócios.

O grupo Empresas eVarejo concentra PequenaseM édias E mpresas, G overnos el nstituições eP essoas F ísicas com baixo val or médio de dívida por pessoa/ empresa. A s avaliações, feitas por carteira de produtos, ocorrem periodicamente, por meio de Programas de G estão de Crédito. E m 2007, para absorver a onda de crescimento do crédito, esses programas permitiram agilização no processo de concessão, com a utilização de modelos de aprovação automática.

Já a área de riscos nos negócios Santander G lobal Banking \& $M$ arketseE mpresas inclui as grandes companhias, quesão distribuí- 
das por setores de atuação e avaliadas individualmente, no mínimo uma vez ao ano ou quando necessário. 0 s clientes são aval iados a partir deum modelo de pré-classificação quefixalimites máximos derisco por meio desistema demedição esegmento decapital econômico.

D esde 2006, o Santander informa, para o Banco da Espanha, os números de Basileiall pela abordagem $S$ tandard, também conhecida como M étodo Padronizado Simplificado, que considera ratings externos deagências internacionais como $M$ oodys, Fitch eStandard $\&$ Poor's.

A instituição também já definiu um cronograma, que é acompanhado por seus reguladores - Banco C entral do Brasil e Banco da E spanha -, para ingressar em $M$ odel os I nternos A vançados (A IR B - A dvanced I nternal R atings B ased), a opção mais completa edemaior sensibilidade ao risco. Essa abordagem utiliza uma extensa base histórica de operações, garantias e ratings internos para medir três fatores básicos do risco de crédito: a probabilidade de inadimplência (PD ) da contraparte, a capacidade de recuperação dos créditos em inadimplência ( $L$ GD ) ea exposição efetiva no momento do default (EAD).

A entrada em M odelos I nternos é de importância vital e estratégica para o Santander, uma vez que os bancos com as melhores práticas de gestão de riscos terão clara vantagem competitiva frente aos demais concorrentes. Com base nos dados comportamentais de cada cliente, o modelo indicará as possíveis estratégias a serem adotadas antes que esse se torne inadimplente.

0 Índice de Basileia do Santander atingiu 13,57\% em junho de 2008, acima do mínimo exigido pelo Banco Central. Entretanto, esse índice vem decrescendo desde 2004, quando atingiu 16,96\% (G ráfico I.7.4).

$\mathrm{N}$ os últimos anos, o banco vem aumentando suas provisões para créditos de liquidação duvidosa. Esse aumento se deve ao crescimento das carteiras de crédito Pessoa F ísica e P equenas e M édias E mpresas, de maior retorno, porém consideradas de maior risco. A inadimplência, entretanto, permaneceu controlada (Valor E conômico, 25/ 10/ 2007). 


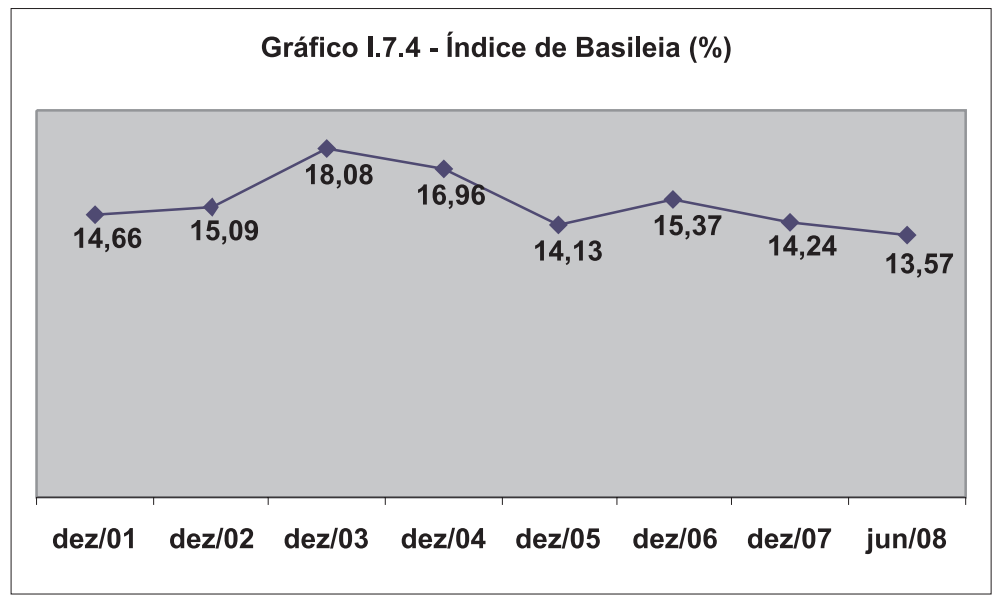

Fonte: Elaboração própria a partir de dados extraídos do site do Banco Central do Brasil.

Com relação à composição da cartei ra decrédito por nível derisco, os créditos classificados entre A A eC representaram 91,1\% do total dacarteira em junho de2008. D esde2005, observa-seumatendência dequeda do percentual deoperações concentradas nessa faixa derisco (Tabela I.7.4). Essa redução se deve ao crescimento das operações de maior risco - Pessoas F ísicas e Pequenas e M édias E mpresas.

Tabela I .7.4 - Composição da Carteira de Crédito por N ível de R isco (\%)

\begin{tabular}{c|c|c|c|c|c|c|c|c|c}
\hline & $\mathbf{2 0 0 0}$ & $\mathbf{2 0 0 1}$ & $\mathbf{2 0 0 2}$ & $\mathbf{2 0 0 3}$ & $\mathbf{2 0 0 4}$ & $\mathbf{2 0 0 5}$ & $\mathbf{2 0 0 6}$ & $\mathbf{2 0 0 7}$ & jun./ 08 \\
\hline AA & 33,0 & 37,0 & 44,8 & 45,7 & 47,3 & 52,0 & 59,2 & 57,1 & 56,2 \\
\hline A & 23,2 & 21,5 & 36,7 & 41,0 & 42,2 & 37,6 & 30,5 & 31,0 & 31,2 \\
\hline B & 5,2 & 25,6 & 6,0 & 3,9 & 3,3 & 2,2 & 1,9 & 1,2 & 1,4 \\
\hline C & 23,9 & 4,3 & 1,9 & 1,7 & 1,2 & 1,1 & 2,3 & 2,1 & 2,3 \\
\hline D & 3,2 & 3,0 & 3,4 & 1,9 & 1,6 & 2,9 & 1,2 & 4,2 & 4,4 \\
\hline E & 0,6 & 0,6 & 1,1 & 0,7 & 0,4 & 0,5 & 0,6 & 0,6 & 0,7 \\
\hline F & 1,3 & 0,6 & 0,5 & 0,4 & 0,4 & 0,4 & 0,6 & 0,7 & 0,9 \\
\hline G & 2,5 & 1,9 & 0,8 & 0,5 & 0,4 & 0,3 & 0,5 & 0,5 & 0,6 \\
\hline H & 7,1 & 5,5 & 4,8 & 4,2 & 3,2 & 3,0 & 3,2 & 2,6 & 2,3 \\
\hline A A - C & 85,3 & 88,4 & 89,4 & 92,3 & 94,0 & 92,9 & 93,9 & 91,4 & 91,1 \\
\hline D-H & 14,7 & 11,6 & 10,6 & 7,7 & 6,0 & 7,1 & 6,1 & 8,6 & 8,9 \\
\hline
\end{tabular}

Fonte: Elaboração própria a partir de dados extraídos do site do Banco Santander. 


\section{Índices de cobertura e de eficiência}

Seguindo umatendência do setor bancário, o Í ndicedeC obertura do Santander vem crescendo significativamente, atingindo 198,3\% em junho de 2008, contra 53,3\% em 1998. Essa evolução se deve ao crescimento de $1.461 \%$ das R eceitas de P restação de Serviços no período de 1998 a 2007, contra um crescimento de somente $349 \%$ das D espesas de Pessoal (Tabela I.7.5).

Tabela I .7.5 - Índice de C obertura (em R \$ milhões)

\begin{tabular}{l|c|c|c|c|c|c|c|c|c|c|c}
\hline & $\mathbf{1 9 9 8}$ & $\mathbf{1 9 9 9}$ & $\mathbf{2 0 0 0}$ & $\mathbf{2 0 0 1}$ & $\mathbf{2 0 0 2}$ & $\mathbf{2 0 0 3}$ & $\mathbf{2 0 0 4}$ & $\mathbf{2 0 0 5}$ & $\mathbf{2 0 0 6}$ & $\mathbf{2 0 0 7}$ & $\mathbf{1}$-S 08 \\
\hline $\begin{array}{l}\text { Rec. Prestação } \\
\text { Serviços }\end{array}$ & 235 & 153 & 211 & 980 & 1.268 & 1.393 & 1.930 & 2.280 & 2.859 & 3.668 & 1.973 \\
\hline $\begin{array}{l}\text { D espesas de } \\
\text { Pessoal }\end{array}$ & 441 & 344 & 469 & 2.531 & 1.742 & 1.722 & 1.893 & 2.107 & 1.938 & 1.981 & 995 \\
\hline $\begin{array}{l}\text { Indice de } \\
\text { Cobertura (\%) }\end{array}$ & 53,3 & 44,5 & 45,0 & 38,7 & 72,8 & 80,9 & 102,0 & 108,2 & 147,5 & 185,2 & 198,3 \\
\hline
\end{tabular}

Fonte: Elaboração própria a partir de dados extraídos do site do Banco C entral do Brasil.

Esse aumento das receitas de prestação de serviços pode ser explicado pela ampliação das operações de maior participação nas receitas totais: operações de crédito, administração de fundos e cartões de crédito, que responderam por 28,8\%,22,5\% e 14,9\% do total de receitas, respectivamente (G ráfico I.7.5).

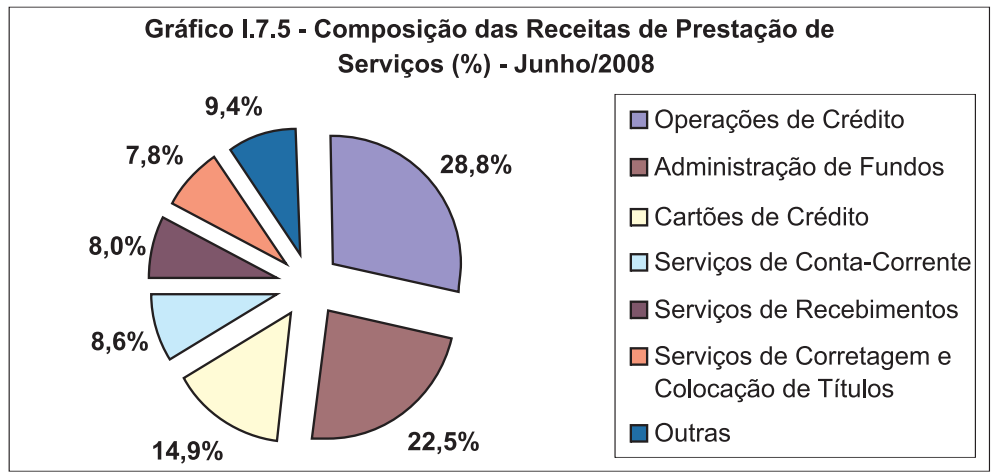

Fonte: Elaboração própria a partir de dados extraídos do site do Banco Santander. 
Em 2007, o Índice de Eficiência do Santander foi de 53,8\%, contra 58,9\% em 2006 (G ráfico I.7.6). Esse índice vem apresentando tendência de queda, sendo que a significativa redução verificada em 2001 foi resultado de um programa de redução dos gastos depessoal, de redução nas despesas de provisão em crédito e do aumento nas receitas de comissões.

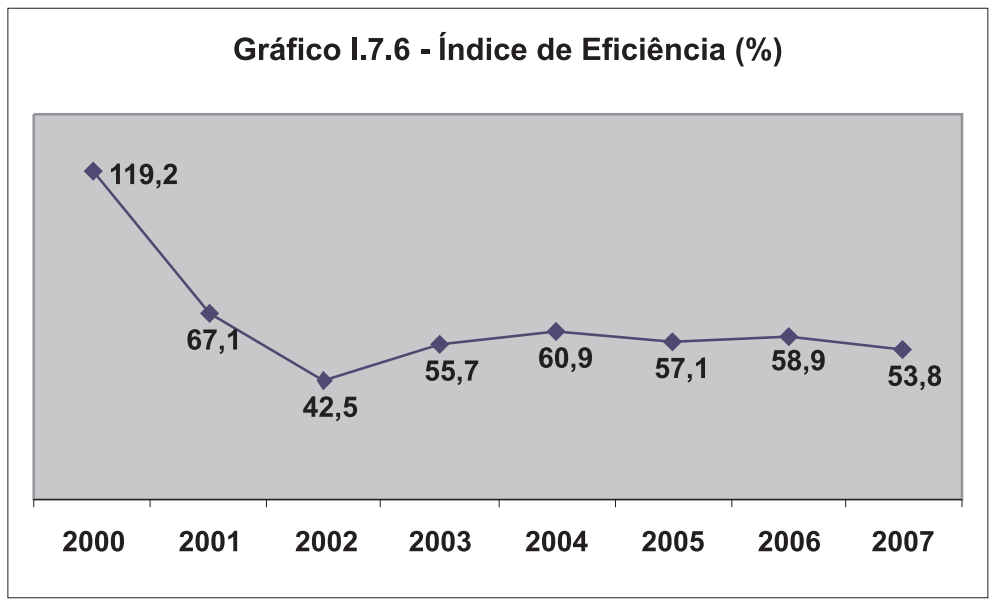

Fonte: Elaboração própria a partir de dados extraídos do site do Banco C entral do Brasil.

Composição dos ativos e das receitas de intermediação financeira

A carteira de A tivos do Santander é composta, principalmente, por $O$ perações de C rédito e A rrendamento $M$ ercantil, que responderam, em junho de 2008, por 32,9\% dos ativos totais. A té 2006, a participação da carteira de T V M e Instrumentos Financeiros D e rivativos era maior do que a da carteira de 0 perações de $C$ rédito e A rrendamento M ercantil entretanto, desde 2007; essa composição se inverteu (Tabela I.7.6). 
Tabelal .7.6 - Composição dos A tivos (em \%)

\begin{tabular}{|c|c|c|c|c|c|c}
\hline D ata & $\begin{array}{c}\text { A plicações } \\
\text { Interfin. }\end{array}$ & $\begin{array}{c}\text { T V M } \\
\text { e Instr. } \\
\text { Financ. } \\
\text { D eriv. }\end{array}$ & $\begin{array}{c}\text { O p. de } \\
\text { Crédito e } \\
\text { A rrend. } \\
\text { M erc. }\end{array}$ & $\begin{array}{c}\text { O utros } \\
\text { C réditos }\end{array}$ & O utros $^{\mathbf{1}}$ & $\begin{array}{c}\text { A tivo Total } \\
\text { (em } \\
\text { R \$ bilhões) }\end{array}$ \\
\hline dez./ 97 & 10,4 & 35,1 & 23,4 & 16,5 & 14,6 & 2,7 \\
\hline dez./ 98 & 7,7 & 30,6 & 30,5 & 15,4 & 15,8 & 11,4 \\
\hline dez./ 99 & 1,7 & 31,3 & 26,1 & 23,3 & 17,6 & 13,2 \\
\hline dez./ 00 & 4,2 & 46,2 & 19,6 & 16,2 & 13,8 & 25,2 \\
\hline dez./ 01 & 5,0 & 45,8 & 20,5 & 17,7 & 11,0 & 57,4 \\
\hline dez./ 02 & 7,5 & 37,7 & 23,3 & 20,2 & 11,3 & 54,6 \\
\hline dez./ 03 & 10,6 & 36,3 & 24,9 & 16,8 & 11,4 & 57,0 \\
\hline dez./ 04 & 11,1 & 35,7 & 28,3 & 14,0 & 10,9 & 66,5 \\
\hline dez./ 05 & 12,1 & 33,6 & 29,7 & 15,4 & 9,2 & 85,0 \\
\hline dez./ 06 & 5,2 & 38,7 & 33,4 & 15,2 & 7,5 & 102,1 \\
\hline dez./ 07 & 21,8 & 17,5 & 33,8 & 18,1 & 8,8 & 116,3 \\
\hline jun./ 08 & 19,6 & 17,4 & 32,9 & 20,3 & 9,8 & 127,3 \\
\hline Cresc. (\%) & $8.870,7$ & $2.249,7$ & $6.593,4$ & $5.725,6$ & $3.117,7$ & $4.614,8$ \\
\hline
\end{tabular}

1) Inclui D isponibilidades, Relações Interfinanceiras, R elações de Interdependências, Provisão para C réditos de L iquidação $\mathrm{D}$ uvidosa, $\mathrm{O}$ utrosValores e Bens, I mobilizado de A rrendamento ePermanente.

Fonte: Elaboração própria a partir de dados extraídos do site do Banco C entral do Brasil.

Verificou-se um significativo crescimento das 0 perações de Crédito e A rrendamento $M$ ercantil, no período de dezembro de 1997 a junho de 2008. Enquanto essas operações cresceram $6.593 \%$, a carteira de T V M cresceu $2.250 \%$ nesse período. A carteira de T V M el nstrumentos F inanceiros $D$ erivativos é composta, principalmente, por títulos públicos. Essa participação, entretanto, vem decrescendo, passando de $84,6 \%$, em 2002, para 68,4\%, em junho de 2008 (Tabela I.7.7).

Tabela I .7.7 - Composição da Carteira deT ítulos eValores M obiliários (\%)

\begin{tabular}{l|c|c|c|c|c|c|c}
\hline & $\mathbf{2 0 0 2}$ & $\mathbf{2 0 0 3}$ & $\mathbf{2 0 0 4}$ & $\mathbf{2 0 0 5}$ & $\mathbf{2 0 0 6}$ & $\mathbf{2 0 0 7}$ & jun./ 08 \\
\hline T ítulos Públicos & 84,6 & 77,8 & 80,4 & 81,2 & 83,0 & 66,2 & 68,4 \\
\hline T ítulos Privados & 15,4 & 22,2 & 19,6 & 18,8 & 17,0 & 33,8 & 31,6 \\
\hline
\end{tabular}

Fonte: Elaboração própria a partir de dados extraídos do site do Banco Central do Brasil. 
A s receitas com $O$ perações de $C$ rédito eA rrendamento $M$ ercantil eas O perações com T V M também são os principais componentes das R eceitas de I ntermediação Financeira do Santander. N o período de 1999 a 2002, as 0 perações com T V M representaram a maior parte das receitas; entretanto, a partir de 2003, as 0 perações de C rédito e A rrendamento $M$ ercantil passaram a ser as principais responsáveis pelas R eceitas de I ntermediação Financeira, com uma participação de 52,2\% no primeiro semestre de 2008 (T abela I.7.8).

T abela I .7.8 - C omposição das R eceitas de I ntermediação Financeira (em \%)

\begin{tabular}{l|c|c|c|c}
\hline D ata & $\begin{array}{c}\text { O p. C rédito e } \\
\text { A rrend. M erc. }\end{array}$ & $\begin{array}{c}\text { O perações com } \\
\text { T V M }\end{array}$ & O utros $^{\mathbf{1}}$ & $\begin{array}{c}\text { Total } \\
\text { (em R \$ bilhões) }\end{array}$ \\
\hline 1998 & 57,5 & 33,9 & 8,6 & 2,4 \\
\hline 1999 & 32,2 & 43,9 & 23,9 & 4,2 \\
\hline 2000 & 41,6 & 57,2 & 1,2 & 3,7 \\
\hline 2001 & 36,4 & 61,3 & 2,3 & 11,2 \\
\hline 2002 & 32,1 & 78,2 & $-10,3$ & 13,4 \\
\hline 2003 & 43,4 & 36,3 & 20,3 & 10,0 \\
\hline 2004 & 45,7 & 43,7 & 10,6 & 10,2 \\
\hline 2005 & 46,0 & 41,1 & 12,9 & 13,7 \\
\hline 2006 & 52,8 & 38,7 & 8,5 & 14,8 \\
\hline 2007 & 53,3 & 39,8 & 6,9 & 16,9 \\
\hline 1052008 & 52,2 & 39,9 & 7,9 & 9,3 \\
\hline Cresc. (\%) & 556,8 & 729,3 & 462,1 & 604,2 \\
\hline
\end{tabular}

1) Inclui $O$ perações com Instrumentos Financeiros D erivativos, 0 perações de $C$ âmbio e A plicações Compulsórias.

Fonte: Elaboração própria a partir de dados extraídos do site do Banco C entral do Brasil.

O crescimento das receitas de operação decrédito earrendamento mercantil verificado nos últimos anos foi consequência, principalmente, do aumento da carteira de crédito, sobretudo da carteira de crédito pessoa física e crédito imobiliário.

$\mathrm{N}$ os últimos anos, o fraco desempenho dos resultados das operações com T V M e instrumentos financeiros derivativos deveu-se, principalmente, aosimpactos negativos da redução das taxas de juros. A pesar disso, no período de 1998 a 2007 as receitas com 0 perações com T V M foram as quemais cresceram - uma ampliação de 729,3\%. 


\section{Resultados}

O lucro líquido do Santander vem apresentando bom desempenho desde 2002, após as aquisições realizadas, al cançando $\mathrm{R} \$ 1,85$ bilhão em 2007 e R \$ 793 milhões no primeiro semestre de 2008 (G ráfico I.7.7). Esse resultado representou $11 \%$ do lucro do grupo (Valor E conômico, 8/ 2/ 2008).

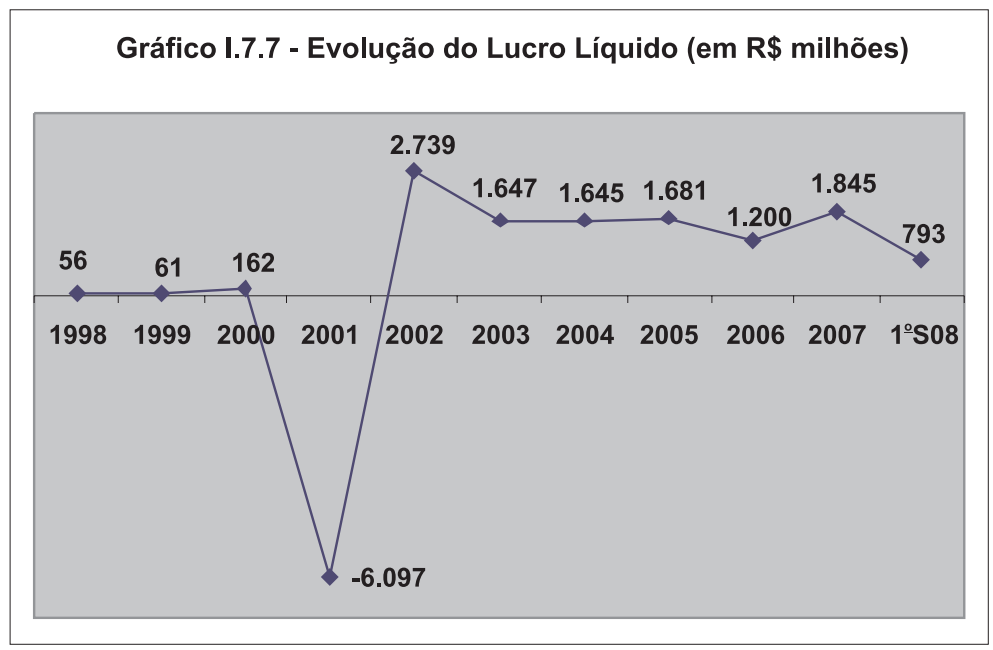

Fonte: Elaboração própria a partir de dados extraídos do site do Banco C entral do Brasil.

N osúltimos anos, o bom desempenho al cançado foi resultado do crescimento da carteira decrédito (Valor E conômico, 25/ 10/ 2007) e da evolução favorável das receitas atreladas aos negócios comerciais: receitas com operações de crédito eprestação deserviços. 0 prejuízo verificado em 2001, por suavez, foi resultado das provisões realizadas após a aquisição do Banespa.

N o primeiro semestre de 2008, entretanto, o resultado foi impactado negativamente pelas novas regras criadas pelo Banco Central para a cobrança de tarifas, que provocaram um menor crescimento das receitas com prestação de serviços. O R etorno A nualizado Sobre o Patrimônio L íquido M édio atingiu 17,1\% no primeiro semestrede 2008, contra 21,3\% em 2007 e 16,1\% em 2006 (G ráfico I. 7.8). 


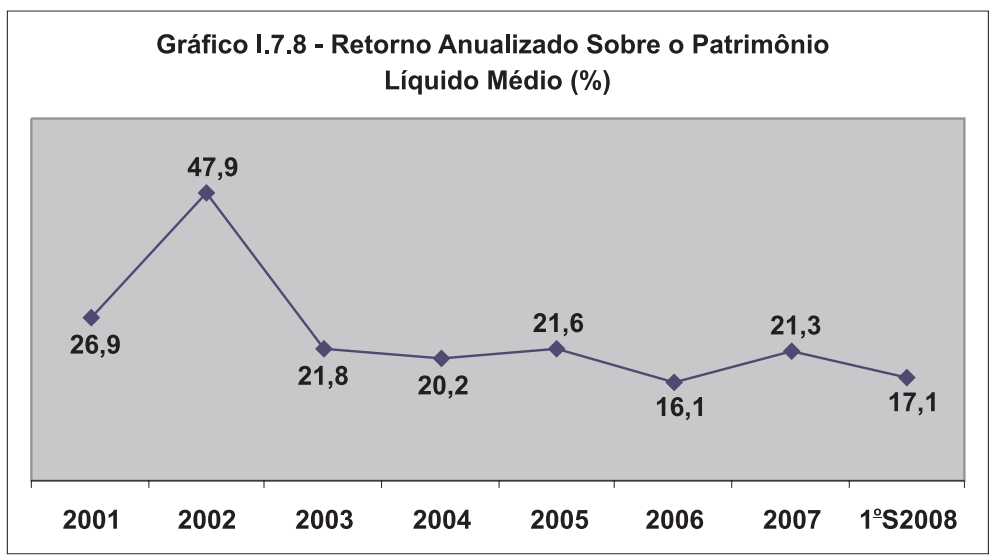

Fonte: Elaboração própria a partir de dados extraídos do site do Banco Santander.

\section{Tendências recentes}

A estratégia do Santander tem sido focada na ampliação do crédito, na bancarização (Valor E conômico, 6/ 7/ 2007), na diversificação do portfolio (Valor E conômico, 17/ 4/ 2007) ena administração defolhas de pagamento. 0 foco na administração de folhas de pagamento permite o aumento da receita por cliente, a penetração de produtos e a ampliação do crédito, principalmente o crédito consignado, 0 financiamento ao consumo e as operações com cartão de crédito (Valor E conômico, 1/ 10/ 2007).

A ampliação do crédito éuma das principais metas do Santander, quetem seespecializado, crescentemente, no varejo. 0 segmento de cartões de crédito, por exemplo, éconsiderado de forte potencial de expansão por ser um produto que tende a se popularizar ainda mais (Valor E conômico, 6/ 7/ 2007).

A instituição começou a operar com leasing para pessoas físicas em 2008 e pretendese concentrar nessesegmento nos próximos anos, com o objetivo de ampliar sua participação no mercado de crédito em geral e, principalmente, no financiamento de automóveis ( $V$ alor E conômico, 8/2/ 2008). 
Em 2008, o Santander foi o primeiro dos grandes bancos a disponibilizar empréstimo pessoal com garantia deimóvel, o chamado "home equity", bem popular em outros países. Semelhante ao que é oferecido no segmento de veículos, o novo produto funcionará como um refinanciamento da moradia já quitada, que permanecerá alienada em nome do banco durante a vigência do contrato. Com essa modalidade, o banco pretende atrair o segmento de pessoas físicas de alta renda e as pequenas e médias empresas (Valor E conômico, 4/ $7 /$ 2008).

N o crédito imobiliário, segmento considerado importante para o banco, a instituição vem firmando parcerias comerciais com empresas incorporadoras, como R odobens, Cyrella, R ossi, Tecnisa e A gra. 0 Santander também vem criando canal de relacionamento com as imobiliárias, estratégia quejá éresponsável por $14 \%$ do fluxo de origem dos negócios. Como exemplo, pode ser citada a parceria firmada com a imobiliária I taplan, para concessão de empréstimos habitacionais (0 Estado de S. Paulo, 27/ 6/ 2008 [2]). A atuação da instituição no crédito habitacional está concentrada, principalmente, nas regiões Sul e Sudeste, onde o valor médio das moradias é maior (Valor E conômico, 1/ 4/ 2008 [1]).

0 banco pretendeampliar sua atuação no crédito imobiliário para baixa renda, por meio de recursos do F G T S, sendo que já começou a operar com essa linha junto aos servidores públicos do Estado de São Paulo. Para o banco, o segmento de mercado queatendefamílias com renda entre cinco e dez salários mínimos é o mais promissor (Valor E conômico, 24/ 1/ 2008; Valor E conômico, 25/ 4/ 2008; Valor E conômico, 4/ 7/ 2008).

O Santander também tem como estratégia a ampliação da sua atuação no segmento de pequenas e médias empresas. Em 2008, o banco lançou três novas linhas de financiamento, uma delas em parceria com a M icrosoft e aT el efônica (D C I - SP, 17/ 9/2008).

Como parte desua estratégia, a instituição também não descarta eventuais aquisições em segmentos específicos, como o definancei ras ou outros nichos de crédito (Valor E conômico, 6/7/2007). A pós as medidas do Banco C entral que liberaram o compulsório, o Santan- 
der anunciou que já comprou dez carteiras de bancos menores em 2008. A instituição ainda negocia a compra de ou tras carteiras (Valor E conômico, 28/ 10/ 2008).

O Santander da Espanha anunciou um investimento deU S\$800 milhões ${ }^{26}$ no Brasil, até 2010 , e a meta de conquistar 3 milhões de novos clientes, além do lançamento de um fundo de U S\$ 1 bilhão para investimento em projetos deinfraestrutura na $A$ mérica $L$ atina, principalmente no Brasil e no M éxico, onde estão concentrados os maiores projetos. A expectativa é que a instituição tenha um papel importante junto aos projetos do Programa de A celeração do C rescimento (PAC). A instituição pretende ampliar sua atuação junto ao que chama de classes médias emergentes, uma vez que, segundo projeções dos economistas do banco, o Brasil deve ser o país no qual mais famílias vão ascender à classemédia. Portanto, uma das estratégias a ser focada pela instituição é a bancarização. Para o Santander, o Brasil é o terceiro país mais importantedo grupo (Valor E conômico, 6/ 7/ 2007).

Para tornar essa estratégia viável, o Santander pretende expandir sua rede de atendimento, reforçando as operações nas regiões onde é mais forte, ou seja, Sul, Sudeste e grandes cidades do país (Valor E conômico, 3/ 11/2008 [2]).

\section{Atuação externa ${ }^{27}$}

O G rupo Santander, fundado em 1857 na Espanha, é a maior instituição financeira da zona do euro por capitalização em bolsa, estando presente em mais de 40 países. Em junho de 2008, contava

26 C orresponde a $40 \%$ do total de recursos que o Santander pretende investir na A mérica L atina até2010, através do Plano A mérica 2010.

27 A s regras contábeis espanholas se diferenciam, em alguns pontos, das regras brasileiras, como na contabilização de venda de papéis e compra de folha de pagamento. Entretanto, essa diferença não irá interferir nesta análise, uma vez que, para possibilitar a comparação, neste item serão adotados os critérios espanhóis também para o Brasil. 
com mais 11 mil agências, 131 mil funcionários, 65 milhões de clientes e volume de recursos administrados superior a 1 trilhão de euros.

O grupo é segmentado em três áreas geográficas: E uropa C ontinental, que é subdividida nas unidades R ed Santander, Banesto, Santander Consumer FinanceePortugal; R eino U nido, representado pelo Banco A bbey, instituição adquirida pelo grupo em 2004; eA mérica $L$ atina, composta pelas unidades do Brasil, M éxico e C hile. A s áreas com maior quantidade de pontos de atendimento são $\mathrm{E}$ uropa Continental e A mérica L atina, com participação de 53,3\% e 40,4\%, respectivamente (G ráfico I.7.9).

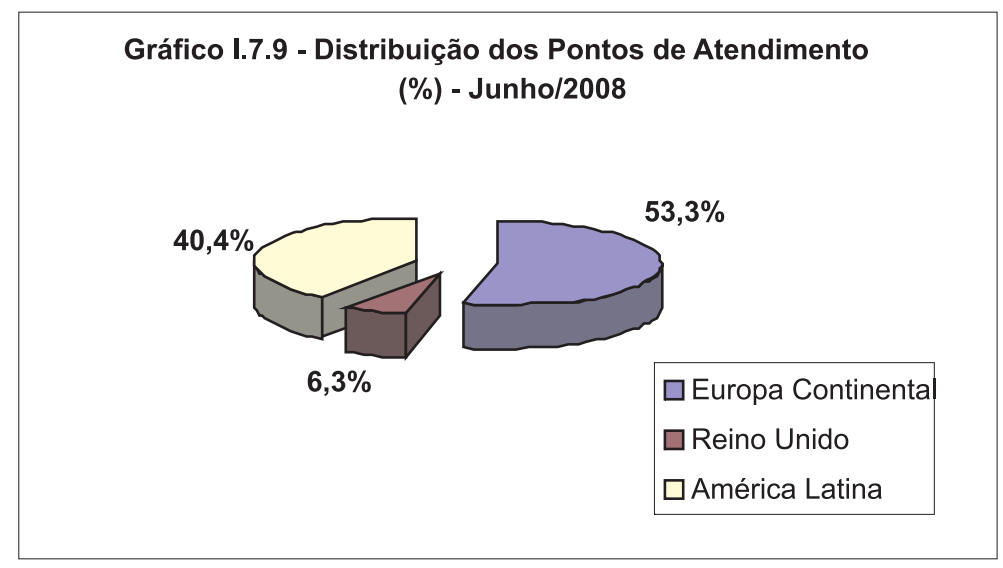

Fonte: Elaboração própria a partir de dados extraídos do site do G rupo Santander.

0 grupo atua, principalmente, em três grandes áreas: Banco C omercial (Varejo), Banco de A tacado G lobal (para grandes clientes) e $\mathrm{G}$ estão de A tivos e Seguros.

A carteira de crédito atingiu 573 bilhões de euros em junho de 2008, um crescimento de 396\% em relação a dezembro de 1998. A instituição vem buscando ampliar a participação da concessão de créditos com garantias reais. E m junho de 2008, essa participação atingiu 56,8\% (G ráfico I .7.10). 


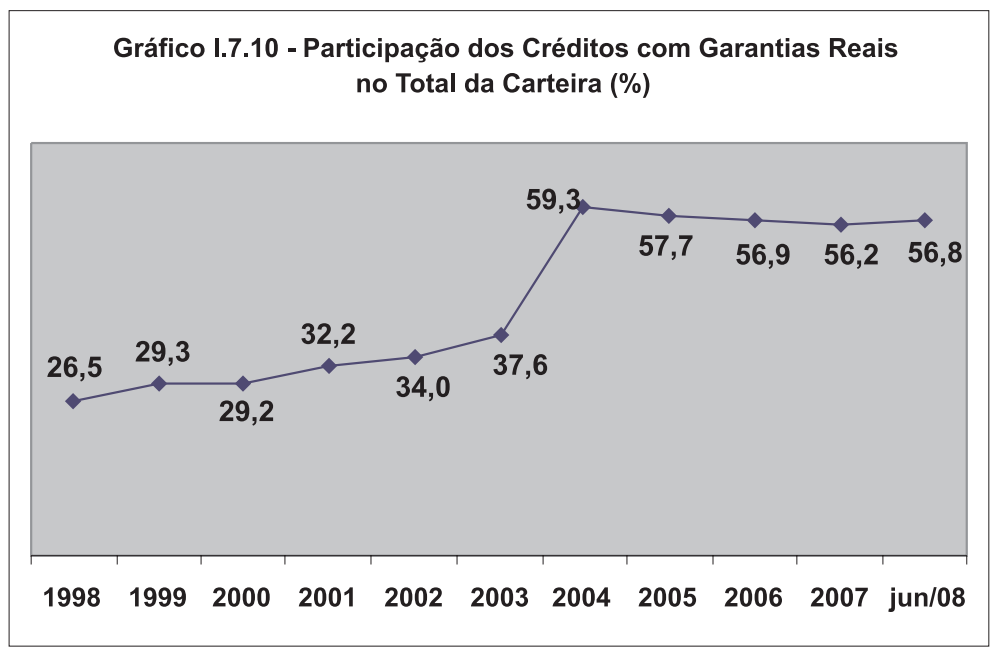

Fonte: Elaboração própria a partir de dados extraídos do site do G rupo Santander.

A participação do crédito no total de ativos do grupo também vem apresentando crescimento. E ssa participação foi de $62,4 \%$ em junho de 2008, contra 48,9\% em 1998 (G ráfico I.7.11).

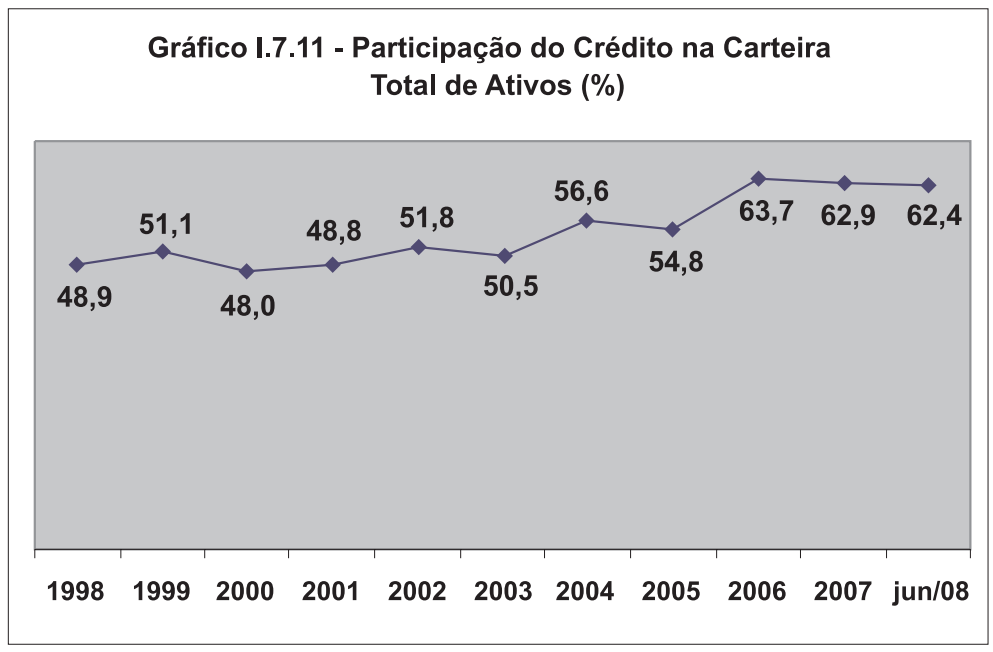

Fonte: Elaboração própria a partir de dados extraídos do site do G rupo Santander. 
A unidade quetem maior participação no crédito total do $G$ rupo Santander éo R eino U nido, seguido pelo R ed Santander. N o período de dezembro de 2005 a junho de 2008, a unidade que apresentou maior crescimento da carteira de crédito foi a situada no Brasil, com uma ampliação de 84,7\% (T abela I.7.9).

T abela I . 7.9 - Participação na C arteira de C rédito T otal (\%)

\begin{tabular}{l|c|c|c|c|c}
\hline & $\mathbf{2 0 0 5}$ & $\mathbf{2 0 0 6}$ & $\mathbf{2 0 0 7}$ & jun./ 08 & C res. (\%) \\
\hline Europa Continental & 48,8 & 52,0 & 55,1 & 57,1 & 50,5 \\
\hline Red Santander & 20,4 & 20,2 & 20,7 & 21,3 & 34,7 \\
\hline Banesto & 11,0 & 11,7 & 13,1 & 13,7 & 60,8 \\
\hline Santander Consumer Finance & 6,8 & 7,6 & 8,1 & 8,6 & 63,3 \\
\hline Portugal & 5,9 & 5,4 & 5,3 & 5,7 & 22,7 \\
\hline O utros & 4,7 & 7,1 & 7,9 & 7,8 & 110,8 \\
\hline R eino U nido & 39,5 & 36,5 & 32,7 & 30,5 & $-0,5$ \\
\hline A mérica L atina & 11,7 & 11,5 & 12,2 & 12,4 & 36,7 \\
\hline Brasil & 2,5 & 2,7 & 3,5 & 3,5 & 84,7 \\
\hline M éxico & 3,0 & 3,0 & 2,5 & 2,7 & 15,9 \\
\hline Chile & 3,4 & 2,9 & 3,0 & 2,9 & 9,6 \\
\hline O utros & 2,8 & 2,9 & 3,2 & 3,3 & 31,5 \\
\hline
\end{tabular}

Fonte: Elaboração própria a partir de dados extraídos do site do G rupo Santander.

Todas as empresas do grupo têm rigorosas regras de conduta, que se enquadram na legislação norte-americana. N o início de 2007, o Santander obteve a certificação da L ei Sarbanes-O xley, que atesta o cumprimento das regras estabelecidas pela legislação norte-americana. A lei defende o interesse dos investidores eprotege a sociedade, estabelecendo critérios de transparência e rigorosos controles internos.

A instituição também se comprometeu formalmente com o Banco de Espanha a utilizar os enfoques mais avançados para fins de cálculo de capital regulatório, tanto em risco de crédito quanto em risco operacional. Tais metodologias fazem uso de model os internos de mensuração de riscos, proporcionando a otimização de alocação de capital regulatório e um ambiente de controle de riscos em linha com as melhores práticas de mercado. 
0 Índice de Basileia do grupo atingiu 11,43\% em junho de 2008, menor do que o verificado em anos anteriores, porém, acima do mínimo exigido pelo A cordo da Basileia, de 8\% (G ráfico I.7.12).

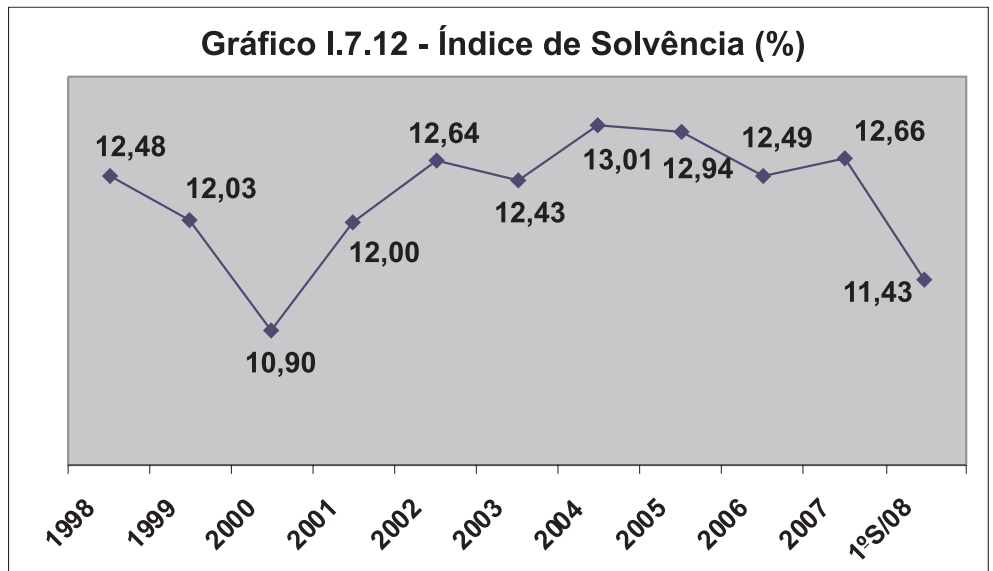

Fonte: Elaboração própria a partir de dados extraídos do site do G rupo Santander.

O ÍndicedeEficiência, por suavez, vem decrescendo nos últimos anos, passando de $62,1 \%$ em 1998 para 40,37\%no primeiro semestre de2008 (G ráfico I.7.13).

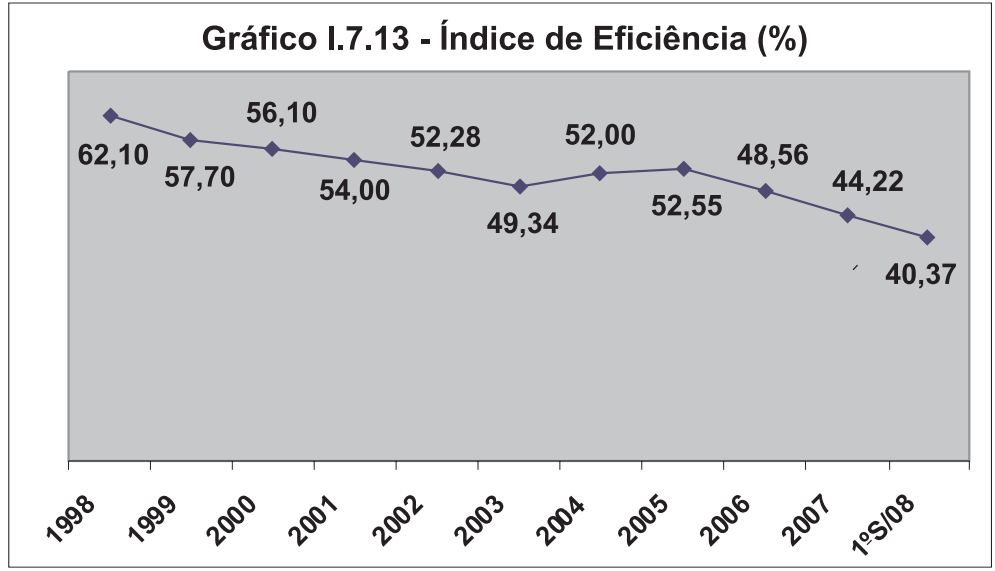

Fonte: Elaboração própria a partir de dados extraídos do site do G rupo Santander. 
O ÍndicedeE ficiência das unidades do grupo também apresentou tendência de queda, sendo que, no primeiro semestre de 2008, as unidades do R eino U nido edePortugal apresentaram índices maiores em relação às demais (T abela I.7.10).

Tabela I.7.10 - Índicede Eficiência (\%)

\begin{tabular}{l|c|c|c|c}
\hline & $\mathbf{2 0 0 5}$ & $\mathbf{2 0 0 6}$ & $\mathbf{2 0 0 7}$ & jun./ 08 \\
\hline Europa Continental & 37,7 & 40,8 & 38,8 & 36,7 \\
\hline Red Santander & 37,9 & 41,0 & 38,7 & 35,7 \\
\hline Banesto & 37,6 & 45,3 & 41,2 & 39,6 \\
\hline Santander Consumer Finance & 30,8 & 34,7 & 29,6 & 27,1 \\
\hline Portugal & 43,5 & 47,3 & 44,0 & 43,3 \\
\hline R eino U nido & 60,1 & 55,1 & 50,1 & 46,7 \\
\hline A mérica L atina & 47,4 & 47,0 & 41,8 & 37,7 \\
\hline Brasil & 46,6 & 46,4 & 39,6 & 36,9 \\
\hline M éxico & 49,9 & 44,0 & 37,7 & 30,7 \\
\hline Chile & 40,9 & 41,5 & 39,2 & 37,7 \\
\hline
\end{tabular}

Fonte: Elaboração própria a partir de dados extraídos do site do G rupo Santander.

Em 2007, o grupo alcançou um lucro líquido de 8,6 bilhões de euros. N o primeiro semestre de 2008, o lucro já atingiu 5 bilhões de euros. N os últimos anos, a tendência tem sido de crescimento (G ráfico I.7.14).

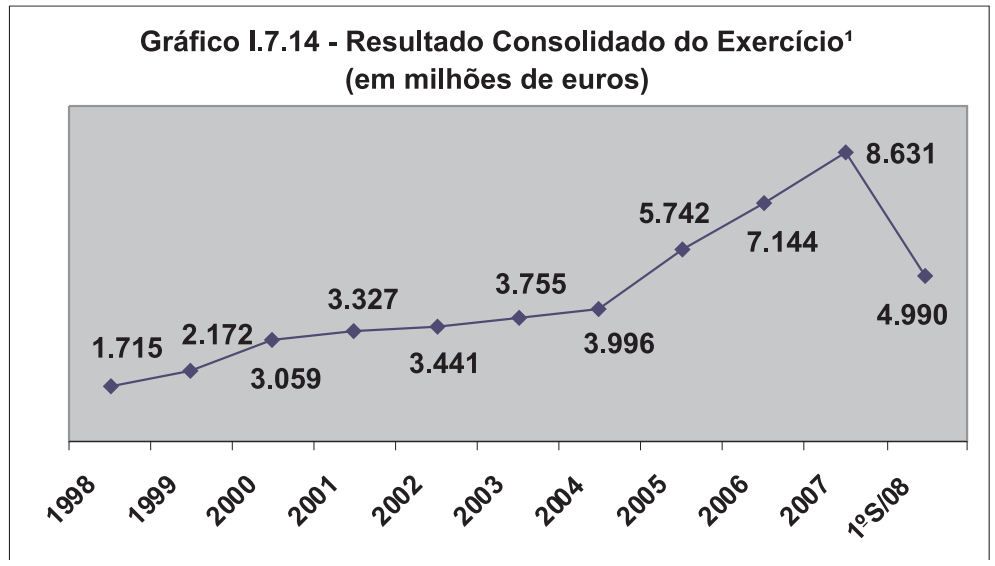

1) Excluindo receitas/ despesas extraordinárias.

Fonte: Elaboração própria a partir de dados extraídos do site do G rupo Santander. 
A unidadequemais contribuiu para o resultado do grup o foi a $R$ ed Santander; entretanto, as unidades daA mérica L atina são as quemais têm apresentado crescimento em sua contribuição (Tabela I.7.11).

Tabela I.7.11 - Benefício A tribuído ao G rupo (\%)

\begin{tabular}{l|c|c|c|c|c}
\hline & $\mathbf{2 0 0 5}$ & $\mathbf{2 0 0 6}$ & $\mathbf{2 0 0 7}$ & jun./ 08 & C resc. (\%) \\
\hline Europa Continental & 53,6 & 51,4 & 53,3 & 53,9 & 48,2 \\
\hline Red Santander & 23,1 & 22,3 & 21,8 & 23,3 & 40,5 \\
\hline Banesto & 9,0 & 8,1 & 8,7 & 8,9 & 34,2 \\
\hline Santander Consumer Finance & 8,7 & 8,4 & 8,7 & 8,6 & 47,6 \\
\hline Portugal & 6,2 & 6,3 & 6,2 & 6,3 & 48 \\
\hline Outros & 6,6 & 6,3 & 7,9 & 6,8 & 95 \\
\hline Reino U nido & 14,5 & 14,8 & 14,5 & 14,1 & 48,1 \\
\hline A mérica L atina & 31,9 & 33,8 & 32,2 & 32 & 50,1 \\
\hline Brasil & 10,6 & 11,1 & 10,9 & 11,3 & 53,2 \\
\hline M éxico & 6,8 & 7,8 & 7,9 & 8,3 & 73,8 \\
\hline Chile & 6,1 & 7,2 & 6,5 & 5,8 & 60,6 \\
\hline Outros & 8,4 & 7,7 & 6,9 & 6,6 & 19,8 \\
\hline
\end{tabular}

Fonte: Elaboração própria a partir de dados extraídos do site do G rupo Santander.

0 R etorno sobreo Patrimônio L íquido do G rupo Santander atingiu $18,6 \%$ no primeiro semestre de 2008 , com tendência de oscilação no período analisado (G ráfico I.7.15).

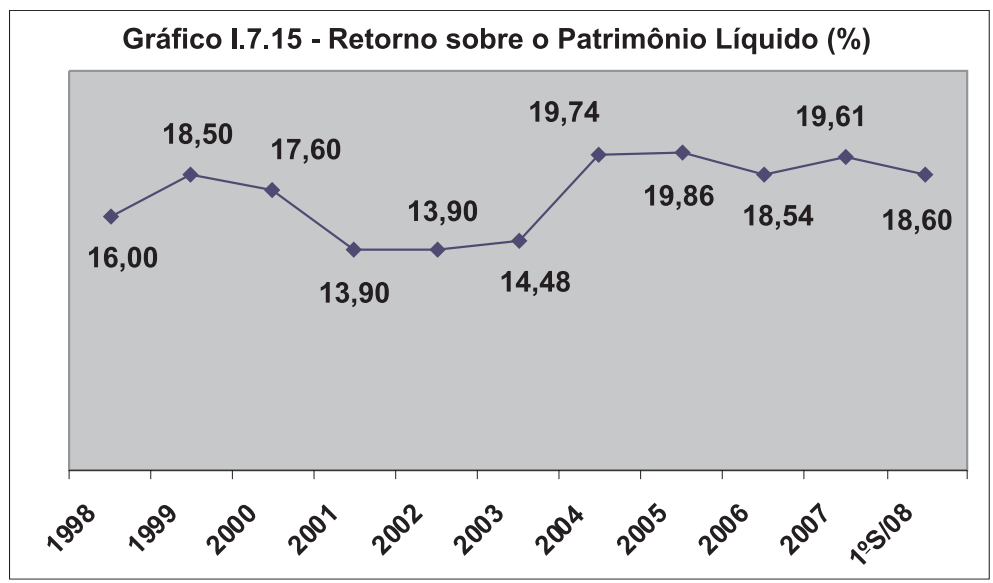

Fonte: Elaboração própria a partir de dados extraídos do site do G rupo Santander. 
Com relação às unidades do grupo, os maiores retornos são do C hile, R eino U nido eBrasil. N o período anal isado, as unidades que mais cresceram com relação a esse índice foram Chile, Portugal, M éxico e Brasil (Tabelal .7.12).

Tabela I .7.12 - R etorno sobre o Patrimônio L íquido das U nidades do G rupo ${ }^{1}$ (\%)

\begin{tabular}{l|c|c|c|c|c}
\hline & $\mathbf{2 0 0 5}$ & $\mathbf{2 0 0 6}$ & $\mathbf{2 0 0 7}$ & jun./ 08 & C res. (\%) \\
\hline Europa Continental & 22,05 & 20,41 & 21,31 & 21,21 & $-3,8$ \\
\hline Red Santander & 22,83 & 21,29 & 22,71 & 24,71 & 8,2 \\
\hline Banesto & 19,38 & 20,61 & 18,26 & 19,95 & 2,9 \\
\hline Santander Consumer Finance & 46,13 & 35,60 & 34,12 & 22,60 & $-51,0$ \\
\hline Portugal & 20,79 & 24,07 & 28,55 & 26,89 & 29,3 \\
\hline R eino U nido & 35,66 & 32,79 & 32,26 & 29,70 & $-16,7$ \\
\hline A mérica L atina & 23,15 & 26,57 & 29,10 & 27,68 & 19,6 \\
\hline Brasil & 23,07 & 28,42 & 28,45 & 29,00 & 25,7 \\
\hline M éxico & 20,42 & 23,08 & 26,48 & 26,08 & 27,7 \\
\hline Chile & 25,03 & 32,15 & 43,81 & 33,14 & 32,4 \\
\hline
\end{tabular}

1) Excluindo as receitas/ despesas extraordinárias.

Fonte: Elaboração própria a partir de dados extraídos do site do G rupo Santander.

Com relação às estratégias recentes, o G rupo Santander tem buscado unificar sua marca em todas as nações onde atua, para simbolizar o fortalecimento dos negócios nos mercados globais. A decisão foi pautada pela crença de que uma assinatura com a qual possa se identificar em todos os mercados é essencial para competir em condições deigual dade com os demais grandes bancos mundiais.

O grupo também procura seconcentrar em clientes pessoas físicas e pequenas e médias empresas, que respondem por $84 \%$ dos resultados do banco. R ecentemente, a instituição também se voltou para produtos mais rentáveis, porém com maior risco, principalmentena A mérica $L$ atina. Essa estratégia provocou o aumento da provisão para créditos duvidosos.

N o mercado de financiamento de imóveis, por exemplo, o Santander élíder naE spanha eno C hile (G azeta M ercantil, 26/ 9/ 2007). 0 grupo também tem forteatuação no mercado definanciamento de veículos (Valor E conômico, 11/ 4/ 2006). 
A s expectativas do Santander com relação à $A$ mérica $L$ atina são bem otimistas (Valor E conômico, 3/ 7/ 2007 [2]). N esse sentido, foi lançado, no final de 2006, o Plano A mérica 2010, que detal ha as estratégias queo banco utilizará para duplicar seu tamanho na região. E stão previstos investimentos de U S\$ 2 bilhões até 2010 (Valor E conômico, 6/ 7/ 2007).

E $m$ julho de 2007, o Santander também lançou um fundo de U S\$ 1 bilhão para investimento em projetos de infraestrutura na A mérica $L$ atina, principalmente no Brasil e no $M$ éxico, onde estão concentrados os maiores projetos. A instituição pretendeampliar sua atuação junto ao que chama de classes médias emergentes, visando dobrar sua fatia de mercado em cinco anos. Os setores prioritários serão transportes, saneamento, habitação e comunicações, segmentos que o Santander classifica como "infraestrutura social" (Valor E conômico, 6/ 7/ 2007).

A aquisição do A BN também faz parte da estratégia do grupo de ampliar seus negócios na A mérica L atina (Valor E conômico, $8 / 10 / 2007$ ). A s projeções do banco para Brasil e A mérica L atina consideram que a região está gerando novas riquezas financeiras e crescendo acima da média dos países desenvolvidos. $\mathrm{N}$ a avaliação dos executivos do Santander, a crise financei ra recente, apesar de ter afetado o valor de várias companhias europeias que investem na região, não irá afetar, na mesma proporção, os investimentos dessas empresas em ativos fixos no B rasil e demais países da região.

0 próprio Santander foi afetado, embora menos do que outros bancos europeus eamericanos. Em dezembro de2006, o banco tinha um valor de mercado de 88 bilhões de euros, capitalização que caiu para 73 bilhões de euros em 30 de junho de 2008, segundo cálculos da instituição. 0 grupo está, então, adaptando sua operação para reduzir os impactos da crise. U ma das medidas adotadas inclui um crescimento mais equilibrado com menor foco no crédito. Essa estratégia, entretanto, não será adotada para os países emergentes, em quea intenção éaumentar o volumedas operações (Valor E conômico, 8/ 7/2008). 


\section{HSBC}

\section{Histórico e estrutura}

O H SBC H oldings foi fundado em 1865 e é sediado em L ondres, Inglaterra. A instituição atua nos segmentos de varejo, commercial, corporate, investment e private banking; trade services; cash management; serviços de tesouraria e mercados de capital; seguros e previdência; empréstimos e financiamentos; fundos de pensão e investimento, dentre outros.

O banco iniciou suas operações no Brasil em 26 demarço de 1997, com a aquisição do Bamerindus. Essa aquisição deu origem ao H SBC Bamerindus S.A ., que, em 1999, passou a se chamar H SBC Bank Brasil S.A . - Banco M últiplo, com alogomarca H SBC + H exágono, seguindo o projeto de unificação mundial da marca no mundo.

O maior acionista do banco é o H SBC Bank, com 99,396\% do capital social, seguido pelo H SBC L easing A rrendamento M ercantil (Brasil) S.A . e por O utras Participações M inoritárias, com participações de 0,601\% e 0,003\%, respectivamente.

\section{Rede de atendimento}

A rede de atendimento do $\mathrm{HSBC}$, presente em 559 municípios brasileiros, écomposta por 924 agências, 453 postos deatendimento bancários, 1.022 postos deatendimento el etrônicos, 2.419 ambientes deautoatendimento, 5.500 caixas automáticos e 26 mil funcionários. O s clientes contam, ainda, com 25 mil caixas automáticos na rede compartilhada com outros bancos no Brasil, banco 24 horas e uma dependência no exterior localizada em $\mathrm{G}$ rand Cayman.

O H SBC disponibiliza, também, 250 agências próprias da Financeira $L$ osango, que oferece financiamento de veículos, $C$ onta L osango, crédito consignado, cartões de crédito, seguros e correspondentes bancários nos pontos de venda. A financeira atua por meio de 21 mil parcerias com grupos varejistas com fortepenetração 
regional (Valor E conômico, 4/ 1/ 2008; Valor E conômico, 20/ 6/ 2008; Valor E conômico, 14/ 7/ 2008).

A maior parte dos pontos de atendimento está concentrada na região Sudeste, sendo que $76,8 \%$ desses pontos estão local izados nas regiões Sudestee Sul (G ráfico I.8.1).

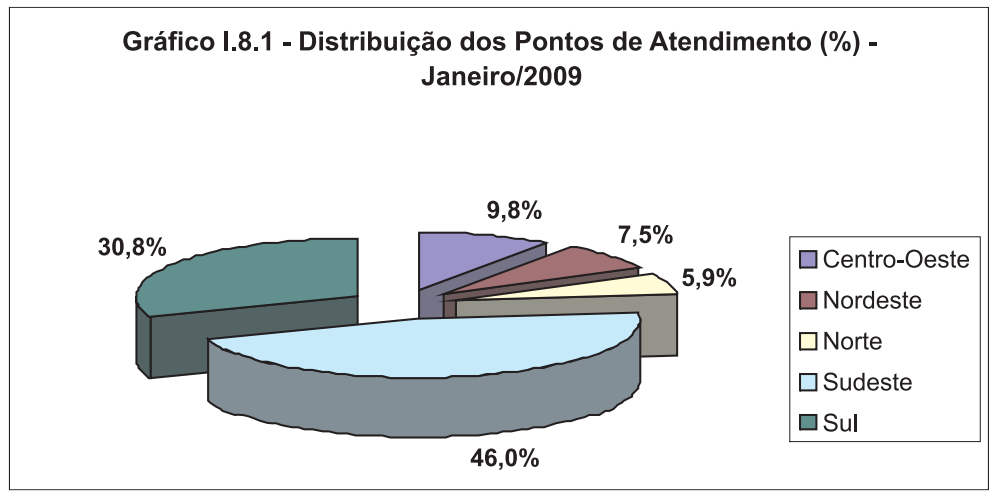

Fonte: Elaboração própria a partir de dados extraídos do site da Febraban.

Internacional mente, o G rupo H SBC está presente em 86 países e territórios, sendo um dos maiores grupos financeiros do mundo. D isponibiliza mais de 1 milhão de caixas automáticos para saques no exterior, por meio da rede Cirrus/ M asterC ard eV isa Plus/ Visa, e aproximadamente 50 milhões de estabelecimentos conveniados com as redes $M$ aster $C$ ard $M$ aestro $\mathrm{eV}$ isa Electron para compras com cartão de débito no Brasil eno exterior.

\section{Base de clientes}

A carteira do H SBC Bank Brasil é de aproximadamente 5,6 miIhões declientes Pessoa F ísica e 347,6 mil declientes Pessoa Jurídica, segmentados em Varejo, Commercial Banking, Corporate, InvestmentBanking and $M$ arkets eP rivateBanking. Por meio daFinanceira $L$ osango, o H SBC atende 18 milhões de clientes ( $G$ azeta M ercantil, 24/3/2008 [2]), concentrados nas classes C, D eE. 
N o segmento dePrivate Bank, a instituição atende clientes com aplicações acima de R \$1,6 milhão, estando presentenos Estados de São Paulo, R io de J aneiro eM inas G erais, nos municípios de Salvador, C uritiba ePorto A legreeno D istrito F ederal (Valor E conômico, 20/5/2008).

\section{Captações}

O H SBC capta recursos principalmente por meio de D epósitos a Prazo, que representaram, em junho de $2008,80,1 \%$ do total de recursos captados. A s captações por depósito representaram 97,9\% do total, contra somente $2,1 \%$ captado por meio do mercado aberto (Tabela I.8.1).

T abela I .8.1 - Composição das C aptações (em \%)

\begin{tabular}{c|c|c|c|c|c|c|c|c}
\hline & $\begin{array}{c}\text { A } \\
\text { Vista }\end{array}$ & Poupança & Interfin. & $\begin{array}{c}\text { A } \\
\text { Prazo }\end{array}$ & O utros & $\begin{array}{c}\text { D epósitos } \\
\text { Totais }\end{array}$ & $\begin{array}{c}\text { Cap. } \\
\text { M erc. } \\
\text { A berto }\end{array}$ & $\begin{array}{c}\text { Total } \\
\text { (em R \$ } \\
\text { bilhões) }\end{array}$ \\
\hline dez./ 97 & 9,3 & 37,5 & 5,6 & 17,8 & 0,1 & 70,3 & 29,7 & 9,5 \\
\hline dez./ 98 & 6,6 & 60,0 & 0,8 & 23,0 & 0,0 & 90,4 & 9,6 & 7,6 \\
\hline dez./ 99 & 12,7 & 41,1 & 0,1 & 26,8 & 0,0 & 80,7 & 19,3 & 7,8 \\
\hline dez./ 00 & 19,5 & 15,0 & 0,4 & 33,6 & 0,0 & 68,5 & 31,5 & 11,6 \\
\hline dez./ 01 & 19,3 & 12,6 & 0,5 & 40,3 & 0,0 & 72,7 & 27,3 & 12,3 \\
\hline dez./ 02 & 23,2 & 12,3 & 0,8 & 60,5 & 0,0 & 96,8 & 3,2 & 13,3 \\
\hline dez./ 03 & 18,9 & 9,9 & 1,1 & 65,6 & 0,0 & 95,5 & 4,5 & 15,8 \\
\hline dez./ 04 & 14,6 & 6,5 & 0,2 & 73,2 & 0,0 & 94,5 & 5,5 & 24,4 \\
\hline dez./ 05 & 11,6 & 4,7 & 0,1 & 67,8 & 0,1 & 84,3 & 15,7 & 34,5 \\
\hline dez./ 06 & 11,7 & 3,9 & 0,7 & 71,0 & 0,2 & 87,5 & 12,5 & 43,1 \\
\hline dez./ 07 & 15,2 & 4,5 & 1,8 & 74,8 & 0,3 & 96,6 & 3,4 & 45,9 \\
\hline jun./ 08 & 11,8 & 4,2 & 1,7 & 80,1 & 0,1 & 97,9 & 2,1 & 54,7 \\
\hline Cresc. & 629,2 & $-36,0$ & 73,1 & $2.510,5$ & $1.534,9$ & 705,3 & $-58,6$ & 475,8 \\
\hline
\end{tabular}

Fonte: Elaboração própria a partir de dados extraídos do site do Banco C entral do Brasil.

O sD epósitosa Prazo foram a forma decaptação quemais cresceu no período de dezembro de 1997 a junho de 2008 - uma ampliação de $2.511 \%$. O s D epósitos à V ista também tiveram participação significativa nas captações totais, de 11,8\% em junho de 2008. 


\section{Carteira de crédito}

A carteira de crédito do H SBC vem apresentando crescimento significativo nos últimos anos, tendo al cançado, em junho de2008, $\mathrm{R} \$ 30,4$ bilhões ( $\mathrm{G}$ ráfico I .8.2).

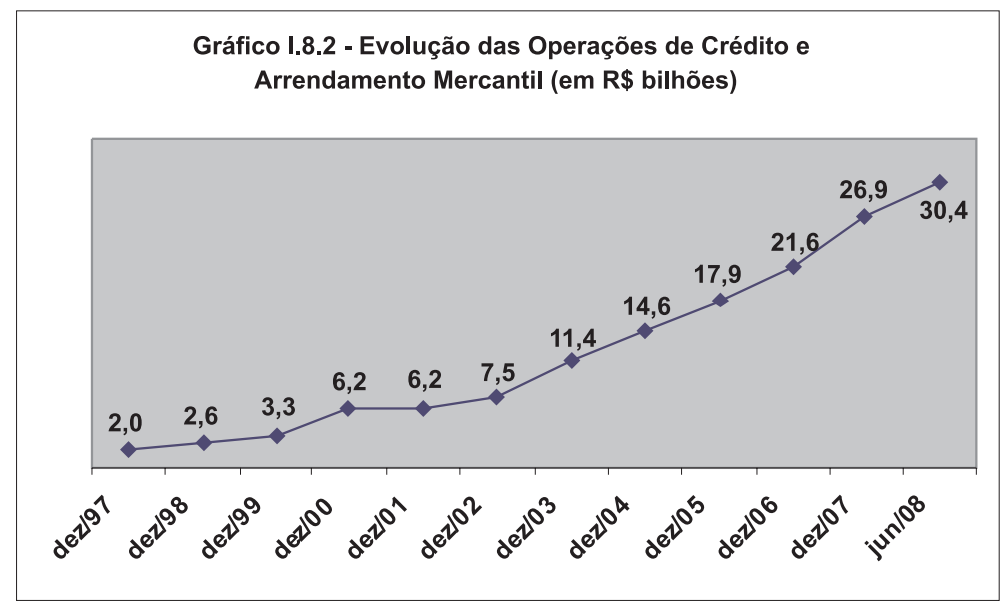

Fonte: Elaboração própria a partir de dados extraídos do site do Banco C entral do Brasil.

Esse crescimento tem sido impulsionado, principalmente, pelo segmento Pessoas F ísicas, que, em junho de 2008, atingiu uma participação de 50,6\% da carteira de crédito total do H SBC. D edezembro de 1999 a junho de 2008, esse segmento apresentou um crescimento de 2.287,8\%, o maior verificado no período (Tabela I.8.2).

A s linhas que mais contribuíram para esse bom desempenho da carteira de Pessoas F ísicas foram o financiamento de veículos e o crédito consignado. No primeiro semestre de 2008, a carteira de financiamento de veículos representava $20 \%$ da carteira total, com um crescimento de $44 \%$ em relação ao primeiro semestre de 2007 . A carteira de crédito consignado, por sua vez, atingiu uma participação de $6 \%$ do total da carteira de crédito, com um crescimento de $53 \%$ em relação ao primeiro semestre de 2007. 
Tabela l .8.2 - Composição da C arteira de C rédito por C liente (\%)

\begin{tabular}{|c|c|c|c|c|c|c|c|c|c|c|c|}
\hline & $\frac{8}{8}$ & $\frac{8}{\frac{8}{0}}$ & $\frac{5}{8}$ & $\frac{8}{8}$ & $\frac{8}{\frac{8}{8}}$ & $\frac{\delta}{d}$ & $\frac{8}{\frac{8}{8}}$ & $\frac{8}{\frac{8}{8}}$ & $\frac{8}{\frac{d}{d}}$ & $\frac{8}{\frac{8}{3}}$ & ن \\
\hline Pessoas Jurídicas & 48,0 & 42,6 & 46,8 & 45,8 & 38,8 & 37,9 & 32,6 & 37,4 & 41,6 & 42,7 & 871,5 \\
\hline Pessoas F ísicas ${ }^{1}$ & 23,2 & 35,4 & 38,1 & 42,7 & 52,1 & 54,9 & 61,0 & 57,5 & 52,7 & 50,6 & $2.287,8$ \\
\hline A gropecuária & 6,5 & 8,6 & 2,9 & 2,9 & 2,4 & 1,8 & 1,4 & 0,9 & 1,1 & 1,0 & 65,3 \\
\hline Crédito Imobiliário & 22,3 & 13,4 & 12,2 & 8,6 & 6,7 & 5,4 & 5,0 & 4,2 & 4,6 & 5,7 & 180,5 \\
\hline Pessoas Físicas & 17,2 & 11,4 & 9,6 & 6,6 & 4,0 & 2,8 & 2,1 & 1,8 & 1,7 & 1,8 & 15,2 \\
\hline Pessoas Jurídicas & 5,1 & 2,0 & 2,6 & 2,0 & 2,7 & 2,6 & 2,9 & 2,4 & 2,9 & 3,9 & 742,0 \\
\hline
\end{tabular}

1) Composto, principalmente, por operações de cartões de crédito, crédito pessoal, empréstimos consignados e CD C veículos.

Fonte: Elaboração própria a partir de dados extraídos do site do Banco H SBC.

O segmento de cartões também vem apresentando resultado positivo. Em 2007, foram colocados no mercado mais de 3 milhões de cartões. Com isso, a unidade brasileira do banco inglês foi a que mais emitiu cartões no mundo, entre os 83 países ondeo H SBC opera (Valor E conômico, 4/ 1/2008). 0 volume de recursos movimentado pelos cartões da instituição cresceu $80 \%$ em 2007, sendo que o banco fechou 0 ano com uma base de 8 milhões de cartões, incluindo os da Financeira L osango, que pertence ao grupo (Valor E conômico, 4/ 1/2008).

Portanto, o resultado operacional do H SBC permaneceu fortementeconcentrado no segmento dePessoas F ísicas, cuja participação cresceu de 29\%, em 2006, para 36\%, em 2007, seguido pelo segmento de Pequenas e M édias Empresas, que representou 31\%, em 2007, contra 34\%, em 2006.

0 segmento de pequenas e médias empresas também vem apresentando crescimento significativo (G azeta M ercantil, 19/ 8/ 2008). N o primeiro semestre de 2008 , de $15 \%$ a $20 \%$ dos recursos destinad os às pequenas empresas foram direcionados para investimento. N 0 caso das médias empresas, esse percentual foi de mais de $30 \%$ (V al or E conômico, 4/ 9/ 2008).

A instituição tem forte atuação no comércio exterior, que vem apresentando altas taxas de crescimento. 0 H SBC usou sua pre- 
sença gl obal como principal estratégia para esse crescimento (V alor E conômico, 4/ 6/ 2008).

A pesar do crescimento da carteira de crédito, o H SBC registrou um índice de inadimplência de 4,9\% em 2007, contra um índice de $6,3 \%$ em 2006, refletindo, assim, uma melhoria da qualidade de crédito. N a Financeira L osango, o índice está estabilizado em torno de 10\%, desdeo início de 2007 (Valor E conômico, 20/ 6/ 2008).

\section{Gestão de riscos}

O controle do H SBC sobre os riscos de mercado é baseado em uma política de limitar as operações de pessoas físicas a operações comerciais, restringindo as negociações dos produtos derivativos mais complexos apenas a escritórios com nível de experiência e conhecimento de produto apropriado esistemas de controle robustos. $\mathrm{N}$ esse processo decrescimento das operações decrédito, ainstituição também busca se concentrar em ativos com garantias reais.

Com relação ao Índice de Basileia, o H SBC alcançou o índice de 13,11\% em junho de2008. D esde2005, esseíndicevem apresentando redução (G ráfico I.8.3).

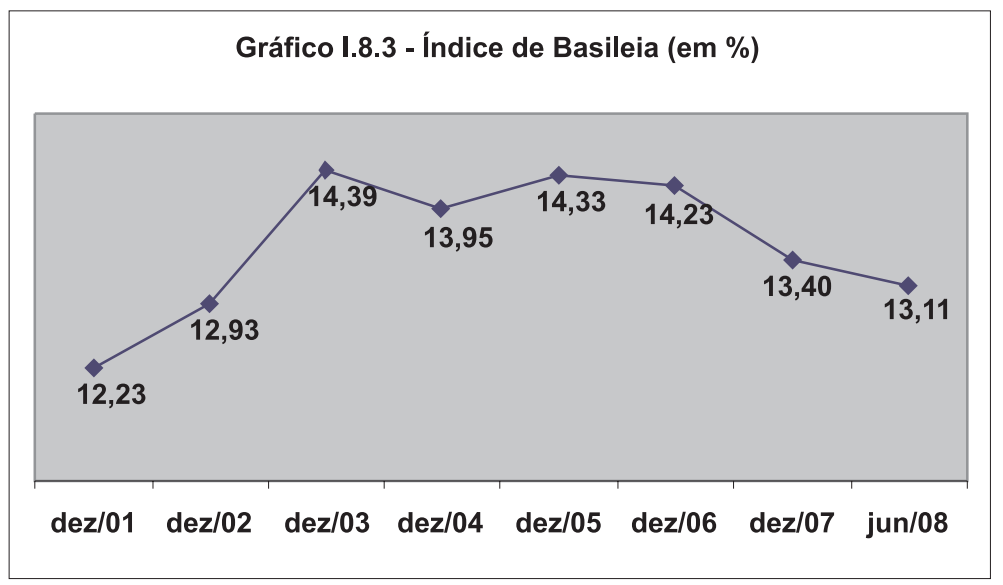

Fonte: Elaboração própria a partir de dados extraídos do site do Banco C entral do Brasil. 
A participação dos créditos concentrados nos níveis $A A, A, B$ e $C$ atingiu 93,4\% em junho de 2008, não tendo sofrido alterações significativas desde 2000. Entretanto, houve uma redistribuição entre esses níveis de risco, com uma diminuição das operações concentradas no nível A A e uma ampliação das operações classificadas como A eB (T abelal .8.3).

Tabelal I.8.3 - Composição da Carteira de C rédito por $\mathrm{N}$ ível de R isco (\%)

\begin{tabular}{c|c|c|c|c|c|c|c|c|c|c}
\hline & dez./ 00 & dez./ 01 & dez./ 02 & dez./ 03 & dez./ 04 & dez./ 05 & dez./ 06 & dez./ 07 & jun./ 08 \\
\hline AA & 85,4 & 81,3 & 68,5 & 51,3 & 51,9 & 53,1 & 30,8 & 32,4 & 33,3 \\
\hline A & 2,5 & 3,8 & 12,6 & 26,6 & 30,8 & 29,1 & 43,7 & 44,8 & 42,6 \\
\hline B & 3,9 & 5,0 & 10,8 & 7,7 & 6,9 & 5,7 & 13,5 & 12,6 & 13,8 \\
\hline C & 2,1 & 2,1 & 2,1 & 3,0 & 2,3 & 2,5 & 3,9 & 3,6 & 3,7 \\
\hline D & 1,2 & 1,9 & 1,1 & 2,5 & 1,1 & 1,3 & 1,3 & 1,3 & 1,3 \\
\hline E & 0,8 & 0,9 & 0,8 & 2,1 & 1,0 & 1,1 & 0,9 & 0,8 & 0,9 \\
\hline F & 0,8 & 0,9 & 0,6 & 0,9 & 0,8 & 0,9 & 0,7 & 0,6 & 0,8 \\
\hline G & 0,5 & 0,6 & 0,4 & 1,2 & 0,7 & 1,0 & 0,7 & 0,7 & 0,7 \\
\hline H & 2,8 & 3,5 & 3,1 & 4,7 & 4,5 & 5,3 & 4,5 & 3,2 & 2,9 \\
\hline AA-C & 93,9 & 92,2 & 94,0 & 88,6 & 91,9 & 90,4 & 91,9 & 93,4 & 93,4 \\
\hline D-H & 6,1 & 7,8 & 6,0 & 11,4 & 8,1 & 9,6 & 8,1 & 6,6 & 6,6 \\
\hline
\end{tabular}

Fonte: Elaboração própria a partir de dados extraídos do site do Banco H SBC.

\section{Índices de cobertura e de eficiência}

O Índice de Coberturado H SBC atingiu 131\%em junho de 2008. $\mathrm{N}$ os últimos anos, verifica-se uma tendência de crescimento desse índice (Tabela I .8.4).

Tabela I .8.4 - Índice de C obertura (em R \$ milhões)

\begin{tabular}{l|c|c|c|c|c|c|c|c|c|c|c|c}
\hline & $\mathbf{1 9 9 7}$ & $\mathbf{1 9 9 8}$ & $\mathbf{1 9 9 9}$ & $\mathbf{2 0 0 0}$ & $\mathbf{2 0 0 1}$ & $\mathbf{2 0 0 2}$ & $\mathbf{2 0 0 3}$ & $\mathbf{2 0 0 4}$ & $\mathbf{2 0 0 5}$ & $\mathbf{2 0 0 6}$ & $\mathbf{2 0 0 7}$ & $\begin{array}{c}\mathbf{1 0 S} \\
\mathbf{2 0 0 8}\end{array}$ \\
\hline $\begin{array}{l}\text { Rec. } \\
\text { Prestação }\end{array}$ & 435,6 & 811,3 & 758,5 & 828,0 & $1.002,5$ & $1.038,8$ & $1.188,8$ & $1.467,5$ & $1.941,3$ & $2.238,1$ & $2.392,7$ & $1.123,6$ \\
\begin{tabular}{l} 
Serviços \\
\hline $\begin{array}{l}\text { Desp. } \\
\text { Pessoal }\end{array}$
\end{tabular} & 588,4 & 873,1 & 919,4 & $1.044,6$ & $1.062,6$ & $1.228,1$ & $1.248,2$ & $1.388,5$ & $1.451,3$ & $1.570,9$ & $1.807,6$ & 857,2 \\
\hline $\begin{array}{l}\text { Indicede } \\
\text { Cobertura } \\
\text { (\%) }\end{array}$ & 74,0 & 92,9 & 82,5 & 79,3 & 94,3 & 84,6 & 95,2 & 105,7 & 133,8 & 142,5 & 132,4 & 131,1 \\
\hline
\end{tabular}

Fonte: Elaboração própria a partir de dados extraídos do site do Banco C entral do Brasil. 
Esse crescimento pode ser explicado pela ampliação de 449,3\% nas R eceitas de P restação de Serviços no período de 1997 a 2007, contra uma ampliação de somente $207,2 \%$ nas D espesas de Pessoal .

O Índice de Eficiência, por sua vez, atingiu 65,9\%, em junho de 2008. A té dezembro de 2006, esse índice apresentava tendência de queda; entretanto, em 2007 e no primeiro semestre de 2008, apresentou crescimento (G ráfico I .8.4).

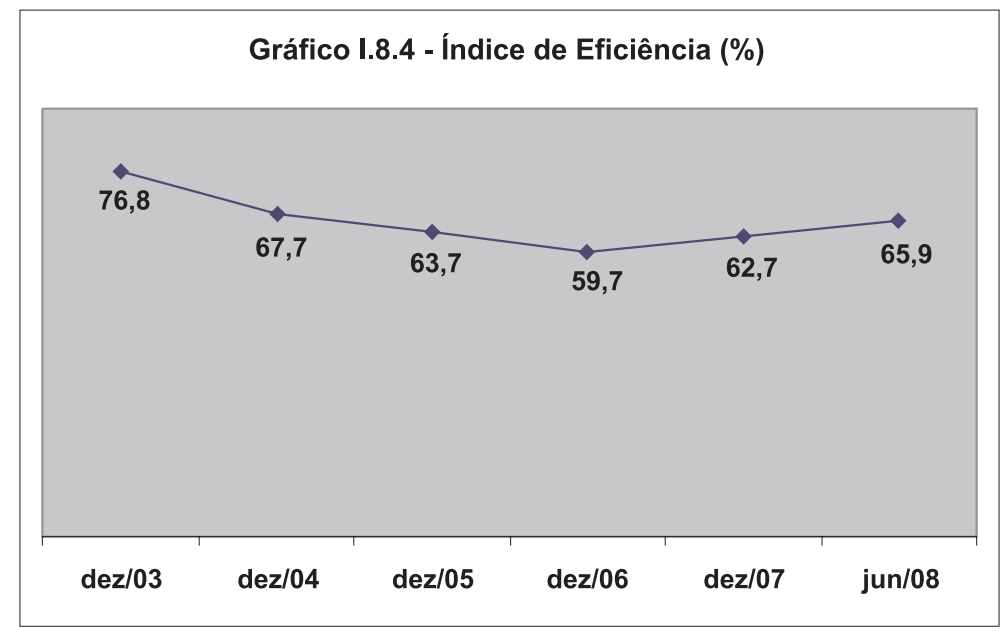

Fonte: Elaboração própria a partir de dados extraídos do site do Banco H SBC.

Composição dos ativos e das receitas de intermediação financeira

A carteira de ativos do H SBC é composta, principalmente, por $O$ perações de $C$ rédito eA rrendamento $M$ ercantil, querepresentaram $31,1 \%$ do total de ativos em junho de 2008. A té2001, as 0 perações com T V M e Instrumentos Financeiros D erivativos eram os principais componentes da carteira, sendo que, em junho de 2008, essa participação atingiu 15,8\%, contra 28,6\% em dezembro de 2001 (Tabela I.8.5). 
Tabelal . 8.5 - Composição dos A tivos (em \%)

\begin{tabular}{|c|c|c|c|c|c|c|}
\hline D ata & $\begin{array}{l}\text { A plicações } \\
\text { Interfin. }\end{array}$ & $\begin{array}{l}\text { T VM } \\
\text { elnstr. } \\
\text { Financ. } \\
\text { D eriv. }\end{array}$ & $\begin{array}{l}\text { Op.de } \\
\text { Crédito e } \\
\text { Arrend. } \\
\text { M erc. }\end{array}$ & $\begin{array}{l}\text { O utros } \\
\text { C réditos }\end{array}$ & O utros & $\begin{array}{l}\text { A tivo T otal } \\
\text { (em } \\
\text { R \$ bilhões) }\end{array}$ \\
\hline dez./ 97 & 23,6 & 25,5 & 15,4 & 17,5 & 18,0 & 13,0 \\
\hline dez./ 98 & 3,1 & 45,0 & 18,4 & 16,8 & 16,7 & 13,9 \\
\hline dez./ 99 & 13,1 & 31,6 & 25,1 & 12,9 & 17,3 & 13,3 \\
\hline dez./ 00 & 14,9 & 29,8 & 28,9 & 15,9 & 10,5 & 21,6 \\
\hline dez./ 01 & 12,6 & 28,6 & 27,8 & 17,9 & 13,1 & 22,4 \\
\hline dez./ 02 & 11,4 & 22,9 & 30,2 & 17,1 & 18,4 & 24,8 \\
\hline dez./ 03 & 9,2 & 19,2 & 43,5 & 14,5 & 13,6 & 26,3 \\
\hline dez./ 04 & 7,7 & 24,6 & 42,4 & 11,4 & 13,9 & 34,4 \\
\hline dez./ 05 & 14,7 & 23,9 & 37,6 & 10,7 & 13,1 & 47,5 \\
\hline dez./ 06 & 15,8 & 20,4 & 37,2 & 12,4 & 14,2 & 58,3 \\
\hline dez./ 07 & 10,8 & 18,6 & 38,0 & 16,0 & 16,6 & 70,8 \\
\hline jun./ 08 & 13,3 & 15,8 & 31,1 & 24,2 & 15,6 & 97,5 \\
\hline Cresc. (\%) & 322,4 & 363,0 & $1.410,3$ & 935,5 & 546,6 & 650,0 \\
\hline
\end{tabular}

1) Inclui D isponibilidades, Relações Interfinanceiras, R elações de Interdependências, Provisão para C réditos de L iquidação $\mathrm{D}$ uvidosa, $\mathrm{O}$ utrosValores e Bens, I mobilizado de A rrendamento ePermanente.

Fonte: Elaboração própria a partir de dados extraídos do site do Banco C entral do Brasil.

N o período de dezembro de 1997 a junho de 2008, as 0 peraç̃ões de $C$ rédito e $A$ rrendamento $M$ ercantil foram os componentes do ativo que mais cresceram - uma ampliação de $1.410 \%$. A carteira de T V M é composta, principalmente, por títulos públicos. Em junho de2008, a partici pação dessestítulos atingiu 81,9\%, contra 88,9\%em dezembro de 2007. D esde 2004, esse percentual vem decrescendo (G ráfico I.8.5).

0 comportamento das R eceitas de I ntermediação Financeira foi semelhante. A s receitas originárias das 0 perações de $C$ rédito e A rrendamento $M$ ercantil representaram $74,6 \%$ do total das receitas no primeiro semestre de 2008. A participação dessas operações vem crescendo significativamente, enquanto as receitas decorrentes das O perações com T VM vêm diminuindo sua participação, desde2002, atingindo 19,4\% em junho de 2008 (T abela I.8.6). 


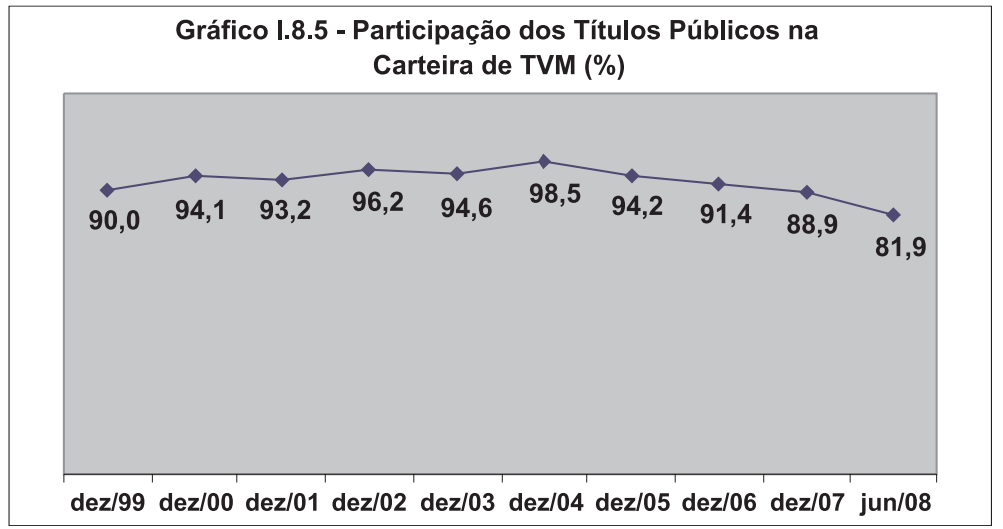

Fonte: Elaboração própria a partir de dados extraídos do site do Banco H SBC.

T abela I .8.6 - C omposição das R eceitas de I ntermediação Financeira (em \%)

\begin{tabular}{|c|c|c|c|c|}
\hline D ata & $\begin{array}{l}\text { Op. C rédito e } \\
\text { Arrend. M erc. }\end{array}$ & $\begin{array}{c}\text { O perações com } \\
\text { T V M }\end{array}$ & O utros ${ }^{1}$ & $\begin{array}{c}\text { Total (em } \\
\text { R \$ bilhões) }\end{array}$ \\
\hline 1997 & 39,8 & 52,0 & 8,2 & 1,5 \\
\hline 1998 & 34,5 & 58,9 & 6,6 & 2,8 \\
\hline 1999 & 39,9 & 51,6 & 8,5 & 3,3 \\
\hline 2000 & 54,4 & 42,7 & 2,9 & 3,6 \\
\hline 2001 & 55,7 & 50,1 & $-5,8$ & 4,3 \\
\hline 2002 & 59,5 & 47,8 & $-7,3$ & 4,7 \\
\hline 2003 & 61,1 & 17,4 & 21,5 & 5,6 \\
\hline 2004 & 69,4 & 19,6 & 11,0 & 7,2 \\
\hline 2005 & 66,5 & 24,5 & 9,0 & 10,0 \\
\hline 2006 & 68,6 & 24,1 & 7,3 & 10,7 \\
\hline 2007 & 72,8 & 21,9 & 5,3 & 11,3 \\
\hline 1052008 & 74,6 & 19,4 & 6,0 & 6,5 \\
\hline Cresc. (\%) & $1.251,1$ & 211,1 & 378,6 & 653,3 \\
\hline
\end{tabular}

1) Inclui O perações com Instrumentos Financeiros D erivativos, O perações de $C$ âmbio e A plicações Compulsórias.

Fonte: Elaboração própria a partir de dados extraídos do site do Banco C entral do Brasil.

\section{Resultados}

O H SBC Bank Brasil obtevelucro líquido de R \$1,24 bilhão em 2007, o maior resultado desde o início de suas operações no país, 
em 26 de março de 1997, representando um crescimento de $31 \%$ em relação a 2006 (G ráfico I .8.6). D esde 2004, o lucro do banco vem crescendo significativamente, sendo que, no primeiro semestre de 2008, o lucro líquido foi de R \$ 769 milhões. 0 crédito foi o grande impulsionador dos resultados positivos da instituição.

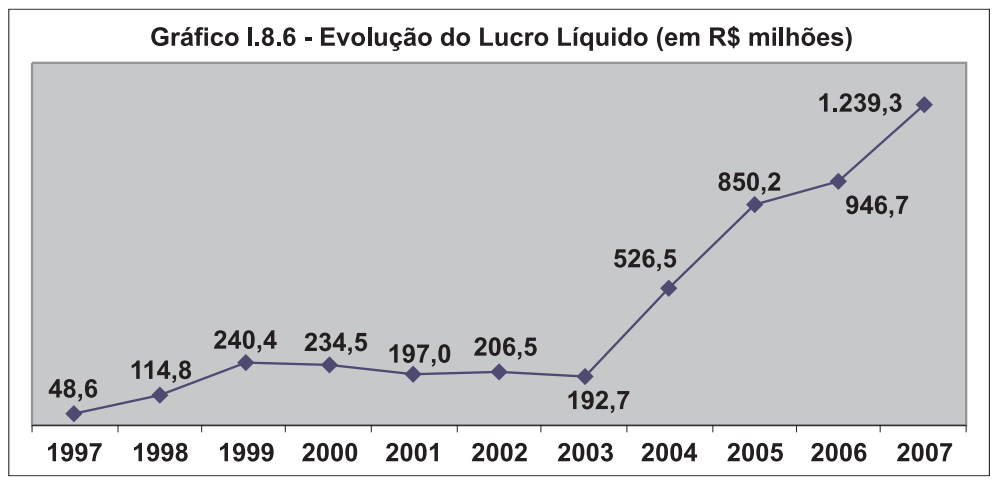

Fonte: Elaboração própria a partir de dados extraídos do site do Banco C entral do Brasil.

O R etorno sobreo Patrimônio L íquido, por suavez, foi de 29,94\% em junho de 2008, sendo que, desde 2004, a instituição mudou seu patamar de retorno, mantendo-se com um desempenho anual acima de 20\% (G ráfico I.8.7).

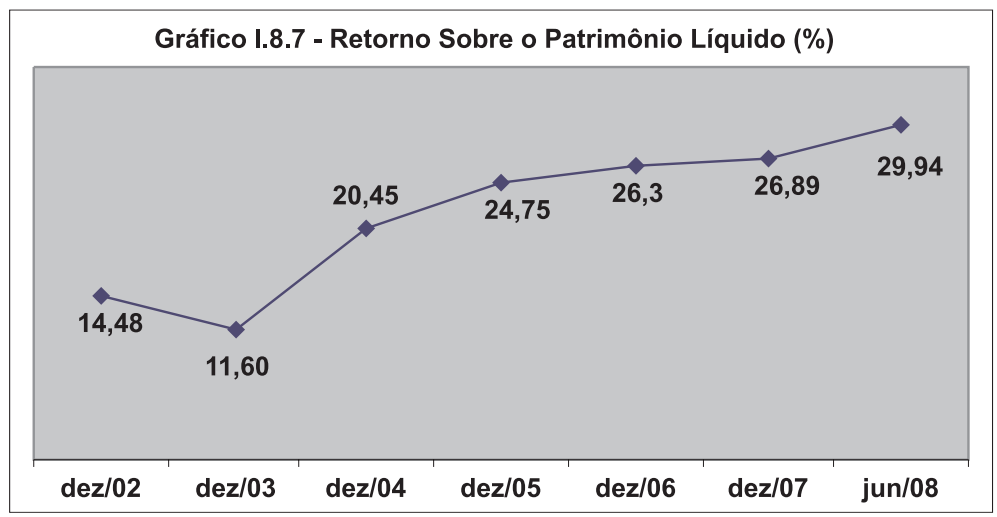

Fonte: Elaboração própria a partir de dados extraídos do site do Banco H SBC. 
Essa alteração foi resultado do direcionamento ao mercado de crédito ao consumidor, suportado pelas aquisições da L osango, Valeu e Credimatone.

\section{Tendências recentes}

A principal estratégia da instituição éampliar a carteira decrédito com garantia, principalmente consignado, veículos e imóveis. N o final de2007, a participação dessetipo de crédito na carteira total foi de $50 \%$, sendo que o H SBC pretendeaumentar esse percentual para $60 \%$ (Valor E conômico, 11/ 12/ 2007). A forte expansão do mercado de crédito veio acompanhada da ampliação dos prazos, que chegaram a níveis inéditos para o financiamento do consumo. Em 2006, o H SBC foi o primeiro banco a lançar o prazo de amortização de 72 meses (Valor E conômico, 30/ 10/ 2007).

O segmento depequenas e médias empresas também tem grande importância para o H SBC . A modalidadedeantecipação derecebíveis tem sido utilizada pel o banco como forma de ampliar a atuação nesse nicho de mercado. O s riscos não são al tos, já quea garantia é um ativo real, possibilitando que as taxas de juros para as empresas sejam menores. A instituição disponibiliza a antecipação de diversos ativos, além do desconto de duplicatas, como cheques, cartão de crédito e aluguéis. Para reforçar o segmento, o H SBC investiu em sistemas e em model os de aval iação de riscos. U ma das principais inovações foi o sistema de desconto via internet, em que o banco cadastra todos os recebíveis das grandes empresas. D essa forma, as pequenas empresas, fornecedoras de serviços para as grandes, podem escolher a data eas taxas dedesconto desses recebíveis (Valor E conômico, 17/ 9/ 2007 (2)).

O H SBC também pretende investir no segmento de cartões. N 0 início de 2008, o banco lançou um cartão que reembolsa o portador, sempre que utilizado em postos de combustível. Serão devolvidos ao cliente, na fatura, 3\% das despesas. Para possibilitar a operacionalização desse produto, o H SBC fechou acordo com algumas redes de postos no país. A lém do "H SBC Cartão Combustível", o banco 
lançou, por meio da L osango, uma conta-corrente "popular" para as classes $D$ e E , com cartão de débito da bandeira Visa e um título de capitalização.

A L osango foi a grande responsável pelo aumento da base de cartões do banco em 2007. Por meio de acordos da financeira com redes varejistas, foram emitidos 1,7 milhão de cartões, destinados, principalmente, a pessoas de menor renda, das classes $C$ e $D$. A lém disso, a financeira vendeu outros 1,4 milhão de cartões do banco. Como resultado, o Brasil foi o maior emissor mundial de cartões do H SBC (Valor E conômico, 4/ 1/ 2008).

O s cartões direcionados para empresas, chamados cartões corporativos, também vêm apresentando al tas taxas de crescimento. 0 H SBC, queentrou no mercado de cartões corporativos em fevereiro de 2007, já emitiu 70 mil cartões. 0 banco pretende lançar novos produtos para o segmento, sendo que uma das possibilidades é disponibilizar para as empresas o cartão que reembolsa na fatura os gastos em postos de combustíveis, atualmente disponível somente para pessoas físicas (Valor E conômico, 7/ 1/ 2008).

A pesar da recenteonda de fusões eaquisições verificada no Brasil, o H SBC pretendepriorizar o crescimento orgânico. Para possibilitar esse crescimento, o banco se concentrará na faixa de menor renda, por meio da L osango. A iniciativa de bancarização do H SBC foi lançada em janei ro de 2008 eincluiu a criação da C onta L osango, que funcionará como uma conta-corrente acoplada à poupança ( $G$ az eta M ercantil, 31/ 3/ 2008 (1)).

Em abril de 2008, o H SBC lançou um projeto de expansão da Financeira $L$ osango, por meio do qual serão montados quiosques dentro de lojas de varejo com as quais a L osango já possui acordo no $C$ rédito $D$ ireto ao $C$ onsumidor (CDC ). A estratégia também inclui o aprofundamento no relacionamento com o cliente, focando produtos como cartão de crédito e C onta L osango, que permitem uma relação mais duradoura com o cliente, em detrimento dos empréstimos pessoais. $\mathrm{O} \mathrm{N}$ ordestetem sido a região em quea financeira mais cresce, mas a intenção é ampliar as operações para todos os $E$ stados do país (Valor E conômico, 20/ 6/ 2008; Valor E conômico, 14/ 7/ 2008). 
A instituição também está investindo no segmento de renda mais alta. 0 H SBC pretende ampliar a base de clientes desse segmento, por meio da abertura de agências exclusivas, chamadas Premier C enters. Somente nos Estados de São Paulo e R io de J aneiro, serão abertas 67 agências (0 G lobo, 8/ 4/ 2008).

\section{Atuação externa ${ }^{28}$}

Com sede em $L$ ondres, a rede internacional do $\mathrm{G}$ rupo $\mathrm{H}$ SBC é composta por 10 mil escritórios em 86 países e por 312 mil colaboradores. 0 grupo atende mais de 128 milhões de clientes e possui ações cotadas nas Bolsas de L ondres, H ong K ong, N ova York, Paris e Bermudas, com mais de 200 mil acionistas em cerca de cem países e territórios.

Em 2008, o grupo financeiro britânico liderou o ranking Forbes 2000 das maiores companhias do planeta. 0 índice anual examinou empresas de 26 setores de atividade em 60 países, classificando-as sob critérios de vendas, lucros, ativos evalor de mercado.

$\mathrm{O}$ grupo divide suas operações em cinco regiões: E uropa, $\mathrm{H}$ ong K ong, Á sia (inclui a A ustrália e os países do O riente M édio), A mérica do $\mathrm{N}$ ortee $\mathrm{A}$ mérica $\mathrm{L}$ atina.

A região com maior participação na cartei ra deativos da instituição éaE uropa, seguidapelaA mérica do N orte, com participações de 50,4\% e $20,8 \%$, respectivamente. Somentea região deH ong K ong representa $15,3 \%$ dos ativos do grupo. A s regiões que mais cresceram desde dezembro de 2004 foram E uropa e A mérica $L$ atina (Tabela I .8.7).

A participação da carteira de crédito nos ativos totais atingiu $36,9 \%$ em 2008, sendo queessa participação vem decrescendo desde 2005 (G ráfico l .8.8).

28 A s regras contábeis inglesas se diferenciam, em al guns pontos, das regras brasileiras; entretanto, essa diferença não irá interferir nesta análise, uma vez que, para possibilitar a comparação, neste item serão adotados os critérios ingleses também para o Brasil. 
Tabela I .8.7 - Distribuição R egional dos A tivos (\%)

\begin{tabular}{l|c|c|c|c|c|c}
\hline & dez./ 04 & dez./ 05 & dez./ 06 & dez./ 07 & dez./ 08 & C resc. \\
\hline Europa & 42,6 & 42,4 & 44,5 & 49,7 & 50,4 & 146,2 \\
\hline H ong K ong & 17,6 & 15,7 & 16,4 & 14,3 & 15,3 & 80,7 \\
\hline Á sia & 9,4 & 9,4 & 9,0 & 9,8 & 9,8 & 117,6 \\
\hline A mérica do N orte & 27,2 & 28,8 & 25,9 & 22,1 & 20,8 & 58,7 \\
\hline A mérica L atina & 3,2 & 3,7 & 4,2 & 4,1 & 3,7 & 142,3 \\
\hline
\end{tabular}

Fonte: Elaboração própria a partir de dados extraídos do site do G rupo H SBC.

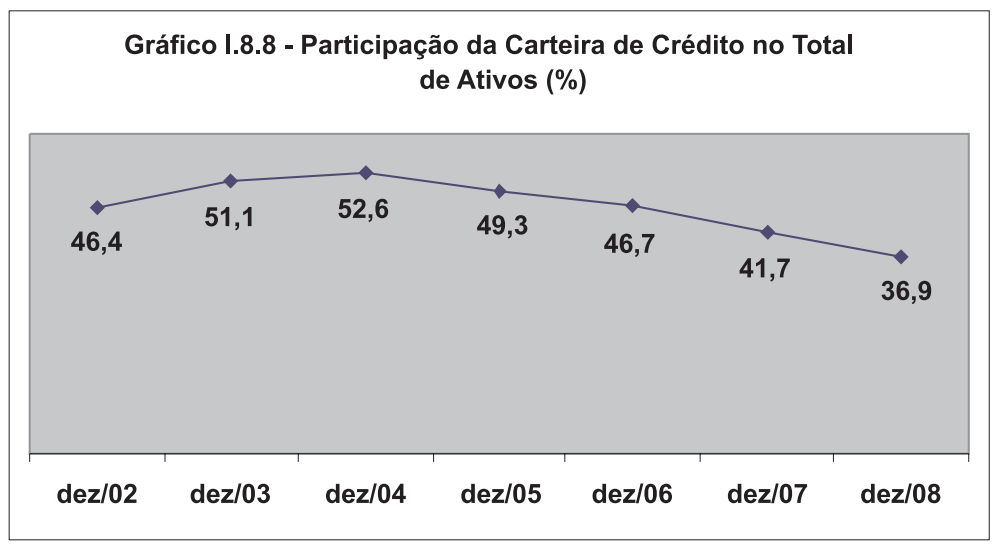

Fonte: Elaboração própria a partir de dados extraídos do site do G rupo H SBC.

Em 2008, a carteira deE mpréstimos Pessoais representou 47,2\% dos empréstimos totais do banco, sendo que os principais componentes dessa carteira têm sido as hipotecas residenciais e os cartões de crédito, com participações de 55,3\% e 17\%, respectivamente.

A s regiões com maior participação na carteira decrédito do grupo são E uropa e A mérica do N orte, que, em 2008, atingiram participações de $45,7 \%$ e 27,5\%, respectivamente. Entretanto, a região que apresentou maior crescimento da carteira de crédito desde 2004 foi a A mérica L atina, com uma ampliação de 169,5\% (T abela I.8.8).

E m 2008, todas as regiões, exceto a A mérica do N orte, registraram crescimento da carteira de crédito, com destaque para os empréstimos para clientes comerciais. 
Tabela I.8.8 - D istribuição R egional da C arteira de C rédito (\%)

\begin{tabular}{l|c|c|c|c|c|c}
\hline & dez./ 04 & dez./ 05 & dez./ 06 & dez./ 07 & dez./ 08 & C resc. \\
\hline Europa & 41,3 & 42,2 & 45,2 & 46,1 & 45,7 & 53,5 \\
\hline H ong K ong & 11,7 & 11,3 & 9,7 & 9,1 & 10,7 & 27,1 \\
\hline Á sia & 9,0 & 9,5 & 9,0 & 10,4 & 11,6 & 78,0 \\
\hline A mérica do N orte & 35,7 & 34,1 & 32,0 & 29,5 & 27,5 & 6,7 \\
\hline A mérica L atina & 2,3 & 2,9 & 4,1 & 4,9 & 4,5 & 169,5 \\
\hline
\end{tabular}

Fonte: Elaboração própria a partir de dados extraídos do site do G rupo H SBC.

A cultura de gerenciamento do risco de crédito do $\mathrm{G}$ rupo H SBC éaplicada em todos os países eregiões ondeatua etem como objetivo minimizar as perdas de crédito e aumentar o retorno sobre o risco ajustado.

0 Índice de Solvência da instituição atingiu 11,4\% em 2008, 0 menor desde 1998, entretanto está acima do mínimo exigido, de 8\% (G ráfico I.8.9).

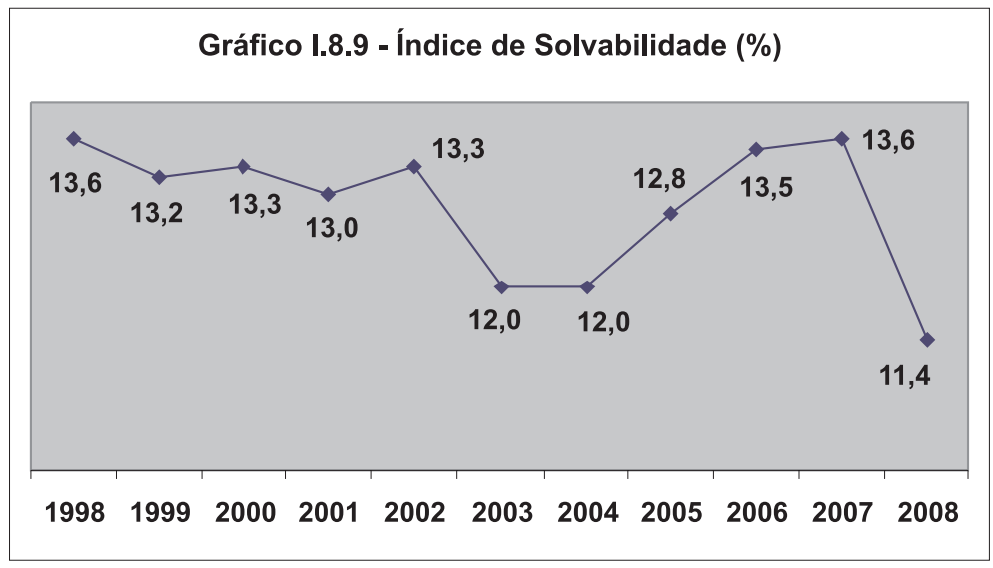

Fonte: Elaboração própria a partir de dados extraídos do site do G rupo H SBC.

Com relação ao Í ndice de Eficiência, verificou-se um aumento significativo em 2008, provocado, principalmente, pelo baixo desempenho da A mérica do $\mathrm{N}$ orte. A s regiões com maiores Índices de Eficiência são Europa e A mérica L atina; entretanto, há uma 
tendência de queda, verificada desde2004. A região de H ong K ong apresentou os menores índices no período (Tabela I .8.9).

A s regiões que mais têm contribuído para o resultado do grupo são E uropa, H ong K ong e A mérica do N orte. Entretanto, em 2007 e 2008, o baixo desempenho da A mérica do N orte afetou negativamente o lucro do H SBC (Tabela I.8.10).

Tabela I.8.9 - Índice deE ficiência (\%)

\begin{tabular}{l|l|l|l|l|l}
\hline & $\mathbf{2 0 0 4}$ & $\mathbf{2 0 0 5}$ & $\mathbf{2 0 0 6}$ & $\mathbf{2 0 0 7}$ & $\mathbf{2 0 0 8}$ \\
\hline Europa & 64,0 & 60,8 & 60,1 & 59,9 & 52,4 \\
\hline H ong K ong & 35,8 & 38,2 & 38,0 & 33,4 & 38,8 \\
\hline Á sia & 54,8 & 55,1 & 52,8 & 47,4 & 48,6 \\
\hline A mérica do N orte & 43,4 & 44,8 & 47,1 & 46,3 & 94,1 \\
\hline A mérica L atina & 62,9 & 60,0 & 61,0 & 58,3 & 57,0 \\
\hline Total & 51,6 & 51,2 & 51,3 & 49,4 & 60,1 \\
\hline
\end{tabular}

Fonte: Elaboração própria a partir de dados extraídos do site do G rupo H SBC.

T abela I .8.10 - Participação no L ucro A ntes dos I mpostos (\%)

\begin{tabular}{l|c|c|c|c|c}
\hline & $\mathbf{2 0 0 4}$ & $\mathbf{2 0 0 5}$ & $\mathbf{2 0 0 6}$ & $\mathbf{2 0 0 7}$ & $\mathbf{2 0 0 8}$ \\
\hline Europa & 30,4 & 30,3 & 31,5 & 35,5 & 116,7 \\
\hline H ong K ong & 25,5 & 21,5 & 23,5 & 30,3 & 58,7 \\
\hline Á sia & 9,8 & 12,3 & 16,0 & 24,8 & 69,5 \\
\hline A mérica do N orte & 27,8 & 28,2 & 21,1 & 0,4 & $-166,8$ \\
\hline A mérica L atina & 6,5 & 7,7 & 7,9 & 9,0 & 21,9 \\
\hline Total & 18.943 & 20.966 & 22.086 & 24.212 & 9.307 \\
\hline
\end{tabular}

Fonte: Elaboração própria a partir de dados extraídos do site do G rupo H SBC.

O bom desempenho do H SBC Brasil em 2007, consequência do crescimento da carteira de crédito, adicionado ao encolhimento da instituição nos Estados U nidos, por conta da desaceleração da economia americana, fez com quea participação brasileira no resultado mundial do banco aumentasse de 1,9\% em 2006 para 3,6\% em 2007. A meta é que em cinco ou dez anos ela chegue a $5 \%$, eque a participação da A mérica L atina suba dos atuais 9\% para 12\% (V alor E conômico, 11/ 12/ 2007). 
O R etorno sobre o Patrimônio L íquido M édio acompanhou 0 desempenho do lucro com uma queda de $15,9 \%$ em 2007 para 4,7\% em 2008 (G ráfico I 8.10). Essa quedafoi provocada, principalmente, pelos resultados negativos da $\mathrm{A}$ mérica do $\mathrm{N}$ orte.

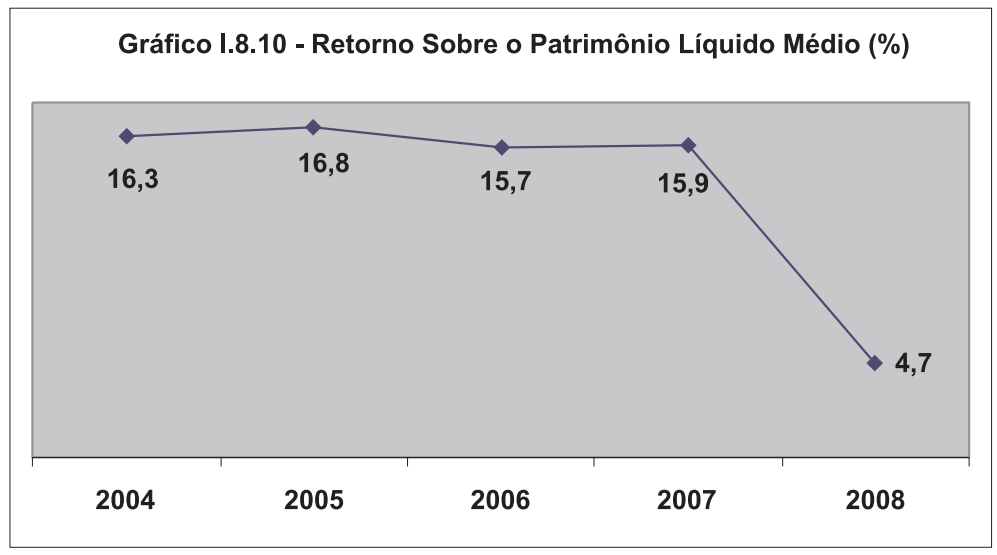

Fonte: Elaboração própria a partir de dados extraídos do site do G rupo H SBC.

O baixo desempenho da A mérica do N orte em 2007 e 2008 foi consequência, principalmente, do aumento, desde2006, da inadimplência nas operações da $\mathrm{H}$ olsehold I nternacional, especializada em financiar compras de imóveis por clientes dealto risco decrédito nos Estados U nidos (Valor E conômico, 4/ 3/ 2008 [2]).

A partir das perdas verificadas na A mérica do $\mathrm{N}$ orte, a instituição chegou à conclusão de que a concessão de empréstimos pessoais diretos em grande escala e de forma indiscriminada não éviável. 0 H SBC , então, adotou a estratégia desuspender essetipo deempréstimo, com exceção dos cartões de crédito, edefechar as unidades que eram responsáveis por sua concessão na $\mathrm{A}$ mérica do $\mathrm{N}$ orte.

Por outro lado, o H SBC reconhece que os países em desenvolvimento estão crescendo mais rápido do que as economias desenvolvidas. $\mathrm{N}$ esse sentido, o banco tem focado os mercados emergentes, principalmente na Á sia. A meta, anunciada em 2008, é obter $60 \%$ do lucro em mercados emergentes (V alor E conômico, 4/ 8/ 2008). 
Em 2007, seguindo essa estratégia, o H SBC adquiriu 51,02\% de participação no K orea Exchange Bank (KEB), o sexto maior banco da Coreia do Sul (V alor E conômico, 3/ 9/ 2007 [3]). E m 2008, adquiriu operações do T he C hinese Bank, em Taiwan, e do IL \&FS I nvestsmart, naÍ ndia. T ambém anunciou a aquisição do Bank Ekonomi, da Indonésia.

A instituição considera quea atividadenaÁ sia émuito mais antiga e consolidada e que os países asiáticos crescem mais rapidamente do que os países da A mérica L atina. Entretanto, a estratégia deavançar entre os emergentes também inclui a A mérica L atina. Em 2006, 0 H SBC comprou o Banistimo, do Panamá, com presença em cinco outros países da região, além de ter adquirido a operação da Banca $\mathrm{N}$ azionaledel $\mathrm{L}$ avoro, da $\mathrm{A}$ rgentina. $\mathrm{A}$ instituição também adotou a estratégia de crescimento orgânico, por meio da criação de um novo banco no Peru (Valor E conômico, 4/ 3/ 2008 (2)).

$\mathrm{N}$ o Brasil, o H SBC vem crescendo a uma velocidade suficiente para manter sua participação de mercado entretanto, segue como 0 demenor volumedenegócios entreas grandes instituições devarejo.

A bancarização éfoco da estratégia de crescimento orgânico em países em desenvolvimento. E $\mathrm{m} \mathrm{H}$ ong Kong, por exemplo, a cada quatro habitantes, três têm conta no HSBC (G azeta M ercantil, 31/ 3/ 2008 [2]).

A A mérica $L$ atina oferece muitas possibilidades de crescimento orgânico, uma vez que o H SBC estima que dois terços da população da região, localizados principal menteno M éxico eno B rasil, não são bancarizados (Valor E conômico, 18/ 4/ 2008). 


\author{
SOBRE O LIVRO \\ Formato: $14 \times 21 \mathrm{~cm}$ \\ Mancha: 23,7 x 42,5 paicas \\ Tipologia: Horley Old Style 10,5/14 \\ 1a edição: 2009 \\ EQUIPE DE REALIZAÇÃO \\ Coordenação Geral \\ Marcos Keith Takahashi
}




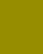

